\title{
The Origin and Evolution of V-rich, Magnetite Dominated Fe-Ti Oxide Mineralization; Northwest River Anorthosite, South-Central Labrador, Canada
}

Anthony A. Valvasori

A thesis submitted to the Department of Earth Sciences in partial fulfillment of the requirements for the degree of Master of Science. 
The Northwest River Anorthosite (NWRA) is a ca. 1625 Ma Paleoproterozoic massif anorthosite located in the Grenville Province of south-central Labrador. Abundant zones of coarse-grained massive to semi-massive Fe-Ti oxide mineralization and disseminated oxide mineralization, which occur in sharp irregular contact with the host anorthosite are present in the NWRA. The Fe-Ti oxide minerals in the NWRA are dominated by magnetite with less abundant ilmenite and pleonaste; all oxide minerals contain abundant and complex exsolution features.

Whole-rock geochemistry, petrography and in situ analyses show that regardless of field texture, oxide mineralization is similar in all of the samples analyzed. Whole-rock analyses of massive to semi-massive Fe-Ti oxide mineralization in the NWRA show values of $\sim 10 \mathrm{wt} . \% \mathrm{TiO}_{2}$ and $2700 \mathrm{ppm} \mathrm{V}\left(0.48 \mathrm{wt} . \% \mathrm{~V}_{2} \mathrm{O}_{5}\right)$. Insitu magnetite analyses contain $<0.5$ wt. $\% \mathrm{TiO}_{2}$ and 0.6-0.7 wt. $\% \mathrm{~V}_{2} \mathrm{O}_{5}$. Composite ilmenite contains $\sim 1$ wt. \% Mg, 5-7 mol\% hematite component and negligible $\mathrm{Cr}$ and $\mathrm{Al}$ content.

Based on oxide mineral chemistry, oxide-anorthosite field relationships, and whole-rock geochemistry, it can be inferred that the formation of the oxide mineralization occurred in a three step process: 1) late-stage magmatic crystallization of impure magnetite; 2) concentration by solid-state remobilization and/or crystal sorting; and 3) reequilibration during subsequent post-emplacement cooling and subsequent Grenvillian metamorphism. These subsolidus processes significantly modified the primary magmatic composition of the oxide minerals through exsolution and reequilibration. 


\section{Acknowledgments}

This research could not have been undertaken without funding provided by the Ignite R\&D Program of the Research and Development Corporation (RDC) of Newfoundland and Labrador, the Atlantic Canada Opportunities Agency (ACOA) and Innovation, Business and Rural Development (IBRD) to M.L.D. Fonkwe.

Tom Benoit and Craig Coady of Ferrum Resources are thanked for allowing access to the field area, permission for sampling, and many days in the field doing geology, which are the best kind of days.

M.L.D. Fonkwe and S.J. Piercey are thanked for helping to get the project off to a good start, and A. Kerr and J. M. Hanchar are thanked for helping get this project back on track to bring it to completion. The entire supervisory team is thanked for their knowledge, editing prowess, and willingness to help.

A big thanks to others who helped with logistics along the way, specifically Brian Joy (EPMA analyses), Marko Prasek and Dany Savard (LA-ICPMS analyses), and the entire staff of the Labrador Institute.

The grad school experience would have been much more unpleasant without the support and friendship of other grad students. You know who you are. Thanks.

Finally, I would like to acknowledge my two girls, Meghan and Qimmie. Thanks for your unwavering faith in me. 


\section{Table of Contents}

Abstract..............................................................................

Acknowledgments..........................................................................................

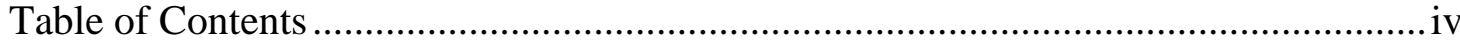

List of Figures ........................................................................................ vii

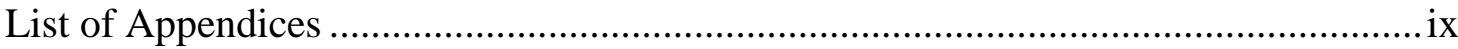

Chapter 1: Introduction ...............................................................................

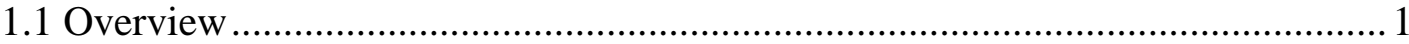

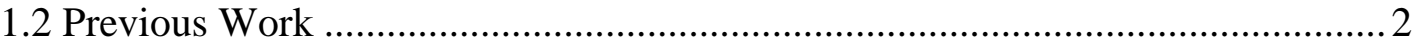

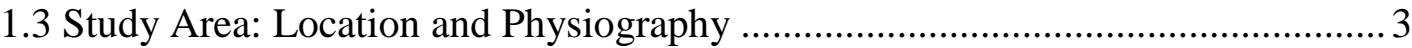

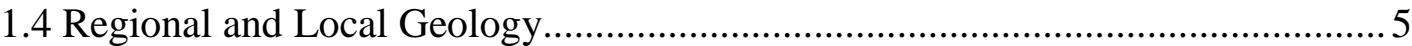

1.4.1 Overview of the regional geology of the Eastern Grenville Province in

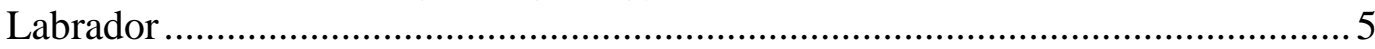

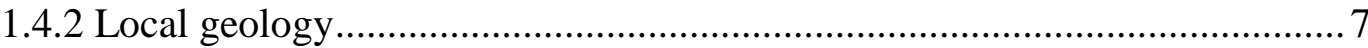

1.5 Fe-Ti oxide mineralization in Proterozoic anorthosite massifs ............................ 9

1.5.1 Liquid Immiscibility ………………………………………………..... 11

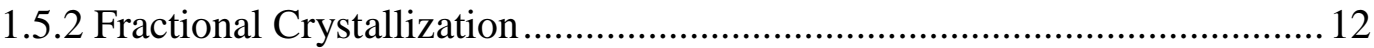

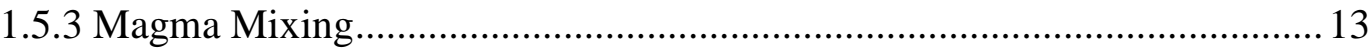

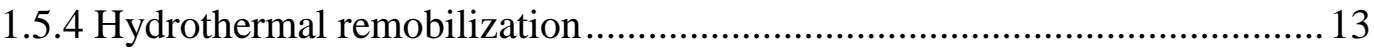

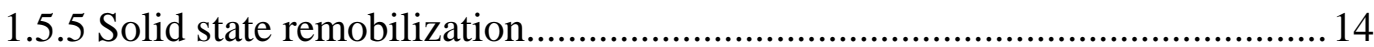

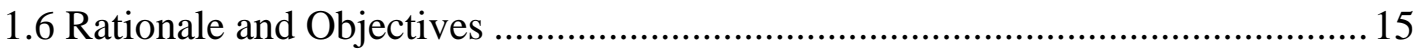

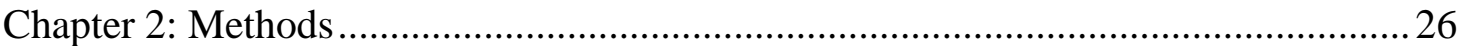

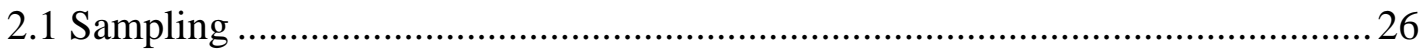

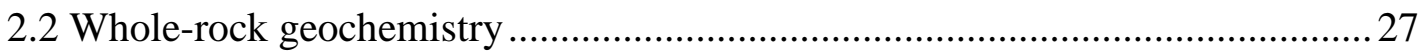

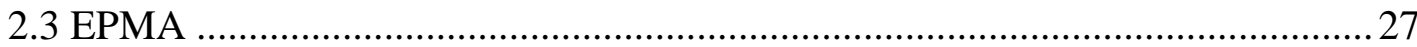

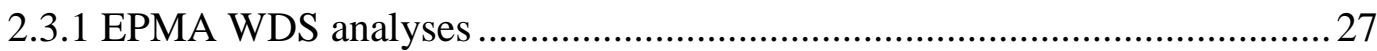

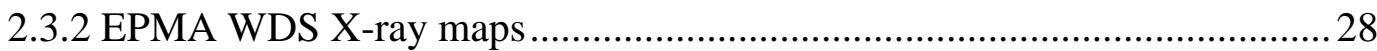

2.3.3 Calculation of $\mathrm{Fe}^{2+}$ and $\mathrm{Fe}^{3+}$ from EPMA analyses ...................................29

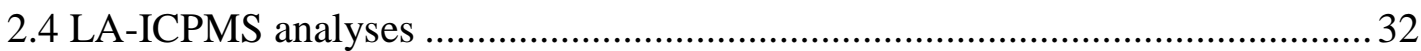

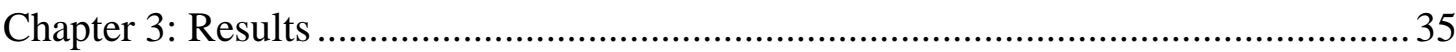

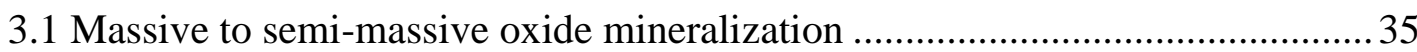

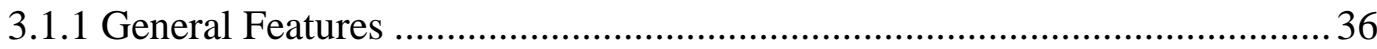

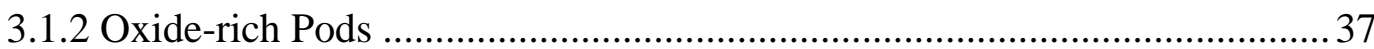




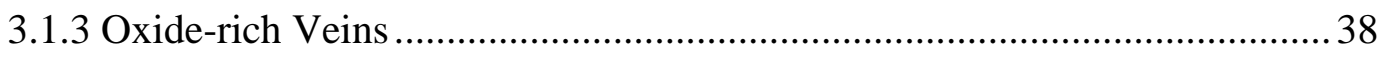

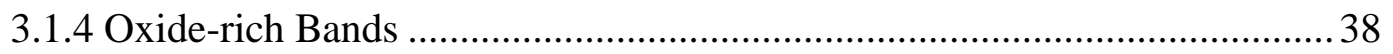

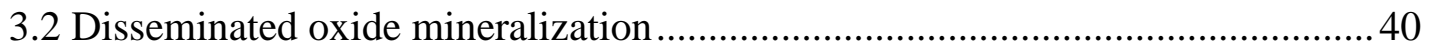

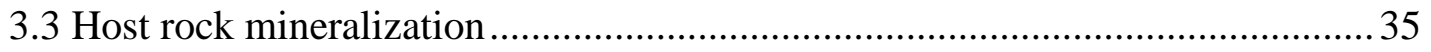

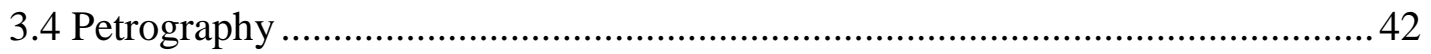

3.4.1 Massive to semi-massive oxide mineralization ........................................... 42

3.4.2 Disseminated oxide mineralization.......................................................... 49

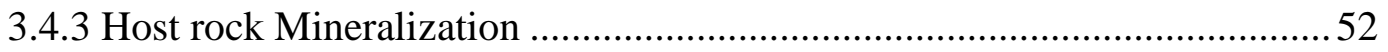

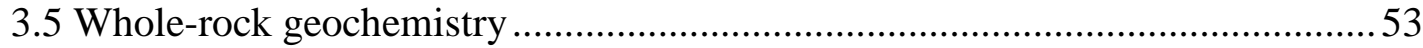

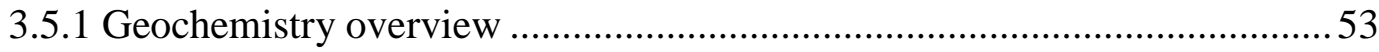

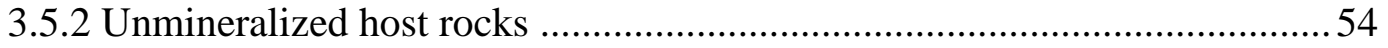

3.5.3 Massive to semi-massive oxide mineralization ...............................................5

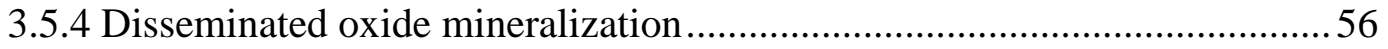

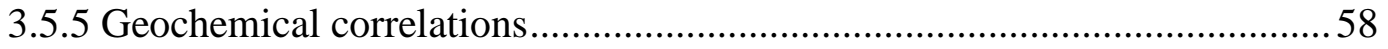

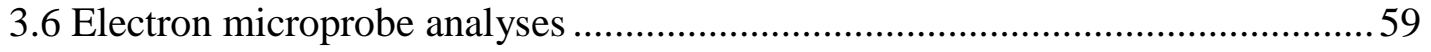

3.6.1 Magnetite Compositions ...........................................................................59

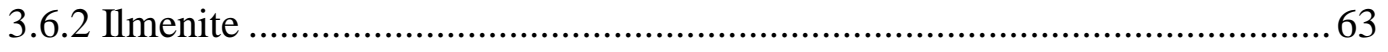

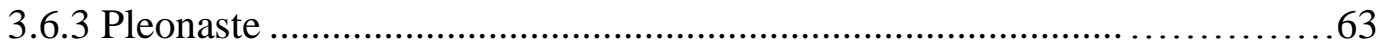

3.7 Mineral compositions determined by LA-ICPMS …….................................... 70

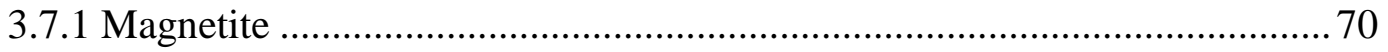

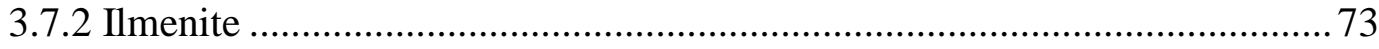

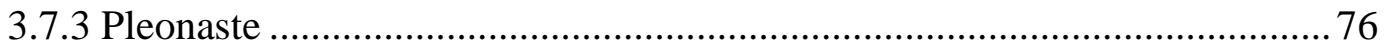

3.7.4 Wavelength Dispersal Spectroscopy (WDS) of Oxide Grains ..................... 79

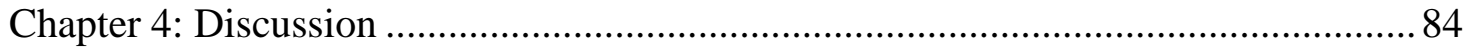

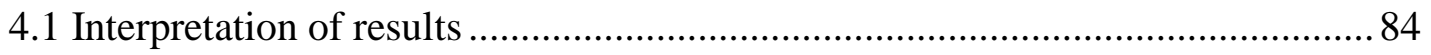

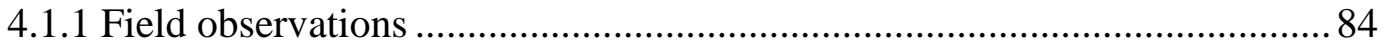

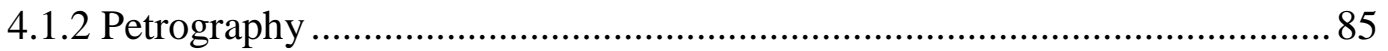

4.1.3 Whole rock major and trace element geochemistry................................... 86

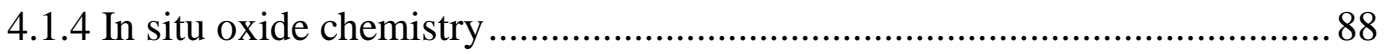

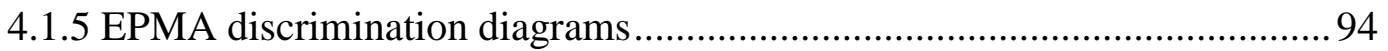

4.1.6 LA-ICPMS Discrimination diagrams .................................................... 100

4.2 Genesis and evolution of oxide mineralization................................................ 100

4.2.1 Liquid Immiscibility ............................................................................. 105 


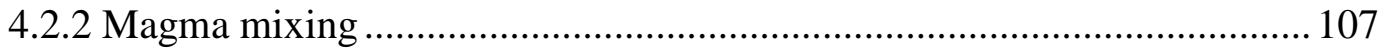

4.2.3 Hydrothermal remobilization ........................................................... 108

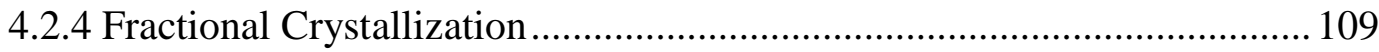

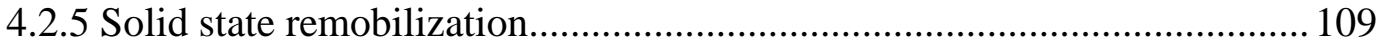

4.2.6 Effect of cooling and metamorphism on oxide chemistry ....................... 110

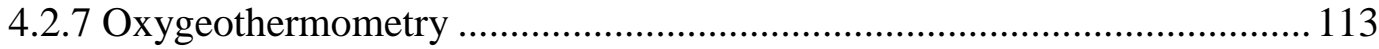

4.2.8 Oxide genesis, concentration and evolution in the NWRA ...................... 115

4.3 Economic Potential of Fe-Ti oxide mineralization in the NWRA ................... 116

Chapter 5: Conclusions and Future Work......................................................... 127

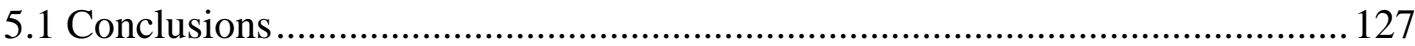

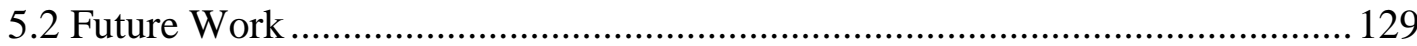




\section{List of Figures}

Figure 1.1 Simplified geological map of Labrador ...................................................... 4

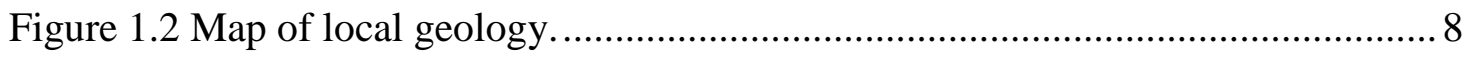

Figure 1.3 Regional aeromagnetic map of the Cape Caribou River allochthon. .......... 10

Figure 3.1 Field photos; barren host rocks and disseminated oxide....................37

Figure 3.2 Field photos; pods of massive to semi-massive oxide mineralization..........39

Figure 3.3 Field photos; veins of oxide mineralization .............................................. 40

Figure 3.4 Field photos; bands of oxide mineralization........................................................42

Figure 3.5. Photomicrographs of massive to semi-massive oxide mineralization...... 443

Figure 3.6 Photomicrographs of massive to semi-massive oxide mineralization........45

Figure 3.7. Photomicrographs of exsolution features in Fe-Ti oxides ..........................4 47

Figure 3.8. Photomicrographs of exsolution features in Fe-Ti oxides..........................50

Figure 3.9. Photomicrographs of Fe-Ti oxides and host rock.......................................51

Figure 3.10 Whole-rock geochemistry element correlation matrix ...............................59

Figure 3.11a, b. Magnetite EPMA box and whisker diagram........................60

Figure 3.12a, b. Ilmenite EPMA box and whisker diagram .........................................67 67

Figure 3.13a, b. Pleonaste EPMA box and whisker diagram ........................................68

Figure 3.14a, b. Magnetite LA-ICPMS box and whisker diagram ................................. 71

Figure 3.15a, b. Ilmenite LA-ICPMS box and whisker diagram................................... 75

Figure 3.16a, b. Pleonaste LA-ICPMS box and whisker diagram ................................. 77

Figure 3.17. X-ray maps of oxide minerals ………………...................................... 79

Figure 4.1. Whole-rock binary variation diagrams of whole-rock analyses .................. 86

Figure 4.2. EPMA magnetite binary element variation diagrams.................................90

Figure 4.3. LA-ICPMS magnetite binary variation diagrams........................................91

Figure 4.4. EPMA ilmenite binary variation diagrams ................................................92

Figure 4.5. LA-ICPMS ilmenite binary element variation diagrams........................... 92

Figure 4.7a, b. Dupuis and Beaudoin (2011) magnetite ore deposit discrimination

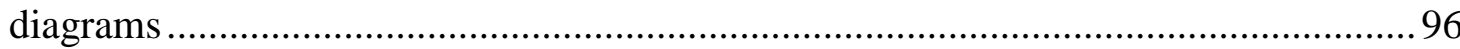

Figure 4.8. Knipping et al. (2015) hydrothermal vs magmatic magnetite discrimination

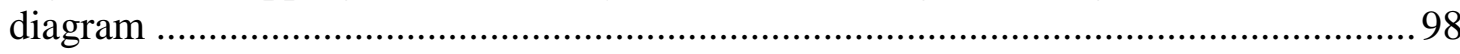

Figure 4.9. Dare et al. (2014) hydrothermal vs magmatic magnetite discrimination diagram.

Figure 4.10a-c. Dare et al. (2014) multielement magnetite discrimination diagram 
Figure 4.11. Data matrix showing plotting position of elements on the Dare et al. (2014) multi-element magnetite discrimination diagram........................................ 104

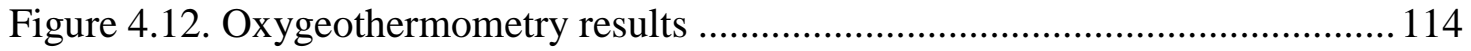




\section{List of Appendices}

Appendix I. List of samples analyzed with EPMA and LA-ICPMS ........................ 131

Appendix II. Average (mean) and standard deviation of whole-rock, EPMA and LA-

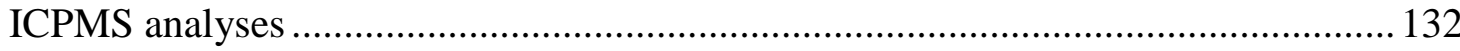

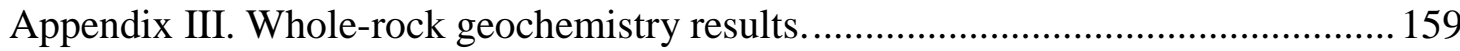

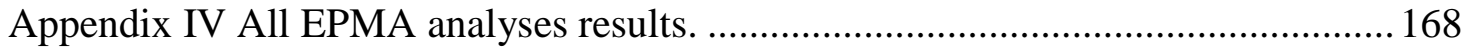

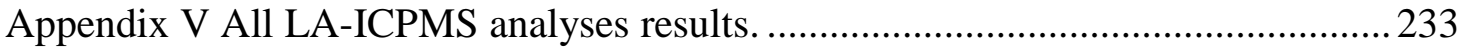

Appendix VI. LA-ICPMS and EPMA spot and line analyses................................2274

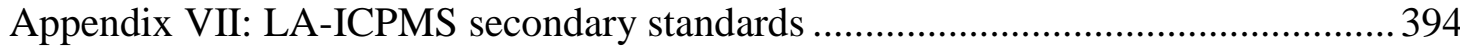




\section{List of Abbreviations}

\begin{tabular}{ll}
\hline AMCG & Anorthosite mangerite charnockite granite \\
CCRA & Cape Caribou River allochthon \\
EPMA & Electron probe microanalyzer \\
$f_{2}$ & Oxygen fugacity \\
HLIS & Harp Lake intrusive suite \\
LA-ICPMS & Laser ablation inductively coupled plasma mass spectrometery \\
LOD & Level of detection \\
MMIS & Mealy Mountains intrusive suite \\
Myr & Million years \\
NPS & Nain plutonic suite \\
NWRA & North West River anorthosite \\
PGE & Platinum group elements \\
WDS & Wavelength dispersive spectroscopy
\end{tabular}




\section{Chapter 1: Introduction}

\subsection{Overview}

Titanium and Vanadium are important industrial elements that are commonly processed from the $\mathrm{Fe}$-Ti oxide minerals magnetite $\left(\mathrm{Fe}_{3} \mathrm{O}_{4}\right)$ and ilmenite $\left(\mathrm{FeTiO}_{3}\right)$ (Force, 1991; Fabjan et al., 2001; Dill, 2010). Economic concentrations of Fe-Ti oxide mineralization are a common feature in Proterozoic anorthosite intrusive complexes including three with currently active mines including Lac Tio, Québec (Charlier et al., 2009), Tellnes, SW Norway (Charlier et al., 2006), and Damiao, China (Chen et al., 2013). Other anorthosite massifs are known to host large, but currently uneconomic concentrations of Fe-Ti oxides including Suwalki (Poland) (Charlier et al., 2009b.), Lac St. Jean (Québec) (Morisset et al., 2010) and Marcy (New York State) (Ashwal, 1982).

Proterozoic anorthosite massifs were defined by Ashwal (2010) as temporally restricted (e.g., largely forming between $\sim 1790$ and $\sim 1060 \mathrm{Ma}$ ) large composite igneous intrusive suites (i.e., massifs) dominantly composed of anorthositic rocks. Labrador contains several anorthosite massifs (Fig. 1.1) including the Nain Plutonic Suite, Mealy Mountains Intrusive Suite (MMIS), including the genetically related North-West River anorthosite (NWRA), as well as the Harp Lake Intrusive Suite, Mistastin Massif, and the Atikonak River Complex (Ashwal, 1993; Kerr et al., 2013).

During the exploration boom following the Voiseys Bay discovery, in 1994, in Labrador (Ryan et al., 1995), numerous occurrences of Fe-Ti-V oxide mineralization were discovered (or rediscovered) in various geological settings throughout Labrador (e.g., Hinchey et al., 1999; MacDonald, 1999; Kerr et al., 2001; Dyke et al., 2004; Kerr 
et al., 2013). Only a few of these occurrences, however, underwent follow-up evaluation and detailed descriptions, as exploration efforts largely targeted magmatic Ni-Cu-Co sulphide deposits (Kerr et al., 2013, and references therein). The oxide zones were considered to be of limited interest, unless they were associated with sulphides and $\mathrm{Ni}, \mathrm{Cu}, \mathrm{Co}$ and PGE enrichment.

There is a general consensus that Fe-Ti oxide mineralization in Proterozoic anorthosite massifs suites is broadly magmatic in origin (e.g., Ashwal, 1982; Duchesne, 1999; Dymek and Owens, 2001; Charlier et al., 2015 and references therein). However, the nature of the processes responsible for oxide formation and/or concentration are subject to ongoing debate. Petrogenetic processes proposed for the formation of oxide-rich mineralization include liquid immiscibility, fractional crystallization, magma mixing, hydrothermal remobilization, and solid state remobilization. The various models and their assumptions and limitations are summarized by Charlier et al. (2015) and are described in more detail in section 1.5.

\subsection{Previous Work}

The study area for the current project, the North West River anorthosite (NWRA) which forms the uppermost unit of the CCRA, was first mapped at the 250,000 scale by Stevenson (1969) with the Geological Survey of Canada, and was subsequently remapped at 1:100,000 (Ryan et al., 1982) and 1:50,000 scale Wardle and Ash $(1984 ; 1986)$ by the Department of Mines and Energy of the Government of Newfoundland and Labrador. Several other research studies were completed following the second phase of mapping, including structural and metamorphic studies (Gower 
and Krogh, 2002; Krauss and Rivers, 2004) as well as U-Pb zircon geochronology which dated the host anorthosite as 1625-1650 Ma (Philippe et al., 1993; Bussy et al., 1995; and Corrigan et al., 1997).

Despite the presence of several known Fe-Ti oxide mineralized areas as well as a large aeromagnetic anomaly (Fig. 1.3), the NWRA has yet to be widely explored for economic mineralization. There were only sporadic prospecting and exploration activities following the Voisey's Bay discovery (Kerr et al., 2013, and references therein). However, semi-massive to massive Fe-Ti oxide mineralization in the NWRA was identified by prospectors T. Benoit and C. Coady in 2011 in anorthositic outcrops in the area west of Grand Lake (Figs. 1.2, 1.3) and this formed the starting point for the present investigation. This study marks the first descriptive work done on oxide mineralization hosted within the NWRA and includes field descriptions, transmitted and reflected light petrography, whole-rock geochemistry, and in-situ EPMA and LAICPMS analyses of magnetite, ilmenite, and pleonaste (a low-Mg spinel intermediate of the spinel-hercynite solid solution).

\subsection{Study Area: Location and Physiography}

The study area for this project is located between latitudes $53.50^{\circ} \mathrm{N}$ and $53.37^{\circ} \mathrm{N}$ and longitudes $60.67^{\circ} \mathrm{W}$ and $60.52^{\circ} \mathrm{W}$, approximately $30 \mathrm{~km}$ northwest of Happy Valley-Goose Bay, Labrador (Figs. 1.1-1.3). It covers approximately 6 square 
kilometers on the western edge of the CCRA, and is largely underlain by anorthositic

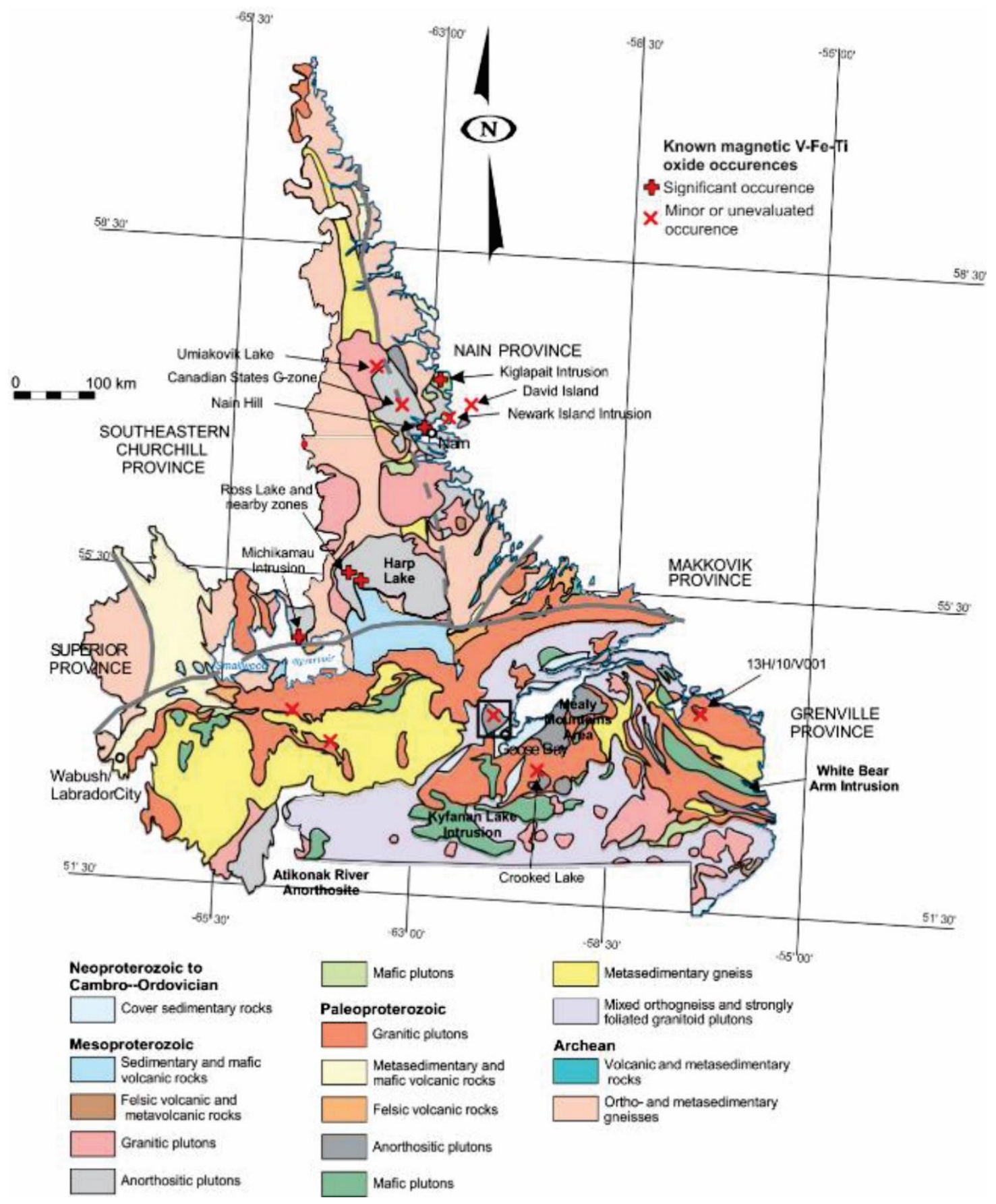

Figure 1.1 Simplified geological map of Labrador showing locations of known magmatic Fe-Ti-V oxide mineralization (shown by red $\mathrm{x}$ and + symbols). The Cape Caribou River allochthon is outlined by a black box (modified from Kerr et al., 2013). 
rocks, grouped as the NWRA by Wardle and Ash, (1984). Field access is via the Grand Lake Road, a well-maintained gravel forestry road that branches from the paved Route 520, which extends from Happy Valley-Goose Bay to North West River. The field area is forested with jack pine, spruce, and fir, with several burnt over zones resulting from forest fires. Although bedrock outcrops are abundant in the area, recovering fresh samples is locally difficult because of surface weathering and the typically smooth, glacially-rounded outcrop surfaces. There is an $80 \mathrm{~m}$ elevation change in the field area, marked by a ridge to the west and low-lying muskeg to the east.

\subsection{Regional and Local Geology}

\subsubsection{Overview of the regional geology of the Central and Eastern Grenville Province in Labrador}

The rocks of the eastern Grenville province were assembled over $\sim 700 \mathrm{Myr}$ along the southeastern ancestral margin of the Laurentian craton, using present-day coordinates; most of these rock units have experienced polyphase, high-grade metamorphism and are gneisses (Li et al., 2008; Rivers, 2015). The oldest exposed rocks within the eastern Grenville province (>1710 Ma; termed pre-Labradorian (Gower, 1992; Gower et al., 1996; Gower and Krogh, 2002; Rivers, 2007) are migmatitic gneisses, the protoliths of which are interpreted to consist of sedimentary rocks that originally formed within a continental-margin basin. Four key subsequent tectono-metamorphic events are recognized within the rocks of the eastern Grenville Province: 1) the Labradorian orogeny ( 1710-1600 Ma); 2) the Pinwarian orogeny 
(1520-1460 Ma); 3) the Elsonian orogeny (1460-1230 Ma); and 4) the Grenvillian orogeny (1250-980 Ma) (Gower and Krogh, 2002; Rivers, 2007).

The oldest components of the Labradorian terrane consist of a volcanic arc dated at 1710 and $1680 \mathrm{Ma}$ (Gower and Krogh, 2002). Arc magmatism ceased at $\sim 1660$ Ma likely due to arc accretion, which led to the continental crust becoming overthickened leading to penetrative ductile deformation coupled with low pressure metamorphism peaking at granulite facies (Gower, 1996; Rivers, 1997; Gower and Krogh, 2002). Subsequent to the arc-accretion events, a pulse of bimodal maficanorthositic-monzogranitic magmatism was emplaced within the eastern Grenville province (Rivers, 1997; Gower and Krogh, 2002). This magmatic pulse, dated at 1650$1625 \mathrm{Ma}$, includes the MMIS and the NWRA which at present lies within the CCRA (Ashwal, 1993; Gower and Krogh, 2002). The MMIS and NWRA and interpreted to have formed as components of a single body and were subsequently separated (Krauss and Rivers, 2004).

The Pinwarian orogeny (1520-1460 Ma) is thought to be associated with arc accretion and active margin shortening in an island arc or continental arc-margin setting (Gower and Krogh, 2002; Augland et al., 2015). The rock record from the Pinwarian orogeny includes dominantly felsic magmatism that intruding into Labradorian crust (Gower and Krogh, 2002; Gower et al., 2008). Deformation and metamorphism associated with the Pinwarian orogeny has been observed throughout the eastern Grenville Province (Augland et al., 2015). 
Following the Pinwarian orogeny is the Elsonian orogeny (1460-1230 Ma). The Elsonian orogeny is thought to have occurred through the complex interactions between the subducting slab and the overriding Laurentian continental margin (Gower and Krogh, 2002). According to Gower and Krogh, rocks of the Elsonian orogeny include the Michael-Shabogamo gabbroic dike swarm as well as numerous anorthosite-mangerite-charnockite-granite (AMCG) suites including the NPS (Rivers, 1997; Gower and Krogh, 2002).

The Grenvillian orogeny (1090 and $980 \mathrm{Ma}$ ), occurred due to the terminal continental collision between Laurentia and Amazonia which led to extensive crustal thickening via imbrication of thrust slices, as well as intense deformation and metamorphism (e.g., Rivers, 1997; Li et al., 2008; Rivers et al., 2012; Rivers, 2015) and references therein). Post-Grenvillian rifting, possibly associated with the opening of the early Paleozoic Iapetus Ocean, created a series of grabens in the Lake Melville area, which now separate the CCRA from the MMIS (Fig. 1.1). The CCRA is believed to represent a portion of the MMIS that was separated during the formation of the Lake Melville rift as a similar assemblage of lithologies occurs in both the CCRA and the MMIS (Wardle et al., 1990; Philippe et al., 1993; Krauss and Rivers, 2004).

\subsubsection{Local geology}

The CCRA (Fig. 1.2) is a $\sim 20-25 \mathrm{~km}$ wide lobate thrust sheet with an aerial extent of $\sim 500 \mathrm{~km}^{2}$ that is dominantly composed of Paleoproterozoic AMCG rocks, and also includes minor layered gabbro monzonite, dioritic to granodioritic orthogneiss, amphibolite, mafic granulite, and minor metasedimentary gneiss (Wardle and Ash, 1984; 1986; Ryan et al., 1982). Penetrative deformation in the CCRA is limited to the 
basal high-strain shear zone whereas the uppermost units including the NWRA have

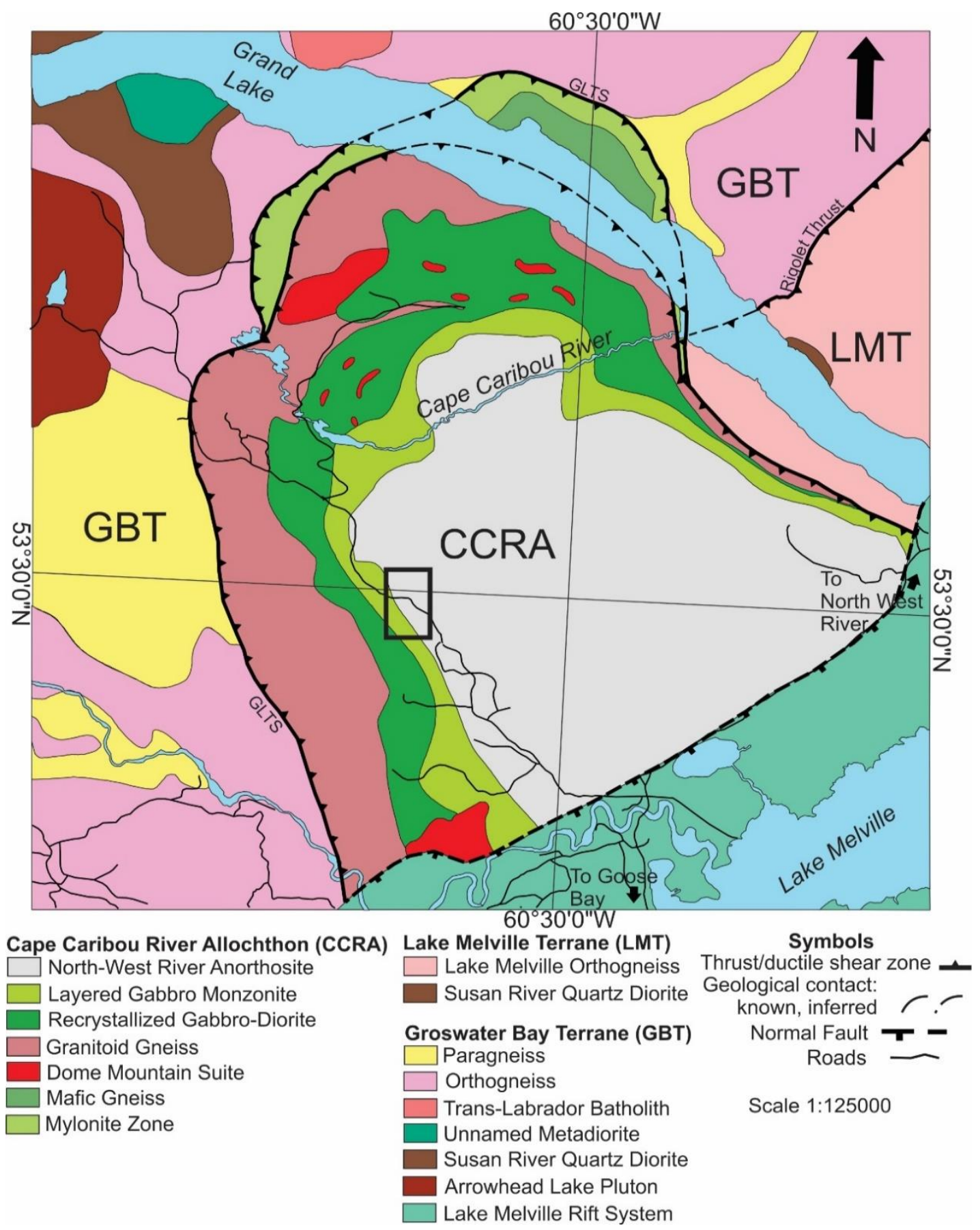

Figure 1.2 Geological map of the Cape Caribou River allochthon showing the North West River anorthosite in the center and surrounding rock units (modified from Krauss and Rivers, 2004). The field area for this study is outlined by the black box. 
undergone only static recrystallization (Krauss and Rivers, 2002). The NWRA is an anorthositic body located at the structural top of the CCRA Allochthon (Fig. 1.2) (Bussy et al., 1995; Krauss and Rivers, 2004).

The NWRA is a heterogeneous unit composed primarily of anorthosite to gabbronoritic rocks composed of several coalesced anorthosite plutons, each with variable mafic components and textures (Krauss, 2002). In general, plagioclase crystals in all coalesced plutons ranges from a few $\mathrm{mm}$ to $20 \mathrm{~cm}$ in size and are unaltered to weakly sericitized. Despite the lack of penetrative deformation associated with thrusting, the NWRA shows evidence of static recrystallization including the presence of garnet in gabbronorites as well as recrystallization textures in plagioclase in the host anorthosite (Krauss, 2002). Fe-Ti oxide mineralization in the NWRA is dominated by magnetite (Valvasori et al., 2015).

\subsection{Fe-Ti oxide mineralization in Proterozoic anorthosite massifs}

Zones of voluminous Fe-Ti oxide mineralization commonly occur in Proterozoic massif anorthosite massifs (Ashwal, 1993; Charlier et al., 2014). The mineralization is generally composed of a combination of ilmenite $\left(\mathrm{FeTiO}_{3}\right)$, magnetite $\left(\mathrm{Fe}_{3} \mathrm{O}_{4}\right)$, and/or spinel, typically pleonaste $\left((\mathrm{Fe}, \mathrm{Mg}) \mathrm{Al}_{2} \mathrm{O}_{4}\right)$ in composition. Although there is a consensus that the Fe-Ti oxide minerals have a magmatic origin, the specific processes by which the oxides formed and subsequently concentrated is not well constrained. 


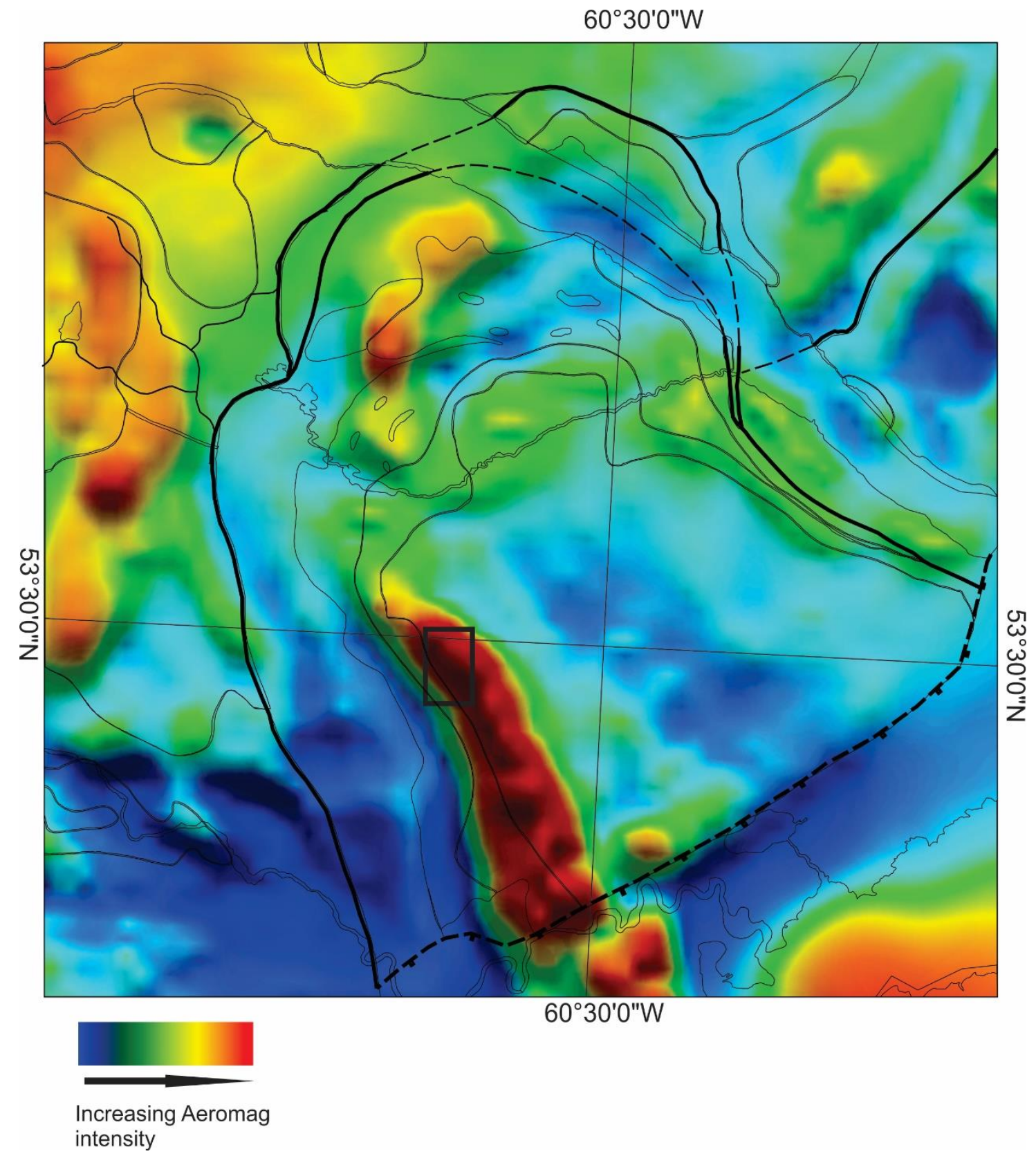

Figure 1.3 Regional aeromagnetic map (NL Geoscience Atlas) overlain by the unit boundaries of the rock units contained within Cape Caribou River allochthon from the NL Geoscience Atlas. Note the relationship between the large aeromagnetic high and the contact between the North West River anorthosite and basal layered monzonite. The field area for this study is outlined by a black solid box. 
Current models for the formation of concentrations of Fe-Ti oxide minerals include: 1) liquid immiscibility; 2) fractional crystallization; 3) magma mixing; 4) hydrothermal remobilization; and 5) subsolidus remobilization (e.g., Charlier et al., 2015 and references therein). These are discussed in the next section and one of the main objectives of this present study is an attempt to test these models for ore formation by assessing the features (i.e., distribution, morphology, size, and chemistry) of oxide mineral accumulations in the study area.

\subsubsection{Liquid Immiscibility}

Liquid immiscibility is a process which has been proposed by some researchers to result in the formation of large zones of nearly pure Fe-Ti oxide mineralization in sharp contact with the host anorthosite. The textural features predicted by this process includes veins of massive oxide mineralization crosscutting the host anorthosite, as well as oxide minerals interstitial to plagioclase in the host anorthosite (Philpotts, 1967; He et al., 2016). In this model, the residual magma after the anorthosite crystallization is inferred to be a ferrodiorite which is a Fe, $\mathrm{Ti}$, and $\mathrm{P}$ rich mafic silicate magma. Eutectic crystallization of ferrodioritic magma is proposed to lead to the formation of oxide-apatite gabbronoritic rocks (OAGN), whereas fractional crystallization of ferrodioritic magma is thought to lead to the generation of an immiscible Fe-Ti-P oxide magma under high $\mathrm{fO}_{2}$ (Chen et al., 2013).

Critics of this model point to a lack of experimental evidence under naturally occurring conditions to support the theory of coexisting oxide and silicate magmas within a single magma chamber (Lindsley, 2003; Lindsley and Epler, 2017). 
Furthermore, no direct evidence of coexisting immiscible silicate and Fe-Ti-P oxide melts have been reported in plutonic settings (Charlier and Grove, 2012).

\subsubsection{Fractional Crystallization}

Jotunites, which are also referred to as ferrodiorites, are a clan of Fe-Ti-Penriched intermediate rocks commonly associated with Proterozoic massif anorthosite suites (Vander Auwera et al., 1998). All known jotunites share similar chemical and textural features, but their origin and relationship, if any, to anorthosites massifs has been debated (Dymek and Owens, 2001). Some researchers suggest that jotunites are genetically linked to anorthosite massifs as either a residual melt from anorthosite crystallization, or the parent magma to the anorthosite massif (e.g., Duchesne et al., 1974; Ashwal, 1982; Owens et al., 1993; Emslie et al., 1994). However, others suggest that jotunites are unrelated to anorthosites (e.g., Philpotts, 1981; Emslie, 1985; Duchesne, 1990). Unlike basaltic magmas, magmas with jotunitic compositions are believed to crystallize Fe-Ti oxide minerals as early liquidus phase minerals (Charlier et al., 2006; 2009; and 2010).

According to the fractional crystallization model for the formation of Fe-Ti oxide minerals, jotunitic magma is carried from depth along with the anorthosite crystal mush as both have similar densities (Vander Auwera and Longhi, 1994). Within the anorthosite crystal mush the jotunitic liquid pools in zones of low pressure, where it begins to fractionally crystallize. Cotectic crystallization values calculated by Charlier et al. $(2007 ; 2008)$ suggest that Fe-Ti oxide minerals should make up $20 \%$ of the crystallized jotunite, along with a combination of olivine, orthopyroxene, clinopyroxene, and apatite. As such, this model cannot adequately explain high-grade 
zones of Fe-Ti oxide minerals, unless the latter are accumulated in some way.

Proponents of fractional crystallization suggest cumulate sorting to "upgrade" the content of Fe-Ti oxides either by lateral remobilization of oxides, or flotation of less dense plagioclase (Charlier et al., 2008).

\subsubsection{Magma Mixing}

Magma mixing has been proposed to explain the formation of stratiform layers of pure oxide minerals including those in layered chromite deposits (e.g., Bushveld complex: Irvine, 1977; Cawthorn, 2003), and Fe-Ti oxide deposits (e.g., Tellnes:

Robinson et al., 2003). The magma mixing model suggests that a fractionating magma is intruded by a more primitive magma, creating a hybrid magma which crystallizes a single oxide phase, which then sinks to the base of the magma chamber, and, thorough adcumulate growth creates a monomineralic layer of oxides (Irvine, 1975; Irvine et al., 1983; Charlier et al., 2010).

Evidence for magma mixing in the field includes parallel layers of massive, monomineralic oxides in sharp, in direct linear contact with the host rock at both the base and top of each layer or, rarely, a sharp contact at the base and a gradational contact at the top of the layer. Geochemical evidence of magma chamber replenishment includes sharp, sawtooth variations in $\mathrm{Mg}, \mathrm{Mn}, \mathrm{V}$, and $\mathrm{Cr}$ contents of both whole rock geochemical analyses and in-situ magnetite, ilmenite and chromite chemical analyses (Charlier et al., 2010).

\subsubsection{Hydrothermal remobilization}

Hydrothermal remobilization is a process that was proposed by Li et al. (2014) in which primary plagioclase, which contains abundant Fe-Ti oxide as 
microinclusions, is metasomatically altered by a late stage F-rich magmatic hydrothermal fluid. The alteration releases $\mathrm{Fe}$ and other metallic elements into the fluid, depositing zones of pure Fe-Ti oxide in pre-existing fractures in anorthosite ( $\mathrm{Li}$ et al., 2014).

Evidence for hydrothermal remobilization as an ore-forming process include presence of altered anorthosite, often with individual plagioclase grains within anorthosite having unaltered cores as well as low homogenization temperatures in fluid inclusions within apatite (Li et al., 2014).

\subsubsection{Solid state remobilization}

Solid-state remobilization suggests that the presence of seams and veins of pure Fe-Ti oxides as well as the interstitial nature of Fe-Ti oxide minerals are the result of a subsolidus process rather than a magmatic process (Duchesne, 1996; 1999). During subsolidus conditions, evidence for oxide-oxide and oxide-silicate reequilibration is commonly observed; microtextural evidence of oxide grain boundary migration is also common (Krause and Pedall, 1980). Fe-Ti oxide minerals behave more ductily than adjacent plagioclase grains and as such, deformation has been shown to cause $\mathrm{Fe}-\mathrm{Ti}$ oxide minerals to migrate towards pressure shadows, and zones of low stress (Paludan et al., 1994). On the scale of an anorthosite massif, particularly those deformed at high temperature, it is plausible that solid state remobilization is responsible for large bodies of pure Fe-Ti oxide in sharp contact with the host anorthosite, as well as interstitial to anorthosite (Duchesne, 1996; 1999).

Evidence of solid state remobilization includes the interstitial nature of $\mathrm{Fe}$-Ti oxide minerals to plagioclase in anorthosite and Fe-Ti oxide minerals in the pressure 
shadows of ferromagnesian silicate minerals, as well as larger concentrations of monomineralic Fe-Ti oxide minerals within the host anorthosite.

\subsection{Rationale and Objectives}

The CCRA was previously mapped at the 1:125000 scale in the early 1980s by the Department of Mines and Energy of the Government of Newfoundland and Labrador, and potential for Fe-Ti oxide mineralization was noted (Ryan et al., 1982; Wardle and Ash, 1984; 1986). Further research was completed regarding the tectonic and metamorphic history of the CCRA (Bussy et al., 1995; Butt, 2000; Krauss and Rivers, 2004; Gower and Krogh, 2002). No detailed work, however, has been completed on Fe-Ti oxide mineralization hosted within the CCRA.

The results from this study are used to: 1) test various models of Fe-Ti oxide genesis; 2) test various models of Fe-Ti oxide genesis in a Proterozoic anorthosite suite; and 3) propose a model for the genesis of Fe-Ti oxide mineralization specific to the NWRA will be proposed. The data from this study will also be used to investigate the utility and validity of magnetite trace element discrimination diagrams that have been previously used in an attempt to classify the geologic environment in which the magnetite crystallized. This marks the first application of this technique to a Proterozoic massif anorthosite suite. Finally, oxide mineralization from the NWRA is compared to other known Fe-Ti- $\mathrm{V}$ oxide deposits to determine the economic potential of the study area within the NWRA.

As such, the specific research objectives of this present study are as follows: 
1) Characterize the Fe-Ti oxide mineralization hosted in the NWRA in terms of field occurrences, geographic distribution, mineralogy, major, minor and trace element oxide chemistry, microtextures, deduced physicochemical conditions of formation;

2) To compare Fe-Ti-V oxide mineralization from the NWRA to other known Fe-Ti deposits worldwide;

3) To determine if discrimination diagrams based on oxide mineral chemistry are of use in classifying and understanding magmatic Fe-Ti oxide mineralization in the NWRA;

4) Based on the aforementioned information, and existing formation models for oxide mineralization, to determine the formation processes of the Fe-Ti-V oxide mineralization in the NWRA.

\section{REFERENCES}

Ashwal LD (1982) Mineralogy of mafic and Fe-Ti oxide-rich differentiates of the Marcy anorthosite massif, Adirondacks, New York. American Mineralogist 67: $14-27$

Ashwal LD (1993) Anorthosites. Spinger-Verlag, Berlin

Ashwal LD (2010) The temporality of anorthosites. Canadian Mineralogist 48: 711728

Augland LE, Moukhsil A, Solgadi F, Indares A (2015) Pinwarian to Grenvillian magmatic evolution in the central Grenville Province: new constraints from IDTIMS U-Pb ages and coupled Lu-Hf S-MC-ICP-MS data. Canadian Journal of Earth Sciences 52: 701-721. 
Bussy F, Krogh T., Wardle RJ (1995) Late Labradorian metamorphism and anorthosite- granitoid intrusion, Cape Caribou River Allochthon, Grenville Province, Labrador: evidence from U-Pb geochronology. Canadian Journal of Earth Sciences 32: 1411-1425

Butt JM (2000) Mineral chemistry and mineral reactions in a meta-anorthosite complex, Cape Caribou River Allochthon, Grenville Province, Labrador. Unpublished B.Sc. Thesis, Memorial University of Newfoundland, St. John's NL, 111 pages

Cawthorn G (2003) Genesis of magmatic oxide deposits - a view from the Bushveld Complex. Norges geologiske undersøkelse Special Publication 9: 11-21

Charlier B, Namur O, Bolle O, Latypov R, Duchesne JC (2015) Fe-Ti-V-P ore deposits associated with Proterozoic massif-type anorthosites and related rocks. Earth-Science Reviews 141: 56-81

Charlier B, Namur O, Malpas S, de Marneffe C, Duschene JC, Vander Auwera J, Bolle O (2010) Origin of the giant Allard Lake ilmenite ore deposit (Canada) by fractional crystallization, multiple magma pulses and mixing. Lithos 117: 119134

Charlier B, Namur O, Duchesne JC, Wisniewska J, Parecki A, Vander Auwera J (2009) Cumulate origin and polybaric crystallization of Fe-Ti oxide ores in the Suwalki anorthosite, NE Poland. Economic Geology 104: 205-221

Charlier B, Sakoma E, Sauvé M, Stanaway K, Vander Auwera J, Duchesne JC (2008) The Grader layered intrusion (Havre-Saint-Pierre Anorthosite, Quebec) and genesis of nelsonite and other Fe-Ti-P ores. Lithos 101: 359-378 
Charlier B, Duchesne JC, Vander Auwera J (2006) Magma chamber processes in the Tellnes ilmenite deposit (Rogaland Anorthosite Province, SW Norway) and the formation of Fe-Ti ores in massif type anorthosites. Chemical Geology 234: 264290

Charlier B, Skår Ø, Korneliussen A, Duchesne JC, Vander Auwera J (2007) Ilmenite composition in the Tellnes Fe-Ti deposit, SW Norway: fractional crystallization, postcumulus evolution and ilmenite-zircon relation. Contributions to Mineralogy and Petrology 154: 119-134

Chen WT, Zhou MF, Zhao TP (2013) Differentiation of nelsonitic magmas in the formation of the $\sim 1.74 \mathrm{Ga}$ Damiao Fe-Ti-P ore deposit, North China. Contribution Mineralogy Petrology 165: 1342-1362

Corrigan D, Rivers T, Dunning GR (1997) Preliminary report on the evolution of the Allochthon Boundary Thrust in eastern Labrador, Mechin River to Goose Bay. East Coast Seismic Offshore-Onshore Transect Meeting 61: 45-56

Dill HG (2010) The “chessboard' classification scheme of mineral deposits: Mineralogy and geology from aluminum to zirconium. Earth-Science Reviews 100: $1-420$

Duchesne JC, Roelandts I, Demaiffe D, Hertogen J, Gijbels R, De Winter J (1974) Rare-earth data on monzonoritic rocks related to anorthosites and their bearing on the nature of the parental magma of the anorthositic series. Earth and Planetary Science Letters 24: 325-335 
Duchesne JC (1990) Origin and evolution of monzonorites related to anorthosites. Schweizerische Mineralogische und Petrographische Mitteilungen 70: 189-198

Duchesne JC (1996) Liquid ilmenite or liquidus ilmenite: a comment on the nature of ilmenite vein deposits. In: Demaiffe D. (ed) Petrology and geochemistry of magmatic suites of rocks in the continental and oceanic crusts. A volume dedicated to Professor Jean Michot. Tervuren, Brussels pp 73-82

Duchesne JC (1999) Fe-Ti deposits in Rogaland anorthosites (South Norway): geochemical characteristics and problems of interpretation. Mineralium Deposita 34: $182-198$

Dyke B, Kerr A, Sylvester PJ (2004) Magmatic sulfide mineralization at the Fraser Lake prospect (NTS Map Area 13L/5), Michikamau Intrusion, Labrador. Current Research, Newfoundland and Labrador Geological Survey, Report 04: 7-22

Dymek RF, Owens BE (2001) Petrogenesis of apatite rich rocks (nelsonites and oxideapatite gabbronorites) associated with massif anorthosites. Economic Geology 96: 797-815

Emslie RF (1985) Proterozoic anorthosite massifs. In: Tobi AC, Jacques LR (ed) The deep Proterozoic crust in the North Atlantic provinces. Springer, Dordrecht, pp. 39-60

Emslie RF, Hamilton MA, Thériault RJ (1994) Petrogenesis of a Mid-Proterozoic Anorthosite-Mangerite-Charnockite-Granite (AMCG) Complex: isotopic and chemical evidence from the Nain Plutonic Suite. Journal of Geology 102: 539-558 
Fabjan C, Garche J, Harrer B, Kolbeck C, Philippi F, Tomazic G, Wagner F (2001)

The vanadium redox-battery: an efficient storage unit for photovoltaic systems.

Electrochimica Acta 47: 825-831

Force E (1991) Geology of titanium-mineral deposits. Geological Society of America, Special Paper 259, $112 \mathrm{p}$

Gower CF (1996) The evolution of the Grenville Province in Eastern Labrador,

Canada. Geological Society of London Special Publications 112: 197-218

Gower CF, Schärer U, Heaman LM (1992) The Labradorian Orogeny in the Grenville

Province, Eastern Labrador. Canadian Journal of Earth Sciences 29: 1944-1957

Gower CF, Krogh TE (2002) A U-Pb geochronological review of the Proterozoic

history of the eastern Grenville Province. Canadian Journal of Earth Sciences 39:

$795-829$

He HL, Yu SY, Song XY, Du ZS, Dai ZH, Xie W (2016) Origin of nelsonite and FeTi oxide ore of the Damiao anorthosite complex, NE China: Evidence from trace element geochemistry of apatite, plagioclase, magnetite and ilmenite. Ore Geology Reviews 79: 367-381

Hinchey JG (1999) Magmatic sulphide-oxide mineralization in the Nain area, northern Labrador: A petrological and geochemical study. Unpublished B.Sc. Thesis, Memorial University, St. John's, NL, 131 pages

Irvine TN (1975) Crystallization sequences in the Muskox intrusion and other layered intrusions - II. Origin of chromitite layers and similar deposits of other magmatic ores. Geochimica et Cosmochimica Acta 39: 991-1020 
Irvine TN (1977) Origin of chromitite layers in the Muskox intrusion and other stratiform intrusions: A new interpretation. Geology 5: 273-277

Irvine TN, Keith DW, Todd SG (1983) The JM platinum-palladium reef of the Stillwater Complex, Montana; II, Origin by double-diffusive convective magma mixing and implications for the Bushveld Complex. Economic Geology 78: $1287-1334$

Kerr A, Macdonald HE, Naldrett AJ (2001) Geochemistry of the Pants Lake Intrusion, Labrador: implications for future mineral exploration. Current Research, Newfoundland and Labrador Geological Survey 2001: 191-228

Kerr A, Walsh JA, Sparkes GW, Hinchey JG (2013) Vanadium potential in Newfoundland and Labrador: a review and assessment. Current Research, Newfoundland and Labrador Geological Survey 13: 137-165

Kilfoil G (2009) Geophysical data from recent airborne surveys, Newfoundland and Labrador. Newfoundland and Labrador Department of Natural Resources, Geological Survey, Report 09-1: 305-314

Krause H, Pedall G (1980) Fe-Ti mineralizations in the Åna-Sira anorthosite, Southern Norway. Metallogeny of the Baltic Shield. Finland Geological Survey Bulletin 307: 56-83

Krauss JB (2002) High-pressure (HP), granulite-facies thrusting in a thick-skinned thrust system in the eastern Grenville Province, central Labrador. Unpublished M.Sc. Thesis, Memorial University of Newfoundland, St. John's NL, 377 pages 
Krauss JB, Rivers T (2004) High pressure granulites in the Grenvillian Grand Lake Thrust System, Labrador: pressure-temperature conditions and tectonic evolution in Proterozoic Tectonic Evolution of the Grenville Orogen in North America: Geological Society of America Memoir 197: 105-134

Li ZX, Bogdanova SV, Collins AS, Davidson A, De Waele B, Ernst RE, Fitzsimons ICW, Fuck RA, Gladkochub DP, Jacobs J, Karlstrom KE, Lu S, Natapov LM, Pease V, Pisarevsky SA, Thrane K, Vernikovsky V (2008) Assembly, configuration, and break-up history of Rodinia: A synthesis. Precambrian Research 160: 179-210

Li H, Li L, Zhang Z, Santosh M, Liu M, Cui Y, Yang X, Chen J, Yao T (2014) Alteration of the Damiao anorthosite complex in the northern North China Craton: Implications for high-grade iron mineralization. Ore Geology Reviews 57: 574-588

Lindsley DH (2003) Do Fe-Ti oxide magmas exist? Geology: yes; Experiments: no! (Extended abstract) Norges geologiske undersøkelse Special Publication 9: 3436

Lindsley and Epler (2017) Do Fe-Ti-oxide magmas exist? Probably not! American Mineralogist 102(11): 2157-2169

MacDonald HE (1999) The geology, petrography and geochemistry of gabbroic rocks of the Pants Lake Intrusive Suite on the Donner/Teck South Voisey's Bay Property, north-central Labrador, Canada Unpublished M.Sc. Thesis, University of Toronto, Toronto, ON, 176 pages 
Morisset CE, Scoates JS, Weis D (2010) Rutile-bearing ilmenite deposits associated with the Proterozoic Saint-Urbain and Lac Allard anorthosite massif, Grenville Province, Quebec. The Canadian Mineralogist 44: 821-849

Namur O, Charlier B, Holness MB (2012) Dual origin of Fe-Ti-P gabbros by immiscibility and fractional crystallization of evolved tholeiitic basalts in the Sept Iles layered intrusion. Lithos 154: 100-114

Owens BE, Rockow MW, Dymek RF (1993) Jotunites from the Grenville Province, Quebec: petrological characteristics and implications for massif anorthosite petrogenesis. Lithos 30: 57-80

Paludan JO, Hansen UB, Olesen NØ (1994) Structural evolution of the Precambrian Bjerkreim-Sokndal intrusion, south Norway. Norsk Geologisk Tidsskrift 74: $185-198$

Philippe S, Wardle RJ, Scharer U (1993) Labradorian and Grenvillian crustal evolution of the Goose Bay Region, Labrador: new U-Pb geochronological constraints. Canadian Journal of Earth Sciences 30: 2315-2327

Philpotts AR (1967) Origin of certain iron-titanium oxide and apatite rocks. Economic Geology 62: 303-315

Philpotts AR (1981) A model for the generation of massif-type anorthosites. Canadian Mineralogist 19: 233-253

Rivers T (1997) Lithotectonic elements of the Grenville Province: review and tectonic implications. Precambrian research 86: 117-154 
Rivers T, Culshaw NG, Hynes A, Indares A, Jamieson R, Martignole J (2012) The Grenville Orogen - A post-Lithoprobe perspective. In Percival JA, Cook FA, and Clowes Rm (ed) Tectonic Styles in Canada: the Lithoprobe perspective. Geological Association of Canada Special Paper, St. John’s, pp 97-236

Robinson P, Kullerud K, Tegner C, Robins B, McEnroe SA (2003) Could the Tellnes ilmenite deposit have been produced by in-situ magma mixing? Ilmenite deposits and their geological environments, Norwegian Geological Survey Bulletin, Special Publication 9: 74-76

Ryan B, Neale T, McGuire J (1982) Descriptive notes to accompany geological maps of the Grand Lake area, Labrador 13F/10, 11, 14, 15: St.-John's, Newfoundland, Newfoundland and Labrador Department of Mines and Energy, Mineral Development Division Maps 82-64 to 82-67

Ryan B, Wardle RJ, Gower CF, Nunn GAG (1995) Nickel-copper-sulfide mineralization in Labrador: the Voisey’s Bay discovery and its exploration implications. Current Research, Newfoundland and Labrador Geological Survey 95: $177-204$

Stevenson IM (1967) Goose Bay map-area, Labrador. Geological Survey of Canada, Paper 67-33: 17-32

Valvasori A, Fonkwe MLD, Piercey SJ, Conliffe J (2015) Magmatic Fe-Ti-V oxide mineralization hosted in Paleoproterozoic anorthosite in the Cape Caribou River Allochthon, Grenville Province, southeast Labrador: preliminary results. Current Research, Newfoundland and Labrador Geological 15: 125-138 
Vander Auwera J, Longhi J (1994) Experimental study of a jotunite (hypersthene monzodiorite): constraints on the parent magma composition and crystallization conditions $\left(\mathrm{P}, \mathrm{T}, f \mathrm{O}_{2}\right)$ of the Bjerkreim-Sokndal layered intrusion (Norway). Contributions to Mineralogy and Petrology 118: 60-78

Vander Auwera J, Longhi J, Duchesne JC (1998) A liquid line of descent of the jotunite (hypersthene monzodiorite) suite. Journal of Petrology 39: 439-468.

Wardle RJ, Ash C (1984) Geology of the Northwest River area, Current Research, Newfoundland and Labrador Geological 84: 53-67

Wardle RJ, Ash C (1986) Geology of the Goose Bay-Goose River area. Current Research, Newfoundland and Labrador Geological Survey 86: 113-123

Wardle RJ, Ryan B, Philippe S, Scharer U (1990) Proterozoic crustal development, Goose Bay Region, Grenville Province, Labrador, Canada in Gower, C.F., Rivers, T., and Ryan, B., eds., Mid-Proterozoic Laurentia-Baltica: Geological Association of Canada, Special Paper 38: 297-214 


\section{Chapter 2: Sampling and Analytical Methods}

\subsection{Sampling}

One hundred and sixty four mineralized and unmineralized samples representative of anorthosite and gabbronorite observed in the field area as well as all associated Fe-Ti oxide mineralization were collected during the summers of 2014, 2015, and 2016. Samples were subdivided into three broad categories: massive to semi-massive oxide mineralization (50-100\% oxide minerals); disseminated oxide mineralization (10-50 \% oxide minerals); and barren anorthosite host rocks (<10 vol\% oxide minerals). The samples were cleaned of any weathering rind by sawing and then cut into blocks for whole-rock major and trace element geochemical analyses and chips for polished thin sections.

Ninety-six samples were sent to Actlabs for whole rock major, minor and trace element geochemical analysis, and 113 samples were sent to Vancouver Petrographics to be made into polished thin sections. Both polished thin sections and the samples for geochemical analysis were taken from the same sample, with multiple thin sections made from selected coarse-grained massive to semi-massive oxide mineralized samples in order to obtain a more representative petrographic sample set. As a result the number of thins sections is greater than the number of samples analyzed for major and trace elements.

Polished thin sections were examined using both reflected and transmitted cross polarized light microscopy. Thin sections were organized based on Fe-Ti oxide mineralization styles observed within the NWRA, with petrographic description focusing on variations in mineralogy and exsolution textures within samples, between 
samples from the same mineralization style, and between samples from different mineralization styles. Representative grains and microtextures of magnetite, ilmenite, and pleonaste were analyzed using both electron probe microanalyzer (EPMA) and laser ablation inductively coupled plasma mass spectrometry (LA-ICPMS) where the grains were sufficiently coarse (i.e., when minerals analyzed were larger than 25 micrometers in their shortest axis).

\subsection{Whole-rock geochemistry}

The samples sent to Actlabs were powdered and prepared for analysis using a lithium metaborate/tetraborate fusion followed by digestion in weak nitric acid. Samples were analyzed using a combination of inductively coupled plasma mass spectrometry (ICP-MS) and inductively coupled plasma optical emission spectroscopy (ICP-OES), with 59 elements quantified including major, minor and trace elements using the Code 4LITHO + 4B1(11+) Major Elements Fusion ICP(WRA)/Trace Elements Fusion ICP/MS(WRA4B2)/Total Digestion ICP(TOTAL) analytical package. Duplicate samples were inserted every 10 analyses to ensure quality of analyses.

\subsection{EPMA}

\subsubsection{EPMA WDS analyses}

Electron microprobe microanalysis (EPMA) using wavelength dispersive spectroscopy (WDS) was performed on nine representative thin sections selected based on field and petrographic observations (i.e. mineralization styles). The analyses were carried out in order to determine if there is any compositional differences between 
similar textures of magnetite, ilmenite and pleonaste between different mineralization styles. The analyses were also intended to provide more chemical information on the various exsolution features in the oxide minerals. The analytical work was carried out at the Queens Facility for Isotope Research (QFIR) in the Department of Geological Sciences and Geological Engineering at Queens University, Kingston, Ontario. A JEOL JXA-8230 electron microprobe equipped with five WDS tunable spectrometers was used to determine the major and minor element compositions magnetite, ilmenite, and spinel in a variety of microtextural settings from the 9 polished thin sections. Specifically, the concentrations of $\mathrm{Si}, \mathrm{Ti}, \mathrm{Al}, \mathrm{Cr}, \mathrm{V}, \mathrm{Fe}, \mathrm{Mn}, \mathrm{Mg}, \mathrm{Ni}, \mathrm{Ca}, \mathrm{Cu}$ and $\mathrm{K}$ were quantified. Analyses with totals outside $100 \pm 1.5 \mathrm{wt}$. \%, as well as analyses below the calculated detection limits were discarded. For details on the diffracting crystal used, X-ray lines used, counting times, standard used and range of detection limits for each element analyzed, see Table 2.2.

\subsubsection{EPMA WDS X-ray maps}

EPMA WDS X-ray maps were made for eight representative textural features on six of the thin sections. Specifically, the major elements Fe and Ti were measured in magnetite and ilmenite, and $\mathrm{Mg}, \mathrm{Fe}$ and $\mathrm{Al}$ were measured in spinel, and the trace element $\mathrm{V}$ was also measured as exploratory analyses showed that its concentration varied significantly. An accelerating voltage of $15 \mathrm{kV}$, a sample current of $250 \mathrm{nA}$, and a dwell time of $200 \mathrm{~ms}$ per step were used for X-ray mapping. Pixel size ranged from $0.5-2 \mu \mathrm{m}$ depending on the grain size of features within the section. 


\subsubsection{Calculation of $\mathrm{Fe}^{2+}$ and $\mathrm{Fe}^{3+}$ from EPMA analyses}

$\mathrm{Fe}^{2+}$ and $\mathrm{Fe}^{3+}$ values in oxide minerals in this study were approximated using a method involving charge balance (B. Joy, personal communication). In order to make this approximation, all measured oxides values are first converted to their elemental values which are then divided by their respective molar masses to determine the amount of each cation present assuming all $\mathrm{Fe}$ is $\mathrm{Fe}^{2+}$. The cations of each element were then normalized to a fixed number equivalent to that in the ideal formula unit of the mineral in question; in spinel group minerals such as magnetite and pleonaste, cations are normalized to 3, whereas in ilmenite cations were normalized to 2. All normalized $\mathrm{Fe}$ is assumed to be divalent. The amount of $\mathrm{Fe}^{3+}$ present was calculated by subtracting the divalent Fe content from the charge value of the anions in the formula unit ( 8 in spinel minerals, 6 in ilmenite.) The $\mathrm{Fe}^{2+}$ content is then adjusted by subtracting the calculated value $\mathrm{Fe}^{3+}$ cations from it. Finally, $\mathrm{Fe}^{2+}$ and $\mathrm{Fe}^{3+}$ are converted into their respective oxides and divided by the normalization factor originally used to achieve the correct cation sum.

However, using charge balance to approximate $\mathrm{Fe}^{2+}$ and $\mathrm{Fe}^{3+}$ contents relies on the assumption that the mineral in question does not contain vacancies within its crystal structure and is charge balanced. As such, calculated values for $\mathrm{Fe}^{2+}$ and $\mathrm{Fe}^{3+}$ contents may be inaccurate when compared to analyses by Mössbauer spectroscopy that can precisely and accurately measure the $\mathrm{Fe}^{2+}$ and $\mathrm{Fe}^{3+}$ contents of minerals which contain both Fe oxidation states. Compared to Mössbauer spectroscopy charge balance calculations as described above can have errors of $\sim 10-15 \%$ relative (M.D. Dyar and J.M. Hanchar, personal communication). 
Table 2.1: Summaries of instrumentation and analytical protocols for EPMA and LA-ICPMS analyses of magnetite, ilmenite and pleonaste.

\begin{tabular}{ll}
\hline EPMA & \\
\hline Model & JEOL JXA-8230 Superprobe \\
Voltage & $15 \mathrm{kV}$ \\
Current & $50 \mathrm{nA}$ \\
Spot size & Focused beam \\
Other relevant information & See Table 2.2 \\
LA-ICPMS & \\
\hline Laser ablation system & Laurin technic S155 RESOlution $(193 \mathrm{~nm})$ ArF laser \\
ICP-MS & Agilent 7700x quadrupole ICPMS \\
Laser frequency & $10 \mathrm{hz}$ \\
Fluence & $5 \mathrm{~mJ} / \mathrm{cm}{ }^{2}$ \\
Stage speed & $5-10 \mu \mathrm{m} / \mathrm{s}$ \\
Beam size & $33-75 \mu \mathrm{m}$ \\
Dwell time & $10 \mathrm{~ms} / \mathrm{peak}$ \\
Analysis & Line \\
& $100-300 \mu \mathrm{m}$ \\
& $30 \mathrm{~s}$ gas blank \\
Internal standard & $\sim 60 \mathrm{~s} \mathrm{signal}$ \\
Reference material for calibration & Al, Ti, Fe (From EPMA) \\
Secondary standards & GSD-1g \\
In-House monitor & GSE-1g, G probe 6 \\
Data reduction & BC-28 \\
\hline
\end{tabular}


Table 2.2: Details of EPMA analytical settings and standards used for elements that were analyzed.

\begin{tabular}{|c|c|c|c|c|c|c|}
\hline Element & $\begin{array}{l}\text { Element } \\
\text { X-ray } \\
\text { Line }\end{array}$ & $\begin{array}{l}\text { Diffracting } \\
\text { Crystal }\end{array}$ & $\begin{array}{l}\text { On-peak } \\
\text { Counting } \\
\text { Time }\end{array}$ & $\begin{array}{l}\text { Off-Peak } \\
\text { Counting Time } \\
\text { (on each side of } \\
\text { peak) }\end{array}$ & Standard & $\begin{array}{l}\text { Range of } \\
\text { detection } \\
\text { limits (ppm) }\end{array}$ \\
\hline $\mathrm{Si}$ & $\mathrm{K} \alpha$ & TAP & 60 & 30 & S-021 synthetic diopside & $50-150$ \\
\hline $\mathrm{Ti}$ & $\mathrm{K} \alpha$ & PET & 30 & 15 & S-208 rutile NMNH 120812 & $130-160$ \\
\hline $\mathrm{Al}$ & $\mathrm{K} \alpha$ & TAP & 60 & 30 & S-354 synthetic spinel & $90-110$ \\
\hline $\mathrm{Cr}$ & $\mathrm{K} \alpha$ & $\mathrm{LiFL}$ & 60 & 30 & $\mathrm{~S}-417$ synthetic $\mathrm{Cr}_{2} \mathrm{O}_{3}$ & $100-120$ \\
\hline $\mathrm{V}$ & $\mathrm{K} \alpha$ & $\mathrm{LiFL}$ & 60 & 30 & $\mathrm{~S}-403$ synthetic $\mathrm{V}_{2} \mathrm{O}_{3}$ & $100-120$ \\
\hline $\mathrm{Fe}$ & $\mathrm{K} \alpha$ & LIF & 10 & 5 & S-125 hematite & $300-420$ \\
\hline $\mathrm{Mn}$ & $\mathrm{K} \alpha$ & LiFL & 60 & 30 & $\begin{array}{l}\text { S-314 synthetic } \mathrm{Mn}_{3} \mathrm{O}_{4} \\
\text { S-194 Tiebaghi chromite NMNH }\end{array}$ & $90-120$ \\
\hline $\mathrm{Mg}$ & $\mathrm{K} \alpha$ & TAP & 60 & 30 & 117075 & $90-160$ \\
\hline $\mathrm{Zn}$ & $\mathrm{K} \alpha$ & $\mathrm{LiFH}$ & 60 & 30 & S-394 gahnite NMNH 145883 & $170-230$ \\
\hline $\mathrm{Ni}$ & $\mathrm{K} \alpha$ & $\mathrm{LiFH}$ & 60 & 30 & S-493 synthetic liebenbergite & $110-140$ \\
\hline $\mathrm{Ca}$ & $\mathrm{K} \alpha$ & PET & 60 & 30 & S-021 synthetic diopside & $40-70$ \\
\hline $\mathrm{Cu}$ & $\mathrm{K} \alpha$ & $\mathrm{LiFH}$ & 60 & 30 & $\mathrm{~S}-061 \mathrm{Cu}$ metal & $120-150$ \\
\hline $\mathrm{K}$ & $\mathrm{K} \alpha$ & PET & 60 & 30 & S-096 adularia Penn State Or-1 & $40-60$ \\
\hline
\end{tabular}


To determine the accuracy of charge balance calculations, EPMA and Mössbauer spectroscopy data for two magnetite samples from the magnetite-apatite ores in Kiruna, Sweden, unrelated to this study were obtained (M.D. Dyar and J.M. Hanchar, personal communication). $\mathrm{Fe}_{(\mathrm{t})}$ values from the EPMA analyses were recalculated via the charge balance method used in this study and the resulting $\mathrm{Fe}^{2+}$ and $\mathrm{Fe}^{3+}$ values were compared to the measured values obtained using Mössbauer spectroscopy. Using the charge balance calculations, both magnetite samples were calculated to contain, on average, $66.6 \mathrm{wt} . \%$ $\mathrm{Fe}_{2} \mathrm{O}_{3}$ and 29.6 wt.\% $\mathrm{FeO}$, whereas when analyzed using Mössbauer spectroscopy, the same samples were measured to contain 65 wt. $\% \mathrm{Fe}_{2} \mathrm{O}_{3}$ and 35 wt. $\% \mathrm{FeO}$ (the stoichiometric end-member proportions for magnetite). It should be noted, that while this difference is real, the EPMA analyses were done in situ and the Mössbauer analyses were done on bulk sample powder. Regardless of this discrepancy, the variation does not significantly affect the results or interpretation of the data.

\subsection{LA-ICPMS analyses}

LA-ICPMS analyses were done on the same thin sections and when possible on the same grains analyzed by EPMA. Like the EPMA analyses, the LA-ICPMS analyses were done to characterize the variation in minor and trace element composition within oxide minerals, between oxide minerals within each sample, and between oxides from different mineralization styles. Line analyses were done on all observed textural variations of magnetite, ilmenite, and pleonaste where coarse enough to do so in order to determine the mean value of the mineral analyzed including both inclusions and micro exsolution features. Large-scale observable exsolution features were avoided in order to ensure that only the targeted oxide mineral was analyzed. However, many smaller scale 
intergrowths could not be analyzed due to spatial limitations of the laser beam diameter. LA-ICPMS analyses for ${ }^{24} \mathrm{Mg},{ }^{25} \mathrm{Mg},{ }^{27} \mathrm{Al},{ }^{29} \mathrm{Si},{ }^{31} \mathrm{P},{ }^{34} \mathrm{~S},{ }^{44} \mathrm{Ca},{ }^{45} \mathrm{Sc},{ }^{47} \mathrm{Ti},{ }^{51} \mathrm{~V},{ }^{52} \mathrm{Cr},{ }^{55} \mathrm{Mn}$, ${ }^{57} \mathrm{Fe},{ }^{59} \mathrm{Co},{ }^{60} \mathrm{Ni},{ }^{63} \mathrm{Cu},{ }^{66} \mathrm{Zn},{ }^{71} \mathrm{Ga},{ }^{74} \mathrm{Ge},{ }^{89} \mathrm{Y},{ }^{90} \mathrm{Zr},{ }^{93} \mathrm{Nb},{ }^{95} \mathrm{Mo},{ }^{118} \mathrm{Sn},{ }^{178} \mathrm{Hf},{ }^{181} \mathrm{Ta},{ }^{182} \mathrm{~W}$ and ${ }^{208} \mathrm{~Pb}$ were done on magnetite, ilmenite, and pleonaste. However, depending on the target mineral, many of these elements proved to be below detection limits, and are therefore not discussed.

Analyses were done at LabMaTer, University of Quebec at Chicoutimi (UQaC) following the methods of Dare et al. (2014) and using an Agilent 7700x ICPMS interfaced to a Laurin technic S155 RESolution (193 nm) ArF excimer laser ablation system.). Variations in $\mathrm{Ti}, \mathrm{S}, \mathrm{Ca}, \mathrm{P}, \mathrm{Al}$ and $\mathrm{Cu}$ content in the oxide minerals were monitored to ensure the mineral analyzed was correctly identified and no mineral inclusions were included in the data integration. Instrument settings are presented in Table 2.1. Line analyses were done in this study in order to monitor elemental zonation as well as to homogenize microscopic exsolution microtextures. During line analyses, visible microtextures were avoided in order to minimize risk of contamination with unwanted material. The ICPMS was calibrated using reference material GSD-1g (USGS) using GeoReM preferred values (Jochum et al., 2005), and reduced using the Iolite version 2.5 software suite (Paton et al., 2011). Values of $\mathrm{Al}$, Ti and $\mathrm{Fe}_{(\mathrm{t})}$ from the EPMA analyses were used as internal standards for pleonaste $\left({ }^{27} \mathrm{Al}\right)$, ilmenite $\left({ }^{47} \mathrm{Ti}\right)$ and magnetite $\left({ }^{57} \mathrm{Fe}\right)$ respectively. Reference material GSE-1g (USGS) and G-probe 6 (BNV1g, USGS) as well as in-house monitor BC-28 (a natural magnetite from the Bushveld Complex in South Africa) were used as secondary standards. LA-ICPMS results, which include average compositions and standard deviations from each mineralization style, are 
presented in appendix II. However in analyses where $n=\leq 3$, standard deviations are not calculated.

\section{REFERENCES}

Dare SA, Barnes SJ, Beaudoin G, Meric J, Boutroy E, Potvin-Doucet C (2014) Trace elements in magnetite as petrogenetic indicators. Mineralium Deposita 49: 785-796

Jochum KP, Willbold M, Raczek I, Stoll B, Herwig K (2005) Chemical Characterization of the USGS reference glasses GSA-1G, GSC-1g, GSD-1g, GSE-1g, BCR-2G, BHVO-2G, and BIR-1G using EPMA, ID-TIMS, ID-ICP-MS and LA-ICPMS. Geostandards and Geoanalytical Research 29: 285-302

Paton C, Hellstrom J, Paul B, Woodhead J, Hergt J (2011) Iolite: freeware for the visualization and processing of mass spectrometric data. Journal of Analytical Atomic Spectrometry 26: 2508-2518 


\section{Chapter 3: Results}

\subsection{Host rock}

The host rock to the oxide mineralization is the NWRA, a heterogeneous unit ranging in composition from anorthosite to gabbronorite (Fig. $3.1 \mathrm{a}, \mathrm{b}$ ). Within the field area which is wooded and dominated by small, rounded outcrops, the host rocks are dominated by medium to coarse-grained plagioclase crystals that range in diameter from $<1 \mathrm{~cm}$ to $\sim 25 \mathrm{~cm}$. Plagioclase crystals are white to light grey, and in rare cases mauve to lilac colour in hand sample. Texturally, the plagioclase is granoblastic to prismatic and weakly saussuritized (i.e., altered to epidote group minerals), with the most intense alteration occurring nearest to the oxide-rich zones. Labradorescence (i.e., blue or green iridescence) is locally found associated with plagioclase in the study area.

The primary ferromagnesian minerals observed in the NWRA include pyroxene (with clinopyroxene in greater abundance than orthopyroxene), amphiboles (hornblende and pargasite) and rare olivine. In hand specimens, orthopyroxene crystals are generally tan to buff in colour, whereas amphiboles are dark green to black. Ferromagnesian silicates occur as individual grains or as clusters of grains, and are irregular in form varying in size proportionally to the adjacent plagioclase grains (commonly between 5 $\mathrm{mm}$ and $20 \mathrm{~cm}$ ). Ferromagnesian minerals occur in patches in host anorthosite accounting for between $0-70 \%$ of the total rock volume.

Fe-Ti oxide minerals are abundant in the NWRA and including massive to semimassive mineralization and disseminated mineralization styles. Oxide mineralization is in sharp irregular contact with host anorthosite. Zones of massive to semi-massive oxide 
mineralization are on the meter scale, discontinuous and dwarfed in size by surrounding anorthosite.
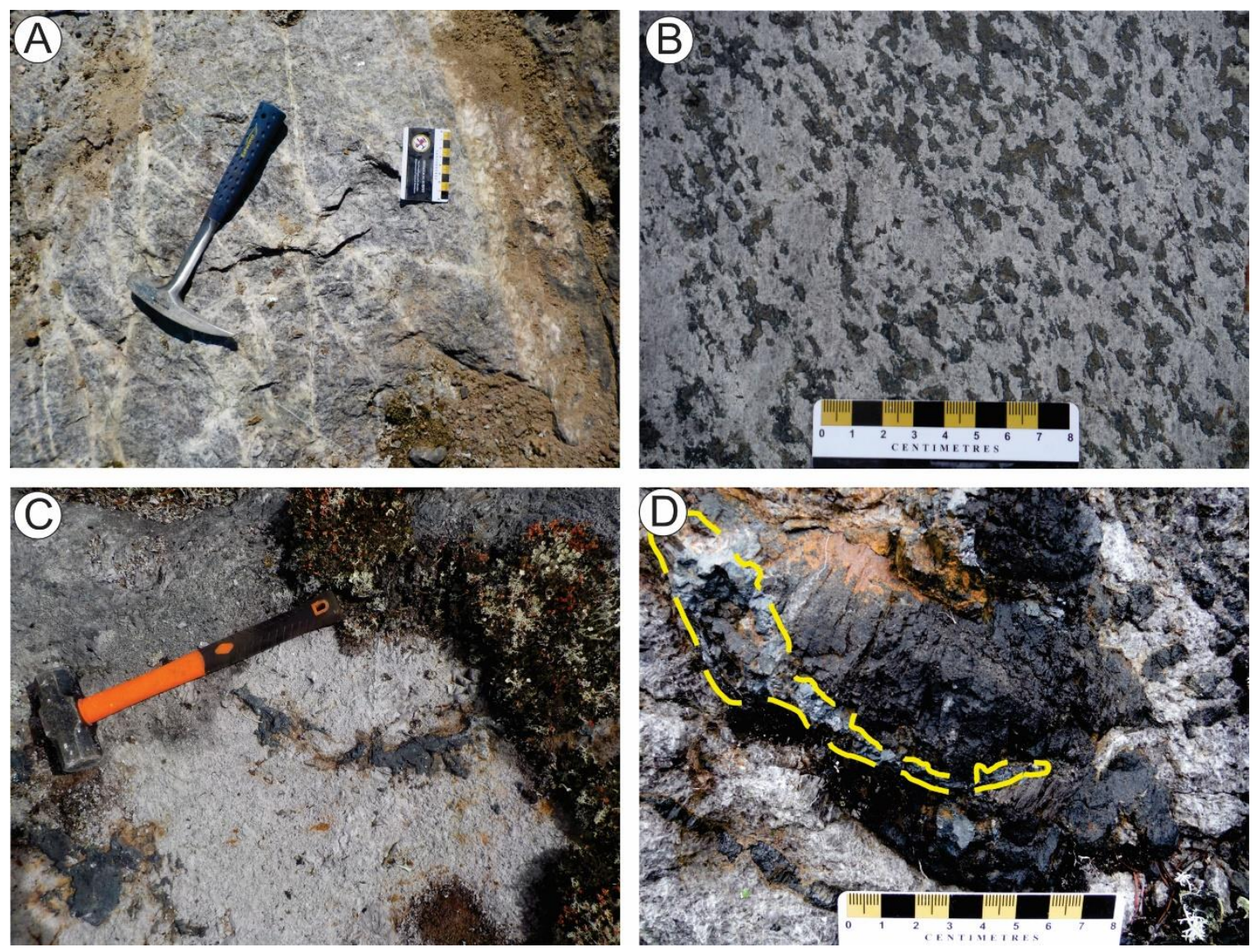

Figure 3.1. Representative field photographs of host rocks as well as disseminated oxide mineralization: A) Outcrop of anorthosite; B) Outcrop of anorthosite, exhibiting irregularshaped blebs of pyroxene rimmed by amphibole and biotite; C) Anorthosite hosted disseminated oxide that is irregular in form; and D) Oxide mineralization (outlined in yellow) crosscutting and partially rimming an orthopyroxene megacryst.

\subsection{Massive to semi-massive oxide mineralization}

\subsubsection{General Features}

Massive to semi-massive oxide mineralization (50-100 vol. \% oxide minerals on the outcrop scale) occurs in 1) oxide-rich pods; 2) oxide-rich veins; and 3) alternating bands of oxide mineralization and host anorthosite (Figs. 3.2, 3.3). Regardless of field context, oxide minerals in massive to semi-massive oxide mineralization are generally 
coarse grained in hand sample $(0.5 \mathrm{~cm}-3 \mathrm{~cm})$ (Fig. 3.2b), and composed of magnetite $\left(\mathrm{Fe}_{3} \mathrm{O}_{4}\right)$, ilmenite $\left(\mathrm{FeTiO}_{3}\right)$, and pleonaste $\left([\mathrm{Fe}, \mathrm{Mg}] \mathrm{Al}_{2} \mathrm{O}_{4}\right)$ in this order of abundance. Aside from the oxide minerals, plagioclase, orthopyroxene, pyrrhotite, pyrite, and chalcopyrite are also commonly observed in hand sample and thin section. Texturally, plagioclase and orthopyroxene occur as resorbed grains or in monomineralic clusters of grains with a dark rim of amphibole and biotite present at the contact between both orthopyroxene and plagioclase and surrounding oxide minerals. Contacts between massive to semi-massive oxide mineralization, and host rock, are sharp and irregular, and commonly show a mm- to $\mathrm{cm}$ - scale rim of hydrous minerals (e.g., biotite, pargasite, hornblende) at the oxide-silicate contact (Fig. 3.3c).

\subsubsection{Oxide-rich Pods}

The oxide-rich pods are the most commonly observed style of massive to semimassive oxide mineralization within the field area (Fig. 3.2a). They vary in size with the largest observed pod measured at more than $8 \mathrm{~m} \times 4.5 \mathrm{~m}$ at surface, with most $1-2 \mathrm{~m}$ in diameter. Although the pods are generally of equant dimensions, they can locally be lenticular to elongate in shape. Surfaces of these oxide-rich pods vary in colour from steel blue to grey. A portable drill was used on a massive oxide pod by prospectors T. Benoit and C. Coady to obtain an $8 \mathrm{~m}$ deep drill core of unknown orientation, which indicates that the minimum length of oxide mineralization in at least one location might be at least

$8 \mathrm{~m}$, as the lower contact with the surrounding anorthosite was not intersected during the drilling. 


\subsubsection{Oxide-rich Veins}

Veins of oxide mineralization are rarely observed in the field area. However where present, they are typically $3-30 \mathrm{~cm}$ in width, and have straight irregular contacts with the host anorthosite (Fig. 3.3a-c). These veins vary in width along strike and can be discontinuous over tens of meters (Fig. 3.3 b). Oxide-rich veins locally contain small inclusions of host anorthosite (Fig. $3.3 \mathrm{c}$ ).

\subsubsection{Oxide-rich Bands}

Alternating oxide and anorthosite bands was observed in only two localities where a maximum of three parallel oxide bands were observed in sequence. When observed, bands of oxide mineralization occurs as two or more broadly parallel bands of continuous massive oxide that are $>30 \mathrm{~cm}$ wide and alternate with variably-sized, but generally thicker bands of anorthosite (Fig. 3.4a). Contacts between the oxide bands and the host anorthosite are sharp and irregular (Fig. 3.4b, c).

Although individual oxide bands appear similar to vein occurrences, they differ in several key ways: 1) The contacts between oxide bands and anorthositic rocks are characterized by thinner bands of hydrous minerals than observed in vein-anorthosite contacts; 2) The oxide bands are more clearly defined and traceable along strike; 3) The larger oxide bands locally contain large anorthosite inclusions (Fig. 3.4d); and 4) the oxide abundance varies within bands, from massive to semi-massive.

\subsubsection{Relationship between massive to semi-massive oxide mineralization styles}

For the purpose of this study, massive to semi-massive oxide mineralization styles were defined solely using their surface expression. As such, it is unclear if there is continuity between various mineralization styles at depth. 

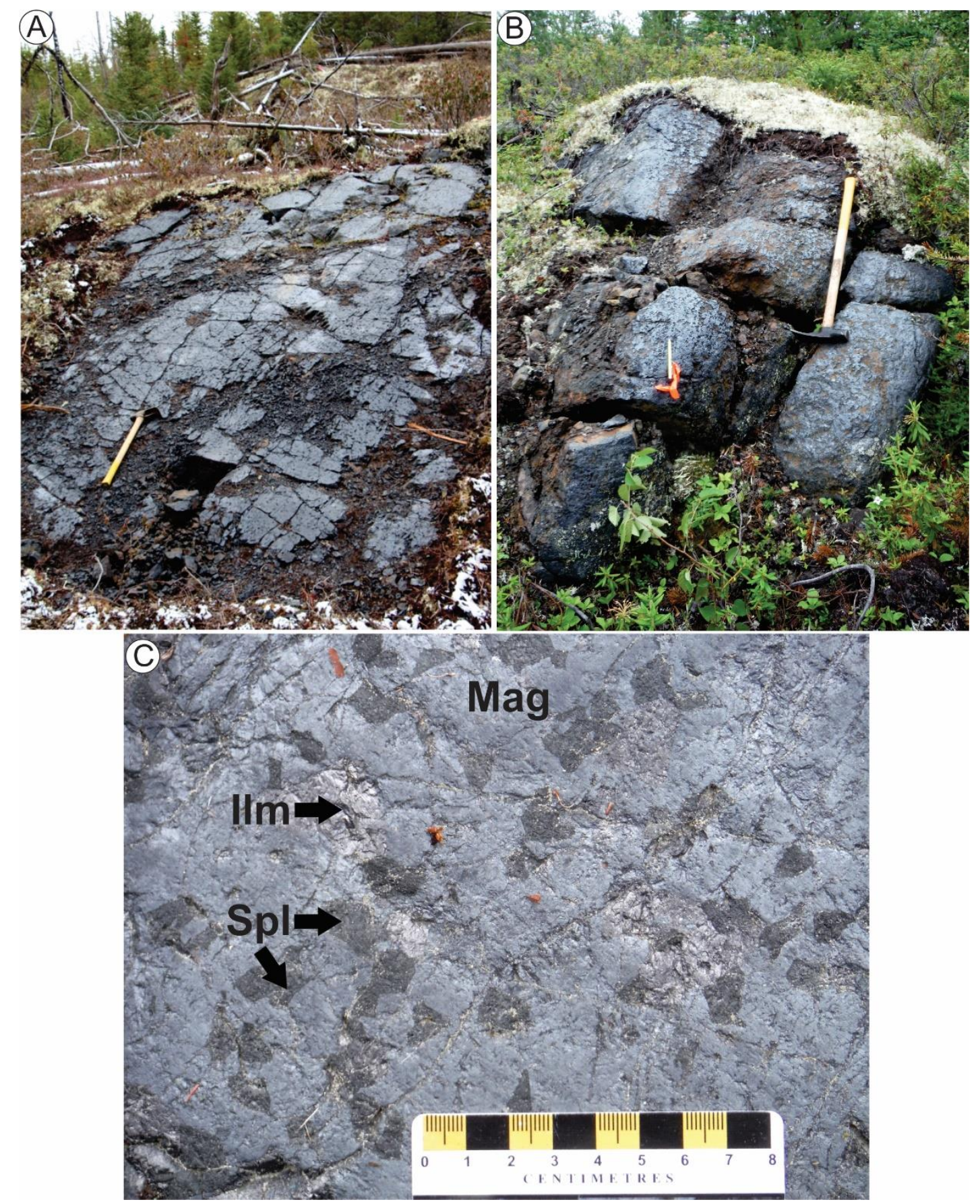

Figure 3.2 Representative field photographs showing pods of massive oxide mineralization: A) large pod of massive to semi-massive oxide mineralization (The hammer is $75 \mathrm{~cm}$ long); B) large pod of oxide mineralization; and C) close-up view of outcrop in A. Note coarse-grained nature of oxide minerals. Abbreviations: Magmagnetite; Ilm- ilmenite; Spl- spinel (pleonaste). 

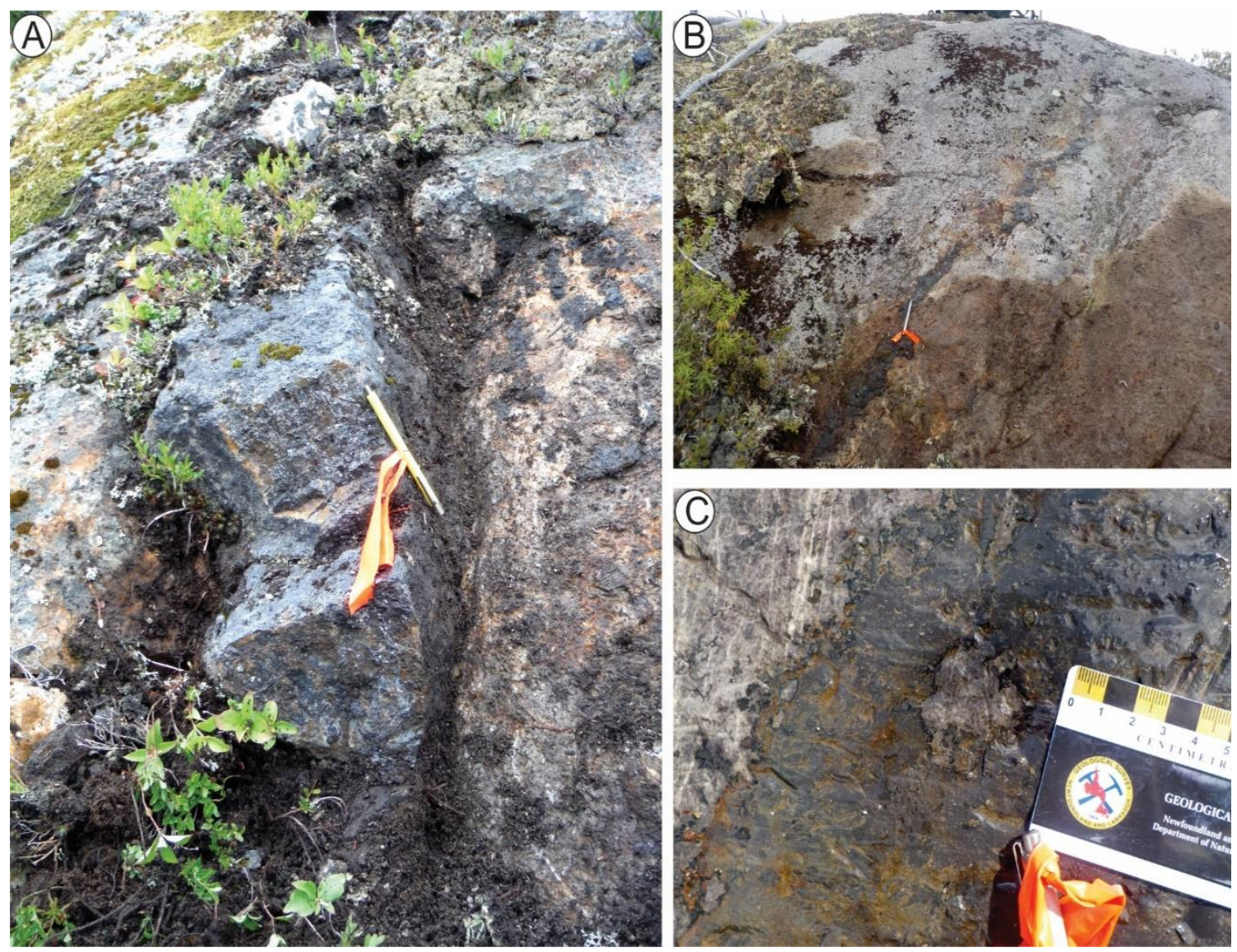

Figure 3.3 Representative field photographs of oxide veins: A) Large vein of oxide mineralization with sharp, recessively weathered contacts with host gabbronorite; B) Discontinuous, discordant vein of oxide mineralization tapering in diameter from bottom to top of the outcrop; and C) Vein of oxide mineralization with sharp irregular contact with host anorthosite and a small inclusion of host anorthosite.

\subsection{Disseminated oxide mineralization}

Disseminated oxide mineralization $(\sim 10-50 \%$ of the mineralized rocks are composed of oxide minerals on the outcrop scale) is the most commonly observed mineralization style in the field area. There are two subtypes of disseminated oxide mineralization present: 1) disseminated oxide mineralization associated with pyroxene (Fig. 3.1d); and 2) disseminated oxide mineralization in the host anorthosite (Fig. 3.1c). 

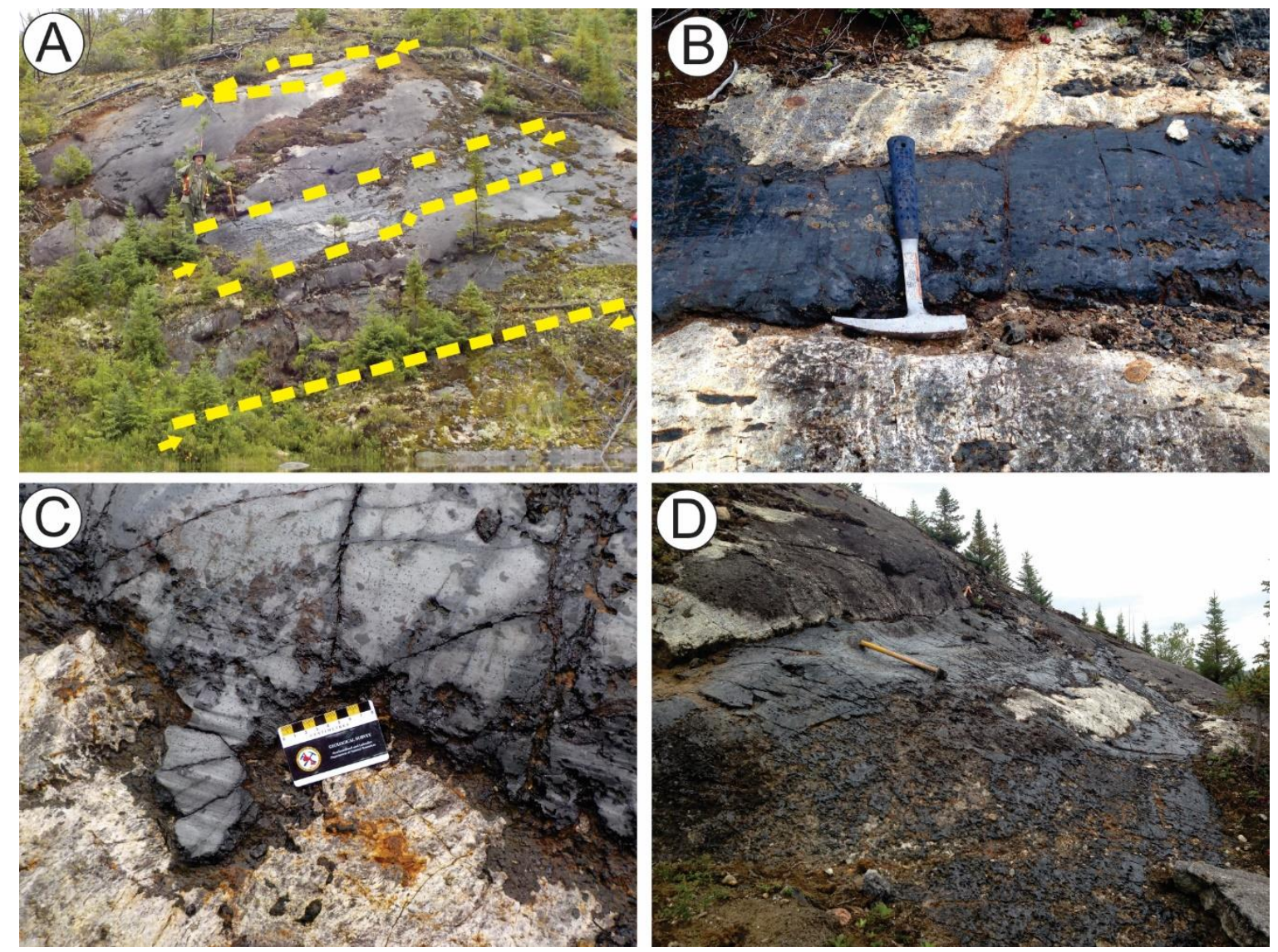

Figure 3.4. Representative field photographs of bands of oxide mineralization: A) large outcrop with three parallel bands of massive oxide mineralization as indicated by the arrows and yellow dashed lines, alternating with anorthosite layers; B) Detail of a band of oxide mineralization (dark grey) shown in A and having sharp, irregular contacts to the host anorthosite (light grey); C) close-up of irregular contact between band of oxide mineralization and host anorthosite, perhaps a density-driven structure; and D) Raft of host anorthosite in thick band of oxide mineralization.

Oxide grains associated with pyroxene are variable in size, and generally form rims around orthopyroxene or occur as cross-cutting features. In contrast, disseminated oxide mineralization hosted by anorthosite tends to be heterogeneously distributed with oxide grains interstitial to plagioclase grains. In both cases, there are polymineralic rims of biotite and amphibole developed around the oxides, ranging from $\sim 3 \mathrm{~mm}-2 \mathrm{~cm}$ in width. 
Disseminated oxide mineralization observed in this study is not composed of small grains of oxide minerals that are evenly distributed throughout the host rock, but instead consists of relatively coarse-grained, irregular-shaped aggregates of Fe-Ti oxide minerals that are widely dispersed throughout the host rock.

Oxide grains associated with pyroxene are variable in size, and generally form rims around orthopyroxene or occur as cross-cutting features. In contrast, disseminated oxide mineralization hosted by anorthosite tends to be heterogeneously distributed with oxide grains interstitial to plagioclase grains. In both cases, there are polymineralic rims of biotite and amphibole developed around the oxides, ranging from $\sim 3 \mathrm{~mm}-2 \mathrm{~cm}$ in width.

Disseminated oxide mineralization observed in this study is not composed of small grains of oxide minerals that are evenly distributed throughout the host rock, but instead consists of relatively coarse-grained, irregular-shaped aggregates of Fe-Ti oxide minerals that are widely dispersed throughout the host rock.

\subsection{Petrography}

\subsubsection{Massive to semi-massive oxide mineralization}

\subsubsection{Mineralogy}

Representative thin sections from massive to semi-massive oxide mineralization including pods, veins, and bands were examined using transmitted and reflected light microscopy. Regardless of the mineralization style, the massive to semi-massive oxide mineralization is dominated by magnetite $\left(\mathrm{Fe}_{3} \mathrm{O}_{4}\right)(\sim 50-70 \%)$, ilmenite $\left(\mathrm{FeTiO}_{3}\right)(\sim 20-$

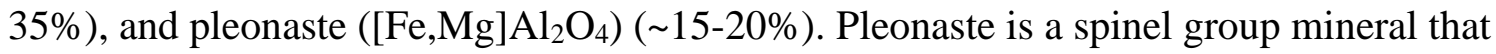



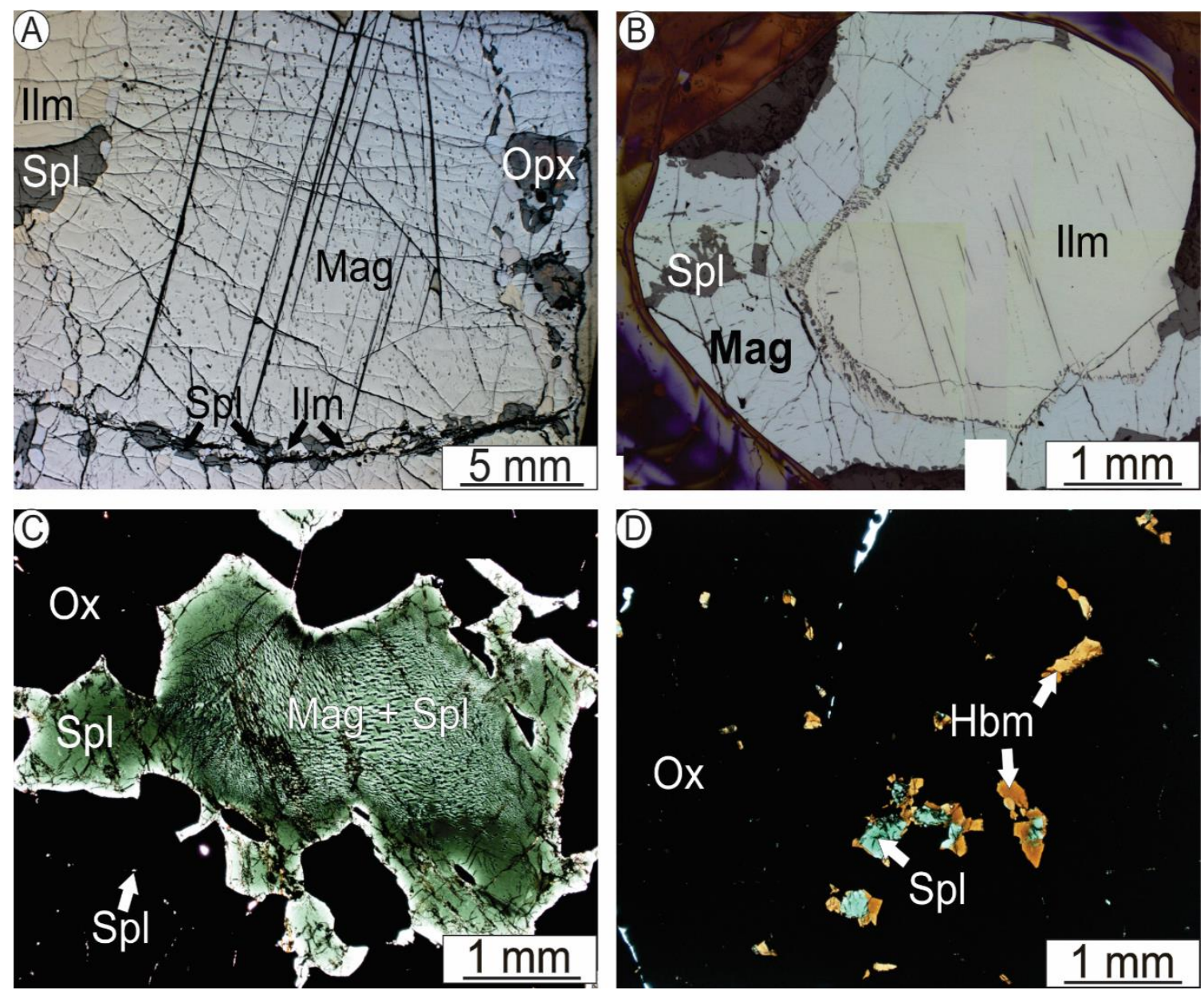

Figure 3.5. Representative photomicrographs of Fe-Ti oxide mineralization: A) Large grain of magnetite containing abundant exsolution microtextures including large lamellae of ilmenite and pleonaste as well as fine-grained granules of pleonaste which occur abundantly throughout magnetite grain. Note granoblastic zone of pleonaste and ilmenite rimming magnetite; B) Composite photomicrograph of coarse grained ilmenite containing lamellae of pleonaste shown by yellow arrow. Note the irregular contact with magnetite and the zone of ilmenite dotted by pleonaste microcrystals at the contact; C) Large grain of pleonaste in massive to semi-massive oxide mineralization. Magnetite lamellae are present in the core of the grain and diminish towards the Fe-Ti oxide minerals. ; D) Pleonaste partially to completely replaced by högbomite [ideally $\left.\left[\left(\mathrm{Fe}^{2+}, \mathrm{Mg}, \mathrm{Zn}, \mathrm{Al}\right)_{3}\left(\mathrm{Al}, \mathrm{Ti}, \mathrm{Fe}^{3+}\right)_{8} \mathrm{O}_{15}(\mathrm{OH})\right]_{2}\right]$. Abbreviations: Mag- magnetite; Ilmilmenite; Spl-spinel (pleonaste); Opx- orthopyroxene; Ox- oxide minerals; Hbmhögbomite. 
is intermediate in composition between the end-members spinel $\left(\mathrm{MgAl}_{2} \mathrm{O}_{4}\right)$ and hercynite $\left(\mathrm{FeAl}_{2} \mathrm{O}_{4}\right)$. It is commonly observed in magnetite-dominated $\mathrm{Fe}-\mathrm{Ti}$ oxide mineralization hosted in anorthosite (Charlier et al., 2015). In transmitted light pleonaste it is forest green and isotropic.

Two textural varieties of magnetite are present in the NWRA; primary magnetite and recrystallized magnetite. Primary magnetite (Fig. 3.5a) is the magnetite interpreted to be the first forming magnetite still present in the samples. It is typically coarse-grained $(\sim 1 \mathrm{~mm}-2 \mathrm{~cm})$, subhedral in form, and contains abundant exsolution microtextures of pleonaste and ilmenite including granules, lamellae, and lenses. Recrystallized magnetite is finer-grained than primary magnetite $(1-3 \mathrm{~mm})$ and is granoblastic in nature. The ilmenite ranges in size from $\sim 6 \mathrm{~mm}-2 \mathrm{~cm}$ and is typically subhedral to anhedral in form (Fig. 3.5b). Only the coarsest ilmenite grains contain lenses or lamellae of hematite, pleonaste and magnetite. Pleonaste is forest green in transmitted light and ranges in diameter from $\sim 3 \mathrm{~mm}-1 \mathrm{~cm}$ (Fig. 3.5c). It is subhedral in form and commonly associated with ilmenite grains of similar size.

Locally, pleonaste is rimmed or replaced by högbomite $\left[\left(\mathrm{Fe}^{2+}, \mathrm{Mg}, \mathrm{Zn}, \mathrm{Al}\right)_{3}\left(\mathrm{Al}, \mathrm{Ti}, \mathrm{Fe}^{3+}\right)_{8} \mathrm{O}_{15}(\mathrm{OH})\right]_{2}$ (Fig. 3.5d), a rare, high-T metamorphic Fe-MgAl-Ti oxide mineral with similar major and minor element composition and visual appearance as the högbomite reported by Sengupta et al. (2009) and Rakotonandrasana et al. (2010). The coarsest granules of pleonaste contain magnetite lamellae. Contacts between oxide minerals are sharp and irregular, commonly with pleonaste occurring at the contact between magnetite and ilmenite, or within ilmenite adjacent to magnetite. 

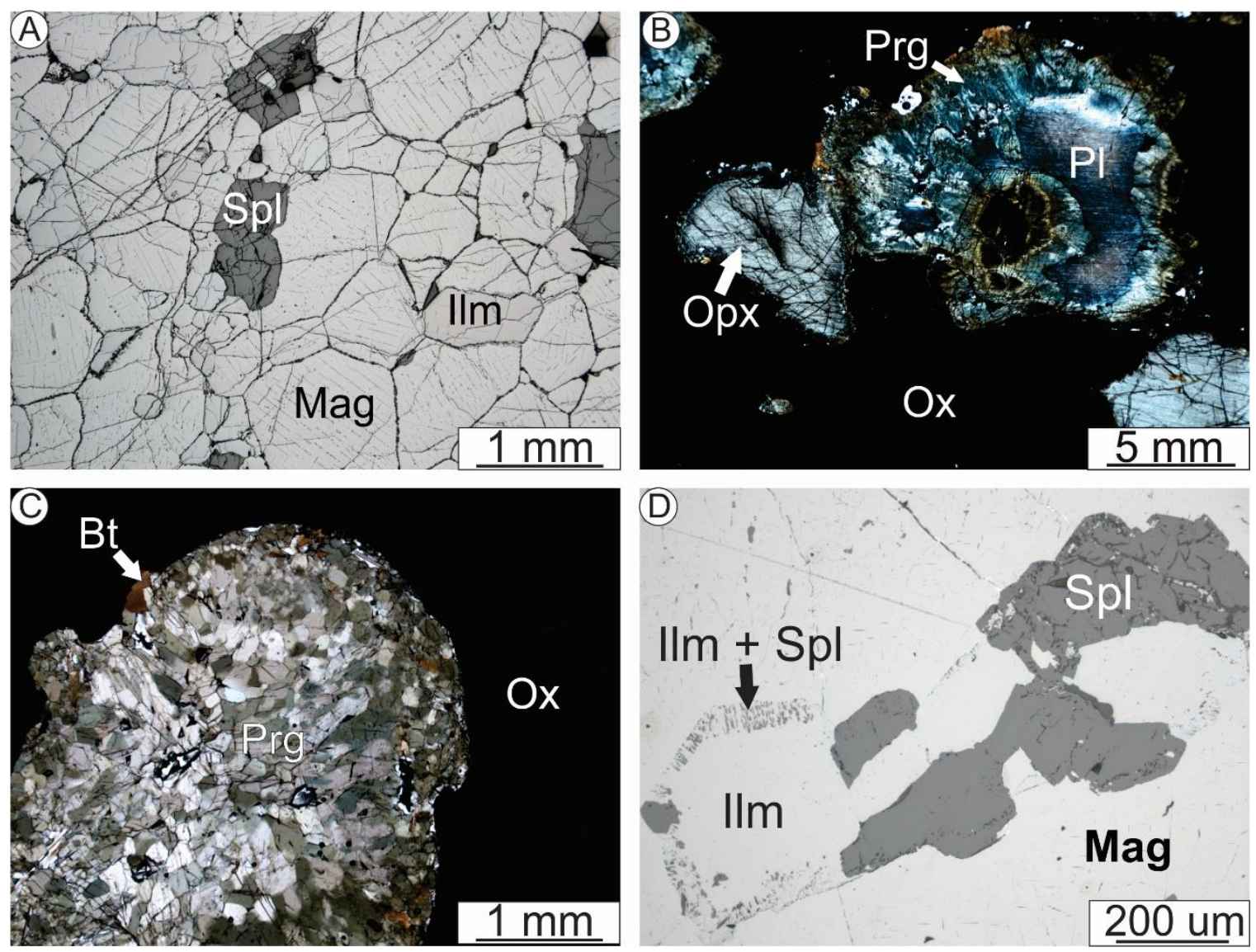

Figure 3.6. Representative photomicrographs of Fe-Ti oxide mineralization. A)

Granoblastic zone of oxide mineralization; B) Representative silicate minerals in massive to semi-massive oxide mineralization including dusty resorbed plagioclase rimmed by pleonaste, and rounded orthopyroxene; C) Cluster of granoblastic pargasite and biotite within massive to semi-massive oxide mineralization; D) Association of composite ilmenite and pleonaste in magnetite. Abbreviations: Mag- magnetite; Ilm- ilmenite; Splspinel (pleonaste); Opx- orthopyroxene; Pl- plagioclase; Ox- oxide minerals; Prgpargasite.

Granoblastic zones (Fig. 3.6a) of magnetite, ilmenite, and pleonaste (average grain size within these zones is $\sim 0.5-2 \mathrm{~mm}$ ) are common within the massive to semi-massive oxide mineralization. Where present, these zones are found either at grain boundaries between coarse-grained oxide minerals, or in patches randomly distributed within samples. It is common for whole areas of thin sections to consist of granoblastic massive 
to semi-massive oxide; a texture normally associated with static recrystallization. Zones of granoblastic oxide are rarely observed in samples containing orthopyroxene or plagioclase.

Plagioclase (Fig. 3.6b) is the most common silicate mineral observed in massive to semi-massive oxide mineralization. It ranges from $\sim 0.4-1 \mathrm{~cm}$ in diameter and occurs as subhedral grains that are equant to partially resorbed or as monomineralic clusters. The plagioclase within the massive to semi-massive oxide mineralization contains more microinclusions compared to plagioclase in the host anorthosite. Orthopyroxene (Fig. $3.6 \mathrm{~b}$ ) is light brown in hand sample and ranges from $\sim 4 \mathrm{~mm}-1 \mathrm{~cm}$ in diameter. It is subhedral to slightly round in form and ubiquitously rimmed by fine-grained symplectic intergrowths of magnetite and orthopyroxene.

Pargasite, \pm hornblende, \pm biotite \pm garnet commonly occur in clusters (Fig. 3.6c) that range in diameter from $\sim 2 \mathrm{~mm}-1 \mathrm{~cm}$. Mineral grains within these clusters range from $\sim 0.3-0.5 \mathrm{~mm}$ and are granoblastic, with the exception of biotite which occurs as laths. Coronas are present at contacts between plagioclase and oxide minerals within the massive to semi-massive mineralization. These coronas are typically composed of three visually distinct amphiboles (Fe-Mg amphibole, pargasite, and hornblende) and biotite (Butt, 2000) and are perpendicular to the oxide grain boundaries.

\subsubsection{Exsolution features}

Exsolution textures are common in the magnetite, ilmenite, and pleonaste in the massive to semi-massive oxide mineralization. These textures observed in magnetite include lenses, granules, and lamellae of pleonaste, and lamellae and granules of ilmenite. Common magnetite-hosted ilmenite exsolution textures were defined by Haggerty (1991) 
using examples from various magnetite -bearing gabbroic rocks from several localities. The exsolution textures observed, using the definitions discussed in Haggerty (1991) in the NWRA include "composite ilmenite", which refers to granular ilmenite within or adjacent to magnetite, "trellis ilmenite" which refers to thin ilmenite lamellae which grow along the $\{111\}$ planes of magnetite (Fig. 3.7c), and "sandwich ilmenite", which are thick ilmenite lamellae growing parallel to only one set of $\{111\}$ planes in magnetite (Fig. 3.7a). "Cloth-textured" ilmenite exsolution was defined by Haggerty (1991) as very fine lamellae of ilmenite parallel to the $\{100\}$ plane of the host magnetite. Cloth-textured ilmenite is commonly observed in the orthopyroxene-bearing magnetite in massive to semi-massive oxide mineralization (Fig. 3.8b).

Texturally similar features are also observed where ilmenite is dotted with pleonaste microcrystals within magnetite. Furthermore, ilmenite dotted with pleonaste microcrystals also occurs at the contact between magnetite and ilmenite (Fig. 3.7d). Microcrystals of pleonaste typically form linear bands where observed in coarse ilmenite (Fig. 3.8a).

Pleonaste occurs as coarse- to fine-grained granules in magnetite as well as in lenses and lamellae (Fig. 3.7b). Coarse-grained granular pleonaste is associated with composite ilmenite of similar grain size (Fig. 3.6d); mid-sized granular pleonaste is found capping ilmenite sandwiches, and fine-grained granules of pleonaste are found randomly scattered throughout the magnetite. Pleonaste is also observed rimming unfilled fractures in magnetite (Fig. 3.7c). 

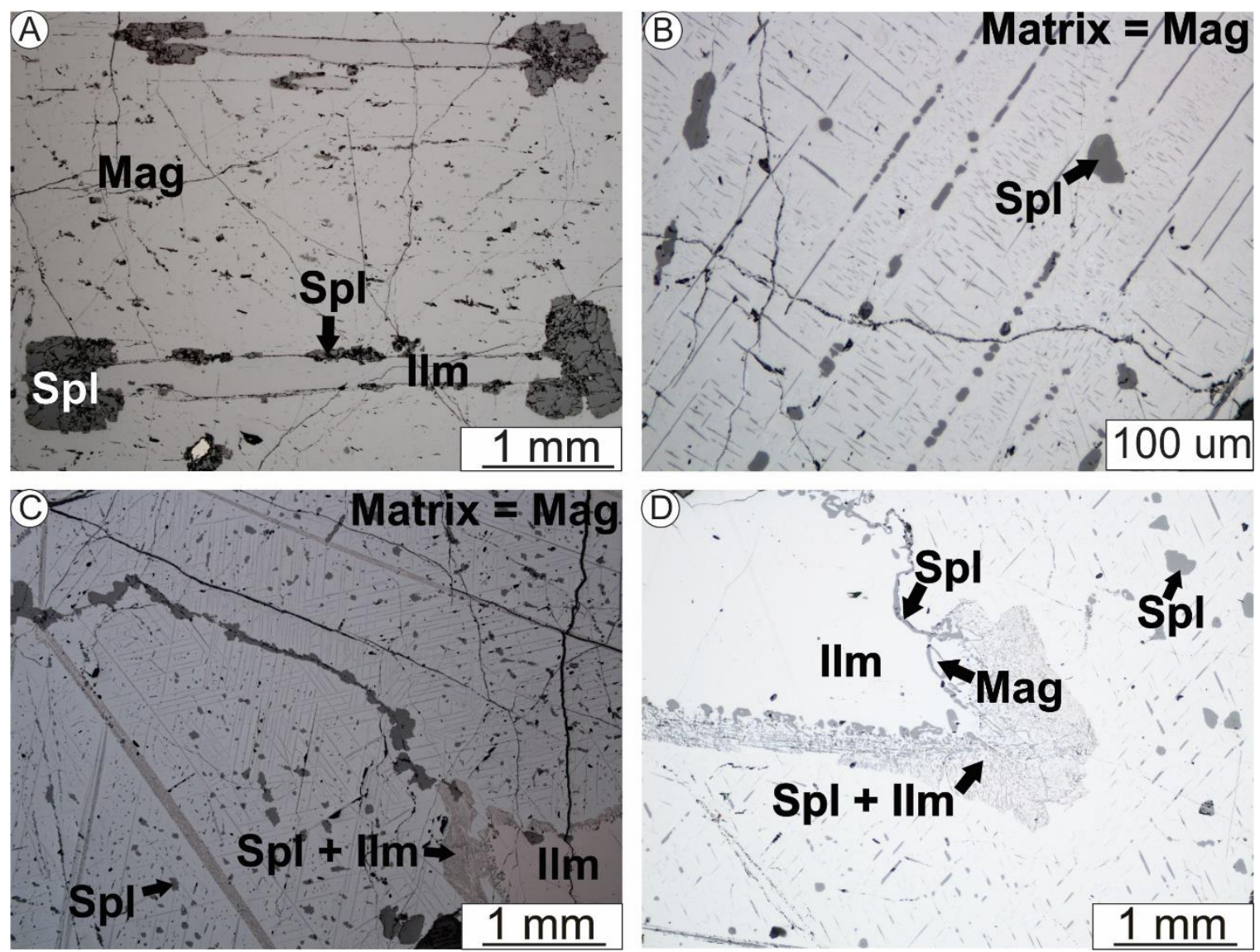

Figure 3.7. Representative photomicrographs of Fe-Ti oxide mineralization: A) Sandwich ilmenite in magnetite capped by granules of pleonaste; B) Variability of pleonaste exsolution in magnetite, note lenses, granules and lamellae; C) Trellis exsolution in magnetite, along with sandwich of ilmenite with microcrystals of pleonaste. Note pleonaste rimming fracture in magnetite; and D) Composite ilmenite in magnetite. Contact between Fe-Ti oxide minerals either ilmenite dotted with pleonaste microcrystals, or irregular with a rim of pleonaste. Abbreviations: Mag- magnetite; Ilm- ilmenite; Spl- spinel (pleonaste).

Coarse-grained ilmenite contains lamellae of magnetite with variable amounts of pleonaste (Fig. 3.8c), as well as hematite lenses (Fig. 3.8d). Hematite lenses can vary in size by orders of magnitude within the same ilmenite grain with the largest lenses being $\sim 10$ um by $\sim 40$ um and the smallest being <1um by <1um, with irregular ilmenite that is $<1$ um in diameter contained within the coarsest hematite lenses. Coarse pleonaste commonly contains lenses of magnetite (Fig. 3.5c). 
The abundance of several exsolution features including pleonaste in magnetite, magnetite in pleonaste, and hematite in ilmenite, are most abundant at the core of their host minerals and least abundant directly adjacent to the contact with other oxide minerals (Fig. 3.5c, 3.7d, 3.8a-d).

\subsubsection{Similarities and Contrasts}

Textural and crystal size differences are observed between the massive to semimassive oxide mineralization that contains orthopyroxene, and mineralization that lacks orthopyroxene. Oxide minerals within orthopyroxene-bearing massive oxide mineralization is coarser grained (commonly $>1 \mathrm{~cm}$ in diameter), and contains more abundant lamellae and granules of pleonaste as well as cloth texture ilmenite. In contrast, the massive to semi-massive oxide mineralization without orthopyroxene is finer grained, commonly granoblastic, and contains equigranular magnetite, ilmenite, and pleonaste. Granoblastic magnetite contains fine-grained pleonaste and ilmenite lenses compared to the coarser magnetite, in which these intergrowth textures are markedly coarser grained.

\subsubsection{Disseminated oxide mineralization}

\subsubsection{Mineralogy}

Disseminated oxide mineralization is present within the host anorthosite, which contains no clinopyroxene or orthopyroxene, and in the orthopyroxene- and clinopyroxene-bearing anorthosite. Regardless of the host rock mineralogy, disseminated oxide mineralization is irregular in form, and typically occurs as clustered aggregates (Fig. 3.9a). Oxide minerals are typically proportional in size to the size of the aggregate 

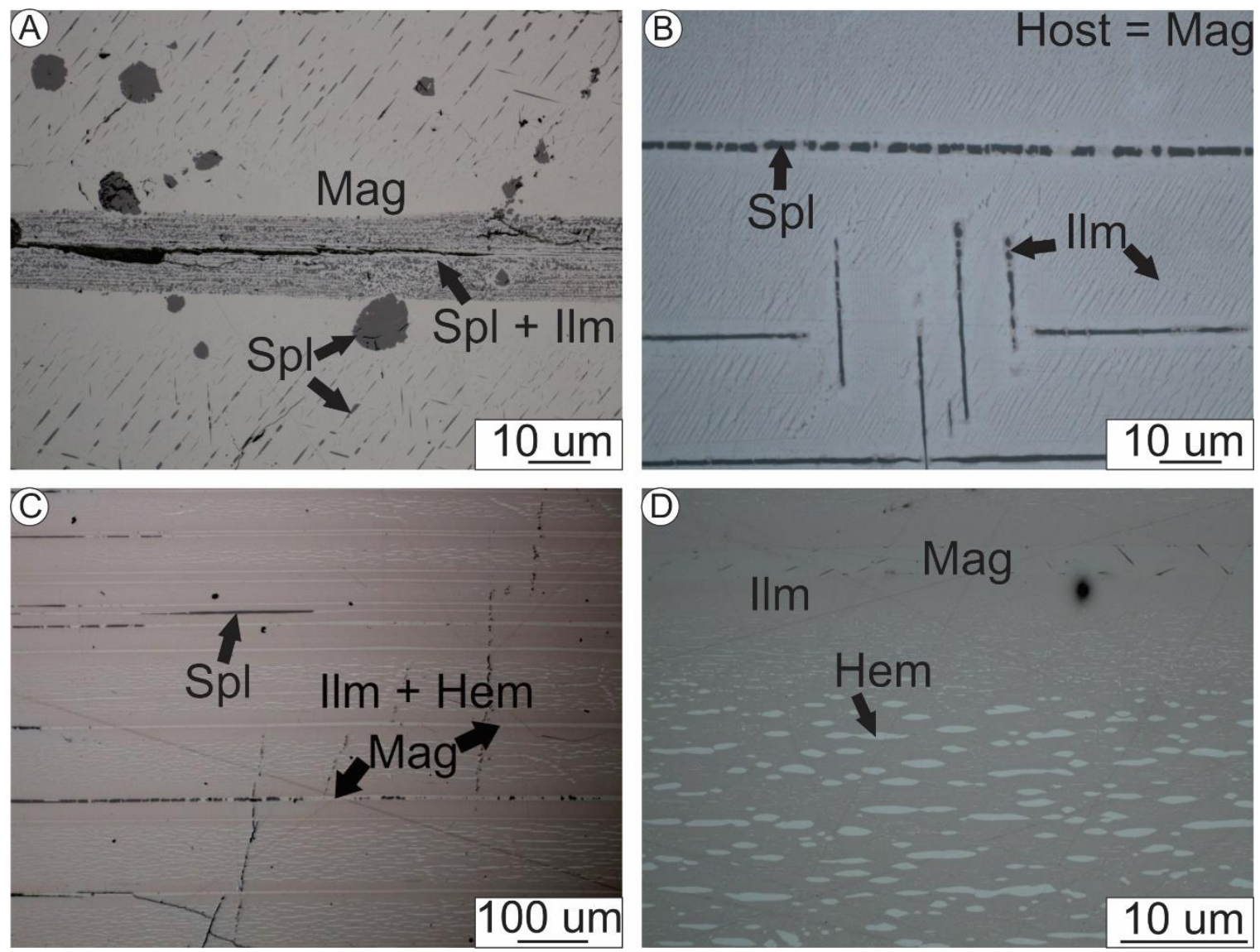

Figure 3.8. Representative photomicrographs of Fe-Ti oxide mineralization: A) Close-up photomicrograph of ilmenite dotted with spinel microcrystals. Pleonaste forms linear features in ilmenite. Note diminishing spinel content in magnetite adjacent to ilmenite dotted with pleonaste microcrystals; B) Cloth texture ilmenite in magnetite. Ilmenite is also present as rims of pleonaste lamellae. Note zones of low ilmenite adjacent to pleonaste; C) Composite ilmenite with lamellae of magnetite and pleonaste parallel to hematite lenses; and D) Close-up photomicrograph of exsolution microtextures in ilmenite including magnetite lamellae and hematite lenses. Note the fine hematite lenses between coarser lenses. Hematite content depletes approaching magnetite lamellae. Abbreviations: Mag- magnetite; Ilm- ilmenite; Spl- spinel (pleonaste); Hem- hematite.

they are contained within; oxide aggregates range in size from $1 \mathrm{~mm}-5 \mathrm{~cm}$ whereas individual oxide minerals range in diameter from $\sim 0.5 \mathrm{~mm}-2 \mathrm{~cm}$. Where hosted by gabbronorite, the oxide minerals are typically spatially associated with pyroxene, and the oxide minerals commonly form as partial rims (Fig. 3.9d). Where hosted in anorthosite, the oxide minerals tend to be interstitial to plagioclase (Fig. 3.9a). 

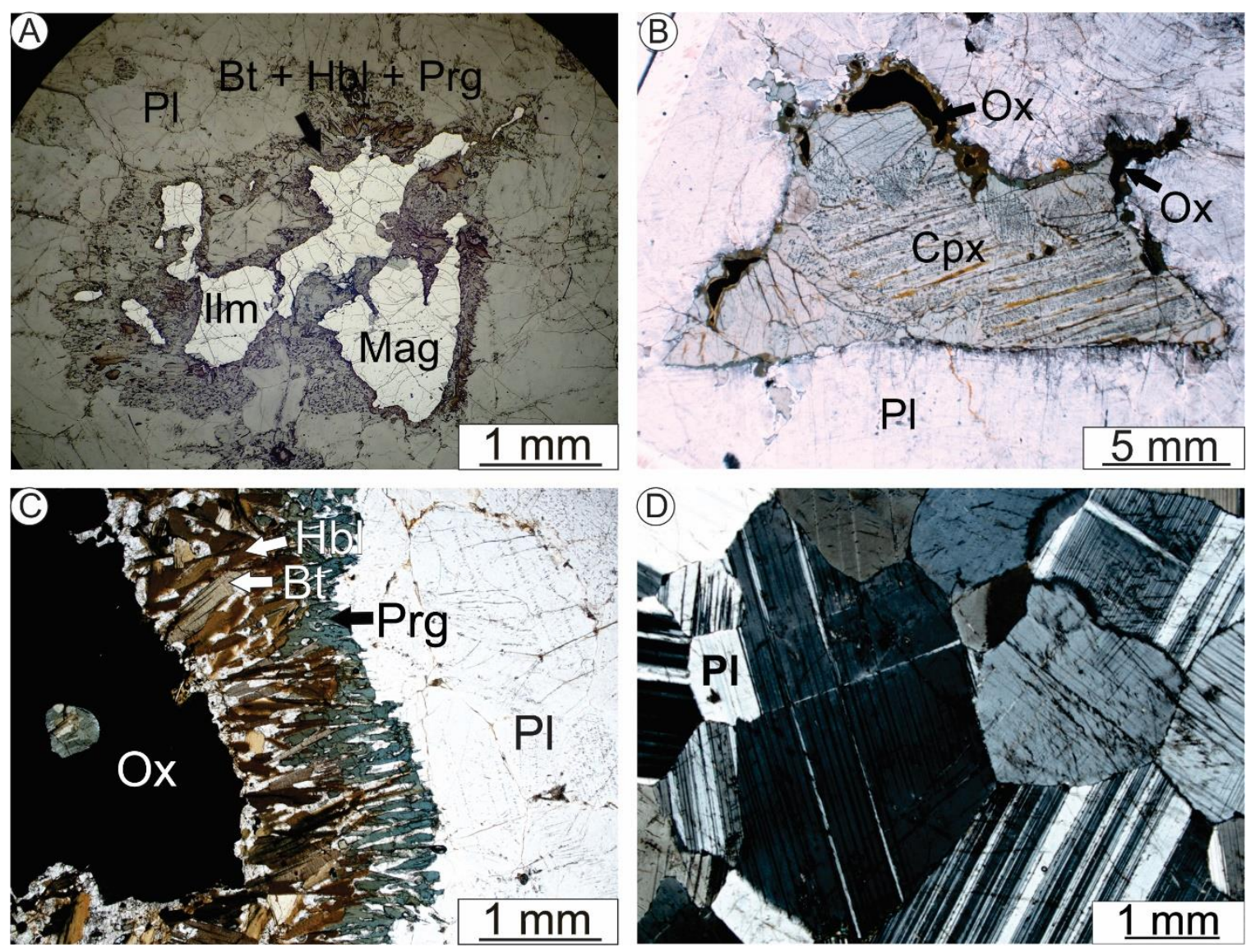

Figure 3.9. Representative photomicrographs of Fe-Ti oxide mineralization and host rocks: A) Typical disseminated oxide mineralization hosted in anorthosite. Note irregular nature and clustered habit; B) Coarse grained clinopyroxene partially rimmed by oxide mineralization.; C) Corona of hydrous minerals at contact between oxide mineralization and host anorthosite; and D) Typical host anorthosite with granoblastic plagioclase Abbreviations: Mag- magnetite; Ilm- ilmenite; Pl- plagioclase; Ox- oxide minerals; Btbiotite; Prg- pargasite; Hbl- hornblende; Cpx- clinopyroxene.

Magnetite and ilmenite are the most abundant oxide minerals in the disseminated oxide mineralization. In contrast to massive to semi-massive oxide mineralization, coarsegrained pleonaste granules are not observed in disseminated oxide mineralization.

Typically, clusters of Fe-Ti oxides range in size from $\sim 5$ to $8 \mathrm{~mm}$ in diameter. Single grains of ilmenite or magnetite within the clusters are between $\sim 3$ and $5 \mathrm{~mm}$ in diameter. 


\subsubsection{Coronas}

Coronas of hydrous minerals are ubiquitous and rim all observed disseminated oxide mineralization throughout the NWRA (Fig. 3.9c). Where associated with the disseminated oxide mineralization, coronas are composed of pargasite, hornblende, and biotite \pm garnet. Hydrous minerals in the coronas typically grew perpendicular to the contact between the oxide and plagioclase.

\subsubsection{Exsolution features}

Disseminated oxide mineralization shares many of the same types of exsolution features that are observed in massive to semi-massive oxide mineralization; although in the disseminated oxide mineralization the exsolution features tend to be finer grained than those that occur in the massive to semi-massive oxide mineralization. The larger the cluster of disseminated oxide mineralization is, the coarser the exsolution features tend to be. In contrast to massive to semi-massive oxide mineralization, the disseminated oxide mineralization typically occurs as lenses and lamellae of pleonaste in ilmenite and magnetite, and only rarely contains fine-grained granules of pleonaste.

As seen in massive to semi-massive oxide mineralization, ilmenite contains hematite lenses, lamellae of pleonaste and thin magnetite lamellae containing variable amounts of pleonaste. Unlike in massive to semi-massive oxide mineralization, thick magnetite lamellae are not present.

\subsubsection{Host-rock to the Fe-Ti Oxide Mineralization}

As previously mentioned, the NWRA is the host rock to the Fe-Ti oxide mineralization that is the focus of this study; it is a heterogeneous unit that ranges from true anorthosite to gabbronorite. Anorthosite and gabbronorite have similar silicate, 
oxide, and sulfide mineral assemblages and exsolution textures, with the distinction resting on the amount of the pyroxene they contain. Silicate minerals in the host rocks include plagioclase, clinopyroxene, biotite and pargasite, with rare orthopyroxene, olivine and apatite.

The most common silicate mineral in the NWRA is plagioclase (Fig. 3.9b). In thin section, plagioclase is typically granoblastic in texture, ranging in size from several $\mathrm{mm}$ to a few cm in diameter. Rarely, large plagioclase grains are observed to be tabular. Plagioclase is commonly "dusty" in nature, a result of opaque micro-inclusions, likely FeTi oxide minerals. Cores of plagioclase grains tend to be dustier than the rims.

Clinopyroxene is the most abundant ferromagnesian mineral in the anorthosite and gabbronorite. It is light green in colour in hand sample and is typically anhedral to interstitial in form, and commonly occurs in monomineralic clusters (Fig. 3.9d).

Biotite and pargasite are typically found either rimming oxide minerals or mafic silicates, or randomly distributed in the host rock adjacent to oxide minerals and mafic silicates.

\subsection{Whole-rock geochemistry}

\subsubsection{Geochemistry overview}

Eighty-six whole-rock analyses were done for major, minor, and trace elements on mineralized and unmineralized samples representative of all the rock types encountered in the study area. A complete list of the samples analyzed and the elements analyzed is presented in Appendix 3.3.

These analyses were grouped into the following categories: 1) barren host rocks (anorthosite, gabbronorite and olivine-bearing anorthosite); 2) disseminated Fe-Ti oxide 
mineralization (anorthosite-hosted and gabbronorite-hosted); and 3) massive to semimassive oxide mineralization (orthopyroxene-bearing and orthopyroxene-poor), based on field and petrographic observations. Averages and standard deviations from each sample group are provided in the appendices. In analyses where $n=<3$, however, standard deviations are not calculated. During the field work sample collecting, many samples were classified as disseminated oxide mineralization (10-25\% oxide); however, later geochemical analyses indicated that many of these samples should instead be classified as barren host rocks (0-10\% oxide minerals). In reality, there is a continuum between barren host rocks and disseminated oxide mineralization with the distinction between the two rock types resting in an artificial boundary meant to help simplify classifying the analyses.

\subsubsection{Unmineralized host rocks}

The unmineralized host rocks account for about half of the samples analyzed, and includes samples from barren anorthosite, barren gabbronorite and barren olivine-bearing anorthosite.

\subsubsection{Major elements}

The barren anorthosite $(n=37)$, gabbronorite $(n=7)$ and olivine-bearing anorthosite $(n=3)$ samples share similar major-element compositions. The average $\mathrm{SiO}_{2}$ content in the barren samples ranges from 48.65-57.15 wt. \%, and $\mathrm{Al}_{2} \mathrm{O}_{3}$ content ranges from 16.828.01 wt. \%. The alkali oxides $\mathrm{CaO}, \mathrm{Na}_{2} \mathrm{O}$, and $\mathrm{K}_{2} \mathrm{O}$ range from 6.93-11.0 wt. \% $\mathrm{CaO}$, 2.84-5.82 wt. $\% \mathrm{Na}_{2} \mathrm{O}$, and $0.4-1.77$ wt. $\% \mathrm{~K}_{2} \mathrm{O}$ respectively. Transition metal oxides including $\mathrm{MnO}, \mathrm{MgO}, \mathrm{FeO}_{(\mathrm{t})}$ and $\mathrm{TiO}_{2}$ range from 0.01-0.17 wt. \% $\mathrm{MnO}, 0.05-9.89$ wt. \% $\mathrm{MgO}, 0.57-11.12$ wt. $\% \mathrm{FeO}_{(\mathrm{t})}$, and 0.07-1.07 wt. \% $\mathrm{TiO}_{2}$ respectively. The $\mathrm{P}_{2} \mathrm{O}_{5}$ content 
has a compositional range of 0.21-0.54 wt. \%. Loss on ignition (LOI) values range from 0-2.61 wt. \%.

\subsubsection{Minor and trace elements}

Appreciable amounts of $\mathrm{Ba}(441-1330 \mathrm{ppm})$ and $\mathrm{Sr}(866-1536 \mathrm{ppm})$ are present in unmineralized host rocks, whereas all other minor and trace elements are present in low concentrations, typically $<100 \mathrm{ppm}$, and for many elements nearing the minimum detection limits.

\subsubsection{Variation between unmineralized sample types}

Although all unmineralized host rock sample types have similar major- and traceelement compositions, there are some key differences. Samples containing ferromagnesian silicate minerals, including the barren gabbronorite and the olivinebearing anorthosite have higher $\mathrm{FeO}_{(\mathrm{t})}, \mathrm{MgO}, \mathrm{Co}, \mathrm{Ni}$, and $\mathrm{Zn}$ content and lower abundances of $\mathrm{SiO}_{2}, \mathrm{Al}_{2} \mathrm{O}_{3}$, alkali oxides, $\mathrm{Sr}$ and $\mathrm{Ba}$ compared to true anorthosite. These differences are consistent with the contrasts in mineralogy, as ferromagnesian minerals would have exactly these attributes, and $\mathrm{Sr}$ and $\mathrm{Ba}$ are largely measures of feldspar abundance.

\subsubsection{Massive to semi-massive oxide mineralization}

\subsubsection{Major elements}

Samples of orthopyroxene-rich $(n=8)$ and orthopyroxene-poor $(n=21)$ massive to semi-massive oxide mineralization share similar major element compositions. These oxide-rich rocks are predominantly composed of transition metal oxides including 48.3573.59 wt. $\% \mathrm{FeO}_{(\mathrm{t})}, 5.70-14.14$ wt. $\% \mathrm{TiO}_{2}, 1.52-7.28$ wt. $\% \mathrm{MgO}$, and 0.16-0.37 wt. \% MnO. $\mathrm{SiO}_{2}$ contents have a wide compositional range of $0.48-18.70 \mathrm{wt}$ \%, whereas 
$\mathrm{Al}_{2} \mathrm{O}_{3}$ ranges from 7.24-14.83 wt. \%. The alkali oxides, $\mathrm{CaO}, \mathrm{Na}_{2} \mathrm{O}$, and $\mathrm{K}_{2} \mathrm{O}$ range from 0.01-3.26 wt. \% $\mathrm{CaO}, 0.02-1.66$ wt. $\% \mathrm{Na}_{2} \mathrm{O}$, and 0.02-2.34 wt. \% $\mathrm{K}_{2} \mathrm{O}$ respectively, depending on the abundance of oxide minerals present. Samples of massive to semimassive oxide mineralization contain low $\mathrm{P}_{2} \mathrm{O}_{5}$ contents ranging from $0.01-0.03 \mathrm{wt}$. \% which indicates the low abundance of phosphate minerals including apatite. LOI is below detection limits within massive to semi-massive mineralization, confirming the absence of any hydrous phases.

\subsubsection{Minor and trace elements}

The massive to semi-massive oxide mineralized samples are enriched in transition metals relative to the unmineralized host rocks. Vanadium and $\mathrm{Cr}$ range from 2,052-3,471 ppm and 690-4,410 ppm respectively, whereas $\mathrm{Co}, \mathrm{Ni}$, and $\mathrm{Zn}$ have ranges of $\sim 100$ to 400 ppm. Sr and Ba have wide ranges from a few ppm to several hundred ppm.

\subsubsection{Variation between massive to semi-massive oxide mineralization sample types}

Regardless of the presence or absence of orthopyroxene, the massive to semimassive oxide mineralization shows similar ranges of most major, minor, and trace elements. Exceptions include relative enrichment in $\mathrm{Mg}$ and $\mathrm{Cr}$ in the orthopyroxenebearing samples, coupled with relative depletions in $\mathrm{Al}, \mathrm{Sr}$, and $\mathrm{Ba}$.

\subsubsection{Disseminated oxide mineralization}

Only a small number of samples of disseminated oxide mineralization hosted in anorthosite $(n=2)$ and gabbronorite $(n=2)$ were collected and analyzed.

\subsubsection{Major elements}

Samples of disseminated oxide mineralization hosted in both anorthosite and gabbronorite show large variations in major element compositions. $\mathrm{SiO}_{2}$ content ranges 
from 33.19-47.47 wt. \%, whereas $\mathrm{Al}_{2} \mathrm{O}_{3}$ content ranges from 14.49-23.03 wt. \%. The alkali oxides, range from 4.69-9.02 wt. \%; $\mathrm{CaO}, 2.5-4.43$ wt. $\%, \mathrm{Na}_{2} \mathrm{O}$, and 0.68-1.07 wt. $\% \mathrm{~K}_{2} \mathrm{O}$ respectively. The transition metal oxides, $\mathrm{FeO}_{(\mathrm{t})}, \mathrm{TiO}_{2}, \mathrm{MgO}$, and $\mathrm{MnO}$ range from 11.59-29.87 wt.\%, FeO, 1.94-4.91 wt.\% $\mathrm{TiO}_{2}, 0.99-6.34$ wt.\% $\mathrm{MgO}$, and 0.05-0.19 wt. \% $\mathrm{MnO}$ respectively. $\mathrm{P}_{2} \mathrm{O}_{5}$ content ranges from $0.03-0.06$ wt. $\%$, which indicates the low abundance of phosphate minerals, whereas LOI ranges from 1.06-2.18 wt. \%.

\subsubsection{Minor and trace elements}

The minor and trace element compositions of the disseminated oxide mineralized samples are intermediate between values for the unmineralized host rock and the massive to semi-massive oxide mineralization. Vanadium, $\mathrm{Cr}$, $\mathrm{Sr}$, and $\mathrm{Ba}$ were the most abundant elements detected ranging from 429-1,163 ppm V, 10-1,370 ppm Cr, 13-643 ppm Sr, and 475-925 ppm Ba, respectively. Cobalt, $\mathrm{Ni}$, and $\mathrm{Zn}$, ranged from tens of ppm to a few hundred ppm. Copper, Zn, and S are especially enriched in one sample that contained observable sulfide minerals. In other samples, however, these elements are typically in the range of 100-300 ppm.

\subsubsection{Variation between disseminated mineralization sample types}

As in the unmineralized host rocks, analyses of the gabbronoritic rocks contain higher concentrations of $\mathrm{MgO}, \mathrm{Co}$, and $\mathrm{Ni}$, and lower concentrations of $\mathrm{Sr}$ and $\mathrm{Ba}$. This reflects a higher abundance of Fe-Mg silicate minerals. 


\subsubsection{Geochemical correlations}

A correlation matrix (Fig. 3.10) was used to display positive and negative correlations between elements detected in appreciable amount in whole-rock analyses.

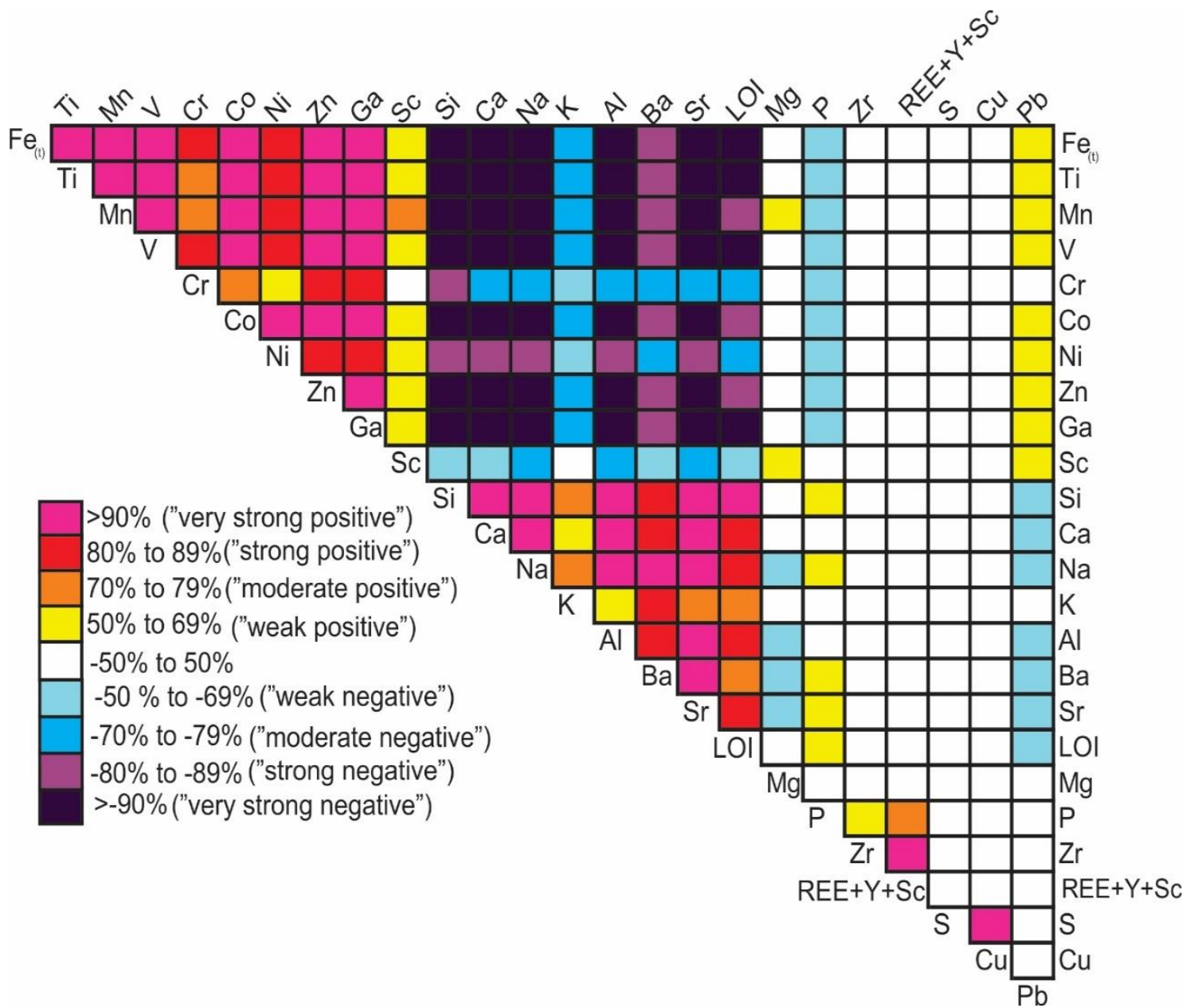

Fig. 3.10 Correlation matrix of elements from whole-rock analyses. Positive correlations are present between all elements associated with Fe-Ti oxide minerals (Fe, Ti, Mn, Cr, $\mathrm{Co}, \mathrm{Ni}, \mathrm{Zn}, \mathrm{Ga}$, and $\mathrm{Sc}$ ), as well as between all elements associated with plagioclase ( $\mathrm{Si}$, $\mathrm{Ca}, \mathrm{Na}, \mathrm{K}, \mathrm{Al}, \mathrm{Ba}, \mathrm{Sr}$, and LOI). Elements associated with Fe-Ti oxide mineralization are negatively correlated with elements associated with plagioclase. Phosphorus, which is correlated to the presence of apatite is weakly positively correlated with plagioclase associated elements and weakly negatively associated with elements associated with FeTi oxide minerals.

Two trends were observed; strong to very strong positive correlations are present between elements compatible in Fe-Ti oxide minerals including Fe, Ti, Mn, V, Cr, Co, $\mathrm{Ni}, \mathrm{Zn}, \mathrm{Ga}$, 
and $\mathrm{Sc}$ as well as between elements that are compatible within plagioclase including $\mathrm{Si}$, $\mathrm{Ca}, \mathrm{Na}, \mathrm{K}, \mathrm{Al}, \mathrm{Ba}$, and $\mathrm{Sr}$. In contrast, elements associated with $\mathrm{Fe}-\mathrm{Ti}$ oxide minerals are negatively to strongly negatively correlated to elements associated with plagioclase. Like elements associated with plagioclase, LOI values are strongly correlated to Si content. Phosphorus, which is typically associated with apatite, is weakly negatively correlated with elements associated with Fe-Ti oxide minerals.

\subsection{Electron microprobe analyses}

\subsubsection{Magnetite Compositions}

\subsubsection{Overview}

Primary $(n=142)$ and recrystallized $(n=12)$ magnetite grains were analyzed in all of the samples. Magnetite lenses and lamellae in ilmenite $(n=49)$, and pleonaste $(n=24)$ were also analyzed where intergrowths were coarse enough to permit the EPMA analyses to be done. Regardless of petrographic context, magnetite typically contains impurities accounting for, on average, $<2$ wt. \% to a maximum value of 6 wt. \% (Fig 3.11 a,b). Magnetite was analyzed for $\mathrm{Si}, \mathrm{Ti}, \mathrm{Al}, \mathrm{Cr}, \mathrm{V}, \mathrm{Fe}, \mathrm{Mn}, \mathrm{Mg}, \mathrm{Zn}, \mathrm{Ni}, \mathrm{Ca}, \mathrm{Cu}$, and $\mathrm{K}$, although some of these present as trace elements proved to be below detection limits and were subsequently not analyzed in those samples. $\mathrm{Fe}^{2+}$ and $\mathrm{Fe}^{3+}$ were approximated from measured $\mathrm{Fe}_{(\mathrm{t})}$ values using calculations based on charge as described previously. However, as noted this approximation may have up to a 10-15\% error compared to the actual values of $\mathrm{Fe}^{2+}$ and $\mathrm{Fe}^{3+}$ in the sample (M.D. Dyar and J.M. Hanchar, personal communication). This does not materially affect the interpretation of the EPMA data. 

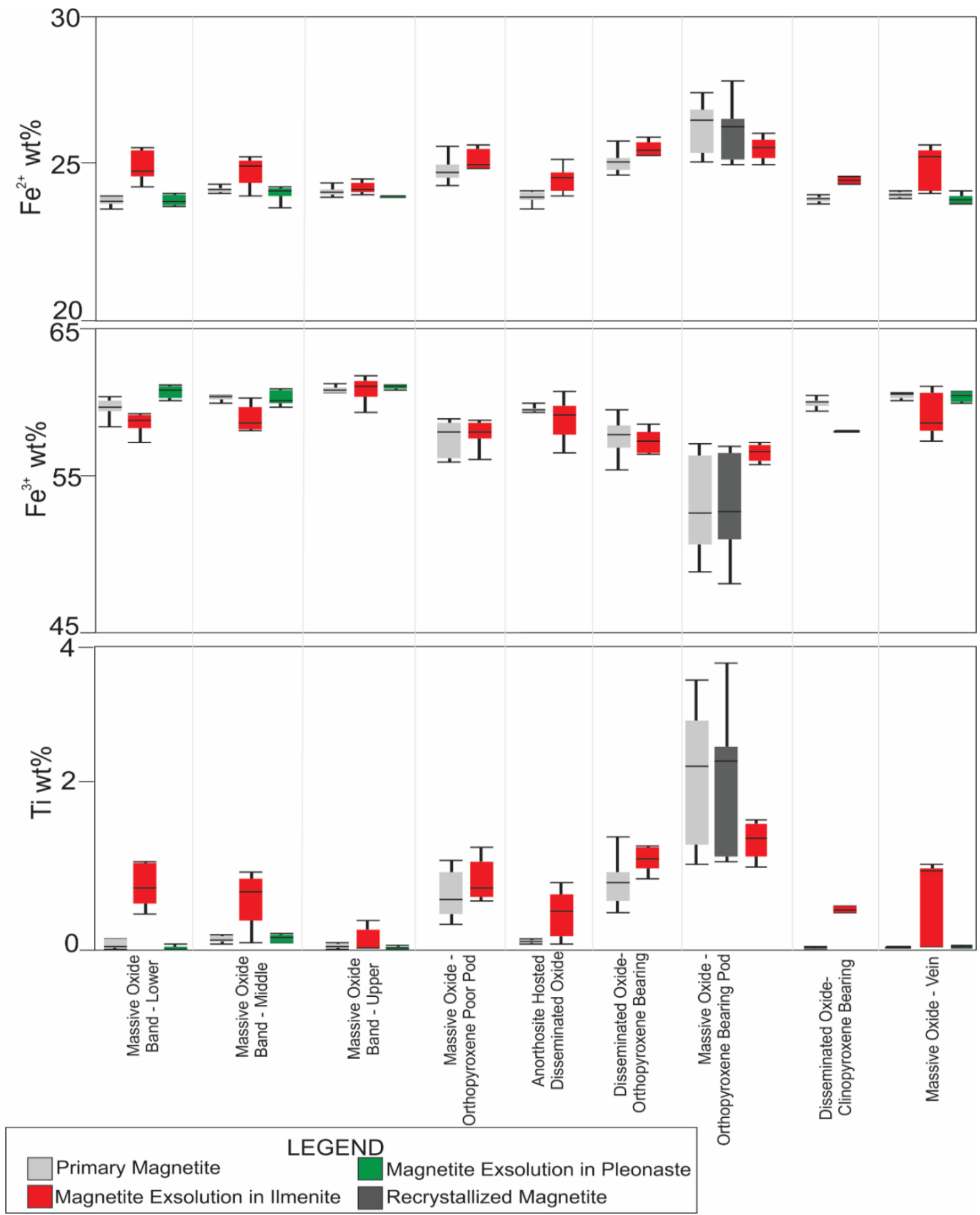

Figure 3.11a Box and whisker plots of $\mathrm{Fe}^{2+}, \mathrm{Fe}^{3+}, \mathrm{Ti}, \mathrm{V}, \mathrm{Al}$ and $\mathrm{Mg}$ in magnetite from different textural settings, plotted as weight $\%$ metal. These plots show the range between the first and third quartiles or data (as the range of the box), the median of the data as the center line and the lines outside of the box showing $95 \%$ of the data. 

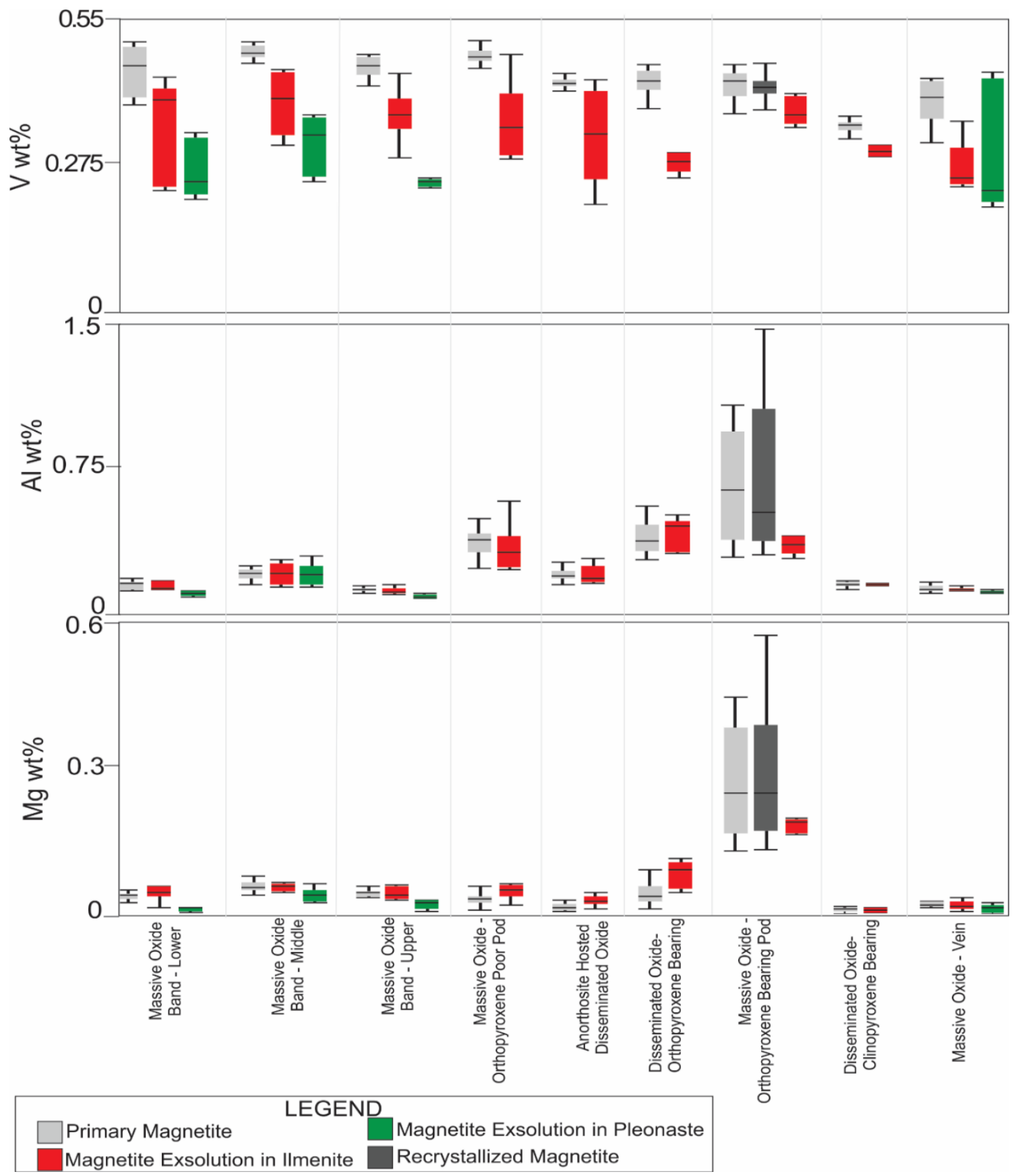

Figure 3.11b Box and whisker plots of $\mathrm{Fe}^{2+}, \mathrm{Fe}^{3+}, \mathrm{Ti}, \mathrm{V}, \mathrm{Al}$ and $\mathrm{Mg}$ in magnetite. These plots show the range between the first and third quartiles of data (as the range of the box), the median of the data as the center line and the lines outside of the box showing $95 \%$ of the data from the style of magnetite. 


\subsubsection{Primary magnetite}

The texturally most primitive magmatic magnetite, hereafter referred to as "primary magnetite" contains $\sim 48-62$ wt. $\% \mathrm{Fe}^{2+}$ and $\sim 23-37$ wt. $\% \mathrm{Fe}^{3+}$. The Ti contents ranges from 0.09-3.78 wt. \%, whereas $\mathrm{Al}, \mathrm{Cr}$, and $\mathrm{V}$, contents range from 0.1-1.5 wt. \% $\mathrm{Al}, 0.16-0.53 \% \mathrm{Cr}$, and $0.31-0.51$ wt. \% V, respectively. Magnesium and $\mathrm{Mn}$ are commonly below the minimum detection limits and, where present, analyzed magnetite contains between 0.06-0.57 wt. \% Mg, and 0.07-0.28 wt. \% Mn (Fig. $3.11 \mathrm{a}, \mathrm{b})$.

\subsubsection{Magnetite lamellae in ilmenite}

Magnetite lamellae hosted in ilmenite are predominantly composed of $\mathrm{Fe}^{2+}$, and $\mathrm{Fe}^{3+}$, with contents ranging from $\sim 24-31$ wt. $\% \mathrm{Fe}^{2+}$ and $\sim 56-62$ wt. $\% \mathrm{Fe}^{3+}$, respectively. Their Ti content ranged from $0.03-1.8$ wt. \% whereas $\mathrm{Al}, \mathrm{Cr}$, and $\mathrm{V}$ contents range from 0.1-0.6 wt. \% Al, 0.01-1.16 wt. \% Cr, and 0.08-0.49 wt. \% V, respectively. Magnesium contents range from below detection limits to $0.19 \mathrm{wt}$ \%. In samples containing both primary magnetite and magnetite lamellae in ilmenite, the magnetite hosted in ilmenite is generally richer in $\mathrm{Ti}$, and poorer in $\mathrm{V}$ and $\mathrm{Cr}$, compared to the primary magnetite (Fig.

\section{$3.11 \mathrm{a}, \mathrm{b})$.}

\subsubsection{Magnetite lenses in pleonaste}

Magnetite lenses hosted in pleonaste are near end-member in composition with $\mathrm{Fe}^{2+}$, and $\mathrm{Fe}^{3+}$ contents ranging from $\sim 24-25$ wt. $\%$ and $\sim 60-61$ wt. $\%$ respectively. Aluminum, $\mathrm{Cr}$, and $\mathrm{V}$ contents are between $0.1-0.3$ wt. \% $\mathrm{Al}, 0.1-0.3$ wt. \% $\mathrm{Cr}$, and 0.20.4 wt. $\% \mathrm{~V}$, respectively. In samples containing both primary magnetite and magnetite lenses in pleonaste, the magnetite hosted in pleonaste is generally poorer in $\mathrm{V}$ and $\mathrm{Cr}$ compared to the primary magnetite (Fig. $3.11 \mathrm{a}, \mathrm{b}$ ). 


\subsubsection{Ilmenite}

\subsubsection{Overview}

The EPMA analyses were done on granular and composite ilmenite with $(n=90)$ and without exsolution $(n=42)$ features, sandwich ilmenite $(n=42)$ and ilmenite dotted

with spinel microcrystals $(n=49)$. Regardless of petrographic context, all ilmenite contains measurable amounts of $\mathrm{V}, \mathrm{Mn}$, and $\mathrm{Mg}$ (Fig. $3.12 \mathrm{a}, \mathrm{b})$.

\subsubsection{Composite ilmenite with exsolution lamellae}

Composite ilmenite containing exsolution lamellae is predominantly composed of Ti and $\mathrm{Fe}^{2+}$ with 28.0-31.7 wt. \% Ti, and $\sim 30-34$ wt. $\% \mathrm{Fe}^{2+}$, respectively. $\mathrm{Fe}^{3+}, \mathrm{V}, \mathrm{Mn}$ and $\mathrm{Mg}$ range from $~ 1-8$ wt.\% $\mathrm{Fe}^{3+}, 0.11-0.24$ wt.\%, V, 0.22-0.94 wt. \% Mn, and 0.242.18 wt.\% Mg (Fig. 3.12 a,b).

\subsubsection{Composite ilmenite without exsolution}

Composite ilmenite grains without exsolution lamellae have $\mathrm{Ti}$ and $\mathrm{Fe}^{2+}$ contents that range from 28.6-31.7 wt. $\% \mathrm{Ti}$, and $\sim 30-35$ wt. $\% \mathrm{Fe}^{2+}$ respectively. $\mathrm{Fe}^{3+}, \mathrm{V}, \mathrm{Mn}$, and $\mathrm{Mg}$ range from $\sim 0-7$ wt. $\% \mathrm{Fe}^{3+}, 0.10-0.24$ wt. $\% \mathrm{~V}, 0.32-1.6$ wt. $\% \mathrm{Mg}$, and 0.18-2.17 wt. \% Mn, respectively. The overall compositions differ little from those of grains that show exsolution lamellae (Fig. 3.12 a,b).

\subsubsection{Sandwich ilmenite}

Thick ilmenite lamellae growing parallel to only one set of $\{111\}$ planes in magnetite, termed sandwich ilmenite, contain $29.2-31.8$ wt. $\%$ Ti and $\sim 31-36$ wt. $\% \mathrm{Fe}^{2+}$. $\mathrm{Fe}^{3+}, \mathrm{V}, \mathrm{Mn}$, and $\mathrm{Mg}$, range from $~ 0-6$ wt. \% $\mathrm{Fe}^{3+}, 0.09-0.25$ wt. \% V, 0.39-2.29 wt. \% Mn, and 0.15-1.39 wt. \% Mg, respectively (Fig. 3.12 a,b). 

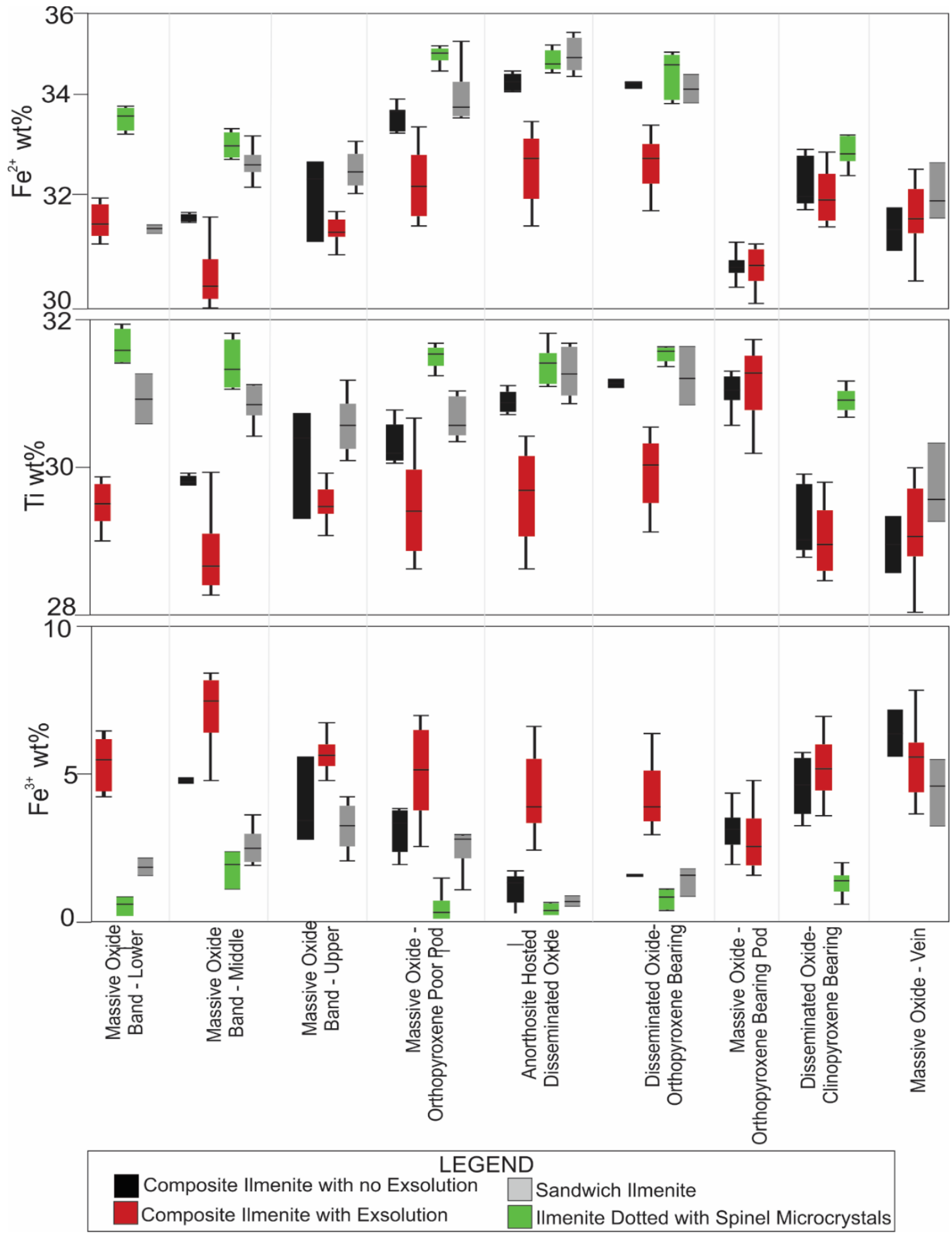

Figure 3.12a. Box and whisker type plot showing variation in $\mathrm{Fe}^{2+}, \mathrm{Ti}, \mathrm{Fe}^{3+}, \mathrm{V}, \mathrm{Mg}$, and $\mathrm{Mn}$ content in ilmenite from various textures and various mineralization styles. 

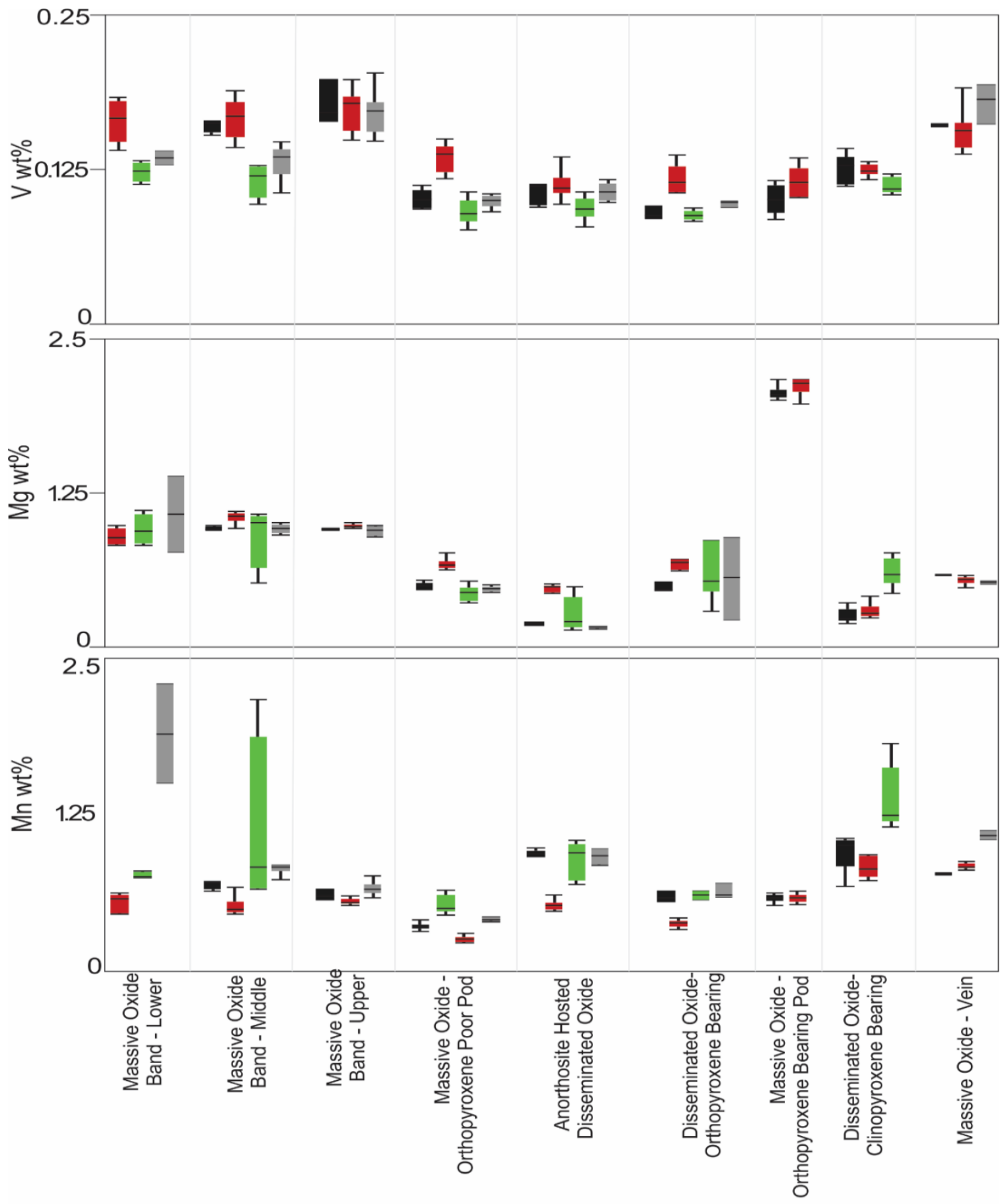

Figure 3.12b Box and whisker type plot showing variation in $\mathrm{Fe}^{2+,} \mathrm{Ti}, \mathrm{Fe}^{3+}, \mathrm{V}, \mathrm{Mg}$, and Mn content in ilmenite from various textures and various mineralization styles. 


\subsubsection{Ilmenite "dotted" with spinel microcrystals}

The ilmenite fraction of ilmenite that is dotted with spinel microcrystals was also analyzed. In terms of $\mathrm{Ti}$ and $\mathrm{Fe}^{2+}$ content, this ilmenite contains 30.7-31.8 wt. \% Ti, and $\sim 33-35$ wt. $\% \mathrm{Fe}^{2+}$, respectively. $\mathrm{Fe}^{3+}, \mathrm{V}, \mathrm{Mn}$ and $\mathrm{Mg}$ range from $\sim 0-2$ wt. $\% \mathrm{Fe}^{3+}, 0.09-$ 0.14 wt. \% V, 0.44-1.82 wt. \% Mn, and 0.14-1.0 wt. \% Mg respectively (Fig. 3.12 a,b).

\subsubsection{Pleonaste}

\subsubsection{Overview}

Only a few pleonaste analyses were done compared to the number of analyses of magnetite and ilmenite, because coarse-grained analyzable pleonaste is relatively uncommon in the samples studied. As such, it is not clear if these pleonaste analyses presented are truly representative of the chemical composition of pleonaste in the NWRA.

Pleonaste within the NWRA occurs with a variety of exsolution textures within the oxide mineralization. Coarse-grained pleonaste containing magnetite exsolution $(\mathrm{n}=15)$, coarse-grained pleonaste without magnetite exsolution $(\mathrm{n}=12)$, pleonaste exsolution microtextures in ilmenite $(\mathrm{n}=11)$, and the pleonaste component of spinel dotted with pleonaste microcrystals $(n=4)$ were analyzed by EPMA. Where analyzed, pleonaste

typically contains detectable amounts of $\mathrm{Ti}, \mathrm{Al}, \mathrm{Cr}, \mathrm{Fe}^{3+}, \mathrm{Fe}^{2+}, \mathrm{Mn}, \mathrm{Mg}$, and $\mathrm{Zn}$ (Fig $3.13 \mathrm{a}, \mathrm{b})$.

\subsubsection{Pleonaste with magnetite exsolution}

Pleonaste containing magnetite exsolution is predominantly composed of $\mathrm{Mg}$, $\mathrm{Fe}^{2+}$ and $\mathrm{Al}$, containing 4.6-7.1 wt. \% $\mathrm{Mg}, \sim 17-21$ wt. $\% \mathrm{Fe}^{2+}$, and 29.6-31.7 wt. \% $\mathrm{Al}$ respectively. Other elements detected include $\mathrm{Cr}, \mathrm{Fe}^{3+}, \mathrm{Mn}$, and $\mathrm{Zn}$ which range from 0.16-0.40 wt. \% Cr, $3-5$ wt. \% $\mathrm{Fe}^{3+}, 0.15-0.35$ wt. \% Mn, and 0.46-1.47 wt. \% Zn, respectively (Fig 3.13 a,b). 


\subsubsection{Pleonaste without magnetite exsolution}

Pleonaste without magnetite exsolution is predominantly composed of $\mathrm{Mg}, \mathrm{Fe}^{2+}$, and $\mathrm{Al}$, containing 4.3-8.8 wt. \% $\mathrm{Mg}, \sim 14-22$ wt. $\% \mathrm{Fe}^{2+}$, and 29.7-32.8 wt. \% $\mathrm{Al}$, respectively. Other elements detected include $\mathrm{Cr}, \mathrm{Fe}^{3+}, \mathrm{Mn}$, and $\mathrm{Zn}$, which range from $0.22-0.35$ wt. $\% \mathrm{Cr}, \sim 2-5$ wt. $\% \mathrm{Fe}^{3+}, 0.14-0.19$ wt. $\% \mathrm{Mn}$, and 0.18-0.73 wt. \% Zn (Fig 3.13a,b), respectively.

\subsubsection{Pleonaste lamellae in ilmenite}

Pleonaste lamellae in ilmenite are composed of $\mathrm{Mg}, \mathrm{Fe}^{2+}$, and $\mathrm{Al}$, containing 4.19.0 wt. $\% \mathrm{Mg}, \sim 15-24$ wt. $\% \mathrm{Fe}^{2+}$, and 30.1-33.3 wt. \% Al, respectively. Other elements detected include $\mathrm{Ti}, \mathrm{Cr}, \mathrm{Fe}^{3+}, \mathrm{Mn}$, and $\mathrm{Zn}$ ranging from 0.30-0.68 wt. \% Ti, 0.34-0.93 wt.\% $\mathrm{Cr}, \sim 1-3$ wt. $\% \mathrm{Fe}^{3+}, 0.1-0.5$ wt. \% Mn, and 0.29-0.65 wt.\% Zn, respectively (Fig $3.13 a, b)$.

\subsubsection{Pleonaste from ilmenite dotted with pleonaste microcrystals}

Pleonaste from ilmenite dotted with pleonaste microcrystals was only analyzed in one sample where it is predominantly composed of $\mathrm{Mg}, \mathrm{Fe}^{2+}$, and $\mathrm{Al}$, with ranges from 4.3-4.5 wt. \% Mg, 22-23 wt. \% $\mathrm{Fe}^{2+}$, and 29.6-29.9 wt. \% Al, respectively. Other

elements detected include $\mathrm{Ti}, \mathrm{Cr}, \mathrm{Fe}^{3+}, \mathrm{Mn}$ and $\mathrm{Zn}$ which range from $0.44-0.78 \mathrm{wt} . \% \mathrm{Ti}$, 0.81-1.02 wt.\% Cr, 1-2 wt. \% Fe ${ }^{3+}, 0.02-0.12$ wt. \% Mn, and 0.46-0.61 wt.\% Zn, respectively (Fig 3.13a,b). 

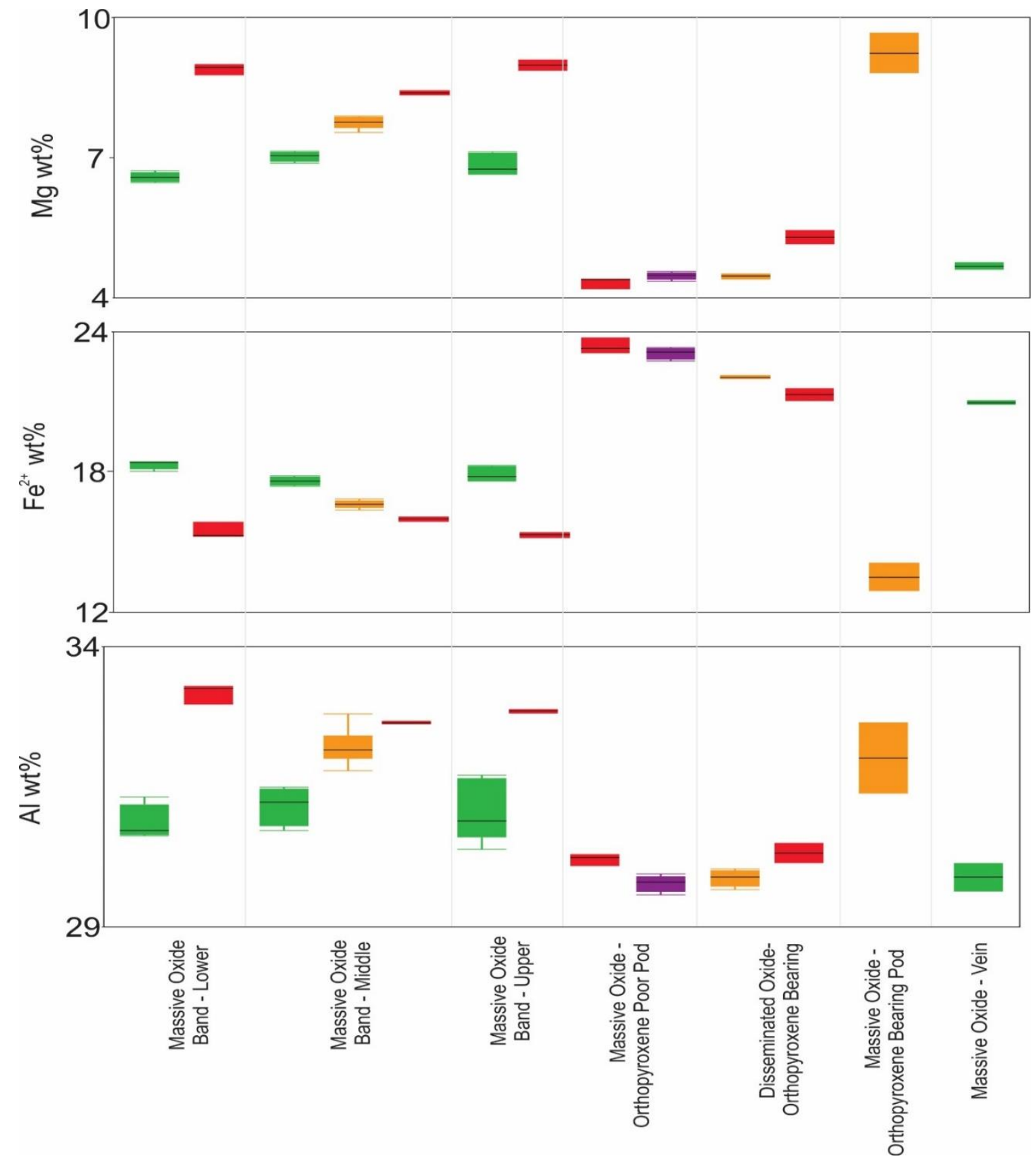

\begin{tabular}{|c|c|}
\hline \multicolumn{2}{|c|}{ LEGEND } \\
$\square$ Pleonaste with Exsolution & Pleonaste hosted in Ilmenite \\
$\square$ Pleonaste without Exsolution & $\begin{array}{l}\text { Pleonaste from Ilmenite Dotted } \\
\text { with Pleonaste Microcrystals }\end{array}$ \\
\hline
\end{tabular}

Figure 3.13a. Box and whisker plot showing variation in $\mathrm{Mg}, \mathrm{Fe}^{2+}, \mathrm{Al}, \mathrm{Fe}^{3+}$, $\mathrm{Ti}$ and $\mathrm{Mn}$ content between various textures of pleonaste from various mineralization styles. 

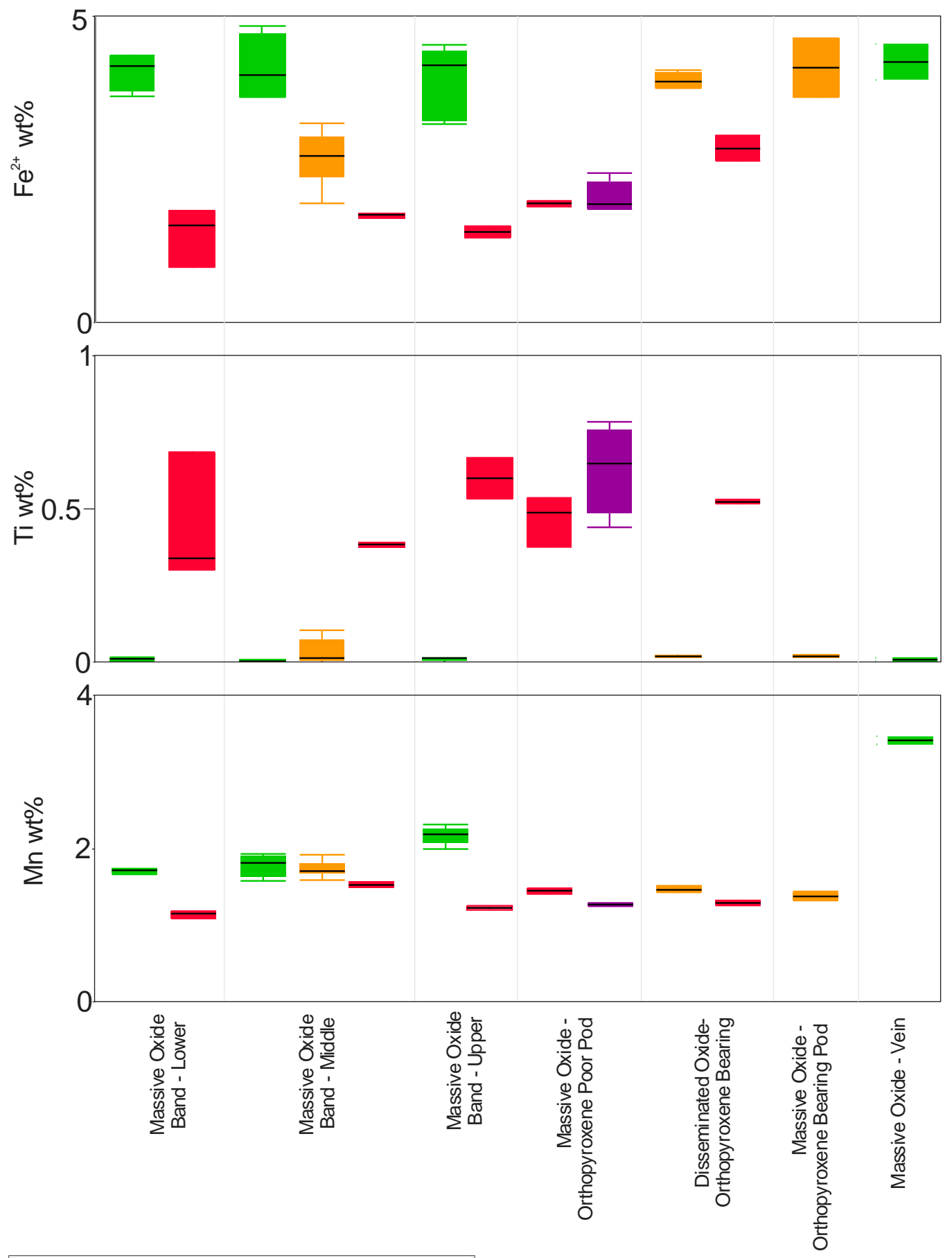

Pleonaste with Exsolution $\quad$ Pleonaste hosted in IImenite Pleonaste without Exsolution $\square$ Pleonaste from Ilmenite Dotted

Figure 3.13b. Box and whisker plot showing variation in $\mathrm{Mg}, \mathrm{Fe}^{2+}, \mathrm{Al}, \mathrm{Fe}^{3+}$, $\mathrm{Ti}$ and $\mathrm{Mn}$ content between various textures of pleonaste from various mineralization styles. 


\subsection{Mineral compositions determined by LA-ICPMS}

\subsubsection{Magnetite}

\subsubsection{Overview}

Primary magmatic $(n=103)$ and granoblastic $(n=13)$ magnetite grains from all mineralization styles were analyzed in situ using LA-ICPMS to determine their trace element compositions (Fig 3.14 a,b). In magnetite, Si, Al, Ga, Mn, Mg, Ti, Zn, Co, V, Ni, and $\mathrm{Cr}$ were detected in appreciable amounts, whereas $\mathrm{Ca}, \mathrm{Y}, \mathrm{P}, \mathrm{Pb}, \mathrm{Zr}, \mathrm{Hf}, \mathrm{Ge}, \mathrm{W}, \mathrm{Sc}$, $\mathrm{Ta}, \mathrm{Nb}, \mathrm{Mo}, \mathrm{Sn}, \mathrm{As}$, and $\mathrm{Sb}$ were limited to $<\sim 10 \mathrm{ppm}$ at maximum when detected.

\subsubsection{Results}

The most abundant trace elements detected in primary magmatic magnetite were Al, Ti, V, Cr, Mg, and Si which ranged from 1,852 ppm-3.3 wt. \% Al, 313 ppm - 4.3 wt. \% Ti, 3,124-6,469 ppm V, 1,464-4,539 ppm Cr, 333-6,000 ppm Mg, and 50-3,000 ppm $\mathrm{Si}$, respectively. Other elements detected include $\mathrm{Ga}, \mathrm{Mn}, \mathrm{Zn}, \mathrm{Co}$, and $\mathrm{Ni}$ which range from 31-85 ppm Ga, 67-1896 ppm Mn, 3-500ppm Zn, 47-206 ppm Co, and 93-507 ppm Ni, respectively (Fig. 3.14 a,b). Analyses show that the recrystallized granoblastic magnetite, like the primary magnetite, contain abundant $\mathrm{Al}, \mathrm{Ti}, \mathrm{V}, \mathrm{Cr}, \mathrm{Mg}$, and $\mathrm{Si}$, ranging from 1.4-2.8 wt. \% Al, 2.4-3.2 wt. \% Ti, 4223-4519 ppm V, 2085-2417 ppm Cr, 5129-6257 ppm Mg, and 56-726 ppm Si, respectively. As in the primary magnetite, in the recrystallized granoblastic magnetite the less abundant elements include $\mathrm{Ga}, \mathrm{Mn}, \mathrm{Zn}, \mathrm{Co}$, and Ni with ranges of 55-67 ppm Ga, 1,848-2,270 ppm Mn, 52-455 ppm Zn, 16-20 ppm Co, and 306-342 ppm Ni, respectively (Fig. 3.14 a,b). 

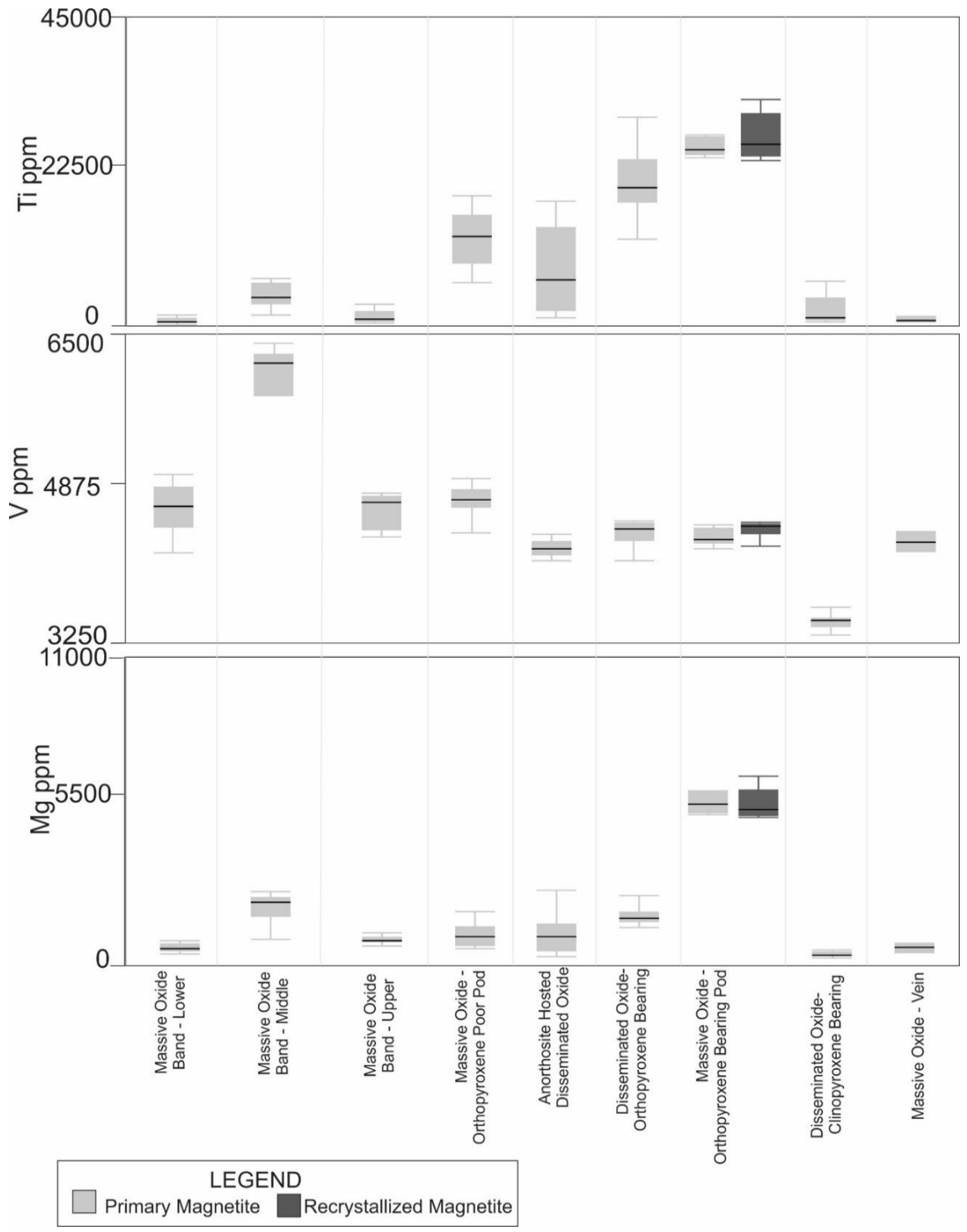

Figure 3.14a. Box and whisker type plots of LA-ICPMS data showing variation in Ti, V, $\mathrm{Mg}, \mathrm{Mn}, \mathrm{Cr}$, and $\mathrm{Ni}$ content in magnetite from various mineralization styles. 


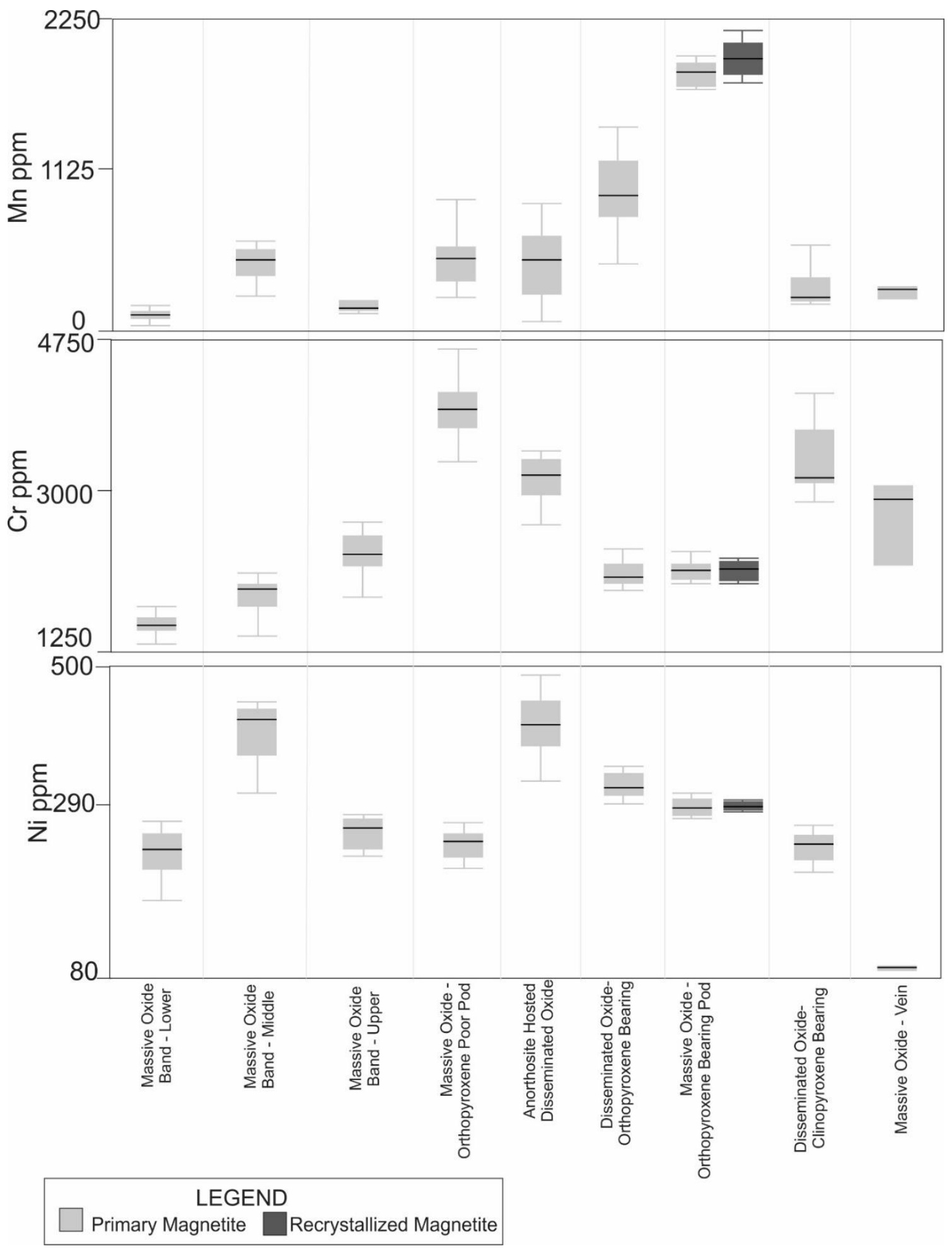

Figure $3.14 \mathrm{~b}$. Box and whisker type plots of LA-ICPMS data showing variation in Ti, V, $\mathrm{Mg}, \mathrm{Mn}, \mathrm{Cr}$, and $\mathrm{Ni}$ content in magnetite from various mineralization styles. 


\subsubsection{Ilmenite}

\subsubsection{Overview}

Composite ilmenite with exsolution of magnetite, hematite and pleonaste, without exsolution, and sandwich ilmenite were also analyzed by LA-ICPMS (Fig. 3.15 a,b). Of all the elements analyzed, $\mathrm{Mg}, \mathrm{Al}, \mathrm{Si}, \mathrm{Sc}, \mathrm{V}, \mathrm{Cr}, \mathrm{Mn}, \mathrm{Co}, \mathrm{Ni}, \mathrm{Zr}$ and $\mathrm{Zn}$ were present in appreciable concentrations whereas $\mathrm{P}, \mathrm{Ca}, \mathrm{Cu}, \mathrm{Ga}, \mathrm{Ge}, \mathrm{As}, \mathrm{Y}, \mathrm{Mo}, \mathrm{Sn}, \mathrm{Sb}, \mathrm{Hf}, \mathrm{Ta}, \mathrm{W}$ and $\mathrm{Pb}$ were limited to $<\sim 10 \mathrm{ppm}$ at maximum when detected.

\subsubsection{Results}

Ilmenite containing exsolution lamellae of magnetite, hematite and pleonaste contain abundant $\mathrm{Mg}, \mathrm{Al}, \mathrm{Si}, \mathrm{V}$, and $\mathrm{Mn}$ ranging from 3,076 ppm to $2.2 \mathrm{wt}$ \% $\mathrm{Mg}, 134-$ 4,470 ppm Al, 45-3,760 ppm Si, 395-2,800 ppm V, and 2.5 ppm to 1.3 wt. \% $\mathrm{Mn}$, respectively. Less abundant elements include $\mathrm{Sc}, \mathrm{Cr}, \mathrm{Co}, \mathrm{Ni}, \mathrm{Zn}, \mathrm{Zr}$, and $\mathrm{Nb}$ which range from 20-69 ppm Sc, 30-434 ppm Cr, 64-123 ppm Co, 14-84 ppm Ni, 5-172 ppm Zn, 6223 ppm Zr, and 2-40 ppm Nb, respectively (Fig. 3.15 a,b).

Composite ilmenite grains without exsolution contain abundant $\mathrm{Mg}, \mathrm{Al}, \mathrm{Si}, \mathrm{V}$, and Mn with ranges including 2,089 ppm to 2.4 wt. \% Mg, 134 ppm to 1.6 wt. \% Al, 44-3,760 ppm Si, 311-2,800 ppm V, and 2,446 ppm to $1.3 \mathrm{wt} . \% \mathrm{Mn}$, respectively. Less abundant

elements include $\mathrm{Sc}, \mathrm{Cr}, \mathrm{Co}, \mathrm{Ni}, \mathrm{Zn}, \mathrm{Zr}$, and $\mathrm{Nb}$, which range from 18-76 ppm Sc, 30-432 ppm Cr, 47-146 ppm Co, 14-84 ppm Ni, 3-226 ppm Zn, 13-223 ppm Zr, and 2-40 ppm $\mathrm{Nb}$ (Fig. 3.24). 

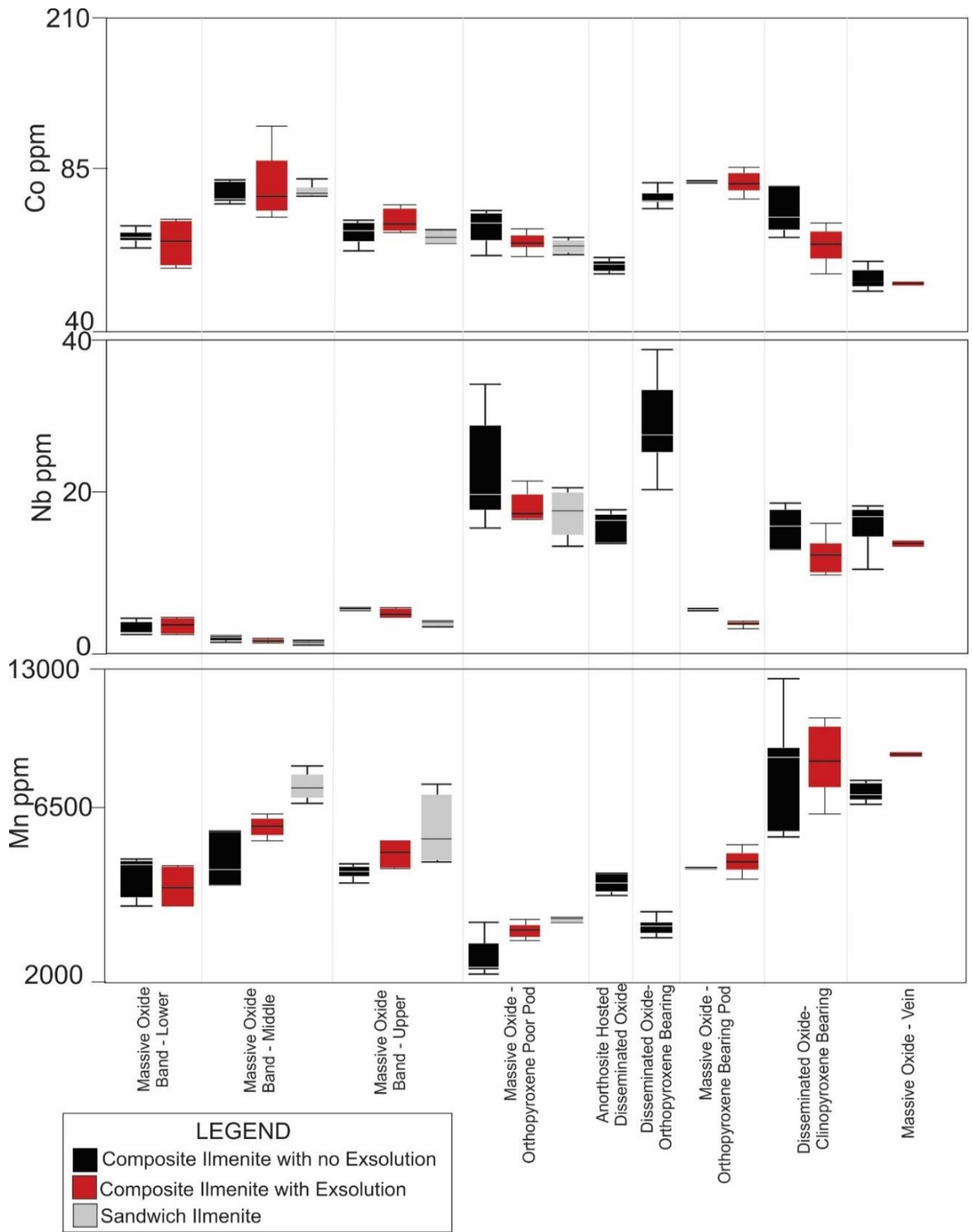

Figure 3.15a. Box and whisker type plots of LA-ICPMS data showing variation in Co, $\mathrm{Nb}, \mathrm{Mn}, \mathrm{V}, \mathrm{Sc}$, and $\mathrm{Zr}$ content in ilmenite from various textures and various mineralization styles. 

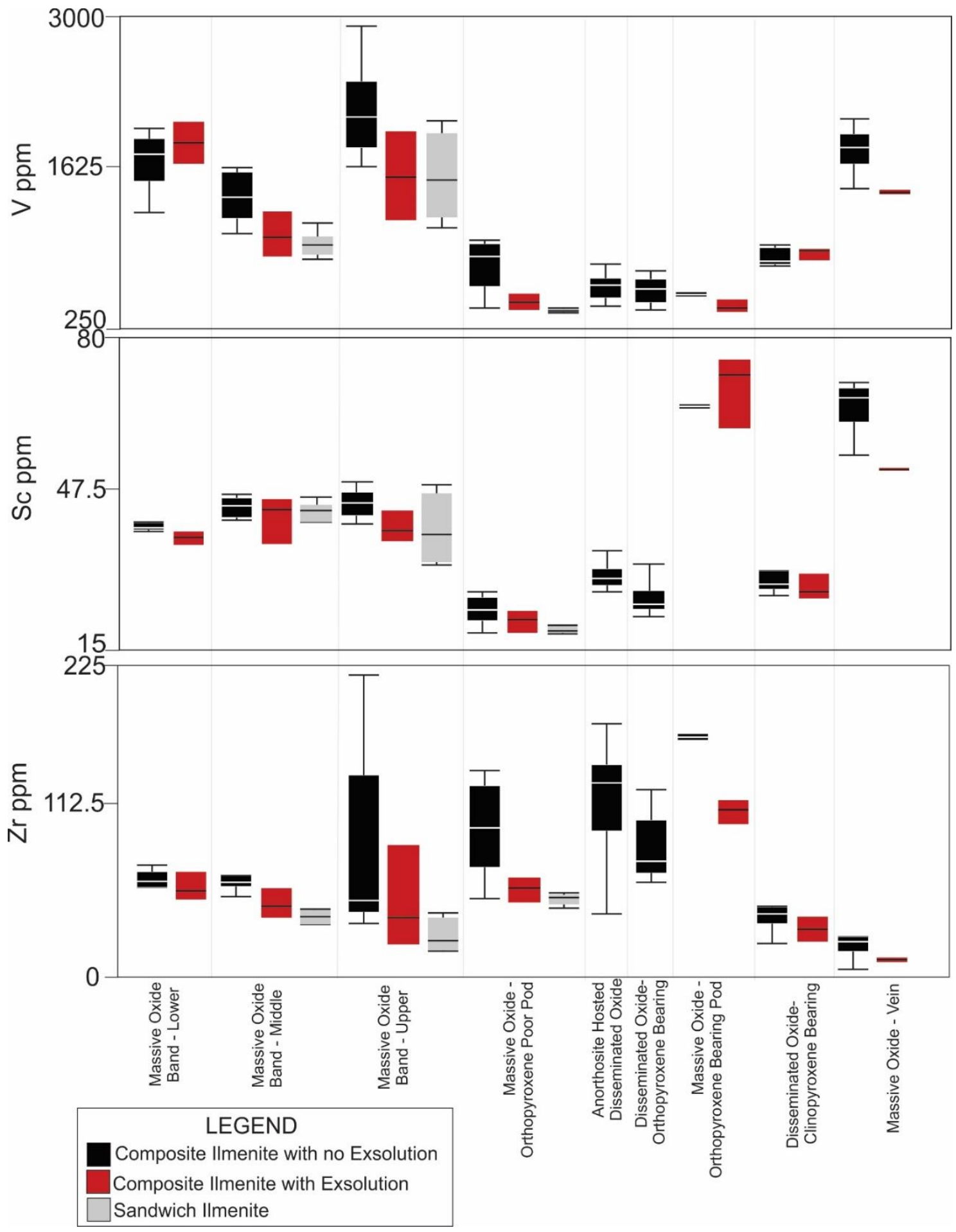

Figure 3.15b. Box and whisker type plots of LA-ICPMS data showing variation in Co, $\mathrm{Nb}, \mathrm{Mn}, \mathrm{V}, \mathrm{Sc}$, and $\mathrm{Zr}$ content in ilmenite from various textures and various mineralization styles. 
Sandwich ilmenite contains abundant $\mathrm{Mg}, \mathrm{Al}, \mathrm{Si}, \mathrm{V}$, and $\mathrm{Mn}$, which range from 4,755 ppm to 1.1 wt. \% Mg, 109-1,060 ppm Al, 374-2,000 ppm Si, 109-1,060 ppm V, and 4,213-9,550 ppm Mn, respectively. Less abundant elements include $\mathrm{Sc}, \mathrm{Cr}, \mathrm{Co}, \mathrm{Ni}, \mathrm{Zn}$ and Zr which range from 20-49 ppm Sc, 99-256 ppm Cr, 83-124 ppm Co, 43-81 ppm Ni, 4-100 ppm Zn, and 19-109 ppm Zr, respectively (Fig. 3.15 a,b).

\subsubsection{Pleonaste}

\subsubsection{Overview}

As noted above, relatively few LA-ICPMS analyses of pleonaste were completed compared to the magnetite and ilmenite analyses due to a lack of coarse-grained pleonaste. Pleonaste containing magnetite exsolution, and medium grained pleonaste without magnetite exsolution were analyzed. $\mathrm{Fe}, \mathrm{Mg}, \mathrm{Si}, \mathrm{Pb}, \mathrm{Ca}, \mathrm{V}, \mathrm{Cr}, \mathrm{Mn}, \mathrm{Co}, \mathrm{Ni}, \mathrm{Zn}$, and $\mathrm{Ga}$ were detected in appreciable amounts (> 1 ppm).

\subsubsection{Results}

Pleonaste granules without exsolution predominantly contain $\mathrm{Si}, \mathrm{Pb}, \mathrm{Ca}$, and $\mathrm{V}$. Specifically, contents range from 500 ppm-1.2 wt. \% Si, 2-189 ppm Pb, 8-352 ppm Ca and 387-2560 ppm V respectively. Chromium, $\mathrm{Mn}, \mathrm{Co}, \mathrm{Ni}, \mathrm{Zn}$, and Ga contents range from 2068-4733 ppm Cr, 1368-2674 ppm Mn, 472-1410 ppm Co, 557-1121 ppm Ni, 3164-9380 ppm Zn, and 166-372 ppm Ga respectively (Fig 3.16 a,b). 

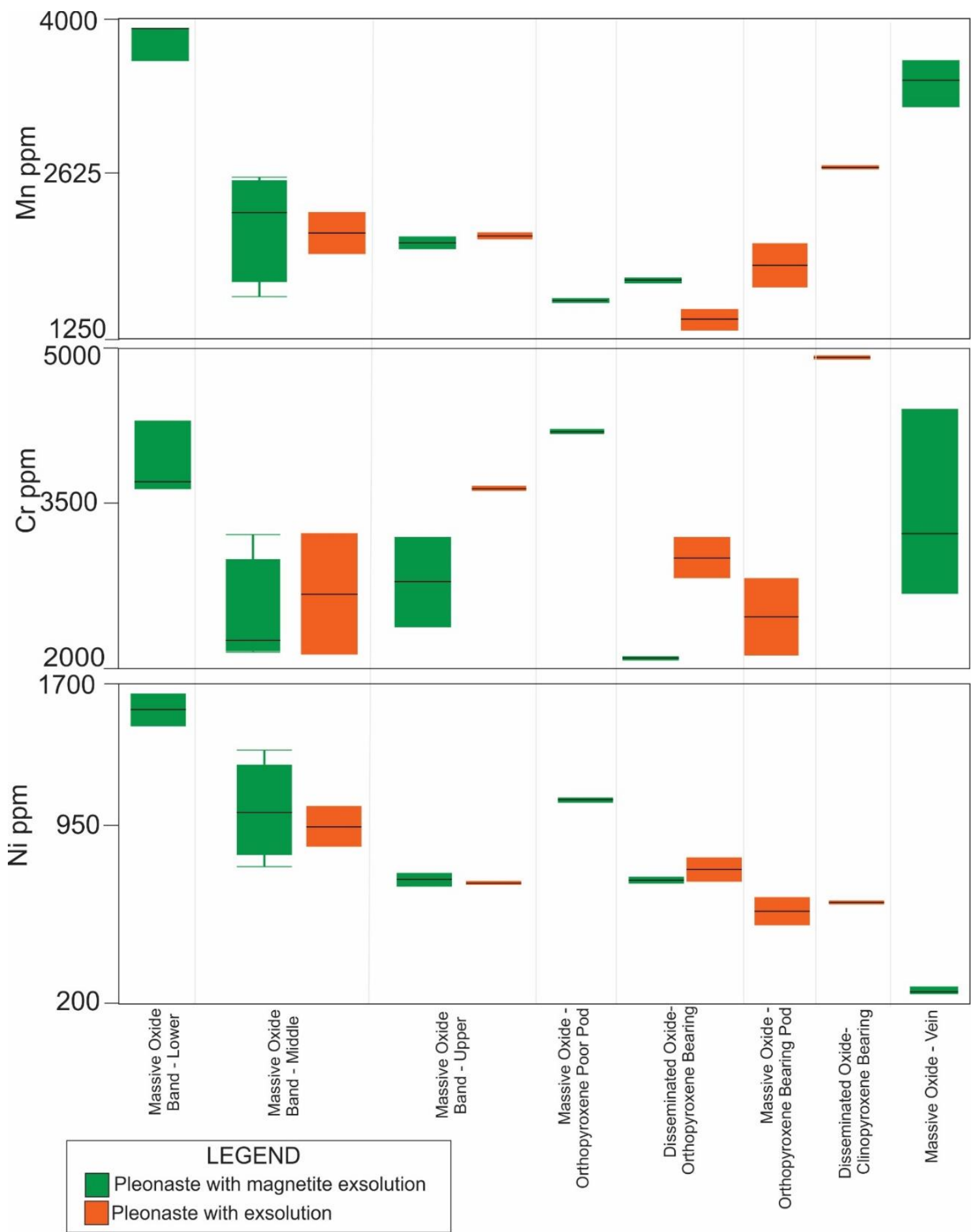

Figure 3.16a. Box and whisker type plots of LA-ICPMS data showing variation in Fe, $\mathrm{Mg}, \mathrm{Cr}, \mathrm{Mn}, \mathrm{Co}$, and $\mathrm{Zn}$ content in pleonaste from various textures and various mineralization styles. 


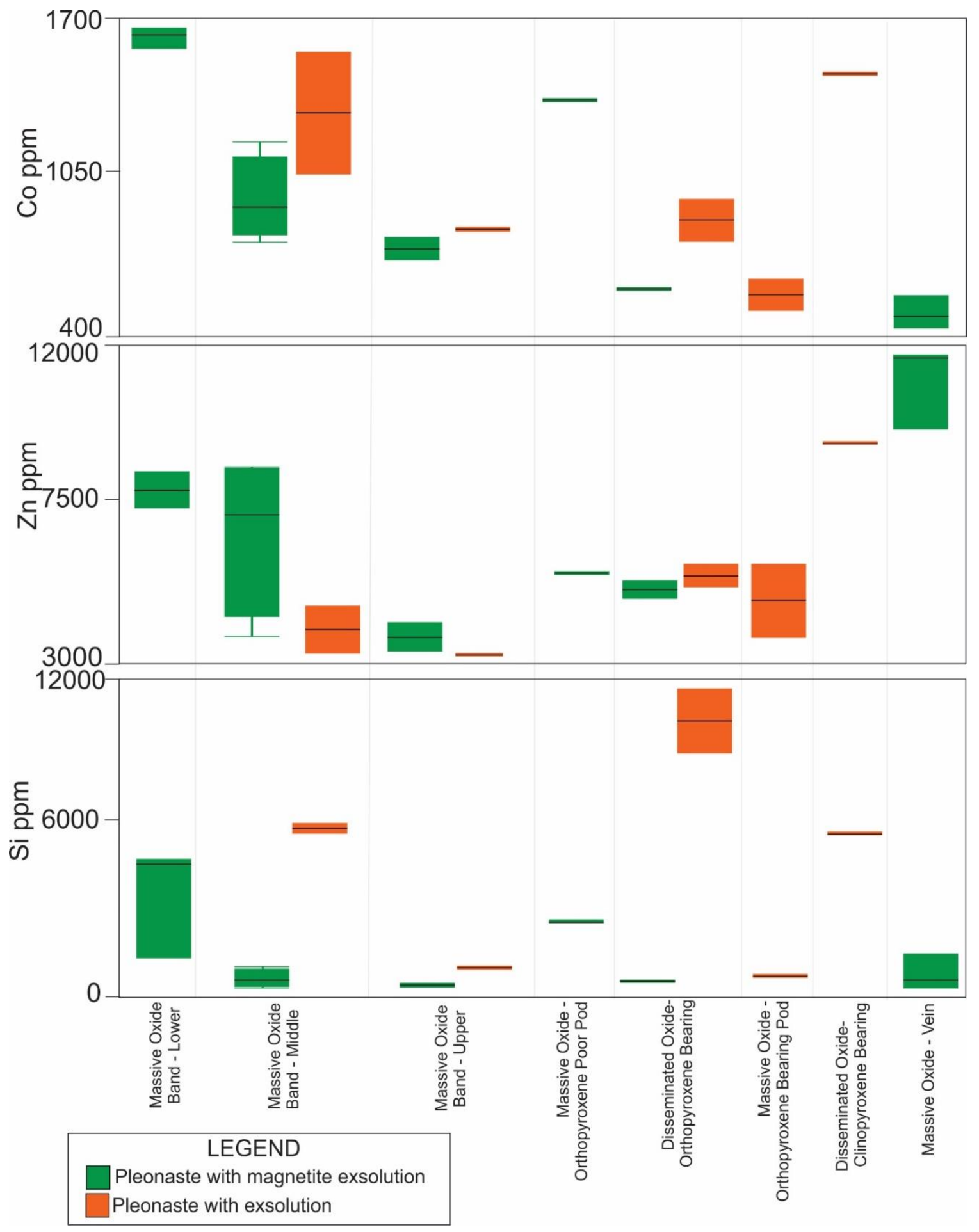

Figure 3.16b Box and whisker type plots of LA-ICPMS data showing variation in Fe, Mg, $\mathrm{Cr}, \mathrm{Mn}, \mathrm{Co}$, and $\mathrm{Zn}$ content in pleonaste from various textures and various mineralization styles. 


\subsubsection{Wavelength Dispersal Spectroscopy (WDS) X-ray maps of Oxide Grains}

Wavelength dispersal spectroscopy (WDS) X-ray maps using the EPMA were made on representative grains of magnetite and ilmenite as well as at contacts between magnetite and ilmenite in order to elucidate the presence of spatial chemical variation and to better understand exsolution features and related textures. Cryptic spatial zonation, as well as growth zoning, has been observed in hydrothermal magnetite by Dare et al. (2014); Knipping et al. (2015); and Broughm et al. (2017).

In this study $\mathrm{Fe}, \mathrm{Ti}, \mathrm{V}, \mathrm{Al}$, and $\mathrm{Mg}$ contents were mapped in eight regions from six thin sections. Maps containing representative results are shown in Fig. 3.17. These maps are semi-quantitative and shown with a colour gradient scale; warm colours representing relative higher abundance of the element in question, whereas cooler colours represent lower abundances of that element (Fig 3.17). In general, similar chemical features are observed for each element in all of the maps made using this technique. Magnetite is relatively homogeneous with a few exceptions. Adjacent to ilmenite, magnetite has a narrow rim that is slightly enriched in $\mathrm{Ti}$, coupled with a slight depletion of $\mathrm{V}$. An increase in $\mathrm{Ti}, \mathrm{Mg}$, and $\mathrm{Al}$ coupled with a depletion of $\mathrm{Fe}$ is present in structures that mimic the typical shape of spinel lenses and ilmenite lamellae observed in magnetite under reflected light. These lenses and lamellae are typically most abundant in the cores of magnetite grains and least abundant in areas near contacts with adjacent silicates or ilmenite.

Ilmenite grains that are adjacent to magnetite typically display a narrow rim enriched in Ti, coupled with a depletion in Fe. Locally, this zone contains irregular zones enriched in $\mathrm{Mg}$ and $\mathrm{Al}$, which correspond to zones of aluminous spinel identified during 

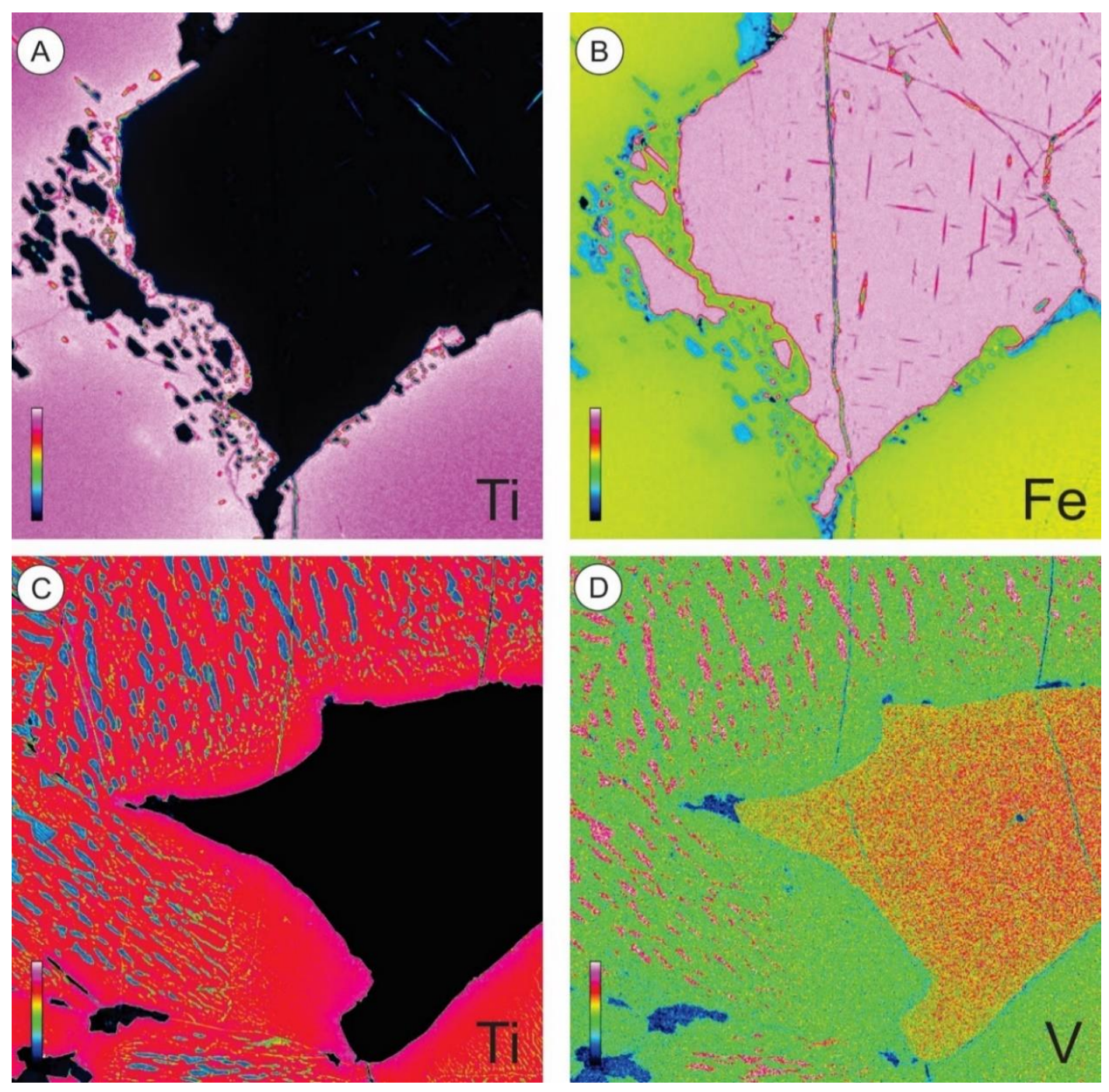

Figure 3.17. Representative EPMA WDS X-ray maps of magnetite, ilmenite, and pleonaste from selected mineralized samples. Maps have a relative "temperature" scale with the warmest colours representing the highest abundance of the element in question: A) Ti content variations at the contact between magnetite and ilmenite; note high Ti rim in ilmenite (pink in colour) at contact with magnetite and lamellae in magnetite slightly enriched in $\mathrm{Ti}$; B) map showing variation in Fe content from the area analyzed in figure A. Note zone of low Fe at contact between magnetite (pink) and ilmenite (yellow). Dark pink lenses in magnetite correspond with pleonaste exsolution features as observed with transmitted light microscopy; C) WDS map of Ti content variation at contact between ilmenite and magnetite. As in A, a high Ti rim is present in ilmenite (red) immediately adjacent to contact between magnetite (black) and ilmenite. Note low Ti lenses in ilmenite correspond with hematite as observed with reflected light microscopy; and D) V content variation from the area analyzed in $\mathrm{C}$. Note slight enrichment in $\mathrm{V}$ content in core of magnetite grain vs rim and enriched $\mathrm{V}$ content in hematite lenses in ilmenite. 
petrography. Two exsolution textures within ilmenite are illustrated well by WDS X-ray mapping.

The first shares a textural form with hematite lenses identified petrographically, and is chemically defined by an enrichment in Fe and V coupled, with a depletion of Ti. Within the largest of these hematite lenses, lamellae enriched in $\mathrm{Ti}$ are present. In general, hematite lenses are most abundant at the core of ilmenite grains and gradationally diminish in abundance approaching the contacts between ilmenite and magnetite. The second intergrowth texture is composed of lamellar features that are enriched in $\mathrm{Al}$ and $\mathrm{Mg}$ and depleted in Fe compared to the host ilmenite. These lamellae correspond with pleonaste observed in thin section. Surrounding these lamellae are zones slightly enriched in Ti and slightly depleted in Fe.

\section{REFERENCES}

Broughm SG, Hanchar JM, Tornos F, Westhaus A, Attersley S (2017) Mineral chemistry of magnetite from magnetite-apatite mineralization and their host rocks: examples from Kiruna, Sweden, and El Laco, Chile. Mineralium Deposita 51: 1223-1244

Butt JM (2000) Mineral chemistry and mineral reactions in a meta-anorthosite complex, Cape Caribou River Allochthon, Grenville Province, Labrador. Unpublished B.Sc. thesis, Memorial University of Newfoundland, St. John's NL, 111 pages

Charlier B, Namur O, Bolle O, Latypov R, Duchesne JC (2015) Fe-Ti-V-P ore deposits associated with Proterozoic massif-type anorthosites and related rocks. EarthScience Reviews 141: 56-81

Dare SA, Barnes SJ, Beaudoin G, Meric J, Boutroy E, Potvin-Doucet C (2014) Trace elements in magnetite as petrogenetic indicators. Mineralium Deposita 49: 785-796 
Duchesne JC (1970) Microtextures of Fe-Ti oxide minerals in the South Rogaland anorthositic complex (Norway). Annales de la Societe Geologique de Belgique 93: $197-251$

Dupuis C, Beaudoin G (2011) Discriminant diagrams for iron oxide trace element fingerprinting of mineral deposit types. Mineralium Deposita 36: 319-355

Knipping JL, Bilenker LD, Simon AC, Reich M, Barra F, Deditus AP, Walle M, Heinrich CA, Holtz F, Munizaga R (2015) Trace elements in magnetite from massive iron oxide-apatite deposits indicate a combined formation by igneous and magmatichydrothermal processes. Geochimica Cosmochimica Acta 171: 15-38

Nadoll P, Angerer T, Mauk JL, French D, Walshe J (2014) The chemistry of hydrothermal magnetite: a review. Ore Geology Reviews 61: 1-32

Rakotonandrasana NOT, Arima M, Miyawaki R, Rambeloson RA (2010) Widespread occurrences of högbomite-2N2S in UHT metapelites from the Betroka Belt, Southern Madagascar; implications on melt or fluid activity during regional metamorphism. Journal of Petrology 51: 869-895.

Ramdohr P (1953) Ulvospinel and its significance in titaniferous iron ores. Economic Geology 48: 677-688

Rudnick R, Gao S (2003) Composition of the continental crust. Treatise on Geochemistry 3: $1-64$

Sengupta P, Bhui EK, Braun I, Dutta U, Mukhopadhyay D (2009) Chemical substitutions, paragenetic relations and physical conditions of formation of högbomite in the Sittampundi layered anorthosite complex, Southern India. American Mineralogist. 94: $1520-1534$ 
Velasco F, Tornos F, Hanchar JM (2016) Immiscible iron- and silica-rich melts and magnetite geochemistry at the El Laco volcano (northern Chile): Evidence for a magmatic origin for the magnetite deposits. Ore Geology Reviews 79: 346-366 


\section{Chapter 4: Discussion}

\subsection{Interpretation of results}

\subsubsection{Field observations}

Massive to semi-massive and disseminated $\mathrm{Fe}$ and $\mathrm{Ti}$ oxide mineralization hosted in granoblastic anorthosite commonly occurs throughout the field area of this study. The mineralization is coarse to very coarse grained $(1-5 \mathrm{~cm})$ and dominated by magnetite ( 60-70\%) along with abundant ilmenite (10-20\%) and pleonaste (10-20\%).

Disseminated oxide mineralization occurs interstitial to plagioclase in the host anorthosite, or associated with or partially rimming clinopyroxene when present. Massive to semi-massive oxide mineralization is observed in discordant veins, pods and bands.

Apatite is not observed to be directly associated with the Fe-Ti oxide mineralization but is a common mineral in the samples studied.

Oxide mineralization in the NWRA is separated into various mineralization styles observed at the outcrop scale during field work to facilitate comparisons between various textural occurrences of Fe-Ti oxide mineralization. An in depth study of the mineralization styles showed that all of the oxide mineralization observed has remarkably similar oxide and silicate mineralogy, mineral textures, and textural relationships with host anorthosite and mineral inclusions. Contact relationships between all massive to semi-massive mineralization styles and the host anorthosite are sharp and irregular, oftentimes with disseminated oxide mineralization adjacent to the massive oxide zone within the host anorthosite. Inclusions of rafts of host anorthosite are commonly observed in massive oxide mineralization. 


\subsubsection{Petrography}

Thin sections representative of each mineralization style observed during fieldwork were examined using transmitted and reflected light microscopy. All observed Fe-Ti oxide mineralization is dominated by magnetite with less abundant ilmenite and pleonaste. Orthopyroxene is present in some samples of bands of oxide mineralization, pods of oxide mineralization, as well as associated with some of the disseminated oxide mineralization. Magnetite, ilmenite, and pleonaste from all mineralization styles observed contain complex microtextures including examples of miscibility gap exsolution, oxidation exsolution, reduction exsolution, and contain evidence of reequilibration between oxide minerals. The presence of these textures shows that the primary magmatic compositions of oxide minerals cannot be accurately determined using in situ, or any other kinds of analyses.

Similar exsolution features are observed in all thin sections examined including massive to semi-massive oxide mineralization and disseminated oxide mineralization. Exsolution features are finer grained in the disseminated oxide mineralization compared to those in massive to semi-massive oxide mineralization; coarse grained granules of pleonaste and ilmenite are not observed associated with disseminated oxide mineralization. Granoblastic zones consisting of equigranular magnetite, ilmenite, and pleonaste are commonly observed within all oxide mineralization. Granoblastic magnetite contains fine grained pleonaste and "cloth textured" (i.e., submicroscopic to microscopic ilmenite lamellae growing parallel to the $\{111\}$ plane in the host magnetite (Duchesne, 1970)). 


\subsubsection{Whole rock major and trace element geochemistry.}

Whole rock geochemistry data from barren host-rock and mineralized samples show strong to very-strong positive correlations between elements associated within FeTi oxide minerals (e.g., $\mathrm{FeO}_{(\mathrm{t})}, \mathrm{TiO}_{2}, \mathrm{~V}_{2} \mathrm{O}_{5}, \mathrm{Cr}_{2} \mathrm{O}_{3}, \mathrm{Co}, \mathrm{Ni}, \mathrm{Zn}$, and $\mathrm{Ga}$ ) as well as between elements associated with plagioclase feldspar $\left(\mathrm{SiO}_{2}, \mathrm{CaO}, \mathrm{Al}_{2} \mathrm{O}_{3}, \mathrm{Na}_{2} \mathrm{O}, \mathrm{K}_{2} \mathrm{O}, \mathrm{Sr}\right.$, and $\left.\mathrm{Ba}\right)$. In contrast, $\mathrm{SiO}_{2}$ and $\mathrm{FeO}_{(\mathrm{t})}$ values are strongly negatively correlated. Phosphorus is weakly positively correlated with elements associated with plagioclase and weakly negatively correlated with elements associated with Fe-Ti oxide minerals suggesting apatite is not associated with Fe-Ti oxide mineralization in the NWRA. Magnesium contents are not correlated with either $\mathrm{SiO}_{2}$ or $\mathrm{FeO}_{(\mathrm{t})}$ and rather are likely controlled by the presence of ferromagnesian silicates like orthopyroxene, clinopyroxene, or rarely olivine, as observed during the petrographic investigation.

Binary variation diagrams were generated using $\mathrm{SiO}_{2}$ and $\mathrm{FeO}_{(\mathrm{t})}$ as variation indices (Fig. 4.1). Each figure contains grey ellipses labelled with a mineral abbreviation which represents the compositional range of that mineral. When the compositional range of that mineral plots outside of the bounds of the graph, the direction of its compositional range is denoted by an arrow. Aside from showing some of the aforementioned correlations, these diagrams show that two distinct clusters of data are present; one cluster is rich in elements that are associated with Fe-Ti oxide minerals and poor in elements that are associated with plagioclase, and the other is rich in elements that are associated with plagioclase and poor in elements that are associated with Fe-Ti oxide minerals. With the exception of a few intermediate samples, the gap in these clusters spans between $\sim 20-45$ wt. $\% \mathrm{SiO}_{2}$ content as well as $\sim 20-45$ wt. $\% \mathrm{FeO}_{(\mathrm{t})}$. 

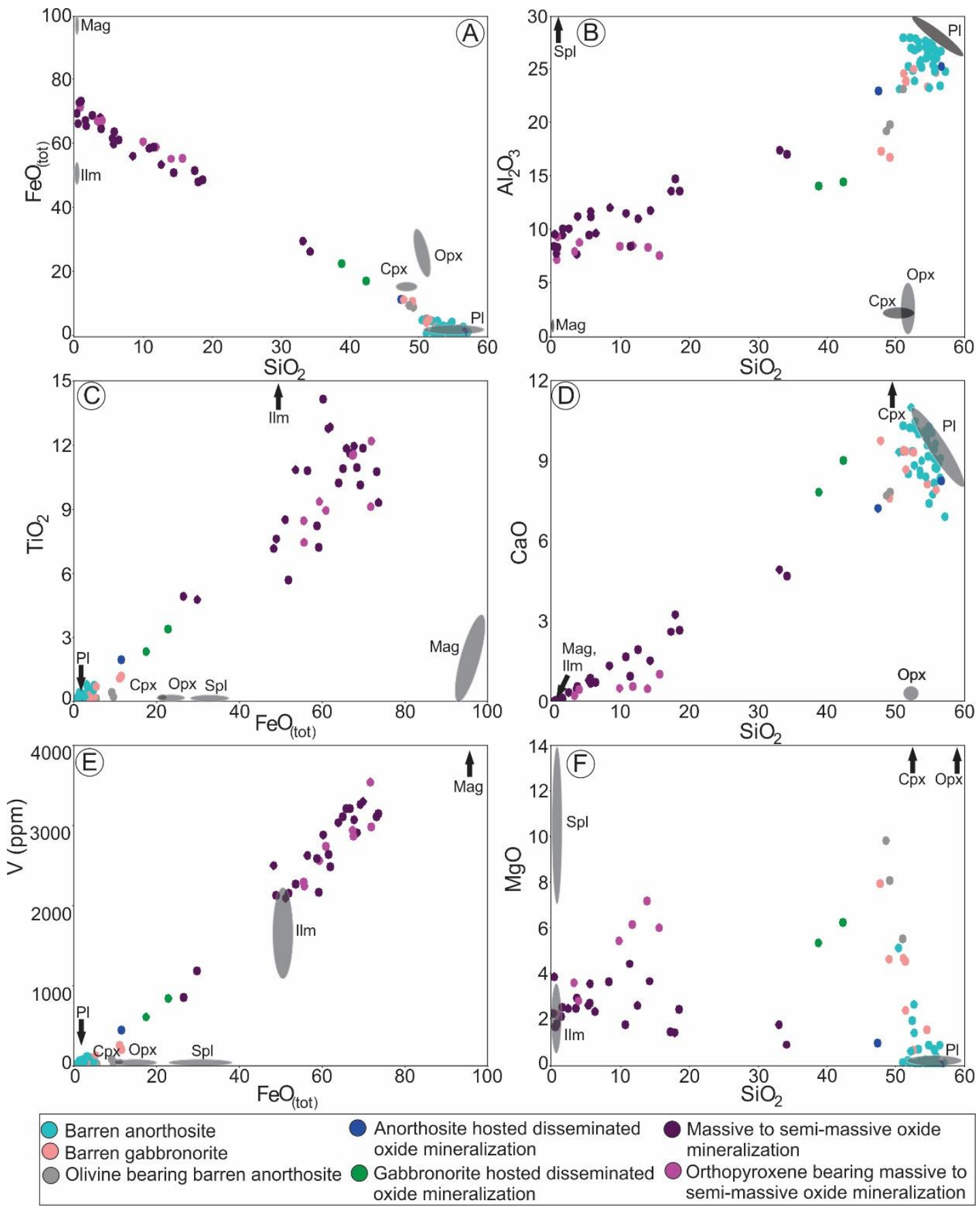

Figure 4.1. Binary variation diagrams of whole-rock geochemical analyses from the North West-River anorthosite (NWRA). Axis units are in wt. \% except for V which is in ppm. Composition ranges of minerals observed are represented by ellipses or indicated by an arrow when beyond the bounds of the graph. Silicate mineral ellipses are based on the typical compositional ranges of those minerals in labradorite-type Proterozoic massif anorthosite suites Charlier et al. (2009). $\mathrm{Pl}=$ plagioclase, Opx = orthopyroxene, $\mathrm{Cpx}=$ clinopyroxene, $\mathrm{Mag}=$ magnetite, $\mathrm{Ilm}=$ ilmenite, and $\mathrm{Spl}=$ spinel (pleonaste) spinel. 
The nature of this gap is unclear, however it may be associated with the lack of observed semi-massive oxide mineralization, or a sampling bias due to the coarse grained nature of the rocks within the study area.

\subsubsection{In situ oxide chemistry}

\subsubsection{Magnetite chemistry}

Magnetite hosted in the NWRA contains abundant and complex exsolution microtextures suggesting that primary magmatic composition of magnetite has not been preserved. This is corroborated by the Ti-poor nature of the magnetite analyzed compared to other known anorthosite hosted Fe-Ti oxide mineralization such as those in the layered Fedorivka complex in which magnetite can contain up to 28 wt. $\% \mathrm{TiO}_{2}$ (Duchesne et al., 2006). Further evidence of modification of the primary magmatic magnetite composition lies in the strong positive correlation between $\mathrm{Fe}^{2+}$ and $\mathrm{Ti}, \mathrm{Al}, \mathrm{Mg}$ and $\mathrm{Mn}$, and strongly negatively correlated with $\mathrm{Fe}^{3+}$ in all analyses (Fig. 4.2). This relationship geochemically confirms the presence of pleonaste and ilmenite exsolution from primary magnetite observed in thin section. In contrast, the $\mathrm{Cr}_{2} \mathrm{O}_{3}$ and $\mathrm{V}_{2} \mathrm{O}_{5}$ contents are similar in all coarse-grained magnetite and is not correlated to any other elements, suggesting that $\mathrm{Cr}_{2} \mathrm{O}_{3}$ and $\mathrm{V}_{2} \mathrm{O}_{5}$ are largely unaffected by exsolution and reequilibration during cooling and metamorphism.

Magnetite from orthopyroxene-bearing oxide mineralization is relatively enriched in $\mathrm{Fe}^{2+}$, $\mathrm{Ti}, \mathrm{Al}, \mathrm{Mg}$, and $\mathrm{Mn}$, and relatively depleted in $\mathrm{Fe}^{3+}$ compared to orthopyroxenepoor samples. Such enrichments suggest that magnetite from orthopyroxene bearing samples has undergone less exsolution and reequilibration compared to orthopyroxenepoor samples. 
Similar trends are present in the magnetite in situ trace element data (Fig. 4.3). Bands of oxide mineralization are depleted in $\mathrm{Al}$ and $\mathrm{Ga}$ relative to the other mineralization styles, whereas orthopyroxene-bearing bands of oxide mineralization are enriched in $\mathrm{Mg}, \mathrm{Mn}, \mathrm{Ti}, \mathrm{Co}, \mathrm{V}, \mathrm{Ni}$, and Ga.

Magnetite in orthopyroxene-poor pods are relatively enriched in $\mathrm{Mn}, \mathrm{Ti}, \mathrm{Cr}$, and $\mathrm{Ga}$, whereas magnetite in orthopyroxene-bearing pods are highly enriched in $\mathrm{Mg}$, as well as somewhat enriched in $\mathrm{Mn}, \mathrm{Al}, \mathrm{Ti}, \mathrm{Co}$, and Ni. The clinopyroxene-bearing disseminated oxide mineralization is relatively enriched in $\mathrm{Cr}$ and depleted in $\mathrm{V}$ and $\mathrm{Ni}$. The anorthosite-hosted disseminated oxide mineralization magnetite is enriched in $\mathrm{Mn}, \mathrm{Ti}, \mathrm{Ni}$ and $\mathrm{Cr}$, whereas the orthopyroxene-associated disseminated oxide mineralization is highly enriched in $\mathrm{Mg}$ as well as slightly enriched in $\mathrm{Mn}, \mathrm{Al}, \mathrm{Ti}, \mathrm{Co}$, and $\mathrm{Ni}$. These variations are likely a function of different local bulk compositions and perhaps due to high-T breakdown of orthopyroxene which could release $\mathrm{Mg}, \mathrm{Al}$ and $\mathrm{Ni}$ to be taken up by proximal magnetite.

\subsubsection{Ilmenite chemistry}

Like in magnetite, ilmenite in the NWRA contains abundant and complex exsolution microtextures, including pleonaste, hematite, and magnetite, suggesting subsolidus chemical modification of ilmenite has occurred, and that ilmenite analyzed is not representative of the primary magmatic ilmenite composition. In situ analyses were done on all four of the observed textural varieties of ilmenite. A strong positive

correlation between $\mathrm{Ti}$ and $\mathrm{Fe}^{2+}$ coupled with a strong negative correlation between $\mathrm{Fe}^{2+}$ and $\mathrm{Fe}^{3+}$ is present in all ilmenite analyses (Fig 4.4). 

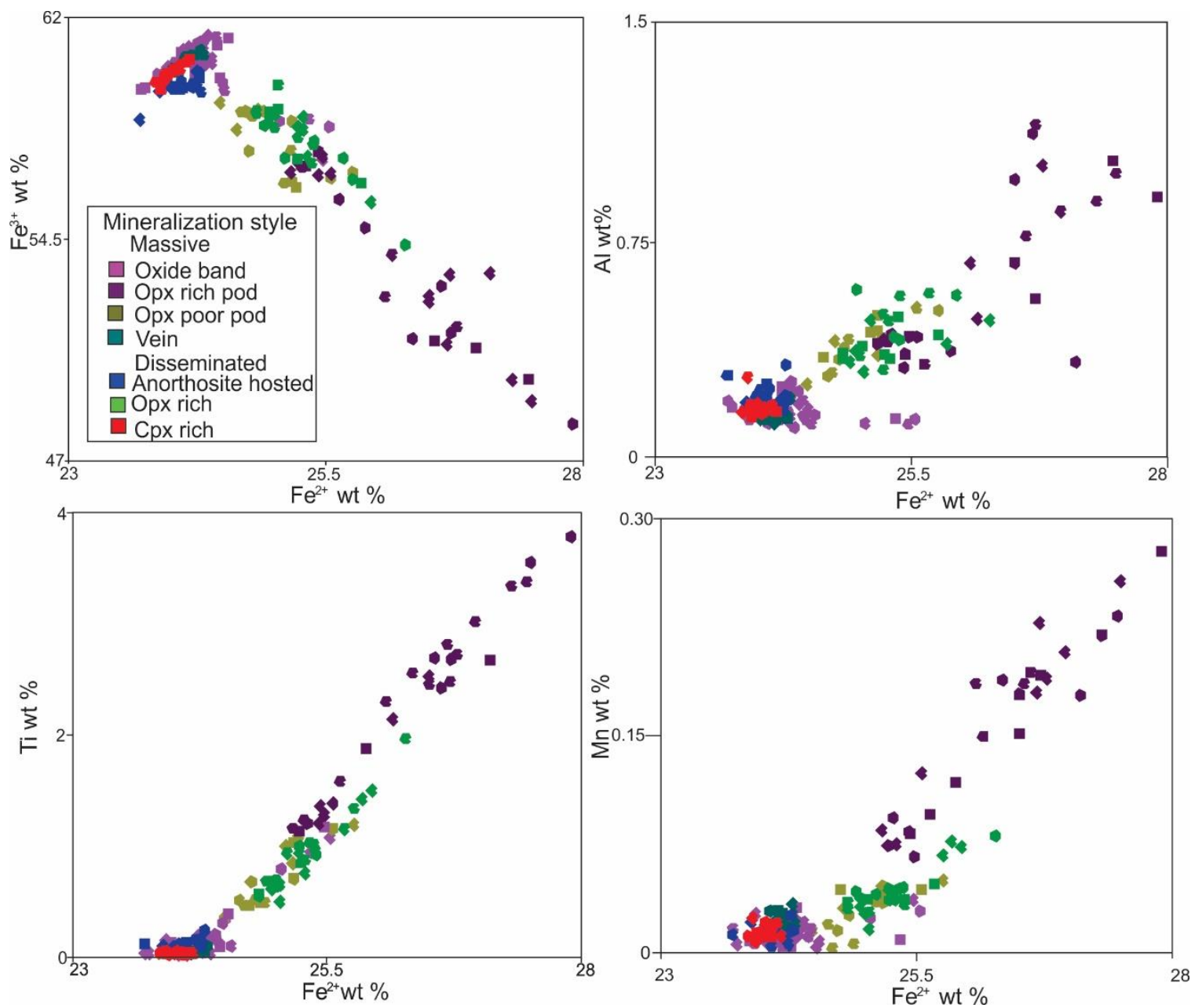

Figure 4.2. Binary element variation diagrams of EPMA magnetite analyses showing a negative correlation between $\mathrm{Fe}^{2+}$ and $\mathrm{Fe}^{3+}$ coupled with positive correlations between $\mathrm{Fe}^{2+}$ and $\mathrm{Mn}, \mathrm{Al}$ (hercynite substitution), and $\mathrm{Ti}$ (ilmenite substitution). The positive correlation between $\mathrm{Mn}$ and $\mathrm{Fe}^{2+}$ suggests the presence of the pyrophanite $\left(\mathrm{MgTiO}_{3}\right)$ substitution which is commonly associated with ilmenite.

Amongst the various ilmenite textural types, a pattern of variation of the ilmenite textures was observed. Ferrous iron is most abundant in the ilmenite containing spinel microcrystals, slightly less abundant in the sandwich ilmenite, and least abundant 

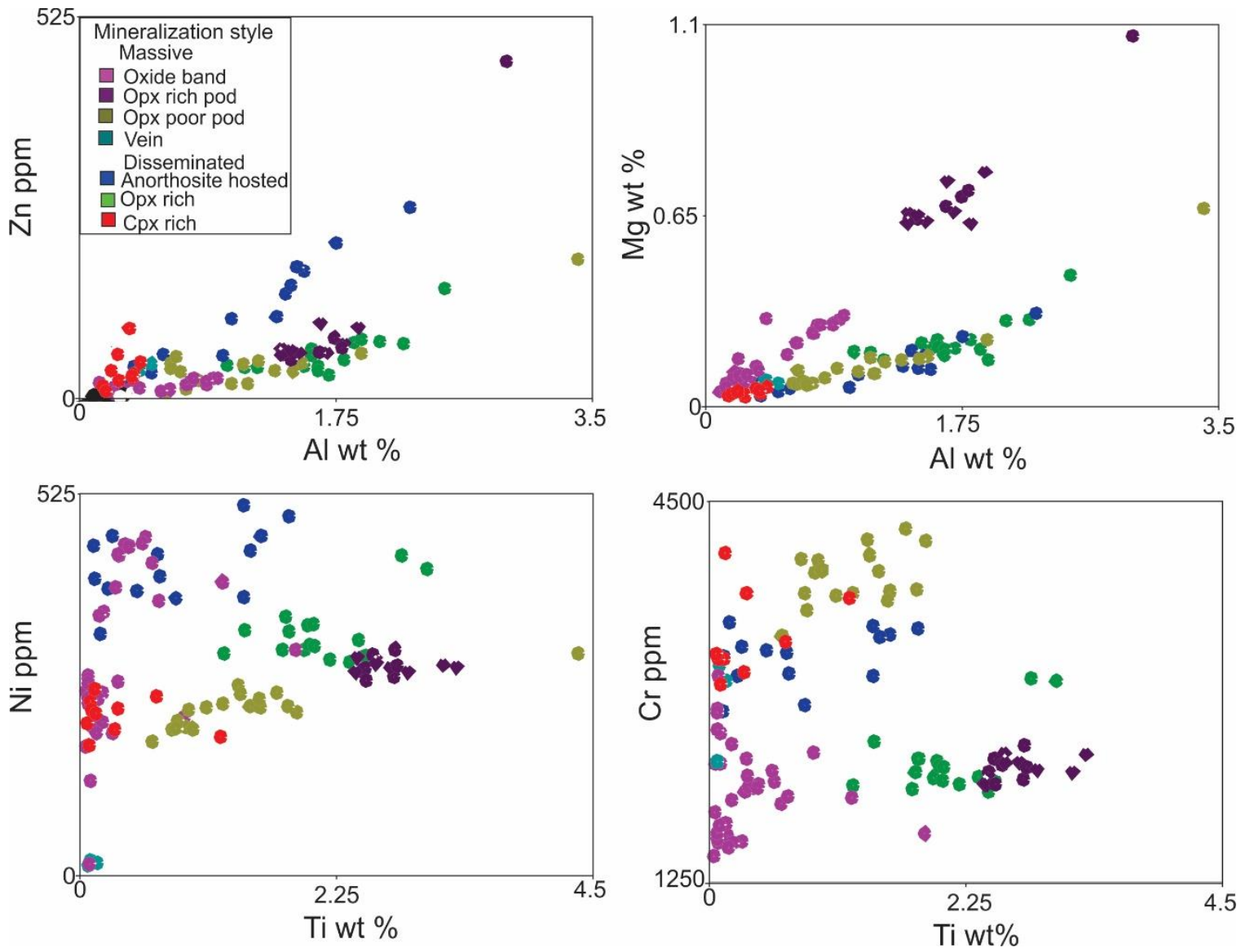

Figure 4.3. Binary variation diagram from LA-ICPMS magnetite analyses showing positive correlations between $\mathrm{Al}$, and $\mathrm{Mg}$ (spinel substitution) as well as $\mathrm{Zn}$, and $\mathrm{Al}$ (gahnite substitution). Two trends are observed on the Ti vs Ni graph; one with a low Ti:Ni ratio and one with a high Ti:Ni ratio. Two trends are also observed on the Ti vs $\mathrm{Cr}$ graph, one with a low Ti:Cr ratio and one with a high ratio.

in composite ilmenite grains with exsolution lamellae. The same pattern is shown by $\mathrm{Ti}$, which is most abundant in samples containing abundant $\mathrm{Fe}^{2+}$, and least abundant in samples that are richer in $\mathrm{Fe}^{3+}$. This pattern suggests a paragenesis of ilmenite; first coarse grained ilmenite with exsolution features are formed, then coarse ilmenite without exsolution features are formed, then sandwich ilmenite, and then finally the ilmenite containing spinel microcrystals are exsolved. 

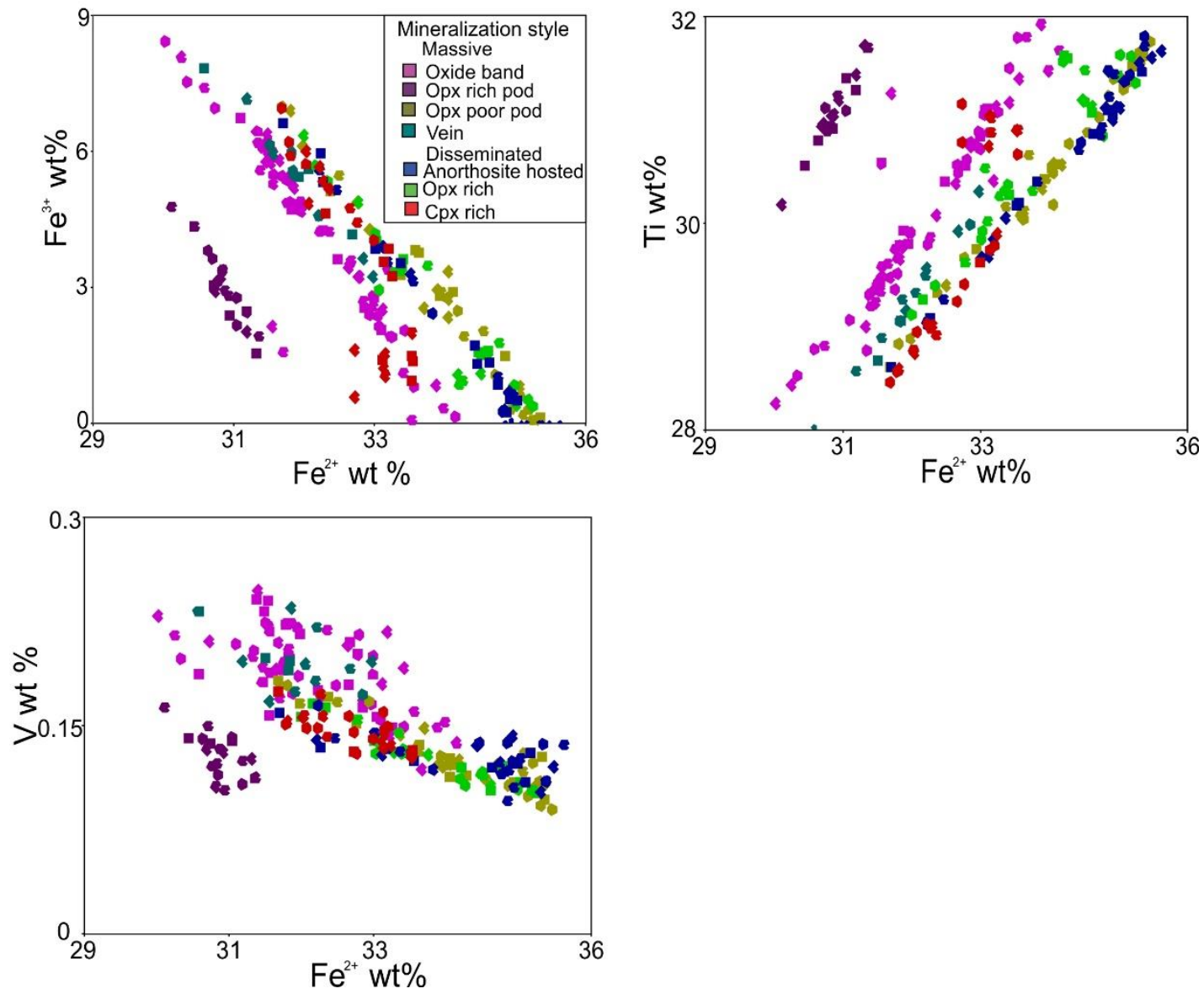

Figure 4.4. Binary variation diagram from EPMA ilmenite analyses showing negative correlations between $\mathrm{Fe}^{2+}$ and both $\mathrm{V}$ and $\mathrm{Fe}^{3+}$ and a positive correlation between $\mathrm{Fe}^{2+}$ and $\mathrm{Ti}$.

The major- and minor-element chemical variation in ilmenite between the different mineralization styles is minimal; $\mathrm{V}$ and $\mathrm{Mg}$ are slightly enriched in bands of oxide mineralization. The largest variation is observed in the orthopyroxene-bearing massive oxide pods in which $\mathrm{Ti}$ and $\mathrm{Mg}$ are enriched, and coupled with a depletion in $\mathrm{Fe}^{2+}$ relative to other samples.

Variations in the trace element composition of ilmenite occur in the different mineralization styles (Fig. 4.5). Orthopyroxene-poor bands of oxide mineralization are 
enriched in $\mathrm{Mg}, \mathrm{Ni}$, and $\mathrm{Sc}$, and slightly depleted in $\mathrm{Nb}$ compared to other mineralization styles. Whereas orthopyroxene-bearing bands are also enriched in Ni and Mn.

Orthopyroxene-poor pods are depleted in Sc and Mn, and orthopyroxene-bearing pods are relatively enriched in $\mathrm{Mg}$ and $\mathrm{Sc}$, and depleted in $\mathrm{Nb}, \mathrm{Cr}$, and $\mathrm{Mn}$.
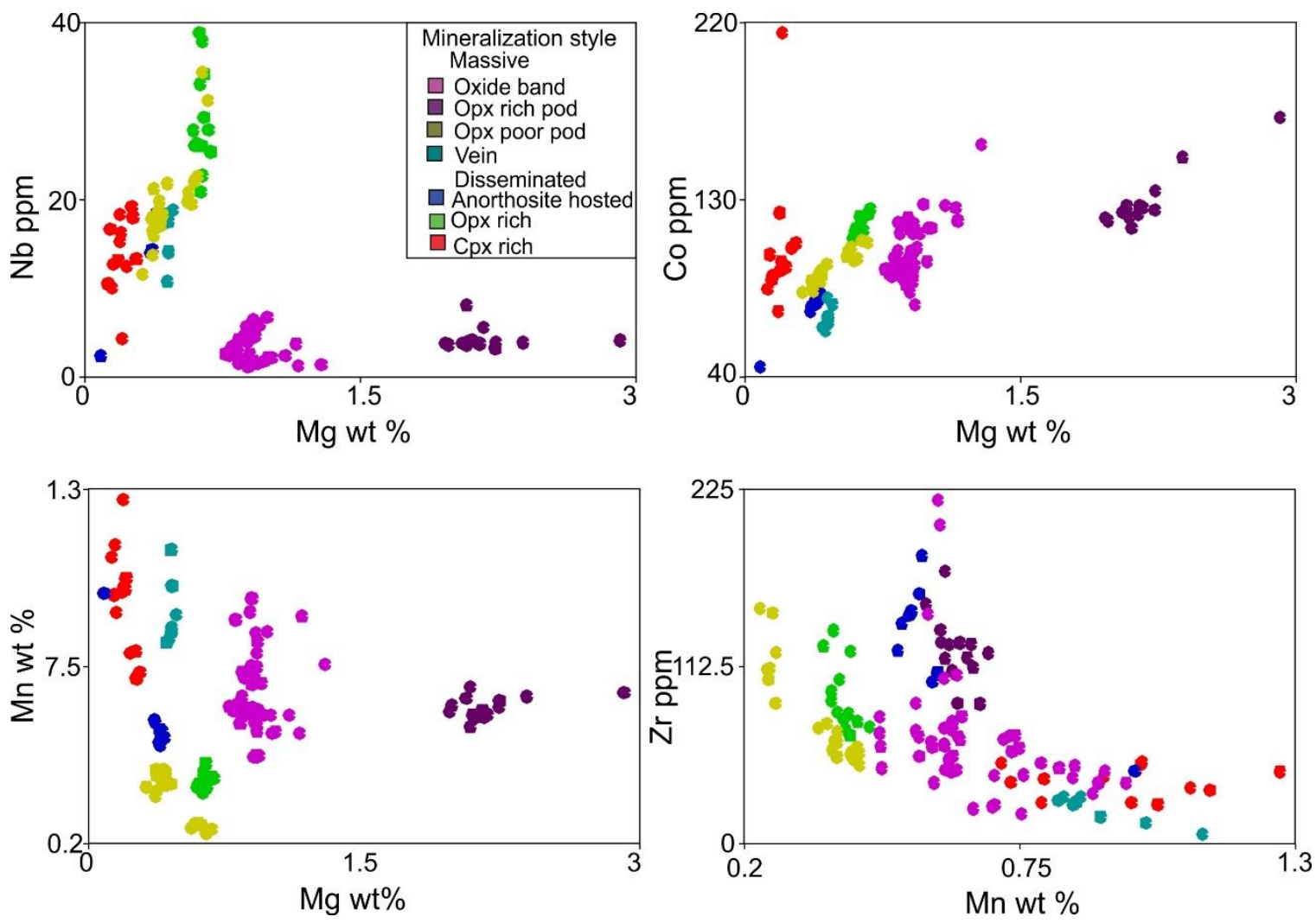

Figure 4.5. Binary element variation diagrams from ilmenite LA-ICPMS analyses. Two trends observed in the $\mathrm{Mg}$ vs $\mathrm{Nb}$ graph, one with high $\mathrm{Nb}$ and low $\mathrm{Mg}$ and the other with low $\mathrm{Nb}$ and high $\mathrm{Mg}$. A positive correlation is present between $\mathrm{Mg}$ and $\mathrm{Co}$. A negative correlation is present between $\mathrm{Mn}$ and $\mathrm{Zr}$. Vertical linear trends in several mineralization styles in the Mg vs Mn binary variation diagram.

Veins of oxide mineralization are relatively enriched in Sc, moderately enriched in $\mathrm{Zn}, \mathrm{Cr}, \mathrm{V}$, and $\mathrm{Mn}$, and depleted in $\mathrm{Co}, \mathrm{Zr}$, and Ni relative to other samples. Anorthositehosted disseminated oxide mineralization and orthopyroxene-bearing disseminated oxide mineralization are enriched in Ni compared to other types, and anorthosite-hosted 
disseminated oxide mineralization is depleted in Co. The clinopyroxene-bearing disseminated oxide mineralization is enriched in $\mathrm{Zn}, \mathrm{Cr}$, and $\mathrm{Mn}$, and depleted in $\mathrm{Mg}$ and $\mathrm{Zr}$ relative to other ilmenite samples.

\subsubsection{Pleonaste chemistry}

Relatively few pleonaste analyses were done during the course of this study due to the lack of analyzable pleonaste in the samples studied rendering it difficult to infer trends in the pleonaste compositions from the different sample types and pleonaste mineralization styles. Pleonaste lamellae hosted in ilmenite, however, are higher in $\mathrm{Ti}$ and lower in $\mathrm{Fe}^{3+}$ compared to coarse-grained pleonaste hosted in magnetite suggesting the chemical composition of pleonaste is associated with the host oxide mineralogy.

\subsubsection{EPMA discrimination diagrams}

The trace- and minor-element composition of magnetite is thought to systematically vary with changes in factors such as temperature of crystallization, as well as both the chemical composition, and redox state of parental fluid or magma during magnetite crystallization (Buddington and Lindsley, 1964; Lindsley, 1976; Dupuis and Beaudoin, 2011; Dare et al., 2014; Knipping et al., 2015).

Based on this principle, several magnetite discrimination diagrams have been proposed with fields based on empirical observations generated from a database of in-situ analyses that have been previously interpreted as hydrothermal and magmatic magnetite associated with various types of ore deposits. Two groups of discrimination diagrams exist: those which differentiate hydrothermal and magmatic magnetite; and those which differentiate magnetite from various ore deposit types. Both types of discrimination diagrams have commonly been used and/or modified in a number of recent studies (e.g., 
Huang et al., 2014; Hu et al., 2015). However, other recent studies have questioned the accuracy, validity, and usefulness of these diagrams (e.g. Hu et al., 2015; Broughm et al., 2017; Wen et al., 2017). In this section, the effectiveness of empirical magnetite discrimination diagrams will be evaluated using analyses from a magnetite dominated magmatic Fe-Ti-V deposit hosted in a Proterozoic massif anorthosite suite.

Dupuis and Beaudoin (2011) proposed two empirical diagrams which discriminate magnetite from various ore deposits. The first, which uses $\mathrm{Ca}+\mathrm{Al}+\mathrm{Mn}$ in wt. $\%$ as the Y-axis variable, and $\mathrm{Ti}+\mathrm{V}$ in wt. $\%$ as the $\mathrm{X}$-axis variable (Fig. 4.7a), does not provide meaningful results for the analyses from the present study. Approximately half of the data plot in the Fe-Ti, V field, whereas other samples plot between the "porphyry" and "Kiruna-type" fields. The data show a strong positive correlation between $\mathrm{Ti}+\mathrm{V}$ content and $\mathrm{Ca}+\mathrm{Al}+\mathrm{Mn}$ content, with orthopyroxene -bearing samples containing the most abundant amounts of both $\mathrm{Ca}+\mathrm{Al}+\mathrm{Mn}$ and $\mathrm{Ti}+\mathrm{V}$.

Likewise, the second Dupuis and Beaudoin (2011) discrimination diagram, which uses $\mathrm{Ni} /(\mathrm{Cr}+\mathrm{Mn})$ that is calculated from ppm values of each element as the $\mathrm{Y}$-axis variable and $\mathrm{Ti}+\mathrm{V}$ in wt.\% as the $\mathrm{X}$-axis variable (Fig. $4.7 \mathrm{~b}$ ) also does not effectively discriminate magnetite data from this study. The data are spread across the "Fe-Ti, V oxide", "porphyry" and "skarn" fields. All magnetite analyses in the present study show similar $\mathrm{Ni} /(\mathrm{Cr}+\mathrm{Mn})$ ratios with widely variable $\mathrm{Ti}$ contents; the highest Ti content is present in the orthopyroxene -bearing samples. In both of the Dupuis and Beaudoin (2011) discrimination diagrams, the samples with the highest Ti contents plot correctly within the "Fe-Ti, V oxide field". 


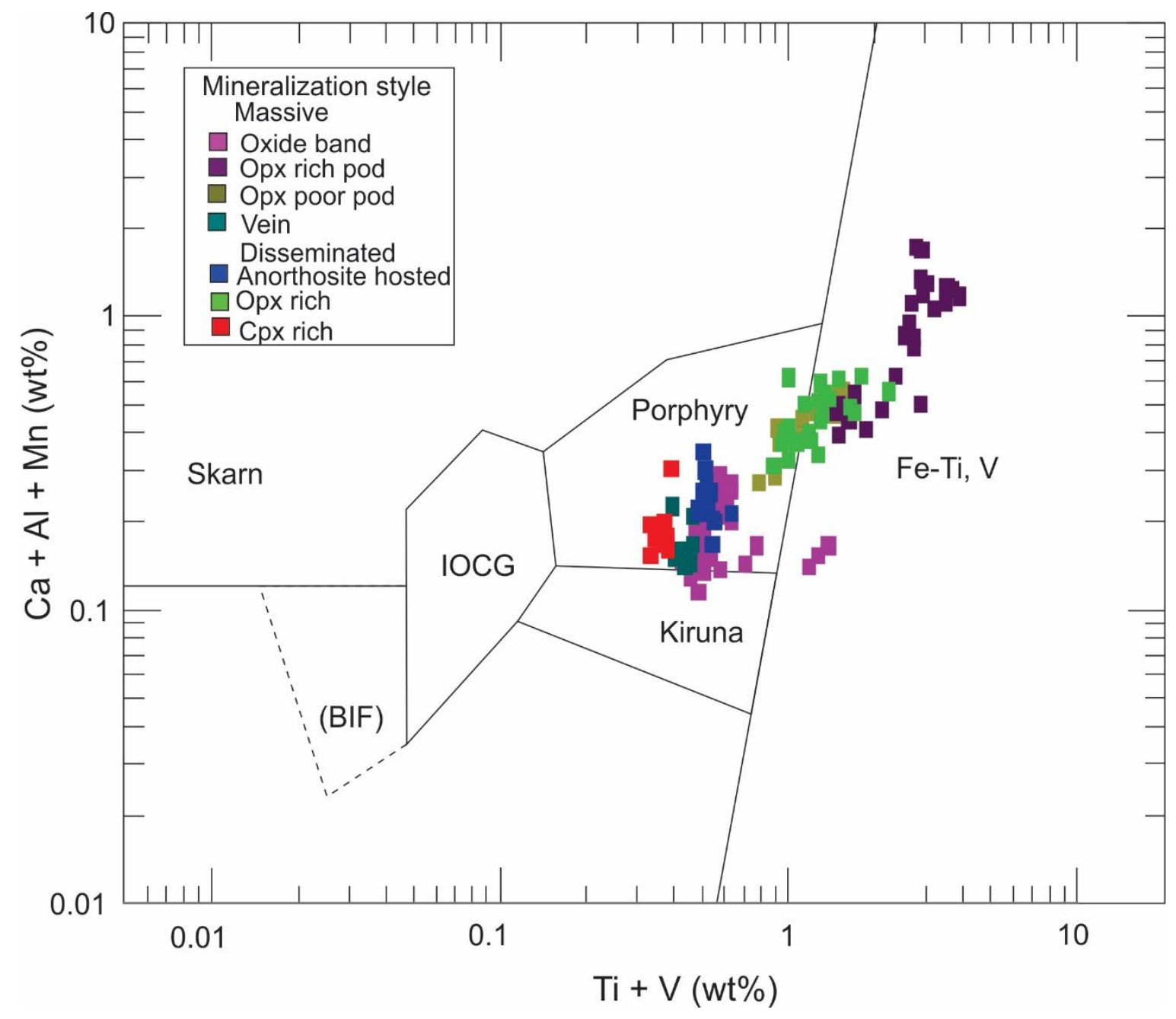

Figure 4.7a. Magnetite ore deposit discrimination diagrams of Dupuis and Beaudoin (2011). A) Diagram using $\mathrm{Ca}+\mathrm{Al}+\mathrm{Mn}$ (wt. \%) as the $\mathrm{Y}$ axis and $\mathrm{Ti}+\mathrm{V}$ (wt. \%) as the $\mathrm{X}$ axis, B) Diagram using $\mathrm{Ni} /(\mathrm{Cr}+\mathrm{Mn})$ as the $\mathrm{Y}$ axis and $\mathrm{Ti}+\mathrm{V}($ wt. \%) as the $\mathrm{X}$ axis. Magnetite analyses from this study were plotted on the diagram. See text for details.

Knipping et al. (2015) proposed an empirical discrimination diagram for discriminating magmatic and hydrothermal magnetite using the in situ Ti and V (ppm) content in magnetite as the respective $\mathrm{X}$ and $\mathrm{Y}$ axes (Fig. 4.8). 


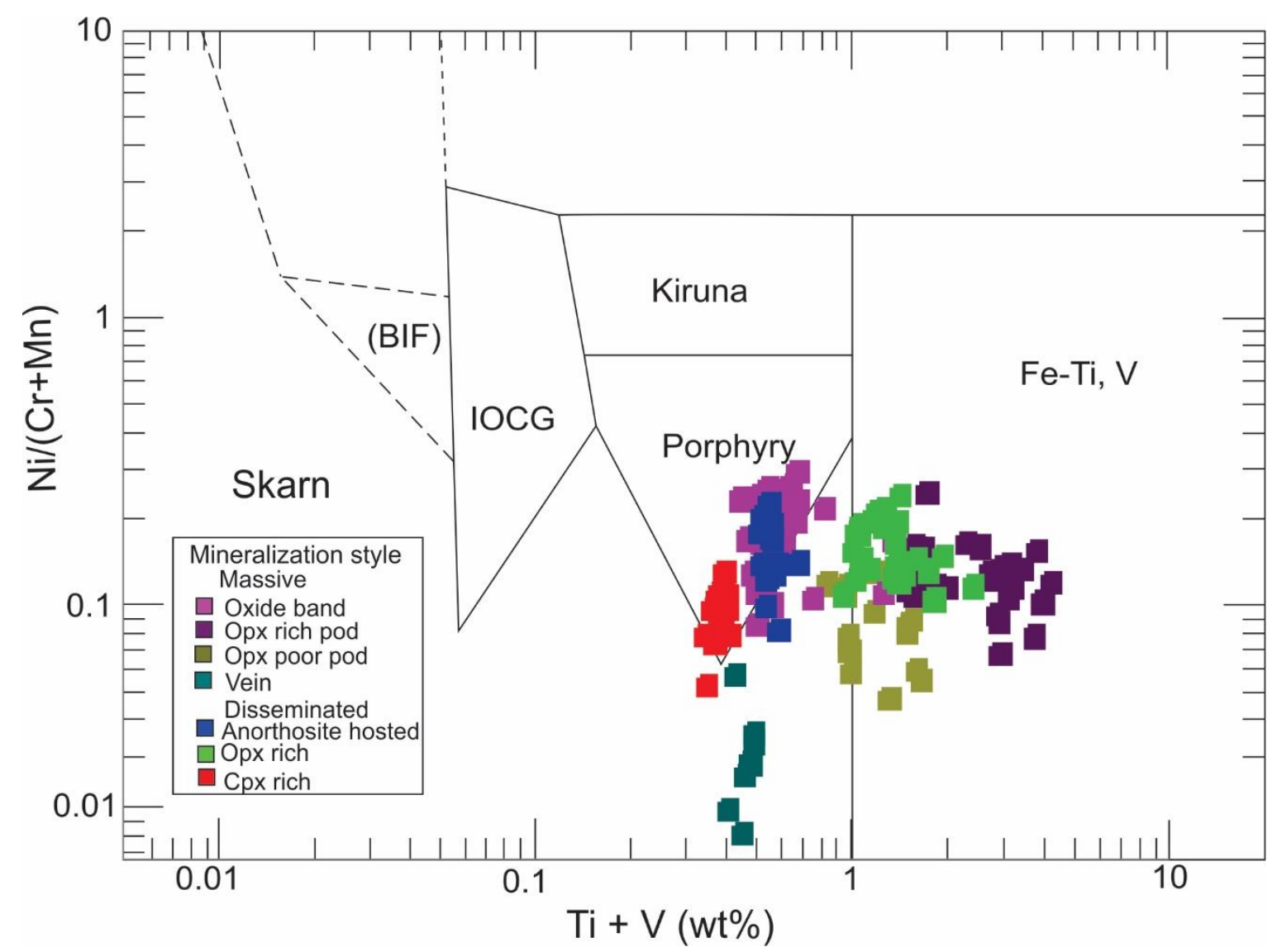

Figure 4.7b. Magnetite ore deposit discrimination diagrams of Dupuis and Beaudoin (2011). A) Diagram using $\mathrm{Ca}+\mathrm{Al}+\mathrm{Mn}$ (wt. \%) as the $\mathrm{Y}$ axis and $\mathrm{Ti}+\mathrm{V}$ (wt. \%) as the $\mathrm{X}$ axis, B) Diagram using $\mathrm{Ni} /(\mathrm{Cr}+\mathrm{Mn}$ ) as the $\mathrm{Y}$ axis and $\mathrm{Ti}+\mathrm{V}$ (wt. \%) as the $\mathrm{X}$ axis. Magnetite analyses from this study were plotted on the diagram. See text for details.

This diagram is not effective for most of the data from the present study; the majority of coarse-grained magnetite data plot above the defined discrimination fields. Data points for primary magnetite have similar $\mathrm{V}$ contents, with the exception of analyses from clinopyroxene associated disseminated oxide mineralization which have slightly lower $\mathrm{V}$ contents. The Ti content is much more variable; samples with the highest $\mathrm{Ti}$ content plot correctly within the magmatic magnetite field.

Dare et al. (2014) presented an empirical diagram to discriminate magmatic and hydrothermal magnetite. The diagram uses $\mathrm{Ni} / \mathrm{Cr}$ and Ti content as the $\mathrm{X}$ and $\mathrm{Y}$ axes, 
respectively (Fig. 4.9). Data from this study plot within the magmatic magnetite field, thus this diagram appears to be effective for the analyses in the present study.

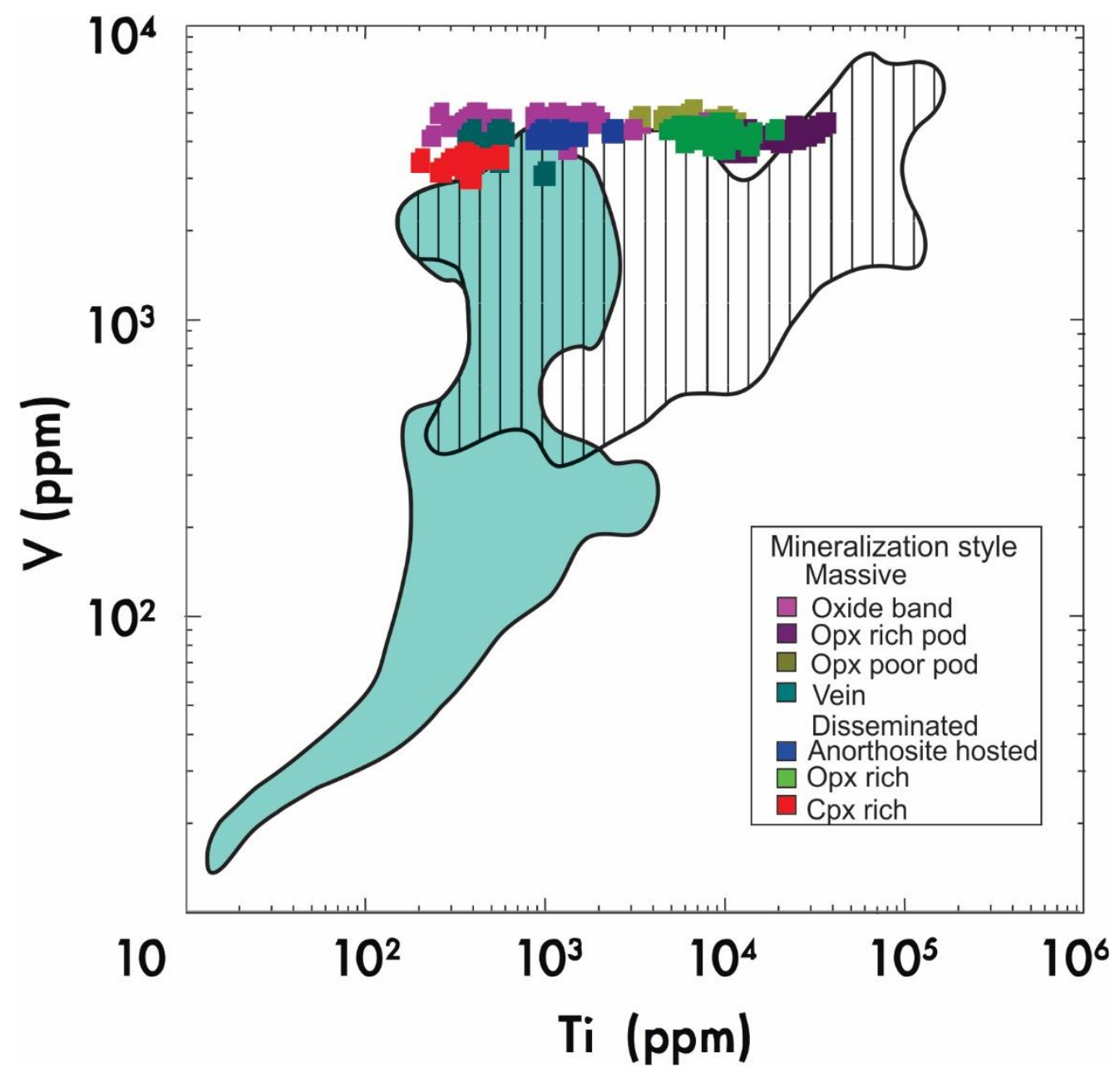

Figure 4.8. Hydrothermal vs magmatic discrimination diagram proposed by Knipping et al. (2015) using Ti as the $\mathrm{X}$ axis and $\mathrm{V}$ for the $\mathrm{Y}$ axis. The diagram contains three fields; a magmatic magnetite field (vertical lines), a hydrothermal magnetite field (teal field) and a magmatic-hydrothermal magnetite field (vertical lines on a teal field) Most primary magnetite data from this study plots above all fields of the discrimination diagram due to its high V content. 


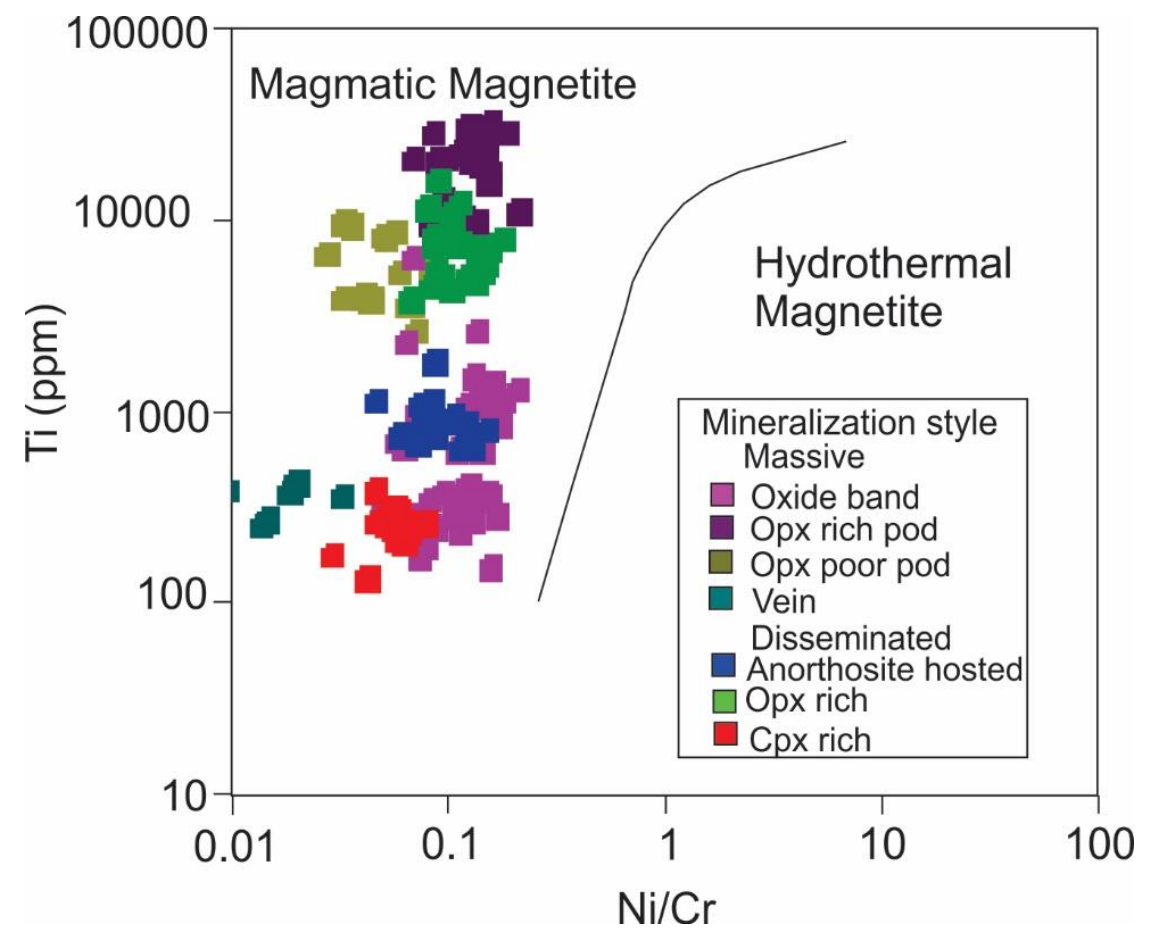

Figure 4.9. Hydrothermal vs magmatic discrimination diagram proposed by Dare et al. (2014) using $\mathrm{Ni} / \mathrm{Cr}$ as the $\mathrm{X}$ axis and $\mathrm{Ti}$ (ppm) as the $\mathrm{Y}$ axis. All magnetite analyses, regardless of mineralization style plot in the magmatic field.

With the exception of the Dare et al. (2014) diagram, the aforementioned discrimination diagrams, which make use of the major- and minor-element composition of magnetite, were ineffective when considering data from this study. There are two possible reasons for this. First, the Ti and/or Al contents are used as axis variables in each of the discrimination diagrams. However, the $\mathrm{Ti}$ and $\mathrm{Al}$ contents in magnetite are known to be modified by exsolution of ilmenite and pleonaste, respectively. Furthermore, reequilibration processes are known to occur during cooling and metamorphism. Because in situ analyses from this study systematically avoided exsolution microtextures, the magnetite analyzed is not representative of its primary magmatic compositions, which is what the fields on the discrimination diagrams are based on. Secondly, the data used to 
generate the Fe-Ti, V field on the Dupuis and Beaudoin (2011) diagrams does not include data from magnetite-dominated Proterozoic massif anorthosite hosted Fe-Ti-V deposits. For this reason, magnetite from the present study most likely do not plot within the Fe-Ti, V oxide field. As such, the Fe-Ti, V oxide field needs to be modified or removed, or magnetite mineral separate analyses could be used instead of in situ analyses. Analyzing magnetite mineral separates could re-homogenized magnetite and contained exsolution features in order to gain insight into the primary magmatic composition of magnetite.

\subsubsection{LA-ICPMS Discrimination diagrams}

Dare et al. (2014) proposed a multi-element empirical discrimination diagram for magnetite. LA-ICPMS analyses of Mg, Al, Si, P, Ca, Sc, Ti, V, Cr, Mn, Co, Ni, Cu, Zn, Ga, Ge, Y, Zr, Nb, Mo, Sn, Hf, Ta, W, and Pb are used in the diagram (Fig. 4.10 a-c). The data are normalized to bulk continental crust values (Rudnick and Gao, 2003). The normalized values are plotted on a line diagram in order of increasing compatibility in magnetite.

Because the trace element composition of magnetite is thought to reflect the composition of the melt or fluid from which it crystallized, discrimination fields for magnetite from magmatic Fe-Ti-V deposits (primitive magnetite), Fe-Ti-P deposits (evolved magnetite), high-T hydrothermal deposits, felsic plutons, and andesite were proposed as different fields on the diagram. For the purpose of this study, only the high-T hydrothermal magnetite and magmatic Fe-Ti-V oxide fields were considered because those fields most closely match proposed models for genesis of Fe-Ti oxide mineralization in Proterozoic massif anorthosite suites (Charlier et al., 2014). The high-T 

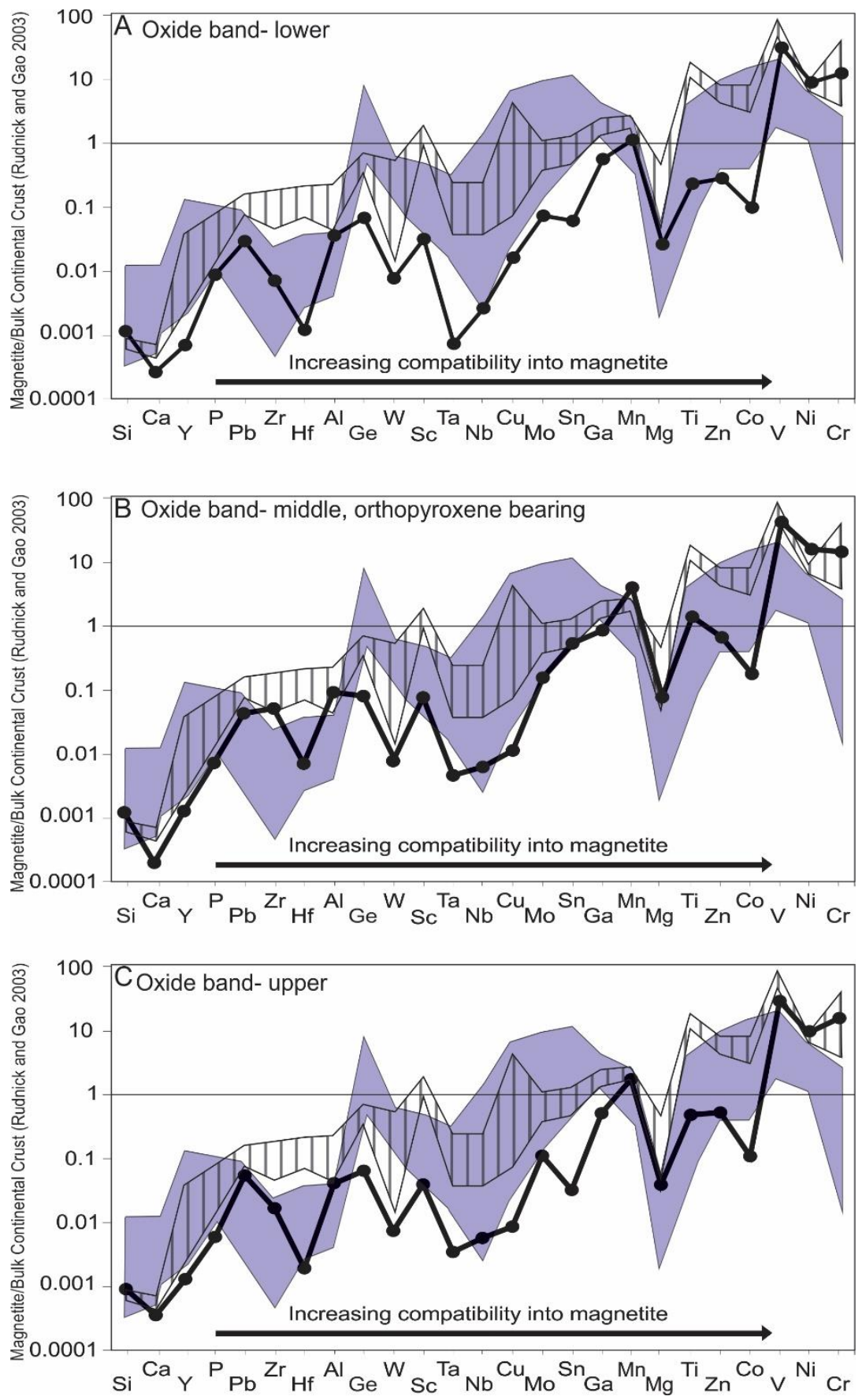

Figure 4.10a. Discrimination diagram for trace-element LA-ICPMS analyses proposed by Dare et al. (2014). The trace element composition of magnetite is normalized to bulk continental crust of Rudnick and Gao (2003) and organized in order of compatibility in magnetite. Discriminant fields for Fe-Ti-V magmatic magnetite (vertical stripes) and high-T hydrothermal magnetite (periwinkle) are plotted. Data from this study were averaged and plotted on separate figures by mineralization style as labelled on each diagram. 

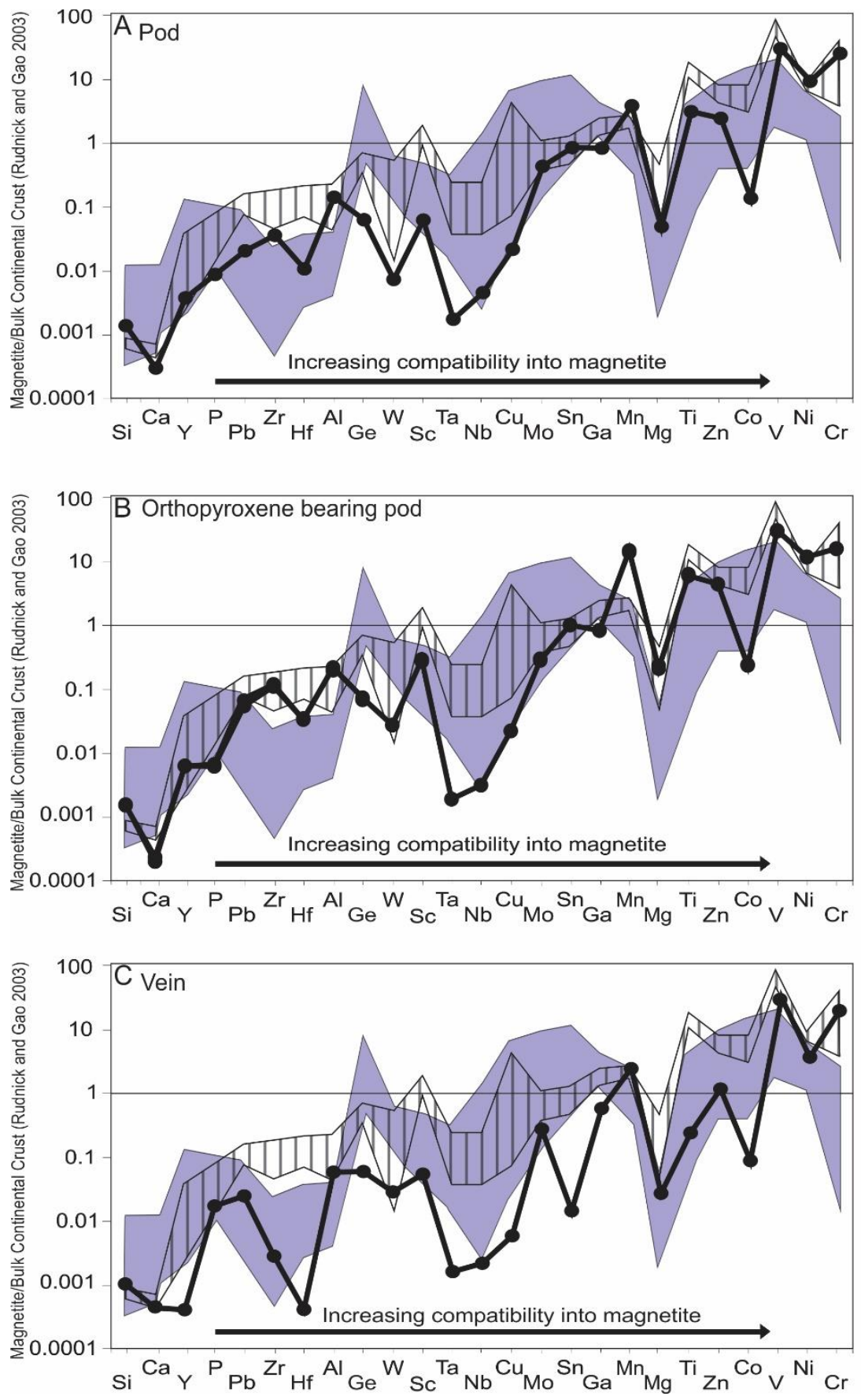

Figure 4.10 b. Discrimination diagram for trace-element LA-ICPMS analyses proposed by Dare et al. (2014). The trace element composition of magnetite is normalized to bulk continental crust of Rudnick and Gao (2003) and organized in order of compatibility in magnetite. Discriminant fields for Fe-Ti-V magmatic magnetite (vertical stripes) and high-T hydrothermal magnetite (periwinkle) are plotted. Data from this study were averaged and plotted on separate figures by mineralization style as labelled on each diagram. 

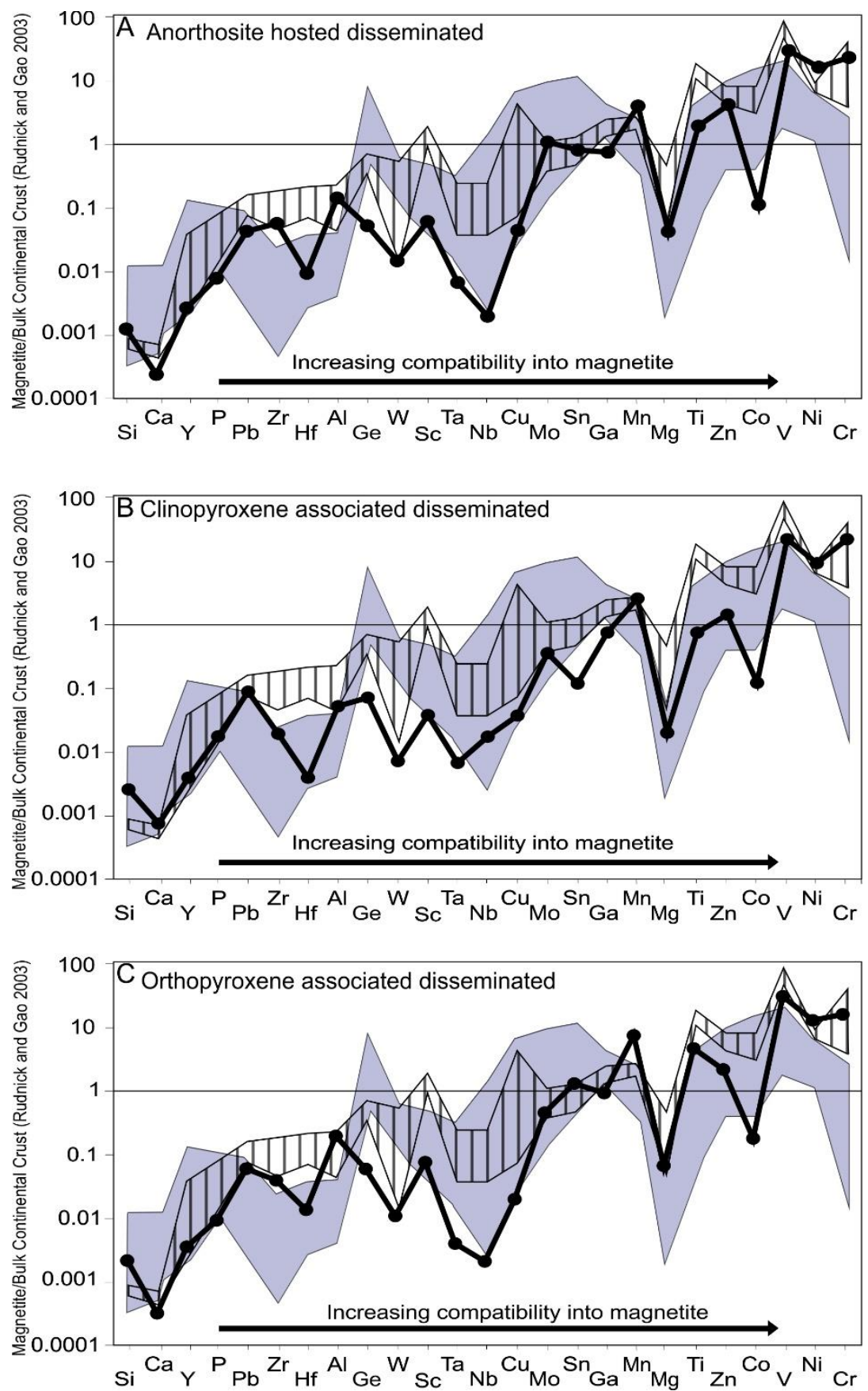

Figure 4.10 c. Discrimination diagram for trace-element LA-ICPMS analyses proposed by Dare et al. (2014). The trace element composition of magnetite is normalized to bulk continental crust of Rudnick and Gao (2003) and organized in order of compatibility in magnetite. Discriminant fields for Fe-Ti-V magmatic magnetite (vertical stripes) and high-T hydrothermal magnetite (periwinkle) are plotted. Data from this study were averaged and plotted on separate figures by mineralization style as labelled on each diagram. 


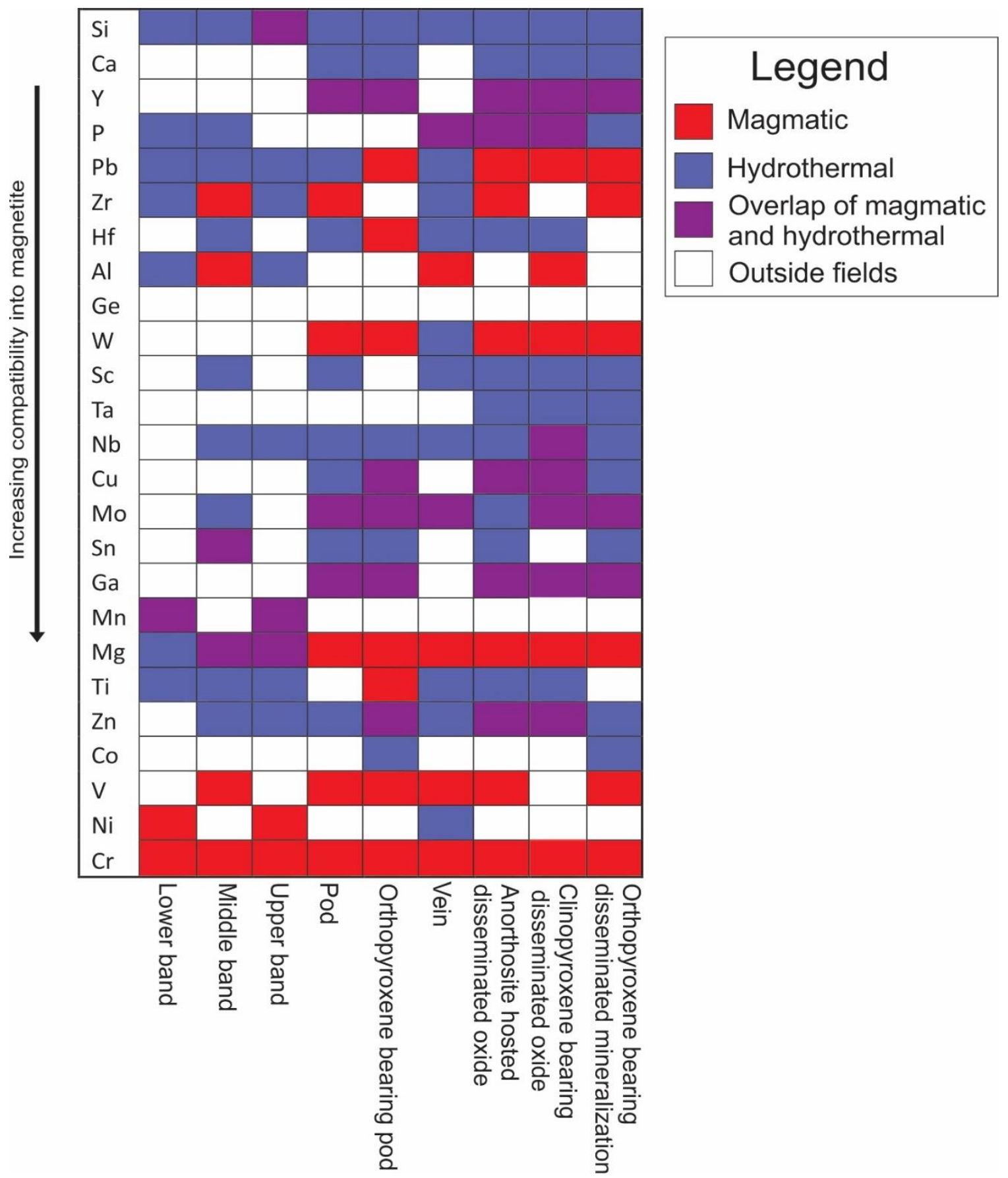

Figure 4.11. Companion figure to Fig. 3.5.7a-c showing the plotting area of magnetite analyses from various mineralization styles. Red squares represent points plotting within the magmatic magnetite field, blue squares represent points plotting within the hydrothermal field, purple squares represent points plotting in the overlap between magmatic and hydrothermal fields and white squares represent points plotting outside of any field. 
hydrothermal and magmatic Fe-Ti-V magnetite fields overlap in the majority of the elements measured in the present study.

Complete overlap occurs with Si, Y, P, Ta, Nb, Cu, Mo, Sn, Ga, Mn, Zn, and Co, and partial overlap occurs in $\mathrm{Ca}, \mathrm{Ge}$, and $\mathrm{W}$, so these elements are not useful for discrimination purposes using this empirical discrimination diagram. Only $\mathrm{Pb}, \mathrm{Zr}, \mathrm{Hf}, \mathrm{Al}$, $\mathrm{Ti}, \mathrm{V}, \mathrm{Ni}$, and $\mathrm{Cr}$ do not have any overlap, so these elements are the most useful for discriminating between magmatic and high-T hydrothermal magnetite, however, the geological rationale for why these elements plot where they do needs to be more adequately explained.

Regardless of the mineralization style, data from this study did not consistently plot uniquely in either field; the analyses plotted variably within the high-T magmatic field, hydrothermal field, at the overlap of both fields, or outside of the fields (Fig. 4.10 ac). The lack of clear affinity with either of the fields defined by Dare et al. (2014) is also illustrated by the block diagram in Fig. 4.11 and suggests a limited utility of this diagram.

The reason that these empirical discrimination diagrams are ineffective is unclear, however, it may have to do with the chemical modification of oxide minerals during subsolidus exsolution and reequilibration of magnetite during hydrothermal alteration or metamorphism, or that the geologic rationale behind the fields defined on the diagrams is not valid.

\subsection{Genesis and evolution of oxide mineralization}

It is well known that Fe-Ti oxide mineralization hosted in Proterozoic massif anorthosite suites is broadly magmatic in nature (Charlier et al., 2014, and references therein). However, the specific processes for oxide formation and concentration varies 
between deposits. In this section, oxide formation models proposed by other workers are summarized, and Fe-Ti oxide mineralization from this study is compared to each model.

\subsubsection{Liquid Immiscibility}

Proponents of liquid immiscibility as a formation process for Fe-Ti oxide mineralization in massif anorthosite suites suggest that residual magma from anorthosite crystallization is mafic in nature and enriched in $\mathrm{Fe}$, Ti, and P. Fractional crystallization of this residual magma is thought to lead to the formation of an immiscible Fe-Ti-P melt and conjugate $\mathrm{K}_{2} \mathrm{O}$-rich silicate rocks, thought to include perthitic norite or mangerite (Chen et al., 2013). The immiscible Fe-Ti-P melt crystallizes into zones of massive apatite-bearing Fe-Ti oxide mineralization that is devoid of silicate minerals, sometimes referred to as nelsonites (Chen et al., 2013).

Liquid immiscibility is thought to generate large zones of nelsonite in discordant veins or pods that have sharp irregular contacts with host anorthosite; disseminated nelsonite is interstitial to plagioclase in the host anorthosite (Philpotts, 1967; Chen et al., 2013; He et al., 2016). Disseminated nelsonite is also known to crosscut plagioclase or pyroxene crystals, form rims on ferromagnesian silicates, and can contain rafts of host anorthosite (Chen et al., 2013).

However, it is unclear if immiscible Fe-Ti oxide melts can exist in nature in these systems. Evidence of coexisting immiscible Fe-Ti oxide and silicate melts has not been observed in the NWRA and has also not been reported in plutonic settings globally. Experiments that generated immiscible Fe-Ti oxide and silicate melts were done at $1420^{\circ} \mathrm{C}$, which is a geologically unreasonable high temperature (Philpotts, 1967; Lindsley, 2003; Charlier and Grove, 2012; Lindsley and Epler, 2017). 
Within the NWRA, discordant zones of massive to semi-massive oxide mineralization, vein-like massive oxide mineralization are commonly observed, and disseminated Fe-Ti oxide minerals occur both interstitial to host plagioclase and partially rimming pyroxene, as predicted by the liquid immiscibility model. However, apatite is not observed to be associated with oxide mineralization in the NWRA, and nelsonites are not observed in the field area as is typical of Fe-Ti oxide mineralization generated via liquid immiscibility (e.g., Kolker, 1982; Chen et al., 2013; She et al., 2014; Peng et al., 2015; She et al., 2016); in fact, in whole rock geochemical analyses, there is a negative correlation between $\mathrm{FeO}$ content (which is associated with Fe-Ti oxide mineralization) and $\mathrm{P}$ content (which is associated with apatite). As such, it is unlikely that liquid immiscibility is responsible for the genesis of Fe-Ti oxide mineralization in the NWRA.

\subsubsection{Magma mixing}

Magma mixing is a process thought to be responsible for formation of stratiform chromite deposits and has been extrapolated for use in stratiform Fe-Ti oxide deposits. In this process, a fractionating mafic magma is intruded by a more primitive mafic magma, or contaminated by a pre-existing siliceous rock. The interaction between the two magmas generates a hybrid magma which crystallizes a single mineral which sinks to the base of the magma chamber creating a mono-mineralic layer of the crystallized mineral (Irvine, 1975; Irvine et al., 1983; Charlier et al., 2010).

Evidence of magma mixing includes rhythmically alternating monomineralic layers of oxide and silicate minerals in sharp, straight contact with the underlying layer and in sharp to gradational contact with the overlying layer (Irvine, 1975; Irvine et al., 1983). Geochemical evidence of magma mixing includes large variations in compatible 
elements such as $\mathrm{Mg}, \mathrm{Mn}, \mathrm{V}$, and $\mathrm{Cr}$ in Fe-Ti oxide minerals between layers (Charlier et al., 2010).

Rhythmically alternating mono-mineralic layers of oxides and silicates are not observed in the NWRA. In fact, aside from host anorthosite, mono-mineralic zones of any texture or composition are not observed in the NWRA. Although all massive oxide mineralization is in sharp contact with host anorthosite the contacts are irregular. Furthermore, the in situ analyses of magnetite and ilmenite show little to no variation in $\mathrm{Cr}$ and $\mathrm{V}$ between samples. As such, it is unlikely that magma mixing is responsible for oxide genesis.

\subsubsection{Hydrothermal remobilization}

Hydrothermal remobilization is a process in which plagioclase containing microinclusions of Fe-Ti oxide minerals is pervasively altered to fine-grained albite, clinozoisite, and sericite (Li et al., 2014). During alteration, the Fe-Ti oxide microinclusions are dissolved into solution until they reprecipitate along pre-existing fractures, or in lenticular bodies generating zones of nelsonite in sharp, irregular contact with the adjacent anorthosite ( $\mathrm{Li}$ et al., 2014). Contacts with host anorthosite are lined by zones of massive chlorite or chloritized anorthosite (Li et al., 2014).

Irregular unconformable zones of massive Fe-Ti oxide mineralization are observed in the NWRA, however these zones are not associated with pre-existing fractures, do not contain apatite, and are not associated with chlorite. Furthermore, plagioclase in the host anorthosite has been minimally altered. As such, hydrothermal remobilization is likely not responsible for the genesis of Fe-Ti oxide mineralization. 


\subsubsection{Fractional Crystallization}

Fe-Ti-P enriched mafic magma termed jotunites or ferrodiorites associated with anorthosite genesis are thought to be carried from depth with diapirically rising anorthosite crystal mush (Vander Auwera and Longhi, 1994). Due to rheological differences, the Fe-Ti-P enriched mafic magma pools in zones of low pressure where it begins to fractionally crystallize. Calculated cotectic crystallization values suggest the resulting rock would be an oxide-bearing gabbronorite containing 20 wt. \% Fe-Ti oxide minerals along with a combination of clinopyroxene, orthopyroxene, olivine, and apatite (Charlier et al., 2007; 2008). Oxide-bearing gabbronorite is not observed in the NWRA and as such, fractional crystallization is likely not the sole process responsible for genesis of oxide mineralization in the NWRA.

\subsubsection{Solid state remobilization}

Solid-state remobilization is a process that concentrates existing oxide minerals into zones of massive to semi-massive mineralization rather than generating new oxide minerals. Due to ductility differences between oxide minerals and plagioclase, Fe-Ti oxide minerals can recrystallize and migrate to zones of low pressure via diffusion creep in subsolidus conditions, such as those present during diapiric uplift of the host anorthosite (Krause and Pedall, 1980; Duchesne 1996; 1999). On the scale of an anorthosite suite, this deformation could concentrate large irregular zones of massive to semi-massive oxide mineralization in sharp, irregular contact with the host anorthosite, disseminated oxide mineralization that is interstitial to plagioclase in the host anorthosite, as well as disseminated oxide mineralization rimming ferromagnesian silicate minerals (Duchesne, 1996; 1999). 
Evidence of solid state remobilization includes zones of massive oxide mineralization in sharp, irregular contact with host anorthosite, veins of oxide discordantly crosscutting host anorthosite, oxide minerals interstitial to plagioclase, and oxides partially rimming and crosscutting clinopyroxene. Furthermore, solid-state remobilization does not predict the presence of apatite associated with oxide mineralization, as is the case in the NWRA. Finally, inclusions and rafts of plagioclase, anorthosite, and orthopyroxene can also be explained via solid state remobilization.

Solid-state remobilization predicts the presence of mono-mineralic ilmenite bodies; however, it is unclear if the process can be used to explain the presence of magnetite, ilmenite and pleonaste which are observed in the NWRA. The presence of orthopyroxene-bearing massive to semi-massive oxide mineralization spatially associated with orthopyroxene-poor massive to semi-massive oxide mineralization cannot be easily explained using this model. Finally, solid-state remobilization can explain concentrations of Fe-Ti oxide minerals, however it cannot explain the genesis of the oxide minerals observed.

\subsubsection{Effect of cooling and metamorphism on oxide chemistry}

Fe-Ti oxide minerals are known to experience extensive amounts of subsolidus reequilibration during periods of slow cooling as well as during metamorphism (Buddington and Lindsley, 1964; Duchesne, 1970; Lindsley, 1991). The net effect of reequilibration is purification of the oxide minerals towards their end-member compositions by means of exsolution, oxide-oxide reequilibration and oxide-silicate reequilibration (Buddington and Lindsley, 1964). 
The presence of abundant and complex exsolution features observed in oxide minerals in the NWRA suggest that the in situ oxide analyses are not representative of primary magmatic compositions, rather, they are representative of the point at which exsolution and inter-oxide reequilibration ceased. Microtextures composed of pleonaste and ilmenite in magnetite, as well as granular ilmenite and pleonaste adjacent to magnetite suggests that primary magmatic magnetite contained higher abundances of $\mathrm{Ti}$, $\mathrm{Al}$ and $\mathrm{Mg}$ compared to the magnetite analyzed. Likewise, the presence of hematite lenses, spinel lamellae and magnetite lamellae in ilmenite suggest that primary ilmenite had a higher hematite component as well as higher $\mathrm{Mg}$ and $\mathrm{Al}$ contents compared to the analyzed ilmenite. Magnetite lenses in pleonaste suggest that primary pleonaste contained more Fe than analyzed pleonaste. Inter-oxide reequilibration is also responsible for oxide purification. For example, adjacent Ti-magnetite and ilmenite interact following the reaction $\mathrm{FeTi}_{2} \mathrm{O}_{4}($ in magnetite $)+\mathrm{Fe}_{2} \mathrm{O}_{3}$ (in ilmenite) $->\mathrm{Fe}_{3} \mathrm{O}_{4}($ in magnetite $)+\mathrm{FeTiO}_{3}$ (in ilmenite) (Buddington and Lindsley, 1964; Duchesne, 1972).

Oxide minerals in the NWRA underwent two periods of reequilibration; 1) during autometamorphism caused by the residual heat of the host anorthosite and 2) during overprinting Grenvillian metamorphism. It is difficult to differentiate which exsolution features are associated with autometamorphism and which are associated with overprinting Grenvillian metamorphism as the grade of Grenvillian metamorphism has not been well constrained within the NWRA. According to Rivers, 2008, the NWRA is located within the Grenvillian orogenic lid, which is thought to have reached a maximum temperature of $\sim 650{ }^{\circ} \mathrm{C}$ (Cherniak, 2000). As coarse-grained granular exsolution features as well as pleonaste exsolution in magnetite occur at $>750{ }^{\circ} \mathrm{C}$ (Buddington and Lindsley, 
1964; Mucke, 2003), those features can be ascribed as autometamorphic features. In contrast, ulvospinel can exsolve from magnetite can occur until $\sim 600^{\circ} \mathrm{C}$ (Buddington and Lindsley, 1964). Ulvospinel exsolution can be subsequently oxidized to ilmenite at a wide range of temperatures (Buddington and Lindsley, 1964). This suggests that finer grained ilmenite exsolutions in magnetite formed at lower temperatures including during Grenvillian metamorphism. The combined effects of autometamorphism and Grenvillian metamorphism significantly modified primary Fe-Ti oxide compositions to their current near end-member compositions, representing a nearly complete reequilibration process.

Recent studies of Fe-Ti oxide mineralization (e.g., Charlier et al., 2009; Charlier et al., 2010) suggest analyzing oxide mineral separates results in a more accurate representation of true magmatic oxide compositions. Re-integration of exsolution features into the host magnetite using relative abundances of exsolution features coupled with in situ analyses of each type of exsolution feature observed has been used in the past (e.g., Bowles, 1977; Pang et al., 2008). However, these approaches are flawed because they cannot accurately constrain inter-oxide reequilibration, oxide-silicate reequilibration, reequilibration between oxide minerals and trapped liquid or the presence and amount of external granule exsolution, wherein ilmenite and pleonaste granules form at the grain boundaries of magnetite during subsolidus conditions (Buddington and Lindsley, 1964; Duchesne, 1972; Charlier et al., 2009).

The relative proportions of primary oxides and those formed through external granule exsolution in the NWRA is unclear. However, the following observations suggest that ilmenite and pleonaste made up only minor components of the primary magmatic oxide mineral assemblage and the ilmenite and pleonaste granules are instead the product 
of external granule exsolution based: 1) in massive oxide mineralization the magnetite is coarser grained than granular ilmenite and pleonaste; 2) in massive oxide mineralization the coarsest ilmenite and pleonaste are spatially associated with each other and are present in clusters; 3) zones enriched in ilmenite or pleonaste relative to magnetite are not observed in either massive to semi-massive mineralization or disseminated oxide mineralization; 4) no coarse granular pleonaste or ilmenite is observed associated with disseminated oxide mineralization; and 5) no disseminated mineralization that is dominated by ilmenite or pleonaste is observed. Similar conclusions are drawn to explain the presence of magnetite-dominated ilmenite-bearing Fe-Ti oxide mineralization hosted in the late Permian, Panzhihua layered gabbro intrusion of southwest China (Pang et al., 2008). Because external granule exsolution occurs at such high temperatures (between $<880-600^{\circ} \mathrm{C}$; Buddington and Lindsley, 1964), the exsolution product itself will be impure and upon cooling will contain exsolution features as are observed in coarse granular ilmenite and pleonaste in the NWRA.

\subsubsection{Oxygeothermometry}

Buddington et al. (1955) showed that in the presence of independent coexisting grains of ilmenite and magnetite, the $\mathrm{TiO}_{2}$ content of magnetite is a function of the temperature of magnetite crystallization, making it a potential candidate for use as a geothermometer. Further work by Buddington and Lindsley (1964) showed that at a

constant temperature, higher $f \mathrm{O}_{2}$ leads to a decrease in the $\mathrm{TiO}_{2}$ content of magnetite and an increase in the $\mathrm{Fe}_{2} \mathrm{O}_{3}$ content of ilmenite, thereby providing a potential magnetiteilmenite oxygeothermometer. More recent improvements of the oxygeothermometer including additional new experimental data, thermodynamic calculations, and improved 
algorithms for data calculation allow for estimates of the equilibrium conditions of magnetite and ilmenite to $\pm 30^{\circ} \mathrm{C}$ and the $f \mathrm{O}_{2}$ to within one order of magnitude (Powell and Powell, 1977; Andersen et al., 1993; Lattard et al., 2005; Ghiorso and Evans, 2008).

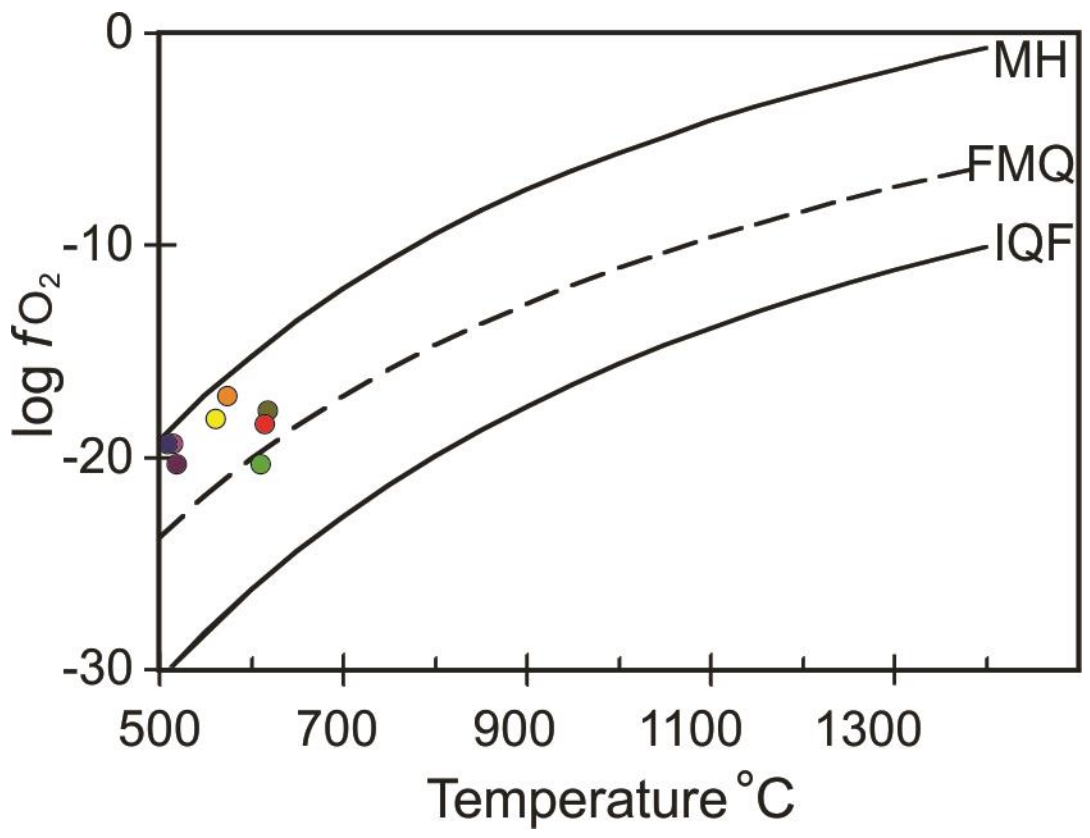

Figure 4.12. Diagram of $\log f \mathrm{O}_{2}$ vs $\mathrm{T}$ (in ${ }^{\circ} \mathrm{C}$ ) values calculated using the magnetiteilmenite oxygeothermometer calculated using in-situ values from ILMAT (Lepage, 2003). The calculated values show the temperature and $\mathrm{fO}_{2}$ conditions at which oxide reequilibration ceased in the NWRA. Buffer assemblage abbreviations: MH- magnetitehematite, FMQ- fayalite magnetite quartz, IQF- iron-quartz-fayalite.

Magnetite-ilmenite oxygeothermometry was applied to analyses of the earliest texturally identifiable magnetite and composite ilmenite containing exsolution microtextures from in situ analyses of samples collected in the NWRA. These textural varieties were selected as they were inferred to have formed at the earliest point of crystallization or subsolidus processes. The method of Stormer (1983) was used to determine the ulvospinel component in magnetite and the ilmenite component in ilmenite and the oxygeothermometer calibration of Andersen and Lindsley (1985) was used to 
calculate the $\mathrm{T}$ and $\mathrm{fO}_{2}$ values for each mineralization style. Calculated equilibration temperatures from all mineralization styles ranged from $487-619^{\circ} \mathrm{C}$, and $\log f \mathrm{O}_{2}$ values ranged from -17.1 to -20.3 (Fig. 4.12). The calculated temperature ranges corresponds with the end of subsolidus reequilibration and exsolution associated with autometamorphism and Grenvillian metamorphism rather than primary magmatic compositions of magnetite and ilmenite (Vincent et al., 1957; Buddington and Lindsley, 1964; Tan et al., 2017).

\subsubsection{Oxide genesis, concentration and evolution in the NWRA}

Summarising the previous conclusions, Fe-Ti oxide mineralization in the NWRA shows evidence of a three-step formation process: 1) late-stage magmatic crystallization of impure magnetite; 2) concentration by solid-state remobilization and/or crystal sorting; and 3) reequilibration during subsequent post-emplacement cooling and subsequent Grenvillian metamorphism. Evidence of the process responsible for the genesis of the oxide mineralization has largely been destroyed during recrystallization of oxides and host anorthosite, oxide remobilization, and subsolidus exsolution and reequilibration of the oxide minerals.

The original formation process of the Fe-Ti oxide mineralization must be able to explain the presence of large quantities of impure magnetite, as well as both orthopyroxene -bearing and orthopyroxene poor oxide mineralization. Either magma mixing or fractional crystallization of a Fe-Ti-P -bearing mafic silicate magma may have been responsible for the genesis of the oxide mineralization, however without further evidence the specific formation process is not clear at present. 
During diapiric rise of the anorthosite suite, two processes are thought to be able to concentrate oxide minerals: 1) differential stress on the host anorthosite causes the more ductile Fe-Ti oxide minerals to concentrate in zones of low pressure in the less ductile anorthosite via diffusion creep (Duchesne, 1996; 1999); or 2) density based crystal sorting concentrates Fe-Ti oxide mineralization (Pang et al., 2008). Either process could create zones of pure mono-mineralic $\mathrm{Ti}, \mathrm{Al}, \mathrm{Mg}$-bearing magnetite in sharp, irregular contact with the host anorthosite. It is evident that deformation ceased at high temperatures as exsolution lamellae of pleonaste and ilmenite in magnetite have not undergone subsequent deformation.

Finally, as the massive mono-mineralic magnetite cooled, it began to exsolve, and reequilibrate to form the textures observed at present. At highest temperatures, coarse granules of pleonaste and ilmenite were formed at grain boundaries of magnetite followed by all other textures of pleonaste, magnetite and ilmenite exsolution. The long period of slow cooling resulted in the coarse to very coarse-grained nature of the oxide mineralization as well as the near end-member concentrations of magnetite and ilmenite.

\subsection{Economic Potential of Fe-Ti oxide mineralization in the NWRA}

Proterozoic massif anorthosite suites are known to contain large concentrations of Fe, Ti, V and $\mathrm{P}$ which are typically hosted in or associated with Fe-Ti oxide mineralization (Charlier et al., 2014). Fe-Ti oxide mineralization in the NWRA contains magnetite and ilmenite which are the typical sources of Fe, Ti and V. The economic potential of Fe-Ti-V oxide mineralization is linked to the grade and abundance of oxide minerals as well as oxide mineralogy, the in situ compositions of oxide minerals including economic and deleterious elements. Presently, Ti can only be economically 
extracted from ilmenite and rutile; Ti hosted in magnetite and titanite is of little value and has low demand because it cannot be economically extracted (Force, 1991; Charlier et al., 2014). In contrast, Fe and V can be economically extracted from magnetite. The trace element composition of oxide minerals also affects economic potential. $\mathrm{Cr}, \mathrm{V}, \mathrm{Mn}, \mathrm{Mg}$ and hematite component in ilmenite are deleterious to extraction of high quality $\mathrm{TiO}_{2}$ and thus, impure ilmenite is less attractive for processing than more pure ilmenite (Force, 1991).

There are currently two operating mines in massif anorthosite suites that predominantly mine Ti. The Lac Tio deposit (Québec), is the largest known hard-rock ilmenite deposit where an ilmenite-rich norite that grades at $32-38 \mathrm{wt} . \% \mathrm{TiO}_{2}$ over $138 \mathrm{Mt}$ is mined (Charlier et al., 2010). Ilmenite from the Lac Tio deposit typically contains 2.5-3 wt. \% $\mathrm{MgO}$ which is considered a moderate value compared to other known deposits (Charlier et al., 2010). The ore of the Tellnes deposit (Norway) is also an ilmenite-rich norite which grades at $\sim 18$ wt. $\% \mathrm{TiO}_{2}$ with over $57 \mathrm{Mt}$ of ore. The $\mathrm{MgO}$ content in ilmenite in the Tellnes deposit ranges from 1.4-4.4 wt. \% with hematite content of ilmenite ranging from 10-14 mol\% (Charlier et al., 2006; 2007). Unlike the two aforementioned deposits, the Damiao (China) deposit contains magnetite, ilmenite, and apatite and is mined for Ti, Fe, V and P. The Damiao deposit averages grades of $36 \mathrm{wt}$ \% $\mathrm{Fe}_{2} \mathrm{O}_{3}, 7.0$ wt. $\% \mathrm{TiO}_{2}, 0.3$ wt. $\% \mathrm{~V}_{2} \mathrm{O}_{5}$ and 2 wt. $\% \mathrm{P}$ and its oxide mineralization is predominantly massive in nature with minor occurrences of disseminated oxides (Charlier et al., 2014). Ilmenite from the Damiao deposit has low concentrations of $\mathrm{Cr}$ and $\mathrm{Mg}$ and a low mol fraction hematite (<7 wt. \%) (Chen et al., 2013). 
Vanadium is not typically mined as the primary commodity in any deposit at present, instead, it is extracted as a byproduct of mining for other metals. The largest global sources of $\mathrm{V}$ are contained within vanadiferous magnetite hosted in large layered mafic intrusions. The Rhovan deposit, which is a part of the Bushveld Complex in South Africa contains the largest reserves of V currently being mined. Ore from the Rhovan deposits is hosted in a titaniferous magnetite gabbro and grades on average at $0.5 \mathrm{wt}$ \% $\mathrm{V}_{2} \mathrm{O}_{5}$ in bulk samples over $26 \mathrm{Mt}$ in proven reserves and $\sim 200 \mathrm{Mt}$ in other types of resource estimates (Glencore website http://www.glencore.com/investors/reports-andresults/reserves-and-resources).

The Panzhihua deposit (China) is hosted in mafic-ultramafic intrusions in the Emishian Large Igneous Province in southwest China and contains reserves of $1.2 \mathrm{Bt}$ grading at $33.2 \% \mathrm{Fe}_{2} \mathrm{O}_{3}, 11.6 \% \mathrm{TiO}_{2}$ and $0.3 \% \mathrm{~V}_{2} \mathrm{O}_{5}$ (Zhou et al., 2013). Undeveloped Canadian V deposits include the Lac Doré and De La Blache deposits which are anorthosite-hosted magnetite-dominated Fe-Ti oxide deposits in the Grenville province of Québec (Charlier et al., 2014). Of the North American deposits, the Lac Doré deposit is the largest with reserves of about $100 \mathrm{Mt}$ at a grade of $0.49 \% \mathrm{~V}_{2} \mathrm{O}_{5}(0.28 \% \mathrm{~V})$ (Taner et al., 2000). The Maracas deposit of Brazil is an orebody of vanadium-rich titanomagnetite which has ore reserves that grade at $1.17 \mathrm{wt} \% \mathrm{~V}_{2} \mathrm{O}_{5}$ over $18.4 \mathrm{Mt}$ and $\sim 50 \mathrm{Mt}$ grading between 0.85 and 1.24 wt.\% $\mathrm{V}_{2} \mathrm{O}_{5}$ (Largo resources website http://www.largoresources.com/investors/financial-reports/default.aspx).

Mineralization in the NWRA is predominantly hosted in irregular zones of massive to semi-massive oxide that is dominated by V-rich magnetite and minor ilmenite. On average, whole-rock geochemistry results of massive to semi-massive oxide 
mineralization in this study show that it contains $\sim 10$ wt.\% $\mathrm{TiO}_{2}, 62 \mathrm{wt} . \% \mathrm{FeO}_{(\mathrm{t})}$ and 2700 ppm V (0.48 wt.\% $\left.\mathrm{V}_{2} \mathrm{O}_{5}\right)$. In-situ magnetite analyses typically contain $<0.5$ wt. $\% \mathrm{TiO}_{2}$ to a maximum value of $\sim 4$ wt. $\%$ whereas $\mathrm{V}_{2} \mathrm{O}_{5}$ contents typically range from $0.6-0.7$ wt. \% . In-situ analyses of coarse ilmenite typically have values of $~ 1 \mathrm{wt} . \% \mathrm{Mg}, 5-7 \mathrm{~mol} \%$ hematite component and negligible $\mathrm{Cr}$ and $\mathrm{Al}$ content which is amenable to economic potential.

Zones of massive to semi-massive oxide mineralization within the NWRA have similar to slightly lower $\mathrm{Fe}, \mathrm{Ti}$, and $\mathrm{V}$ grades compared to the deposits described above. However, at surface, zones of massive oxide mineralization are sporadically distributed and dwarfed in volume by barren anorthosite. The amount of barren anorthosite between zones of massive oxide mineralization significantly dilutes the grades of the ore.

Furthermore, individual pods of massive to semi-massive oxide mineralization are too small to be efficiently targeted for extraction while avoiding the unmineralized anorthosite. If mineralization at depth is similar to the mineralization observed at surface, the economic potential of the NWRA is limited. However, it is impossible to accurately determine the grade and abundance of oxide mineralization without having a proper 3-D context provided by either detailed geophysical analysis or drill core. Unfortunately, this work has not yet been completed in the NWRA.

\section{REFERENCES}

Andersen DJ, Lindsley DH, Davidson PM (1993) QUILF: A pascal program to assess equilibria among Fe-Mg-Mn-Ti oxides, pyroxenes, olivine, and quartz. Computers \& Geosciences 19: 1333-1350 
Andersen DJ, Lindsley DH (1985) New (and final!) models for the Ti-magnetite/ilmenite geothermometer and oxygen barometer. Abstract AGU 1985 Spring Meeting EOS Transactions. American Geophysical Union 66, 416

Ashwal LD (1993) Anorthosites. Spinger-Verlag, Berlin

Bowles JF (1977) A method of tracing the temperature and oxygen-fugacity histories of complex magnetite-ilmenite grains. Mineralogical Magazine 41: 103-109

Broughm SG, Hanchar JM, Tornos F, Westhaus A, Attersley S (2017) Mineral chemistry of magnetite from magnetite-apatite mineralization and their host rocks: examples from Kiruna, Sweden and El Laco, Chile. Mineralium Deposita 52: 1223-1244

Buddington AF, Lindsley DH (1964) Iron-titanium oxide minerals and synthetic equivalents. Journal of Petrology 5: 310-357

Buddington AF, Fahey J, Vlisidis A (1955) Thermometric and petrogenetic significance of titaniferous magnetite. American Journal of Science 497-532

Charlier B, Grove TL (2012) Experiments on liquid immiscibility along tholeiitic liquid lines of descent. Contributions to Mineralogy and Petrology 164: 27-44

Charlier B, Namur O, Bolle O, Latypov R, Duchesne JC (2014) Fe-Ti-V-P ore deposits associated with Proterozoic massif-type anorthosites and related rocks. EarthScience Reviews 141: 56-81

Charlier B, Namur O, Malpas S, de Marneffe C, Duschene JC, Vander Auwera J, Bolle O (2010) Origin of the giant Allard Lake ilmenite ore deposit (Canada) by fractional crystallization, multiple magma pulses and mixing. Lithos 117: 119-134 
Charlier B, Namur O, Duchesne JC, Wisniewska J, Parecki A, Vander Auwera J (2009) Cumulate origin and polybaric crystallization of Fe-Ti oxide ores in the Suwalki anorthosite, NE Poland. Economic Geology 104: 205-221

Charlier B, Sakoma E, Sauvé M, Stanaway K, Vander Auwera J, Duchesne JC (2008) The Grader layered intrusion (Havre-Saint-Pierre Anorthosite, Quebec) and genesis of nelsonite and other Fe-Ti-P ores. Lithos 101: 359-378

Charlier B, Duchesne JC, Vander Auwera J (2006) Magma chamber processes in the Tellnes ilmenite deposit (Rogaland Anorthosite Province, SW Norway) and the formation of Fe-Ti ores in massif type anorthosites. Chemical Geology 234: 264290

Charlier B, Skår Ø, Korneliussen A, Duchesne JC, Vander Auwera J (2007) Ilmenite composition in the Tellnes Fe-Ti deposit, SW Norway: fractional crystallization, postcumulus evolution and ilmenite-zircon relation. Contributions to Mineralogy and Petrology 154: 119-134

Chen WT, Zhou MF, Zhao TP (2013) Differentiation of nelsonitic magmas in the formation of the $\sim 1.74 \mathrm{Ga}$ Damiao Fe-Ti-P ore deposit, North China. Contributions to Mineralogy and Petrology 165: 1342-1362

Dare SA, Barnes SJ, Beaudoin G, Meric J, Boutroy E, Potvin-Doucet C (2014) Trace elements in magnetite as petrogenetic indicators. Mineralium Deposita 49: 785-796

Duchesne JC (1970) Microtextures of Fe-Ti oxide minerals in the South Rogaland anorthositic complex (Norway). Annales de la Societe Geologique de Belgique 93: 197-251 
Duchesne JC (1972) Iron-titanium oxide minerals in the Bjerkrem-Sogndal Massif, southwestern Norway. Journal of Petrology 13: 57-81

Duchesne JC (1996) Liquid ilmenite or liquidus ilmenite: a comment on the nature of ilmenite vein deposits. In: Demaiffe D. (ed) Petrology and geochemistry of magmatic suites of rocks in the continental and oceanic crust. A volume dedicated to Professor Jean Michot, Universite Libre de Bruxelles, Royal Museum for Central Africa, pp 73-82

Duchesne JC (1999) Fe-Ti deposits in Rogaland anorthosites (South Norway): geochemical characteristics and problems of interpretation. Mineralium Deposita 34: $182-198$

Dupuis C, Beaudoin G (2011) Discriminant diagrams for iron oxide trace element fingerprinting of mineral deposit types. Mineralium Deposita 36: 319-355.

Force E (1991) Geology of titanium-mineral deposits. Geological Society of America, Special Paper 259

Ghiorso MS, Evans BW (2008) Thermodynamics of rhombohedral oxide solid solutions and a revision of the Fe-Ti two oxide geothermometer and oxygen-barometer. American Journal of Science 308: 957-1039

Glencore Resources (2016) 2016 reserves and resources report, August 2, 2017. [For updated information see Glencore Resources website http://www.glencore.com/investors/reports-and-results/reserves-and-resources) 
He HL, Yu SY, Song XY, Du ZS, Dai ZH, Xie W (2016) Origin of nelsonite and Fe-Ti oxide ore of the Damiao anorthosite complex, NE China: Evidence from trace element geochemistry of apatite, plagioclase, magnetite and ilmenite. Ore Geology Reviews 79: 367-381

Hu H, Li JW, Lentz D, Ren Z, Zhao XF, Deng XD, Hall D (2014) Dissolutionreprecipitation process of magnetite from the Chengchao iron deposit: insights into ore genesis and implication for in-situ chemical analysis of magnetite. Ore Geology Reviews 57: 393-405

Huang XW, Gao JF, Qi L, Meng YM, Wang YC, Dai ZH (2015) In-situ LA-ICPMS trace element analysis of magnetite: the Fenghuangshan $\mathrm{Cu}-\mathrm{Fe}-\mathrm{Au}$ deposit, Tongling, Eastern China. Ore Geology Reviews 72: 746-759

Irvine TN (1975) Crystallization sequences in the Muskox intrusion and other layered intrusions - II. Origin of chromitite layers and similar deposits of other magmatic ores. Geochimica et Cosmochimica Acta 39: 991-1020

Irvine TN, Keith DW, Todd SG (1983) The JM platinum-palladium reef of the Stillwater Complex, Montana; II, Origin by double-diffusive convective magma mixing and implications for the Bushveld Complex. Economic Geology 78: 1287-1334

Kerr A, Walsh JA, Sparkes GW, Hinchey JG (2013) Vanadium potential in Newfoundland and Labrador: a review and assessment. Current Research, Newfoundland and Labrador Geological Survey 13: 137-165 
Knipping JL, Bilenker LD, Simon AC, Reich M, Barra F, Deditus AP, Walle M, Heinrich CA, Holtz F, Munizaga R (2015) Trace elements in magnetite from massive iron oxide-apatite deposits indicate a combined formation by igneous and magmatichydrothermal processes. Geochimica Cosmochimica Acta 171: 15-38

Krause H, Pedall G (1980) Fe-Ti mineralization in the Åna-Sira anorthosite, Southern Norway. Metallogeny of the Baltic Shield. Finland Geological Survey Bulletin 307: $56-83$

Largo Resources (2016) Annual consolidated financial statements for the years ending December 31, 2016 and 2015, August 2, 2017. [For updated information see Largo Resources website - http://www.largoresources.com/investors/financialreports/default.aspx]

Li H, Li L, Zhang Z, Santosh M, Liu M, Cui Y, Yang X, Chen J, Yao T (2014) Alteration of the Damiao anorthosite complex in the northern North China Craton: Implications for high-grade iron mineralization. Ore Geology Reviews 57: 574-588

Lindsley and Epler (2017) Do Fe-Ti-oxide magmas exist? Probably not! American Mineralogist 102: 2157-2169

Lindsley DH (1976) The crystal chemistry and structure of oxide minerals as exemplified by the Fe-Ti oxides. In Oxide Minerals. Mineralogical Society of America, Short Course Notes 3: L1-L60

Lindsley DH (1991) Experimental studies of oxide minerals. Reviews in Mineralogy and Geochemistry 25: 69-109

Lindsley DH (2003) Do Fe-Ti oxide magmas exist? Geology: yes; Experiments: no! (Extended abstract) Norges geologiske undersøkelse Special Publication 9: 34-36 
Pang KN, Zhou MF, Lindsley D, Zhao D, Malpas J (2008) Origin of Fe-Ti oxide ores in mafic intrusions: evidence from the Panzhihua intrusion, SW China. Journal of Petrology 49: 295-313

Philpotts AR (1967) Origin of certain iron-titanium oxide and apatite rocks. Economic Geology 62: 303-315

Powell R, Powell M (1977) Geothermometry and oxygen barometry using coexisting iron-titanium oxides: a reappraisal. Mineralogical Magazine 41: 257-263.

Rudnick RL, Gao S (2003) Composition of the continental crust. Treatise on Geochemistry 3: 1-64

Stormer JC (1983) The effects of recalculation on estimates of temperature and oxygen fugacity from analyses of multicomponent iron-titanium oxides. American Mineralogist 68: 586-594

Tan W, Lie P, He H, Wang CY, Liang X (2017) Mineralogy and origin of exsolution in Tirich magnetite from different magmatic $\mathrm{Fe}-\mathrm{Ti}$ oxide-bearing intrusions. The Canadian Mineralogist 54: 539-55

Taner MF, Gault RA, Ercit TA (2000) Vanadium mineralization and its industry in Canada. Geological Association of Canada, Mineral Deposits Division. The Gangue, Issue 65. Vander Auwera J, Longhi J (1994) Experimental study of a jotunite (hypersthene monzodiorite): constraints on the parent magma composition and crystallization conditions $\left(\mathrm{P}, \mathrm{T}, f \mathrm{O}_{2}\right)$ of the Bjerkreim-Sokndal layered intrusion (Norway). Contributions to Mineralogy and Petrology 118: 60-78

Vincent EA, Wright JB, Chevallier R, Mathieu S (1957) Heating experiments on some natural titaniferous magnetites. Mineralogical Magazine 31: 625-655 
Wen G, Li JW, Hofstra AH, Koenig AE, Lowers HA, Adams D (2017) Hydrothermal reequilibration of igneous magnetite in altered granitic plutons and its implications for magnetite classification schemes: Insights from the Handan-Xingtai iron district, North China Craton. Geochimica et Cosmochimica Acta 213: 255-270

Zhou T, Fan Y, Yuan F, Zhang L, Qian B, Ma L, Yang X (2013) Geology and Geochronology of magnetite-apatite deposits in the Ning-Wu volcanic basin, eastern China. Journal of Asian Earth Sciences 66: 90-107 


\section{Chapter 5: Conclusions and Future Work}

\subsection{Conclusions}

1) Fe-Ti oxide mineralization in the NWRA is coarse-grained and magnetitedominated, containing minor ilmenite and pleonaste. Fe-Ti oxide mineralization is present in zones of massive to semi-massive oxide mineralization and as disseminated oxide mineralization. Fe-Ti oxide mineralization is in sharp, irregular, contact with the host anorthosite. No textural or in situ chemical variation is observed between mineralization styles.

2) Subsolidus processes including exsolution and reequilibration that occurred during slow cooling of the host anorthosite body coupled with Grenvillian metamorphism have significantly modified the magnetite, ilmenite, and pleonaste chemical compositions, and as a result primary magmatic oxide compositions are not preserved. Therefore the in situ analyses are not representative of the equilibrium conditions of magnetite, ilmenite and pleonaste, rather than their crystallization conditions. It is clear that subsolidus processes occurred both during the post-emplacement period and in response to Grenvillian metamorphism. However, the extent of the subsolidus processes during each event is unclear.

3) EPMA magnetite discrimination diagrams including those by Dupuis and Beaudoin (2011) and Knipping et al. (2015) were not effective. The reason for this ineffectiveness is unclear; however, the use of $\mathrm{Ti}$ and/or $\mathrm{Al}$ as axis variables for each discrimination diagram may play a role as the $\mathrm{Ti}$ and $\mathrm{Al}$ content in magnetite is known to be significantly modified during subsolidus exsolution of ilmenite and pleonaste respectively as well as during reequilibration. 
4) The multi-element magnetite LA-ICPMS discrimination diagram of Dare et al. (2014) is ineffective for discrimination of magnetite in the case of this study with analyses spread between the magmatic and high-T hydrothermal fields as well as outside of either field.

5) The formation and evolution of Fe-Ti oxide mineralization in the NWRA occurred through three distinct processes: 1) late-stage magmatic crystallization of impure magnetite; 2) concentration by solid-state remobilization and/or crystal sorting; and 3) reequilibration during subsequent post-emplacement cooling and subsequent Grenvillian metamorphism. Textural and chemical evidence of the primary oxide forming process has largely not been preserved during subsequent slow cooling and metamorphism. However, magma mixing or fractional crystallization of Fe-Ti-P enriched mafic silicate magma could also be responsible. Impure magnetite is concentrated in zones of low pressure during the diapiric rise of the host anorthosite through either solid-state remobilization (Duchesne, 1996; 1999) or crystal sorting. During slow cooling and metamorphism the zones of mono-mineralic magnetite underwent exsolution and reequilibration giving rise to the present magnetite, ilmenite and pleonaste mineral assemblage, as well as oxide textures and chemical composition including the coarse-grained granoblastic nature of the Fe-Ti oxide mineralization.

6) Whole-rock massive to semi-massive oxide mineralization and in situ magnetite and ilmenite analyses from the NWRA have similar chemical compositions as ores in presently operating mines and advanced $\mathrm{Fe}-\mathrm{Ti}-\mathrm{V}$ prospects. Whole-rock analyses of massive to semi-massive Fe-Ti oxide mineralization in the NWRA contains $~ 10$ wt. \% $\mathrm{TiO}_{2}$ and $2700 \mathrm{ppm} \mathrm{V}\left(0.48\right.$ wt. $\left.\% \mathrm{~V}_{2} \mathrm{O}_{5}\right)$. In-situ magnetite typically contain $<0.5$ wt. \% 
$\mathrm{TiO}_{2}$ and 0.6-0.7 wt. $\% \mathrm{~V}_{2} \mathrm{O}_{5}$. Composite ilmenite contains $\sim 1 \mathrm{wt} . \% \mathrm{Mg}, 5-7 \mathrm{~mol} \%$ hematite component and negligible $\mathrm{Cr}$ and $\mathrm{Al}$ content. However, in the NWRA the observed zones of massive to semi-massive oxide mineralization are relatively small and discontinuous compared to the amounts of adjacent anorthosite. It is unclear, due to lack of drill core and geophysical surveys, if the mineralization at depth is similar to that observed at surface, but if so, the economic potential of the field area within the NWRA is limited.

\subsection{Future Work}

1) A detailed geological map of the area of this study including the spatial relationships between oxide mineralization and host anorthosite, and specifically the orientation of veins and bands of massive to semi-massive oxide mineralization would be invaluable to better understand the formation processes of the Fe-Ti oxide mineralization in the NWRA

2) A detailed geophysical study would help test formation model in 3-D environment and determine continuity of mineralization at depth

3) Oxygen isotope studies to help determine the origin of the Fe-Ti oxide mineralization in the NWRA

4) Ar-Ar geochronology on biotite observed in coronas surrounding oxide mineralization could help to constrain timing of oxide formation/emplacement and cooling history of the NWRA.

5) $\mathrm{U}-\mathrm{Pb}$ geochronology of zircon and apatite in the oxide mineralization and host anorthosite, and Lu-Hf in zircon and Sm-Nd in the apatite to add additional constraints to 
the timing of emplacement, alteration, mineralization, and metamorphism, and the source of the mineralizing fluids.

6) Mineral separate analyses of magnetite, ilmenite and pleonaste to better understand the pre-exsolution chemistry of oxide minerals and to help determine if chemical variations between mineral separate analysis and in situ oxide analysis affect the interpretations and model presented in this study. It is noted, however, that due to external granule exsolution as well as oxide-silicate reequilibration, it is impossible to recreate the primary magnetite chemical composition. 
Appendix I. Sample list with GPS location, and mineralization style of samples analyzed with EPMA and LA-ICPMS.

\begin{tabular}{|c|c|c|c|c|}
\hline Sample & $\begin{array}{l}\text { UTM } \\
\text { easting }\end{array}$ & $\begin{array}{l}\text { UTM } \\
\text { northing }\end{array}$ & Mineralization style & Notes \\
\hline CCOO8 & 658736 & 5929043 & Massive to semi-massive oxide mineralization & $\begin{array}{l}\text { Bands of oxide mineralization - } \\
\text { lower }\end{array}$ \\
\hline CC010 & 658736 & 5929043 & Massive to semi-massive oxide mineralization & $\begin{array}{l}\text { Bands of oxide mineralization - } \\
\text { middle }\end{array}$ \\
\hline CC013 & 658736 & 5929043 & Massive to semi-massive oxide mineralization & upper \\
\hline CCO25 & 657619 & 5929902 & Massive to semi-massive oxide mineralization & Pod of oxide mineralization \\
\hline CC031 & 657605 & 5929747 & Disseminated oxide mineralization & Anorthosite hosted \\
\hline CC054 & 667754 & 5919493 & Disseminated oxide mineralization & Orthopyroxene-bearing \\
\hline CCO72 & 657744 & 5929747 & Massive to semi-massive oxide mineralization & Orthopyroxene-bearing \\
\hline CCO74 & 658516 & 5930210 & Disseminated oxide mineralization & Clinopyroxene-bearing \\
\hline CC076B & 658237 & 5929903 & Massive to semi-massive oxide mineralization & Vein of oxide mineralization \\
\hline
\end{tabular}


Appendix II a. Average (mean) and 2 $\sigma$ standard deviation of major, minor and trace element compositions of whole-rock analyses from various rock types observed in the field area.

\begin{tabular}{|c|c|c|c|c|c|c|c|c|c|c|}
\hline wt.\% & $\begin{array}{l}\text { Barren Ol - } \\
\text { bearing } \\
\text { anorthosite } \\
\text { avg }\end{array}$ & $\begin{array}{l}n=3 \\
\text { stdev }\end{array}$ & $\begin{array}{l}\text { Barren } \\
\text { anorthosite } \\
\text { avg }\end{array}$ & $\begin{array}{l}\mathrm{n}=37 \\
\text { stdev }\end{array}$ & $\begin{array}{l}\text { Barren } \\
\text { gabbronorite } \\
\text { avg }\end{array}$ & $\begin{array}{l}n=7 \\
\text { stdev }\end{array}$ & $\begin{array}{l}\text { Disseminated } \\
\text { oxide } \\
\text { avg }\end{array}$ & $\begin{array}{l}n=2 \\
\text { stdev }\end{array}$ & $\begin{array}{l}\text { disseminated } \\
\text { hosted in } \\
\text { gabbronorite } \\
\text { avg }\end{array}$ & $\begin{array}{l}\mathrm{n}=2 \\
\text { stdev }\end{array}$ \\
\hline $\mathrm{SiO} 2$ & 49.65 & 1.29 & 54.38 & 1.66 & 52.86 & 1.93 & 40.33 & 10.10 & 38.35 & 5.73 \\
\hline $\mathrm{Al} 2 \mathrm{O} 3$ & 20.79 & 2.11 & 26.17 & 1.31 & 24.31 & 0.64 & 20.26 & 3.92 & 15.79 & 1.83 \\
\hline $\mathrm{FeO}(\mathrm{t})$ & 8.18 & 2.29 & 2.00 & 1.33 & 4.18 & 1.12 & 20.74 & 12.92 & 22.03 & 6.38 \\
\hline $\mathrm{MnO}$ & 0.12 & 0.03 & 0.02 & 0.02 & 0.05 & 0.03 & 0.10 & 0.06 & 0.16 & 0.04 \\
\hline $\mathrm{MgO}$ & 7.89 & 2.15 & 0.60 & 0.96 & 2.41 & 1.94 & 1.46 & 0.57 & 3.67 & 3.78 \\
\hline $\mathrm{CaO}$ & 8.30 & 0.92 & 9.22 & 0.91 & 8.81 & 0.66 & 6.09 & 1.63 & 6.86 & 3.06 \\
\hline $\mathrm{Na} 2 \mathrm{O}$ & 3.22 & 0.41 & 5.01 & 0.47 & 4.49 & 0.67 & 3.64 & 1.12 & 2.92 & 0.59 \\
\hline $\mathrm{K} 2 \mathrm{O}$ & 0.61 & 0.03 & 1.14 & 0.29 & 1.04 & 0.33 & 1.03 & 0.06 & 0.83 & 0.21 \\
\hline $\mathrm{TiO} 2$ & 0.25 & 0.13 & 0.27 & 0.19 & 0.29 & 0.22 & 3.34 & 1.98 & 3.63 & 1.82 \\
\hline P2O5 & 0.05 & 0.01 & 0.06 & 0.06 & 0.05 & 0.03 & 0.05 & 0.01 & 0.04 & 0.01 \\
\hline LOI & 0.17 & 0.20 & 0.97 & 0.58 & 0.86 & 0.31 & 1.17 & 0.11 & 1.62 & 0.79 \\
\hline \multicolumn{11}{|l|}{$\mathrm{ppm}$} \\
\hline V & 43 & 30 & 37 & 27 & 53 & 49 & 796 & 519 & 712 & 169 \\
\hline $\mathrm{Cr}$ & 10 & 0 & 31 & 37 & 23 & 20 & 455 & 7 & 690 & 962 \\
\hline Co & 53 & 14 & 7 & 7 & 23 & 7 & 51 & 29 & 96 & 44 \\
\hline $\mathrm{Ni}$ & 130 & 36 & 25 & 23 & 91 & 64 & 109 & 8 & 184 & 141 \\
\hline $\mathrm{Zn}$ & 56 & 16 & 16 & 15 & 27 & 11 & 128 & 95 & 135 & 44 \\
\hline$S$ & 440 & 61 & 882 & 1080 & 2666.7 & 3201.4 & 1610 & 1075 & 9110 & 8613 \\
\hline $\mathrm{Cu}$ & 16 & 8 & 44 & 58 & 143 & 181 & 229 & 110 & 698 & 639 \\
\hline Ga & 14 & 1 & 18 & 1 & 17 & 2 & 30 & 8 & 27 & 6 \\
\hline $\mathrm{Sr}$ & 985 & 114 & 1379 & 114 & 1272 & 142 & 1074 & 323 & 798 & 218 \\
\hline $\mathrm{Ba}$ & 573 & 61 & 929 & 239 & 925 & 330 & 851 & 105 & 576 & 142 \\
\hline$\Sigma R E E+Y+S C$ & 14 & 3 & 15 & 3 & 20 & 9 & 19 & 0.3 & 20 & 11 \\
\hline
\end{tabular}




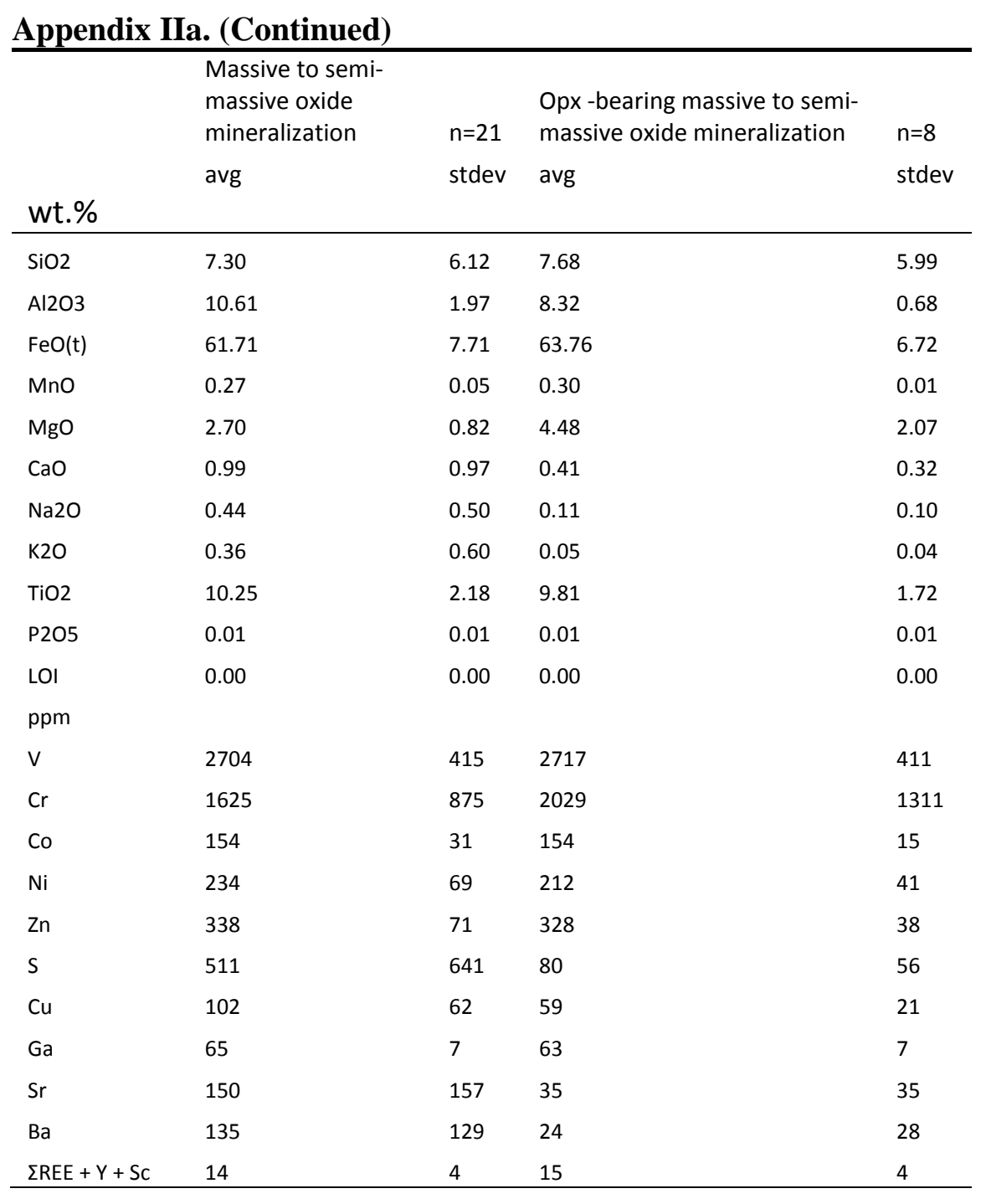


Appendix II b. Average (mean) and $2 \sigma$ standard deviation of in-situ EPMA analyses of observed oxide minerals from various textural occurrences. Total*: total accounting for recalculated $\mathrm{FeO} ; \mathrm{FeO}^{*}$ : measured $\mathrm{FeO}$ content.

\begin{tabular}{|c|c|c|c|c|c|c|c|c|c|c|c|c|}
\hline $\begin{array}{l}\text { Magnetite- most } \\
\text { primary }\end{array}$ & $\begin{array}{l}\text { Massive } \\
\text { oxide band- } \\
\text { lower } \\
n=9\end{array}$ & & $\begin{array}{l}\text { Massive } \\
\text { oxide } \\
\text { band- } \\
\text { middle } \\
\mathrm{n}=13\end{array}$ & & $\begin{array}{l}\text { Massive } \\
\text { oxide } \\
\text { band- } \\
\text { upper } \\
\mathrm{n}=19\end{array}$ & & $\begin{array}{l}\text { Massive } \\
\text { oxide pod } \\
n=15\end{array}$ & & $\begin{array}{c}\text { Massive } \\
\text { oxide vein } \\
n=12\end{array}$ & & $\begin{array}{c}\text { Orthopyroxene } \\
\text {-bearing oxide } \\
\text { pod } \\
n=12\end{array}$ & \\
\hline & avg & stdev & avg & stdev & avg & stdev & avg & stdev & avg & stdev & avg & stdev \\
\hline $\mathrm{SiO}_{2}$ & 0.02 & 0.01 & 0.01 & 0.01 & 0.02 & 0.01 & 0.03 & 0.01 & 0.01 & 0.00 & 0.03 & 0.01 \\
\hline $\mathrm{TiO}_{2}$ & 0.11 & 0.08 & 0.27 & 0.11 & 0.30 & 0.51 & 1.22 & 0.49 & 0.09 & 0.03 & 3.59 & 1.34 \\
\hline $\mathrm{Al}_{2} \mathrm{O}_{3}$ & 0.32 & 0.03 & 0.40 & 0.05 & 0.25 & 0.03 & 0.73 & 0.15 & 0.26 & 0.05 & 1.41 & 0.82 \\
\hline $\mathrm{Cr}_{2} \mathrm{O}_{3}$ & 0.27 & 0.02 & 0.27 & 0.04 & 0.42 & 0.06 & 0.60 & 0.04 & 0.48 & 0.05 & 0.33 & 0.02 \\
\hline $\mathrm{V}_{2} \mathrm{O}_{3}$ & 0.69 & 0.05 & 0.72 & 0.02 & 0.67 & 0.03 & 0.71 & 0.02 & 0.60 & 0.06 & 0.62 & 0.04 \\
\hline $\mathrm{FeO} *$ & 90.80 & 0.53 & 91.79 & 0.32 & 91.99 & 0.74 & 89.98 & 0.81 & 91.72 & 0.34 & 87.38 & 1.98 \\
\hline $\mathrm{Fe}_{2} \mathrm{O}_{3}$ recalculated & 66.71 & 0.42 & 67.23 & 0.33 & 67.35 & 1.21 & 64.26 & 1.20 & 67.36 & 0.26 & 59.64 & 3.21 \\
\hline FeO recalculated & 30.77 & 0.17 & 31.30 & 0.11 & 31.39 & 0.43 & 32.16 & 0.45 & 31.10 & 0.12 & 33.72 & 1.04 \\
\hline $\mathrm{MnO}$ & 0.01 & 0.01 & 0.02 & 0.01 & 0.02 & 0.01 & 0.04 & 0.02 & 0.03 & 0.01 & 0.19 & 0.08 \\
\hline $\mathrm{MgO}$ & 0.06 & 0.01 & 0.09 & 0.02 & 0.07 & 0.01 & 0.05 & 0.02 & 0.03 & 0.01 & 0.48 & 0.24 \\
\hline $\mathrm{ZnO}$ & 0.02 & 0.01 & 0.01 & 0.00 & 0.02 & 0.01 & 0.02 & 0.01 & 0.01 & 0.00 & 0.02 & 0.01 \\
\hline $\mathrm{NiO}$ & 0.03 & 0.01 & 0.04 & 0.01 & 0.03 & 0.01 & 0.03 & 0.01 & 0.01 & 0.00 & 0.03 & 0.01 \\
\hline total* & 99.00 & & 100.38 & & 100.53 & & 99.85 & & 99.99 & & 100.07 & \\
\hline Total measured & 92.32 & 0.53 & 93.64 & 0.26 & 93.79 & 0.39 & 93.41 & 0.52 & 93.24 & 0.32 & 94.10 & 0.53 \\
\hline
\end{tabular}


Appendix II b. (Continued)

\begin{tabular}{|c|c|c|c|c|c|c|}
\hline Magnetite host & $\begin{array}{c}\text { Disseminated } \\
\text { oxide hosted } \\
\text { in } \\
\text { anorthosite } \\
\text { n=17 } \\
\text { avg }\end{array}$ & stdev & $\begin{array}{l}\text { Orthopyroxene } \\
\text {-bearing } \\
\text { disseminated } \\
\text { oxide } \\
\mathrm{n}=24 \\
\text { avg }\end{array}$ & stdev & $\begin{array}{c}\text { Clinopyroxene } \\
\text {-bearing } \\
\text { disseminated } \\
\text { oxide } \\
\mathrm{n}=18 \\
\text { avg }\end{array}$ & stdev \\
\hline $\mathrm{SiO}_{2}$ & 0.03 & 0.01 & 0.03 & 0.01 & 0.02 & 0.01 \\
\hline $\mathrm{TiO}_{2}$ & 0.21 & 0.06 & 1.55 & 0.59 & 0.06 & 0.01 \\
\hline $\mathrm{Al}_{2} \mathrm{O}_{3}$ & 0.41 & 0.07 & 0.78 & 0.17 & 0.32 & 0.05 \\
\hline $\mathrm{Cr}_{2} \mathrm{O}_{3}$ & 0.52 & 0.09 & 0.34 & 0.03 & 0.57 & 0.08 \\
\hline $\mathrm{V}_{2} \mathrm{O}_{3}$ & 0.63 & 0.01 & 0.64 & 0.03 & 0.51 & 0.02 \\
\hline $\mathrm{FeO}^{*}$ & 90.69 & 0.52 & 90.32 & 0.79 & 91.06 & 0.36 \\
\hline $\begin{array}{l}\mathrm{Fe}_{2} \mathrm{O}_{3} \\
\text { recalculated }\end{array}$ & 66.32 & 0.39 & 64.21 & 1.32 & 66.86 & 0.28 \\
\hline FeO recalculated & 31.01 & 0.20 & 32.54 & 0.48 & 30.89 & 0.11 \\
\hline $\mathrm{MnO}$ & 0.02 & 0.01 & 0.06 & 0.02 & 0.02 & 0.01 \\
\hline $\mathrm{MgO}$ & 0.02 & 0.01 & 0.07 & 0.04 & 0.02 & 0.01 \\
\hline $\mathrm{ZnO}$ & 0.01 & 0.01 & 0.02 & 0.01 & 0.01 & 0.00 \\
\hline $\mathrm{NiO}$ & 0.04 & 0.01 & 0.03 & 0.01 & 0.03 & 0.00 \\
\hline total* & 99.22 & & 100.27 & & 99.31 & \\
\hline Total measured & 92.58 & 0.56 & 93.84 & 0.36 & 92.61 & 0.34 \\
\hline
\end{tabular}




\begin{tabular}{|c|c|c|c|c|c|c|c|c|c|c|c|c|}
\hline \multirow{2}{*}{$\begin{array}{l}\text { Magnetite in } \\
\text { ilmenite }\end{array}$} & \multicolumn{2}{|l|}{$\begin{array}{l}\text { Massive } \\
\text { oxide } \\
\text { band- } \\
\text { lower }\end{array}$} & \multicolumn{2}{|l|}{$\begin{array}{l}\text { Massive } \\
\text { oxide } \\
\text { band- } \\
\text { middle }\end{array}$} & \multicolumn{2}{|l|}{$\begin{array}{l}\text { Massive } \\
\text { oxide } \\
\text { band- } \\
\text { upper }\end{array}$} & \multicolumn{2}{|l|}{$\begin{array}{l}\text { Massive } \\
\text { oxide } \\
\text { pod }\end{array}$} & \multicolumn{2}{|l|}{$\begin{array}{l}\text { Massive } \\
\text { oxide } \\
\text { vein }\end{array}$} & \multicolumn{2}{|c|}{$\begin{array}{c}\text { Orthopyroxene } \\
\text {-bearing oxide } \\
\text { pod }\end{array}$} \\
\hline & $\begin{array}{l}\text { avg } \\
\mathrm{n}=5\end{array}$ & stdev & $\begin{array}{l}\text { avg } \\
\mathrm{n}=2\end{array}$ & stdev & $\begin{array}{c}\text { avg } \\
n=10\end{array}$ & stdev & $\begin{array}{l}\text { avg } \\
\mathrm{n}=8\end{array}$ & stdev & $\begin{array}{l}\text { avg } \\
\mathrm{n}=9\end{array}$ & stdev & $\begin{array}{l}\text { avg } \\
\mathrm{n}=5\end{array}$ & stdev \\
\hline $\mathrm{SiO}_{2}$ & 0.01 & 0.00 & 0.02 & 0.01 & 0.01 & 0.00 & 0.01 & 0.00 & 0.01 & 0.00 & 0.01 & 0.00 \\
\hline $\mathrm{TiO}_{2}$ & 1.18 & 0.32 & 0.51 & 0.46 & 0.10 & 0.10 & 1.53 & 0.43 & 1.58 & 0.57 & 2.43 & 0.41 \\
\hline $\mathrm{Al}_{2} \mathrm{O}_{3}$ & 0.28 & 0.04 & 0.50 & 0.08 & 0.25 & 0.03 & 0.67 & 0.23 & 0.26 & 0.02 & 0.70 & 0.10 \\
\hline $\mathrm{Cr}_{2} \mathrm{O}_{3}$ & 0.23 & 0.12 & 0.21 & 0.01 & 0.32 & 0.05 & 0.40 & 0.05 & 0.25 & 0.07 & 0.20 & 0.02 \\
\hline $\mathrm{V}_{2} \mathrm{O}_{3}$ & 0.47 & 0.15 & 0.48 & 0.03 & 0.56 & 0.09 & 0.52 & 0.10 & 0.38 & 0.06 & 0.56 & 0.04 \\
\hline $\mathrm{FeO}^{*}$ & 91.17 & 0.54 & 91.49 & 0.09 & 92.58 & 0.49 & 90.72 & 0.55 & 91.47 & 0.68 & 89.93 & 0.38 \\
\hline $\mathrm{Fe}_{2} \mathrm{O}_{3}$ recalculated & 65.70 & 0.37 & 66.74 & 0.69 & 68.09 & 0.44 & 64.63 & 0.92 & 65.37 & 1.00 & 63.22 & 0.61 \\
\hline $\mathrm{MgO}$ & 0.07 & 0.03 & 0.10 & 0.01 & 0.07 & 0.02 & 0.09 & 0.04 & 0.03 & 0.01 & 0.30 & 0.03 \\
\hline $\mathrm{ZnO}$ & 0.02 & 0.01 & 0.01 & 0.00 & 0.02 & 0.01 & 0.01 & 0.00 & 0.01 & 0.00 & 0.01 & 0.00 \\
\hline $\mathrm{NiO}$ & 0.02 & 0.01 & 0.03 & 0.01 & 0.03 & 0.01 & 0.03 & 0.01 & 0.01 & 0.01 & 0.04 & 0.01 \\
\hline total* & 100.04 & & 100.05 & & 100.75 & & 100.47 & & 100.58 & & 100.57 & \\
\hline Total measured & 93.45 & 0.70 & 93.37 & 0.41 & 93.95 & 0.44 & 93.99 & 0.30 & 94.04 & 0.68 & 94.23 & 0.54 \\
\hline
\end{tabular}




\section{Appendix II b. (Continued)}

\begin{tabular}{lcccc}
\hline & $\begin{array}{c}\text { Disseminated } \\
\text { oxide hosted } \\
\text { in } \\
\text { anorthosite }\end{array}$ & & $\begin{array}{c}\text { Orthopyroxene } \\
\text {-bearing } \\
\text { disseminated } \\
\text { oxide }\end{array}$ & \\
Magnetite in ilmenite & avg & stdev & avg & stdev \\
& $\mathrm{n}=5$ & & $\mathrm{n}=5$ & \\
\hline $\mathrm{SiO}_{2}$ & 0.01 & 0.00 & 0.01 & 0.01 \\
$\mathrm{TiO}_{2}$ & 1.04 & 0.31 & 2.03 & 0.28 \\
$\mathrm{Al}_{2} \mathrm{O}_{3}$ & 0.48 & 0.20 & 0.81 & 0.17 \\
$\mathrm{Cr}_{2} \mathrm{O}_{3}$ & 0.38 & 0.01 & 0.23 & 0.01 \\
$\mathrm{~V}_{2} \mathrm{O}_{3}$ & 0.36 & 0.05 & 0.42 & 0.03 \\
$\mathrm{FeO}^{*}$ & 91.12 & 0.45 & 90.58 & 0.82 \\
$\mathrm{Fe}_{2} \mathrm{O}_{3}$ recalculated & 65.74 & 0.57 & 63.98 & 0.86 \\
$\mathrm{FeO}$ recalculated & 31.96 & 0.40 & 33.01 & 0.32 \\
$\mathrm{MnO}_{\mathrm{MgO}}$ & 0.01 & 0.00 & 0.02 & 0.01 \\
$\mathrm{ZnO}$ & 0.07 & 0.04 & 0.14 & 0.05 \\
$\mathrm{NiO}$ & 0.02 & 0.01 & 0.02 & 0.01 \\
total* & 0.05 & 0.01 & 0.04 & 0.01 \\
$\mathrm{Total}$ measured & 100.12 & & 100.70 & \\
\hline & 93.52 & 0.46 & 94.28 & 0.58 \\
\hline
\end{tabular}




\section{Appendix II b. (Continued)}

\begin{tabular}{|c|c|c|c|c|c|c|c|c|}
\hline $\begin{array}{l}\text { Magnetite in } \\
\text { pleonaste }\end{array}$ & $\begin{array}{c}\text { Massive } \\
\text { oxide } \\
\text { band- } \\
\text { lower } \\
\text { n=6 } \\
\text { avg }\end{array}$ & stdev & $\begin{array}{l}\text { Massive } \\
\text { oxide } \\
\text { band- } \\
\text { middle } \\
\mathrm{n}=10 \\
\text { avg }\end{array}$ & stdev & $\begin{array}{c}\text { Massive } \\
\text { oxide } \\
\text { band- } \\
\text { upper } \\
\text { n=4 } \\
\text { avg }\end{array}$ & stdev & $\begin{array}{c}\text { Massive } \\
\text { oxide } \\
\text { vein } \\
n=4 \\
\text { avg }\end{array}$ & stdev \\
\hline $\mathrm{SiO}_{2}$ & 0.01 & 0.00 & 0.01 & 0.00 & 0.02 & 0.01 & 0.01 & 0.00 \\
\hline $\mathrm{TiO}_{2}$ & 0.06 & 0.04 & 0.29 & 0.08 & 0.07 & 0.03 & 0.07 & 0.04 \\
\hline $\mathrm{Al}_{2} \mathrm{O}_{3}$ & 0.21 & 0.03 & 0.40 & 0.11 & 0.18 & 0.02 & 0.21 & 0.03 \\
\hline $\mathrm{Cr}_{2} \mathrm{O}_{3}$ & 0.16 & 0.01 & 0.17 & 0.01 & 0.26 & 0.02 & 0.38 & 0.03 \\
\hline $\mathrm{V}_{2} \mathrm{O}_{3}$ & 0.39 & 0.08 & 0.46 & 0.07 & 0.36 & 0.01 & 0.31 & 0.02 \\
\hline $\mathrm{FeO} *$ & 91.77 & 0.66 & 91.67 & 0.65 & 92.24 & 0.16 & 91.41 & 0.39 \\
\hline $\mathrm{Fe}_{2} \mathrm{O}_{3}$ recalculated & 67.68 & 0.50 & 67.24 & 0.49 & 68.03 & 0.17 & 67.38 & 0.35 \\
\hline FeO recalculated & 30.87 & 0.23 & 31.17 & 0.26 & 31.03 & 0.03 & 30.77 & 0.09 \\
\hline $\mathrm{MnO}$ & 0.02 & 0.01 & 0.03 & 0.01 & 0.03 & 0.01 & 0.05 & 0.01 \\
\hline $\mathrm{MgO}$ & 0.02 & 0.01 & 0.07 & 0.02 & 0.03 & 0.02 & 0.02 & 0.01 \\
\hline $\mathrm{ZnO}$ & 0.03 & 0.03 & 0.04 & 0.02 & 0.04 & 0.02 & 0.12 & 0.03 \\
\hline $\mathrm{NiO}$ & 0.03 & 0.01 & 0.03 & 0.01 & 0.04 & 0.01 & 0.01 & 0.00 \\
\hline Total* & 99.48 & & 99.90 & & 100.09 & & 99.33 & \\
\hline Total measured & 92.71 & 0.69 & 93.18 & 0.75 & 93.28 & 0.10 & 92.59 & 0.39 \\
\hline
\end{tabular}




\section{Appendix II b. (Continued)}

\begin{tabular}{|c|c|c|c|c|c|c|c|c|c|c|c|}
\hline $\begin{array}{l}\text { Composite ilmenite } \\
\text { with exsolution }\end{array}$ & $\begin{array}{l}\text { Massive } \\
\text { oxide band- } \\
\text { lower } \\
\mathrm{n}=8 \\
\text { average }\end{array}$ & stdev & & $\begin{array}{l}\text { Massive } \\
\text { oxide } \\
\text { band- } \\
\text { middle } \\
\mathrm{n}=6 \\
\text { average }\end{array}$ & stdev & $\begin{array}{l}\text { Massive } \\
\text { oxide band- } \\
\text { upper } \\
n=15 \\
\text { average }\end{array}$ & stdev & $\begin{array}{l}\text { Massive } \\
\text { oxide pod } \\
\mathrm{n}=9 \\
\text { average }\end{array}$ & stdev & $\begin{array}{l}\text { Massive } \\
\text { oxide vein } \\
\mathrm{n}=9 \\
\text { average }\end{array}$ & stdev \\
\hline $\mathrm{SiO}_{2}$ & 0.01 & 0.00 & & 0.01 & - & 0.01 & 0.00 & 0.01 & 0.00 & 0.01 & 0.00 \\
\hline $\mathrm{TiO}_{2}$ & 49.20 & 0.48 & & 48.04 & 0.99 & 49.18 & 0.50 & 49.18 & 1.11 & 48.62 & 1.02 \\
\hline $\mathrm{Al}_{2} \mathrm{O}_{3}$ & 0.02 & 0.01 & & 0.04 & 0.00 & 0.02 & 0.01 & 0.05 & 0.01 & 0.03 & 0.03 \\
\hline $\mathrm{Cr}_{2} \mathrm{O}_{3}$ & 0.01 & 0.01 & & 0.01 & 0.01 & 0.02 & 0.01 & 0.02 & 0.01 & 0.02 & 0.01 \\
\hline $\mathrm{V}_{2} \mathrm{O}_{3}$ & 0.36 & 0.03 & & 0.36 & 0.04 & 0.38 & 0.03 & 0.29 & 0.02 & 0.34 & 0.03 \\
\hline $\mathrm{FeO}^{*}$ & 47.79 & 0.69 & & 48.67 & 0.83 & 48.01 & 0.52 & 48.41 & 1.08 & 48.06 & 0.76 \\
\hline $\mathrm{Fe}_{2} \mathrm{O}_{3}$ recalculated & 7.69 & 1.22 & & 10.29 & 1.85 & 8.06 & 0.80 & 7.24 & 2.18 & 7.83 & 1.78 \\
\hline FeO recalculated & 40.87 & 0.43 & & 39.41 & 0.85 & 40.66 & 0.31 & 41.90 & 0.89 & 41.02 & 0.86 \\
\hline $\mathrm{MnO}$ & 0.71 & 0.10 & & 0.67 & 0.10 & 0.72 & 0.03 & 0.33 & 0.03 & 1.09 & 0.03 \\
\hline $\mathrm{MgO}$ & 1.49 & 0.11 & & 1.75 & 0.08 & 1.64 & 0.03 & 1.12 & 0.07 & 0.91 & 0.05 \\
\hline $\mathrm{ZnO}$ & 0.01 & 0.00 & & 0.01 & 0.00 & 0.01 & 0.00 & 0.01 & 0.00 & 0.01 & 0.00 \\
\hline $\mathrm{NiO}$ & 0.01 & & - & 0.01 & - & 0.01 & 0.00 & 0.01 & 0.00 & 0.01 & 0.00 \\
\hline Total measured & 99.54 & 0.39 & & 99.51 & 0.27 & 99.92 & 0.29 & 99.37 & 0.33 & 99.03 & 0.39 \\
\hline
\end{tabular}




\section{Appendix II b. (Continued)}

\begin{tabular}{|c|c|c|c|c|c|c|c|c|}
\hline $\begin{array}{l}\text { Composite } \\
\text { ilmenite with } \\
\text { exsolution }\end{array}$ & $\begin{array}{l}\text { Orthopyroxene } \\
\text {-bearing oxide } \\
\text { pod } \\
n=6 \\
\text { average }\end{array}$ & stdev & $\begin{array}{l}\text { Disseminated } \\
\text { oxide hosted } \\
\text { in } \\
\text { anorthosite } \\
n=13 \\
\text { average }\end{array}$ & stdev & $\begin{array}{l}\text { Orthopyroxene } \\
\text {-bearing } \\
\text { disseminated } \\
\text { oxide } \\
\mathrm{n}=12 \\
\text { average }\end{array}$ & stdev & $\begin{array}{l}\text { Clinopyroxene } \\
\text {-bearing } \\
\text { disseminated } \\
\text { oxide } \\
\mathrm{n}=12 \\
\text { average }\end{array}$ & stdev \\
\hline $\mathrm{SiO}_{2}$ & 0.01 & - & 0.01 & 0.00 & 0.01 & 0.00 & 0.01 & 0.00 \\
\hline $\mathrm{TiO}_{2}$ & 51.96 & 0.90 & 49.96 & 0.78 & 49.37 & 0.96 & 48.45 & 0.77 \\
\hline $\mathrm{Al}_{2} \mathrm{O}_{3}$ & 0.03 & 0.02 & 0.04 & 0.01 & 0.02 & 0.01 & 0.01 & 0.01 \\
\hline $\mathrm{Cr}_{2} \mathrm{O}_{3}$ & 0.01 & 0.00 & 0.01 & 0.01 & 0.02 & 0.01 & 0.04 & 0.02 \\
\hline $\mathrm{V}_{2} \mathrm{O}_{3}$ & 0.25 & 0.03 & 0.25 & 0.02 & 0.25 & 0.02 & 0.27 & 0.02 \\
\hline $\begin{array}{l}\mathrm{FeO}^{*} \\
\mathrm{Fe}_{2} \mathrm{O}_{3}\end{array}$ & 43.22 & 0.91 & 47.82 & 0.78 & 47.90 & 0.84 & 48.31 & 0.74 \\
\hline $\begin{array}{l}\text { recalculated } \\
\mathrm{FeO}\end{array}$ & 3.93 & 1.63 & 6.00 & 1.50 & 6.24 & 1.87 & 7.46 & 1.49 \\
\hline recalculated & 39.69 & 0.56 & 42.42 & 0.67 & 42.29 & 0.86 & 41.60 & 0.69 \\
\hline $\mathrm{MnO}$ & 0.76 & 0.05 & 0.49 & 0.04 & 0.69 & 0.05 & 1.08 & 0.11 \\
\hline $\mathrm{MgO}$ & 3.51 & 0.13 & 1.12 & 0.16 & 0.79 & 0.04 & 0.49 & 0.09 \\
\hline $\mathrm{ZnO}$ & 0.02 & 0.01 & 0.02 & 0.01 & 0.01 & 0.00 & 0.01 & 0.00 \\
\hline $\mathrm{NiO}$ & 0.01 & 0.00 & 0.01 & 0.01 & 0.01 & 0.00 & 0.01 & . \\
\hline Total measured & 99.72 & 0.14 & 99.69 & 0.25 & 99.02 & 0.30 & 98.64 & 0.49 \\
\hline
\end{tabular}




\section{Appendix II b. (Continued)}

\begin{tabular}{|c|c|c|c|c|c|c|c|c|c|c|c|c|}
\hline $\begin{array}{l}\text { Composite ilmenite } \\
\text { without exsolution }\end{array}$ & $\begin{array}{l}\text { Massive } \\
\text { oxide } \\
\text { band- } \\
\text { middle } \\
\mathrm{n}=4 \\
\text { average }\end{array}$ & stdev & $\begin{array}{l}\text { Massive } \\
\text { oxide } \\
\text { band- } \\
\text { upper } \\
\mathrm{n}=3 \\
\text { average }\end{array}$ & stdev & $\begin{array}{l}\text { Massive } \\
\text { oxide pod } \\
n=7 \\
\text { average }\end{array}$ & stdev & $\begin{array}{l}\text { Massive } \\
\text { oxide vein } \\
\mathrm{n}=2 \\
\text { average }\end{array}$ & stdev & $\begin{array}{l}\text { Orthopyroxene } \\
\text {-bearing oxide } \\
\text { pod } \\
n=13 \\
\text { average }\end{array}$ & stdev & $\begin{array}{l}\text { Disseminated } \\
\text { oxide hosted } \\
\text { in anorthosite } \\
n=3 \\
\text { average }\end{array}$ & stdev \\
\hline $\mathrm{SiO}_{2}$ & 0.01 & - & 0.01 & - & 0.01 & 0.00 & 0.01 & - & 0.01 & 0.00 & 0.01 & . \\
\hline $\mathrm{TiO}_{2}$ & 49.74 & 0.12 & 50.29 & 1.23 & 50.61 & 0.49 & 48.31 & 0.90 & 51.81 & 0.46 & 51.94 & 0.09 \\
\hline $\mathrm{Al}_{2} \mathrm{O}_{3}$ & 0.04 & 0.01 & 0.02 & 0.01 & 0.03 & 0.01 & 0.02 & 0.00 & 0.03 & 0.01 & 0.02 & 0.01 \\
\hline $\mathrm{Cr}_{2} \mathrm{O}_{3}$ & 0.01 & 0.01 & 0.02 & 0.01 & 0.02 & 0.01 & 0.02 & 0.01 & 0.01 & 0.01 & 0.01 & . \\
\hline $\mathrm{V}_{2} \mathrm{O}_{3}$ & 0.35 & 0.01 & 0.39 & 0.04 & 0.22 & 0.02 & 0.35 & 0.00 & 0.22 & 0.02 & 0.19 & 0.01 \\
\hline $\mathrm{FeO} *$ & 47.11 & 0.08 & 46.66 & 0.80 & 47.59 & 0.68 & 48.90 & 0.62 & 43.70 & 0.56 & 46.49 & 0.13 \\
\hline $\mathrm{Fe}_{2} \mathrm{O}_{3}$ recalculated & 6.83 & 0.14 & 5.62 & 2.10 & 4.44 & 1.10 & 9.12 & 1.56 & 4.42 & 0.93 & 2.23 & 0.06 \\
\hline FeO recalculated & 40.97 & 0.11 & 41.60 & 1.09 & 43.60 & 0.36 & 40.69 & 0.79 & 39.72 & 0.30 & 44.48 & 0.08 \\
\hline $\mathrm{MnO}$ & 0.90 & 0.05 & 0.79 & 0.05 & 0.47 & 0.04 & 1.01 & 0.02 & 0.76 & 0.04 & 0.77 & 0.06 \\
\hline MgO & 1.60 & 0.03 & 1.59 & 0.01 & 0.80 & 0.10 & 0.97 & 0.01 & 3.42 & 0.08 & 0.81 & 0.06 \\
\hline $\mathrm{ZnO}$ & 0.01 & - & 0.01 & 0.00 & 0.02 & 0.01 & 0.02 & 0.01 & 0.01 & 0.00 & 0.02 & 0.02 \\
\hline $\mathrm{NiO}$ & 0.01 & - & 0.01 & - & 0.01 & 0.01 & 0.01 & - & 0.01 & 0.00 & 0.01 & 0.01 \\
\hline Total measured & 99.71 & 0.12 & 99.71 & 0.41 & 99.74 & 0.19 & 99.53 & 0.30 & 99.94 & 0.29 & 100.24 & 0.08 \\
\hline
\end{tabular}




\begin{tabular}{|c|c|c|c|c|}
\hline $\begin{array}{l}\text { Composite ilmenite } \\
\text { without exsolution }\end{array}$ & $\begin{array}{l}\text { Orthopyroxene } \\
\text {-bearing } \\
\text { disseminated } \\
\text { oxide } \\
\mathrm{n}=5 \\
\text { average }\end{array}$ & stdev & $\begin{array}{l}\text { Clinopyroxene } \\
\text {-bearing } \\
\text { disseminated } \\
\text { oxide } \\
\mathrm{n}=5 \\
\text { average }\end{array}$ & stdev \\
\hline $\mathrm{SiO}_{2}$ & 0.01 & - & 0.01 & 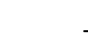 \\
\hline $\mathrm{TiO}_{2}$ & 51.53 & 0.25 & 48.82 & 0.80 \\
\hline $\mathrm{Al}_{2} \mathrm{O}_{3}$ & 0.02 & 0.01 & 0.02 & 0.01 \\
\hline $\mathrm{Cr}_{2} \mathrm{O}_{3}$ & 0.02 & 0.01 & 0.05 & 0.02 \\
\hline $\mathrm{V}_{2} \mathrm{O}_{3}$ & 0.23 & 0.02 & 0.27 & 0.03 \\
\hline $\mathrm{FeO}^{*}$ & 46.00 & 0.50 & 47.81 & 0.66 \\
\hline $\mathrm{Fe}_{2} \mathrm{O}_{3}$ recalculated & 1.62 & 0.77 & 6.57 & 1.42 \\
\hline $\mathrm{FeO}$ recalculated & 44.54 & 0.23 & 41.89 & 0.67 \\
\hline $\mathrm{MnO}$ & 1.22 & 0.03 & 1.23 & 0.20 \\
\hline $\mathrm{MgO}$ & 0.31 & 0.02 & 0.42 & 0.11 \\
\hline $\mathrm{ZnO}$ & 0.02 & 0.01 & 0.02 & 0.01 \\
\hline $\mathrm{NiO}$ & 0.01 & 0.00 & 0.01 & 0.01 \\
\hline Total measured & 99.31 & 0.27 & 98.61 & 0.37 \\
\hline
\end{tabular}




\section{Appendix II b. (Continued)}

\begin{tabular}{|c|c|c|c|c|c|c|c|c|c|c|c|}
\hline $\begin{array}{l}\text { Sandwich } \\
\text { ilmenite }\end{array}$ & $\begin{array}{l}\text { Massive } \\
\text { oxide band- } \\
\text { lower } \\
\mathrm{n}=2 \\
\text { average }\end{array}$ & $\begin{array}{l}\text { Massive } \\
\text { oxide } \\
\text { band- } \\
\text { middle } \\
n=10 \\
\text { average }\end{array}$ & stdev & $\begin{array}{l}\text { Massive } \\
\text { oxide } \\
\text { band- } \\
\text { upper } \\
n=9 \\
\text { average }\end{array}$ & stdev & $\begin{array}{l}\text { Massive } \\
\text { oxide } \\
\text { pod } \\
n=9 \\
\text { average }\end{array}$ & stdev & $\begin{array}{l}\text { Massive } \\
\text { oxide } \\
\text { vein } \\
n=3 \\
\text { average }\end{array}$ & $\begin{array}{l}\text { Disseminated } \\
\text { oxide hosted } \\
\text { in } \\
\text { anorthosite } \\
n=3 \\
\text { average }\end{array}$ & $\begin{array}{l}\text { Orthopyroxene } \\
\text {-bearing } \\
\text { disseminated } \\
\text { oxide } \\
\mathrm{n}=6 \\
\text { average }\end{array}$ & \\
\hline $\mathrm{SiO}_{2}$ & 0.02 & 0.01 & 0.00 & 0.01 & 0.00 & 0.01 & 0.00 & 0.01 & 0.01 & 0.01 & 0.00 \\
\hline $\mathrm{TiO}_{2}$ & 51.60 & 51.60 & 0.64 & 50.85 & 0.95 & 51.26 & 0.75 & 49.58 & 52.10 & 52.19 & 0.59 \\
\hline $\mathrm{Al}_{2} \mathrm{O}_{3}$ & 0.46 & 0.02 & 0.01 & 0.03 & 0.00 & 0.02 & 0.01 & 0.01 & 0.01 & 0.01 & 0.00 \\
\hline $\mathrm{Cr}_{2} \mathrm{O}_{3}$ & 0.05 & 0.01 & 0.01 & 0.02 & 0.01 & 0.01 & 0.01 & 0.10 & 0.02 & 0.01 & 0.01 \\
\hline $\mathrm{V}_{2} \mathrm{O}_{3}$ & 0.29 & 0.29 & 0.03 & 0.37 & 0.04 & 0.21 & 0.02 & 0.39 & 0.21 & 0.23 & 0.02 \\
\hline $\mathrm{FeO} *$ & 43.07 & 45.47 & 0.92 & 46.54 & 0.83 & 46.93 & 0.82 & 47.32 & 46.16 & 45.00 & 0.83 \\
\hline $\begin{array}{l}\mathrm{Fe}_{2} \mathrm{O}_{3} \\
\text { recalculated } \\
\mathrm{FeO}\end{array}$ & 2.65 & 3.40 & 1.42 & 4.91 & 1.70 & 3.16 & 1.46 & 6.34 & 2.00 & 0.51 & 0.55 \\
\hline recalculated & 40.69 & 42.41 & 0.38 & 42.13 & 0.76 & 44.14 & 0.66 & 41.62 & 44.36 & 45.25 & 0.46 \\
\hline $\mathrm{MnO}$ & 2.46 & 1.11 & 0.19 & 0.86 & 0.07 & 0.54 & 0.03 & 1.40 & 0.82 & 1.19 & 0.08 \\
\hline $\mathrm{MgO}$ & 1.79 & 1.60 & 0.06 & 1.53 & 0.14 & 0.78 & 0.03 & 0.87 & 0.93 & 0.26 & 0.01 \\
\hline ZnO & 0.06 & 0.02 & 0.01 & 0.01 & 0.01 & 0.02 & 0.01 & 0.01 & 0.02 & 0.02 & 0.01 \\
\hline $\mathrm{NiO}$ & 0.01 & 0.01 & 0.00 & 0.01 & 0.00 & 0.01 & 0.00 & 0.01 & 0.01 & 0.01 & 0.00 \\
\hline Total measured & 99.74 & 100.08 & 0.29 & 100.17 & 0.25 & 99.76 & 0.27 & 99.62 & 100.24 & 98.89 & 0.33 \\
\hline
\end{tabular}




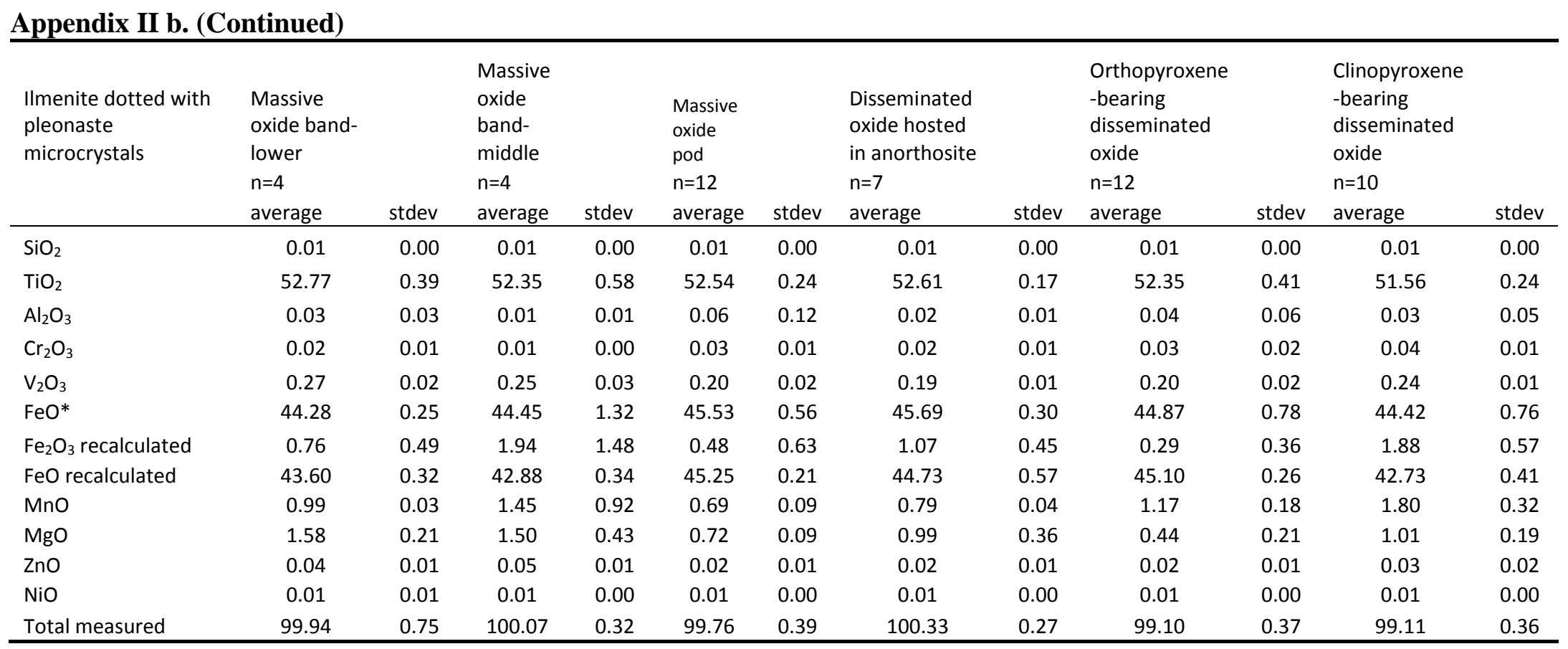


Appendix II b. (Continued)

\begin{tabular}{|c|c|c|c|c|c|c|c|c|}
\hline $\begin{array}{l}\text { Pleonaste with } \\
\text { magnetite } \\
\text { exsolution }\end{array}$ & $\begin{array}{l}\text { Massive } \\
\text { oxide } \\
\text { band- } \\
\text { lower } \\
\mathrm{n}=4 \\
\text { average }\end{array}$ & stdev & $\begin{array}{l}\text { Massive } \\
\text { oxide } \\
\text { band- } \\
\text { middle } \\
n=4 \\
\text { average }\end{array}$ & stdev & $\begin{array}{l}\text { Massive } \\
\text { oxide } \\
\text { band- } \\
\text { upper } \\
\mathrm{n}=5 \\
\text { average }\end{array}$ & stdev & $\begin{array}{l}\text { Massive } \\
\text { oxide vein } \\
\mathrm{n}=2 \\
\text { average }\end{array}$ & stdev \\
\hline $\mathrm{SiO}_{2}$ & 0.01 & - & 0.01 & - & 0.01 & - & 0.01 & - \\
\hline $\mathrm{TiO}_{2}$ & 0.02 & 0.01 & 0.01 & - & 0.01 & - & 0.01 & - \\
\hline $\mathrm{Al}_{2} \mathrm{O}_{3}$ & 58.28 & 0.61 & 58.88 & 0.67 & 58.72 & 1.05 & 56.47 & 0.66 \\
\hline $\mathrm{Cr}_{2} \mathrm{O}_{3}$ & 0.28 & 0.04 & 0.26 & 0.01 & 0.46 & 0.09 & 0.55 & 0.06 \\
\hline $\mathrm{V}_{2} \mathrm{O}_{3}$ & 0.09 & 0.01 & 0.08 & 0.02 & 0.08 & 0.01 & 0.09 & 0.02 \\
\hline $\mathrm{FeO} *$ & 28.85 & 0.31 & 27.99 & 0.98 & 28.09 & 1.12 & 32.46 & 0.68 \\
\hline $\mathrm{Fe}_{2} \mathrm{O}_{3}$ recalculated & 5.88 & 0.46 & 5.93 & 0.80 & 5.62 & 0.86 & 6.09 & 0.59 \\
\hline FeO recalculated & 23.56 & 0.25 & 22.65 & 0.27 & 23.03 & 0.43 & 26.98 & 0.14 \\
\hline $\mathrm{MnO}$ & 0.22 & 0.00 & 0.23 & 0.02 & 0.28 & 0.02 & 0.44 & 0.01 \\
\hline $\mathrm{MgO}$ & 10.93 & 0.18 & 11.65 & 0.20 & 11.36 & 0.39 & 7.76 & 0.18 \\
\hline $\mathrm{ZnO}$ & 0.64 & 0.03 & 0.67 & 0.03 & 0.60 & 0.02 & 1.77 & 0.09 \\
\hline $\mathrm{NiO}$ & 0.11 & 0.00 & 0.10 & 0.01 & 0.10 & 0.01 & 0.05 & 0.01 \\
\hline Total & 100.01 & 0.38 & 100.48 & 0.24 & 100.28 & 0.38 & 100.20 & 0.21 \\
\hline
\end{tabular}


Appendix II b. (Continued)

\begin{tabular}{|c|c|c|c|c|c|c|}
\hline $\begin{array}{l}\text { Pleonaste with no } \\
\text { exsolution } \\
\text { Comment }\end{array}$ & $\begin{array}{l}\text { Massive oxide } \\
\text { band- middle } \\
n=6 \\
\text { average }\end{array}$ & stdev & $\begin{array}{l}\text { Orthopyroxene } \\
\text {-bearing oxide } \\
\text { pod } \\
n=2 \\
\text { average }\end{array}$ & stdev & $\begin{array}{l}\text { Disseminated } \\
\text { oxide hosted } \\
\text { in } \\
\text { anorthosite } \\
n=4 \\
\text { average }\end{array}$ & stdev \\
\hline $\mathrm{SiO}_{2}$ & 0.02 & 0.03 & 0.01 & - & 0.01 & - \\
\hline $\mathrm{TiO}_{2}$ & 0.06 & 0.07 & 0.03 & 0.01 & 0.03 & 0.00 \\
\hline $\mathrm{Al}_{2} \mathrm{O}_{3}$ & 60.86 & 0.63 & 60.50 & 1.68 & 56.45 & 0.30 \\
\hline $\mathrm{Cr}_{2} \mathrm{O}_{3}$ & 0.36 & 0.04 & 0.39 & 0.01 & 0.47 & 0.03 \\
\hline $\mathrm{V}_{2} \mathrm{O}_{3}$ & 0.07 & 0.01 & 0.06 & 0.00 & 0.07 & 0.00 \\
\hline $\mathrm{FeO} *$ & 24.82 & 0.64 & 22.70 & 1.95 & 33.47 & 0.16 \\
\hline $\mathrm{Fe}_{2} \mathrm{O}_{3}$ recalculated & 3.84 & 0.64 & 5.95 & 0.97 & 5.66 & 0.18 \\
\hline FeO recalculated & 21.36 & 0.23 & 17.35 & 1.08 & 28.38 & 0.04 \\
\hline $\mathrm{MnO}$ & 0.22 & 0.01 & 0.18 & 0.01 & 0.19 & 0.01 \\
\hline $\mathrm{MgO}$ & 12.85 & 0.23 & 15.33 & 1.00 & 7.39 & 0.10 \\
\hline $\mathrm{ZnO}$ & 0.43 & 0.10 & 0.77 & 0.04 & 0.89 & 0.02 \\
\hline $\mathrm{NiO}$ & 0.10 & 0.01 & 0.06 & 0.01 & 0.11 & 0.02 \\
\hline Total & 100.17 & 0.16 & 100.61 & 0.62 & 99.65 & 0.34 \\
\hline
\end{tabular}




\section{Appendix II b. (Continued)}

\begin{tabular}{|c|c|c|c|c|c|}
\hline $\begin{array}{l}\text { Pleonaste in ilmenite } \\
\text { Comment }\end{array}$ & $\begin{array}{l}\text { Massive } \\
\text { oxide } \\
\text { band- } \\
\text { lower } \\
\mathrm{n}=3 \\
\text { average }\end{array}$ & $\begin{array}{l}\text { Massive } \\
\text { oxide } \\
\text { band- } \\
\text { middle } \\
\mathrm{n}=1\end{array}$ & $\begin{array}{l}\text { Massive } \\
\text { oxide } \\
\text { band- } \\
\text { upper } \\
\mathrm{n}=2 \\
\text { average }\end{array}$ & $\begin{array}{l}\text { Massive } \\
\text { oxide } \\
\text { pod } \\
\mathrm{n}=3 \\
\text { average }\end{array}$ & $\begin{array}{l}\text { Disseminated } \\
\text { oxide hosted } \\
\text { in } \\
\text { anorthosite } \\
n=2 \\
\text { average }\end{array}$ \\
\hline $\mathrm{SiO}_{2}$ & 0.02 & 0.01 & 0.01 & 0.09 & 0.01 \\
\hline $\mathrm{TiO}_{2}$ & 0.74 & 0.64 & 1.00 & 0.78 & 0.87 \\
\hline $\mathrm{Al}_{2} \mathrm{O}_{3}$ & 62.68 & 61.66 & 62.07 & 57.07 & 57.28 \\
\hline $\mathrm{Cr}_{2} \mathrm{O}_{3}$ & 0.57 & 0.50 & 0.73 & 1.07 & 0.51 \\
\hline $\mathrm{V}_{2} \mathrm{O}_{3}$ & 0.06 & 0.06 & 0.08 & 0.08 & 0.07 \\
\hline $\mathrm{FeO}^{*}$ & 21.72 & 22.83 & 21.56 & 32.59 & 31.09 \\
\hline $\mathrm{Fe}_{2} \mathrm{O}_{3}$ recalculated & 2.06 & 2.52 & 2.11 & 2.78 & 4.07 \\
\hline FeO recalculated & 19.87 & 20.56 & 19.66 & 30.09 & 27.42 \\
\hline $\mathrm{MnO}$ & 0.15 & 0.20 & 0.16 & 0.19 & 0.17 \\
\hline MgO & 14.76 & 13.92 & 14.90 & 7.17 & 8.79 \\
\hline $\mathrm{ZnO}$ & 0.38 & 0.42 & 0.49 & 0.51 & 0.80 \\
\hline $\mathrm{NiO}$ & 0.08 & 0.07 & 0.07 & 0.11 & 0.12 \\
\hline Total & 101.36 & 100.57 & 101.26 & 99.93 & 100.10 \\
\hline
\end{tabular}




\section{Appendix II b. (Continued)}

\begin{tabular}{lll}
$\begin{array}{l}\text { Pleonaste from } \\
\text { ilmenite dotted } \\
\text { with spinel } \\
\text { microcrystals }\end{array}$ & $\begin{array}{l}\text { Massive } \\
\text { oxide pod } \\
\mathrm{n}=4\end{array}$ & \\
Comment & average & stdev \\
\hline $\mathrm{SiO}_{2}$ & 0.10 & 0.07 \\
$\mathrm{TiO}_{2}$ & 1.05 & 0.24 \\
$\mathrm{Al}_{2} \mathrm{O}_{3}$ & 56.26 & 0.29 \\
$\mathrm{Cr}_{2} \mathrm{O}_{3}$ & 1.38 & 0.14 \\
$\mathrm{~V}_{2} \mathrm{O}_{3}$ & 0.07 & 0.01 \\
$\mathrm{FeO}^{*}$ & 32.33 & 0.23 \\
$\mathrm{Fe} \mathrm{O}_{3}$ & & \\
recalculated & 2.91 & 0.39 \\
$\mathrm{FeO}$ recalculated & 29.71 & 0.33 \\
$\mathrm{MnO}$ & 0.16 & 0.00 \\
$\mathrm{MgO}$ & 7.41 & 0.15 \\
$\mathrm{ZnO}$ & 0.67 & 0.08 \\
$\mathrm{NiO}^{\mathrm{Total}}$ & 0.11 & 0.01 \\
& & 0.42 \\
\hline
\end{tabular}


Appendix II c. Average (mean) and $2 \sigma$ standard deviation of LA-ICPMS magnetite analyses from various observed textural occurrences.

\begin{tabular}{|c|c|c|c|c|c|c|c|c|}
\hline & $\begin{array}{l}\text { Massive oxide } \\
\text { band- lower }\end{array}$ & & $\begin{array}{l}\text { Massive oxide } \\
\text { band-middle }\end{array}$ & & $\begin{array}{l}\text { Massive oxide } \\
\text { band- upper }\end{array}$ & & $\begin{array}{l}\text { Massive oxide } \\
\text { pod }\end{array}$ & \\
\hline & $\mathrm{n}=12$ & & $\mathrm{n}=14$ & & $\mathrm{n}=10$ & & $\mathrm{n}=18$ & \\
\hline ppm & avg & stdev & avg & stdev & avg & stdev & avg & stdev \\
\hline${ }^{29} \mathrm{Si}$ & 269 & 152 & 305 & 240 & 197 & 152 & 338 & 293 \\
\hline${ }^{44} \mathrm{Ca}$ & 10 & 5 & 8 & 5 & 12 & 18 & 11 & 8 \\
\hline${ }^{89} \mathrm{Y}$ & 0.001 & 0.000 & 0.003 & 0.003 & 0.003 & 0.004 & 0.008 & 0.007 \\
\hline${ }^{31} \mathrm{p}$ & 3 & 1 & 3 & 1 & 2 & 0.3 & 3 & 2 \\
\hline${ }^{208} \mathrm{~Pb}$ & 0.3 & 0.1 & 0.4 & 0.4 & 1 & 0.2 & 0.2 & 0.1 \\
\hline${ }^{90} \mathrm{Zr}$ & 0.1 & 0.1 & 1 & 1 & 0.3 & 0.3 & 1 & 0.4 \\
\hline${ }^{178} \mathrm{Hf}$ & 0.00 & 0.00 & 0.02 & 0.03 & 0.01 & 0.01 & 0.04 & 0.02 \\
\hline${ }^{27} \mathrm{Al}$ & 2758 & 614 & 7291 & 1982 & 3097 & 468 & 11663 & 6393 \\
\hline${ }^{74} \mathrm{Ge}$ & 1 & 0.11 & 1 & 0.14 & 1 & 0.1 & 1 & 0.11 \\
\hline${ }^{182} \mathrm{~W}$ & 0.01 & 0.01 & 0.01 & 0.00 & 0.01 & 0.01 & 0.01 & 0.00 \\
\hline${ }^{45} \mathrm{SC}$ & 1 & 0 & 2 & 0 & 1 & 0 & 1 & 0 \\
\hline${ }^{181} \mathrm{Ta}$ & 0.000 & 0.000 & 0.003 & 0.005 & 0.002 & 0.002 & 0.001 & 0.001 \\
\hline${ }^{93} \mathrm{Nb}$ & 0.02 & 0.01 & 0.05 & 0.08 & 0.04 & 0.05 & 0.03 & 0.03 \\
\hline${ }^{63} \mathrm{Cu}$ & 1 & 1 & 1 & 0.4 & 0.4 & 0.2 & 1 & 1 \\
\hline${ }^{95} \mathrm{Mo}$ & 0.05 & 0.04 & 0.12 & 0.03 & 0.08 & 0.02 & 0.35 & 0.06 \\
\hline${ }^{118} \mathrm{Sn}$ & 0.1 & 0.1 & 1 & 0.2 & 0.0 & 0.1 & 1 & 0.1 \\
\hline${ }^{69} \mathrm{Ga}$ & 39 & 3 & 60 & 9 & 36 & 2 & 62 & 10 \\
\hline${ }^{55} \mathrm{Mn}$ & 151 & 41 & 531 & 137 & 243 & 111 & 559 & 189 \\
\hline${ }^{24} \mathrm{Mg}$ & 668 & 162 & 2052 & 540 & 983 & 191 & 1332 & 1138 \\
\hline${ }^{47} \mathrm{Ti}$ & 928 & 676 & 5687 & 4520 & 1994 & 2568 & 13904 & 8122 \\
\hline${ }^{66} \mathrm{Zn}$ & 7 & 5 & 17 & 8 & 14 & 20 & 70 & 114 \\
\hline${ }^{59} \mathrm{Co}$ & 72 & 8 & 131 & 17 & 78 & 3 & 104 & 30 \\
\hline${ }^{51} \mathrm{~V}$ & 4682 & 264 & 5960 & 716 & 4660 & 190 & 4734 & 181 \\
\hline${ }^{60} \mathrm{Ni}$ & 248 & 57 & 428 & 39 & 288 & 21 & 274 & 23 \\
\hline${ }^{52} \mathrm{Cr}$ & 1764 & 406 & 1954 & 211 & 2407 & 234 & 3903 & 284 \\
\hline${ }^{75} \mathrm{As}$ & 0.3 & 0.2 & 1 & 0.2 & 1 & 0.1 & 0.3 & 0.2 \\
\hline${ }^{121} \mathrm{Sb}$ & 0.01 & 0.01 & 0.04 & 0.07 & 0.03 & 0.02 & 0.01 & 0.01 \\
\hline
\end{tabular}




\section{Appendix II c. (Continued)}

\begin{tabular}{|c|c|c|c|c|c|c|c|c|c|c|}
\hline \multirow[b]{2}{*}{ ppm } & \multirow{2}{*}{$\begin{array}{l}\text { Massive } \\
\text { oxide } \\
\text { vein } \\
\mathrm{n}=3 \\
\text { avg }\end{array}$} & \multirow[b]{2}{*}{ stdev } & \multirow{2}{*}{$\begin{array}{l}\text { Orthopyroxene - } \\
\text { bearing oxide } \\
\text { pod } \\
n=7 \\
\text { avg }\end{array}$} & \multicolumn{2}{|c|}{$\begin{array}{l}\text { Disseminated } \\
\text { oxide hosted } \\
\text { in } \\
\text { anorthosite } \\
\quad n=14\end{array}$} & \multirow[b]{2}{*}{ stdev } & \multirow{2}{*}{$\begin{array}{l}\text { Orthopyroxen } \\
\text {-bearing } \\
\text { disseminated } \\
\text { oxide } \\
\mathrm{n}=16 \\
\text { avg }\end{array}$} & \multirow{2}{*}{ e } & \multirow{2}{*}{$\begin{array}{l}\text { Clinopyroxene - } \\
\text { bearing } \\
\text { disseminated } \\
\text { oxide } \\
\mathrm{n}=10 \\
\text { avg }\end{array}$} & \multirow[b]{2}{*}{ stdev } \\
\hline & & & & stdev & avg & & & & & \\
\hline${ }^{29} \mathrm{Si}$ & 235 & 121 & 381 & 250 & 309 & 198 & 593 & 688 & 526 & 474 \\
\hline${ }^{44} \mathrm{Ca}$ & 16 & 17 & 8 & 2 & 9 & 4 & 14 & 13 & 23 & 30 \\
\hline${ }^{89} \mathrm{Y}$ & 0.001 & 0.01 & 0.014 & 0.01 & 0.006 & 0.01 & 0.009 & 0.01 & 0.007 & 0.01 \\
\hline${ }^{31} \mathrm{p}$ & 6 & 7 & 3 & 1 & 3 & 1 & 4 & 2 & 6 & 8 \\
\hline${ }^{208} \mathrm{~Pb}$ & 0.2 & 0.1 & 1 & 0.1 & 0.4 & 0.1 & 1 & 0.2 & 1 & 0.2 \\
\hline${ }^{90} \mathrm{Zr}$ & 0.0 & 0.1 & 2 & 0.4 & 1 & 0.4 & 1 & 0.2 & 0.3 & 0.3 \\
\hline${ }^{178} \mathrm{Hf}$ & 0.00 & 0.00 & 0.11 & 0.01 & 0.03 & 0.02 & 0.05 & 0.01 & 0.01 & 0.01 \\
\hline${ }^{27} \mathrm{Al}$ & 4387 & 1421 & 17501 & 5057 & 11286 & 5669 & 16744 & 3649 & 3700 & 843 \\
\hline${ }^{74} \mathrm{Ge}$ & 1 & 0.15 & 1 & 0.06 & 1 & 0.1 & 1 & 0.1 & 1 & 0.14 \\
\hline${ }^{182} \mathrm{~W}$ & 0.03 & 0.00 & 0.01 & 0.01 & 0.01 & 0.03 & 0.01 & 0.01 & 0.01 & 0.01 \\
\hline${ }^{45} \mathrm{Sc}$ & 1 & 1 & 6 & 1 & 1 & 0 & 2 & 0 & 1 & 0 \\
\hline${ }^{181} \mathrm{Ta}$ & 0.001 & 0.01 & 0.001 & 0.01 & 0.004 & 0.01 & 0.003 & 0.05 & 0.004 & 0.01 \\
\hline${ }^{93} \mathrm{Nb}$ & 0.01 & 0.00 & 0.02 & 0.02 & 0.01 & 0.01 & 0.02 & 0.01 & 0.11 & 0.17 \\
\hline${ }^{63} \mathrm{Cu}$ & 0.3 & 0.2 & 1 & 1 & 2 & 2 & 1 & 1 & 2 & 4 \\
\hline${ }^{95} \mathrm{Mo}$ & 0.21 & 0.10 & 0.22 & 0.05 & 0.85 & 0.11 & 0.37 & 0.06 & 0.26 & 0.04 \\
\hline${ }^{118} \mathrm{Sn}$ & 0.0 & 0.0 & 2 & 0.1 & 1 & 0.3 & 2 & 0.3 & 0.2 & 0.1 \\
\hline${ }^{69} \mathrm{Ga}$ & 40 & 5 & 59 & 4 & 52 & 9 & 69 & 7 & 52 & 4 \\
\hline${ }^{55} \mathrm{Mn}$ & 325 & 46 & 1943 & 93 & 533 & 268 & 1057 & 288 & 355 & 172 \\
\hline${ }^{24} \mathrm{Mg}$ & 675 & 146 & 6360 & 1871 & 1115 & 666 & 1901 & 594 & 455 & 94 \\
\hline${ }^{47} \mathrm{Ti}$ & 940 & 420 & 25637 & 1399 & 7960 & 6070 & 20522 & 4537 & 3015 & 3645 \\
\hline${ }^{66} \mathrm{Zn}$ & 31 & 21 & 121 & 148 & 113 & 75 & 61 & 28 & 38 & 25 \\
\hline${ }^{59} \mathrm{Co}$ & 62 & 4 & 179 & 13 & 82 & 25 & 140 & 18 & 83 & 8 \\
\hline${ }^{51} \mathrm{~V}$ & 4307 & 110 & 4358 & 102 & 4194 & 204 & 4480 & 297 & 3438 & 79 \\
\hline${ }^{60} \mathrm{Ni}$ & 98 & 3 & 322 & 13 & 438 & 41 & 362 & 35 & 267 & 21 \\
\hline${ }^{52} \mathrm{Cr}$ & 2783 & 443 & 2228 & 111 & 3178 & 242 & 2274 & 297 & 3348 & 357 \\
\hline${ }^{75} \mathrm{As}$ & 1 & 0.3 & 1 & 0.1 & 1 & 0.2 & 1 & 0.3 & 2 & 0.4 \\
\hline${ }^{121} \mathrm{Sb}$ & 0.02 & 0.02 & 0.03 & 0.01 & 0.04 & 0.02 & 0.04 & 0.04 & 0.05 & 0.06 \\
\hline
\end{tabular}




\section{Appendix II c. (Continued)}

\begin{tabular}{|c|c|c|c|c|c|c|c|c|}
\hline $\begin{array}{l}\text { Composite } \\
\text { ilmenite } \\
\text { with } \\
\text { exsolution } \\
\text { ppm }\end{array}$ & $\begin{array}{l}\text { Massive } \\
\text { oxide band- } \\
\text { lower } \\
\mathrm{n}=8 \\
\text { average }\end{array}$ & stdev & $\begin{array}{l}\text { Massive } \\
\text { oxide band- } \\
\text { middle } \\
\mathrm{n}=7 \\
\text { average } \\
\end{array}$ & stdev & $\begin{array}{l}\text { Massive oxide } \\
\text { band- upper } \\
\mathrm{n}=11 \\
\text { average }\end{array}$ & stdev & $\begin{array}{l}\text { Massive oxide } \\
\text { pod } \\
\mathrm{n}=11 \\
\text { average }\end{array}$ & stdev \\
\hline${ }^{24} \mathrm{Mg}$ & 9196 & 552 & 10468 & 1133 & 9831 & 309 & 6477 & 898 \\
\hline${ }^{27} \mathrm{Al}$ & 987 & 1484 & 272 & 72 & 405 & 172 & 362 & 109 \\
\hline${ }^{29} \mathrm{Si}$ & 278 & 125 & 363 & 333 & 400 & 278 & 235 & 99 \\
\hline${ }^{31} \mathrm{p}$ & 3 & 1 & 2 & 1 & 5 & 3 & 2 & 0 \\
\hline${ }^{44} \mathrm{Ca}$ & 6 & 1 & 7 & 5 & 17 & 11 & 8 & 6 \\
\hline${ }^{45} \mathrm{Sc}$ & 41 & 1 & 44 & 2 & 45 & 3 & 24 & 2 \\
\hline${ }^{47} \mathrm{Ti}$ & 293338 & 2265 & 287281 & 6652 & 295364 & 5842 & 290618 & 3794 \\
\hline${ }^{51} \mathrm{~V}$ & 1661 & 233 & 1351 & 206 & 2082 & 363 & 811 & 181 \\
\hline${ }^{52} \mathrm{Cr}$ & 135 & 38 & 136 & 29 & 243 & 35 & 147 & 40 \\
\hline${ }^{55} \mathrm{Mn}$ & 5832 & 671 & 6321 & 895 & 5926 & 205 & 2875 & 557 \\
\hline${ }^{59} \mathrm{Co}$ & 93 & 3 & 115 & 5 & 95 & 6 & 99 & 7 \\
\hline${ }^{60} \mathrm{Ni}$ & 46 & 6 & 69 & 9 & 47 & 4 & 50 & 2 \\
\hline${ }^{63} \mathrm{Cu}$ & 4 & 5 & 1 & 0.2 & 3 & 1 & 3 & 1 \\
\hline${ }^{66} \mathrm{Zn}$ & 15 & 14 & 8 & 4 & 17 & 17 & 8 & 2 \\
\hline${ }^{69} \mathrm{Ga}$ & 3 & 3 & 1 & 0.3 & 2 & 0.5 & 1 & 0.2 \\
\hline${ }^{74} \mathrm{Ge}$ & 0.2 & 0.03 & 0.1 & 0.03 & 0.2 & 0.1 & 0.1 & 0.01 \\
\hline${ }^{75} \mathrm{As}$ & 0.5 & 0.1 & 1 & 0.2 & 1 & 0.3 & 0.2 & 0.1 \\
\hline${ }^{89} \mathrm{Y}$ & 0.1 & 0.01 & 0.1 & 0.01 & 0.1 & 0.01 & 0.1 & 0.01 \\
\hline${ }^{90} \mathrm{Zr}$ & 70 & 10 & 72 & 10 & 95 & 68 & 107 & 28 \\
\hline${ }^{93} \mathrm{Nb}$ & 4 & 1 & 3 & 1 & 6 & 1 & 23 & 6 \\
\hline${ }^{95} \mathrm{Mo}$ & 0.4 & 0.1 & 0 & 0.1 & 1 & 0.1 & 1 & 0.1 \\
\hline${ }^{118} \mathrm{Sn}$ & 3 & 1 & 3 & 0.2 & 2 & 1 & 3 & 1 \\
\hline${ }^{121} \mathrm{Sb}$ & 0.1 & 0.01 & 0.04 & 0.01 & 0.1 & 0.04 & 0.1 & 0.03 \\
\hline${ }^{178} \mathrm{Hf}$ & 2 & 0.3 & 2 & 0.2 & 2 & 1 & 4 & 1 \\
\hline${ }^{181} \mathrm{Ta}$ & 0 & 0.1 & 0.1 & 0.1 & 0.4 & 0.1 & 1 & 1 \\
\hline${ }^{182} \mathrm{~W}$ & 0.009 & 0.005 & 0.02 & 0.01 & 0.1 & 0.01 & 0.1 & 0.04 \\
\hline${ }^{208} \mathrm{~Pb}$ & 1 & 0.15 & 1 & 0.2 & 2 & 1 & 0.5 & 0.1 \\
\hline
\end{tabular}




\section{Appendix II c. (Continued)}

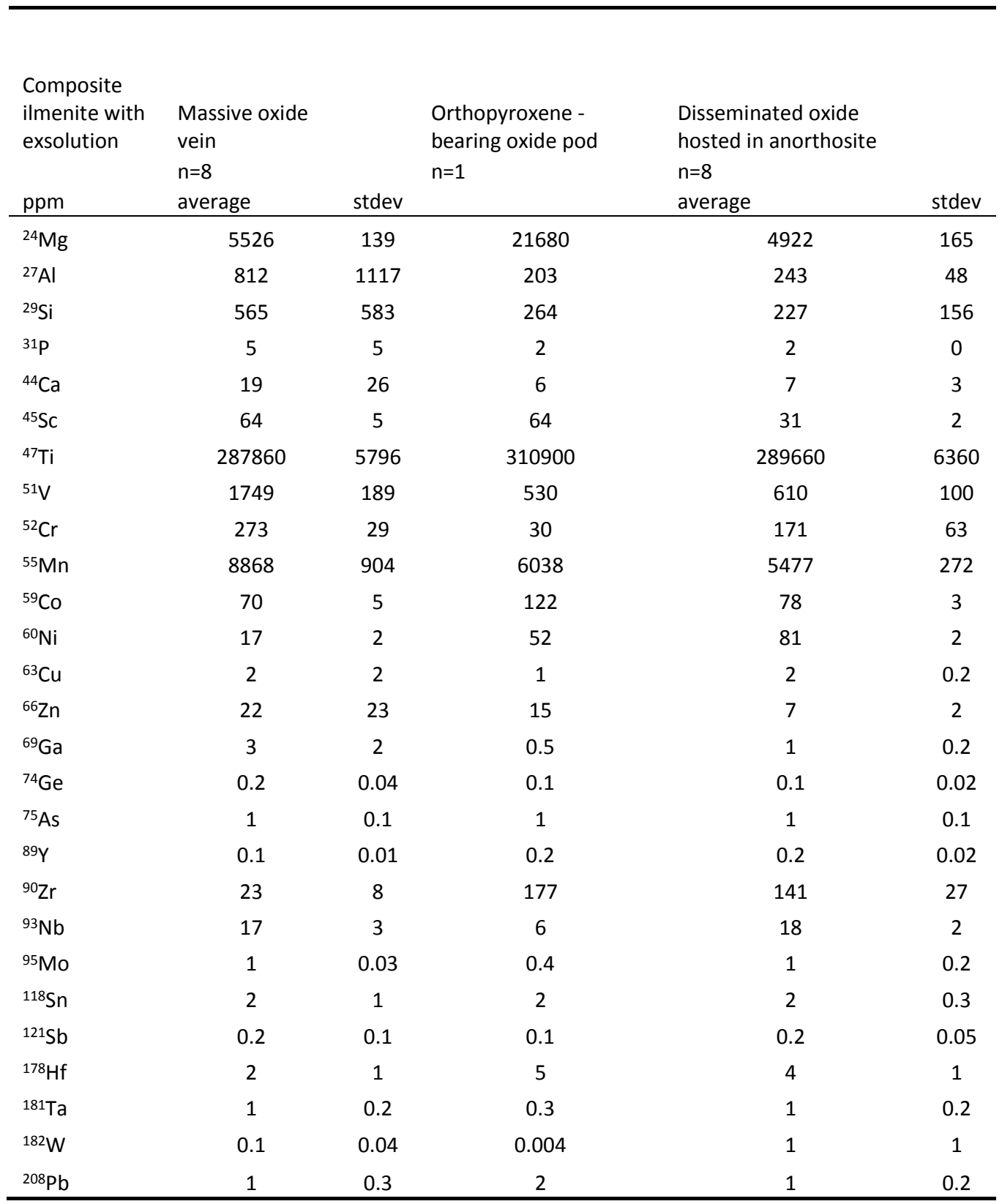




\section{Appendix II c. (Continued)}

\begin{tabular}{|c|c|c|c|c|}
\hline $\begin{array}{l}\text { Composite } \\
\text { ilmenite with } \\
\text { exsolution } \\
\text { ppm }\end{array}$ & $\begin{array}{l}\text { Orthopyroxene } \\
\text {-bearing } \\
\text { disseminated } \\
\text { oxide } \\
\mathrm{n}=11 \\
\text { average }\end{array}$ & & $\begin{array}{l}\text { Clinopyroxene } \\
\text {-bearing } \\
\text { disseminated } \\
\text { oxide } \\
\mathrm{n}=5 \\
\text { average }\end{array}$ & stdev \\
\hline${ }^{24} \mathrm{Mg}$ & 7311 & 206 & 3514 & 375 \\
\hline${ }^{27} \mathrm{Al}$ & 288 & 87 & 263 & 90 \\
\hline${ }^{29} \mathrm{Si}$ & 397 & 213 & 536 & 651 \\
\hline 31P & 3 & 2 & 6 & 5 \\
\hline${ }^{44} \mathrm{Ca}$ & 12 & 9 & 10 & 7 \\
\hline${ }^{45} \mathrm{Sc}$ & 27 & 3 & 31 & 2 \\
\hline${ }^{47} \mathrm{Ti}$ & 301712 & 7482 & 291480 & 2080 \\
\hline${ }^{51} \mathrm{~V}$ & 559 & 119 & 862 & 69 \\
\hline${ }^{22} \mathrm{Cr}$ & 82 & 14 & 379 & 73 \\
\hline${ }^{55} \mathrm{Mn}$ & 4087 & 250 & 8416 & 1337 \\
\hline${ }^{59} \mathrm{Co}$ & 114 & 4 & 100 & 5 \\
\hline${ }^{60} \mathrm{Ni}$ & 67 & 4 & 48 & 4 \\
\hline${ }^{63} \mathrm{Cu}$ & 3 & 1 & 2 & 0.4 \\
\hline${ }^{66} \mathrm{Zn}$ & 14 & 5 & 28 & 11 \\
\hline${ }^{69} \mathrm{Ga}$ & 1 & 0.4 & 2 & 0.1 \\
\hline${ }^{74} \mathrm{Ge}$ & 0.1 & 0.04 & 0.2 & 0.02 \\
\hline${ }^{75} \mathrm{As}$ & 1 & 0.2 & 2 & 1 \\
\hline${ }^{89} \mathrm{Y}$ & 0.1 & 0.02 & 0.1 & 0.03 \\
\hline${ }^{90} \mathrm{Zr}$ & 96 & 25 & 47 & 6 \\
\hline${ }^{93} \mathrm{Nb}$ & 30 & 6 & 17 & 2 \\
\hline${ }^{95} \mathrm{Mo}$ & 0.4 & 0.1 & 1 & 0.2 \\
\hline${ }^{118} \mathrm{Sn}$ & 2 & 0.4 & 2 & 0.3 \\
\hline${ }^{121} \mathrm{Sb}$ & 0.04 & 0.01 & 0.1 & 0.04 \\
\hline${ }^{178} \mathrm{Hf}$ & 3 & 1 & 2 & 0.2 \\
\hline${ }^{181} \mathrm{Ta}$ & 1 & 0.4 & 1 & 0.1 \\
\hline $182 \mathrm{~W}$ & 0.1 & 0.02 & 0.04 & 0.01 \\
\hline${ }^{208} \mathrm{~Pb}$ & 1 & 0.5 & 2 & 1 \\
\hline
\end{tabular}




\section{Appendix II c. (Continued)}

\begin{tabular}{|c|c|c|c|c|c|c|c|c|}
\hline $\begin{array}{l}\text { Composite } \\
\text { ilmenite } \\
\text { without } \\
\text { exsolution }\end{array}$ & $\begin{array}{l}\text { Massive } \\
\text { oxide } \\
\text { band- } \\
\text { lower } \\
\mathrm{n}=2 \\
\text { average }\end{array}$ & stdev & $\begin{array}{l}\text { Massive } \\
\text { oxide } \\
\text { band- } \\
\text { middle } \\
\mathrm{n}=4 \\
\text { average }\end{array}$ & stdev & $\begin{array}{l}\text { Massive oxide } \\
\text { band- upper } \\
\mathrm{n}=1 \\
\text { none }\end{array}$ & $\begin{array}{l}\text { Massive } \\
\text { oxide } \\
\text { pod } \\
n=9 \\
\text { average }\end{array}$ & stdev & $\begin{array}{l}\text { Massive oxide } \\
\text { vein } \\
n=1 \\
\text { none }\end{array}$ \\
\hline${ }^{24} \mathrm{Mg}$ & 9872 & 182 & 9881 & 208 & 10250 & 5230 & 714 & 5558 \\
\hline${ }^{27} \mathrm{Al}$ & 366 & 80 & 240 & 55 & 479 & 252 & 137 & 237 \\
\hline${ }^{29} \mathrm{Si}$ & 1436 & 1647 & 425 & 175 & 279 & 208 & 169 & 385 \\
\hline${ }^{31} \mathrm{p}$ & 7 & 8 & 2 & 1 & 3 & 2 & 0 & 2 \\
\hline${ }^{44} \mathrm{Ca}$ & 198 & 271 & 7 & 7 & 9 & 6 & 3 & 4 \\
\hline${ }^{45} \mathrm{SC}$ & 40 & 0 & 43 & 4 & 45 & 22 & 3 & 52 \\
\hline${ }^{47} \mathrm{Ti}$ & 295800 & 566 & 292750 & 1708 & 293500 & 300244 & 2589 & 284300 \\
\hline${ }^{51} \mathrm{~V}$ & 1893 & 195 & 1076 & 199 & 1861 & 497 & 135 & 1393 \\
\hline${ }^{52} \mathrm{Cr}$ & 150 & 28 & 148 & 20 & 270 & 173 & 54 & 267 \\
\hline${ }^{55} \mathrm{Mn}$ & 4777 & 14 & 7439 & 371 & 6027 & 3830 & 457 & 9928 \\
\hline${ }^{59} \mathrm{Co}$ & 79 & 4 & 110 & 5 & 110 & 90 & 5 & 68 \\
\hline${ }^{60} \mathrm{Ni}$ & 29 & 2 & 62 & 9 & 76 & 48 & 3 & 18 \\
\hline${ }^{63} \mathrm{Cu}$ & 2 & 2 & 1 & 0 & 3 & 3 & 3 & 1 \\
\hline${ }^{66} \mathrm{Zn}$ & 7 & 2 & 14 & 10 & 12 & 8 & 6 & 11 \\
\hline${ }^{69} \mathrm{Ga}$ & 2 & 0 & 1 & 0 & 4 & 0.5 & 0.2 & 1 \\
\hline${ }^{74} \mathrm{Ge}$ & 0 & 0 & 0 & 0 & 0 & 0.1 & 0.02 & 0.2 \\
\hline${ }^{75} \mathrm{As}$ & 1 & 1 & 1 & 0 & 1 & 0.2 & 0.1 & 0.5 \\
\hline${ }^{89} \mathrm{Y}$ & 0 & 0 & 0 & 0 & 0 & 0.1 & 0.01 & 0.1 \\
\hline${ }^{90} \mathrm{Zr}$ & 72 & 14 & 57 & 11 & 63 & 70 & 22 & 13 \\
\hline${ }^{93} \mathrm{Nb}$ & 5 & 0 & 3 & 0 & 7 & 19 & 3 & 15 \\
\hline${ }^{95} \mathrm{Mo}$ & 0 & 0 & 0 & 0 & 1 & 0.4 & 0.04 & 1 \\
\hline${ }^{118} \mathrm{Sn}$ & 3 & 0 & 3 & 0 & 2 & 2 & 0.3 & 0.1 \\
\hline${ }^{121} \mathrm{Sb}$ & 0 & 0 & 0 & 0 & 0 & 0.04 & 0.03 & 0.2 \\
\hline${ }^{178} \mathrm{Hf}$ & 3 & 0 & 2 & 0 & 2 & 3 & 1 & 0.5 \\
\hline${ }^{181} \mathrm{Ta}$ & 0 & 0 & 0 & 0 & 0 & 1 & 0.2 & 0.5 \\
\hline${ }^{182} \mathrm{~W}$ & 0 & 0 & 0 & 0 & 0 & 0.1 & 0.04 & 0.2 \\
\hline${ }^{208} \mathrm{~Pb}$ & 1 & 1 & 1 & 0 & 2 & 0.5 & 0.1 & 1 \\
\hline
\end{tabular}




\section{Appendix II c. (Continued)}

\begin{tabular}{|c|c|c|c|c|c|}
\hline $\begin{array}{l}\text { Composite } \\
\text { ilmenite } \\
\text { without } \\
\text { exsolution }\end{array}$ & $\begin{array}{l}\text { Orthopyroxene } \\
\text {-bearing oxide } \\
\text { pod } \\
n=12 \\
\text { average }\end{array}$ & stdev & $\begin{array}{l}\text { Disseminated } \\
\text { oxide hosted } \\
\text { in anorthosite } \\
n=1\end{array}$ & $\begin{array}{l}\text { Clinopyroxene } \\
\text {-bearing } \\
\text { disseminated } \\
\text { oxide } \\
\mathrm{n}=5 \\
\text { average }\end{array}$ & stdev \\
\hline${ }^{24} \mathrm{Mg}$ & 21253 & 1099 & 2089 & 2878 & 348 \\
\hline${ }^{27} \mathrm{Al}$ & 937 & 1936 & 310 & 367 & 268 \\
\hline${ }^{29} \mathrm{Si}$ & 325 & 165 & 488 & 816 & 237 \\
\hline${ }^{31} \mathrm{p}$ & 2 & 1 & 2 & 4 & 3 \\
\hline${ }^{44} \mathrm{Ca}$ & 9 & 8 & 12 & 16 & 10 \\
\hline${ }^{45} \mathrm{Sc}$ & 67 & 8 & 29 & 28 & 2 \\
\hline${ }^{47} \mathrm{Ti}$ & 305608 & 5813 & 294900 & 290894 & 3745 \\
\hline${ }^{51} \mathrm{~V}$ & 432 & 76 & 433 & 862 & 90 \\
\hline${ }^{52} \mathrm{Cr}$ & 93 & 45 & 216 & 328 & 54 \\
\hline${ }^{55} \mathrm{Mn}$ & 6244 & 333 & 9711 & 9515 & 1178 \\
\hline${ }^{59} \mathrm{Co}$ & 122 & 9 & 47 & 89 & 10 \\
\hline${ }^{60} \mathrm{Ni}$ & 58 & 9 & 53 & 39 & 6 \\
\hline${ }^{63} \mathrm{Cu}$ & 2 & 1 & 3 & 4 & 4 \\
\hline${ }^{66} \mathrm{Zn}$ & 29 & 62 & 10 & 32 & 17 \\
\hline${ }^{69} \mathrm{Ga}$ & 1 & 2 & 1 & 1 & 1 \\
\hline${ }^{74} \mathrm{Ge}$ & 0.1 & 0.03 & 0.03 & 0.2 & 0.03 \\
\hline${ }^{75} \mathrm{As}$ & 1 & 0.1 & 1 & 2 & 0.2 \\
\hline${ }^{89} \mathrm{Y}$ & 0.2 & 0.02 & 0.1 & 0.2 & 0.1 \\
\hline${ }^{90} \mathrm{Zr}$ & 124 & 16 & 47 & 35 & 9 \\
\hline${ }^{93} \mathrm{Nb}$ & 5 & 1 & 3 & 14 & 2 \\
\hline${ }^{95} \mathrm{Mo}$ & 0.4 & 0.04 & 1 & 1 & 0.1 \\
\hline${ }^{118} \mathrm{Sn}$ & 2 & 0.3 & 2 & 2 & 0.4 \\
\hline${ }^{121} \mathrm{Sb}$ & 0.1 & 0.03 & 0.1 & 0.1 & 0.01 \\
\hline${ }^{178} \mathrm{Hf}$ & 4 & 0.4 & 2 & 2 & 0.3 \\
\hline${ }^{181} \mathrm{Ta}$ & 0.1 & 0.1 & 0.1 & 1 & 0.3 \\
\hline $182 \mathrm{~W}$ & 0.01 & 0.004 & 0.2 & 0.04 & 0.02 \\
\hline${ }^{208} \mathrm{~Pb}$ & 1 & 0.2 & 1 & 1 & 0.3 \\
\hline
\end{tabular}




\section{Appendix II c. (Continued)}

\begin{tabular}{|c|c|c|c|c|c|c|}
\hline $\begin{array}{l}\text { Sandwich } \\
\text { ilmenite } \\
\text { ppm }\end{array}$ & $\begin{array}{l}\text { Massive } \\
\text { oxide } \\
\text { band- } \\
\text { middle } \\
\mathrm{n}=5 \\
\text { average }\end{array}$ & stdev & $\begin{array}{l}\text { Massive } \\
\text { oxide } \\
\text { band- } \\
\text { upper } \\
\mathrm{n}=6 \\
\text { average }\end{array}$ & stdev & $\begin{array}{l}\text { Massive } \\
\text { oxide } \\
\text { pod } \\
\mathrm{n}=5 \\
\text { average }\end{array}$ & stdev \\
\hline${ }^{24} \mathrm{Mg}$ & 9877 & 346 & 9414 & 403 & 4931 & 213 \\
\hline${ }^{27} \mathrm{Al}$ & 222 & 171 & 297 & 175 & 142 & 19 \\
\hline${ }^{29} \mathrm{Si}$ & 342 & 349 & 395 & 337 & 336 & 205 \\
\hline 31P & 3 & 2 & 6 & 5 & 2 & 0.4 \\
\hline${ }^{44} \mathrm{Ca}$ & 6 & 4 & 15 & 9 & 6 & 2 \\
\hline${ }^{45} \mathrm{Sc}$ & 43 & 2 & 39 & 5 & 21 & 1 \\
\hline${ }^{47} \mathrm{Ti}$ & 309780 & 2616 & 297483 & 9953 & 304340 & 1313 \\
\hline${ }^{51} \mathrm{~V}$ & 965 & 111 & 1401 & 345 & 391 & 16 \\
\hline${ }^{52} \mathrm{Cr}$ & 125 & 26 & 192 & 55 & 130 & 22 \\
\hline${ }^{55} \mathrm{Mn}$ & 8800 & 531 & 7202 & 934 & 4300 & 76 \\
\hline${ }^{59} \mathrm{Co}$ & 117 & 4 & 94 & 5 & 87 & 4 \\
\hline${ }^{60} \mathrm{Ni}$ & 73 & 9 & 48 & 6 & 47 & 2 \\
\hline${ }^{63} \mathrm{Cu}$ & 2 & 0 & 3 & 1 & 2 & 1 \\
\hline${ }^{66} \mathrm{Zn}$ & 32 & 38 & 31 & 22 & 5 & 1 \\
\hline${ }^{69} \mathrm{Ga}$ & 1 & 1 & 1 & 1 & 0.3 & 0.04 \\
\hline${ }^{74} \mathrm{Ge}$ & 0.1 & 0.03 & 0.2 & 0.05 & 0.05 & 0.03 \\
\hline${ }^{75} \mathrm{As}$ & 1 & 0.2 & 1 & 0 & 0.2 & 0.1 \\
\hline${ }^{89} \mathrm{Y}$ & 0.1 & 0.004 & 0.12 & 0.01 & 0.1 & 0.02 \\
\hline${ }^{90} \mathrm{Zr}$ & 45 & 5 & 28 & 10 & 57 & 4 \\
\hline${ }^{93} \mathrm{Nb}$ & 2 & 0.2 & 5 & 1 & 19 & 3 \\
\hline${ }^{95} \mathrm{Mo}$ & 1 & 0.1 & 0.5 & 0.1 & 0.5 & 0.1 \\
\hline${ }^{118} \mathrm{Sn}$ & 3 & 0.2 & 1 & 0.4 & 2 & 0.1 \\
\hline${ }^{121} \mathrm{Sb}$ & 0.1 & 0.01 & 0.1 & 0.03 & 0.04 & 0.01 \\
\hline${ }^{178} \mathrm{Hf}$ & 2 & 0.1 & 1 & 0.3 & 2 & 0.2 \\
\hline${ }^{181} \mathrm{Ta}$ & 0.1 & 0.04 & 0.3 & 0.1 & 1 & 0.2 \\
\hline${ }^{182} \mathrm{~W}$ & 0.02 & 0.01 & 0.1 & 0.02 & 0.05 & 0.02 \\
\hline${ }^{208 \mathrm{~Pb}}$ & 1 & 0.1 & 2 & 0.5 & 0.5 & 0.2 \\
\hline
\end{tabular}




\section{Appendix II c. (Continued)}

\begin{tabular}{|c|c|c|c|c|c|c|c|}
\hline $\begin{array}{l}\text { Composite } \\
\text { pleonaste } \\
\text { with } \\
\text { magnetite } \\
\text { exsolution } \\
\text { ppm }\end{array}$ & $\begin{array}{l}\text { Massive } \\
\text { oxide } \\
\text { band- } \\
\text { lower } \\
n=3 \\
\text { average }\end{array}$ & $\begin{array}{l}\text { Massive } \\
\text { oxide } \\
\text { band- } \\
\text { middle } \\
\mathrm{n}=4 \\
\text { average }\end{array}$ & stdev & $\begin{array}{l}\text { Massive } \\
\text { oxide band- } \\
\text { upper } \\
\mathrm{n}=2 \\
\text { average }\end{array}$ & $\begin{array}{l}\text { Massive } \\
\text { oxide pod } \\
n=1\end{array}$ & $\begin{array}{l}\text { Massive } \\
\text { oxide } \\
\text { vein } \\
n=3 \\
\text { average }\end{array}$ & $\begin{array}{l}\text { Disseminated oxide } \\
\text { hosted in } \\
\text { anorthosite } \\
\mathrm{n}=2 \\
\text { average }\end{array}$ \\
\hline${ }^{24} \mathrm{Mg}$ & 141030 & 81785 & 11926 & 62280 & 47560 & 46157 & 40855 \\
\hline${ }^{29} \mathrm{Si}$ & 3697 & 441 & 391 & 180 & 2590 & 602 & 345 \\
\hline${ }^{31} \mathrm{p}$ & 38 & 12 & 9 & 10 & 3 & 8 & 21 \\
\hline${ }^{44} \mathrm{Ca}$ & 36 & 10 & 1 & 11 & 24 & 12 & 37 \\
\hline${ }^{45} \mathrm{SC}$ & 0.5 & 0.1 & 0.1 & 0.1 & 1 & 0.1 & 0.1 \\
\hline${ }^{47} \mathrm{Ti}$ & 0.01 & 0.04 & 0.04 & 0.02 & 0.3 & 363 & 0.04 \\
\hline${ }^{51} \mathrm{~V}$ & 1233 & 752 & 176 & 561 & 484 & 544 & 590 \\
\hline${ }^{52} \mathrm{Cr}$ & 3781 & 2411 & 499 & 2723 & 4067 & 3349 & 2045 \\
\hline${ }^{55} \mathrm{Mn}$ & 3712 & 2213 & 439 & 2070 & 1607 & 3361 & 1767 \\
\hline${ }^{59} \mathrm{Co}$ & 1465 & 875 & 153 & 697 & 1237 & 463 & 552 \\
\hline${ }^{60} \mathrm{Ni}$ & 1583 & 1102 & 230 & 772 & 1155 & 240 & 769 \\
\hline${ }^{66} \mathrm{Zn}$ & 8007 & 6740 & 2380 & 3685 & 5580 & 11237 & 5068 \\
\hline${ }^{69} \mathrm{Ga}$ & 455 & 254 & 34 & 219 & 363 & 211 & 183 \\
\hline${ }^{74} \mathrm{Ge}$ & 0.3 & 0.3 & 0.1 & 0.4 & 0.03 & 0.2 & 1 \\
\hline${ }^{89} \mathrm{Y}$ & 0.004 & 0.004 & 0.001 & 0.004 & 0.003 & 0.003 & 0.003 \\
\hline${ }^{90} \mathrm{Zr}$ & 0.04 & 0.02 & 0.01 & 0.02 & 3 & 0.1 & 0.5 \\
\hline${ }^{93} \mathrm{Nb}$ & 0.008 & 0.01 & 0.003 & 0.01 & 1 & 0.01 & 0.02 \\
\hline${ }^{95} \mathrm{Mo}$ & 0.2 & 0.1 & 0.01 & 0.2 & 0.3 & 0.1 & 0.1 \\
\hline${ }^{118} \mathrm{Sn}$ & 0.1 & 0.1 & 0.1 & 0.1 & 0.3 & 0.2 & 0.1 \\
\hline${ }^{178} \mathrm{Hf}$ & 0.004 & 0.03 & 0.03 & 0.03 & 0.1 & 0.01 & 0.1 \\
\hline${ }^{181} \mathrm{Ta}$ & 0.003 & 0.01 & 0.02 & 0.01 & 0.02 & 0.001 & 0.03 \\
\hline${ }^{182} \mathrm{~W}$ & 0.03 & 0.03 & 0.01 & 0.03 & 0.02 & 0.02 & 0.02 \\
\hline${ }^{208} \mathrm{~Pb}$ & 0.4 & 0.3 & 0.2 & 0.3 & 0.003 & 0.3 & 0.5 \\
\hline${ }^{75} \mathrm{As}$ & 1 & 1 & 0.3 & 1 & 0.5 & 1 & 1 \\
\hline${ }^{121} \mathrm{Sb}$ & 0.04 & 0.01 & 0.01 & 0.02 & 0.03 & 0.04 & 0.02 \\
\hline
\end{tabular}




\section{Appendix II c. (Continued)}

\begin{tabular}{|c|c|c|c|c|c|c|}
\hline $\begin{array}{l}\text { Composite } \\
\text { pleonaste } \\
\text { with no } \\
\text { exsolution } \\
\text { ppm }\end{array}$ & $\begin{array}{l}\text { Massive } \\
\text { oxide band- } \\
\text { lower } \\
n=1\end{array}$ & $\begin{array}{l}\text { Massive } \\
\text { oxide band- } \\
\text { middle } \\
\mathrm{n}=2 \\
\text { average }\end{array}$ & $\begin{array}{l}\text { Massive } \\
\text { oxide band- } \\
\text { upper }\end{array}$ & $\begin{array}{l}\text { Orthopyroxene } \\
\text {-bearing oxide } \\
\text { pod } \\
n=2 \\
\text { average }\end{array}$ & $\begin{array}{l}\text { Orthopyroxene } \\
\text {-bearing } \\
\text { disseminated } \\
\text { oxide } \\
\mathrm{n}=2 \\
\text { average }\end{array}$ & $\begin{array}{l}\text { Clinopyroxene } \\
\text {-bearing } \\
\text { disseminated } \\
\text { oxide } \\
n=1\end{array}$ \\
\hline${ }^{24} \mathrm{Mg}$ & 73730 & 74735 & 65850 & 83650 & 42155 & 36040 \\
\hline${ }^{29} \mathrm{Si}$ & 2300 & 6220 & 860 & 540 & 10370 & 6000 \\
\hline 31P & 3 & 6 & 3 & 5 & 165 & 63 \\
\hline${ }^{44} \mathrm{Ca}$ & 300 & 36 & 10 & 18 & 286 & 149 \\
\hline${ }^{45} \mathrm{SC}$ & 2 & 1 & 0.4 & 0.4 & 1 & 0.02 \\
\hline${ }^{47} \mathrm{Ti}$ & 22800 & 3900 & 4450 & 0.002 & 0.1 & 0.001 \\
\hline${ }^{51} \mathrm{~V}$ & 1780 & 1497 & 546 & 603 & 549 & 388 \\
\hline${ }^{52} \mathrm{Cr}$ & 3110 & 2617 & 3560 & 2409 & 2939 & 4733 \\
\hline${ }^{55} \mathrm{Mn}$ & 2390 & 2147 & 2125 & 1885 & 1450 & 2674 \\
\hline${ }^{59} \mathrm{Co}$ & 1054 & 1190 & 765 & 529 & 801 & 1333 \\
\hline${ }^{60} \mathrm{Ni}$ & 963 & 1025 & 755 & 622 & 821 & 661 \\
\hline${ }^{66} \mathrm{Zn}$ & 5710 & 3903 & 3164 & 4750 & 5490 & 9380 \\
\hline${ }^{69} \mathrm{Ga}$ & 301 & 352 & 206 & 195 & 179 & 251 \\
\hline${ }^{74} \mathrm{Ge}$ & 0.5 & 0.5 & 0.3 & 0.3 & 0.3 & 0.2 \\
\hline${ }^{89} Y$ & 0.02 & 0.02 & 0.002 & 0.003 & 0.2 & 0.003 \\
\hline${ }^{90} \mathrm{Zr}$ & 2 & 1 & 1 & 0.2 & 0.2 & 0 \\
\hline${ }^{93} \mathrm{Nb}$ & 0.4 & 0.01 & 0.004 & 0.01 & 0.01 & 0.01 \\
\hline${ }^{95} \mathrm{Mo}$ & 0.1 & 0.1 & 0.1 & 0.1 & 0.3 & 0.1 \\
\hline${ }^{118} \mathrm{Sn}$ & 0.6 & 0.5 & 0.1 & 0.1 & 0.3 & 0.01 \\
\hline${ }^{178} \mathrm{Hf}$ & 0.1 & 0.02 & 0.004 & 0.03 & 0.01 & 0.002 \\
\hline${ }^{181} \mathrm{Ta}$ & 0.03 & 0.3 & 0.01 & 0.01 & 0.001 & 0.00 \\
\hline${ }^{182} W$ & 0.02 & 0.1 & 0.024 & 0.0 & 0.2 & 0.01 \\
\hline${ }^{208} \mathrm{~Pb}$ & 0.3 & 1 & 1 & 0.5 & 1 & 0.4 \\
\hline${ }^{75} \mathrm{As}$ & 1 & 1 & 1 & 1 & 1 & 1 \\
\hline${ }^{121} \mathrm{Sb}$ & 0.2 & 0.1 & 0.004 & 0.1 & 0.04 & 0.04 \\
\hline
\end{tabular}


Appendix III. Whole-rock geochemistry results.

\begin{tabular}{|c|c|c|c|c|c|c|c|c|c|c|c|}
\hline \multicolumn{4}{|l|}{ Sample ID } & CC001 & $\mathrm{CCOO2}$ & $\mathrm{CCOO3}$ & CCOO4 & $\mathrm{CCO07}$ & $\mathrm{CCO08}$ & cc009 & CC010A \\
\hline \multicolumn{4}{|l|}{ Easting } & 658748 & 658748 & 658748 & 658748 & 658778 & 658736 & 658736 & 658736 \\
\hline \multicolumn{4}{|l|}{ Westing } & 5929229 & 5929229 & 5929229 & 5929229 & 5928890 & 5929043 & 5929043 & 5929043 \\
\hline \multicolumn{4}{|l|}{ Description } & BAR & BAR & MAS & MAS & TRO & MAS & BAR & OMAS \\
\hline & & Idl & & & & & & & & & \\
\hline $\mathrm{SiO}_{2}$ & $\%$ & 0.01 & FUS-ICP & 55.22 & 54.53 & 18.08 & 5.8 & 49.18 & 2.7 & 53.53 & 11.91 \\
\hline $\mathrm{Al}_{2} \mathrm{O}_{3}$ & $\%$ & 0.01 & FUS-ICP & 27.53 & 26.23 & 14.83 & 11.75 & 19.89 & 10.15 & 25.63 & 8.54 \\
\hline $\mathrm{Fe}_{2} \mathrm{O}_{3(\mathrm{~T})}$ & $\%$ & 0.01 & FUS-ICP & 1.14 & 0.91 & 53.73 & 66.99 & 10.3 & 76.9 & 3.93 & 65.95 \\
\hline $\mathrm{MnO}$ & $\%$ & 0.001 & FUS-ICP & 0.012 & 0.009 & 0.156 & 0.239 & 0.128 & 0.218 & 0.022 & 0.31 \\
\hline $\mathrm{MgO}$ & $\%$ & 0.01 & FUS-ICP & 0.2 & 0.17 & 1.52 & 2.79 & 8.17 & 2.56 & 0.25 & 6.24 \\
\hline $\mathrm{CaO}$ & $\%$ & 0.01 & FUS-ICP & 10.05 & 9.82 & 3.26 & 0.88 & 7.84 & 0.35 & 8.65 & 0.56 \\
\hline $\mathrm{Na}_{2} \mathrm{O}$ & $\%$ & 0.01 & FUS-ICP & 5.06 & 5.01 & 1.66 & 0.26 & 3.18 & 0.17 & 5.09 & 0.13 \\
\hline $\mathrm{K}_{2} \mathrm{O}$ & $\%$ & 0.01 & FUS-ICP & 0.98 & 1.07 & 0.29 & 0.19 & 0.6 & 0.05 & 1.22 & 0.05 \\
\hline $\mathrm{TiO}_{2}$ & $\%$ & 0.001 & FUS-ICP & 0.166 & 0.09 & 7.144 & 14.14 & 0.403 & 10.14 & 0.52 & 9.347 \\
\hline $\mathrm{P}_{2} \mathrm{O}_{5}$ & $\%$ & 0.01 & FUS-ICP & 0.05 & 0.05 & 0.03 & $<0.01$ & 0.05 & 0.02 & 0.04 & $<0.01$ \\
\hline LOI & $\%$ & & FUS-ICP & 0.46 & 0.65 & -1.61 & -2.49 & 0 & -2.58 & 1.07 & -2.2 \\
\hline Total & $\%$ & 0.01 & FUS-ICP & 100.9 & 98.55 & 99.08 & 100.6 & 99.75 & 100.7 & 99.95 & 100.9 \\
\hline Sc & $\mathrm{ppm}$ & 1 & FUS-ICP & $<1$ & $<1$ & 6 & 12 & 5 & 9 & $<1$ & 17 \\
\hline $\mathrm{Be}$ & $\mathrm{ppm}$ & 1 & FUS-ICP & $<1$ & $<1$ & $<1$ & $<1$ & $<1$ & $<1$ & $<1$ & $<1$ \\
\hline v & $\mathrm{ppm}$ & 5 & FUS-ICP & 20 & 7 & 2454 & 2829 & 77 & 3200 & 96 & 2511 \\
\hline $\mathrm{Cr}$ & $\mathrm{ppm}$ & 20 & FUS-MS & $<20$ & $<20$ & 820 & 910 & $<20$ & 1330 & 120 & 1090 \\
\hline Co & $\mathrm{ppm}$ & 1 & FUS-MS & 4 & 3 & 126 & 169 & 57 & 208 & 14 & 146 \\
\hline $\mathrm{Ni}$ & $\mathrm{ppm}$ & 1 & TD-ICP & 21 & 28 & 226 & 239 & 115 & 318 & 78 & 226 \\
\hline $\mathrm{Zn}$ & $\mathrm{ppm}$ & 1 & TD-ICP & 14 & 6 & 229 & 353 & 65 & 360 & 23 & 351 \\
\hline $\mathrm{Cd}$ & $\mathrm{ppm}$ & 0.5 & TD-ICP & $<0.5$ & $<0.5$ & 0.5 & 0.7 & $<0.5$ & 0.8 & $<0.5$ & 1.1 \\
\hline S & $\%$ & 0.001 & TD-ICP & 0.05 & 0.097 & 0.062 & 0.013 & 0.041 & 0.22 & 0.182 & 0.018 \\
\hline $\mathrm{Cu}$ & $\mathrm{ppm}$ & 1 & TD-ICP & 16 & 61 & 93 & 44 & 21 & 231 & 231 & 61 \\
\hline $\mathrm{Ag}$ & $\mathrm{ppm}$ & 0.3 & TD-ICP & $<0.3$ & 0.3 & $<0.3$ & 0.7 & $<0.3$ & 0.8 & 0.6 & 0.5 \\
\hline $\mathrm{Pb}$ & $\mathrm{ppm}$ & 5 & TD-ICP & $<5$ & $<5$ & 14 & 15 & $<5$ & 16 & $<5$ & 15 \\
\hline $\mathrm{Ga}$ & $\mathrm{ppm}$ & 1 & FUS-MS & 18 & 17 & 56 & 67 & 15 & 74 & 19 & 56 \\
\hline $\mathrm{Ge}$ & $\mathrm{ppm}$ & 1 & FUS-MS & $<1$ & 1 & 1 & 2 & 1 & 2 & 1 & 2 \\
\hline As & $\mathrm{ppm}$ & 5 & FUS-MS & $<5$ & $<5$ & $<5$ & $<5$ & $<5$ & $<5$ & $<5$ & $<5$ \\
\hline $\mathrm{Rb}$ & $\mathrm{ppm}$ & 2 & FUS-MS & 8 & 4 & $<2$ & 3 & $<2$ & $<2$ & 10 & 2 \\
\hline $\mathrm{Sr}$ & $\mathrm{ppm}$ & 2 & FUS-ICP & 1390 & 1413 & 451 & 112 & 995 & 52 & 1449 & 34 \\
\hline $\mathrm{Y}$ & $\mathrm{ppm}$ & 2 & FUS-ICP & 2 & $<2$ & $<2$ & $<2$ & $<2$ & $<2$ & $<2$ & $<2$ \\
\hline $\mathrm{Zr}$ & $\mathrm{ppm}$ & 4 & FUS-ICP & 9 & 5 & 6 & 12 & 5 & 7 & 5 & 9 \\
\hline $\mathrm{Nb}$ & $\mathrm{ppm}$ & 1 & FUS-MS & $<1$ & $<1$ & $<1$ & $<1$ & $<1$ & $<1$ & $<1$ & $<1$ \\
\hline Mo & $\mathrm{ppm}$ & 2 & FUS-MS & $<2$ & $<2$ & $<2$ & 3 & $<2$ & $<2$ & $<2$ & $<2$ \\
\hline In & $\mathrm{ppm}$ & 0.2 & FUS-MS & $<0.2$ & $<0.2$ & $<0.2$ & $<0.2$ & $<0.2$ & $<0.2$ & $<0.2$ & $<0.2$ \\
\hline Sn & $\mathrm{ppm}$ & 1 & FUS-MS & $<1$ & $<1$ & 1 & 2 & $<1$ & 1 & $<1$ & 1 \\
\hline $\mathrm{Sb}$ & $\mathrm{ppm}$ & 0.5 & FUS-MS & $<0.5$ & $<0.5$ & $<0.5$ & $<0.5$ & $<0.5$ & $<0.5$ & $<0.5$ & $<0.5$ \\
\hline Cs & $\mathrm{ppm}$ & 0.5 & FUS-MS & $<0.5$ & $<0.5$ & $<0.5$ & $<0.5$ & $<0.5$ & $<0.5$ & $<0.5$ & $<0.5$ \\
\hline $\mathrm{Ba}$ & $\mathrm{ppm}$ & 3 & FUS-ICP & 919 & 937 & 264 & 98 & 609 & 38 & 1043 & 21 \\
\hline La & ppm & 0.1 & FUS-MS & 3.7 & 2.8 & 1 & 0.3 & 2.4 & 0.2 & 3.7 & $<0.1$ \\
\hline $\mathrm{Ce}$ & $\mathrm{ppm}$ & 0.1 & FUS-MS & 6.7 & 4.6 & 1.7 & 0.6 & 4.2 & 0.3 & 5.9 & 0.2 \\
\hline $\mathrm{Pr}$ & $\mathrm{ppm}$ & 0.05 & FUS-MS & 0.79 & 0.53 & 0.2 & 0.07 & 0.53 & $<0.05$ & 0.71 & $<0.05$ \\
\hline $\mathrm{Nd}$ & $\mathrm{ppm}$ & 0.1 & FUS-MS & 3.3 & 2 & 0.9 & 0.3 & 2.2 & 0.1 & 2.8 & 0.2 \\
\hline Sm & $\mathrm{ppm}$ & 0.1 & FUS-MS & 0.5 & 0.3 & 0.1 & $<0.1$ & 0.4 & $<0.1$ & 0.4 & $<0.1$ \\
\hline $\mathrm{Eu}$ & $\mathrm{ppm}$ & 0.05 & FUS-MS & 0.87 & 0.74 & 0.22 & 0.09 & 0.62 & $<0.05$ & 0.82 & 0.05 \\
\hline $\mathrm{Gd}$ & $\mathrm{ppm}$ & 0.1 & FUS-MS & 0.4 & 0.2 & $<0.1$ & $<0.1$ & 0.3 & $<0.1$ & 0.2 & 0.1 \\
\hline $\mathrm{Tb}$ & $\mathrm{ppm}$ & 0.1 & FUS-MS & $<0.1$ & $<0.1$ & $<0.1$ & $<0.1$ & $<0.1$ & $<0.1$ & $<0.1$ & $<0.1$ \\
\hline Dy & $\mathrm{ppm}$ & 0.1 & FUS-MS & 0.3 & $<0.1$ & $<0.1$ & $<0.1$ & 0.3 & $<0.1$ & 0.1 & 0.1 \\
\hline Ho & $\mathrm{ppm}$ & 0.1 & FUS-MS & $<0.1$ & $<0.1$ & $<0.1$ & $<0.1$ & $<0.1$ & $<0.1$ & $<0.1$ & $<0.1$ \\
\hline $\mathrm{Er}$ & $\mathrm{ppm}$ & 0.1 & FUS-MS & $<0.1$ & $<0.1$ & $<0.1$ & $<0.1$ & 0.1 & $<0.1$ & $<0.1$ & 0.1 \\
\hline $\mathrm{Tm}$ & $\mathrm{ppm}$ & 0.05 & FUS-MS & $<0.05$ & $<0.05$ & $<0.05$ & $<0.05$ & $<0.05$ & $<0.05$ & $<0.05$ & $<0.05$ \\
\hline $\mathrm{Yb}$ & $\mathrm{ppm}$ & 0.1 & FUS-MS & $<0.1$ & $<0.1$ & $<0.1$ & $<0.1$ & 0.1 & $<0.1$ & $<0.1$ & 0.1 \\
\hline Lu & $\mathrm{ppm}$ & 0.04 & FUS-MS & $<0.04$ & $<0.04$ & $<0.04$ & $<0.04$ & $<0.04$ & $<0.04$ & $<0.04$ & $<0.04$ \\
\hline $\mathrm{Hf}$ & $\mathrm{ppm}$ & 0.2 & FUS-MS & $<0.2$ & $<0.2$ & 0.2 & 0.5 & $<0.2$ & 0.3 & $<0.2$ & 0.4 \\
\hline $\mathrm{Ta}$ & ppm & 0.1 & FUS-MS & $<0.1$ & $<0.1$ & $<0.1$ & 0.1 & $<0.1$ & $<0.1$ & $<0.1$ & $<0.1$ \\
\hline w & $\mathrm{ppm}$ & 1 & FUS-MS & 2 & 1 & 2 & 8 & 1 & 4 & $<1$ & 3 \\
\hline $\mathrm{Tl}$ & $\mathrm{ppm}$ & 0.1 & FUS-MS & 0.2 & $<0.1$ & $<0.1$ & 0.1 & $<0.1$ & $<0.1$ & $<0.1$ & $<0.1$ \\
\hline $\mathrm{Bi}$ & $\mathrm{ppm}$ & 0.4 & FUS-MS & $<0.4$ & $<0.4$ & $<0.4$ & $<0.4$ & $<0.4$ & $<0.4$ & $<0.4$ & $<0.4$ \\
\hline Th & $\mathrm{ppm}$ & 0.1 & FUS-MS & $<0.1$ & $<0.1$ & $<0.1$ & $<0.1$ & $<0.1$ & $<0.1$ & $<0.1$ & $<0.1$ \\
\hline U & $\mathrm{ppm}$ & 0.1 & FUS-MS & 0.1 & $<0.1$ & 0.2 & 0.3 & $<0.1$ & 0.1 & $<0.1$ & $<0.1$ \\
\hline Abbreviations: & & Rock ty & & & & & & & & & \\
\hline MAS & & Massive to sem & nassive oxi & mineraliza & & & & BAR & Barren an & thosite & \\
\hline OMAS & & Orthopyroxene & earing mas & ve-semi-ma & sive oxide $\mathrm{m}$ & eralization & & DIS & Dissemina & d oxide $\mathrm{mi}$ & ralization \\
\hline GAB & & Gabbronorite & & & & & & TRO & Troctolite & & \\
\hline
\end{tabular}




\section{Appendix III. (Continued)}

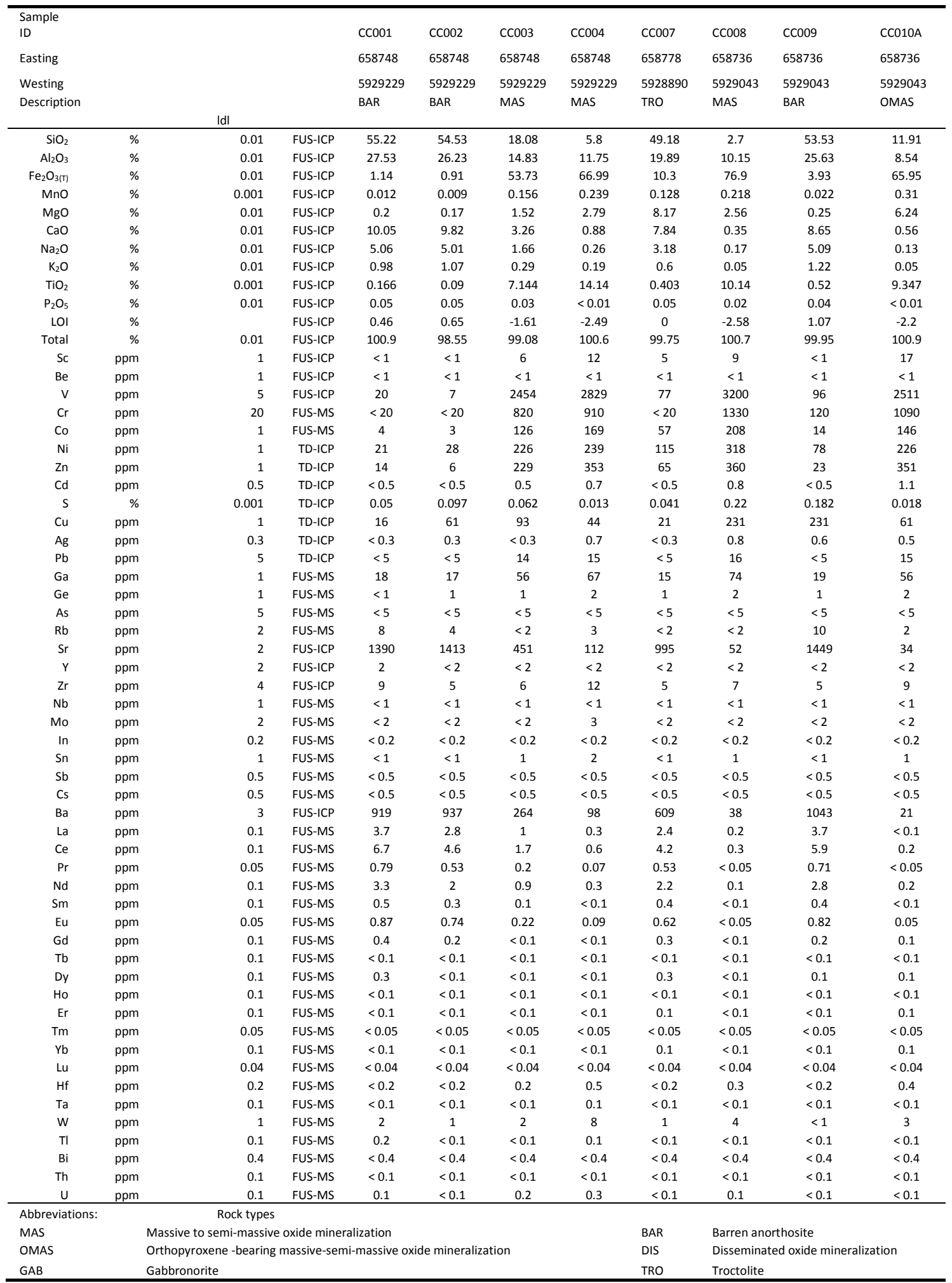




\section{Appendix III. (Continued)}

\begin{tabular}{|c|c|c|c|c|c|c|c|c|c|c|c|}
\hline Sample ID & & & & CC021 & $\mathrm{CCO} 22$ & $\mathrm{CCO} 23$ & $\mathrm{CCO24}$ & $\mathrm{CCO} 25$ & CC026A & CC026B & CC027A \\
\hline Easting & & & & 658257 & 658257 & 658257 & 658177 & 657619 & 657488 & 657488 & 657488 \\
\hline Westing & & & & 5929027 & 5929027 & 5929027 & 5929766 & 5929902 & 5929960 & 5929960 & 5929960 \\
\hline \multirow[t]{2}{*}{ Description } & & & & MAS & OMAS & MAS & BAR & MAS & BAR & OMAS & GAB \\
\hline & & Idl & & & & & & & & & \\
\hline $\mathrm{SiO}_{2}$ & $\%$ & 0.01 & FUS-ICP & 12.67 & 15.8 & 34.29 & 57.15 & 10.97 & 55.39 & 0.99 & 55.83 \\
\hline $\mathrm{Al}_{2} \mathrm{O}_{3}$ & $\%$ & 0.01 & FUS-ICP & 11.05 & 7.62 & 17.08 & 24.89 & 11.6 & 25.47 & 9.39 & 24.77 \\
\hline $\mathrm{Fe}_{2} \mathrm{O}_{3(\mathrm{~T})}$ & $\%$ & 0.01 & FUS-ICP & 59.65 & 61.89 & 29.5 & 1.63 & 65.34 & 2.27 & 79.7 & 2.83 \\
\hline $\mathrm{MnO}$ & $\%$ & 0.001 & FUS-ICP & 0.287 & 0.308 & 0.135 & 0.013 & 0.225 & 0.016 & 0.296 & 0.017 \\
\hline $\mathrm{MgO}$ & $\%$ & 0.01 & FUS-ICP & 2.69 & 6.09 & 0.99 & 0.19 & 1.86 & 0.26 & 2.3 & 0.19 \\
\hline $\mathrm{CaO}$ & $\%$ & 0.01 & FUS-ICP & 1.95 & 1.01 & 4.69 & 6.93 & 1.68 & 7.76 & 0.04 & 7.93 \\
\hline $\mathrm{Na}_{2} \mathrm{O}$ & $\%$ & 0.01 & FUS-ICP & 1.08 & 0.31 & 3.33 & 5.82 & 0.68 & 5.54 & 0.04 & 5.46 \\
\hline $\mathrm{K}_{2} \mathrm{O}$ & $\%$ & 0.01 & FUS-ICP & 0.25 & 0.12 & 0.98 & 1.77 & 0.28 & 1.44 & 0.02 & 1.46 \\
\hline $\mathrm{TiO}_{2}$ & $\%$ & 0.001 & FUS-ICP & 10.83 & 7.43 & 4.913 & 0.406 & 8.204 & 0.272 & 9.103 & 0.152 \\
\hline $\mathrm{P}_{2} \mathrm{O}_{5}$ & $\%$ & 0.01 & FUS-ICP & 0.02 & 0.02 & 0.03 & 0.03 & $<0.01$ & 0.08 & $<0.01$ & 0.05 \\
\hline LOI & $\%$ & & FUS-ICP & -2.15 & -2.29 & 2.18 & 0.82 & -2.38 & 2.21 & -3.34 & 1.17 \\
\hline Total & $\%$ & 0.01 & FUS-ICP & 98.32 & 98.31 & 98.13 & 99.66 & 98.47 & 100.7 & 98.56 & 99.86 \\
\hline Sc & $\mathrm{ppm}$ & 1 & FUS-ICP & 14 & 16 & 6 & $<1$ & 9 & 1 & 8 & 1 \\
\hline $\mathrm{Be}$ & ppm & 1 & FUS-ICP & $<1$ & $<1$ & $<1$ & $<1$ & $<1$ & $<1$ & $<1$ & $<1$ \\
\hline V & $\mathrm{ppm}$ & 5 & FUS-ICP & 2221 & 2198 & 831 & 57 & 2533 & 58 & 3471 & 20 \\
\hline $\mathrm{Cr}$ & ppm & 20 & FUS-MS & 940 & 980 & 1370 & 40 & 2620 & 60 & 1380 & 20 \\
\hline Co & $\mathrm{ppm}$ & 1 & FUS-MS & 125 & 129 & 127 & 6 & 133 & 6 & 182 & 22 \\
\hline $\mathrm{Ni}$ & $\mathrm{ppm}$ & 1 & TD-ICP & 143 & 136 & 284 & 31 & 178 & 25 & 263 & 105 \\
\hline $\mathrm{Zn}$ & $\mathrm{ppm}$ & 1 & TD-ICP & 317 & 283 & 166 & 13 & 461 & 13 & 303 & 11 \\
\hline $\mathrm{Cd}$ & $\mathrm{ppm}$ & 0.5 & TD-ICP & 0.7 & 0.9 & $<0.5$ & $<0.5$ & 0.9 & $<0.5$ & $<0.5$ & $<0.5$ \\
\hline$S$ & $\%$ & 0.001 & TD-ICP & 0.026 & 0.005 & 1.52 & 0.158 & 0.015 & 0.055 & 0.007 & 0.747 \\
\hline $\mathrm{Cu}$ & $\mathrm{ppm}$ & 1 & TD-ICP & 90 & 43 & 1150 & 127 & 34 & 107 & 45 & 268 \\
\hline $\mathrm{Ag}$ & $\mathrm{ppm}$ & 0.3 & TD-ICP & 0.7 & 0.4 & 0.4 & $<0.3$ & 0.7 & $<0.3$ & 0.5 & $<0.3$ \\
\hline $\mathrm{Pb}$ & $\mathrm{ppm}$ & 5 & TD-ICP & 14 & 13 & 5 & 6 & 15 & $<5$ & 17 & $<5$ \\
\hline Ga & $\mathrm{ppm}$ & 1 & FUS-MS & 52 & 56 & 31 & 20 & 70 & 19 & 74 & 18 \\
\hline $\mathrm{Ge}$ & $\mathrm{ppm}$ & 1 & FUS-MS & 1 & 2 & 1 & 1 & 2 & 1 & 2 & 1 \\
\hline As & $\mathrm{ppm}$ & 5 & FUS-MS & $<5$ & $<5$ & $<5$ & $<5$ & $<5$ & $<5$ & $<5$ & $<5$ \\
\hline $\mathrm{Rb}$ & $\mathrm{ppm}$ & 2 & FUS-MS & $<2$ & 3 & 7 & 6 & 3 & 8 & $<2$ & 6 \\
\hline $\mathrm{Sr}$ & $\mathrm{ppm}$ & 2 & FUS-ICP & 333 & 101 & 952 & 1280 & 285 & 1525 & 10 & 1460 \\
\hline$Y$ & $\mathrm{ppm}$ & 2 & FUS-ICP & $<2$ & $<2$ & $<2$ & $<2$ & $<2$ & 2 & $<2$ & $<2$ \\
\hline $\mathrm{Zr}$ & $\mathrm{ppm}$ & 4 & FUS-ICP & 24 & 15 & 17 & 8 & 33 & 7 & 7 & 7 \\
\hline $\mathrm{Nb}$ & $\mathrm{ppm}$ & 1 & FUS-MS & 2 & $<1$ & 2 & $<1$ & $<1$ & $<1$ & $<1$ & $<1$ \\
\hline Mo & $\mathrm{ppm}$ & 2 & FUS-MS & $<2$ & $<2$ & $<2$ & $<2$ & $<2$ & $<2$ & $<2$ & $<2$ \\
\hline In & $\mathrm{ppm}$ & 0.2 & FUS-MS & $<0.2$ & $<0.2$ & $<0.2$ & $<0.2$ & $<0.2$ & $<0.2$ & $<0.2$ & $<0.2$ \\
\hline Sn & $\mathrm{ppm}$ & 1 & FUS-MS & 2 & 2 & $<1$ & $<1$ & 2 & $<1$ & 2 & $<1$ \\
\hline $\mathrm{Sb}$ & ppm & 0.5 & FUS-MS & $<0.5$ & $<0.5$ & $<0.5$ & $<0.5$ & $<0.5$ & $<0.5$ & $<0.5$ & $<0.5$ \\
\hline Cs & $\mathrm{ppm}$ & 0.5 & FUS-MS & $<0.5$ & $<0.5$ & $<0.5$ & $<0.5$ & $<0.5$ & $<0.5$ & $<0.5$ & $<0.5$ \\
\hline $\mathrm{Ba}$ & $\mathrm{ppm}$ & 3 & FUS-ICP & 232 & 71 & 676 & 1072 & 208 & 1293 & $<3$ & 1288 \\
\hline La & $\mathrm{ppm}$ & 0.1 & FUS-MS & 1.2 & 0.6 & 3.4 & 6.6 & 1.6 & 5.8 & $<0.1$ & 5.3 \\
\hline $\mathrm{Ce}$ & $\mathrm{ppm}$ & 0.1 & FUS-MS & 2 & 1.2 & 5.4 & 9.6 & 2.9 & 9.9 & 0.1 & 8.6 \\
\hline $\operatorname{Pr}$ & $\mathrm{ppm}$ & 0.05 & FUS-MS & 0.18 & 0.16 & 0.56 & 0.97 & 0.36 & 1.19 & $<0.05$ & 0.94 \\
\hline $\mathrm{Nd}$ & $\mathrm{ppm}$ & 0.1 & FUS-MS & 0.7 & 0.8 & 2.3 & 3.6 & 1.3 & 4.7 & $<0.1$ & 3.6 \\
\hline $\mathrm{Sm}$ & $\mathrm{ppm}$ & 0.1 & FUS-MS & 0.1 & 0.2 & 0.2 & 0.4 & 0.2 & 0.6 & $<0.1$ & 0.5 \\
\hline $\mathrm{Eu}$ & $\mathrm{ppm}$ & 0.05 & FUS-MS & 0.23 & 0.11 & 0.67 & 1.21 & 0.2 & 1.07 & $<0.05$ & 1.17 \\
\hline $\mathrm{Gd}$ & $\mathrm{ppm}$ & 0.1 & FUS-MS & $<0.1$ & 0.2 & 0.2 & 0.2 & 0.2 & 0.5 & $<0.1$ & 0.3 \\
\hline $\mathrm{Tb}$ & $\mathrm{ppm}$ & 0.1 & FUS-MS & $<0.1$ & $<0.1$ & $<0.1$ & $<0.1$ & $<0.1$ & $<0.1$ & $<0.1$ & $<0.1$ \\
\hline Dy & $\mathrm{ppm}$ & 0.1 & FUS-MS & $<0.1$ & 0.2 & 0.1 & $<0.1$ & 0.1 & 0.3 & $<0.1$ & 0.2 \\
\hline Ho & $\mathrm{ppm}$ & 0.1 & FUS-MS & $<0.1$ & $<0.1$ & $<0.1$ & $<0.1$ & $<0.1$ & $<0.1$ & $<0.1$ & $<0.1$ \\
\hline $\mathrm{Er}$ & $\mathrm{ppm}$ & 0.1 & FUS-MS & $<0.1$ & 0.2 & $<0.1$ & $<0.1$ & $<0.1$ & 0.1 & $<0.1$ & 0.1 \\
\hline $\mathrm{Tm}$ & $\mathrm{ppm}$ & 0.05 & FUS-MS & $<0.05$ & $<0.05$ & $<0.05$ & $<0.05$ & $<0.05$ & $<0.05$ & $<0.05$ & $<0.05$ \\
\hline $\mathrm{Yb}$ & $\mathrm{ppm}$ & 0.1 & FUS-MS & $<0.1$ & 0.2 & $<0.1$ & $<0.1$ & $<0.1$ & 0.1 & $<0.1$ & $<0.1$ \\
\hline Lu & $\mathrm{ppm}$ & 0.04 & FUS-MS & $<0.04$ & $<0.04$ & $<0.04$ & $<0.04$ & $<0.04$ & $<0.04$ & $<0.04$ & $<0.04$ \\
\hline $\mathrm{Hf}$ & $\mathrm{ppm}$ & 0.2 & FUS-MS & 0.7 & 0.6 & 0.4 & $<0.2$ & 0.9 & $<0.2$ & 0.3 & $<0.2$ \\
\hline $\mathrm{Ta}$ & $\mathrm{ppm}$ & 0.1 & FUS-MS & 0.1 & $<0.1$ & $<0.1$ & $<0.1$ & $<0.1$ & $<0.1$ & $<0.1$ & $<0.1$ \\
\hline w & $\mathrm{ppm}$ & 1 & FUS-MS & 1 & 2 & $<1$ & $<1$ & 2 & 1 & 2 & 2 \\
\hline $\mathrm{Tl}$ & $\mathrm{ppm}$ & 0.1 & FUS-MS & $<0.1$ & $<0.1$ & $<0.1$ & $<0.1$ & $<0.1$ & $<0.1$ & $<0.1$ & $<0.1$ \\
\hline $\mathrm{Bi}$ & $\mathrm{ppm}$ & 0.4 & FUS-MS & $<0.4$ & $<0.4$ & $<0.4$ & $<0.4$ & $<0.4$ & $<0.4$ & $<0.4$ & $<0.4$ \\
\hline Th & $\mathrm{ppm}$ & 0.1 & FUS-MS & $<0.1$ & $<0.1$ & $<0.1$ & $<0.1$ & $<0.1$ & $<0.1$ & $<0.1$ & $<0.1$ \\
\hline U & $\mathrm{ppm}$ & 0.1 & FUS-MS & $<0.1$ & $<0.1$ & $<0.1$ & $<0.1$ & $<0.1$ & $<0.1$ & $<0.1$ & $<0.1$ \\
\hline Abbreviations: & & Rock type & & & & & & & & & \\
\hline MAS & Massiv & o semi-ma & ive oxide $m$ & teralization & & & & BAR & Barren a & thosite & \\
\hline OMAS & Orthop & oxene -bea & g massive & emi-massiv & xide miner & ization & & DIS & Dissemin & d oxide mi & ralization \\
\hline GAB & Gabbrc & orite & & & & & & TRO & Troctolite & & \\
\hline
\end{tabular}


Appendix III. (Continued)

\begin{tabular}{|c|c|c|c|c|c|c|c|c|c|c|c|}
\hline Sample ID & & & & CC027B & CC028A & CC029A & сC030 & сC031 & CC032 & CC034 & CC035 \\
\hline Easting & & & & 657488 & 656993 & 657661 & 657734 & 657605 & 657605 & 659545 & 659379 \\
\hline Westing & & & & 5929960 & 5930964 & 5929749 & 5929752 & 5929747 & 5929747 & 5927682 & 5927636 \\
\hline Description & & & & BAR & MAS & MAS & OMAS & DIS & BAR & BAR & BAR \\
\hline & & dl & & & & & & & & & \\
\hline $\mathrm{SiO}_{2}$ & $\%$ & 0.01 & FUS-ICP & 56.43 & 67.91 & 3.96 & 4.16 & 47.47 & 55.39 & 54.63 & 55.66 \\
\hline $\mathrm{Al}_{2} \mathrm{O}_{3}$ & $\%$ & 0.01 & FUS-ICP & 23.52 & 16.1 & 11.31 & 8.84 & 23.03 & 27.06 & 26.61 & 24.89 \\
\hline $\mathrm{Fe}_{2} \mathrm{O}_{3(\mathrm{~T})}$ & $\%$ & 0.01 & FUS-ICP & 3.32 & 3.38 & 72.31 & 75.04 & 12.89 & 1.25 & 0.74 & 2.56 \\
\hline $\mathrm{MnO}$ & $\%$ & 0.001 & FUS-ICP & 0.045 & 0.022 & 0.294 & 0.313 & 0.054 & 0.013 & 0.008 & 0.029 \\
\hline $\mathrm{MgO}$ & $\%$ & 0.01 & FUS-ICP & 0.97 & 0.7 & 3.03 & 2.91 & 1.06 & 0.2 & 0.11 & 0.73 \\
\hline $\mathrm{CaO}$ & $\%$ & 0.01 & FUS-ICP & 8.38 & 3.43 & 0.56 & 0.45 & 7.24 & 9.44 & 9.61 & 8.75 \\
\hline $\mathrm{Na}_{2} \mathrm{O}$ & $\%$ & 0.01 & FUS-ICP & 5.25 & 5.13 & 0.26 & 0.18 & 4.43 & 5.16 & 5.06 & 5.16 \\
\hline $\mathrm{K}_{2} \mathrm{O}$ & $\%$ & 0.01 & FUS-ICP & 1.45 & 0.99 & 0.07 & 0.08 & 0.99 & 1.18 & 1.1 & 1.37 \\
\hline $\mathrm{TiO}_{2}$ & $\%$ & 0.001 & FUS-ICP & 0.219 & 0.296 & 10.89 & 11.56 & 1.941 & 0.149 & 0.101 & 0.324 \\
\hline $\mathrm{P}_{2} \mathrm{O}_{5}$ & $\%$ & 0.01 & FUS-ICP & 0.06 & 0.24 & 0.01 & $<0.01$ & 0.04 & 0.04 & 0.05 & 0.08 \\
\hline LOI & $\%$ & & FUS-ICP & 1.17 & 0.89 & -2.56 & -2.79 & 1.09 & 1 & 0.42 & 0.53 \\
\hline Total & $\%$ & 0.01 & FUS-ICP & 100.8 & 99.09 & 100.1 & 100.7 & 100.2 & 100.9 & 98.44 & 100.1 \\
\hline $\mathrm{Sc}$ & $\mathrm{ppm}$ & 1 & FUS-ICP & 7 & $<1$ & 11 & 14 & 4 & 1 & $<1$ & 3 \\
\hline $\mathrm{Be}$ & $\mathrm{ppm}$ & 1 & FUS-ICP & $<1$ & 3 & $<1$ & $<1$ & $<1$ & $<1$ & $<1$ & $<1$ \\
\hline v & $\mathrm{ppm}$ & 5 & FUS-ICP & 28 & 38 & 3049 & 2815 & 429 & 20 & 10 & 52 \\
\hline $\mathrm{Cr}$ & $\mathrm{ppm}$ & 20 & FUS-MS & 30 & 20 & 1200 & 1690 & 450 & $<20$ & $<20$ & 60 \\
\hline Co & $\mathrm{ppm}$ & 1 & FUS-MS & 20 & 23 & 168 & 157 & 30 & 4 & $<1$ & 7 \\
\hline $\mathrm{Ni}$ & ppm & 1 & TD-ICP & 95 & 46 & 262 & 199 & 103 & 24 & 10 & 31 \\
\hline $\mathrm{Zn}$ & ppm & 1 & TD-ICP & 16 & 27 & 369 & 332 & 61 & 8 & 6 & 17 \\
\hline $\mathrm{Cd}$ & $\mathrm{ppm}$ & 0.5 & TD-ICP & $<0.5$ & $<0.5$ & 0.6 & 1 & $<0.5$ & $<0.5$ & $<0.5$ & $<0.5$ \\
\hline $\mathrm{S}$ & $\%$ & 0.001 & TD-ICP & 0.579 & 0.547 & 0.009 & 0.004 & 0.085 & 0.091 & 0.052 & 0.089 \\
\hline $\mathrm{Cu}$ & $\mathrm{ppm}$ & 1 & TD-ICP & 191 & 266 & 107 & 68 & 151 & 45 & 7 & 60 \\
\hline $\mathrm{Ag}$ & $\mathrm{ppm}$ & 0.3 & TD-ICP & 0.4 & 0.5 & 0.7 & 0.5 & $<0.3$ & $<0.3$ & $<0.3$ & 0.4 \\
\hline $\mathrm{Pb}$ & $\mathrm{ppm}$ & 5 & TD-ICP & $<5$ & 26 & 77 & 20 & 6 & $<5$ & $<5$ & $<5$ \\
\hline Ga & $\mathrm{ppm}$ & 1 & FUS-MS & 18 & 21 & 72 & 65 & 24 & 18 & 17 & 18 \\
\hline $\mathrm{Ge}$ & $\mathrm{ppm}$ & 1 & FUS-MS & 1 & 1 & 2 & 2 & 1 & 1 & 1 & 1 \\
\hline As & $\mathrm{ppm}$ & 5 & FUS-MS & $<5$ & $<5$ & $<5$ & $<5$ & $<5$ & $<5$ & $<5$ & $<5$ \\
\hline $\mathrm{Rb}$ & $\mathrm{ppm}$ & 2 & FUS-MS & 7 & 30 & $<2$ & $<2$ & 7 & 8 & 2 & 4 \\
\hline $\mathrm{Sr}$ & $\mathrm{ppm}$ & 2 & FUS-ICP & 1365 & 1601 & 86 & 74 & 1302 & 1382 & 1369 & 1451 \\
\hline $\mathrm{Y}$ & $\mathrm{ppm}$ & 2 & FUS-ICP & 4 & 4 & $<2$ & $<2$ & $<2$ & $<2$ & $<2$ & 3 \\
\hline $\mathrm{Zr}$ & $\mathrm{ppm}$ & 4 & FUS-ICP & 11 & 154 & 12 & 14 & 9 & 6 & 5 & 11 \\
\hline $\mathrm{Nb}$ & $\mathrm{ppm}$ & 1 & FUS-MS & $<1$ & 2 & $<1$ & $<1$ & $<1$ & $<1$ & $<1$ & $<1$ \\
\hline Mo & $\mathrm{ppm}$ & 2 & FUS-MS & $<2$ & $<2$ & $<2$ & $<2$ & $<2$ & $<2$ & $<2$ & $<2$ \\
\hline In & $\mathrm{ppm}$ & 0.2 & FUS-MS & $<0.2$ & $<0.2$ & $<0.2$ & $<0.2$ & $<0.2$ & $<0.2$ & $<0.2$ & $<0.2$ \\
\hline Sn & $\mathrm{ppm}$ & 1 & FUS-MS & $<1$ & $<1$ & 2 & 2 & $<1$ & $<1$ & $<1$ & $<1$ \\
\hline $\mathrm{Sb}$ & ppm & 0.5 & FUS-MS & $<0.5$ & $<0.5$ & $<0.5$ & $<0.5$ & $<0.5$ & $<0.5$ & $<0.5$ & $<0.5$ \\
\hline Cs & $\mathrm{ppm}$ & 0.5 & FUS-MS & $<0.5$ & 0.7 & $<0.5$ & $<0.5$ & $<0.5$ & $<0.5$ & $<0.5$ & $<0.5$ \\
\hline $\mathrm{Ba}$ & ppm & 3 & FUS-ICP & 1213 & 467 & 57 & 60 & 925 & 1021 & 978 & 1196 \\
\hline La & $\mathrm{ppm}$ & 0.1 & FUS-MS & 5.7 & 97.9 & 0.2 & 0.2 & 3.7 & 3.9 & 3.7 & 5.1 \\
\hline $\mathrm{Ce}$ & $\mathrm{ppm}$ & 0.1 & FUS-MS & 9.7 & 174 & 0.4 & 0.3 & 6.1 & 6.1 & 6.3 & 8.8 \\
\hline $\mathrm{Pr}$ & ppm & 0.05 & FUS-MS & 1.21 & 18 & 0.05 & $<0.05$ & 0.68 & 0.71 & 0.74 & 1.07 \\
\hline $\mathrm{Nd}$ & $\mathrm{ppm}$ & 0.1 & FUS-MS & 5.4 & 57.7 & 0.2 & 0.2 & 2.7 & 2.7 & 2.6 & 4.1 \\
\hline $\mathrm{Sm}$ & $\mathrm{ppm}$ & 0.1 & FUS-MS & 0.9 & 6.2 & $<0.1$ & $<0.1$ & 0.4 & 0.4 & 0.4 & 0.7 \\
\hline $\mathrm{Eu}$ & $\mathrm{ppm}$ & 0.05 & FUS-MS & 1.33 & 1.24 & 0.06 & $<0.05$ & 0.78 & 0.95 & 0.84 & 1.08 \\
\hline $\mathrm{Gd}$ & $\mathrm{ppm}$ & 0.1 & FUS-MS & 0.7 & 2.3 & $<0.1$ & $<0.1$ & 0.2 & 0.3 & 0.2 & 0.5 \\
\hline $\mathrm{Tb}$ & $\mathrm{ppm}$ & 0.1 & FUS-MS & 0.1 & 0.2 & $<0.1$ & $<0.1$ & $<0.1$ & $<0.1$ & $<0.1$ & $<0.1$ \\
\hline Dy & ppm & 0.1 & FUS-MS & 0.7 & 0.9 & $<0.1$ & $<0.1$ & 0.1 & 0.1 & 0.2 & 0.4 \\
\hline Ho & $\mathrm{ppm}$ & 0.1 & FUS-MS & 0.1 & 0.1 & $<0.1$ & $<0.1$ & $<0.1$ & $<0.1$ & $<0.1$ & $<0.1$ \\
\hline $\mathrm{Er}$ & ppm & 0.1 & FUS-MS & 0.3 & 0.3 & $<0.1$ & $<0.1$ & $<0.1$ & $<0.1$ & $<0.1$ & 0.2 \\
\hline $\mathrm{Tm}$ & ppm & 0.05 & FUS-MS & $<0.05$ & $<0.05$ & $<0.05$ & $<0.05$ & $<0.05$ & $<0.05$ & $<0.05$ & $<0.05$ \\
\hline $\mathrm{Yb}$ & $\mathrm{ppm}$ & 0.1 & FUS-MS & 0.2 & 0.2 & $<0.1$ & $<0.1$ & $<0.1$ & $<0.1$ & $<0.1$ & 0.2 \\
\hline Lu & $\mathrm{ppm}$ & 0.04 & FUS-MS & $<0.04$ & $<0.04$ & $<0.04$ & $<0.04$ & $<0.04$ & $<0.04$ & $<0.04$ & $<0.04$ \\
\hline $\mathrm{Hf}$ & $\mathrm{ppm}$ & 0.2 & FUS-MS & $<0.2$ & 3.2 & 0.4 & 0.5 & 0.2 & $<0.2$ & $<0.2$ & $<0.2$ \\
\hline $\mathrm{Ta}$ & $\mathrm{ppm}$ & 0.1 & FUS-MS & $<0.1$ & $<0.1$ & $<0.1$ & $<0.1$ & $<0.1$ & $<0.1$ & $<0.1$ & $<0.1$ \\
\hline w & ppm & 1 & FUS-MS & $<1$ & $<1$ & 2 & 2 & $<1$ & $<1$ & $<1$ & 2 \\
\hline $\mathrm{TI}$ & $\mathrm{ppm}$ & 0.1 & FUS-MS & $<0.1$ & $<0.1$ & $<0.1$ & $<0.1$ & $<0.1$ & $<0.1$ & $<0.1$ & $<0.1$ \\
\hline $\mathrm{Bi}$ & $\mathrm{ppm}$ & 0.4 & FUS-MS & $<0.4$ & $<0.4$ & $<0.4$ & $<0.4$ & $<0.4$ & $<0.4$ & $<0.4$ & $<0.4$ \\
\hline Th & $\mathrm{ppm}$ & 0.1 & FUS-MS & $<0.1$ & 25.4 & $<0.1$ & $<0.1$ & $<0.1$ & $<0.1$ & $<0.1$ & $<0.1$ \\
\hline U & $\mathrm{ppm}$ & 0.1 & FUS-MS & $<0.1$ & 0.8 & $<0.1$ & $<0.1$ & $<0.1$ & $<0.1$ & $<0.1$ & $<0.1$ \\
\hline Abbreviations: & & Rock type & & & & & & & & & \\
\hline MAS & \multicolumn{7}{|c|}{ Massive to semi-massive oxide mineralization } & BAR & \multicolumn{3}{|c|}{ Barren anorthosite } \\
\hline OMAS & \multicolumn{7}{|c|}{ Orthopyroxene -bearing massive-semi-massive oxide mineralization } & DIS & \multicolumn{3}{|c|}{ Disseminated oxide mineralization } \\
\hline GAB & \multicolumn{7}{|c|}{ Gabbronorite } & TRO & \multicolumn{3}{|c|}{ Troctolite } \\
\hline
\end{tabular}


Appendix III. (Continued)

\begin{tabular}{|c|c|c|c|c|c|c|c|c|c|c|c|c|}
\hline \multicolumn{2}{|l|}{ Sample ID } & & & сC036 & CC037 & CC038 & CC039 & CC041 & CCO42A & CCO43 & CC045 & CC046 \\
\hline \multicolumn{4}{|l|}{ Easting } & 659118 & 659390 & 659554 & 658920 & 658884 & 659021 & 658632 & 658107 & 657985 \\
\hline \multicolumn{4}{|l|}{ Westing } & 5927608 & 5927870 & 5927859 & 5927761 & 5928070 & 5928177 & 5928536 & 5928784 & 5928761 \\
\hline \multicolumn{4}{|l|}{ Description } & BAR & BAR & BAR & TRO & GAB & BAR & GAB & TRO & BAR \\
\hline $\mathrm{SiO}_{2}$ & $\%$ & 0.01 & FUS-ICP & 56.53 & 50.5 & 54.37 & 51.11 & 47.85 & 54.74 & 51.15 & 48.65 & 52.88 \\
\hline $\mathrm{Al}_{2} \mathrm{O}_{3}$ & $\%$ & 0.01 & FUS-ICP & 26.77 & 23.19 & 27.15 & 23.2 & 17.37 & 26.93 & 24.7 & 19.27 & 27.97 \\
\hline $\mathrm{Fe}_{2} \mathrm{O}_{3(\mathrm{~T})}$ & $\%$ & 0.01 & FUS-ICP & 1.01 & 5.76 & 0.89 & 6.16 & 12.86 & 0.88 & 4.98 & 10.8 & 1.08 \\
\hline $\mathrm{CaO}$ & $\%$ & 0.01 & FUS-ICP & 9.12 & 9.35 & 10.15 & 9.36 & 9.77 & 9.18 & 9.4 & 7.71 & 10.5 \\
\hline $\mathrm{Na}_{2} \mathrm{O}$ & $\%$ & 0.01 & FUS-ICP & 5.36 & 3.52 & 4.82 & 3.65 & 2.72 & 5.14 & 3.8 & 2.84 & 4.82 \\
\hline $\mathrm{K}_{2} \mathrm{O}$ & $\%$ & 0.01 & FUS-ICP & 1.25 & 0.55 & 0.96 & 0.65 & 0.53 & 1.31 & 0.75 & 0.59 & 0.4 \\
\hline $\mathrm{TiO}_{2}$ & $\%$ & 0.001 & FUS-ICP & 0.124 & 0.171 & 0.104 & 0.151 & 1.173 & 0.07 & 0.094 & 0.2 & 0.136 \\
\hline $\mathrm{P}_{2} \mathrm{O}_{5}$ & $\%$ & 0.01 & FUS-ICP & 0.05 & 0.05 & 0.03 & 0.05 & 0.11 & 0.03 & 0.02 & 0.04 & 0.05 \\
\hline LOI & $\%$ & & FUS-ICP & 0.64 & 1.96 & 0.51 & 0.39 & 0.23 & 1.48 & 1.23 & 0.13 & 0.75 \\
\hline $\mathrm{Cr}$ & $\mathrm{ppm}$ & 20 & FUS-MS & 20 & $<20$ & $<20$ & $<20$ & 140 & $<20$ & $<20$ & $<20$ & $<20$ \\
\hline Co & $\mathrm{ppm}$ & 1 & FUS-MS & 1 & 34 & 2 & 38 & 58 & 2 & 30 & 65 & 3 \\
\hline $\mathrm{Ni}$ & $\mathrm{ppm}$ & 1 & TD-ICP & 7 & 97 & 8 & 104 & 161 & 11 & 84 & 171 & 13 \\
\hline $\mathrm{Zn}$ & $\mathrm{ppm}$ & 1 & TD-ICP & 8 & 38 & 6 & 38 & 72 & 4 & 32 & 65 & 7 \\
\hline $\mathrm{Cd}$ & $\mathrm{ppm}$ & 0.5 & TD-ICP & $<0.5$ & $<0.5$ & $<0.5$ & $<0.5$ & $<0.5$ & $<0.5$ & $<0.5$ & $<0.5$ & $<0.5$ \\
\hline $\mathrm{S}$ & $\%$ & 0.001 & TD-ICP & 0.047 & 0.041 & 0.041 & 0.051 & 0.076 & 0.043 & 0.04 & 0.04 & 0.06 \\
\hline $\mathrm{Cu}$ & $\mathrm{ppm}$ & 1 & TD-ICP & 8 & 7 & $<1$ & 20 & 97 & 9 & 4 & 6 & 20 \\
\hline $\mathrm{Ag}$ & $\mathrm{ppm}$ & 0.3 & TD-ICP & $<0.3$ & $<0.3$ & $<0.3$ & $<0.3$ & $<0.3$ & $<0.3$ & $<0.3$ & $<0.3$ & 0.4 \\
\hline $\mathrm{Pb}$ & $\mathrm{ppm}$ & 5 & TD-ICP & $<5$ & $<5$ & $<5$ & $<5$ & $<5$ & $<5$ & $<5$ & $<5$ & $<5$ \\
\hline Ga & $\mathrm{ppm}$ & 1 & FUS-MS & 18 & 16 & 17 & 15 & 20 & 18 & 15 & 13 & 18 \\
\hline Ge & $\mathrm{ppm}$ & 1 & FUS-MS & 1 & 1 & 1 & 1 & 2 & 1 & 1 & 2 & 1 \\
\hline As & $\mathrm{ppm}$ & 5 & FUS-MS & $<5$ & $<5$ & $<5$ & $<5$ & $<5$ & $<5$ & $<5$ & $<5$ & $<5$ \\
\hline $\mathrm{Sb}$ & ppm & 0.5 & FUS-MS & $<0.5$ & $<0.5$ & $<0.5$ & $<0.5$ & $<0.5$ & $<0.5$ & $<0.5$ & $<0.5$ & $<0.5$ \\
\hline Cs & $\mathrm{ppm}$ & 0.5 & FUS-MS & $<0.5$ & 0.6 & $<0.5$ & $<0.5$ & $<0.5$ & 0.7 & $<0.5$ & $<0.5$ & $<0.5$ \\
\hline $\mathrm{Ba}$ & $\mathrm{ppm}$ & 3 & FUS-ICP & 1100 & 441 & 816 & 608 & 137 & 870 & 521 & 503 & 724 \\
\hline La & $\mathrm{ppm}$ & 0.1 & FUS-MS & 3.9 & 2.6 & 3 & 2.7 & 8.2 & 3.2 & 2 & 2.1 & 3.9 \\
\hline $\mathrm{Ce}$ & $\mathrm{ppm}$ & 0.1 & FUS-MS & 6.5 & 4.7 & 5 & 5 & 18.5 & 5.1 & 3.4 & 3.8 & 7.1 \\
\hline $\mathrm{Pr}$ & ppm & 0.05 & FUS-MS & 0.71 & 0.56 & 0.6 & 0.61 & 2.59 & 0.56 & 0.42 & 0.45 & 0.89 \\
\hline $\mathrm{Nd}$ & $\mathrm{ppm}$ & 0.1 & FUS-MS & 2.9 & 2.5 & 2.2 & 2.5 & 11.6 & 2 & 1.6 & 1.6 & 3.7 \\
\hline $\mathrm{Sm}$ & $\mathrm{ppm}$ & 0.1 & FUS-MS & 0.4 & 0.4 & 0.4 & 0.4 & 3.2 & 0.3 & 0.3 & 0.3 & 0.6 \\
\hline $\mathrm{Eu}$ & $\mathrm{ppm}$ & 0.05 & FUS-MS & 0.92 & 0.59 & 0.79 & 0.66 & 1.12 & 0.72 & 0.51 & 0.57 & 0.83 \\
\hline $\mathrm{Gd}$ & $\mathrm{ppm}$ & 0.1 & FUS-MS & 0.2 & 0.2 & 0.2 & 0.3 & 3.2 & 0.2 & 0.2 & 0.2 & 0.4 \\
\hline $\mathrm{Tb}$ & $\mathrm{ppm}$ & 0.1 & FUS-MS & $<0.1$ & $<0.1$ & $<0.1$ & $<0.1$ & 0.6 & $<0.1$ & $<0.1$ & $<0.1$ & $<0.1$ \\
\hline Dy & ppm & 0.1 & FUS-MS & 0.1 & 0.2 & $<0.1$ & 0.2 & 3.5 & 0.1 & $<0.1$ & $<0.1$ & 0.3 \\
\hline Ho & $\mathrm{ppm}$ & 0.1 & FUS-MS & $<0.1$ & $<0.1$ & $<0.1$ & $<0.1$ & 0.7 & $<0.1$ & $<0.1$ & $<0.1$ & $<0.1$ \\
\hline $\mathrm{Er}$ & $\mathrm{ppm}$ & 0.1 & FUS-MS & $<0.1$ & $<0.1$ & $<0.1$ & 0.1 & 2 & $<0.1$ & $<0.1$ & $<0.1$ & 0.1 \\
\hline $\mathrm{Tm}$ & $\mathrm{ppm}$ & 0.05 & FUS-MS & $<0.05$ & $<0.05$ & $<0.05$ & $<0.05$ & 0.29 & $<0.05$ & $<0.05$ & $<0.05$ & $<0.05$ \\
\hline $\mathrm{Yb}$ & $\mathrm{ppm}$ & 0.1 & FUS-MS & $<0.1$ & $<0.1$ & $<0.1$ & $<0.1$ & 1.8 & $<0.1$ & $<0.1$ & $<0.1$ & 0.1 \\
\hline Lu & $\mathrm{ppm}$ & 0.04 & FUS-MS & $<0.04$ & $<0.04$ & $<0.04$ & $<0.04$ & 0.31 & $<0.04$ & $<0.04$ & $<0.04$ & $<0.04$ \\
\hline $\mathrm{Hf}$ & $\mathrm{ppm}$ & 0.2 & FUS-MS & $<0.2$ & $<0.2$ & $<0.2$ & $<0.2$ & 1.8 & $<0.2$ & $<0.2$ & $<0.2$ & $<0.2$ \\
\hline $\mathrm{Ta}$ & $\mathrm{ppm}$ & 0.1 & FUS-MS & $<0.1$ & $<0.1$ & $<0.1$ & $<0.1$ & 0.4 & $<0.1$ & $<0.1$ & $<0.1$ & $<0.1$ \\
\hline w & $\mathrm{ppm}$ & 1 & FUS-MS & $<1$ & 1 & $<1$ & 1 & 1 & 1 & $<1$ & $<1$ & 2 \\
\hline $\mathrm{TI}$ & $\mathrm{ppm}$ & 0.1 & FUS-MS & $<0.1$ & $<0.1$ & $<0.1$ & $<0.1$ & 0.4 & 0.4 & 0.3 & 0.1 & 0.1 \\
\hline $\mathrm{Bi}$ & $\mathrm{ppm}$ & 0.4 & FUS-MS & $<0.4$ & $<0.4$ & $<0.4$ & $<0.4$ & $<0.4$ & $<0.4$ & $<0.4$ & $<0.4$ & $<0.4$ \\
\hline Th & $\mathrm{ppm}$ & 0.1 & FUS-MS & $<0.1$ & 0.1 & $<0.1$ & $<0.1$ & 1 & 0.1 & $<0.1$ & $<0.1$ & $<0.1$ \\
\hline u & $\mathrm{ppm}$ & 0.1 & FUS-MS & $<0.1$ & 0.2 & $<0.1$ & $<0.1$ & 0.4 & $<0.1$ & $<0.1$ & $<0.1$ & $<0.1$ \\
\hline Abbreviations: & & Rock type & & & & & & & & & & \\
\hline
\end{tabular}


Appendix III. (Continued)

\begin{tabular}{|c|c|c|c|c|c|c|c|c|c|c|c|}
\hline Sample ID & & & & CC047 & $\mathrm{CCO48}$ & CC050A & CC050BA & $\mathrm{CC} 050 \mathrm{C}$ & CC051A & CC051B & CC052A \\
\hline Easting & & & & 658396 & 658384 & 658392 & 658392 & 658392 & 667719 & 667719 & 667982 \\
\hline Westing & & & & 5928496 & 5928579 & 5928617 & 5928617 & 5928617 & 5919434 & 5919434 & 5919407 \\
\hline Description & & & & $\mathrm{GAB}$ & BAR & MAS & BAR & MAS & BAR & BAR & BAR \\
\hline & & $|d|$ & & & & & & & & & \\
\hline $\mathrm{SiO}_{2}$ & $\%$ & 0.01 & FUS-ICP & 51.49 & 54.4 & 1.04 & 52.7 & 18.7 & 51.07 & 52.13 & 53.36 \\
\hline $\mathrm{Al}_{2} \mathrm{O}_{3}$ & $\%$ & 0.01 & FUS-ICP & 24.03 & 26.08 & 8.42 & 23.96 & 13.67 & 28.01 & 28 & 27.1 \\
\hline $\mathrm{Fe}_{2} \mathrm{O}_{3(\mathrm{~T})}$ & $\%$ & 0.01 & FUS-ICP & 5.63 & 3.8 & 81.78 & 5.44 & 54.42 & 1.16 & 1.27 & 1.72 \\
\hline $\mathrm{MnO}$ & $\%$ & 0.001 & FUS-ICP & 0.075 & 0.024 & 0.304 & 0.066 & 0.259 & 0.013 & 0.013 & 0.025 \\
\hline $\mathrm{MgO}$ & $\%$ & 0.01 & FUS-ICP & 4.62 & 0.27 & 1.9 & 2.74 & 2.53 & 0.23 & 0.21 & 0.78 \\
\hline $\mathrm{CaO}$ & $\%$ & 0.01 & FUS-ICP & 9.38 & 8.41 & 0.07 & 8.85 & 2.68 & 10.32 & 10.24 & 10.01 \\
\hline $\mathrm{Na}_{2} \mathrm{O}$ & $\%$ & 0.01 & FUS-ICP & 3.84 & 5.35 & 0.05 & 4.42 & 1.46 & 4.39 & 4.32 & 4.36 \\
\hline $\mathrm{K}_{2} \mathrm{O}$ & $\%$ & 0.01 & FUS-ICP & 0.7 & 1.22 & 0.04 & 1.07 & 0.4 & 1.33 & 1.37 & 1.07 \\
\hline $\mathrm{TiO}_{2}$ & $\%$ & 0.001 & FUS-ICP & 0.202 & 0.671 & 9.302 & 0.525 & 7.616 & 0.146 & 0.175 & 0.161 \\
\hline $\mathrm{P}_{2} \mathrm{O}_{5}$ & $\%$ & 0.01 & FUS-ICP & 0.05 & 0.05 & $<0.01$ & 0.07 & 0.02 & 0.03 & 0.04 & 0.03 \\
\hline LOI & $\%$ & & FUS-ICP & 0.64 & 0.49 & -3.08 & 0.46 & -1.31 & 2.57 & 2.61 & 0.94 \\
\hline Total & $\%$ & 0.01 & FUS-ICP & 100.7 & 100.8 & 99.83 & 100.3 & 100.4 & 99.26 & 100.4 & 99.56 \\
\hline Sc & $\mathrm{ppm}$ & 1 & FUS-ICP & 2 & 1 & 9 & 6 & 11 & 1 & $<1$ & 2 \\
\hline $\mathrm{Be}$ & $\mathrm{ppm}$ & 1 & FUS-ICP & $<1$ & $<1$ & $<1$ & $<1$ & $<1$ & $<1$ & $<1$ & $<1$ \\
\hline v & $\mathrm{ppm}$ & 5 & FUS-ICP & 25 & 111 & 3091 & 74 & 2088 & 22 & 26 & 28 \\
\hline $\mathrm{Cr}$ & $\mathrm{ppm}$ & 20 & FUS-MS & $<20$ & 180 & 3480 & 60 & 2590 & $<20$ & $<20$ & 30 \\
\hline Co & $\mathrm{ppm}$ & 1 & FUS-MS & 30 & 9 & 160 & 20 & 112 & 2 & 2 & 4 \\
\hline $\mathrm{Ni}$ & ppm & 1 & TD-ICP & 84 & 21 & 212 & 39 & 143 & 9 & 10 & 13 \\
\hline $\mathrm{Zn}$ & $\mathrm{ppm}$ & 1 & TD-ICP & 37 & 26 & 336 & 39 & 303 & 10 & 7 & 12 \\
\hline $\mathrm{Cd}$ & $\mathrm{ppm}$ & 0.5 & TD-ICP & $<0.5$ & $<0.5$ & 1.2 & $<0.5$ & $<0.5$ & $<0.5$ & $<0.5$ & $<0.5$ \\
\hline $\mathrm{S}$ & $\%$ & 0.001 & TD-ICP & 0.045 & 0.065 & 0.001 & 0.079 & 0.017 & 0.052 & 0.049 & 0.047 \\
\hline $\mathrm{Cu}$ & $\mathrm{ppm}$ & 1 & TD-ICP & 10 & 27 & 29 & 30 & 147 & 3 & 11 & 12 \\
\hline $\mathrm{Ag}$ & $\mathrm{ppm}$ & 0.3 & TD-ICP & $<0.3$ & $<0.3$ & 0.8 & $<0.3$ & 0.4 & $<0.3$ & $<0.3$ & $<0.3$ \\
\hline $\mathrm{Pb}$ & $\mathrm{ppm}$ & 5 & TD-ICP & $<5$ & $<5$ & 17 & $<5$ & 9 & $<5$ & $<5$ & $<5$ \\
\hline $\mathrm{Ga}$ & $\mathrm{ppm}$ & 1 & FUS-MS & 15 & 20 & 71 & 19 & 59 & 17 & 17 & 17 \\
\hline $\mathrm{Ge}$ & $\mathrm{ppm}$ & 1 & FUS-MS & 1 & 1 & 2 & 1 & 2 & 1 & $<1$ & 1 \\
\hline As & $\mathrm{ppm}$ & 5 & FUS-MS & $<5$ & $<5$ & $<5$ & $<5$ & $<5$ & $<5$ & $<5$ & $<5$ \\
\hline $\mathrm{Rb}$ & $\mathrm{ppm}$ & 2 & FUS-MS & 3 & 3 & $<2$ & 3 & $<2$ & 17 & 17 & 9 \\
\hline $\mathrm{Sr}$ & $\mathrm{ppm}$ & 2 & FUS-ICP & 1101 & 1491 & 16 & 1281 & 502 & 1286 & 1285 & 1305 \\
\hline$Y$ & $\mathrm{ppm}$ & 2 & FUS-ICP & $<2$ & $<2$ & $<2$ & 3 & $<2$ & $<2$ & $<2$ & $<2$ \\
\hline $\mathrm{Zr}$ & $\mathrm{ppm}$ & 4 & FUS-ICP & 6 & 7 & 9 & 13 & 14 & 6 & 6 & 5 \\
\hline $\mathrm{Nb}$ & $\mathrm{ppm}$ & 1 & FUS-MS & $<1$ & $<1$ & $<1$ & $<1$ & 1 & $<1$ & $<1$ & $<1$ \\
\hline Mo & $\mathrm{ppm}$ & 2 & FUS-MS & $<2$ & $<2$ & $<2$ & $<2$ & $<2$ & $<2$ & $<2$ & $<2$ \\
\hline In & $\mathrm{ppm}$ & 0.2 & FUS-MS & $<0.2$ & $<0.2$ & $<0.2$ & $<0.2$ & $<0.2$ & $<0.2$ & $<0.2$ & $<0.2$ \\
\hline Sn & $\mathrm{ppm}$ & 1 & FUS-MS & $<1$ & 1 & 2 & $<1$ & 2 & $<1$ & $<1$ & $<1$ \\
\hline $\mathrm{Sb}$ & $\mathrm{ppm}$ & 0.5 & FUS-MS & $<0.5$ & $<0.5$ & $<0.5$ & $<0.5$ & $<0.5$ & $<0.5$ & $<0.5$ & $<0.5$ \\
\hline Cs & $\mathrm{ppm}$ & 0.5 & FUS-MS & $<0.5$ & $<0.5$ & $<0.5$ & $<0.5$ & $<0.5$ & 0.9 & 1 & $<0.5$ \\
\hline $\mathrm{Ba}$ & $\mathrm{ppm}$ & 3 & FUS-ICP & 629 & 1162 & 9 & 1053 & 389 & 577 & 569 & 574 \\
\hline La & $\mathrm{ppm}$ & 0.1 & FUS-MS & 3.3 & 4.2 & 0.1 & 5 & 1.5 & 2.3 & 2.3 & 2.5 \\
\hline $\mathrm{Ce}$ & $\mathrm{ppm}$ & 0.1 & FUS-MS & 6 & 6.8 & 0.2 & 8.9 & 2.4 & 4.2 & 4.1 & 4.3 \\
\hline $\mathrm{Pr}$ & $\mathrm{ppm}$ & 0.05 & FUS-MS & 0.75 & 0.79 & $<0.05$ & 1.1 & 0.29 & 0.5 & 0.52 & 0.51 \\
\hline $\mathrm{Nd}$ & $\mathrm{ppm}$ & 0.1 & FUS-MS & 3.3 & 2.5 & $<0.1$ & 4.5 & 0.9 & 2.4 & 2.2 & 2.3 \\
\hline $\mathrm{Sm}$ & $\mathrm{ppm}$ & 0.1 & FUS-MS & 0.5 & 0.5 & $<0.1$ & 0.9 & 0.2 & 0.4 & 0.4 & 0.3 \\
\hline $\mathrm{Eu}$ & $\mathrm{ppm}$ & 0.05 & FUS-MS & 0.71 & 0.93 & $<0.05$ & 1.03 & 0.33 & 0.59 & 0.58 & 0.64 \\
\hline $\mathrm{Gd}$ & $\mathrm{ppm}$ & 0.1 & FUS-MS & 0.4 & 0.3 & $<0.1$ & 0.7 & 0.1 & 0.2 & 0.3 & 0.2 \\
\hline $\mathrm{Tb}$ & $\mathrm{ppm}$ & 0.1 & FUS-MS & $<0.1$ & $<0.1$ & $<0.1$ & 0.1 & $<0.1$ & $<0.1$ & $<0.1$ & $<0.1$ \\
\hline Dy & $\mathrm{ppm}$ & 0.1 & FUS-MS & 0.3 & 0.2 & $<0.1$ & 0.6 & $<0.1$ & 0.2 & 0.2 & 0.2 \\
\hline Ho & $\mathrm{ppm}$ & 0.1 & FUS-MS & $<0.1$ & $<0.1$ & $<0.1$ & 0.1 & $<0.1$ & $<0.1$ & $<0.1$ & $<0.1$ \\
\hline $\mathrm{Er}$ & $\mathrm{ppm}$ & 0.1 & FUS-MS & 0.1 & $<0.1$ & $<0.1$ & 0.3 & $<0.1$ & $<0.1$ & $<0.1$ & $<0.1$ \\
\hline $\mathrm{Tm}$ & $\mathrm{ppm}$ & 0.05 & FUS-MS & $<0.05$ & $<0.05$ & $<0.05$ & $<0.05$ & $<0.05$ & $<0.05$ & $<0.05$ & $<0.05$ \\
\hline $\mathrm{Yb}$ & $\mathrm{ppm}$ & 0.1 & FUS-MS & $<0.1$ & $<0.1$ & $<0.1$ & 0.3 & $<0.1$ & $<0.1$ & $<0.1$ & $<0.1$ \\
\hline Lu & $\mathrm{ppm}$ & 0.04 & FUS-MS & $<0.04$ & $<0.04$ & $<0.04$ & 0.04 & $<0.04$ & $<0.04$ & $<0.04$ & $<0.04$ \\
\hline $\mathrm{Hf}$ & $\mathrm{ppm}$ & 0.2 & FUS-MS & $<0.2$ & $<0.2$ & 0.4 & 0.3 & 0.5 & $<0.2$ & $<0.2$ & $<0.2$ \\
\hline $\mathrm{Ta}$ & $\mathrm{ppm}$ & 0.1 & FUS-MS & $<0.1$ & $<0.1$ & $<0.1$ & $<0.1$ & $<0.1$ & $<0.1$ & $<0.1$ & $<0.1$ \\
\hline w & $\mathrm{ppm}$ & 1 & FUS-MS & $<1$ & $<1$ & 1 & $<1$ & 1 & $<1$ & $<1$ & $<1$ \\
\hline $\mathrm{TI}$ & $\mathrm{ppm}$ & 0.1 & FUS-MS & $<0.1$ & $<0.1$ & $<0.1$ & $<0.1$ & $<0.1$ & 0.1 & 0.1 & $<0.1$ \\
\hline $\mathrm{Bi}$ & $\mathrm{ppm}$ & 0.4 & FUS-MS & $<0.4$ & $<0.4$ & $<0.4$ & $<0.4$ & $<0.4$ & $<0.4$ & $<0.4$ & $<0.4$ \\
\hline Th & $\mathrm{ppm}$ & 0.1 & FUS-MS & $<0.1$ & $<0.1$ & $<0.1$ & $<0.1$ & $<0.1$ & 0.4 & 0.3 & $<0.1$ \\
\hline U & $\mathrm{ppm}$ & 0.1 & FUS-MS & $<0.1$ & $<0.1$ & $<0.1$ & $<0.1$ & $<0.1$ & $<0.1$ & $<0.1$ & $<0.1$ \\
\hline Abbreviations & & Rock type & & & & & & & & & \\
\hline MAS & \multicolumn{7}{|c|}{ Massive to semi-massive oxide mineralization } & BAR & \multicolumn{2}{|c|}{ Barren anorthosite } & \\
\hline OMAS & \multicolumn{7}{|c|}{ Orthopyroxene -bearing massive-semi-massive oxide mineralization } & DIS & \multicolumn{3}{|c|}{ Disseminated oxide mineralization } \\
\hline GAB & \multicolumn{7}{|c|}{ Gabbronorite } & TRO & \multicolumn{3}{|l|}{ Troctolite } \\
\hline
\end{tabular}


Appendix III. (Continued)

\begin{tabular}{|c|c|c|c|c|c|c|c|c|c|c|c|}
\hline Sample ID & & & & CC052B & CC052D & CC053 & CC054A & CC059A & CC059B & CC060 & CC061 \\
\hline Easting & & & & 667982 & 667982 & 667754 & 667754 & 658741 & 658741 & 659434 & 657858 \\
\hline Westing & & & & 5919407 & 5919407 & 5919493 & 5919493 & 5929050 & 5929050 & 5928198 & 5929930 \\
\hline Description & & & & BAR & BAR & MAS & GAB & MAS & GAB & MAS & BAR \\
\hline & & Idl & & & & & & & & & \\
\hline $\mathrm{SiO}_{2}$ & $\%$ & 0.01 & FUS-ICP & 54.84 & 51.86 & 17.49 & 51.51 & 8.59 & 52.56 & 0.48 & 55.93 \\
\hline $\mathrm{Al}_{2} \mathrm{O}_{3}$ & $\%$ & 0.01 & FUS-ICP & 23.35 & 25.31 & 13.65 & 23.86 & 12.08 & 25.1 & 8.52 & 26.1 \\
\hline $\mathrm{Fe}_{2} \mathrm{O}_{3(\mathrm{~T})}$ & $\%$ & 0.01 & FUS-ICP & 5.14 & 5.59 & 57.69 & 6.04 & 62.82 & 3.47 & 77.61 & 2.07 \\
\hline $\mathrm{MnO}$ & $\%$ & 0.001 & FUS-ICP & 0.113 & 0.082 & 0.193 & 0.071 & 0.277 & 0.022 & 0.287 & 0.018 \\
\hline $\mathrm{MgO}$ & $\%$ & 0.01 & FUS-ICP & 0.97 & 0.29 & 1.56 & 2.49 & 3.73 & 0.74 & 2.34 & 0.48 \\
\hline $\mathrm{CaO}$ & $\%$ & 0.01 & FUS-ICP & 7.42 & 8.53 & 2.61 & 8.68 & 1.34 & 9.33 & $<0.01$ & 8.73 \\
\hline $\mathrm{Na}_{2} \mathrm{O}$ & $\%$ & 0.01 & FUS-ICP & 5.48 & 4.85 & 1.28 & 4.1 & 0.46 & 4.9 & 0.02 & 5.33 \\
\hline $\mathrm{K}_{2} \mathrm{O}$ & $\%$ & 0.01 & FUS-ICP & 1.51 & 1.22 & 0.45 & 1.01 & 0.19 & 0.9 & 0.04 & 1.22 \\
\hline $\mathrm{TiO}_{2}$ & $\%$ & 0.001 & FUS-ICP & 0.625 & 0.752 & 5.695 & 0.681 & 10.8 & 0.213 & 11.86 & 0.273 \\
\hline $\mathrm{P}_{2} \mathrm{O}_{5}$ & $\%$ & 0.01 & FUS-ICP & 0.2 & 0.34 & 0.01 & 0.04 & 0.02 & 0.03 & $<0.01$ & 0.04 \\
\hline LOI & $\%$ & & FUS-ICP & 1.32 & 1.15 & -1.27 & 0.46 & -2.02 & 0.95 & -2.83 & 0.69 \\
\hline Total & $\%$ & 0.01 & FUS-ICP & 101 & 99.98 & 99.36 & 98.93 & 98.29 & 98.21 & 98.31 & 100.9 \\
\hline $\mathrm{Sc}$ & $\mathrm{ppm}$ & 1 & FUS-ICP & 8 & 4 & 7 & 6 & 15 & 2 & 13 & 1 \\
\hline $\mathrm{Be}$ & $\mathrm{ppm}$ & 1 & FUS-ICP & $<1$ & 1 & $<1$ & $<1$ & $<1$ & $<1$ & $<1$ & $<1$ \\
\hline v & $\mathrm{ppm}$ & 5 & FUS-ICP & 39 & 41 & 2109 & 127 & 2573 & 34 & 3231 & 48 \\
\hline $\mathrm{Cr}$ & $\mathrm{ppm}$ & 20 & FUS-MS & $<20$ & $<20$ & 1280 & 60 & 1210 & $<20$ & 1700 & 20 \\
\hline Co & $\mathrm{ppm}$ & 1 & FUS-MS & 7 & 8 & 118 & 20 & 191 & 24 & 177 & 6 \\
\hline $\mathrm{Ni}$ & ppm & 1 & TD-ICP & 17 & 16 & 188 & 54 & 300 & 205 & 283 & 24 \\
\hline $\mathrm{Zn}$ & $\mathrm{ppm}$ & 1 & TD-ICP & 69 & 63 & 306 & 39 & 339 & 17 & 311 & 15 \\
\hline $\mathrm{Cd}$ & $\mathrm{ppm}$ & 0.5 & TD-ICP & $<0.5$ & $<0.5$ & 0.8 & $<0.5$ & 0.6 & $<0.5$ & 0.7 & $<0.5$ \\
\hline $\mathrm{S}$ & $\%$ & 0.001 & TD-ICP & 0.079 & 0.104 & 0.04 & 0.094 & 0.184 & 0.603 & 0.004 & 0.065 \\
\hline $\mathrm{Cu}$ & $\mathrm{ppm}$ & 1 & TD-ICP & 47 & 89 & 64 & 91 & 229 & 454 & 71 & 42 \\
\hline $\mathrm{Ag}$ & $\mathrm{ppm}$ & 0.3 & TD-ICP & $<0.3$ & $<0.3$ & $<0.3$ & 0.3 & 0.4 & 0.4 & 0.4 & 0.4 \\
\hline $\mathrm{Pb}$ & $\mathrm{ppm}$ & 5 & TD-ICP & 5 & 6 & 12 & $<5$ & 15 & 6 & 19 & $<5$ \\
\hline Ga & $\mathrm{ppm}$ & 1 & FUS-MS & 22 & 20 & 62 & 20 & 62 & 17 & 71 & 18 \\
\hline $\mathrm{Ge}$ & $\mathrm{ppm}$ & 1 & FUS-MS & 2 & 1 & 2 & 1 & 2 & 1 & 2 & 1 \\
\hline As & $\mathrm{ppm}$ & 5 & FUS-MS & $<5$ & $<5$ & $<5$ & $<5$ & $<5$ & $<5$ & $<5$ & $<5$ \\
\hline $\mathrm{Rb}$ & $\mathrm{ppm}$ & 2 & FUS-MS & 12 & 14 & 5 & 4 & 2 & 5 & $<2$ & 5 \\
\hline $\mathrm{Sr}$ & $\mathrm{ppm}$ & 2 & FUS-ICP & 1101 & 1275 & 419 & 1269 & 193 & 1333 & 4 & 1536 \\
\hline $\mathrm{Y}$ & $\mathrm{ppm}$ & 2 & FUS-ICP & 7 & 8 & $<2$ & 2 & $<2$ & $<2$ & $<2$ & $<2$ \\
\hline $\mathrm{Zr}$ & $\mathrm{ppm}$ & 4 & FUS-ICP & 34 & 11 & 23 & 7 & 11 & 5 & 10 & 5 \\
\hline $\mathrm{Nb}$ & $\mathrm{ppm}$ & 1 & FUS-MS & $<1$ & 4 & $<1$ & $<1$ & $<1$ & $<1$ & $<1$ & $<1$ \\
\hline Mo & $\mathrm{ppm}$ & 2 & FUS-MS & $<2$ & $<2$ & $<2$ & $<2$ & $<2$ & $<2$ & $<2$ & $<2$ \\
\hline In & $\mathrm{ppm}$ & 0.2 & FUS-MS & $<0.2$ & $<0.2$ & $<0.2$ & $<0.2$ & $<0.2$ & $<0.2$ & $<0.2$ & $<0.2$ \\
\hline Sn & $\mathrm{ppm}$ & 1 & FUS-MS & $<1$ & $<1$ & 2 & $<1$ & 2 & $<1$ & 1 & $<1$ \\
\hline $\mathrm{Sb}$ & ppm & 0.5 & FUS-MS & $<0.5$ & $<0.5$ & $<0.5$ & $<0.5$ & $<0.5$ & $<0.5$ & $<0.5$ & $<0.5$ \\
\hline Cs & $\mathrm{ppm}$ & 0.5 & FUS-MS & $<0.5$ & $<0.5$ & $<0.5$ & $<0.5$ & $<0.5$ & $<0.5$ & $<0.5$ & $<0.5$ \\
\hline $\mathrm{Ba}$ & ppm & 3 & FUS-ICP & 857 & 752 & 299 & 841 & 149 & 950 & $<3$ & 1104 \\
\hline La & $\mathrm{ppm}$ & 0.1 & FUS-MS & 11.6 & 10.1 & 1.2 & 3.7 & 0.6 & 3.1 & $<0.1$ & 3.5 \\
\hline $\mathrm{Ce}$ & $\mathrm{ppm}$ & 0.1 & FUS-MS & 21.2 & 21.4 & 2.2 & 5.9 & 1.1 & 5.1 & $<0.1$ & 5.6 \\
\hline $\mathrm{Pr}$ & ppm & 0.05 & FUS-MS & 2.77 & 2.91 & 0.27 & 0.65 & 0.14 & 0.59 & $<0.05$ & 0.65 \\
\hline $\mathrm{Nd}$ & $\mathrm{ppm}$ & 0.1 & FUS-MS & 11.6 & 12.9 & 1.1 & 2.8 & 0.5 & 2.3 & $<0.1$ & 2.3 \\
\hline $\mathrm{Sm}$ & $\mathrm{ppm}$ & 0.1 & FUS-MS & 2.2 & 2.4 & 0.2 & 0.4 & $<0.1$ & 0.4 & $<0.1$ & 0.4 \\
\hline $\mathrm{Eu}$ & $\mathrm{ppm}$ & 0.05 & FUS-MS & 2.03 & 1.45 & 0.25 & 0.86 & 0.13 & 0.74 & $<0.05$ & 0.79 \\
\hline $\mathrm{Gd}$ & $\mathrm{ppm}$ & 0.1 & FUS-MS & 1.8 & 2 & 0.1 & 0.3 & $<0.1$ & 0.2 & $<0.1$ & 0.2 \\
\hline $\mathrm{Tb}$ & $\mathrm{ppm}$ & 0.1 & FUS-MS & 0.3 & 0.2 & $<0.1$ & $<0.1$ & $<0.1$ & $<0.1$ & $<0.1$ & $<0.1$ \\
\hline Dy & ppm & 0.1 & FUS-MS & 1.6 & 1.4 & $<0.1$ & 0.2 & $<0.1$ & 0.1 & $<0.1$ & 0.1 \\
\hline Ho & $\mathrm{ppm}$ & 0.1 & FUS-MS & 0.3 & 0.2 & $<0.1$ & $<0.1$ & $<0.1$ & $<0.1$ & $<0.1$ & $<0.1$ \\
\hline $\mathrm{Er}$ & ppm & 0.1 & FUS-MS & 0.8 & 0.7 & $<0.1$ & 0.1 & $<0.1$ & $<0.1$ & $<0.1$ & $<0.1$ \\
\hline $\mathrm{Tm}$ & ppm & 0.05 & FUS-MS & 0.12 & 0.1 & $<0.05$ & $<0.05$ & $<0.05$ & $<0.05$ & $<0.05$ & $<0.05$ \\
\hline $\mathrm{Yb}$ & $\mathrm{ppm}$ & 0.1 & FUS-MS & 0.8 & 0.6 & $<0.1$ & 0.1 & $<0.1$ & $<0.1$ & $<0.1$ & $<0.1$ \\
\hline Lu & $\mathrm{ppm}$ & 0.04 & FUS-MS & 0.11 & 0.09 & $<0.04$ & $<0.04$ & $<0.04$ & $<0.04$ & $<0.04$ & $<0.04$ \\
\hline $\mathrm{Hf}$ & $\mathrm{ppm}$ & 0.2 & FUS-MS & 0.7 & 0.3 & 0.6 & $<0.2$ & 0.4 & $<0.2$ & 0.4 & $<0.2$ \\
\hline $\mathrm{Ta}$ & $\mathrm{ppm}$ & 0.1 & FUS-MS & $<0.1$ & $<0.1$ & $<0.1$ & $<0.1$ & $<0.1$ & $<0.1$ & $<0.1$ & $<0.1$ \\
\hline$w$ & ppm & 1 & FUS-MS & $<1$ & $<1$ & 2 & 2 & 2 & $<1$ & 1 & $<1$ \\
\hline $\mathrm{TI}$ & $\mathrm{ppm}$ & 0.1 & FUS-MS & $<0.1$ & 0.1 & $<0.1$ & $<0.1$ & $<0.1$ & 0.1 & $<0.1$ & $<0.1$ \\
\hline $\mathrm{Bi}$ & ppm & 0.4 & FUS-MS & $<0.4$ & $<0.4$ & $<0.4$ & $<0.4$ & $<0.4$ & $<0.4$ & $<0.4$ & $<0.4$ \\
\hline Th & $\mathrm{ppm}$ & 0.1 & FUS-MS & $<0.1$ & $<0.1$ & $<0.1$ & $<0.1$ & $<0.1$ & $<0.1$ & $<0.1$ & $<0.1$ \\
\hline U & $\mathrm{ppm}$ & 0.1 & FUS-MS & $<0.1$ & $<0.1$ & $<0.1$ & $<0.1$ & 0.2 & 0.2 & 0.3 & $<0.1$ \\
\hline Abbreviations: & & Rock type & & & & & & & & & \\
\hline MAS & \multicolumn{6}{|c|}{ Massive to semi-massive oxide mineralization } & BAR & \multicolumn{2}{|c|}{ Barren anorthosite } & & \\
\hline OMAS & \multicolumn{6}{|c|}{ Orthopyroxene -bearing massive-semi-massive oxide mineralization } & DIS & \multicolumn{4}{|c|}{ Disseminated oxide mineralization } \\
\hline GAB & \multicolumn{6}{|c|}{ Gabbronorite } & TRO & \multicolumn{4}{|c|}{ Troctolite } \\
\hline
\end{tabular}


Appendix III. (Continued)

\begin{tabular}{|c|c|c|c|c|c|c|c|c|c|c|c|c|}
\hline Sample ID & & & & CC063A & СС063B & CC064 & CC065A & CC065B & CC066 & CC067A & CC067B & CC068 \\
\hline Easting & & & & 657451 & 657451 & 657507 & 657731 & 657731 & 657825 & 657914 & 657914 & 658275 \\
\hline Westing & & & & 5929961 & 5929961 & 5929978 & 5930062 & 5930062 & 5930109 & 5930069 & 5930069 & 5929492 \\
\hline \multirow{2}{*}{\multicolumn{2}{|c|}{ Description }} & & & MAS & BAR & DIS & BAR & BAR & BAR & OMAS & BAR & BAR \\
\hline & & Idl & & & & & & & & & & \\
\hline $\mathrm{SiO}_{2}$ & $\%$ & 0.01 & FUS-ICP & 14.46 & 53.62 & 56.61 & 56.21 & 56.13 & 55.77 & 14.12 & 53.78 & 52.26 \\
\hline $\mathrm{Al}_{2} \mathrm{O}_{3}$ & $\%$ & 0.01 & FUS-ICP & 11.81 & 25.88 & 25.35 & 26.65 & 26.63 & 26.53 & 8.39 & 25.27 & 27.07 \\
\hline $\mathrm{Fe}_{2} \mathrm{O}_{3(\mathrm{~T})}$ & $\%$ & 0.01 & FUS-ICP & 56.87 & 3.64 & 1.77 & 0.72 & 0.63 & 1.3 & 61.77 & 2.5 & 2.06 \\
\hline $\mathrm{MnO}$ & $\%$ & 0.001 & FUS-ICP & 0.271 & 0.022 & 0.012 & 0.007 & 0.006 & 0.012 & 0.298 & 0.015 & 0.022 \\
\hline $\mathrm{MgO}$ & $\%$ & 0.01 & FUS-ICP & 3.76 & 0.22 & 0.13 & 0.05 & 0.06 & 0.3 & 7.28 & 0.18 & 0.7 \\
\hline $\mathrm{CaO}$ & $\%$ & 0.01 & FUS-ICP & 1.53 & 8.48 & 8.26 & 8.9 & 8.92 & 9.66 & 0.47 & 9.01 & 11 \\
\hline $\mathrm{Na}_{2} \mathrm{O}$ & $\%$ & 0.01 & FUS-ICP & 0.24 & 5.25 & 5.55 & 5.5 & 5.54 & 5.14 & 0.04 & 5.13 & 4.32 \\
\hline $\mathrm{K}_{2} \mathrm{O}$ & $\%$ & 0.01 & FUS-ICP & 2.34 & 1.12 & 1.46 & 1.19 & 1.18 & 1.02 & 0.03 & 1.19 & 0.97 \\
\hline $\mathrm{TiO}_{2}$ & $\%$ & 0.001 & FUS-ICP & 8.494 & 0.781 & 0.11 & 0.102 & 0.099 & 0.136 & 8.443 & 0.346 & 0.254 \\
\hline $\mathrm{P}_{2} \mathrm{O}_{5}$ & $\%$ & 0.01 & FUS-ICP & 0.01 & 0.04 & 0.06 & 0.05 & 0.05 & 0.04 & 0.01 & 0.04 & 0.1 \\
\hline LOI & $\%$ & & FUS-ICP & -0.09 & 0.55 & 0.76 & 0.66 & 0.71 & 0.8 & -2.06 & 0.95 & 1.9 \\
\hline Total & $\%$ & 0.01 & FUS-ICP & 99.7 & 99.63 & 100.1 & 100 & 99.95 & 100.7 & 98.79 & 98.4 & 100.7 \\
\hline Sc & $\mathrm{ppm}$ & 1 & FUS-ICP & 13 & 1 & $<1$ & $<1$ & $<1$ & $<1$ & 17 & $<1$ & 3 \\
\hline $\mathrm{Be}$ & $\mathrm{ppm}$ & 1 & FUS-ICP & $<1$ & $<1$ & $<1$ & $<1$ & $<1$ & $<1$ & $<1$ & $<1$ & $<1$ \\
\hline v & ppm & 5 & FUS-ICP & 2052 & 107 & 9 & 6 & 6 & 21 & 2246 & 69 & 34 \\
\hline $\mathrm{Cr}$ & $\mathrm{ppm}$ & 20 & FUS-MS & 760 & 100 & $<20$ & $<20$ & $<20$ & $<20$ & 3770 & 70 & 20 \\
\hline Co & ppm & 1 & FUS-MS & 135 & 9 & 14 & $<1$ & $<1$ & 3 & 154 & 5 & 6 \\
\hline $\mathrm{Ni}$ & $\mathrm{ppm}$ & 1 & TD-ICP & 260 & 27 & 60 & 7 & 6 & 23 & 243 & 23 & 27 \\
\hline $\mathrm{Zn}$ & $\mathrm{ppm}$ & 1 & TD-ICP & 283 & 21 & 6 & 7 & 4 & 8 & 273 & 15 & 15 \\
\hline $\mathrm{Cd}$ & $\mathrm{ppm}$ & 0.5 & TD-ICP & $<0.5$ & $<0.5$ & $<0.5$ & $<0.5$ & $<0.5$ & $<0.5$ & 0.7 & $<0.5$ & $<0.5$ \\
\hline $\mathrm{s}$ & $\%$ & 0.001 & TD-ICP & 0.111 & 0.048 & 0.441 & 0.04 & 0.039 & 0.071 & 0.007 & 0.069 & 0.05 \\
\hline $\mathrm{Cu}$ & ppm & 1 & TD-ICP & 111 & 22 & 203 & 5 & 6 & 40 & 72 & 41 & 14 \\
\hline $\mathrm{Ag}$ & $\mathrm{ppm}$ & 0.3 & TD-ICP & $<0.3$ & $<0.3$ & 0.4 & 0.4 & 0.4 & 0.4 & 0.5 & 0.4 & $<0.3$ \\
\hline $\mathrm{Pb}$ & $\mathrm{ppm}$ & 5 & TD-ICP & 14 & $<5$ & $<5$ & $<5$ & $<5$ & $<5$ & 11 & $<5$ & $<5$ \\
\hline $\mathrm{Ga}$ & $\mathrm{ppm}$ & 1 & FUS-MS & 50 & 20 & 18 & 18 & 18 & 17 & 53 & 18 & 17 \\
\hline Ge & $\mathrm{ppm}$ & 1 & FUS-MS & 2 & 1 & 1 & 1 & 1 & 1 & 2 & 1 & 1 \\
\hline As & $\mathrm{ppm}$ & 5 & FUS-MS & $<5$ & $<5$ & $<5$ & $<5$ & $<5$ & $<5$ & $<5$ & $<5$ & $<5$ \\
\hline $\mathrm{Rb}$ & $\mathrm{ppm}$ & 2 & FUS-MS & 57 & 4 & 4 & 5 & 5 & 3 & $<2$ & 5 & 17 \\
\hline $\mathrm{Sr}$ & $\mathrm{ppm}$ & 2 & FUS-ICP & 211 & 1496 & 1460 & 1520 & 1519 & 1450 & 8 & 1467 & 1296 \\
\hline$Y$ & $\mathrm{ppm}$ & 2 & FUS-ICP & $<2$ & $<2$ & $<2$ & $<2$ & $<2$ & $<2$ & $<2$ & $<2$ & 3 \\
\hline $\mathrm{Zr}$ & $\mathrm{ppm}$ & 4 & FUS-ICP & 11 & 8 & 6 & 5 & 5 & 5 & 9 & 5 & 11 \\
\hline $\mathrm{Nb}$ & ppm & 1 & FUS-MS & $<1$ & $<1$ & $<1$ & 2 & $<1$ & $<1$ & $<1$ & $<1$ & $<1$ \\
\hline Mo & $\mathrm{ppm}$ & 2 & FUS-MS & $<2$ & $<2$ & $<2$ & $<2$ & $<2$ & $<2$ & $<2$ & $<2$ & $<2$ \\
\hline In & $\mathrm{ppm}$ & 0.2 & FUS-MS & $<0.2$ & $<0.2$ & $<0.2$ & $<0.2$ & $<0.2$ & $<0.2$ & $<0.2$ & $<0.2$ & $<0.2$ \\
\hline Sn & $\mathrm{ppm}$ & 1 & FUS-MS & 1 & $<1$ & $<1$ & $<1$ & $<1$ & $<1$ & 1 & 1 & $<1$ \\
\hline $\mathrm{Sb}$ & $\mathrm{ppm}$ & 0.5 & FUS-MS & $<0.5$ & $<0.5$ & $<0.5$ & $<0.5$ & $<0.5$ & $<0.5$ & $<0.5$ & $<0.5$ & $<0.5$ \\
\hline Cs & $\mathrm{ppm}$ & 0.5 & FUS-MS & 2.5 & $<0.5$ & $<0.5$ & $<0.5$ & $<0.5$ & $<0.5$ & $<0.5$ & $<0.5$ & $<0.5$ \\
\hline $\mathrm{Ba}$ & ppm & 3 & FUS-ICP & 422 & 1078 & 1330 & 1156 & 1100 & 956 & $<3$ & 1042 & 463 \\
\hline La & $\mathrm{ppm}$ & 0.1 & FUS-MS & 1 & 3.8 & 4.6 & 4.1 & 3.6 & 2.7 & $<0.1$ & 3.3 & 3.2 \\
\hline $\mathrm{Ce}$ & ppm & 0.1 & FUS-MS & 1.7 & 6.3 & 7.6 & 6.8 & 5.9 & 4.2 & 0.2 & 5.2 & 6.3 \\
\hline $\mathrm{Pr}$ & $\mathrm{ppm}$ & 0.05 & FUS-MS & 0.22 & 0.71 & 0.84 & 0.78 & 0.65 & 0.48 & $<0.05$ & 0.56 & 0.88 \\
\hline $\mathrm{Nd}$ & $\mathrm{ppm}$ & 0.1 & FUS-MS & 0.7 & 2.6 & 3.3 & 3.1 & 2.5 & 2 & 0.2 & 2.3 & 3.8 \\
\hline $\mathrm{Sm}$ & $\mathrm{ppm}$ & 0.1 & FUS-MS & 0.1 & 0.4 & 0.5 & 0.3 & 0.4 & 0.3 & $<0.1$ & 0.3 & 0.8 \\
\hline $\mathrm{Eu}$ & $\mathrm{ppm}$ & 0.05 & FUS-MS & 0.28 & 0.9 & 1.11 & 0.92 & 0.86 & 0.72 & $<0.05$ & 0.78 & 0.69 \\
\hline $\mathrm{Gd}$ & $\mathrm{ppm}$ & 0.1 & FUS-MS & 0.1 & 0.3 & 0.3 & 0.2 & 0.2 & 0.2 & $<0.1$ & 0.2 & 0.7 \\
\hline $\mathrm{Tb}$ & $\mathrm{ppm}$ & 0.1 & FUS-MS & $<0.1$ & $<0.1$ & $<0.1$ & $<0.1$ & $<0.1$ & $<0.1$ & $<0.1$ & $<0.1$ & $<0.1$ \\
\hline Dy & $\mathrm{ppm}$ & 0.1 & FUS-MS & $<0.1$ & 0.2 & 0.2 & 0.1 & 0.1 & $<0.1$ & $<0.1$ & $<0.1$ & 0.5 \\
\hline Ho & $\mathrm{ppm}$ & 0.1 & FUS-MS & $<0.1$ & $<0.1$ & $<0.1$ & $<0.1$ & $<0.1$ & $<0.1$ & $<0.1$ & $<0.1$ & 0.1 \\
\hline $\mathrm{Er}$ & $\mathrm{ppm}$ & 0.1 & FUS-MS & $<0.1$ & $<0.1$ & $<0.1$ & $<0.1$ & $<0.1$ & $<0.1$ & $<0.1$ & $<0.1$ & 0.3 \\
\hline $\mathrm{Tm}$ & ppm & 0.05 & FUS-MS & $<0.05$ & $<0.05$ & $<0.05$ & $<0.05$ & $<0.05$ & $<0.05$ & $<0.05$ & $<0.05$ & $<0.05$ \\
\hline $\mathrm{Yb}$ & $\mathrm{ppm}$ & 0.1 & FUS-MS & $<0.1$ & $<0.1$ & $<0.1$ & $<0.1$ & $<0.1$ & $<0.1$ & 0.1 & $<0.1$ & 0.2 \\
\hline Lu & ppm & 0.04 & FUS-MS & $<0.04$ & $<0.04$ & $<0.04$ & $<0.04$ & $<0.04$ & $<0.04$ & $<0.04$ & $<0.04$ & $<0.04$ \\
\hline $\mathrm{Hf}$ & $\mathrm{ppm}$ & 0.2 & FUS-MS & 0.5 & $<0.2$ & $<0.2$ & $<0.2$ & $<0.2$ & $<0.2$ & 0.4 & $<0.2$ & $<0.2$ \\
\hline $\mathrm{Ta}$ & $\mathrm{ppm}$ & 0.1 & FUS-MS & 0.1 & $<0.1$ & $<0.1$ & $<0.1$ & $<0.1$ & $<0.1$ & $<0.1$ & $<0.1$ & $<0.1$ \\
\hline w & ppm & 1 & FUS-MS & 1 & 1 & $<1$ & $<1$ & $<1$ & $<1$ & 1 & $<1$ & $<1$ \\
\hline $\mathrm{TI}$ & $\mathrm{ppm}$ & 0.1 & FUS-MS & $<0.1$ & 0.1 & $<0.1$ & $<0.1$ & $<0.1$ & $<0.1$ & $<0.1$ & $<0.1$ & $<0.1$ \\
\hline $\mathrm{Bi}$ & $\mathrm{ppm}$ & 0.4 & FUS-MS & $<0.4$ & $<0.4$ & $<0.4$ & $<0.4$ & $<0.4$ & $<0.4$ & $<0.4$ & $<0.4$ & $<0.4$ \\
\hline Th & ppm & 0.1 & FUS-MS & $<0.1$ & $<0.1$ & $<0.1$ & 0.5 & $<0.1$ & $<0.1$ & $<0.1$ & $<0.1$ & $<0.1$ \\
\hline$U$ & $\mathrm{ppm}$ & 0.1 & FUS-MS & 0.2 & $<0.1$ & $<0.1$ & $<0.1$ & $<0.1$ & $<0.1$ & $<0.1$ & $<0.1$ & $<0.1$ \\
\hline Abbreviations: & & Rock ty & & & & & & & & & & \\
\hline MAS & Massiv & to semi- & ssive oxid & ineralizat & & & & BAR & Barren & hosite & & \\
\hline OMAS & Orthop & roxene - & aring mass & e-semi-mas & ve oxide $\mathrm{mi}$ & ralization & & DIS & Dissemin & d oxide $m$ & ralization & \\
\hline
\end{tabular}


Appendix III. (Continued)

\begin{tabular}{|c|c|c|c|c|c|c|c|c|c|c|c|}
\hline Sample ID & & & & CC069 & CC071 & CC072 & CC073 & CC074 & CC075 & CC076A & CC076B \\
\hline Easting & & & & 658424 & 658527 & 657744 & 658070 & 658516 & 658220 & 658237 & 658237 \\
\hline Westing & & & & 5929537 & 5929467 & 5929747 & 5930061 & 5930210 & 5930258 & 5929903 & 5929903 \\
\hline Description & & & & MAS & MAS & OMAS & BAR & BAR & BAR & BAR & MAS \\
\hline & & Idl & & & & & & & & & \\
\hline $\mathrm{SiO}_{2}$ & $\%$ & 0.01 & FUS-ICP & 0.64 & 1.78 & 3.49 & 55.64 & 52.76 & 53.3 & 54.31 & 6.57 \\
\hline $\mathrm{Al}_{2} \mathrm{O}_{3}$ & $\%$ & 0.01 & FUS-ICP & 9.6 & 10.16 & 8.02 & 26.89 & 26.9 & 27.66 & 27.71 & 9.69 \\
\hline $\mathrm{Fe}_{2} \mathrm{O}_{3(\mathrm{~T})}$ & $\%$ & 0.01 & FUS-ICP & 74.07 & 73.19 & 74.89 & 1.3 & 2.99 & 1.13 & 1.56 & 68.4 \\
\hline $\mathrm{MnO}$ & $\%$ & 0.001 & FUS-ICP & 0.315 & 0.302 & 0.325 & 0.009 & 0.034 & 0.01 & 0.014 & 0.365 \\
\hline $\mathrm{MgO}$ & $\%$ & 0.01 & FUS-ICP & 3.94 & 2.62 & 3.7 & 0.1 & 1.51 & 0.11 & 0.23 & 2.42 \\
\hline $\mathrm{CaO}$ & $\%$ & 0.01 & FUS-ICP & 0.01 & 0.09 & 0.21 & 9.43 & 10.23 & 10.1 & 10.07 & 0.72 \\
\hline $\mathrm{Na}_{2} \mathrm{O}$ & $\%$ & 0.01 & FUS-ICP & 0.03 & 0.07 & 0.04 & 5.26 & 4.34 & 4.96 & 5.18 & 0.23 \\
\hline $\mathrm{K}_{2} \mathrm{O}$ & $\%$ & 0.01 & FUS-ICP & 0.05 & 0.04 & 0.02 & 1.1 & 0.65 & 0.93 & 0.61 & 0.76 \\
\hline $\mathrm{TiO}_{2}$ & $\%$ & 0.001 & FUS-ICP & 11.63 & 11.84 & 11.51 & 0.189 & 0.227 & 0.164 & 0.257 & 12.78 \\
\hline $\mathrm{P}_{2} \mathrm{O}_{5}$ & $\%$ & 0.01 & FUS-ICP & 0.01 & 0.01 & $<0.01$ & 0.03 & 0.04 & 0.03 & 0.05 & 0.02 \\
\hline LOI & $\%$ & & FUS-ICP & -2.2 & -2.17 & -2.81 & 0.45 & 0.73 & 1.06 & 0.67 & -1.9 \\
\hline Total & $\%$ & 0.01 & FUS-ICP & 98.1 & 97.93 & 99.4 & 100.4 & 100.4 & 99.46 & 100.7 & 100 \\
\hline $\mathrm{Sc}$ & ppm & 1 & FUS-ICP & 17 & 13 & 16 & $<1$ & 2 & $<1$ & $<1$ & 20 \\
\hline $\mathrm{Be}$ & $\mathrm{ppm}$ & 1 & FUS-ICP & $<1$ & $<1$ & $<1$ & $<1$ & $<1$ & $<1$ & $<1$ & $<1$ \\
\hline v & $\mathrm{ppm}$ & 5 & FUS-ICP & 3154 & 3147 & 2883 & 31 & 39 & 23 & 34 & 2584 \\
\hline $\mathrm{Cr}$ & $\mathrm{ppm}$ & 20 & FUS-MS & 1330 & 1190 & 1740 & $<20$ & 40 & $<20$ & $<20$ & 1880 \\
\hline Co & ppm & 1 & FUS-MS & 209 & 160 & 162 & 2 & 11 & 1 & 3 & 87 \\
\hline $\mathrm{Ni}$ & $\mathrm{ppm}$ & 1 & TD-ICP & 333 & 333 & 220 & 10 & 27 & 9 & 11 & 82 \\
\hline $\mathrm{Zn}$ & $\mathrm{ppm}$ & 1 & TD-ICP & 306 & 296 & 354 & 14 & 19 & 12 & 11 & 533 \\
\hline $\mathrm{Cd}$ & $\mathrm{ppm}$ & 0.5 & TD-ICP & $<0.5$ & 0.8 & 0.8 & $<0.5$ & $<0.5$ & $<0.5$ & $<0.5$ & 1 \\
\hline $\mathrm{s}$ & $\%$ & 0.001 & TD-ICP & 0.01 & 0.067 & 0.006 & 0.044 & 0.053 & 0.045 & 0.047 & 0.031 \\
\hline $\mathrm{Cu}$ & $\mathrm{ppm}$ & 1 & TD-ICP & 24 & 107 & 97 & 11 & 18 & 5 & 8 & 53 \\
\hline $\mathrm{Ag}$ & $\mathrm{ppm}$ & 0.3 & TD-ICP & 1 & 0.4 & 0.4 & $<0.3$ & $<0.3$ & $<0.3$ & $<0.3$ & 0.5 \\
\hline $\mathrm{Pb}$ & $\mathrm{ppm}$ & 5 & TD-ICP & 13 & 18 & 17 & $<5$ & $<5$ & $<5$ & $<5$ & 12 \\
\hline $\mathrm{Ga}$ & $\mathrm{ppm}$ & 1 & FUS-MS & 71 & 72 & 65 & 18 & 16 & 16 & 18 & 64 \\
\hline $\mathrm{Ge}$ & $\mathrm{ppm}$ & 1 & FUS-MS & 2 & 2 & 2 & 1 & 1 & 1 & 1 & 2 \\
\hline As & $\mathrm{ppm}$ & 5 & FUS-MS & $<5$ & $<5$ & $<5$ & $<5$ & $<5$ & $<5$ & $<5$ & $<5$ \\
\hline $\mathrm{Rb}$ & $\mathrm{ppm}$ & 2 & FUS-MS & $<2$ & $<2$ & $<2$ & $<2$ & $<2$ & 8 & 5 & 18 \\
\hline $\mathrm{Sr}$ & $\mathrm{ppm}$ & 2 & FUS-ICP & 6 & 20 & 10 & 1462 & 1270 & 1332 & 1399 & 105 \\
\hline$Y$ & $\mathrm{ppm}$ & 2 & FUS-ICP & $<2$ & $<2$ & $<2$ & $<2$ & $<2$ & $<2$ & 2 & $<2$ \\
\hline $\mathrm{Zr}$ & $\mathrm{ppm}$ & 4 & FUS-ICP & 8 & 8 & 13 & 5 & 5 & 5 & 10 & 41 \\
\hline $\mathrm{Nb}$ & $\mathrm{ppm}$ & 1 & FUS-MS & $<1$ & $<1$ & $<1$ & $<1$ & $<1$ & $<1$ & $<1$ & 1 \\
\hline Mo & $\mathrm{ppm}$ & 2 & FUS-MS & $<2$ & $<2$ & $<2$ & $<2$ & $<2$ & $<2$ & $<2$ & $<2$ \\
\hline In & $\mathrm{ppm}$ & 0.2 & FUS-MS & $<0.2$ & $<0.2$ & $<0.2$ & $<0.2$ & $<0.2$ & $<0.2$ & $<0.2$ & $<0.2$ \\
\hline Sn & $\mathrm{ppm}$ & 1 & FUS-MS & 2 & 1 & 2 & $<1$ & $<1$ & $<1$ & $<1$ & 1 \\
\hline $\mathrm{Sb}$ & $\mathrm{ppm}$ & 0.5 & FUS-MS & $<0.5$ & $<0.5$ & $<0.5$ & $<0.5$ & $<0.5$ & $<0.5$ & $<0.5$ & $<0.5$ \\
\hline Cs & $\mathrm{ppm}$ & 0.5 & FUS-MS & $<0.5$ & $<0.5$ & $<0.5$ & $<0.5$ & $<0.5$ & $<0.5$ & $<0.5$ & 0.9 \\
\hline $\mathrm{Ba}$ & $\mathrm{ppm}$ & 3 & FUS-ICP & 3 & 11 & $<3$ & 1073 & 649 & 638 & 685 & 163 \\
\hline La & $\mathrm{ppm}$ & 0.1 & FUS-MS & 0.3 & $<0.1$ & $<0.1$ & 3.1 & 2.2 & 2.5 & 3.5 & 0.8 \\
\hline $\mathrm{Ce}$ & $\mathrm{ppm}$ & 0.1 & FUS-MS & 0.7 & $<0.1$ & 0.2 & 5 & 3.8 & 4.2 & 6.6 & 1.8 \\
\hline $\mathrm{Pr}$ & $\mathrm{ppm}$ & 0.05 & FUS-MS & 0.09 & $<0.05$ & $<0.05$ & 0.58 & 0.46 & 0.51 & 0.81 & 0.19 \\
\hline $\mathrm{Nd}$ & $\mathrm{ppm}$ & 0.1 & FUS-MS & 0.5 & $<0.1$ & 0.2 & 2.1 & 2 & 2 & 3.2 & 0.8 \\
\hline $\mathrm{Sm}$ & ppm & 0.1 & FUS-MS & $<0.1$ & $<0.1$ & $<0.1$ & 0.3 & 0.4 & 0.4 & 0.5 & 0.1 \\
\hline $\mathrm{Eu}$ & $\mathrm{ppm}$ & 0.05 & FUS-MS & $<0.05$ & $<0.05$ & $<0.05$ & 0.84 & 0.65 & 0.58 & 0.68 & 0.18 \\
\hline $\mathrm{Gd}$ & $\mathrm{ppm}$ & 0.1 & FUS-MS & 0.1 & $<0.1$ & $<0.1$ & 0.2 & 0.2 & 0.2 & 0.4 & 0.1 \\
\hline $\mathrm{Tb}$ & $\mathrm{ppm}$ & 0.1 & FUS-MS & $<0.1$ & $<0.1$ & $<0.1$ & $<0.1$ & $<0.1$ & $<0.1$ & $<0.1$ & $<0.1$ \\
\hline Dy & $\mathrm{ppm}$ & 0.1 & FUS-MS & $<0.1$ & $<0.1$ & $<0.1$ & $<0.1$ & 0.2 & $<0.1$ & 0.3 & $<0.1$ \\
\hline Ho & $\mathrm{ppm}$ & 0.1 & FUS-MS & $<0.1$ & $<0.1$ & $<0.1$ & $<0.1$ & $<0.1$ & $<0.1$ & $<0.1$ & $<0.1$ \\
\hline $\mathrm{Er}$ & ppm & 0.1 & FUS-MS & $<0.1$ & $<0.1$ & $<0.1$ & $<0.1$ & $<0.1$ & $<0.1$ & $<0.1$ & $<0.1$ \\
\hline $\mathrm{Tm}$ & $\mathrm{ppm}$ & 0.05 & FUS-MS & $<0.05$ & $<0.05$ & $<0.05$ & $<0.05$ & $<0.05$ & $<0.05$ & $<0.05$ & $<0.05$ \\
\hline $\mathrm{Yb}$ & $\mathrm{ppm}$ & 0.1 & FUS-MS & $<0.1$ & $<0.1$ & $<0.1$ & $<0.1$ & $<0.1$ & $<0.1$ & 0.1 & $<0.1$ \\
\hline Lu & $\mathrm{ppm}$ & 0.04 & FUS-MS & $<0.04$ & $<0.04$ & $<0.04$ & $<0.04$ & $<0.04$ & $<0.04$ & $<0.04$ & $<0.04$ \\
\hline $\mathrm{Hf}$ & $\mathrm{ppm}$ & 0.2 & FUS-MS & 0.4 & 0.3 & 0.6 & $<0.2$ & $<0.2$ & $<0.2$ & $<0.2$ & 1.1 \\
\hline $\mathrm{Ta}$ & $\mathrm{ppm}$ & 0.1 & FUS-MS & $<0.1$ & $<0.1$ & $<0.1$ & $<0.1$ & $<0.1$ & $<0.1$ & $<0.1$ & 0.1 \\
\hline$w$ & $\mathrm{ppm}$ & 1 & FUS-MS & 2 & 1 & 2 & $<1$ & 1 & $<1$ & $<1$ & 1 \\
\hline $\mathrm{Tl}$ & $\mathrm{ppm}$ & 0.1 & FUS-MS & $<0.1$ & $<0.1$ & $<0.1$ & $<0.1$ & $<0.1$ & $<0.1$ & $<0.1$ & $<0.1$ \\
\hline $\mathrm{Bi}$ & ppm & 0.4 & FUS-MS & $<0.4$ & $<0.4$ & $<0.4$ & $<0.4$ & $<0.4$ & $<0.4$ & $<0.4$ & $<0.4$ \\
\hline Th & $\mathrm{ppm}$ & 0.1 & FUS-MS & $<0.1$ & $<0.1$ & $<0.1$ & $<0.1$ & $<0.1$ & $<0.1$ & $<0.1$ & $<0.1$ \\
\hline U & $\mathrm{ppm}$ & 0.1 & FUS-MS & $<0.1$ & 0.1 & $<0.1$ & $<0.1$ & $<0.1$ & $<0.1$ & $<0.1$ & $<0.1$ \\
\hline Abbreviations: & \multirow{2}{*}{\multicolumn{7}{|c|}{$\begin{array}{l}\text { Rock types } \\
\text { Massive to semi-massive oxide mineralization }\end{array}$}} & & \multirow{2}{*}{\multicolumn{3}{|c|}{ Barren anorthosite }} \\
\hline MAS & & & & & & & & BAR & & & \\
\hline OMAS & \multicolumn{7}{|c|}{ Orthopyroxene -bearing massive-semi-massive oxide mineralization } & DIS & \multicolumn{3}{|c|}{ Disseminated oxide mineralization } \\
\hline GAB & Gabbrs & norite & & & & & & TRO & \multicolumn{3}{|c|}{ Troctolite } \\
\hline
\end{tabular}


Appendix IV a. EPMA magnetite analyses results. Spot locations are shown on BSE images in Appendix VI. Total recalculated refers to the total value with recalculated $\mathrm{FeO}$ content.

\begin{tabular}{|c|c|c|c|c|c|c|c|c|c|}
\hline Sample & CC008 & CC008 & CC008 & CC008 & CCOO8 & CC008 & CC008 & $\mathrm{CCOO8}$ & CC008 \\
\hline Mineralization type & MAS & MAS & MAS & MAS & MAS & MAS & MAS & MAS & MAS \\
\hline Descriptor & BAN & BAN & BAN & BAN & BAN & BAN & BAN & BAN & BAN \\
\hline Circle Number & A & A & $A$ & B & B & B & B & $\mathrm{C}$ & C \\
\hline Mineral analyzed & MAG & MAG & MAG & MAG & MAG & MAG & MAG & MAG & MAG \\
\hline Mineral host & MAG & MAG & MAG & PLE & PLE & PLE & PLE & ILM & ILM \\
\hline Point & 7 & $\varepsilon$ & 9 & 10 & 11 & 12 & 13 & 16 & 1 \\
\hline $\mathrm{SiO}_{2}$ & 0.03 & 0.01 & 0.01 & 0.00 & 0.00 & 0.01 & 0.02 & - & - \\
\hline $\mathrm{TiO}_{2}$ & 0.09 & 0.09 & 0.22 & 0.14 & 0.05 & 0.04 & 0.01 & 1.03 & 1.07 \\
\hline $\mathrm{Al}_{2} \mathrm{O}_{3}$ & 0.34 & 0.31 & 0.32 & 0.22 & 0.18 & 0.25 & 0.24 & 0.26 & 0.25 \\
\hline $\mathrm{Cr}_{2} \mathrm{O}_{3}$ & 0.25 & 0.25 & 0.25 & 0.17 & 0.14 & 0.16 & 0.15 & 0.37 & 0.35 \\
\hline $\mathrm{V}_{2} \mathrm{O}_{3}$ & 0.68 & 0.68 & 0.57 & 0.38 & 0.35 & 0.48 & 0.50 & 0.65 & 0.62 \\
\hline $\mathrm{FeO} *$ & 91.56 & 90.79 & 90.71 & 90.95 & 91.51 & 92.51 & 92.36 & 91.43 & 90.88 \\
\hline $\mathrm{Fe}_{2} \mathrm{O}_{3}$ recalculated & 67.27 & 66.77 & 66.54 & 66.97 & 67.56 & 68.20 & 68.08 & 65.92 & 65.57 \\
\hline FeO recalculated & 31.03 & 30.71 & 30.83 & 30.69 & 30.72 & 31.14 & 31.10 & 32.11 & 31.88 \\
\hline $\mathrm{MnO}$ & 0.01 & 0.01 & 0.02 & 0.02 & 0.02 & 0.02 & 0.02 & 0.01 & 0.02 \\
\hline MgO & 0.07 & 0.07 & 0.05 & 0.02 & 0.02 & 0.01 & 0.00 & 0.02 & 0.07 \\
\hline $\mathrm{ZnO}$ & - & 0.00 & 0.04 & 0.02 & 0.06 & 0.02 & 0.02 & 0.01 & 0.01 \\
\hline $\mathrm{NiO}$ & 0.02 & 0.03 & 0.02 & 0.03 & 0.03 & 0.05 & 0.02 & 0.01 & 0.03 \\
\hline $\mathrm{CaO}$ & 0.00 & 0.00 & - & 0.00 & - & - & 0.01 & - & - \\
\hline $\mathrm{Cu}_{2} \mathrm{O}$ & - & 0.01 & - & - & - & 0.00 & - & 0.00 & - \\
\hline $\mathrm{K}_{2} \mathrm{O}$ & 0.00 & - & - & - & 0.00 & 0.00 & 0.00 & - & 0.00 \\
\hline Total measured & 93.05 & 92.25 & 92.21 & 91.95 & 92.36 & 93.54 & 93.34 & 93.80 & 93.30 \\
\hline Total recalculated & 99.80 & 98.94 & 98.88 & 98.66 & 99.13 & 100.37 & 100.16 & 100.40 & 99.87 \\
\hline MAS & \multicolumn{4}{|c|}{ Massive to semi-massive mineralization } & OBAN & \multicolumn{4}{|c|}{ Orthopyroxene -bearing bands of oxide mineralization } \\
\hline DIS & \multicolumn{4}{|c|}{ Disseminated mineralization } & POD & \multicolumn{4}{|c|}{ Pod of oxide mineralization } \\
\hline BAN & \multicolumn{4}{|c|}{ Bands of oxide mineralization } & OPOD & \multicolumn{4}{|c|}{ Orthopyroxene -bearing pod of oxide mineralization } \\
\hline ANO & \multicolumn{4}{|c|}{ Anorthosite hosted disseminated } & VEIN & \multicolumn{4}{|c|}{ Vein of oxide mineralization } \\
\hline ORT & \multicolumn{4}{|c|}{ Orthopyroxene associated } & MAG & \multicolumn{4}{|c|}{ Magnetite } \\
\hline $\mathrm{CLI}$ & \multicolumn{4}{|c|}{ Clinopyroxene associated } & ILM & Ilmenite & & PLE & Pleonaste \\
\hline
\end{tabular}




\section{Appendix IV a. (Continued)}

\begin{tabular}{|c|c|c|c|c|c|c|c|c|c|}
\hline Sample & CC008 & CC008 & CC008 & CC008 & CC008 & CC008 & CC008 & CC008 & CCOO8 \\
\hline Mineralization type & MAS & MAS & MAS & MAS & MAS & MAS & MAS & MAS & MAS \\
\hline Descriptor & BAN & BAN & BAN & BAN & BAN & BAN & BAN & BAN & BAN \\
\hline Circle Number & C & C & $\mathrm{C}$ & D & $\mathrm{D}$ & D & $\mathrm{D}$ & $\mathrm{F}$ & $\mathrm{F}$ \\
\hline Mineral analyzed & MAG & MAG & MAG & MAG & MAG & MAG & MAG & MAG & MAG \\
\hline Mineral host & MAG & MAG & MAG & PLE & PLE & MAG & MAG & MAG & MAG \\
\hline Point & 23 & 24 & 25 & 29 & 30 & 36 & 37 & 42 & 43 \\
\hline $\mathrm{SiO}_{2}$ & 0.01 & 0.02 & 0.02 & 0.01 & 0.02 & 0.02 & 0.01 & 0.02 & 0.01 \\
\hline $\mathrm{TiO}_{2}$ & 0.07 & 0.06 & 0.09 & 0.07 & 0.04 & 0.07 & 0.04 & 1.58 & 1.80 \\
\hline $\mathrm{Al}_{2} \mathrm{O}_{3}$ & 0.32 & 0.36 & 0.33 & 0.19 & 0.21 & 0.29 & 0.32 & 0.25 & 0.24 \\
\hline $\mathrm{Cr}_{2} \mathrm{O}_{3}$ & 0.25 & 0.25 & 0.28 & 0.14 & 0.18 & 0.28 & 0.27 & 0.37 & 0.37 \\
\hline $\mathrm{V}_{2} \mathrm{O}_{3}$ & 0.73 & 0.69 & 0.71 & 0.31 & 0.33 & 0.74 & 0.75 & 0.60 & 0.58 \\
\hline $\mathrm{FeO}^{*}$ & 90.19 & 90.08 & 90.93 & 91.14 & 92.16 & 91.18 & 91.42 & 91.18 & 91.17 \\
\hline $\mathrm{Fe}_{2} \mathrm{O}_{3}$ recalculated & 66.28 & 66.21 & 66.84 & 67.28 & 68.02 & 67.06 & 67.23 & 65.10 & 64.81 \\
\hline FeO recalculated & 30.55 & 30.50 & 30.78 & 30.60 & 30.95 & 30.84 & 30.93 & 32.60 & 32.85 \\
\hline $\mathrm{MnO}$ & 0.01 & 0.02 & 0.03 & 0.02 & 0.04 & 0.02 & 0.01 & 0.01 & 0.04 \\
\hline MgO & 0.04 & 0.05 & 0.08 & 0.02 & 0.02 & 0.06 & 0.05 & 0.06 & 0.06 \\
\hline $\mathrm{ZnO}$ & - & 0.01 & 0.00 & 0.07 & 0.04 & 0.01 & 0.02 & 0.03 & 0.01 \\
\hline $\mathrm{NiO}$ & 0.03 & 0.03 & 0.03 & 0.04 & 0.03 & 0.04 & 0.02 & 0.03 & 0.03 \\
\hline $\mathrm{CaO}$ & 0.01 & 0.00 & - & - & 0.00 & - & - & 0.02 & 0.01 \\
\hline $\mathrm{Cu}_{2} \mathrm{O}$ & - & - & 0.01 & - & - & 0.01 & - & 0.00 & - \\
\hline $\mathrm{K}_{2} \mathrm{O}$ & - & - & - & - & - & 0.00 & - & 0.00 & 0.00 \\
\hline Total measured & 91.66 & 91.57 & 92.52 & 92.01 & 93.07 & 92.73 & 92.91 & 94.16 & 94.32 \\
\hline Total recalculated & 98.30 & 98.21 & 99.22 & 98.75 & 99.88 & 99.44 & 99.65 & 100.68 & 100.82 \\
\hline MAS & $\begin{array}{l}\text { Massive to } \\
\text { semi-massive } \\
\text { mineralization }\end{array}$ & & OBAN & $\begin{array}{l}\text { Orthopyroxene } \\
\text {-bearing bands } \\
\text { of oxide } \\
\text { mineralization }\end{array}$ & & & & & \\
\hline DIS & Disseminated min & ralization & & & POD & \multirow{2}{*}{\multicolumn{2}{|c|}{$\begin{array}{l}\text { Pod of oxide mineralization } \\
\text { Orthopyroxene -bearing } \\
\text { pod of oxide mineralization }\end{array}$}} & & \\
\hline BAN & Bands of oxide mi & eralization & & & OPOD & & & & \\
\hline ANO & Anorthosite hoste & disseminated & & & VEIN & \multicolumn{2}{|c|}{ Vein of oxide mineralization } & & \\
\hline
\end{tabular}




\begin{tabular}{|c|c|c|c|c|c|c|c|c|c|}
\hline Sample & CC008 & CC008 & CC008 & CC008 & CC008 & CC008 & CC010 & \multicolumn{2}{|l|}{ CC010 } \\
\hline Mineralization type & MAS & MAS & MAS & MAS & MAS & MAS & MAS & MAS & \\
\hline Descriptor & BAN & BAN & BAN & BAN & BAN & BAN & OBAN & OBAN & \\
\hline Circle Number & $\mathrm{F}$ & $\mathrm{F}$ & $\mathrm{F}$ & I & I & I & A & A & \\
\hline Mineral analyzed & MAG & MAG & MAG & MAG & MAG & MAG & MAG & MAG & \\
\hline Mineral host & MAG & ILM & ILM & ILM & ILM & ILM & PLE & \multicolumn{2}{|l|}{ PLE } \\
\hline $\mathrm{TiO}_{2}$ & 0.26 & 1.93 & 1.94 & 0.79 & 1.39 & 1.60 & 0.17 & 0.35 & \\
\hline $\mathrm{Al}_{2} \mathrm{O}_{3}$ & 0.24 & 0.25 & 1.01 & 0.27 & 0.35 & 0.28 & 0.44 & 0.48 & \\
\hline $\mathrm{Cr}_{2} \mathrm{O}_{3}$ & 0.30 & 0.33 & 0.33 & 0.16 & 0.14 & 0.14 & 0.16 & 0.16 & \\
\hline $\mathrm{V}_{2} \mathrm{O}_{3}$ & 0.68 & 0.62 & 0.59 & 0.39 & 0.35 & 0.34 & 0.49 & 0.49 & \\
\hline $\mathrm{FeO} *$ & 90.36 & 91.57 & 90.54 & 90.88 & 90.67 & 91.99 & 92.14 & 91.41 & \\
\hline $\mathrm{ZnO}$ & - & 0.03 & 0.04 & 0.03 & - & - & 0.04 & 0.03 & \\
\hline $\mathrm{NiO}$ & 0.04 & 0.03 & 0.04 & 0.03 & 0.00 & 0.02 & 0.04 & 0.04 & \\
\hline $\mathrm{CaO}$ & 0.00 & 0.01 & 0.01 & 0.01 & - & - & - & - & \\
\hline $\mathrm{Cu}_{2} \mathrm{O}$ & 0.01 & 0.02 & - & 0.01 & - & - & - & 0.01 & \\
\hline $\mathrm{K}_{2} \mathrm{O}$ & - & - & 0.00 & 0.00 & 0.01 & 0.00 & - & - & \\
\hline Total measured & 91.99 & 94.91 & 94.76 & 92.65 & 93.03 & 94.46 & 93.62 & 93.09 & \\
\hline Total recalculated & 98.63 & 101.42 & 101.18 & 99.27 & 99.55 & 101.05 & 100.40 & 99.79 & \\
\hline MAS & Massive to $\mathrm{s}$ & -massive mine & ization & OBAN & Orthopyroxe & -bearing ba & $\mathrm{s}$ of oxide mir & neralization & \\
\hline DIS & Disseminate & ineralization & & POD & Pod of oxide & ineralization & & & \\
\hline BAN & Bands of oxi & nineralization & & OPOD & Orthopyroxe & -bearing po & f oxide mine & ralization & \\
\hline
\end{tabular}




\begin{tabular}{|c|c|c|c|c|c|c|c|c|}
\hline Sample & $\mathrm{CCO10}$ & $\mathrm{CCO10}$ & $\mathrm{CCO10}$ & CC010 & $\mathrm{CCO10}$ & $\mathrm{CCO10}$ & CC010 & $\mathrm{CCO10}$ \\
\hline Mineralization type & MAS & MAS & MAS & MAS & MAS & MAS & MAS & MAS \\
\hline Descriptor & OBAN & OBAN & OBAN & OBAN & OBAN & OBAN & OBAN & OBAN \\
\hline Circle Number & A & A & A & $A$ & $\mathrm{C}$ & $\mathrm{C}$ & $\mathrm{C}$ & $\mathrm{C}$ \\
\hline Mineral analyzed & MAG & MAG & MAG & MAG & MAG & MAG & MAG & MAG \\
\hline Mineral host & PLE & PLE & PLE & PLE & PLE & PLE & PLE & PLE \\
\hline Point & 3 & & 5 & & 6 & 11 & 1 & 13 \\
\hline $\mathrm{SiO}_{2}$ & 0.01 & 0.01 & 0.01 & 0.02 & 0.02 & 0.01 & 0.01 & 0.01 \\
\hline $\mathrm{TiO}_{2}$ & 0.31 & 0.16 & 0.35 & 0.37 & 0.19 & 0.29 & 0.30 & 0.38 \\
\hline $\mathrm{Al}_{2} \mathrm{O}_{3}$ & 0.28 & 0.30 & 0.60 & 0.53 & 0.41 & 0.40 & 0.30 & 0.30 \\
\hline $\mathrm{Cr}_{2} \mathrm{O}_{3}$ & 0.15 & 0.16 & 0.18 & 0.17 & 0.15 & 0.17 & 0.16 & 0.19 \\
\hline $\mathrm{V}_{2} \mathrm{O}_{3}$ & 0.38 & 0.38 & 0.55 & 0.54 & 0.50 & 0.54 & 0.41 & 0.36 \\
\hline $\mathrm{FeO} *$ & 91.24 & 90.40 & 91.72 & 91.60 & 92.38 & 92.26 & 92.41 & 91.14 \\
\hline $\mathrm{Fe}_{2} \mathrm{O}_{3}$ recalculated & 66.98 & 66.52 & 67.08 & 67.04 & 67.89 & 67.62 & 67.82 & 66.78 \\
\hline FeO recalculated & 30.97 & 30.54 & 31.36 & 31.28 & 31.29 & 31.41 & 31.38 & 31.05 \\
\hline $\mathrm{MnO}$ & 0.02 & 0.03 & 0.03 & 0.04 & 0.03 & 0.02 & 0.02 & 0.02 \\
\hline $\mathrm{MgO}$ & 0.04 & 0.04 & 0.09 & 0.10 & 0.08 & 0.07 & 0.05 & 0.04 \\
\hline $\mathrm{ZnO}$ & 0.06 & 0.02 & 0.01 & 0.05 & 0.06 & 0.02 & 0.04 & 0.04 \\
\hline $\mathrm{NiO}$ & 0.04 & 0.05 & 0.04 & 0.04 & 0.01 & 0.03 & 0.03 & 0.03 \\
\hline $\mathrm{CaO}$ & 0.01 & 0.00 & 0.01 & 0.00 & - & 0.00 & 0.00 & - \\
\hline $\mathrm{Cu}_{2} \mathrm{O}$ & - & - & - & - & 0.02 & - & - & - \\
\hline $\mathrm{K}_{2} \mathrm{O}$ & - & 0.01 & - & 0.00 & - & 0.01 & 0.00 & - \\
\hline Total measured & 92.55 & 91.56 & 93.58 & 93.46 & 93.85 & 93.81 & 93.74 & 92.52 \\
\hline Total recalculated & 99.26 & 98.22 & 100.30 & 100.18 & 100.66 & 100.59 & 100.53 & 99.21 \\
\hline MAS & \multicolumn{3}{|c|}{ Massive to semi-massive mineralization } & OBAN & \multicolumn{4}{|c|}{ Orthopyroxene -bearing bands of oxide mineralization } \\
\hline DIS & \multicolumn{3}{|c|}{ Disseminated mineralization } & POD & \multicolumn{4}{|c|}{ Pod of oxide mineralization } \\
\hline BAN & \multicolumn{3}{|c|}{ Bands of oxide mineralization } & OPOD & \multicolumn{4}{|c|}{ Orthopyroxene -bearing pod of oxide mineralization } \\
\hline ANO & \multicolumn{3}{|c|}{ Anorthosite hosted disseminated } & VEIN & \multicolumn{4}{|c|}{ Vein of oxide mineralization } \\
\hline ORT & \multicolumn{3}{|c|}{ Orthopyroxene associated } & MAG & \multicolumn{4}{|c|}{ Magnetite } \\
\hline $\mathrm{CLI}$ & \multicolumn{3}{|c|}{ Clinopyroxene associated } & ILM & Ilmenite & & PLE & Pleonaste \\
\hline
\end{tabular}




\begin{tabular}{|c|c|c|c|c|c|c|c|c|}
\hline Sample & $\mathrm{CCO10}$ & $\mathrm{CCO10}$ & $\mathrm{CCO10}$ & CC010 & $\mathrm{CCO10}$ & $\mathrm{CCO10}$ & CC010 & $\mathrm{CCO10}$ \\
\hline Mineralization type & MAS & MAS & MAS & MAS & MAS & MAS & MAS & MAS \\
\hline Descriptor & OBAN & OBAN & OBAN & OBAN & OBAN & OBAN & OBAN & OBAN \\
\hline Circle Number & $\mathrm{D}$ & $\mathrm{D}$ & $\mathrm{D}$ & $\mathrm{D}$ & $\mathrm{D}$ & $\mathrm{E}$ & $\mathrm{E}$ & $\mathrm{E}$ \\
\hline Mineral analyzed & MAG & MAG & MAG & MAG & MAG & MAG & MAG & MAG \\
\hline Mineral host & MAG & MAG & MAG & ILM & ILM & MAG & MAG & MAG \\
\hline Point & 18 & 15 & 2 & 24 & 2 & $3 \varepsilon$ & 3 & 4 \\
\hline $\mathrm{SiO}_{2}$ & 0.02 & 0.03 & 0.02 & 0.00 & 0.01 & 0.02 & 0.02 & 0.01 \\
\hline $\mathrm{TiO}_{2}$ & 0.19 & 0.24 & 0.25 & 1.71 & 1.52 & 0.21 & 0.28 & 0.58 \\
\hline $\mathrm{Al}_{2} \mathrm{O}_{3}$ & 0.37 & 0.42 & 0.42 & 0.31 & 0.27 & 0.49 & 0.43 & 0.31 \\
\hline $\mathrm{Cr}_{2} \mathrm{O}_{3}$ & 0.24 & 0.25 & 0.25 & 0.31 & 0.33 & 0.28 & 0.26 & 0.39 \\
\hline $\mathrm{V}_{2} \mathrm{O}_{3}$ & 0.75 & 0.69 & 0.73 & 0.60 & 0.59 & 0.72 & 0.73 & 0.70 \\
\hline $\mathrm{FeO} *$ & 92.53 & 91.57 & 91.60 & 90.98 & 91.10 & 91.94 & 92.01 & 91.33 \\
\hline $\mathrm{Fe}_{2} \mathrm{O}_{3}$ recalculated & 67.88 & 67.12 & 67.07 & 64.78 & 65.13 & 67.40 & 67.37 & 66.47 \\
\hline FeO recalculated & 31.45 & 31.18 & 31.25 & 32.69 & 32.49 & 31.30 & 31.39 & 31.52 \\
\hline $\mathrm{MnO}$ & 0.01 & 0.03 & 0.03 & 0.01 & 0.03 & 0.04 & 0.03 & 0.00 \\
\hline $\mathrm{MgO}$ & 0.09 & 0.12 & 0.06 & 0.08 & 0.07 & 0.11 & 0.09 & 0.08 \\
\hline $\mathrm{ZnO}$ & 0.01 & - & 0.01 & 0.00 & - & 0.01 & - & - \\
\hline $\mathrm{NiO}$ & 0.04 & 0.03 & 0.03 & 0.04 & 0.04 & 0.03 & 0.03 & 0.05 \\
\hline $\mathrm{CaO}$ & - & - & - & - & - & - & 0.01 & - \\
\hline $\mathrm{Cu}_{2} \mathrm{O}$ & - & 0.00 & - & - & - & - & 0.00 & 0.00 \\
\hline $\mathrm{K}_{2} \mathrm{O}$ & - & - & - & 0.01 & - & - & 0.01 & 0.00 \\
\hline Total measured & 94.24 & 93.37 & 93.40 & 94.05 & 93.97 & 93.85 & 93.89 & 93.45 \\
\hline Total recalculated & 101.04 & 100.09 & 100.12 & 100.54 & 100.50 & 100.60 & 100.64 & 100.11 \\
\hline MAS & \multicolumn{3}{|c|}{ Massive to semi-massive mineralization } & OBAN & \multicolumn{4}{|c|}{ Orthopyroxene -bearing bands of oxide mineralization } \\
\hline DIS & \multicolumn{3}{|c|}{ Disseminated mineralization } & POD & \multicolumn{4}{|c|}{ Pod of oxide mineralization } \\
\hline BAN & \multicolumn{3}{|c|}{ Bands of oxide mineralization } & OPOD & \multicolumn{4}{|c|}{ Orthopyroxene -bearing pod of oxide mineralization } \\
\hline ANO & \multicolumn{3}{|c|}{ Anorthosite hosted disseminated } & VEIN & \multicolumn{4}{|c|}{ Vein of oxide mineralization } \\
\hline ORT & \multicolumn{3}{|c|}{ Orthopyroxene associated } & MAG & \multicolumn{4}{|c|}{ Magnetite } \\
\hline $\mathrm{CLI}$ & \multicolumn{3}{|c|}{ Clinopyroxene associated } & ILM & Ilmenite & & PLE & Pleonaste \\
\hline
\end{tabular}




\begin{tabular}{|c|c|c|c|c|c|c|c|c|}
\hline Sample & $\mathrm{CCO10}$ & $\mathrm{CCO10}$ & $\mathrm{CCO10}$ & $\mathrm{CCO10}$ & $\mathrm{CCO10}$ & $\mathrm{CCO10}$ & $\mathrm{CCO10}$ & CC010 \\
\hline Mineralization type & MAS & MAS & MAS & MAS & MAS & MAS & MAS & MAS \\
\hline Descriptor & OBAN & OBAN & OBAN & OBAN & OBAN & OBAN & OBAN & OBAN \\
\hline Circle Number & $\mathrm{F}$ & $\mathrm{F}$ & $\mathrm{F}$ & $\mathrm{F}$ & $\mathrm{F}$ & $\mathrm{H}$ & $\mathrm{H}$ & $\mathrm{H}$ \\
\hline Mineral analyzed & MAG & MAG & MAG & MAG & MAG & MAG & MAG & MAG \\
\hline Mineral host & MAG & MAG & MAG & ILM & ILM & MAG & MAG & MAG \\
\hline Point & 44 & 45 & 4 & 47 & 48 & & & 59 \\
\hline $\mathrm{SiO}_{2}$ & 0.02 & 0.02 & 0.02 & 0.02 & 0.02 & 0.01 & 0.01 & 0.01 \\
\hline $\mathrm{TiO}_{2}$ & 0.15 & 0.34 & 0.21 & 1.33 & 1.26 & 0.26 & 0.29 & 0.22 \\
\hline $\mathrm{Al}_{2} \mathrm{O}_{3}$ & 0.37 & 0.34 & 0.35 & 0.51 & 0.41 & 0.40 & 0.44 & 0.46 \\
\hline $\mathrm{Cr}_{2} \mathrm{O}_{3}$ & 0.27 & 0.31 & 0.26 & 0.36 & 0.36 & 0.26 & 0.26 & 0.24 \\
\hline $\mathrm{V}_{2} \mathrm{O}_{3}$ & 0.74 & 0.69 & 0.72 & 0.66 & 0.67 & 0.72 & 0.74 & 0.71 \\
\hline $\mathrm{FeO}^{*}$ & 91.79 & 91.88 & 91.81 & 90.66 & 91.47 & 91.93 & 91.73 & 91.89 \\
\hline $\mathrm{Fe}_{2} \mathrm{O}_{3}$ recalculated & 67.37 & 67.22 & 67.34 & 64.96 & 65.67 & 67.39 & 67.15 & 67.37 \\
\hline FeO recalculated & 31.17 & 31.39 & 31.22 & 32.21 & 32.38 & 31.30 & 31.31 & 31.27 \\
\hline $\mathrm{MnO}$ & 0.01 & 0.02 & 0.03 & 0.04 & 0.03 & 0.02 & 0.03 & 0.04 \\
\hline $\mathrm{MgO}$ & 0.08 & 0.09 & 0.07 & 0.11 & 0.09 & 0.10 & 0.09 & 0.10 \\
\hline $\mathrm{ZnO}$ & 0.02 & - & 0.02 & 0.01 & 0.01 & 0.02 & - & - \\
\hline $\mathrm{NiO}$ & 0.03 & 0.04 & 0.03 & 0.05 & 0.05 & 0.04 & 0.05 & 0.04 \\
\hline $\mathrm{CaO}$ & - & - & 0.00 & - & 0.00 & - & - & - \\
\hline $\mathrm{Cu}_{2} \mathrm{O}$ & - & 0.01 & - & - & 0.02 & - & 0.01 & - \\
\hline $\mathrm{K}_{2} \mathrm{O}$ & 0.00 & - & 0.00 & - & 0.00 & - & 0.00 & 0.00 \\
\hline Total measured & 93.49 & 93.75 & 93.50 & 93.75 & 94.39 & 93.76 & 93.64 & 93.71 \\
\hline Total recalculated & 100.24 & 100.48 & 100.25 & 100.26 & 100.97 & 100.52 & 100.36 & 100.47 \\
\hline MAS & \multicolumn{3}{|c|}{ Massive to semi-massive mineralization } & OBAN & \multicolumn{4}{|c|}{ Orthopyroxene -bearing bands of oxide mineralization } \\
\hline DIS & \multicolumn{3}{|c|}{ Disseminated mineralization } & POD & \multicolumn{4}{|c|}{ Pod of oxide mineralization } \\
\hline BAN & \multicolumn{3}{|c|}{ Bands of oxide mineralization } & OPOD & \multicolumn{4}{|c|}{ Orthopyroxene -bearing pod of oxide mineralization } \\
\hline ANO & \multicolumn{3}{|c|}{ Anorthosite hosted disseminated } & VEIN & \multicolumn{4}{|c|}{ Vein of oxide mineralization } \\
\hline ORT & \multicolumn{3}{|c|}{ Orthopyroxene associated } & MAG & \multicolumn{4}{|c|}{ Magnetite } \\
\hline $\mathrm{CLI}$ & \multicolumn{3}{|c|}{ Clinopyroxene associated } & ILM & Ilmenite & & PLE & Pleonaste \\
\hline
\end{tabular}




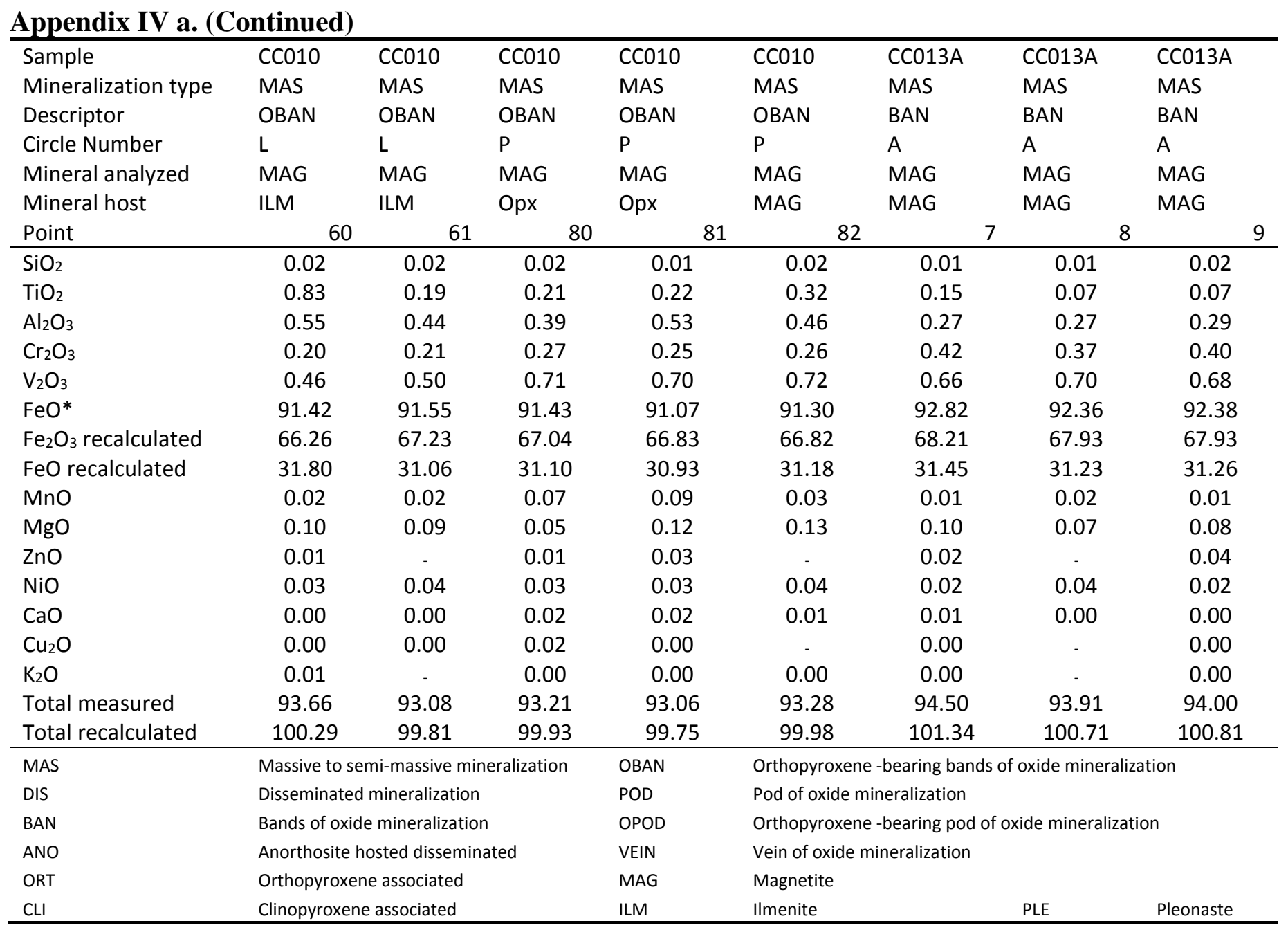




\begin{tabular}{|c|c|c|c|c|c|c|c|c|c|}
\hline $\begin{array}{l}\text { Sample } \\
\text { Mineralization }\end{array}$ & CC013A & CC013A & CC013A & CC013A & CC013A & CC013A & CC013A & CC013A & CC013A \\
\hline type & MAS & MAS & MAS & MAS & MAS & MAS & MAS & MAS & MAS \\
\hline Descriptor & BAN & BAN & BAN & BAN & BAN & BAN & BAN & BAN & BAN \\
\hline Circle Number & B & B & B & C & C & C & $\mathrm{D}$ & $\mathrm{D}$ & $\mathrm{D}$ \\
\hline $\begin{array}{l}\text { Mineral } \\
\text { analyzed }\end{array}$ & MAG & MAG & MAG & MAG & MAG & MAG & MAG & MAG & MAG \\
\hline Mineral host & MAG & MAG & MAG & MAG & MAG & MAG & ILM & ILM & ILM \\
\hline Point & 18 & 19 & 20 & 24 & 25 & 26 & 27 & 28 & 2 \\
\hline $\mathrm{SiO}_{2}$ & 0.00 & 0.01 & 0.01 & 0.01 & 0.02 & 0.01 & 0.01 & 0.00 & 0.01 \\
\hline $\mathrm{TiO}_{2}$ & 0.15 & 0.08 & 0.05 & 0.08 & 0.16 & 0.08 & 0.08 & 0.07 & 0.39 \\
\hline $\mathrm{Al}_{2} \mathrm{O}_{3}$ & 0.24 & 0.25 & 0.22 & 0.26 & 0.27 & 0.23 & 0.31 & 0.26 & 0.28 \\
\hline $\mathrm{Cr}_{2} \mathrm{O}_{3}$ & 0.36 & 0.37 & 0.37 & 0.42 & 0.46 & 0.41 & 0.31 & 0.34 & 0.29 \\
\hline $\mathrm{V}_{2} \mathrm{O}_{3}$ & 0.63 & 0.69 & 0.67 & 0.71 & 0.69 & 0.71 & 0.53 & 0.53 & 0.53 \\
\hline $\mathrm{FeO}^{*}$ & 91.93 & 92.34 & 91.84 & 92.11 & 92.92 & 92.49 & 92.13 & 92.48 & 92.84 \\
\hline $\mathrm{Fe}_{2} \mathrm{O}_{3}$ & & & & & & & & & \\
\hline $\begin{array}{l}\text { recalculated } \\
\text { FeO }\end{array}$ & 67.57 & 67.92 & 67.61 & 67.74 & 68.15 & 68.04 & 67.62 & 67.83 & 68.13 \\
\hline recalculated & 31.13 & 31.23 & 31.01 & 31.16 & 31.59 & 31.27 & 31.78 & 31.10 & 31.18 \\
\hline $\mathrm{MnO}$ & 0.01 & 0.01 & 0.01 & 0.01 & 0.01 & 0.03 & 0.00 & 0.00 & 0.01 \\
\hline $\mathrm{MgO}$ & 0.08 & 0.07 & 0.07 & 0.08 & 0.06 & 0.06 & 0.10 & 0.10 & 0.10 \\
\hline $\mathrm{ZnO}$ & 0.00 & 0.02 & 0.01 & 0.02 & 0.02 & 0.03 & - & 0.01 & - \\
\hline $\mathrm{NiO}$ & 0.04 & 0.04 & 0.03 & 0.03 & 0.02 & 0.04 & 0.03 & 0.02 & 0.02 \\
\hline $\mathrm{CaO}$ & 0.00 & 0.00 & 0.01 & 0.00 & - & 0.01 & 0.00 & 0.00 & - \\
\hline $\mathrm{Cu}_{2} \mathrm{O}$ & - & 0.00 & - & - & - & - & 0.01 & 0.00 & 0.00 \\
\hline $\mathrm{K}_{2} \mathrm{O}$ & - & 0.01 & 0.01 & - & 0.00 & - & 0.00 & 0.00 & - \\
\hline $\begin{array}{l}\text { Total measured } \\
\text { Total }\end{array}$ & 93.44 & 93.90 & 93.30 & 93.73 & 94.63 & 94.11 & 93.51 & 93.82 & 94.47 \\
\hline recalculated & 100.21 & 100.70 & 100.07 & 100.52 & 101.46 & 100.92 & 100.78 & 100.27 & 100.94 \\
\hline MAS & \multicolumn{4}{|c|}{ Massive to semi-massive mineralization } & OBAN & \multicolumn{4}{|c|}{ Orthopyroxene -bearing bands of oxide mineralization } \\
\hline DIS & \multicolumn{4}{|c|}{ Disseminated mineralization } & POD & \multicolumn{4}{|c|}{ Pod of oxide mineralization } \\
\hline BAN & \multicolumn{4}{|c|}{ Bands of oxide mineralization } & OPOD & \multicolumn{4}{|c|}{ Orthopyroxene -bearing pod of oxide mineralization } \\
\hline ANO & \multicolumn{4}{|c|}{ Anorthosite hosted disseminated } & VEIN & $\begin{array}{l}\text { Vein of oxide } \\
\text { mineralization }\end{array}$ & & & \\
\hline ORT & \multicolumn{4}{|c|}{ Orthopyroxene associated } & MAG & \multicolumn{4}{|l|}{ Magnetite } \\
\hline $\mathrm{CLI}$ & \multicolumn{4}{|c|}{ Clinopyroxene associated } & ILM & Ilmenite & & PLE & Pleonaste \\
\hline
\end{tabular}




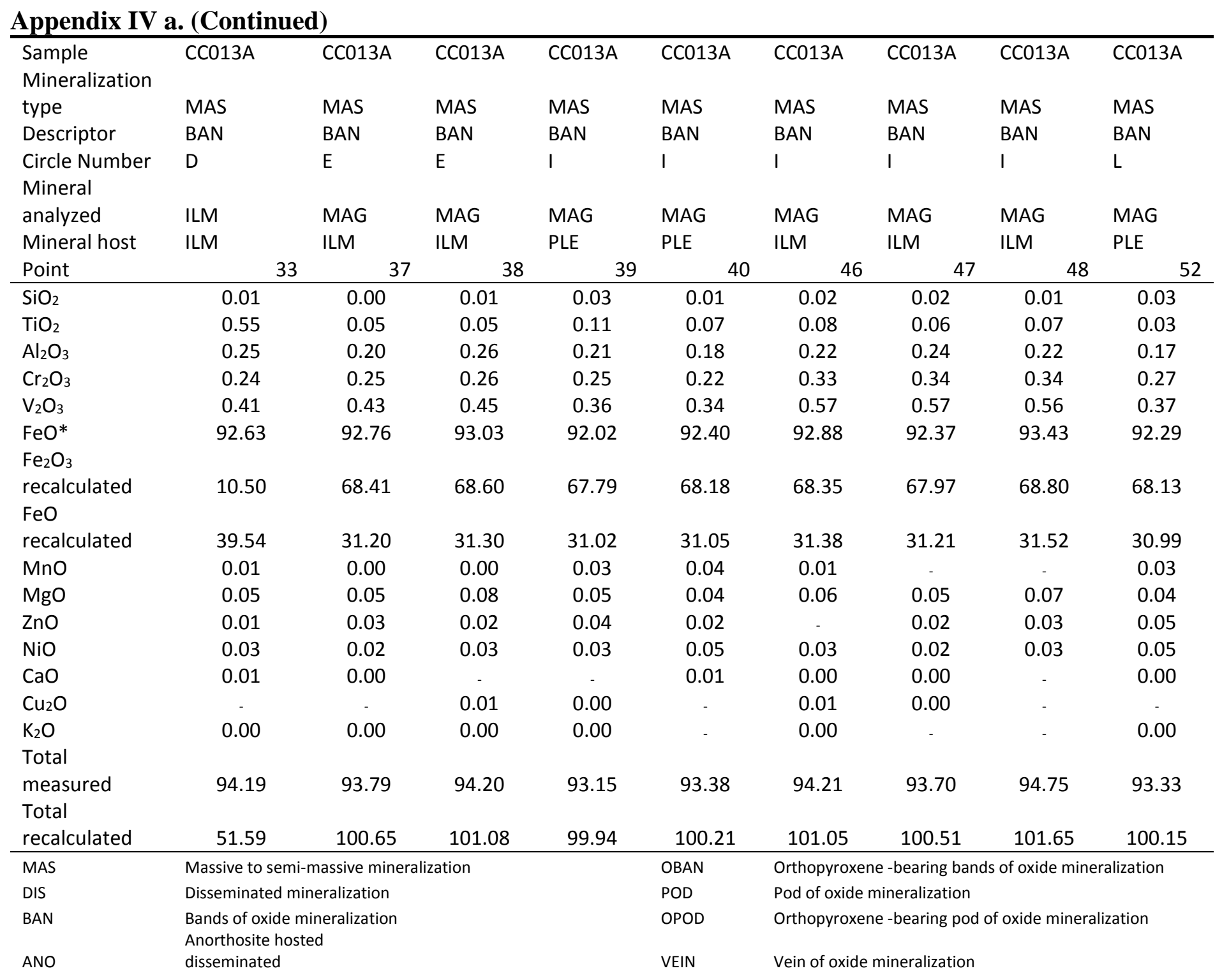




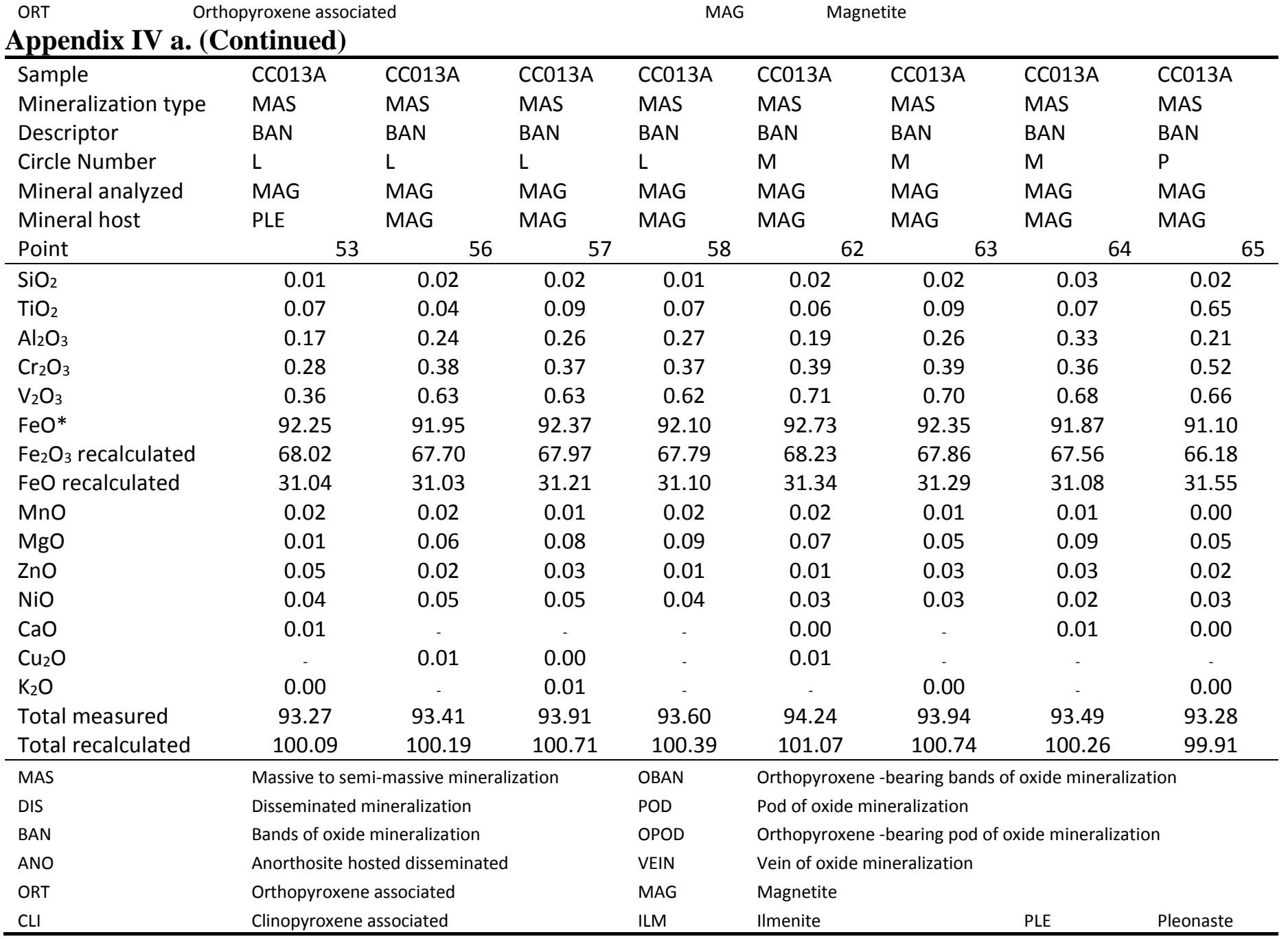




\section{Appendix IV a. (Continued)}

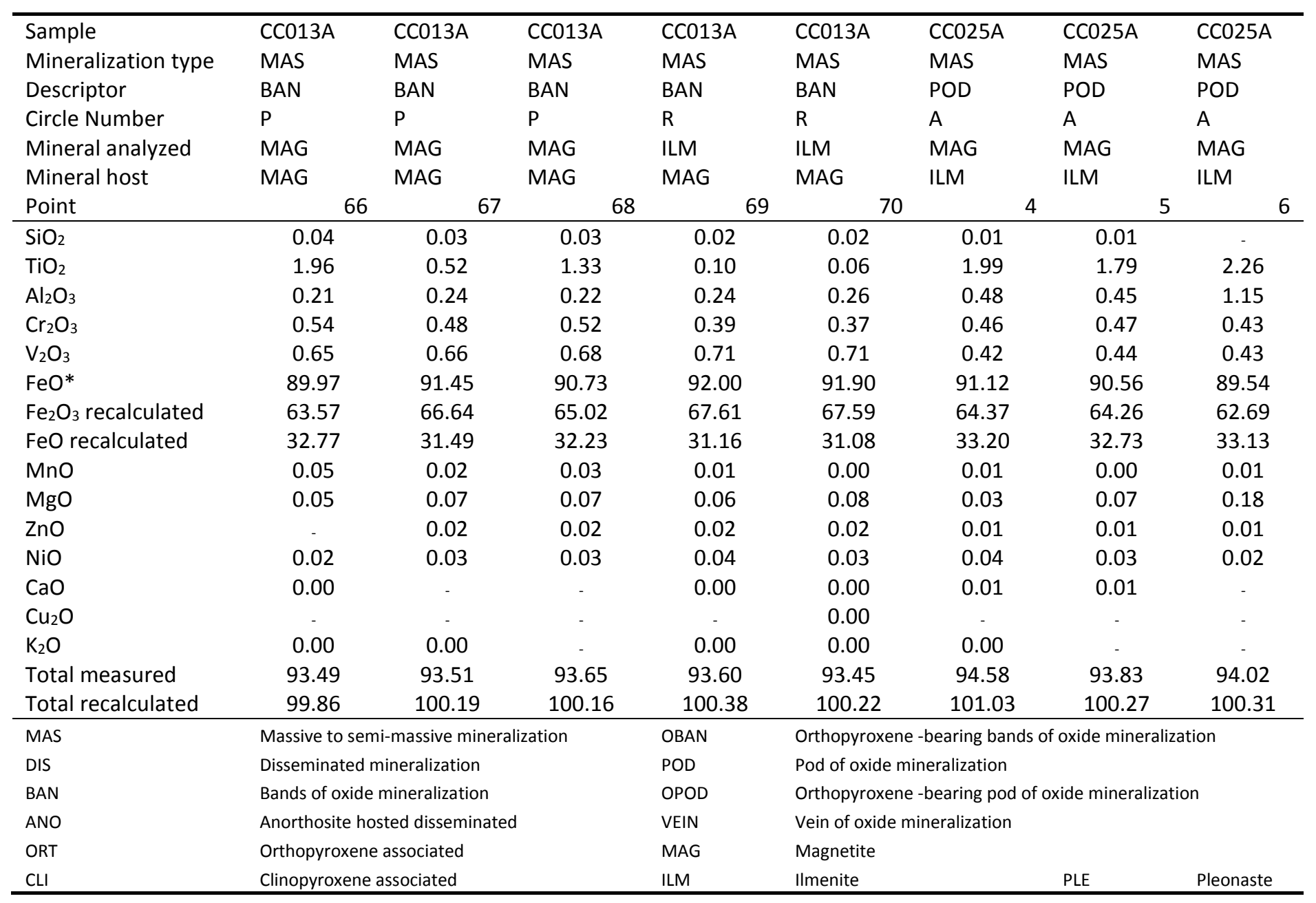




\begin{tabular}{|c|c|c|c|c|c|c|c|c|}
\hline Sample & CC025A & CC025A & CCO25A & CC025A & CC025A & CC025A & CC025A & CC025A \\
\hline Mineralization type & MAS & MAS & MAS & MAS & MAS & MAS & MAS & MAS \\
\hline Descriptor & POD & POD & POD & POD & POD & POD & POD & POD \\
\hline Circle Number & $A$ & A & $A$ & B & B & C & $\mathrm{C}$ & $\mathrm{C}$ \\
\hline Mineral analyzed & MAG & MAG & MAG & MAG & MAG & MAG & MAG & MAG \\
\hline Mineral host & MAG & MAG & MAG & ILM & ILM & MAG & MAG & MAG \\
\hline Point & 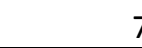 & 8 & 9 & 13 & 14 & 20 & 21 & 22 \\
\hline $\mathrm{SiO}_{2}$ & 0.03 & 0.04 & 0.03 & - & 0.01 & 0.02 & 0.02 & 0.04 \\
\hline $\mathrm{TiO}_{2}$ & 0.78 & 0.78 & 0.86 & 1.09 & 1.18 & 0.58 & 0.85 & 1.13 \\
\hline $\mathrm{Al}_{2} \mathrm{O}_{3}$ & 0.53 & 0.55 & 0.63 & 0.82 & 0.49 & 0.47 & 0.65 & 0.75 \\
\hline $\mathrm{Cr}_{2} \mathrm{O}_{3}$ & 0.66 & 0.63 & 0.62 & 0.34 & 0.34 & 0.63 & 0.61 & 0.63 \\
\hline $\mathrm{V}_{2} \mathrm{O}_{3}$ & 0.72 & 0.72 & 0.70 & 0.71 & 0.63 & 0.72 & 0.72 & 0.75 \\
\hline $\mathrm{FeO}^{*}$ & 90.58 & 90.65 & 90.56 & 90.94 & 91.09 & 90.63 & 89.91 & 89.34 \\
\hline $\mathrm{Fe}_{2} \mathrm{O}_{3}$ recalculated & 65.37 & 65.39 & 65.20 & 65.30 & 65.40 & 65.71 & 64.69 & 63.89 \\
\hline FeO recalculated & 31.76 & 31.82 & 31.90 & 32.18 & 32.24 & 31.50 & 31.70 & 31.85 \\
\hline $\mathrm{MnO}$ & 0.00 & 0.02 & 0.04 & 0.02 & 0.00 & 0.02 & 0.03 & 0.06 \\
\hline MgO & 0.07 & 0.05 & 0.04 & 0.10 & 0.06 & 0.03 & 0.02 & 0.05 \\
\hline $\mathrm{ZnO}$ & - & - & - & - & - & 0.03 & - & 0.03 \\
\hline $\mathrm{NiO}$ & 0.04 & 0.04 & 0.02 & 0.03 & 0.04 & 0.04 & 0.02 & 0.03 \\
\hline $\mathrm{CaO}$ & - & - & - & - & 0.00 & 0.01 & 0.00 & 0.00 \\
\hline $\mathrm{Cu}_{2} \mathrm{O}$ & - & 0.02 & 0.01 & 0.02 & 0.01 & - & - & 0.00 \\
\hline $\mathrm{K}_{2} \mathrm{O}$ & 0.00 & - & 0.01 & 0.00 & 0.00 & - & 0.00 & - \\
\hline Total measured & 93.41 & 93.50 & 93.52 & 94.09 & 93.86 & 93.17 & 92.83 & 92.82 \\
\hline Total recalculated & 99.96 & 100.05 & 100.05 & 100.63 & 100.41 & 99.76 & 99.31 & 99.22 \\
\hline MAS & \multicolumn{3}{|c|}{ Massive to semi-massive mineralization } & OBAN & \multicolumn{4}{|c|}{ Orthopyroxene -bearing bands of oxide mineralization } \\
\hline DIS & \multicolumn{3}{|c|}{ Disseminated mineralization } & POD & \multicolumn{4}{|c|}{ Pod of oxide mineralization } \\
\hline BAN & \multicolumn{3}{|c|}{ Bands of oxide mineralization } & OPOD & \multicolumn{4}{|c|}{ Orthopyroxene -bearing pod of oxide mineralization } \\
\hline ANO & \multicolumn{3}{|c|}{ Anorthosite hosted disseminated } & VEIN & \multicolumn{4}{|c|}{ Vein of oxide mineralization } \\
\hline ORT & \multicolumn{3}{|c|}{ Orthopyroxene associated } & MAG & \multicolumn{4}{|c|}{ Magnetite } \\
\hline $\mathrm{CLI}$ & \multicolumn{3}{|c|}{ Clinopyroxene associated } & ILM & Ilmenite & & PLE & Pleonaste \\
\hline
\end{tabular}




\begin{tabular}{|c|c|c|c|c|c|c|c|c|}
\hline Sample & CC025A & CC025A & CC025A & CC025A & CC025A & CCO25A & CCO25A & CC025A \\
\hline Mineralization type & MAS & MAS & MAS & MAS & MAS & MAS & MAS & MAS \\
\hline Descriptor & POD & POD & POD & POD & POD & POD & POD & POD \\
\hline Circle Number & $\mathrm{D}$ & $\mathrm{D}$ & $\mathrm{D}$ & $\mathrm{E}$ & $\mathrm{E}$ & $\mathrm{E}$ & I & I \\
\hline Mineral analyzed & MAG & MAG & MAG & MAG & MAG & MAG & MAG & MAG \\
\hline Mineral host & MAG & MAG & MAG & MAG & MAG & MAG & MAG & MAG \\
\hline Point & 35 & 36 & 37 & 48 & 49 & 50 & 62 & 63 \\
\hline $\mathrm{SiO}_{2}$ & 0.02 & 0.05 & 0.03 & 0.03 & 0.03 & 0.03 & 0.04 & 0.05 \\
\hline $\mathrm{TiO}_{2}$ & 1.41 & 1.99 & 1.93 & 1.72 & 1.67 & 1.81 & 0.82 & 0.82 \\
\hline $\mathrm{Al}_{2} \mathrm{O}_{3}$ & 0.82 & 0.95 & 0.97 & 0.92 & 0.81 & 0.78 & 0.77 & 0.71 \\
\hline $\mathrm{Cr}_{2} \mathrm{O}_{3}$ & 0.59 & 0.58 & 0.60 & 0.60 & 0.57 & 0.60 & 0.64 & 0.51 \\
\hline $\mathrm{V}_{2} \mathrm{O}_{3}$ & 0.70 & 0.69 & 0.67 & 0.68 & 0.72 & 0.70 & 0.71 & 0.71 \\
\hline $\mathrm{FeO}^{*}$ & 89.89 & 89.92 & 89.44 & 88.85 & 88.69 & 88.70 & 90.86 & 90.85 \\
\hline $\mathrm{Fe}_{2} \mathrm{O}_{3}$ recalculated & 63.91 & 63.09 & 62.86 & 62.75 & 62.68 & 62.52 & 65.39 & 65.45 \\
\hline FeO recalculated & 32.38 & 33.15 & 32.87 & 32.38 & 32.29 & 32.44 & 32.03 & 31.96 \\
\hline $\mathrm{MnO}$ & 0.05 & 0.06 & 0.06 & 0.06 & 0.05 & 0.06 & 0.01 & 0.03 \\
\hline $\mathrm{MgO}$ & 0.06 & 0.06 & 0.08 & 0.09 & 0.05 & 0.06 & 0.06 & 0.04 \\
\hline $\mathrm{ZnO}$ & - & 0.01 & 0.02 & 0.01 & - & - & 0.00 & 0.03 \\
\hline $\mathrm{NiO}$ & 0.01 & 0.02 & 0.02 & 0.03 & 0.03 & 0.03 & 0.02 & 0.02 \\
\hline $\mathrm{CaO}$ & - & 0.00 & - & 0.01 & 0.01 & 0.01 & 0.01 & 0.01 \\
\hline $\mathrm{Cu}_{2} \mathrm{O}$ & 0.02 & - & 0.00 & 0.01 & 0.02 & 0.01 & 0.01 & - \\
\hline $\mathrm{K}_{2} \mathrm{O}$ & 0.00 & 0.00 & 0.00 & 0.00 & - & - & - & 0.01 \\
\hline Total measured & 93.59 & 94.34 & 93.81 & 93.01 & 92.64 & 92.77 & 93.94 & 93.79 \\
\hline Total recalculated & 99.99 & 100.66 & 100.11 & 99.29 & 98.92 & 99.04 & 100.49 & 100.34 \\
\hline MAS & \multicolumn{3}{|c|}{ Massive to semi-massive mineralization } & OBAN & \multicolumn{4}{|c|}{ Orthopyroxene -bearing bands of oxide mineralization } \\
\hline DIS & \multicolumn{3}{|c|}{ Disseminated mineralization } & POD & \multicolumn{4}{|c|}{ Pod of oxide mineralization } \\
\hline BAN & \multicolumn{3}{|c|}{ Bands of oxide mineralization } & OPOD & \multicolumn{4}{|c|}{ Orthopyroxene -bearing pod of oxide mineralization } \\
\hline ANO & \multicolumn{3}{|c|}{ Anorthosite hosted disseminated } & VEIN & \multicolumn{4}{|c|}{ Vein of oxide mineralization } \\
\hline ORT & \multicolumn{3}{|c|}{ Orthopyroxene associated } & MAG & \multicolumn{4}{|c|}{ Magnetite } \\
\hline $\mathrm{CLI}$ & \multicolumn{3}{|c|}{ Clinopyroxene associated } & ILM & Ilmenite & & PLE & Pleonaste \\
\hline
\end{tabular}




\begin{tabular}{|c|c|c|c|c|c|c|c|c|c|}
\hline Sample & CC025A & CC025A & CCO25A & CC025A & CC031A & CC031A & CC031A & CC031A & CC031A \\
\hline Mineralization type & MAS & MAS & MAS & MAS & DIS & DIS & DIS & DIS & DIS \\
\hline Descriptor & POD & POD & POD & POD & ANO & ANO & ANO & ANO & ANO \\
\hline Circle Number & I & $\mathrm{K}$ & K & $\mathrm{K}$ & A & A & A & B & B \\
\hline Mineral analyzed & MAG & MAG & MAG & MAG & MAG & MAG & MAG & MAG & MAG \\
\hline Mineral host & MAG & ILM & ILM & ILM & MAG & MAG & MAG & MAG & MAG \\
\hline Point & 64 & 68 & 69 & 70 & 1 & 2 & 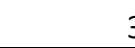 & 12 & 13 \\
\hline $\mathrm{SiO}_{2}$ & 0.03 & 0.01 & 0.01 & 0.01 & 0.02 & 0.02 & 0.04 & 0.03 & 0.02 \\
\hline $\mathrm{TiO}_{2}$ & 1.18 & 1.29 & 1.49 & 1.17 & 0.22 & 0.15 & 0.20 & 0.20 & 0.19 \\
\hline $\mathrm{Al}_{2} \mathrm{O}_{3}$ & 0.66 & 0.62 & 0.71 & 0.63 & 0.44 & 0.39 & 0.60 & 0.40 & 0.39 \\
\hline $\mathrm{Cr}_{2} \mathrm{O}_{3}$ & 0.52 & 0.37 & 0.40 & 0.40 & 0.52 & 0.51 & 0.49 & 0.44 & 0.41 \\
\hline $\mathrm{V}_{2} \mathrm{O}_{3}$ & 0.70 & 0.52 & 0.53 & 0.51 & 0.64 & 0.62 & 0.61 & 0.64 & 0.65 \\
\hline $\mathrm{FeO} *$ & 90.88 & 90.59 & 90.60 & 91.30 & 90.65 & 90.56 & 91.19 & 90.67 & 90.61 \\
\hline $\mathrm{Fe}_{2} \mathrm{O}_{3}$ recalculated & 65.01 & 64.88 & 64.60 & 65.57 & 66.26 & 66.35 & 66.64 & 66.33 & 66.33 \\
\hline FeO recalculated & 32.38 & 32.21 & 32.47 & 32.30 & 31.03 & 30.86 & 31.23 & 30.99 & 30.93 \\
\hline $\mathrm{MnO}$ & 0.04 & 0.01 & 0.02 & 0.02 & 0.02 & 0.02 & 0.03 & 0.01 & 0.02 \\
\hline MgO & 0.01 & 0.08 & 0.09 & 0.08 & 0.01 & 0.02 & 0.04 & 0.02 & - \\
\hline $\mathrm{ZnO}$ & - & 0.02 & 0.01 & - & - & 0.01 & 0.01 & - & 0.01 \\
\hline $\mathrm{NiO}$ & 0.04 & 0.03 & 0.05 & 0.02 & 0.05 & 0.05 & 0.03 & 0.04 & 0.06 \\
\hline $\mathrm{CaO}$ & - & - & - & 0.00 & 0.00 & 0.00 & 0.00 & - & - \\
\hline $\mathrm{Cu}_{2} \mathrm{O}$ & 0.01 & 0.01 & - & - & - & 0.02 & 0.00 & 0.00 & 0.00 \\
\hline $\mathrm{K}_{2} \mathrm{O}$ & - & 0.00 & - & 0.00 & - & - & - & 0.00 & - \\
\hline Total measured & 94.07 & 93.54 & 93.90 & 94.13 & 92.57 & 92.37 & 93.27 & 92.46 & 92.36 \\
\hline Total recalculated & 100.58 & 100.04 & 100.37 & 100.70 & 99.21 & 99.02 & 99.94 & 99.10 & 99.00 \\
\hline MAS & \multicolumn{3}{|c|}{ Massive to semi-massive mineralization } & OBAN & \multicolumn{5}{|c|}{ Orthopyroxene -bearing bands of oxide mineralization } \\
\hline DIS & \multicolumn{3}{|c|}{ Disseminated mineralization } & POD & \multicolumn{5}{|c|}{ Pod of oxide mineralization } \\
\hline BAN & \multicolumn{3}{|c|}{ Bands of oxide mineralization } & OPOD & \multicolumn{5}{|c|}{ Orthopyroxene -bearing pod of oxide mineralization } \\
\hline ANO & \multicolumn{3}{|c|}{ Anorthosite hosted disseminated } & VEIN & \multicolumn{5}{|c|}{ Vein of oxide mineralization } \\
\hline ORT & \multicolumn{3}{|c|}{ Orthopyroxene associated } & MAG & \multicolumn{5}{|c|}{ Magnetite } \\
\hline $\mathrm{CLI}$ & \multicolumn{3}{|c|}{ Clinopyroxene associated } & ILM & Ilmenite & & PLE & Pleonaste & \\
\hline
\end{tabular}




\begin{tabular}{|c|c|c|c|c|c|c|c|c|c|}
\hline Sample & CC031A & CC031A & CC031A & CC031A & CC031A & CC031A & CC031A & CC031A & CC031A \\
\hline Mineralization type & DIS & DIS & DIS & DIS & DIS & DIS & DIS & DIS & DIS \\
\hline Descriptor & ANO & ANO & ANO & ANO & ANO & ANO & ANO & ANO & ANO \\
\hline Circle Number & B & C & C & $\mathrm{C}$ & $\mathrm{C}$ & C & $\mathrm{D}$ & $\mathrm{D}$ & $\mathrm{D}$ \\
\hline Mineral analyzed & MAG & MAG & MAG & MAG & MAG & MAG & MAG & MAG & MAG \\
\hline Mineral host & MAG & ILM & ILM & MAG & MAG & MAG & MAG & MAG & MAG \\
\hline Point & 14 & 18 & 19 & 22 & 23 & 24 & 30 & 31 & 32 \\
\hline $\mathrm{SiO}_{2}$ & 0.04 & 0.02 & 0.00 & 0.04 & 0.04 & 0.03 & 0.03 & - & 0.04 \\
\hline $\mathrm{TiO}_{2}$ & 0.26 & 1.48 & 1.08 & 0.25 & 0.20 & 0.20 & 0.20 & 0.17 & 0.15 \\
\hline $\mathrm{Al}_{2} \mathrm{O}_{3}$ & 0.36 & 0.38 & 0.53 & 0.31 & 0.48 & 0.40 & 0.53 & 0.35 & 0.36 \\
\hline $\mathrm{Cr}_{2} \mathrm{O}_{3}$ & 0.68 & 1.68 & 1.71 & 0.77 & 0.56 & 0.51 & 0.47 & 0.46 & 0.41 \\
\hline $\mathrm{V}_{2} \mathrm{O}_{3}$ & 0.63 & 0.64 & 0.61 & 0.63 & 0.65 & 0.65 & 0.63 & 0.61 & 0.63 \\
\hline $\mathrm{FeO}^{*}$ & 90.81 & 89.24 & 89.03 & 90.98 & 90.57 & 91.36 & 89.05 & 90.25 & 90.54 \\
\hline $\mathrm{Fe}_{2} \mathrm{O}_{3}$ recalculated & 66.31 & 63.22 & 63.58 & 66.44 & 66.21 & 66.83 & 65.07 & 66.14 & 66.31 \\
\hline FeO recalculated & 31.14 & 32.35 & 31.82 & 31.20 & 30.99 & 31.23 & 30.50 & 30.74 & 30.87 \\
\hline $\mathrm{MnO}$ & 0.01 & 0.03 & 0.04 & 0.01 & 0.02 & 0.02 & 0.02 & 0.03 & 0.01 \\
\hline $\mathrm{MgO}$ & 0.03 & 0.04 & 0.05 & 0.03 & 0.05 & 0.01 & 0.03 & 0.01 & - \\
\hline $\mathrm{ZnO}$ & 0.04 & 0.02 & 0.04 & 0.01 & 0.01 & 0.00 & 0.00 & 0.00 & 0.01 \\
\hline $\mathrm{NiO}$ & 0.03 & 0.04 & 0.04 & 0.05 & 0.04 & 0.06 & 0.04 & 0.04 & 0.05 \\
\hline $\mathrm{CaO}$ & - & - & 0.00 & - & 0.00 & - & 0.01 & 0.00 & 0.01 \\
\hline $\mathrm{Cu}_{2} \mathrm{O}$ & - & 0.02 & 0.00 & 0.02 & 0.01 & - & - & 0.00 & - \\
\hline $\mathrm{K}_{2} \mathrm{O}$ & 0.00 & - & 0.01 & - & - & 0.00 & 0.00 & 0.01 & - \\
\hline Total measured & 92.89 & 93.60 & 93.14 & 93.11 & 92.61 & 93.24 & 91.00 & 91.93 & 92.21 \\
\hline Total recalculated & 99.54 & 99.93 & 99.51 & 99.76 & 99.25 & 99.94 & 97.52 & 98.56 & 98.86 \\
\hline MAS & \multicolumn{3}{|c|}{ Massive to semi-massive mineralization } & OBAN & \multicolumn{5}{|c|}{ Orthopyroxene -bearing bands of oxide mineralization } \\
\hline DIS & \multicolumn{3}{|c|}{ Disseminated mineralization } & POD & \multicolumn{5}{|c|}{ Pod of oxide mineralization } \\
\hline BAN & \multicolumn{3}{|c|}{ Bands of oxide mineralization } & OPOD & \multicolumn{5}{|c|}{ Orthopyroxene -bearing pod of oxide mineralization } \\
\hline ANO & \multicolumn{3}{|c|}{ Anorthosite hosted disseminated } & VEIN & \multicolumn{5}{|c|}{ Vein of oxide mineralization } \\
\hline ORT & \multicolumn{3}{|c|}{ Orthopyroxene associated } & MAG & \multicolumn{5}{|c|}{ Magnetite } \\
\hline $\mathrm{CLI}$ & \multicolumn{3}{|c|}{ Clinopyroxene associated } & ILM & Ilmenite & & PLE & Pleonaste & \\
\hline
\end{tabular}




\begin{tabular}{|c|c|c|c|c|c|c|c|c|}
\hline Sample & CC031A & CC031A & CC031A & CC031A & CC031A & CC031A & CC031A & CC031A \\
\hline Mineralization type & DIS & DIS & DIS & DIS & DIS & DIS & DIS & DIS \\
\hline Descriptor & ANO & ANO & ANO & ANO & ANO & ANO & ANO & ANO \\
\hline Circle Number & $\mathrm{E}$ & $\mathrm{E}$ & $\mathrm{E}$ & $\mathrm{F}$ & $\mathrm{F}$ & $\mathrm{F}$ & G & G \\
\hline Mineral analyzed & MAG & MAG & MAG & MAG & MAG & MAG & MAG & MAG \\
\hline Mineral host & MAG & MAG & MAG & ILM & ILM & ILM & ILM & ILM \\
\hline Point & 42 & & 44 & 48 & 49 & 50 & 53 & 54 \\
\hline $\mathrm{SiO}_{2}$ & 0.02 & 0.02 & 0.02 & 0.02 & 0.03 & 0.01 & 0.02 & 0.01 \\
\hline $\mathrm{TiO}_{2}$ & 0.40 & 0.16 & 0.17 & 0.35 & 0.30 & 0.18 & 1.24 & 1.18 \\
\hline $\mathrm{Al}_{2} \mathrm{O}_{3}$ & 0.37 & 0.39 & 0.44 & 0.32 & 0.33 & 0.40 & 0.30 & 0.32 \\
\hline $\mathrm{Cr}_{2} \mathrm{O}_{3}$ & 0.51 & 0.52 & 0.50 & 0.47 & 0.49 & 0.54 & 0.85 & 1.07 \\
\hline $\mathrm{V}_{2} \mathrm{O}_{3}$ & 0.65 & 0.66 & 0.63 & 0.47 & 0.52 & 0.55 & 0.58 & 0.60 \\
\hline $\mathrm{FeO} *$ & 90.75 & 91.40 & 90.50 & 90.74 & 91.25 & 91.62 & 90.32 & 90.03 \\
\hline $\mathrm{Fe}_{2} \mathrm{O}_{3}$ recalculated & 66.12 & 66.90 & 66.22 & 66.36 & 66.72 & 67.14 & 64.65 & 64.44 \\
\hline FeO recalculated & 31.26 & 31.21 & 30.91 & 31.03 & 31.22 & 31.21 & 32.15 & 32.05 \\
\hline $\mathrm{MnO}$ & 0.02 & - & 0.02 & 0.01 & 0.02 & 0.01 & 0.02 & 0.02 \\
\hline $\mathrm{MgO}$ & - & - & 0.02 & 0.04 & 0.03 & 0.04 & 0.02 & 0.02 \\
\hline $\mathrm{ZnO}$ & 0.03 & 0.02 & 0.02 & 0.01 & - & 0.00 & 0.00 & 0.01 \\
\hline $\mathrm{NiO}$ & 0.04 & 0.03 & 0.03 & 0.06 & 0.05 & 0.06 & 0.06 & 0.05 \\
\hline $\mathrm{CaO}$ & - & 0.01 & - & 0.00 & - & 0.01 & - & 0.00 \\
\hline $\mathrm{Cu}_{2} \mathrm{O}$ & - & - & 0.00 & 0.01 & 0.01 & - & 0.01 & - \\
\hline $\mathrm{K}_{2} \mathrm{O}$ & 0.00 & 0.00 & 0.00 & - & - & - & 0.01 & 0.01 \\
\hline Total measured & 92.79 & 93.21 & 92.36 & 92.50 & 93.03 & 93.44 & 93.43 & 93.31 \\
\hline Total recalculated & 99.41 & 99.92 & 98.99 & 99.15 & 99.72 & 100.17 & 99.91 & 99.77 \\
\hline MAS & \multicolumn{3}{|c|}{ Massive to semi-massive mineralization } & OBAN & \multicolumn{4}{|c|}{ Orthopyroxene -bearing bands of oxide mineralization } \\
\hline DIS & \multicolumn{3}{|c|}{ Disseminated mineralization } & POD & \multicolumn{4}{|c|}{ Pod of oxide mineralization } \\
\hline BAN & \multicolumn{3}{|c|}{ Bands of oxide mineralization } & OPOD & \multicolumn{4}{|c|}{ Orthopyroxene -bearing pod of oxide mineralization } \\
\hline ANO & \multicolumn{3}{|c|}{ Anorthosite hosted disseminated } & VEIN & \multicolumn{4}{|c|}{ Vein of oxide mineralization } \\
\hline ORT & \multicolumn{3}{|c|}{ Orthopyroxene associated } & MAG & \multicolumn{4}{|c|}{ Magnetite } \\
\hline $\mathrm{CLI}$ & \multicolumn{3}{|c|}{ Clinopyroxene associated } & ILM & Ilmenite & & PLE & Pleonaste \\
\hline
\end{tabular}




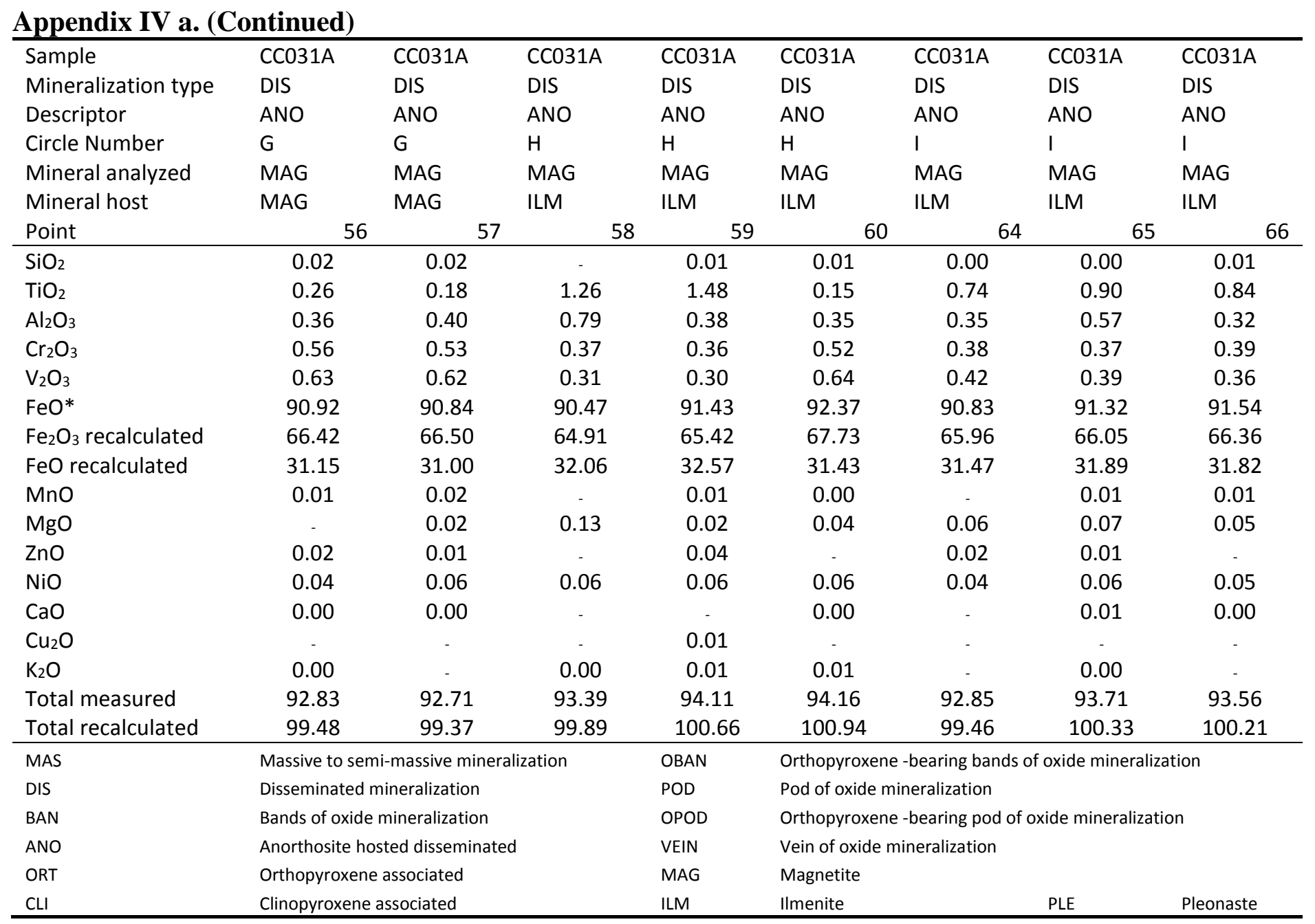




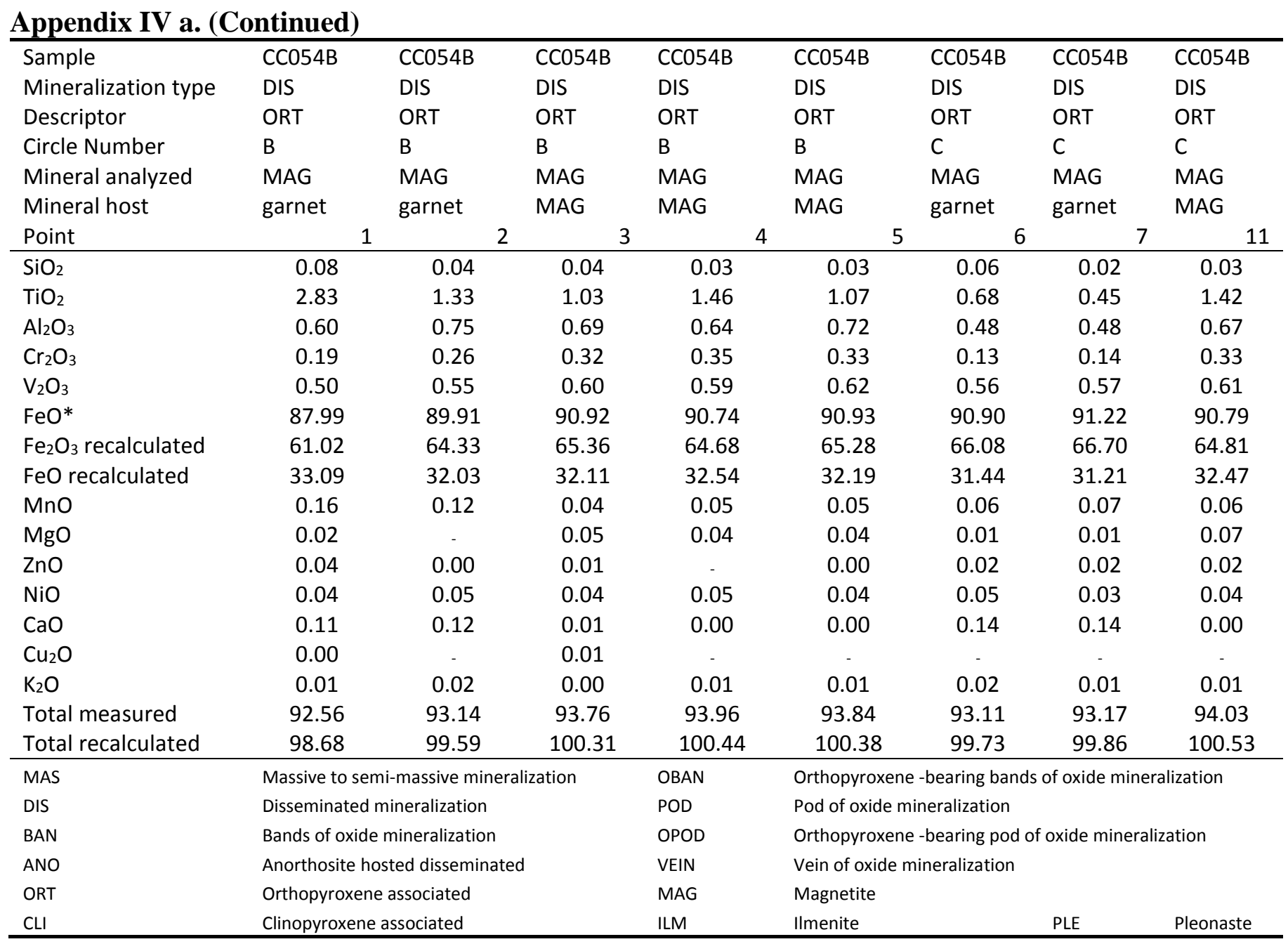




\begin{tabular}{|c|c|c|c|c|c|c|c|c|}
\hline Sample & CC054B & CC054B & CC054B & CC054B & CC054B & CC054B & CC054B & CC054B \\
\hline Mineralization type & DIS & DIS & DIS & DIS & DIS & DIS & DIS & DIS \\
\hline Descriptor & ORT & ORT & ORT & ORT & ORT & ORT & ORT & ORT \\
\hline Circle Number & $\mathrm{C}$ & $\mathrm{C}$ & $\mathrm{D}$ & $\mathrm{D}$ & $\mathrm{E}$ & $\mathrm{E}$ & $\mathrm{E}$ & $\mathrm{F}$ \\
\hline Mineral analyzed & MAG & MAG & MAG & MAG & MAG & MAG & MAG & MAG \\
\hline Mineral host & MAG & MAG & ILM & ILM & MAG & MAG & MAG & MAG \\
\hline Point & 12 & 13 & 14 & 15 & 29 & & 3 & 34 \\
\hline $\mathrm{SiO}_{2}$ & 0.04 & 0.04 & 0.00 & - & 0.03 & 0.05 & 0.02 & 0.02 \\
\hline $\mathrm{TiO}_{2}$ & 1.61 & 1.09 & 2.02 & 2.29 & 0.92 & 1.70 & 0.95 & 1.03 \\
\hline $\mathrm{Al}_{2} \mathrm{O}_{3}$ & 0.76 & 0.55 & 0.90 & 0.62 & 0.64 & 0.91 & 0.68 & 1.09 \\
\hline $\mathrm{Cr}_{2} \mathrm{O}_{3}$ & 0.34 & 0.35 & 0.24 & 0.22 & 0.34 & 0.35 & 0.36 & 0.33 \\
\hline $\mathrm{V}_{2} \mathrm{O}_{3}$ & 0.62 & 0.62 & 0.41 & 0.44 & 0.68 & 0.69 & 0.67 & 0.67 \\
\hline $\mathrm{FeO}^{*}$ & 90.37 & 91.12 & 90.63 & 91.25 & 90.80 & 89.73 & 90.72 & 90.60 \\
\hline $\mathrm{Fe}_{2} \mathrm{O}_{3}$ recalculated & 64.14 & 65.46 & 64.06 & 64.14 & 65.41 & 63.45 & 65.32 & 65.00 \\
\hline FeO recalculated & 32.66 & 32.22 & 32.99 & 33.54 & 31.95 & 32.64 & 31.95 & 32.12 \\
\hline $\mathrm{MnO}$ & 0.05 & 0.04 & 0.02 & 0.01 & 0.04 & 0.06 & 0.05 & 0.05 \\
\hline $\mathrm{MgO}$ & 0.06 & 0.05 & 0.19 & 0.07 & 0.03 & 0.07 & 0.05 & 0.09 \\
\hline $\mathrm{ZnO}$ & 0.00 & 0.01 & 0.03 & 0.01 & 0.03 & 0.01 & - & 0.03 \\
\hline $\mathrm{NiO}$ & 0.03 & 0.03 & 0.04 & 0.04 & 0.03 & 0.03 & 0.03 & 0.04 \\
\hline $\mathrm{CaO}$ & 0.00 & - & - & - & 0.00 & - & 0.01 & 0.01 \\
\hline $\mathrm{Cu}_{2} \mathrm{O}$ & - & 0.00 & - & 0.01 & - & - & 0.03 & 0.00 \\
\hline $\mathrm{K}_{2} \mathrm{O}$ & 0.00 & 0.00 & 0.01 & 0.00 & - & 0.01 & 0.00 & - \\
\hline Total measured & 93.88 & 93.91 & 94.48 & 94.97 & 93.54 & 93.60 & 93.55 & 93.95 \\
\hline Total recalculated & 100.31 & 100.47 & 100.89 & 101.40 & 100.09 & 99.95 & 100.10 & 100.46 \\
\hline MAS & \multicolumn{3}{|c|}{ Massive to semi-massive mineralization } & OBAN & \multicolumn{4}{|c|}{ Orthopyroxene -bearing bands of oxide mineralization } \\
\hline DIS & \multicolumn{3}{|c|}{ Disseminated mineralization } & POD & \multicolumn{4}{|c|}{ Pod of oxide mineralization } \\
\hline BAN & \multicolumn{3}{|c|}{ Bands of oxide mineralization } & OPOD & \multicolumn{4}{|c|}{ Orthopyroxene -bearing pod of oxide mineralization } \\
\hline ANO & \multicolumn{3}{|c|}{ Anorthosite hosted disseminated } & VEIN & \multicolumn{4}{|c|}{ Vein of oxide mineralization } \\
\hline ORT & \multicolumn{3}{|c|}{ Orthopyroxene associated } & MAG & \multicolumn{4}{|c|}{ Magnetite } \\
\hline $\mathrm{CLI}$ & \multicolumn{3}{|c|}{ Clinopyroxene associated } & ILM & Ilmenite & & PLE & Pleonaste \\
\hline
\end{tabular}




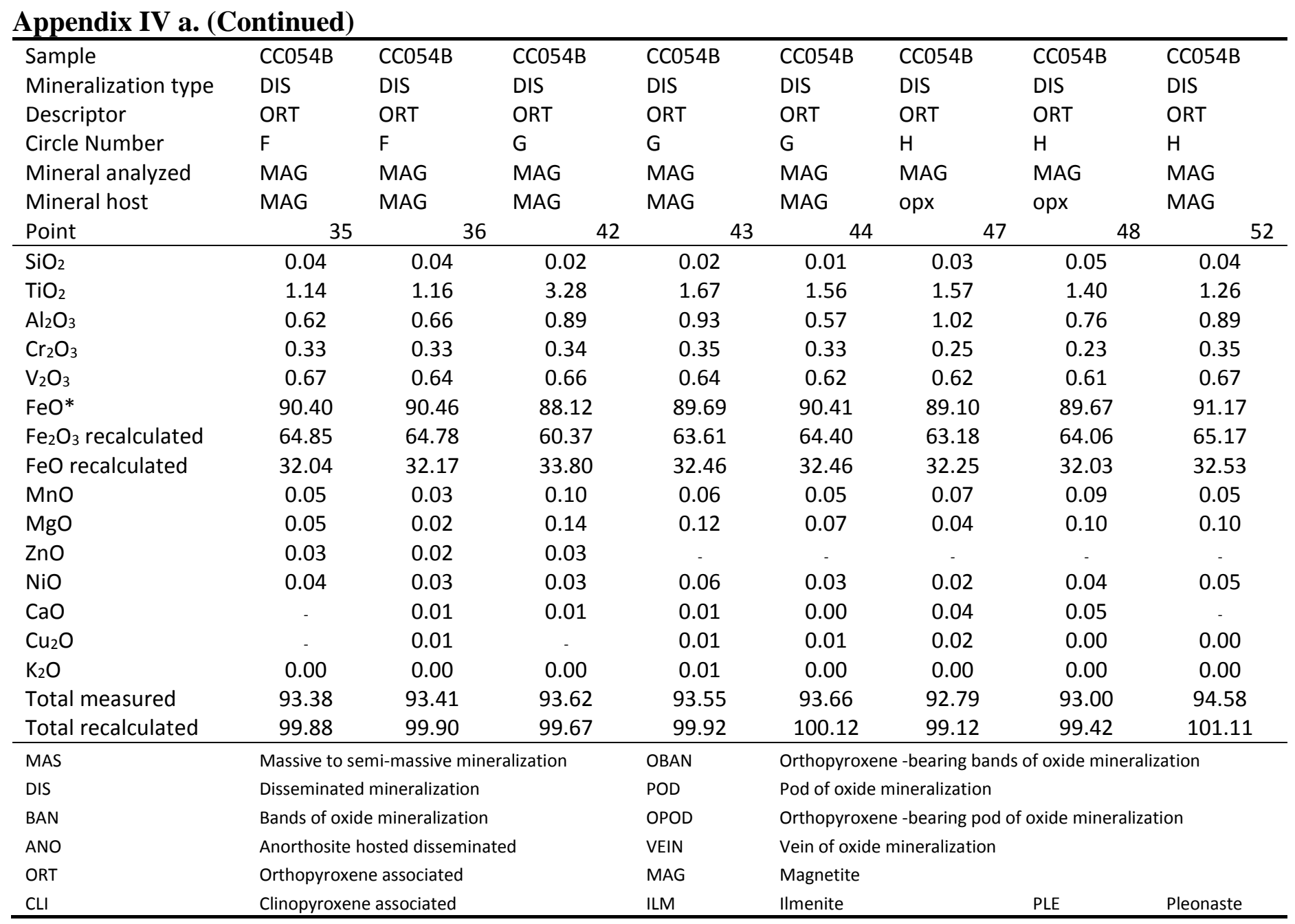




\begin{tabular}{|c|c|c|c|c|c|c|c|c|}
\hline Sample & CC054B & CC054B & CC054B & CC054B & CC054B & CC054B & CC054B & CC054B \\
\hline Mineralization type & DIS & DIS & DIS & DIS & DIS & DIS & DIS & DIS \\
\hline Descriptor & ORT & ORT & ORT & ORT & ORT & ORT & ORT & ORT \\
\hline Circle Number & $\mathrm{H}$ & $\mathrm{H}$ & J & J & J & $\mathrm{L}$ & $\mathrm{L}$ & $\mathrm{L}$ \\
\hline Mineral analyzed & MAG & MAG & MAG & MAG & MAG & MAG & MAG & MAG \\
\hline Mineral host & MAG & MAG & MAG & MAG & MAG & MAG & MAG & MAG \\
\hline Point & 53 & 5 & 60 & 61 & 62 & 68 & 6 & 7 \\
\hline $\mathrm{SiO}_{2}$ & 0.02 & 0.02 & 0.04 & 0.02 & 0.03 & 0.02 & 0.04 & 0.03 \\
\hline $\mathrm{TiO}_{2}$ & 1.54 & 1.93 & 2.24 & 2.38 & 1.72 & 1.57 & 2.50 & 0.83 \\
\hline $\mathrm{Al}_{2} \mathrm{O}_{3}$ & 1.05 & 1.07 & 0.79 & 0.74 & 0.78 & 0.89 & 1.05 & 0.55 \\
\hline $\mathrm{Cr}_{2} \mathrm{O}_{3}$ & 0.36 & 0.37 & 0.30 & 0.31 & 0.31 & 0.47 & 0.36 & 0.35 \\
\hline $\mathrm{V}_{2} \mathrm{O}_{3}$ & 0.68 & 0.66 & 0.61 & 0.59 & 0.56 & 0.64 & 0.64 & 0.66 \\
\hline $\mathrm{FeO} *$ & 90.49 & 90.28 & 89.67 & 89.67 & 89.88 & 89.56 & 89.14 & 91.94 \\
\hline $\mathrm{Fe}_{2} \mathrm{O}_{3}$ recalculated & 64.26 & 63.63 & 62.82 & 62.70 & 63.67 & 63.64 & 61.97 & 66.37 \\
\hline FeO recalculated & 32.67 & 33.03 & 33.15 & 33.26 & 32.59 & 32.30 & 33.38 & 32.22 \\
\hline $\mathrm{MnO}$ & 0.04 & 0.06 & 0.09 & 0.10 & 0.06 & 0.05 & 0.09 & 0.02 \\
\hline $\mathrm{MgO}$ & 0.12 & 0.15 & 0.05 & 0.06 & 0.04 & 0.13 & 0.09 & 0.03 \\
\hline $\mathrm{ZnO}$ & - & 0.00 & 0.02 & 0.00 & 0.03 & 0.02 & 0.02 & - \\
\hline $\mathrm{NiO}$ & 0.04 & 0.03 & 0.03 & 0.02 & 0.02 & 0.05 & 0.04 & 0.02 \\
\hline $\mathrm{CaO}$ & 0.01 & - & - & - & 0.01 & 0.01 & - & - \\
\hline $\mathrm{Cu}_{2} \mathrm{O}$ & - & - & 0.00 & - & - & 0.00 & - & 0.02 \\
\hline $\mathrm{K}_{2} \mathrm{O}$ & 0.00 & - & 0.01 & 0.01 & 0.00 & - & 0.01 & 0.00 \\
\hline Total measured & 94.36 & 94.57 & 93.85 & 93.91 & 93.44 & 93.41 & 93.97 & 94.47 \\
\hline Total recalculated & 100.80 & 100.95 & 100.14 & 100.19 & 99.82 & 99.79 & 100.18 & 101.12 \\
\hline MAS & \multicolumn{3}{|c|}{ Massive to semi-massive mineralization } & OBAN & \multicolumn{4}{|c|}{ Orthopyroxene -bearing bands of oxide mineralization } \\
\hline DIS & \multicolumn{3}{|c|}{ Disseminated mineralization } & POD & \multicolumn{4}{|c|}{ Pod of oxide mineralization } \\
\hline BAN & \multicolumn{3}{|c|}{ Bands of oxide mineralization } & OPOD & \multicolumn{4}{|c|}{ Orthopyroxene -bearing pod of oxide mineralization } \\
\hline ANO & \multicolumn{3}{|c|}{ Anorthosite hosted disseminated } & VEIN & \multicolumn{4}{|c|}{ Vein of oxide mineralization } \\
\hline ORT & \multicolumn{3}{|c|}{ Orthopyroxene associated } & MAG & \multicolumn{4}{|c|}{ Magnetite } \\
\hline $\mathrm{CLI}$ & \multicolumn{3}{|c|}{ Clinopyroxene associated } & ILM & Ilmenite & & PLE & Pleonaste \\
\hline
\end{tabular}




\begin{tabular}{|c|c|c|c|c|c|c|c|c|c|}
\hline Sample & CC054B & CC054B & CC054B & CCO72 & $\mathrm{CCO} 72$ & CC072 & $\mathrm{CCO72}$ & $\mathrm{CCO72}$ & $\mathrm{CCO} 72$ \\
\hline Mineralization type & DIS & DIS & DIS & MAS & MAS & MAS & MAS & MAS & MAS \\
\hline Descriptor & ORT & ORT & ORT & OPOD & OPOD & OPOD & OPOD & OPOD & OPOD \\
\hline Circle Number & 0 & 0 & $\mathrm{O}$ & $A$ & $A$ & A & A & $A$ & $A$ \\
\hline Mineral analyzed & MAG & MAG & MAG & MAG & MAG & MAG & MAG & MAG & MAG \\
\hline Mineral host & ILM & ILM & ILM & MAG & MAG & MAG & MAG & MAG & MAG \\
\hline Point & 74 & 75 & 76 & 1 & 2 & 3 & & & 5 \\
\hline $\mathrm{SiO}_{2}$ & 0.00 & 0.02 & - & 0.03 & 0.03 & 0.02 & 0.02 & 0.05 & 0.02 \\
\hline $\mathrm{TiO}_{2}$ & 1.58 & 2.01 & 2.24 & 4.47 & 4.46 & 6.31 & 4.70 & 5.64 & 5.93 \\
\hline $\mathrm{Al}_{2} \mathrm{O}_{3}$ & 0.64 & 1.01 & 0.89 & 2.17 & 0.62 & 1.70 & 2.11 & 1.93 & 1.85 \\
\hline $\mathrm{Cr}_{2} \mathrm{O}_{3}$ & 0.24 & 0.20 & 0.23 & 0.33 & 0.33 & 0.32 & 0.31 & 0.32 & 0.33 \\
\hline $\mathrm{V}_{2} \mathrm{O}_{3}$ & 0.42 & 0.44 & 0.37 & 0.66 & 0.64 & 0.69 & 0.66 & 0.68 & 0.68 \\
\hline $\mathrm{FeO} *$ & 91.49 & 89.55 & 89.99 & 85.71 & 88.22 & 84.15 & 85.27 & 85.10 & 84.41 \\
\hline $\mathrm{Fe}_{2} \mathrm{O}_{3}$ recalculated & 65.29 & 63.13 & 63.28 & 57.05 & 59.29 & 53.63 & 56.61 & 55.30 & 54.49 \\
\hline FeO recalculated & 32.75 & 32.75 & 33.05 & 34.37 & 34.87 & 35.90 & 34.33 & 35.34 & 35.38 \\
\hline $\mathrm{MnO}$ & 0.02 & 0.03 & 0.02 & 0.25 & 0.23 & 0.36 & 0.23 & 0.30 & 0.33 \\
\hline $\mathrm{MgO}$ & 0.10 & 0.15 & 0.16 & 0.63 & 0.29 & 0.49 & 0.74 & 0.72 & 0.71 \\
\hline $\mathrm{ZnO}$ & - & - & 0.02 & 0.01 & 0.02 & 0.03 & 0.02 & 0.01 & - \\
\hline $\mathrm{NiO}$ & 0.05 & 0.04 & 0.03 & 0.03 & 0.04 & 0.05 & 0.03 & 0.05 & 0.04 \\
\hline $\mathrm{CaO}$ & 0.00 & - & 0.00 & - & 0.00 & - & 0.01 & - & - \\
\hline $\mathrm{Cu}_{2} \mathrm{O}$ & - & 0.01 & - & - & - & - & 0.01 & 0.01 & - \\
\hline $\mathrm{K}_{2} \mathrm{O}$ & 0.00 & - & - & - & 0.01 & - & 0.00 & 0.01 & - \\
\hline Total measured & 94.54 & 93.47 & 93.97 & 94.29 & 94.88 & 94.10 & 94.11 & 94.82 & 94.30 \\
\hline Total recalculated & 101.08 & 99.79 & 100.31 & 100.00 & 100.82 & 99.47 & 99.79 & 100.36 & 99.76 \\
\hline MAS & \multicolumn{3}{|c|}{ Massive to semi-massive mineralization } & OBAN & \multicolumn{5}{|c|}{ Orthopyroxene -bearing bands of oxide mineralization } \\
\hline DIS & \multicolumn{3}{|c|}{ Disseminated mineralization } & POD & \multicolumn{5}{|c|}{ Pod of oxide mineralization } \\
\hline BAN & \multicolumn{3}{|c|}{ Bands of oxide mineralization } & OPOD & \multicolumn{5}{|c|}{ Orthopyroxene -bearing pod of oxide mineralization } \\
\hline ANO & \multicolumn{3}{|c|}{ Anorthosite hosted disseminated } & VEIN & \multicolumn{5}{|c|}{ Vein of oxide mineralization } \\
\hline ORT & \multicolumn{3}{|c|}{ Orthopyroxene associated } & MAG & \multicolumn{5}{|c|}{ Magnetite } \\
\hline $\mathrm{CLI}$ & \multicolumn{3}{|c|}{ Clinopyroxene associated } & ILM & Ilmenite & & PLE & Pleonaste & \\
\hline
\end{tabular}




\section{Appendix IV a. (Continued)}

\begin{tabular}{|c|c|c|c|c|c|c|c|c|c|}
\hline Sample & CC072 & CCO72 & CC072 & CCO72 & $\mathrm{CCO} 72$ & CC072 & $\mathrm{CCO} 72$ & CC072 & CCO72 \\
\hline Mineralization type & MAS & MAS & MAS & MAS & MAS & MAS & MAS & MAS & MAS \\
\hline Descriptor & OPOD & OPOD & OPOD & OPOD & OPOD & OPOD & OPOD & OPOD & OPOD \\
\hline Circle Number & B & B & B & B & B & B & $\mathrm{C}$ & $\mathrm{C}$ & C \\
\hline Mineral analyzed & MAG & MAG & MAG & MAG & MAG & MAG & MAG & MAG & MAG \\
\hline Mineral host & opx & opx & opx & MAG & MAG & MAG & MAG & MAG & MAG \\
\hline Point & 15 & 16 & 17 & 18 & 19 & 20 & & 27 & 28 \\
\hline $\mathrm{SiO}_{2}$ & 0.02 & 0.03 & 0.04 & 0.02 & 0.03 & 0.02 & 0.02 & 0.02 & 0.03 \\
\hline $\mathrm{TiO}_{2}$ & 4.40 & 4.77 & 2.34 & 4.14 & 4.04 & 2.31 & 3.84 & 5.58 & 4.55 \\
\hline $\mathrm{Al}_{2} \mathrm{O}_{3}$ & 1.38 & 2.15 & 0.84 & 1.03 & 1.44 & 0.78 & 1.26 & 1.67 & 1.90 \\
\hline $\mathrm{Cr}_{2} \mathrm{O}_{3}$ & 0.28 & 0.33 & 0.30 & 0.33 & 0.36 & 0.33 & 0.32 & 0.32 & 0.32 \\
\hline $\mathrm{V}_{2} \mathrm{O}_{3}$ & 0.61 & 0.62 & 0.51 & 0.68 & 0.62 & 0.65 & 0.64 & 0.65 & 0.65 \\
\hline $\mathrm{FeO}^{*}$ & 86.44 & 84.88 & 89.13 & 87.66 & 87.18 & 89.60 & 86.11 & 84.87 & 86.01 \\
\hline $\mathrm{Fe}_{2} \mathrm{O}_{3}$ recalculated & 57.92 & 56.09 & 62.55 & 59.23 & 58.82 & 63.03 & 58.40 & 55.27 & 57.29 \\
\hline FeO recalculated & 34.33 & 34.41 & 32.85 & 34.37 & 34.25 & 32.88 & 33.56 & 35.14 & 34.46 \\
\hline $\mathrm{MnO}$ & 0.27 & 0.45 & 0.15 & 0.29 & 0.25 & 0.16 & 0.24 & 0.28 & 0.25 \\
\hline $\mathrm{MgO}$ & 0.44 & 0.52 & 0.22 & 0.36 & 0.41 & 0.28 & 0.41 & 0.63 & 0.60 \\
\hline $\mathrm{ZnO}$ & - & 0.02 & 0.02 & - & 0.00 & - & 0.01 & 0.02 & 0.01 \\
\hline $\mathrm{NiO}$ & 0.03 & 0.04 & 0.02 & 0.03 & 0.04 & 0.03 & 0.04 & 0.02 & 0.04 \\
\hline $\mathrm{CaO}$ & 0.01 & 0.01 & 0.00 & 0.00 & - & 0.01 & 0.01 & - & - \\
\hline $\mathrm{Cu}_{2} \mathrm{O}$ & 0.03 & 0.01 & 0.00 & - & - & - & - & 0.01 & 0.01 \\
\hline $\mathrm{K}_{2} \mathrm{O}$ & 0.01 & - & - & 0.00 & - & - & 0.00 & - & - \\
\hline Total measured & 93.92 & 93.81 & 93.57 & 94.54 & 94.38 & 94.17 & 92.90 & 94.07 & 94.37 \\
\hline Total recalculated & 99.72 & 99.43 & 99.84 & 100.48 & 100.27 & 100.48 & 98.75 & 99.61 & 100.11 \\
\hline MAS & \multicolumn{3}{|c|}{ Massive to semi-massive mineralization } & OBAN & \multicolumn{5}{|c|}{ Orthopyroxene -bearing bands of oxide mineralization } \\
\hline DIS & \multicolumn{3}{|c|}{ Disseminated mineralization } & POD & \multicolumn{5}{|c|}{ Pod of oxide mineralization } \\
\hline BAN & \multicolumn{3}{|c|}{ Bands of oxide mineralization } & OPOD & \multicolumn{5}{|c|}{ Orthopyroxene -bearing pod of oxide mineralization } \\
\hline ANO & \multicolumn{3}{|c|}{ Anorthosite hosted disseminated } & VEIN & \multicolumn{5}{|c|}{ Vein of oxide mineralization } \\
\hline ORT & \multicolumn{3}{|c|}{ Orthopyroxene associated } & MAG & \multicolumn{5}{|c|}{ Magnetite } \\
\hline $\mathrm{CLI}$ & \multicolumn{3}{|c|}{ Clinopyroxene associated } & ILM & Ilmenite & & PLE & Pleonaste & \\
\hline
\end{tabular}




\begin{tabular}{|c|c|c|c|c|c|c|c|c|}
\hline Sample & $\mathrm{CCO72}$ & $\mathrm{CCO} 72$ & $\mathrm{CCO72}$ & $\mathrm{CCO72}$ & $\mathrm{CCO72}$ & $\mathrm{CCO72}$ & $\mathrm{CCO72}$ & CC072 \\
\hline Mineralization type & MAS & MAS & MAS & MAS & MAS & MAS & MAS & MAS \\
\hline Descriptor & OPOD & OPOD & OPOD & OPOD & OPOD & OPOD & OPOD & OPOD \\
\hline Mineral analyzed & MAG & MAG & MAG & MAG & MAG & MAG & MAG & MAG \\
\hline Mineral host & MAG & MAG & MAG & MAG & MAG & MAG & opx & opx \\
\hline $\mathrm{TiO}_{2}$ & 1.89 & 5.04 & 3.57 & 2.14 & 2.01 & 2.06 & 3.13 & 3.40 \\
\hline $\mathrm{Al}_{2} \mathrm{O}_{3}$ & 0.76 & 1.60 & 0.90 & 0.78 & 0.80 & 0.75 & 1.30 & 0.97 \\
\hline $\mathrm{Cr}_{2} \mathrm{O}_{3}$ & 0.31 & 0.32 & 0.33 & 0.37 & 0.33 & 0.33 & 0.32 & 0.30 \\
\hline $\mathrm{V}_{2} \mathrm{O}_{3}$ & 0.55 & 0.63 & 0.60 & 0.61 & 0.56 & 0.55 & 0.58 & 0.62 \\
\hline $\mathrm{FeO} *$ & 89.60 & 85.50 & 87.63 & 90.09 & 89.55 & 89.45 & 87.70 & 87.39 \\
\hline $\mathrm{ZnO}$ & - & 0.00 & 0.00 & 0.04 & 0.02 & - & - & 0.00 \\
\hline $\mathrm{NiO}$ & 0.02 & 0.04 & 0.05 & 0.04 & 0.02 & 0.04 & 0.04 & 0.04 \\
\hline $\mathrm{CaO}$ & - & 0.00 & 0.00 & 0.00 & 0.01 & - & 0.00 & 0.01 \\
\hline $\mathrm{Cu}_{2} \mathrm{O}$ & 0.01 & - & - & - & 0.00 & 0.01 & - & 0.01 \\
\hline $\mathrm{K}_{2} \mathrm{O}$ & - & - & 0.00 & 0.00 & 0.00 & 0.00 & - & 0.00 \\
\hline Total measured & 93.53 & 94.05 & 93.67 & 94.56 & 93.72 & 93.62 & 93.69 & 93.33 \\
\hline Total recalculated & 99.89 & 99.71 & 99.68 & 100.94 & 100.07 & 99.96 & 99.76 & 99.33 \\
\hline MAS & \multicolumn{3}{|c|}{ Massive to semi-massive mineralization } & OBAN & \multicolumn{4}{|c|}{ Orthopyroxene -bearing bands of oxide mineralization } \\
\hline DIS & \multicolumn{3}{|c|}{ Disseminated mineralization } & POD & \multicolumn{4}{|c|}{ Pod of oxide mineralization } \\
\hline BAN & \multicolumn{3}{|c|}{ Bands of oxide mineralization } & OPOD & \multicolumn{4}{|c|}{ Orthopyroxene -bearing pod of oxide mineralization } \\
\hline
\end{tabular}




\begin{tabular}{|c|c|c|c|c|c|c|c|c|c|}
\hline Sample & CC072 & CC072 & CC072 & CC072 & $\mathrm{CCO72}$ & CC072 & CCO72 & CC072 & CC072 \\
\hline Mineralization type & MAS & MAS & MAS & MAS & MAS & MAS & MAS & MAS & MAS \\
\hline Descriptor & OPOD & OPOD & OPOD & OPOD & OPOD & OPOD & OPOD & OPOD & OPOD \\
\hline Circle Number & D & $\mathrm{E}$ & $\mathrm{E}$ & $\mathrm{E}$ & G & G & G & G & $\mathrm{H}$ \\
\hline Mineral analyzed & MAG & MAG & MAG & MAG & MAG & MAG & MAG & MAG & MAG \\
\hline Mineral host & opx & MAG & MAG & MAG & ILM & ILM & opx & opx & ILM \\
\hline Point & 40 & 43 & 44 & 45 & 52 & 53 & 54 & 55 & 59 \\
\hline $\mathrm{SiO}_{2}$ & 0.03 & 0.04 & 0.03 & 0.04 & 0.00 & - & 0.03 & 0.03 & - \\
\hline $\mathrm{TiO}_{2}$ & 3.73 & 2.64 & 4.22 & 1.94 & 2.70 & 2.88 & 3.54 & 3.51 & 1.83 \\
\hline $\mathrm{Al}_{2} \mathrm{O}_{3}$ & 1.60 & 0.60 & 1.27 & 0.74 & 0.80 & 0.78 & 1.53 & 1.01 & 0.71 \\
\hline $\mathrm{Cr}_{2} \mathrm{O}_{3}$ & 0.31 & 0.32 & 0.31 & 0.31 & 0.24 & 0.22 & 0.28 & 0.28 & 0.21 \\
\hline $\mathrm{V}_{2} \mathrm{O}_{3}$ & 0.62 & 0.62 & 0.63 & 0.61 & 0.53 & 0.51 & 0.57 & 0.56 & 0.60 \\
\hline $\mathrm{FeO} *$ & 86.21 & 88.83 & 86.49 & 89.15 & 89.30 & 90.28 & 87.02 & 87.34 & 89.91 \\
\hline $\mathrm{Fe}_{2} \mathrm{O}_{3}$ recalculated & 58.55 & 62.07 & 58.22 & 63.09 & 62.38 & 62.88 & 59.43 & 59.77 & 63.98 \\
\hline FeO recalculated & 33.52 & 32.98 & 34.10 & 32.38 & 33.17 & 33.70 & 33.54 & 33.56 & 32.34 \\
\hline $\mathrm{MnO}$ & 0.20 & 0.12 & 0.23 & 0.11 & 0.05 & 0.05 & 0.19 & 0.20 & 0.02 \\
\hline $\mathrm{MgO}$ & 0.53 & 0.29 & 0.46 & 0.22 & 0.32 & 0.32 & 0.50 & 0.32 & 0.31 \\
\hline $\mathrm{ZnO}$ & 0.01 & - & 0.02 & 0.00 & 0.02 & - & 0.01 & 0.02 & 0.01 \\
\hline $\mathrm{NiO}$ & 0.03 & 0.03 & 0.02 & 0.04 & 0.04 & 0.04 & 0.02 & 0.02 & 0.03 \\
\hline $\mathrm{CaO}$ & - & - & 0.01 & - & 0.00 & 0.00 & 0.01 & 0.01 & - \\
\hline $\mathrm{Cu}_{2} \mathrm{O}$ & - & 0.01 & 0.02 & - & - & 0.00 & - & - & 0.01 \\
\hline $\mathrm{K}_{2} \mathrm{O}$ & - & - & - & - & - & - & 0.00 & 0.01 & 0.00 \\
\hline Total measured & 93.28 & 93.50 & 93.69 & 93.15 & 94.01 & 95.09 & 93.73 & 93.31 & 93.64 \\
\hline Total recalculated & 99.15 & 99.72 & 99.52 & 99.47 & 100.26 & 101.39 & 99.68 & 99.30 & 100.05 \\
\hline MAS & \multicolumn{3}{|c|}{ Massive to semi-massive mineralization } & OBAN & \multicolumn{5}{|c|}{ Orthopyroxene -bearing bands of oxide mineralization } \\
\hline DIS & \multicolumn{3}{|c|}{ Disseminated mineralization } & POD & \multicolumn{5}{|c|}{ Pod of oxide mineralization } \\
\hline BAN & \multicolumn{3}{|c|}{ Bands of oxide mineralization } & OPOD & \multicolumn{5}{|c|}{ Orthopyroxene -bearing pod of oxide mineralization } \\
\hline ANO & \multicolumn{3}{|c|}{ Anorthosite hosted disseminated } & VEIN & \multicolumn{5}{|c|}{ Vein of oxide mineralization } \\
\hline ORT & \multicolumn{3}{|c|}{ Orthopyroxene associated } & MAG & \multicolumn{5}{|c|}{ Magnetite } \\
\hline $\mathrm{CLI}$ & \multicolumn{3}{|c|}{ Clinopyroxene associated } & ILM & Ilmenite & & PLE & Pleonaste & \\
\hline
\end{tabular}




\begin{tabular}{|c|c|c|c|c|c|c|c|c|}
\hline Sample & $\mathrm{CCO72}$ & $\mathrm{CCO72}$ & $\mathrm{CCO72}$ & $\mathrm{CCO72}$ & $\mathrm{CCO} 72$ & $\mathrm{CCO72}$ & $\mathrm{CCO72}$ & $\mathrm{CCO72}$ \\
\hline Mineralization type & MAS & MAS & MAS & MAS & MAS & MAS & MAS & MAS \\
\hline Descriptor & OPOD & OPOD & OPOD & OPOD & OPOD & OPOD & OPOD & OPOD \\
\hline Circle Number & $\mathrm{H}$ & $\mathrm{H}$ & I & I & I & I & I & I \\
\hline Mineral analyzed & MAG & MAG & MAG & MAG & MAG & MAG & MAG & MAG \\
\hline Mineral host & ILM & ILM & MAG & MAG & MAG & MAG & MAG & MAG \\
\hline Point & 60 & 61 & 62 & 63 & 64 & 65 & 66 & 67 \\
\hline $\mathrm{SiO}_{2}$ & 0.00 & 0.02 & 0.03 & 0.04 & 0.03 & 0.02 & 0.03 & 0.02 \\
\hline $\mathrm{TiO}_{2}$ & 2.46 & 2.28 & 4.50 & 4.27 & 4.10 & 3.13 & 2.27 & 2.01 \\
\hline $\mathrm{Al}_{2} \mathrm{O}_{3}$ & 0.66 & 0.56 & 2.86 & 2.88 & 1.81 & 0.69 & 0.67 & 0.58 \\
\hline $\mathrm{Cr}_{2} \mathrm{O}_{3}$ & 0.18 & 0.18 & 0.33 & 0.33 & 0.33 & 0.31 & 0.31 & 0.31 \\
\hline $\mathrm{V}_{2} \mathrm{O}_{3}$ & 0.59 & 0.54 & 0.64 & 0.61 & 0.63 & 0.61 & 0.55 & 0.60 \\
\hline $\mathrm{FeO} *$ & 90.05 & 90.12 & 85.22 & 85.02 & 86.69 & 88.19 & 89.40 & 90.19 \\
\hline $\mathrm{Fe}_{2} \mathrm{O}_{3}$ recalculated & 63.28 & 63.55 & 56.74 & 56.82 & 58.44 & 61.00 & 62.99 & 63.88 \\
\hline FeO recalculated & 33.11 & 32.93 & 34.17 & 33.89 & 34.10 & 33.30 & 32.72 & 32.71 \\
\hline $\mathrm{MnO}$ & 0.05 & 0.03 & 0.24 & 0.24 & 0.20 & 0.15 & 0.11 & 0.11 \\
\hline $\mathrm{MgO}$ & 0.28 & 0.27 & 0.95 & 0.91 & 0.65 & 0.31 & 0.26 & 0.21 \\
\hline $\mathrm{ZnO}$ & 0.01 & - & 0.02 & 0.01 & - & 0.01 & 0.00 & 0.00 \\
\hline $\mathrm{NiO}$ & 0.06 & 0.03 & 0.04 & 0.04 & 0.03 & 0.04 & 0.06 & 0.03 \\
\hline $\mathrm{CaO}$ & 0.00 & - & 0.00 & 0.00 & 0.00 & - & 0.01 & 0.01 \\
\hline $\mathrm{Cu}_{2} \mathrm{O}$ & 0.01 & 0.02 & 0.02 & 0.01 & - & 0.00 & - & 0.00 \\
\hline $\mathrm{K}_{2} \mathrm{O}$ & 0.00 & 0.00 & - & 0.00 & 0.00 & - & - & 0.01 \\
\hline Total measured & 94.36 & 94.06 & 94.84 & 94.37 & 94.46 & 93.47 & 93.67 & 94.07 \\
\hline Total recalculated & 100.70 & 100.43 & 100.53 & 100.06 & 100.32 & 99.58 & 99.98 & 100.47 \\
\hline MAS & \multicolumn{3}{|c|}{ Massive to semi-massive mineralization } & OBAN & \multicolumn{4}{|c|}{ Orthopyroxene -bearing bands of oxide mineralization } \\
\hline DIS & \multicolumn{3}{|c|}{ Disseminated mineralization } & POD & \multicolumn{4}{|c|}{ Pod of oxide mineralization } \\
\hline BAN & \multicolumn{3}{|c|}{ Bands of oxide mineralization } & OPOD & \multicolumn{4}{|c|}{ Orthopyroxene -bearing pod of oxide mineralization } \\
\hline ANO & \multicolumn{3}{|c|}{ Anorthosite hosted disseminated } & VEIN & \multicolumn{4}{|c|}{ Vein of oxide mineralization } \\
\hline ORT & \multicolumn{3}{|c|}{ Orthopyroxene associated } & MAG & \multicolumn{4}{|c|}{ Magnetite } \\
\hline $\mathrm{CLI}$ & \multicolumn{3}{|c|}{ Clinopyroxene associated } & ILM & Ilmenite & & PLE & Pleonaste \\
\hline
\end{tabular}




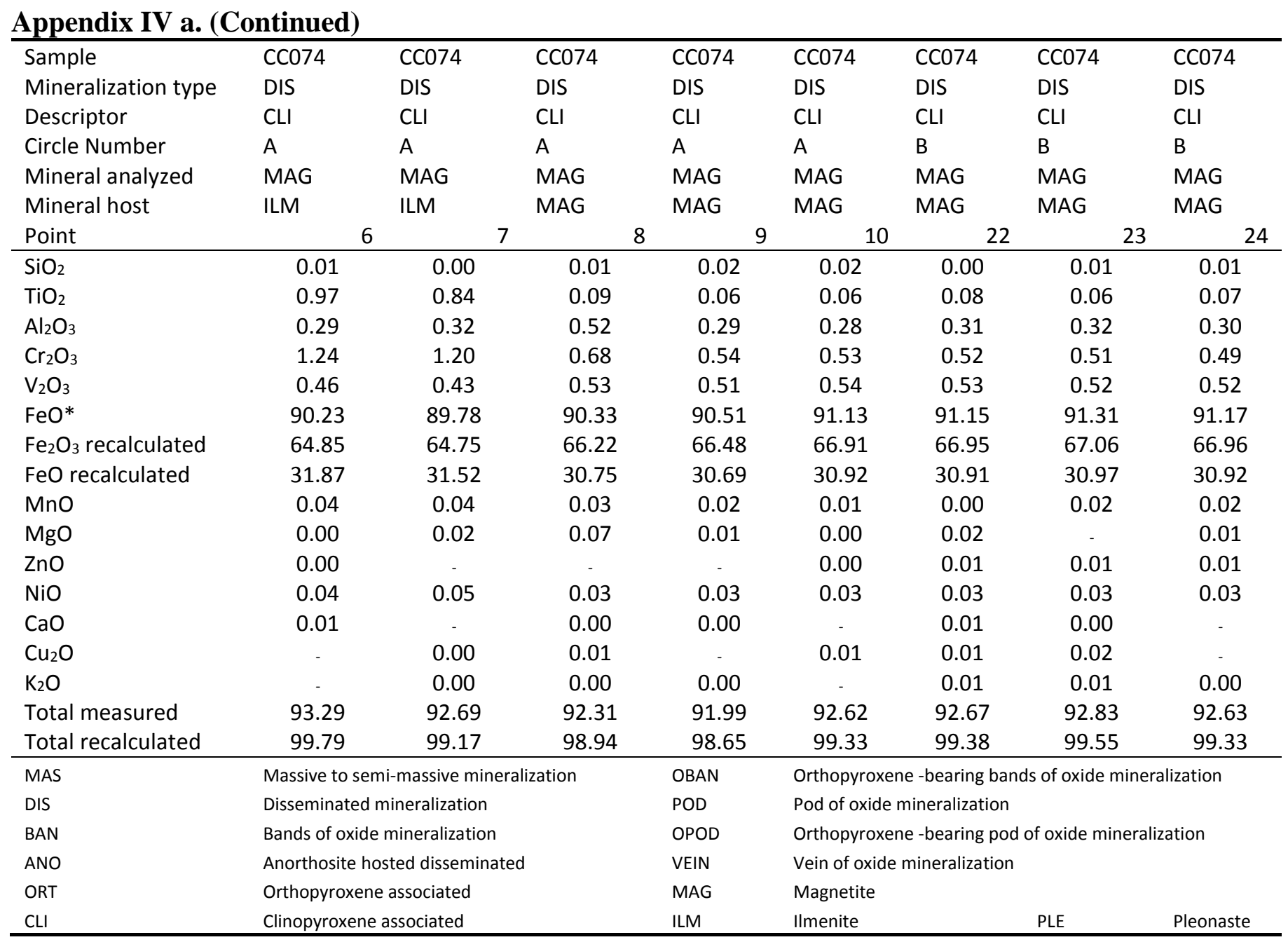




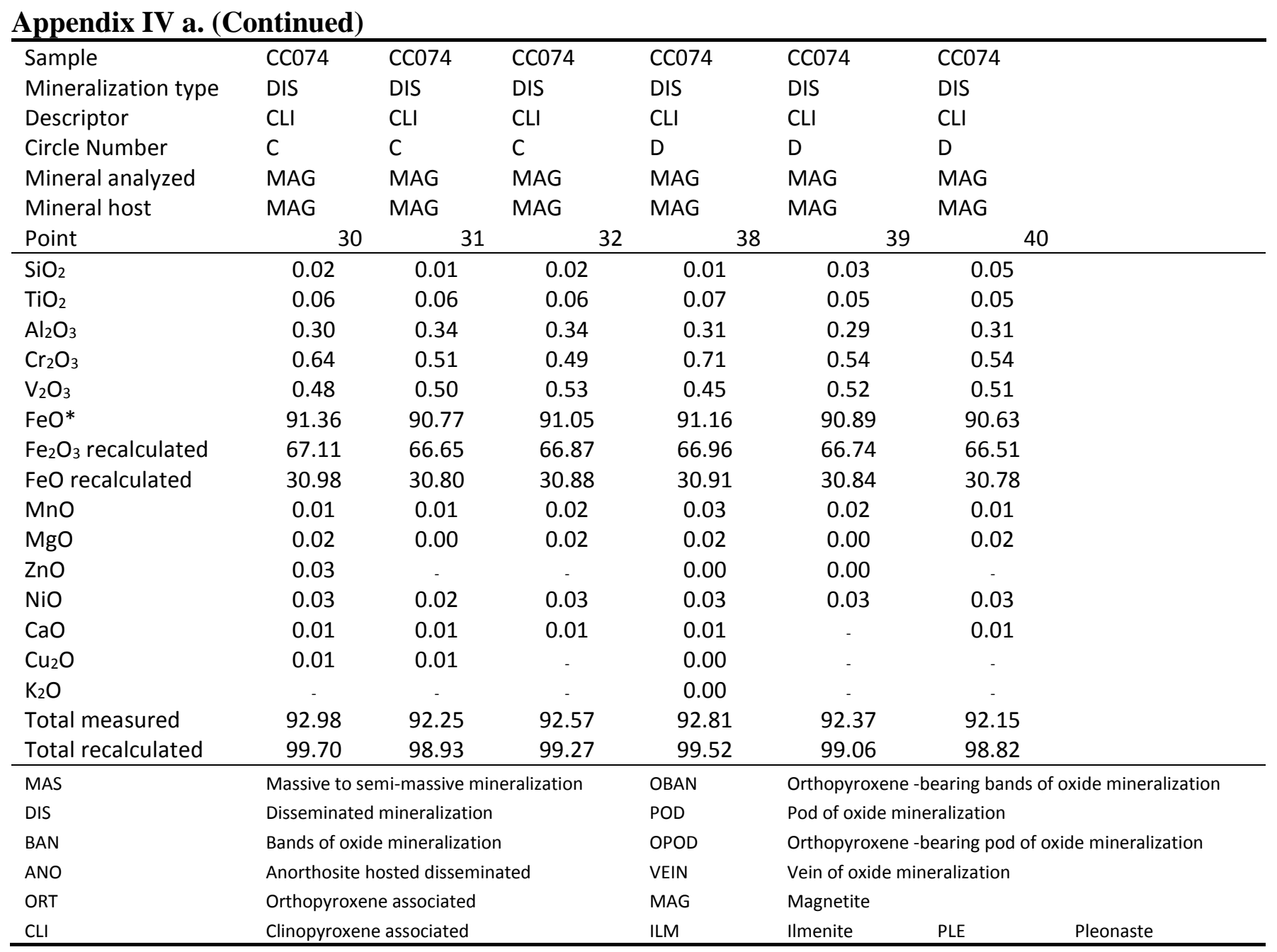




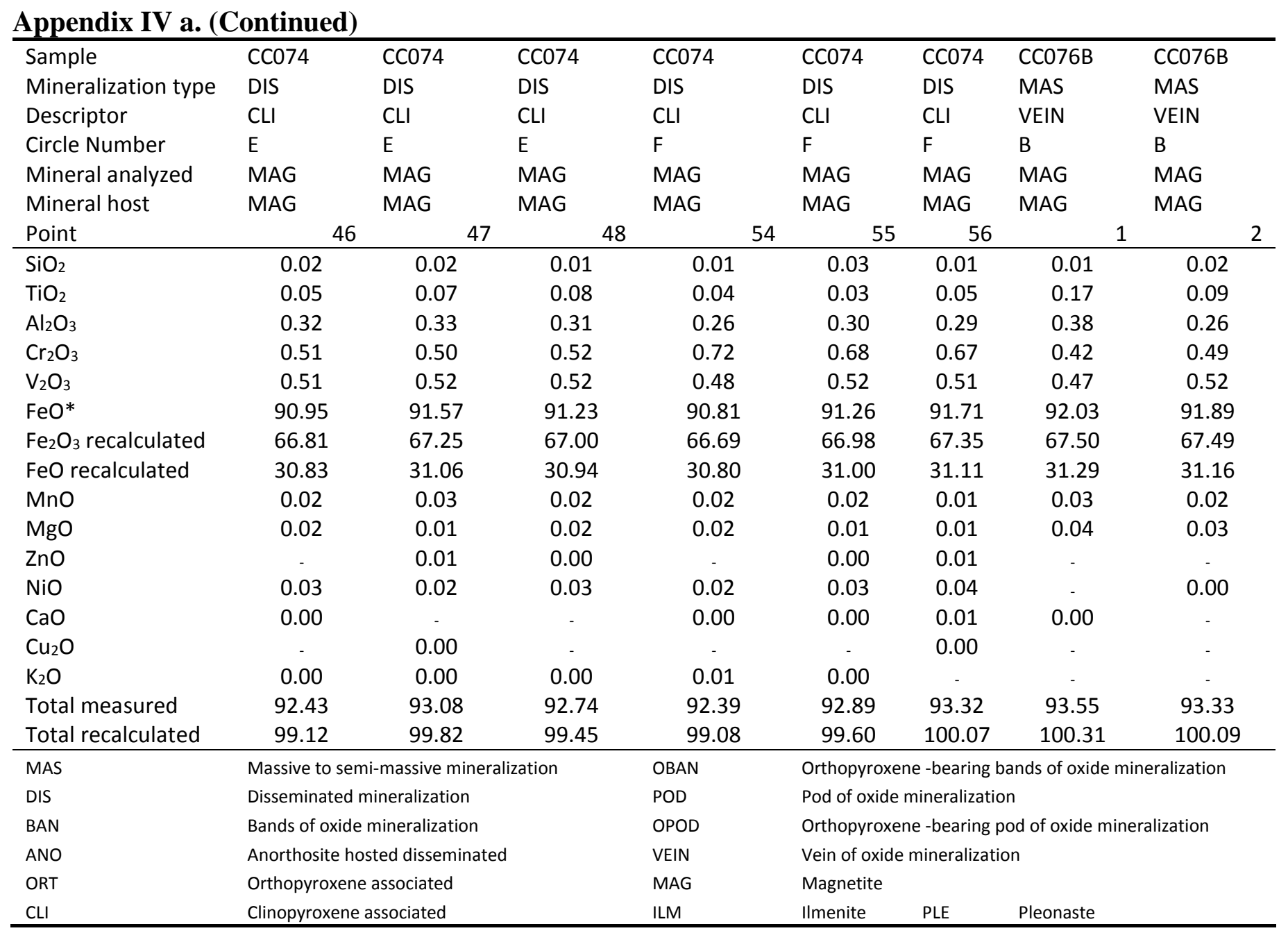




\begin{tabular}{|c|c|c|c|c|c|c|c|c|c|}
\hline Sample & CC076B & CC076B & CC076B & CC076B & CC076B & CC076B & CC076B & CC076B & CC076B \\
\hline Mineralization type & MAS & MAS & MAS & MAS & MAS & MAS & MAS & MAS & MAS \\
\hline Descriptor & VEIN & VEIN & VEIN & VEIN & VEIN & VEIN & VEIN & VEIN & VEIN \\
\hline Circle Number & B & B & B & C & C & C & C & C & C \\
\hline Mineral analyzed & MAG & MAG & MAG & MAG & MAG & MAG & MAG & MAG & MAG \\
\hline Mineral host & MAG & PLE & PLE & MAG & MAG & MAG & MAG & MAG & MAG \\
\hline Point & 3 & 11 & 12 & 16 & 17 & 18 & 19 & 20 & 21 \\
\hline $\mathrm{SiO}_{2}$ & 0.01 & 0.01 & 0.01 & 0.02 & 0.02 & 0.01 & 0.01 & 0.01 & 0.02 \\
\hline $\mathrm{TiO}_{2}$ & 0.09 & 0.08 & 0.02 & 0.10 & 0.09 & 0.07 & 0.10 & 0.07 & 0.09 \\
\hline $\mathrm{Al}_{2} \mathrm{O}_{3}$ & 0.24 & 0.23 & 0.18 & 0.26 & 0.33 & 0.25 & 0.24 & 0.23 & 0.25 \\
\hline $\mathrm{Cr}_{2} \mathrm{O}_{3}$ & 0.53 & 0.36 & 0.38 & 0.46 & 0.48 & 0.46 & 0.60 & 0.48 & 0.47 \\
\hline $\mathrm{V}_{2} \mathrm{O}_{3}$ & 0.55 & 0.34 & 0.29 & 0.64 & 0.65 & 0.65 & 0.62 & 0.65 & 0.66 \\
\hline $\mathrm{FeO} *$ & 91.68 & 91.69 & 91.74 & 92.06 & 91.23 & 91.22 & 91.13 & 91.75 & 92.15 \\
\hline $\mathrm{Fe}_{2} \mathrm{O}_{3}$ recalculated & 67.39 & 67.58 & 67.73 & 67.58 & 66.98 & 67.03 & 66.86 & 67.45 & 67.68 \\
\hline FeO recalculated & 31.04 & 30.89 & 30.80 & 31.25 & 30.96 & 30.91 & 30.97 & 31.06 & 31.25 \\
\hline $\mathrm{MnO}$ & 0.03 & 0.04 & 0.04 & 0.03 & 0.04 & 0.02 & 0.02 & 0.04 & 0.04 \\
\hline $\mathrm{MgO}$ & 0.05 & 0.01 & 0.01 & 0.03 & 0.04 & 0.03 & 0.02 & 0.04 & 0.03 \\
\hline $\mathrm{ZnO}$ & 0.02 & 0.14 & 0.14 & - & 0.02 & 0.02 & - & 0.01 & 0.01 \\
\hline $\mathrm{NiO}$ & 0.02 & 0.02 & - & 0.01 & 0.01 & 0.01 & - & - & - \\
\hline $\mathrm{CaO}$ & 0.00 & 0.00 & 0.00 & - & 0.01 & - & 0.00 & 0.01 & 0.01 \\
\hline $\mathrm{Cu}_{2} \mathrm{O}$ & - & - & - & 0.01 & 0.00 & 0.00 & - & 0.00 & 0.01 \\
\hline $\mathrm{K}_{2} \mathrm{O}$ & 0.00 & - & 0.00 & - & - & 0.00 & - & 0.00 & 0.00 \\
\hline Total measured & 93.21 & 92.91 & 92.81 & 93.63 & 92.91 & 92.74 & 92.75 & 93.28 & 93.75 \\
\hline Total recalculated & 99.96 & 99.68 & 99.60 & 100.40 & 99.62 & 99.45 & 99.45 & 100.04 & 100.53 \\
\hline MAS & \multicolumn{3}{|c|}{ Massive to semi-massive mineralization } & OBAN & \multicolumn{5}{|c|}{ Orthopyroxene -bearing bands of oxide mineralization } \\
\hline DIS & \multicolumn{3}{|c|}{ Disseminated mineralization } & POD & \multicolumn{5}{|c|}{ Pod of oxide mineralization } \\
\hline BAN & \multicolumn{3}{|c|}{ Bands of oxide mineralization } & OPOD & \multicolumn{5}{|c|}{ Orthopyroxene -bearing pod of oxide mineralization } \\
\hline ANO & \multicolumn{3}{|c|}{ Anorthosite hosted disseminated } & VEIN & \multicolumn{5}{|c|}{ Vein of oxide mineralization } \\
\hline ORT & \multicolumn{3}{|c|}{ Orthopyroxene associated } & MAG & Magnetite & & & & \\
\hline $\mathrm{CLI}$ & \multicolumn{3}{|c|}{ Clinopyroxene associated } & ILM & Ilmenite & PLE & Pleonaste & & \\
\hline
\end{tabular}




\begin{tabular}{|c|c|c|c|c|c|c|c|c|c|}
\hline Sample & CC076B & CC076B & CC076B & CC076B & CC076B & CC076B & CC076B & CC076B & CC076B \\
\hline Mineralization type & MAS & MAS & MAS & MAS & MAS & MAS & MAS & MAS & MAS \\
\hline Descriptor & VEIN & VEIN & VEIN & VEIN & VEIN & VEIN & VEIN & VEIN & VEIN \\
\hline Circle Number & $\mathrm{D}$ & $\mathrm{D}$ & $\mathrm{D}$ & $\mathrm{D}$ & $\mathrm{D}$ & $\mathrm{D}$ & $\mathrm{E}$ & $\mathrm{E}$ & $\mathrm{E}$ \\
\hline Mineral analyzed & MAG & MAG & MAG & MAG & MAG & MAG & MAG & MAG & MAG \\
\hline Mineral host & ILM & ILM & ILM & ILM & ILM & ILM & Grt & Grt & Grt \\
\hline Point & 22 & 23 & 24 & 25 & 26 & 27 & 31 & 32 & 33 \\
\hline $\mathrm{SiO}_{2}$ & 0.01 & 0.01 & 0.01 & 0.01 & 0.02 & 0.02 & 0.01 & 0.03 & 0.02 \\
\hline $\mathrm{TiO}_{2}$ & 1.49 & 1.75 & 1.81 & 0.08 & 0.08 & 0.09 & 0.08 & 0.05 & 0.10 \\
\hline $\mathrm{Al}_{2} \mathrm{O}_{3}$ & 0.31 & 0.24 & 0.23 & 0.24 & 0.29 & 0.27 & 0.28 & 0.32 & 0.30 \\
\hline $\mathrm{Cr}_{2} \mathrm{O}_{3}$ & 0.22 & 0.21 & 0.21 & 0.39 & 0.41 & 0.42 & 0.64 & 0.66 & 0.65 \\
\hline $\mathrm{V}_{2} \mathrm{O}_{3}$ & 0.37 & 0.37 & 0.36 & 0.46 & 0.53 & 0.53 & 0.86 & 0.72 & 0.70 \\
\hline $\mathrm{FeO} *$ & 91.87 & 91.42 & 92.15 & 92.46 & 92.03 & 92.04 & 91.66 & 91.02 & 91.04 \\
\hline $\mathrm{Fe}_{2} \mathrm{O}_{3}$ recalculated & 65.78 & 65.16 & 65.59 & 68.04 & 67.61 & 67.64 & 67.16 & 66.82 & 66.85 \\
\hline FeO recalculated & 32.68 & 32.79 & 33.13 & 31.24 & 31.19 & 31.17 & 31.22 & 30.90 & 30.89 \\
\hline $\mathrm{MnO}$ & 0.02 & 0.03 & 0.04 & 0.00 & 0.02 & 0.02 & 0.01 & 0.15 & 0.17 \\
\hline $\mathrm{MgO}$ & 0.04 & 0.04 & 0.03 & 0.05 & 0.02 & 0.03 & 0.03 & 0.01 & 0.01 \\
\hline $\mathrm{ZnO}$ & 0.02 & 0.02 & - & - & 0.02 & 0.02 & 0.02 & 0.00 & - \\
\hline $\mathrm{NiO}$ & 0.01 & 0.01 & 0.01 & - & 0.00 & 0.02 & - & 0.00 & 0.02 \\
\hline $\mathrm{CaO}$ & 0.01 & - & - & 0.01 & - & 0.00 & - & 0.04 & 0.06 \\
\hline $\mathrm{Cu}_{2} \mathrm{O}$ & 0.01 & 0.01 & 0.02 & 0.00 & 0.01 & 0.00 & 0.01 & - & - \\
\hline $\mathrm{K}_{2} \mathrm{O}$ & - & 0.00 & - & 0.00 & 0.01 & 0.01 & - & 0.02 & 0.01 \\
\hline Total measured & 94.38 & 94.11 & 94.87 & 93.70 & 93.43 & 93.45 & 93.60 & 93.02 & 93.07 \\
\hline Total recalculated & 100.97 & 100.64 & 101.44 & 100.52 & 100.20 & 100.23 & 100.33 & 99.72 & 99.77 \\
\hline MAS & \multicolumn{3}{|c|}{ Massive to semi-massive mineralization } & OBAN & \multicolumn{5}{|c|}{ Orthopyroxene -bearing bands of oxide mineralization } \\
\hline DIS & \multicolumn{3}{|c|}{ Disseminated mineralization } & POD & \multicolumn{5}{|c|}{ Pod of oxide mineralization } \\
\hline BAN & \multicolumn{3}{|c|}{ Bands of oxide mineralization } & OPOD & \multicolumn{5}{|c|}{ Orthopyroxene -bearing pod of oxide mineralization } \\
\hline ANO & \multicolumn{3}{|c|}{ Anorthosite hosted disseminated } & VEIN & \multicolumn{5}{|c|}{ Vein of oxide mineralization } \\
\hline ORT & \multicolumn{3}{|c|}{ Orthopyroxene associated } & MAG & Magnetite & & & & \\
\hline $\mathrm{CLI}$ & \multicolumn{3}{|c|}{ Clinopyroxene associated } & ILM & Ilmenite & PLE & Pleonaste & & \\
\hline
\end{tabular}




\begin{tabular}{|c|c|c|c|c|c|c|c|c|c|c|}
\hline Sample & CC076B & CC076B & CC076B & CC076B & CC076B & CC076B & CC076B & CC076B & CC076B & CC076B \\
\hline Mineralization type & MAS & MAS & MAS & MAS & MAS & MAS & MAS & MAS & MAS & MAS \\
\hline Descriptor & VEIN & VEIN & VEIN & VEIN & VEIN & VEIN & VEIN & VEIN & VEIN & VEIN \\
\hline Circle Number & $\mathrm{F}$ & $\mathrm{F}$ & $\mathrm{F}$ & G & G & G & G & G & G & G \\
\hline Mineral analyzed & MAG & MAG & MAG & MAG & MAG & MAG & MAG & MAG & MAG & MAG \\
\hline Mineral host & ILM & ILM & ILM & ILM & ILM & PLE & PLE & MAG & MAG & MAG \\
\hline Point & 34 & 35 & 36 & 40 & 41 & 42 & 43 & 44 & 45 & 46 \\
\hline $\mathrm{SiO}_{2}$ & 0.00 & 0.00 & 0.01 & 0.01 & 0.01 & 0.02 & 0.02 & 0.02 & 0.01 & 0.02 \\
\hline $\mathrm{TiO}_{2}$ & 1.89 & 1.75 & 1.88 & 1.82 & 1.72 & 0.10 & 0.07 & 0.08 & 0.09 & 0.06 \\
\hline $\mathrm{Al}_{2} \mathrm{O}_{3}$ & 0.25 & 0.27 & 0.26 & 0.24 & 0.25 & 0.22 & 0.22 & 0.25 & 0.24 & 0.22 \\
\hline $\mathrm{Cr}_{2} \mathrm{O}_{3}$ & 0.23 & 0.23 & 0.22 & 0.25 & 0.26 & 0.35 & 0.42 & 0.44 & 0.44 & 0.44 \\
\hline $\mathrm{V}_{2} \mathrm{O}_{3}$ & 0.38 & 0.39 & 0.35 & 0.35 & 0.35 & 0.31 & 0.32 & 0.60 & 0.59 & 0.63 \\
\hline $\mathrm{FeO} *$ & 92.09 & 91.52 & 91.34 & 90.15 & 90.68 & 90.90 & 91.29 & 91.86 & 91.81 & 91.78 \\
\hline $\mathrm{Fe}_{2} \mathrm{O}_{3}$ recalculated & 65.43 & 65.24 & 64.84 & 64.07 & 64.61 & 66.92 & 67.32 & 67.48 & 67.45 & 67.45 \\
\hline FeO recalculated & 33.21 & 32.82 & 32.99 & 32.50 & 32.55 & 30.69 & 30.72 & 31.14 & 31.12 & 31.08 \\
\hline $\mathrm{MnO}$ & 0.01 & 0.02 & 0.02 & 0.03 & 0.05 & 0.05 & 0.06 & 0.03 & 0.04 & 0.03 \\
\hline $\mathrm{MgO}$ & 0.04 & 0.05 & 0.01 & 0.01 & 0.02 & 0.00 & 0.03 & 0.03 & 0.02 & 0.02 \\
\hline $\mathrm{ZnO}$ & 0.01 & 0.01 & - & - & 0.02 & 0.08 & 0.14 & - & - & 0.00 \\
\hline $\mathrm{NiO}$ & 0.00 & 0.03 & - & 0.01 & - & 0.01 & 0.01 & - & 0.00 & 0.01 \\
\hline $\mathrm{CaO}$ & - & 0.00 & 0.00 & 0.00 & - & - & - & - & 0.00 & 0.01 \\
\hline $\mathrm{Cu}_{2} \mathrm{O}$ & - & - & 0.00 & 0.01 & - & - & - & 0.00 & - & 0.00 \\
\hline $\mathrm{K}_{2} \mathrm{O}$ & 0.01 & - & 0.00 & - & 0.00 & 0.00 & 0.01 & - & - & 0.01 \\
\hline Total measured & 94.92 & 94.27 & 94.09 & 92.89 & 93.37 & 92.04 & 92.58 & 93.31 & 93.25 & 93.22 \\
\hline Total recalculated & 101.48 & 100.81 & 100.58 & 99.31 & 99.84 & 98.75 & 99.32 & 100.07 & 100.01 & 99.98 \\
\hline MAS & \multicolumn{3}{|c|}{ Massive to semi-massive mineralization } & OBAN & \multicolumn{6}{|c|}{ Orthopyroxene -bearing bands of oxide mineralization } \\
\hline DIS & \multicolumn{3}{|c|}{ Disseminated mineralization } & POD & \multicolumn{6}{|c|}{ Pod of oxide mineralization } \\
\hline BAN & \multicolumn{3}{|c|}{ Bands of oxide mineralization } & OPOD & \multicolumn{6}{|c|}{ Orthopyroxene -bearing pod of oxide mineralization } \\
\hline ANO & \multicolumn{3}{|c|}{ Anorthosite hosted disseminated } & VEIN & \multicolumn{6}{|c|}{ Vein of oxide mineralization } \\
\hline ORT & \multicolumn{3}{|c|}{ Orthopyroxene associated } & MAG & Magnetite & & & & & \\
\hline $\mathrm{CLI}$ & \multicolumn{3}{|c|}{ Clinopyroxene associated } & ILM & Ilmenite & PLE & Pleonaste & & & \\
\hline
\end{tabular}




\begin{tabular}{|c|c|c|c|c|c|c|c|c|c|c|c|c|}
\hline Sample \# & CC008 & CC008 & CC008 & CC008 & CC008 & CC008 & CC008 & CC008 & CC008 & CC008 & CC008 & CC008 \\
\hline Circle Number & A & A & A & $\mathrm{C}$ & C & $\mathrm{C}$ & $\mathrm{C}$ & $\mathrm{C}$ & $\mathrm{D}$ & $\mathrm{D}$ & $\mathrm{D}$ & $\mathrm{E}$ \\
\hline Mineralization type & MAS & MAS & MAS & MAS & MAS & MAS & MAS & MAS & MAS & MAS & MAS & MAS \\
\hline Descriptor & BAN & BAN & BAN & BAN & BAN & BAN & BAN & BAN & BAN & BAN & BAN & BAN \\
\hline mineral host & ILM & ILM & ILM & ILM & ILM & ILM & MAG & MAG & ILM & ILM & ILM & MAG \\
\hline Mineral analyzed & ILM & ILM & ILM & ILM & ILM & ILM & ILM & ILM & ILM & ILM & ILM & ILM \\
\hline exsolution feature type & host & host & host & host & host & host & in rim & in rim & host & host & host & lens \\
\hline Point & 4 & 5 & 6 & 20 & 21 & 22 & 26 & 27 & 33 & 34 & 35 & 38 \\
\hline $\mathrm{SiO}_{2}$ & 0.00 & 0.01 & 0.00 & 0.01 & 0.00 & 0.01 & 0.00 & 0.00 & 0.01 & 0.00 & 0.00 & 0.03 \\
\hline $\mathrm{TiO}_{2}$ & 50.07 & 48.78 & 49.25 & 50.27 & 49.16 & 50.56 & 52.86 & 52.53 & 49.72 & 48.39 & 49.83 & 51.03 \\
\hline $\mathrm{Al}_{2} \mathrm{O}_{3}$ & 0.02 & 0.02 & 0.02 & 0.04 & 0.01 & 0.03 & 0.02 & 0.02 & 0.03 & 0.03 & 0.03 & 0.89 \\
\hline $\mathrm{Cr}_{2} \mathrm{O}_{3}$ & 0.00 & 0.01 & 0.02 & 0.00 & 0.00 & 0.01 & 0.02 & 0.03 & 0.00 & 0.01 & 0.01 & 0.06 \\
\hline $\mathrm{V}_{2} \mathrm{O}_{3}$ & 0.31 & 0.28 & 0.33 & 0.30 & 0.32 & 0.27 & 0.20 & 0.22 & 0.26 & 0.29 & 0.25 & 0.23 \\
\hline $\mathrm{FeO}^{*}$ & 46.55 & 48.51 & 47.17 & 46.47 & 48.05 & 46.14 & 44.11 & 44.14 & 46.89 & 48.60 & 46.99 & 43.34 \\
\hline $\mathrm{Fe}_{2} \mathrm{O}_{3}$ recalculated & 5.40 & 8.91 & 6.98 & 5.04 & 8.05 & 4.37 & 0.21 & 0.47 & 6.04 & 9.22 & 6.09 & 3.06 \\
\hline FeO recalculated & 41.69 & 40.50 & 40.89 & 41.93 & 40.81 & 42.20 & 43.92 & 43.72 & 41.45 & 40.31 & 41.51 & 40.59 \\
\hline $\mathrm{MnO}$ & 0.79 & 0.74 & 0.80 & 0.76 & 0.79 & 0.76 & 0.98 & 1.04 & 0.79 & 0.77 & 0.81 & 2.96 \\
\hline $\mathrm{MgO}$ & 1.41 & 1.48 & 1.46 & 1.41 & 1.46 & 1.39 & 1.46 & 1.37 & 1.39 & 1.37 & 1.39 & 1.29 \\
\hline $\mathrm{ZnO}$ & 0.03 & 0.00 & 0.00 & 0.00 & 0.00 & 0.01 & 0.04 & 0.03 & 0.00 & 0.00 & 0.01 & 0.05 \\
\hline $\mathrm{NiO}$ & 0.00 & 0.00 & 0.00 & 0.00 & 0.00 & 0.02 & 0.00 & 0.00 & 0.00 & 0.00 & 0.01 & 0.00 \\
\hline $\mathrm{CaO}$ & 0.01 & 0.00 & 0.01 & 0.00 & 0.00 & 0.00 & 0.00 & 0.00 & 0.00 & 0.00 & 0.00 & 0.00 \\
\hline $\mathrm{Cu}_{2} \mathrm{O}$ & 0.00 & 0.00 & 0.00 & 0.00 & 0.01 & 0.01 & 0.00 & 0.01 & 0.00 & 0.00 & 0.00 & 0.00 \\
\hline $\mathrm{K}_{2} \mathrm{O}$ & 0.00 & 0.00 & 0.00 & 0.00 & 0.01 & 0.00 & 0.00 & 0.00 & 0.01 & 0.00 & 0.00 & 0.00 \\
\hline Total measured & 99.19 & 99.84 & 99.04 & 99.27 & 99.82 & 99.21 & 99.69 & 99.41 & 99.09 & 99.48 & 99.33 & 99.88 \\
\hline MAS & \multicolumn{3}{|c|}{$\begin{array}{l}\text { Massive to semi-massive } \\
\text { mineralization }\end{array}$} & OBAN & Orthopyr & xene -bea & ing bands & of oxide $n$ & ineralizatic & & & \\
\hline DIS & \multicolumn{3}{|c|}{ Disseminated mineralization } & POD & Pod of ox & de minera & zation & & & & & \\
\hline BAN & \multicolumn{3}{|c|}{ Bands of oxide mineralization } & OPOD & Orthopyr & xene -bea & ing pod o & oxide mir & eralization & & & \\
\hline ANO & \multicolumn{3}{|c|}{ Anorthosite hosted disseminated } & VEIN & Vein of o & de miner & lization & & & & & \\
\hline ORT & \multicolumn{3}{|c|}{ Orthopyroxene associated } & MAG & Magnetit & & & & & & & \\
\hline $\mathrm{CLI}$ & \multicolumn{3}{|c|}{ Clinopyroxene associated } & ILM & Ilmenite & PLE & \multicolumn{4}{|c|}{ Pleonaste } & & \\
\hline
\end{tabular}




\begin{tabular}{|c|c|c|c|c|c|c|c|c|c|c|c|c|}
\hline Sample \# & CC008 & CC008 & CC008 & CC008 & CC008 & CC008 & CC008 & CC010 & CC010 & CC010 & CC010 & $\mathrm{CCO10}$ \\
\hline Circle Number & $\mathrm{E}$ & $\mathrm{F}$ & $\mathrm{F}$ & $\mathrm{F}$ & 1 & 1 & 1 & A & $\mathrm{C}$ & C & $\mathrm{D}$ & $\mathrm{D}$ \\
\hline Mineralization type & MAS & MAS & MAS & MAS & MAS & MAS & MAS & MAS & MAS & MAS & MAS & MAS \\
\hline Descriptor & BAN & BAN & BAN & BAN & BAN & BAN & BAN & BAN & OBAN & OBAN & OBAN & OBAN \\
\hline mineral host & MAG & MAG & ILM & ILM & ILM & ILM & ILM & PLE & PLE & PLE & ILM & ILM \\
\hline Mineral analyzed & ILM & ILM & ILM & ILM & ILM & ILM & ILM & ILM & ILM & ILM & ILM & ILM \\
\hline exsolution feature type & lens & ig & host & host & host & host & host & lath & lath & lath & Host & Host \\
\hline Point & 39 & 41 & 45 & 46 & 52 & 53 & 54 & 7 & 16 & 17 & 21 & 22 \\
\hline $\mathrm{SiO}_{2}$ & 0.01 & 0.00 & 0.01 & 0.00 & 0.01 & 0.01 & 0.00 & 0.00 & 0.00 & 0.00 & 0.00 & 0.00 \\
\hline $\mathrm{TiO}_{2}$ & 52.16 & 53.28 & 49.69 & 51.41 & 48.96 & 49.18 & 49.48 & 51.75 & 51.62 & 51.49 & 47.45 & 47.15 \\
\hline $\mathrm{Al}_{2} \mathrm{O}_{3}$ & 0.02 & 0.01 & 0.02 & 0.02 & 0.03 & 0.03 & 0.02 & 0.03 & 0.03 & 0.03 & 0.04 & 0.05 \\
\hline $\mathrm{Cr}_{2} \mathrm{O}_{3}$ & 0.04 & 0.00 & 0.00 & 0.01 & 0.01 & 0.01 & 0.02 & 0.02 & 0.02 & 0.02 & 0.02 & 0.01 \\
\hline $\mathrm{V}_{2} \mathrm{O}_{3}$ & 0.25 & 0.22 & 0.31 & 0.25 & 0.33 & 0.31 & 0.30 & 0.20 & 0.21 & 0.19 & 0.32 & 0.34 \\
\hline $\mathrm{FeO}^{*}$ & 42.80 & 44.65 & 47.35 & 45.61 & 48.29 & 47.78 & 48.05 & 44.51 & 46.03 & 45.67 & 49.32 & 49.47 \\
\hline $\mathrm{Fe}_{2} \mathrm{O}_{3}$ recalculated & 2.24 & 1.19 & 6.65 & 3.04 & 8.56 & 7.80 & 7.89 & 2.32 & 3.53 & 3.17 & 11.55 & 12.05 \\
\hline FeO recalculated & 40.79 & 43.58 & 41.36 & 42.88 & 40.58 & 40.76 & 40.95 & 42.42 & 42.86 & 42.82 & 38.93 & 38.62 \\
\hline $\mathrm{MnO}$ & 1.95 & 0.97 & 0.78 & 0.83 & 0.60 & 0.60 & 0.60 & 1.28 & 1.05 & 1.16 & 0.66 & 0.67 \\
\hline $\mathrm{MgO}$ & 2.30 & 1.84 & 1.42 & 1.41 & 1.59 & 1.60 & 1.64 & 1.55 & 1.39 & 1.28 & 1.73 & 1.74 \\
\hline $\mathrm{ZnO}$ & 0.06 & 0.06 & 0.02 & 0.00 & 0.02 & 0.01 & 0.02 & 0.06 & 0.02 & 0.03 & 0.00 & 0.00 \\
\hline $\mathrm{NiO}$ & 0.01 & 0.02 & 0.00 & 0.01 & 0.00 & 0.00 & 0.01 & 0.01 & 0.02 & 0.00 & 0.01 & 0.00 \\
\hline $\mathrm{CaO}$ & 0.00 & 0.01 & 0.00 & 0.01 & 0.00 & 0.00 & 0.00 & 0.00 & 0.00 & 0.00 & 0.00 & 0.00 \\
\hline $\mathrm{Cu}_{2} \mathrm{O}$ & 0.00 & 0.00 & 0.00 & 0.00 & 0.00 & 0.00 & 0.00 & 0.01 & 0.01 & 0.01 & 0.01 & 0.00 \\
\hline $\mathrm{K}_{2} \mathrm{O}$ & 0.00 & 0.01 & 0.00 & 0.00 & 0.00 & 0.00 & 0.00 & 0.00 & 0.00 & 0.00 & 0.00 & 0.00 \\
\hline Total measured & 99.60 & 101.06 & 99.60 & 99.55 & 99.83 & 99.54 & 100.15 & 99.42 & 100.40 & 99.89 & 99.55 & 99.44 \\
\hline MAS & \multicolumn{4}{|c|}{ Massive to semi-massive mineralization } & OBAN & \multicolumn{7}{|c|}{ Orthopyroxene -bearing bands of oxide mineralization } \\
\hline DIS & \multicolumn{4}{|c|}{ Disseminated mineralization } & POD & \multicolumn{7}{|c|}{ Pod of oxide mineralization } \\
\hline BAN & \multicolumn{4}{|c|}{ Bands of oxide mineralization } & OPOD & \multicolumn{7}{|c|}{ Orthopyroxene -bearing pod of oxide mineralization } \\
\hline ANO & \multicolumn{4}{|c|}{ Anorthosite hosted disseminated } & VEIN & \multicolumn{7}{|c|}{ Vein of oxide mineralization } \\
\hline ORT & \multicolumn{4}{|c|}{ Orthopyroxene associated } & MAG & \multicolumn{7}{|c|}{ Magnetite } \\
\hline $\mathrm{CLI}$ & \multicolumn{4}{|c|}{ Clinopyroxene associated } & ILM & Ilmenite & PLE & \multicolumn{5}{|c|}{ Pleonaste } \\
\hline
\end{tabular}




\begin{tabular}{|c|c|c|c|c|c|c|c|c|}
\hline Sample \# & CC010 & CC010 & CC010 & CC010 & CC010 & CC010 & CC010 & CC010 \\
\hline Circle Number & D & D & $\mathrm{E}$ & $\mathrm{E}$ & $E$ & $E$ & $E$ & $E$ \\
\hline Mineralization type & MAS & MAS & MAS & MAS & MAS & MAS & MAS & MAS \\
\hline Descriptor & OBAN & OBAN & OBAN & OBAN & OBAN & OBAN & OBAN & OBAN \\
\hline mineral host & ILM & ILM & MAG & MAG & MAG & MAG & MAG & MAG \\
\hline Mineral analyzed & ILM & ILM & ILM & ILM & ILM & $\begin{array}{l}\text { ILM } \\
\text { rim around }\end{array}$ & ILM & ILM \\
\hline exsolution feature type & Host & rim & Sandwich & Sandwich & Sandwich & sandwich & Composite & Composite \\
\hline Point & 23 & 26 & 28 & 29 & 30 & 31 & 32 & 33 \\
\hline $\mathrm{SiO}_{2}$ & 0.01 & 0.00 & 0.00 & 0.00 & 0.00 & 0.01 & 0.01 & 0.01 \\
\hline $\mathrm{TiO}_{2}$ & 49.09 & 51.82 & 51.00 & 51.91 & 50.74 & 53.07 & 49.41 & 51.61 \\
\hline $\mathrm{Al}_{2} \mathrm{O}_{3}$ & 0.03 & 0.03 & 0.03 & 0.02 & 0.03 & 0.02 & 0.03 & 0.03 \\
\hline $\mathrm{Cr}_{2} \mathrm{O}_{3}$ & 0.01 & 0.01 & 0.01 & 0.01 & 0.01 & 0.02 & 0.02 & 0.02 \\
\hline $\mathrm{V}_{2} \mathrm{O}_{3}$ & 0.33 & 0.23 & 0.26 & 0.23 & 0.26 & 0.17 & 0.29 & 0.24 \\
\hline $\mathrm{FeO} *$ & 48.18 & 45.56 & 46.53 & 45.23 & 46.43 & 42.61 & 47.61 & 45.86 \\
\hline $\mathrm{Fe}_{2} \mathrm{O}_{3}$ recalculated & 8.77 & 3.39 & 5.03 & 2.95 & 5.17 & -0.78 & 7.66 & 3.80 \\
\hline FeO recalculated & 40.29 & 42.51 & 42.01 & 42.57 & 41.78 & 43.31 & 40.72 & 42.44 \\
\hline $\mathrm{MnO}$ & 0.70 & 0.85 & 0.96 & 1.07 & 0.95 & 2.81 & 0.90 & 1.00 \\
\hline MgO & 1.77 & 1.79 & 1.60 & 1.68 & 1.60 & 0.87 & 1.56 & 1.66 \\
\hline $\mathrm{ZnO}$ & 0.01 & 0.05 & 0.02 & 0.03 & 0.04 & 0.04 & 0.03 & 0.01 \\
\hline $\mathrm{NiO}$ & 0.00 & 0.00 & 0.01 & 0.01 & 0.02 & 0.00 & 0.00 & 0.01 \\
\hline $\mathrm{CaO}$ & 0.00 & 0.01 & 0.00 & 0.00 & 0.00 & 0.00 & 0.00 & 0.00 \\
\hline $\mathrm{Cu}_{2} \mathrm{O}$ & 0.00 & 0.02 & 0.00 & 0.00 & 0.01 & 0.00 & 0.00 & 0.00 \\
\hline $\mathrm{K}_{2} \mathrm{O}$ & 0.00 & 0.00 & 0.01 & 0.00 & 0.00 & 0.00 & 0.00 & 0.00 \\
\hline Total measured & 100.12 & 100.35 & 100.45 & 100.19 & 100.09 & 99.62 & 99.88 & 100.45 \\
\hline MAS & \multicolumn{3}{|c|}{$\begin{array}{l}\text { Massive to semi-massive } \\
\text { mineralization }\end{array}$} & OBAN & \multicolumn{4}{|c|}{ Orthopyroxene -bearing bands of oxide mineralization } \\
\hline DIS & \multicolumn{3}{|c|}{ Disseminated mineralization } & POD & \multicolumn{4}{|c|}{ Pod of oxide mineralization } \\
\hline BAN & \multicolumn{3}{|c|}{ Bands of oxide mineralization } & OPOD & \multicolumn{4}{|c|}{ Orthopyroxene -bearing pod of oxide mineralization } \\
\hline ANO & \multicolumn{3}{|c|}{ Anorthosite hosted disseminated } & VEIN & \multicolumn{4}{|c|}{ Vein of oxide mineralization } \\
\hline ORT & \multicolumn{3}{|c|}{ Orthopyroxene associated } & MAG & Magnetite & & & \\
\hline $\mathrm{CLI}$ & \multicolumn{3}{|c|}{ Clinopyroxene associated } & ILM & Ilmenite & PLE & Pleonaste & PLE \\
\hline
\end{tabular}




\section{Appendix IV a. (Continued)}

\begin{tabular}{|c|c|c|c|c|c|c|c|c|}
\hline Sample \# & CC010 & CC010 & CC010 & CC010 & CC010 & CC010 & CC010 & CC010 \\
\hline Circle Number & $\mathrm{E}$ & $\mathrm{F}$ & $\mathrm{F}$ & $\mathrm{F}$ & I & I & 1 & $\mathrm{H}$ \\
\hline Mineralization type & MAS & MAS & MAS & MAS & MAS & MAS & MAS & MAS \\
\hline Descriptor & OBAN & OBAN & OBAN & OBAN & OBAN & OBAN & OBAN & OBAN \\
\hline mineral host & MAG & ILM & ILM & ILM & MAG & MAG & MAG & MAG \\
\hline Mineral analyzed & ILM & ILM & ILM & ILM & ILM & ILM & ILM & ILM \\
\hline exsolution feature type & Composite & Host & Host & Host & Composite & Composite & Composite & Composite \\
\hline Point & 34 & 41 & 42 & 43 & 51 & 52 & 53 & 54 \\
\hline $\mathrm{SiO}_{2}$ & 0.00 & 0.00 & 0.00 & 0.01 & 0.00 & 0.00 & 0.00 & 0.01 \\
\hline $\mathrm{TiO}_{2}$ & 49.53 & 49.70 & 49.71 & 48.08 & 51.42 & 49.91 & 53.36 & 51.63 \\
\hline $\mathrm{Al}_{2} \mathrm{O}_{3}$ & 0.05 & 0.03 & 0.04 & 0.04 & 0.03 & 0.03 & 0.00 & 0.02 \\
\hline $\mathrm{Cr}_{2} \mathrm{O}_{3}$ & 0.02 & 0.01 & 0.02 & 0.03 & 0.02 & 0.02 & 0.01 & 0.01 \\
\hline $\mathrm{V}_{2} \mathrm{O}_{3}$ & 0.30 & 0.29 & 0.29 & 0.31 & 0.21 & 0.27 & 0.21 & 0.22 \\
\hline $\mathrm{FeO}^{*}$ & 47.61 & 47.19 & 47.00 & 48.48 & 45.75 & 47.13 & 42.74 & 45.42 \\
\hline $\mathrm{Fe}_{2} \mathrm{O}_{3}$ recalculated & 7.60 & 6.93 & 6.74 & 9.94 & 3.88 & 6.68 & -2.23 & 3.35 \\
\hline FeO recalculated & 40.77 & 40.95 & 40.94 & 39.53 & 42.26 & 41.11 & 44.75 & 42.40 \\
\hline $\mathrm{MnO}$ & 0.91 & 0.93 & 0.93 & 0.87 & 0.88 & 0.83 & 2.48 & 1.00 \\
\hline $\mathrm{MgO}$ & 1.59 & 1.57 & 1.58 & 1.60 & 1.72 & 1.64 & 0.39 & 1.68 \\
\hline $\mathrm{ZnO}$ & 0.03 & 0.00 & 0.00 & 0.00 & 0.03 & 0.00 & 0.04 & 0.04 \\
\hline $\mathrm{NiO}$ & 0.00 & 0.00 & 0.01 & 0.00 & 0.01 & 0.01 & 0.00 & 0.00 \\
\hline $\mathrm{CaO}$ & 0.00 & 0.00 & 0.00 & 0.00 & 0.00 & 0.01 & 0.00 & 0.00 \\
\hline $\mathrm{Cu}_{2} \mathrm{O}$ & 0.00 & 0.00 & 0.00 & 0.00 & 0.02 & 0.00 & 0.00 & 0.00 \\
\hline $\mathrm{K}_{2} \mathrm{O}$ & 0.00 & 0.01 & 0.00 & 0.00 & 0.00 & 0.00 & 0.00 & 0.00 \\
\hline Total measured & 100.04 & 99.74 & 99.58 & 99.41 & 100.09 & 99.86 & 99.24 & 100.03 \\
\hline MAS & \multicolumn{3}{|c|}{ Massive to semi-massive mineralization } & OBAN & \multicolumn{4}{|c|}{ Orthopyroxene -bearing bands of oxide mineralization } \\
\hline DIS & \multicolumn{3}{|c|}{ Disseminated mineralization } & POD & \multicolumn{4}{|c|}{ Pod of oxide mineralization } \\
\hline BAN & \multicolumn{3}{|c|}{ Bands of oxide mineralization } & OPOD & \multicolumn{4}{|c|}{ Orthopyroxene -bearing pod of oxide mineralization } \\
\hline ANO & \multicolumn{3}{|c|}{ Anorthosite hosted disseminated } & VEIN & \multicolumn{4}{|c|}{ Vein of oxide mineralization } \\
\hline ORT & \multicolumn{3}{|c|}{ Orthopyroxene associated } & MAG & Magnetite & & & \\
\hline $\mathrm{CLI}$ & \multicolumn{3}{|c|}{ Clinopyroxene associated } & ILM & Ilmenite & PLE & Pleonaste & \\
\hline
\end{tabular}




\begin{tabular}{|c|c|c|c|c|c|c|c|c|c|}
\hline Sample \# & CC010 & CC010 & CC010 & CC010 & CC010 & cC010 & CC010 & CC010 & CC010 \\
\hline Circle Number & $\mathrm{H}$ & $\mathrm{H}$ & L & $\mathrm{L}$ & $\mathrm{L}$ & L & M & M & M \\
\hline Mineralization type & MAS & MAS & MAS & MAS & MAS & MAS & MAS & MAS & MAS \\
\hline Descriptor & OBAN & OBAN & OBAN & OBAN & OBAN & OBAN & OBAN & OBAN & OBAN \\
\hline mineral host & MAG & MAG & ILM & ILM & Opx & Opx & MAG & MAG & MAG \\
\hline Mineral analyzed & ILM & ILM & ILM & ILM & ILM & ILM & ILM & ILM & ILM \\
\hline exsolution feature type & Composite & Composite & Host & Host & Granule & Granule & Sandwich & Sandwich & Sandwich \\
\hline Point & 55 & 56 & 62 & 63 & 65 & 66 & 69 & 70 & 71 \\
\hline $\mathrm{SiO}_{2}$ & 0.00 & 0.00 & 0.01 & 0.00 & 0.05 & 0.03 & 0.00 & 0.00 & 0.00 \\
\hline $\mathrm{TiO}_{2}$ & 49.64 & 51.63 & 48.03 & 47.60 & 49.65 & 51.02 & 51.86 & 51.30 & 51.32 \\
\hline $\mathrm{Al}_{2} \mathrm{O}_{3}$ & 0.05 & 0.03 & 0.04 & 0.03 & 0.02 & 0.03 & 0.02 & 0.02 & 0.02 \\
\hline $\mathrm{Cr}_{2} \mathrm{O}_{3}$ & 0.02 & 0.01 & 0.01 & 0.01 & 0.04 & 0.03 & 0.01 & 0.00 & 0.01 \\
\hline $\mathrm{V}_{2} \mathrm{O}_{3}$ & 0.29 & 0.22 & 0.28 & 0.29 & 0.34 & 0.36 & 0.22 & 0.25 & 0.24 \\
\hline $\mathrm{FeO}^{*}$ & 47.12 & 45.57 & 48.87 & 48.72 & 44.75 & 44.14 & 45.23 & 45.56 & 45.44 \\
\hline $\mathrm{Fe}_{2} \mathrm{O}_{3}$ recalculated & 6.96 & 3.48 & 10.59 & 10.78 & 4.01 & 2.07 & 2.73 & 3.66 & 3.43 \\
\hline FeO recalculated & 40.86 & 42.44 & 39.34 & 39.02 & 41.14 & 42.28 & 42.77 & 42.27 & 42.35 \\
\hline $\mathrm{MnO}$ & 0.91 & 0.99 & 0.63 & 0.59 & 0.57 & 0.80 & 1.09 & 1.08 & 1.09 \\
\hline $\mathrm{MgO}$ & 1.60 & 1.67 & 1.80 & 1.79 & 1.62 & 1.46 & 1.52 & 1.54 & 1.52 \\
\hline $\mathrm{ZnO}$ & 0.02 & 0.01 & 0.00 & 0.00 & 0.03 & 0.05 & 0.03 & 0.03 & 0.00 \\
\hline $\mathrm{NiO}$ & 0.00 & 0.01 & 0.01 & 0.01 & 0.01 & 0.00 & 0.01 & 0.00 & 0.00 \\
\hline $\mathrm{CaO}$ & 0.00 & 0.00 & 0.01 & 0.00 & 0.06 & 0.14 & 0.01 & 0.01 & 0.00 \\
\hline $\mathrm{Cu}_{2} \mathrm{O}$ & 0.00 & 0.01 & 0.01 & 0.01 & 0.00 & 0.00 & 0.00 & 0.00 & 0.00 \\
\hline $\mathrm{K}_{2} \mathrm{O}$ & 0.00 & 0.00 & 0.00 & 0.00 & 0.00 & 0.00 & 0.00 & 0.00 & 0.00 \\
\hline Total measured & 99.64 & 100.16 & 99.69 & 99.07 & 97.13 & 98.06 & 100.01 & 99.79 & 99.64 \\
\hline MAS & \multicolumn{3}{|c|}{ Massive to semi-massive mineralization } & OBAN & \multicolumn{5}{|c|}{ Orthopyroxene -bearing bands of oxide mineralization } \\
\hline DIS & \multicolumn{3}{|c|}{ Disseminated mineralization } & POD & \multicolumn{5}{|c|}{ Pod of oxide mineralization } \\
\hline BAN & \multicolumn{3}{|c|}{ Bands of oxide mineralization } & OPOD & \multicolumn{5}{|c|}{ Orthopyroxene -bearing pod of oxide mineralization } \\
\hline ANO & \multicolumn{3}{|c|}{ Anorthosite hosted disseminated } & VEIN & \multicolumn{5}{|c|}{ Vein of oxide mineralization } \\
\hline ORT & \multicolumn{3}{|c|}{ Orthopyroxene associated } & MAG & Magnetite & & & & \\
\hline $\mathrm{CLI}$ & \multicolumn{3}{|c|}{ Clinopyroxene associated } & ILM & Ilmenite & PLE & Pleonaste & & \\
\hline
\end{tabular}




\begin{tabular}{|c|c|c|c|c|c|c|c|c|c|c|}
\hline Sample \# & cC010 & CC010 & $\mathrm{CCO10}$ & CC010 & CC010 & CC010 & CC010 & CC013A & CC013A & CC013A \\
\hline Circle Number & $\mathrm{M}$ & M & $\mathrm{M}$ & M & M & $\mathrm{O}$ & $\mathrm{O}$ & A & A & A \\
\hline Mineralization type & MAS & MAS & MAS & MAS & MAS & MAS & MAS & MAS & MAS & MAS \\
\hline Descriptor & OBAN & OBAN & OBAN & OBAN & OBAN & OBAN & OBAN & BAN & BAN & BAN \\
\hline mineral host & MAG & ILM & ILM & MAG & MAG & MAG & MAG & MAG & MAG & MAG \\
\hline Mineral analyzed & ILM & PLE & PLE & PLE & PLE & ILM & ILM & ILM & ILM & ILM \\
\hline exsolution feature type & Sandwich & Cap & Cap & granule & granule & Sandwich & Sandwich & Sandwich & Sandwich & Sandwich \\
\hline Point & 72 & 73 & 74 & 75 & 76 & 77 & 79 & 1 & 2 & 3 \\
\hline $\mathrm{SiO}_{2}$ & 0.01 & 0.00 & 0.02 & 0.00 & 0.09 & 0.00 & 0.00 & 0.01 & 0.00 & 0.00 \\
\hline $\mathrm{TiO}_{2}$ & 53.06 & 0.00 & 0.01 & 0.17 & 0.03 & 51.37 & 51.89 & 51.53 & 50.75 & 51.09 \\
\hline $\mathrm{Al}_{2} \mathrm{O}_{3}$ & 0.02 & 60.61 & 60.05 & 60.89 & 61.97 & 0.03 & 0.02 & 0.03 & 0.03 & 0.03 \\
\hline $\mathrm{Cr}_{2} \mathrm{O}_{3}$ & 0.01 & 0.34 & 0.33 & 0.43 & 0.34 & 0.02 & 0.03 & 0.02 & 0.02 & 0.03 \\
\hline $\mathrm{V}_{2} \mathrm{O}_{3}$ & 0.19 & 0.08 & 0.08 & 0.06 & 0.06 & 0.24 & 0.21 & 0.26 & 0.32 & 0.32 \\
\hline $\mathrm{FeO}^{*}$ & 43.23 & 25.16 & 25.83 & 24.45 & 24.09 & 45.72 & 45.27 & 45.83 & 47.07 & 46.35 \\
\hline $\mathrm{Fe}_{2} \mathrm{O}_{3}$ recalculated & 0.10 & 4.24 & 4.65 & 3.59 & 2.79 & 3.85 & 3.04 & 3.58 & 4.86 & 4.62 \\
\hline FeO recalculated & 43.14 & 21.34 & 21.64 & 21.22 & 21.58 & 42.26 & 42.53 & 42.61 & 42.70 & 42.19 \\
\hline $\mathrm{MnO}$ & 1.63 & 0.20 & 0.22 & 0.23 & 0.25 & 1.06 & 1.10 & 0.80 & 0.81 & 0.85 \\
\hline $\mathrm{MgO}$ & 1.64 & 12.76 & 12.49 & 12.98 & 13.06 & 1.61 & 1.68 & 1.63 & 1.19 & 1.61 \\
\hline $\mathrm{ZnO}$ & 0.03 & 0.47 & 0.50 & 0.43 & 0.23 & 0.00 & 0.03 & 0.02 & 0.00 & 0.03 \\
\hline $\mathrm{NiO}$ & 0.00 & 0.11 & 0.09 & 0.09 & 0.09 & 0.01 & 0.01 & 0.00 & 0.00 & 0.00 \\
\hline $\mathrm{CaO}$ & 0.00 & 0.01 & 0.00 & 0.01 & 0.00 & 0.00 & 0.00 & 0.01 & 0.00 & 0.00 \\
\hline $\mathrm{Cu}_{2} \mathrm{O}$ & 0.00 & 0.00 & 0.00 & 0.01 & 0.01 & 0.00 & 0.01 & 0.00 & 0.02 & 0.00 \\
\hline $\mathrm{K}_{2} \mathrm{O}$ & 0.00 & 0.01 & 0.00 & 0.00 & 0.00 & 0.00 & 0.00 & 0.00 & 0.01 & 0.00 \\
\hline Total measured & 99.82 & 99.75 & 99.61 & 99.75 & 100.22 & 100.06 & 100.25 & 100.14 & 100.21 & 100.32 \\
\hline MAS & \multicolumn{3}{|c|}{$\begin{array}{l}\text { Massive to semi-massive } \\
\text { mineralization }\end{array}$} & OBAN & Orthopyro & ne -bearing & nds of oxide $n$ & eralization & & \\
\hline DIS & \multicolumn{3}{|c|}{ Disseminated mineralization } & POD & Pod of oxi & mineralizatic & & & & \\
\hline BAN & \multicolumn{3}{|c|}{ Bands of oxide mineralization } & OPOD & \multicolumn{4}{|c|}{ Orthopyroxene -bearing pod of oxide mineralization } & & \\
\hline ANO & \multicolumn{3}{|c|}{ Anorthosite hosted disseminated } & VEIN & \multicolumn{4}{|c|}{ Vein of oxide mineralization } & & \\
\hline ORT & \multicolumn{3}{|c|}{ Orthopyroxene associated } & MAG & Magnetite & & & & & \\
\hline $\mathrm{CLI}$ & \multicolumn{3}{|c|}{ Clinopyroxene associated } & ILM & Ilmenite & PLE & Pleonaste & & & \\
\hline
\end{tabular}




\begin{tabular}{|c|c|c|c|c|c|c|c|c|c|}
\hline Sample \# & CC013A & CC013A & CC013A & CC013A & CC013A & CC013A & CC013A & CC013A & CC013A \\
\hline Circle Number & A & $\mathrm{A}$ & $\mathrm{A}$ & $\mathrm{B}$ & $\mathrm{B}$ & $\mathrm{B}$ & $\mathrm{C}$ & $\mathrm{C}$ & $\mathrm{D}$ \\
\hline Mineralization type & MAS & MAS & MAS & MAS & MAS & MAS & MAS & MAS & MAS \\
\hline Descriptor & BAN & BAN & BAN & BAN & BAN & BAN & BAN & BAN & BAN \\
\hline mineral host & MAG & MAG & MAG & ILM & ILM & ILM & MAG & MAG & ILM \\
\hline Mineral analyzed & ILM & ILM & ILM & ILM & ILM & ILM & ILM & ILM & MAG \\
\hline exsolution feature type & Composite & Composite & Composite & Host & Host & Host & Sandwich & Sandwich & thick lam \\
\hline Point & 4 & 5 & 6 & 15 & 16 & 17 & 22 & 23 & 30 \\
\hline $\mathrm{SiO}_{2}$ & 0.01 & 0.00 & 0.01 & 0.00 & 0.00 & 0.00 & 0.01 & 0.01 & 0.00 \\
\hline $\mathrm{TiO}_{2}$ & 49.68 & 49.73 & 49.91 & 49.11 & 49.20 & 49.10 & 50.99 & 50.87 & 49.46 \\
\hline $\mathrm{Al}_{2} \mathrm{O}_{3}$ & 0.03 & 0.02 & 0.02 & 0.03 & 0.01 & 0.03 & 0.02 & 0.03 & 0.03 \\
\hline $\mathrm{Cr}_{2} \mathrm{O}_{3}$ & 0.02 & 0.02 & 0.02 & 0.01 & 0.00 & 0.03 & 0.03 & 0.03 & 0.02 \\
\hline $\mathrm{V}_{2} \mathrm{O}_{3}$ & 0.33 & 0.32 & 0.32 & 0.35 & 0.32 & 0.33 & 0.30 & 0.31 & 0.29 \\
\hline $\mathrm{FeO}^{*}$ & 47.67 & 47.38 & 47.30 & 47.97 & 47.66 & 48.18 & 46.32 & 46.65 & 47.76 \\
\hline $\mathrm{Fe}_{2} \mathrm{O}_{3}$ recalculated & 7.43 & 6.99 & 6.84 & 8.22 & 7.85 & 8.51 & 4.62 & 5.14 & 67.96 \\
\hline FeO recalculated & 40.99 & 41.09 & 41.14 & 40.57 & 40.60 & 40.52 & 42.16 & 42.03 & 31.69 \\
\hline $\mathrm{MnO}$ & 0.77 & 0.72 & 0.75 & 0.75 & 0.73 & 0.71 & 0.88 & 0.88 & 0.69 \\
\hline $\mathrm{MgO}$ & 1.64 & 1.62 & 1.68 & 1.59 & 1.63 & 1.63 & 1.57 & 1.59 & 1.65 \\
\hline $\mathrm{ZnO}$ & 0.01 & 0.02 & 0.00 & 0.00 & 0.01 & 0.02 & 0.01 & 0.01 & 0.00 \\
\hline $\mathrm{NiO}$ & 0.00 & 0.01 & 0.00 & 0.00 & 0.00 & 0.00 & 0.01 & 0.00 & 0.00 \\
\hline $\mathrm{CaO}$ & 0.00 & 0.00 & 0.00 & 0.00 & 0.00 & 0.00 & 0.00 & 0.00 & 0.00 \\
\hline $\mathrm{Cu}_{2} \mathrm{O}$ & 0.00 & 0.00 & 0.00 & 0.00 & 0.00 & 0.00 & 0.00 & 0.02 & 0.01 \\
\hline $\mathrm{K}_{2} \mathrm{O}$ & 0.00 & 0.01 & 0.01 & 0.00 & 0.00 & 0.00 & 0.00 & 0.00 & 0.01 \\
\hline Total measured & 100.15 & 99.85 & 100.02 & 99.83 & 99.56 & 100.04 & 100.13 & 100.40 & 99.91 \\
\hline MAS & \multicolumn{3}{|c|}{ Massive to semi-massive mineralization } & OBAN & \multicolumn{5}{|c|}{ Orthopyroxene -bearing bands of oxide mineralization } \\
\hline DIS & \multicolumn{3}{|c|}{ Disseminated mineralization } & POD & \multicolumn{5}{|c|}{ Pod of oxide mineralization } \\
\hline BAN & \multicolumn{3}{|c|}{ Bands of oxide mineralization } & OPOD & \multicolumn{5}{|c|}{ Orthopyroxene -bearing pod of oxide mineralization } \\
\hline ANO & \multicolumn{3}{|c|}{ Anorthosite hosted disseminated } & VEIN & \multicolumn{5}{|c|}{ Vein of oxide mineralization } \\
\hline ORT & \multicolumn{3}{|c|}{ Orthopyroxene associated } & MAG & \multicolumn{5}{|c|}{ Magnetite } \\
\hline $\mathrm{CLI}$ & \multicolumn{3}{|c|}{ Clinopyroxene associated } & ILM & IImenite & PLE & Pleonaste & & \\
\hline
\end{tabular}




\begin{tabular}{|c|c|c|c|c|c|c|c|c|c|}
\hline Sample \# & CC013A & CC013A & CC013A & CC013A & CC013A & CC013A & CC013A & CC013A & CC013A \\
\hline Circle Number & $\mathrm{D}$ & $\mathrm{E}$ & $\mathrm{E}$ & $\mathrm{E}$ & I & I & 1 & $\mathrm{~L}$ & $\mathrm{~L}$ \\
\hline Mineralization type & MAS & MAS & MAS & MAS & MAS & MAS & MAS & MAS & MAS \\
\hline Descriptor & BAN & BAN & BAN & BAN & BAN & BAN & BAN & BAN & BAN \\
\hline mineral host & ILM & ILM & ILM & ILM & ILM & ILM & ILM & ILM & ILM \\
\hline Mineral analyzed & ILM & ILM & ILM & ILM & ILM & ILM & ILM & ILM & ILM \\
\hline exsolution feature type & Host & Host & Host & Host & Host & Host & Host & Composite & Composite \\
\hline Point & 32 & 34 & 35 & 36 & 43 & 44 & 45 & 49 & 51 \\
\hline $\mathrm{SiO}_{2}$ & 0.00 & 0.00 & 0.00 & 0.00 & 0.01 & 0.01 & 0.00 & 0.02 & 0.01 \\
\hline $\mathrm{TiO}_{2}$ & 48.00 & 49.36 & 48.99 & 49.41 & 48.50 & 49.02 & 49.49 & 50.70 & 51.26 \\
\hline $\mathrm{Al}_{2} \mathrm{O}_{3}$ & 0.02 & 0.02 & 0.02 & 0.03 & 0.03 & 0.03 & 0.03 & 0.02 & 0.01 \\
\hline $\mathrm{Cr}_{2} \mathrm{O}_{3}$ & 0.01 & 0.02 & 0.02 & 0.01 & 0.01 & 0.02 & 0.01 & 0.01 & 0.01 \\
\hline $\mathrm{V}_{2} \mathrm{O}_{3}$ & 0.30 & 0.28 & 0.27 & 0.28 & 0.31 & 0.34 & 0.33 & 0.31 & 0.29 \\
\hline $\mathrm{FeO}^{*}$ & 48.98 & 47.40 & 47.91 & 48.19 & 48.67 & 48.71 & 47.78 & 46.40 & 46.02 \\
\hline $\mathrm{Fe}_{2} \mathrm{O}_{3}$ recalculated & 8.86 & 7.55 & 8.26 & 8.30 & 9.63 & 9.12 & 7.64 & 4.90 & 3.98 \\
\hline FeO recalculated & 40.32 & 40.61 & 40.47 & 40.72 & 40.00 & 40.50 & 40.91 & 41.99 & 42.44 \\
\hline $\mathrm{MnO}$ & 0.69 & 0.71 & 0.70 & 0.78 & 0.71 & 0.68 & 0.70 & 0.78 & 0.85 \\
\hline $\mathrm{MgO}$ & 1.63 & 1.71 & 1.60 & 1.63 & 1.63 & 1.63 & 1.61 & 1.59 & 1.58 \\
\hline $\mathrm{ZnO}$ & 0.03 & 0.00 & 0.01 & 0.01 & 0.01 & 0.00 & 0.00 & 0.00 & 0.00 \\
\hline $\mathrm{NiO}$ & 0.01 & 0.02 & 0.01 & 0.01 & 0.01 & 0.00 & 0.00 & 0.00 & 0.00 \\
\hline $\mathrm{CaO}$ & 0.00 & 0.00 & 0.00 & 0.01 & 0.00 & 0.00 & 0.01 & 0.00 & 0.00 \\
\hline $\mathrm{Cu}_{2} \mathrm{O}$ & 0.01 & 0.00 & 0.00 & 0.00 & 0.02 & 0.01 & 0.01 & 0.00 & 0.00 \\
\hline $\mathrm{K}_{2} \mathrm{O}$ & 0.00 & 0.01 & 0.01 & 0.01 & 0.00 & 0.00 & 0.00 & 0.01 & 0.01 \\
\hline Total measured & 99.69 & 99.53 & 99.54 & 100.36 & 99.89 & 100.46 & 99.99 & 99.84 & 100.04 \\
\hline MAS & \multicolumn{3}{|c|}{ Massive to semi-massive mineralization } & OBAN & \multicolumn{5}{|c|}{ Orthopyroxene -bearing bands of oxide mineralization } \\
\hline DIS & \multicolumn{3}{|c|}{ Disseminated mineralization } & POD & \multicolumn{5}{|c|}{ Pod of oxide mineralization } \\
\hline BAN & \multicolumn{3}{|c|}{ Bands of oxide mineralization } & OPOD & \multicolumn{5}{|c|}{ Orthopyroxene -bearing pod of oxide mineralization } \\
\hline ANO & \multicolumn{3}{|c|}{ Anorthosite hosted disseminated } & VEIN & \multicolumn{5}{|c|}{ Vein of oxide mineralization } \\
\hline ORT & \multicolumn{3}{|c|}{ Orthopyroxene associated } & MAG & \multicolumn{5}{|l|}{ Magnetite } \\
\hline $\mathrm{CLI}$ & \multicolumn{3}{|c|}{ Clinopyroxene associated } & ILM & IImenite & PLE & Pleonaste & & \\
\hline
\end{tabular}




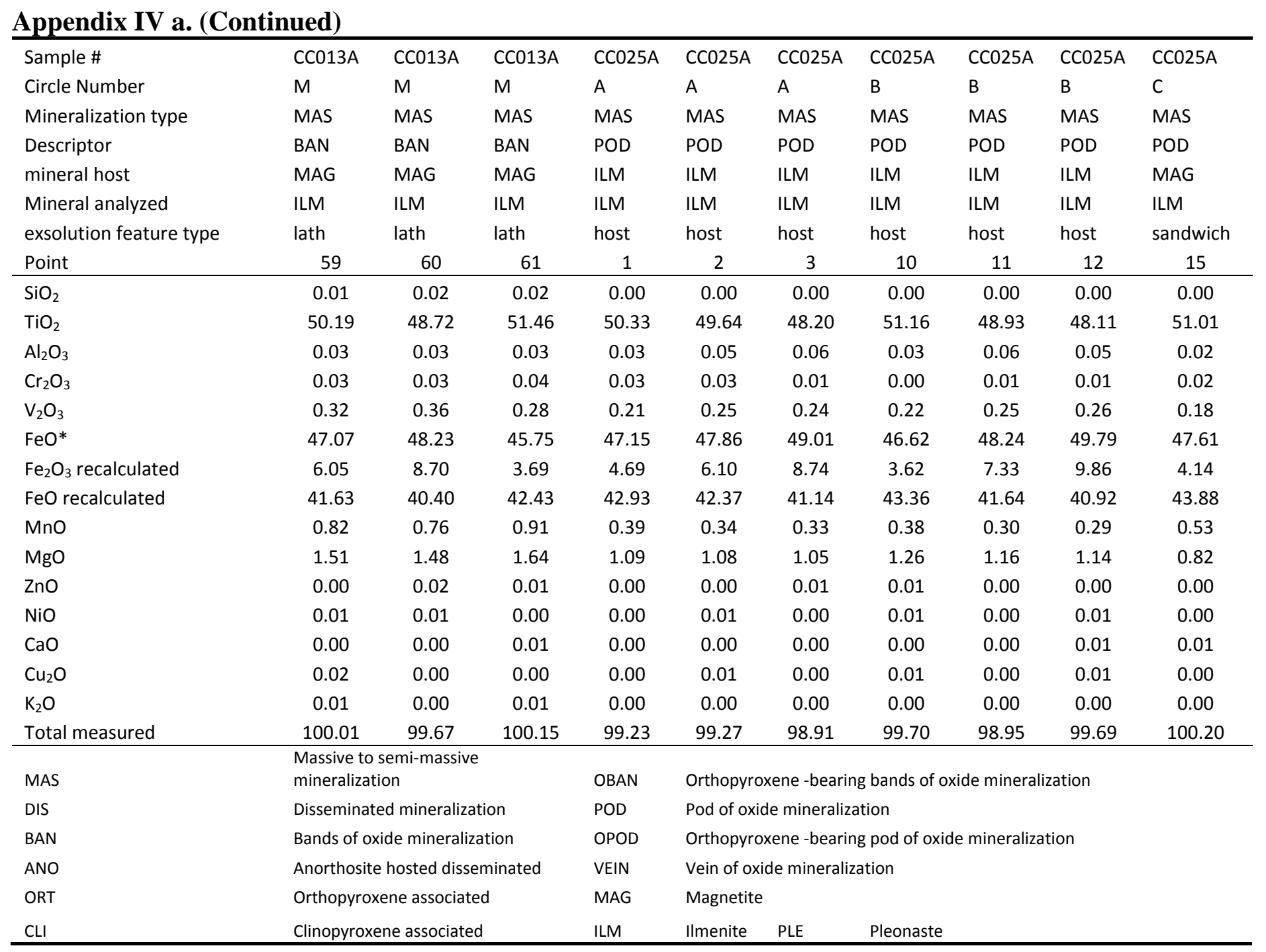




\begin{tabular}{|c|c|c|c|c|c|c|c|c|c|}
\hline Sample \# & CCO25A & CCO25A & CCO25A & CCO25A & CCO25A & CCO25A & CC025A & CCO25A & CCO25A \\
\hline Circle Number & $\mathrm{C}$ & $\mathrm{C}$ & $\mathrm{C}$ & $\mathrm{D}$ & $\mathrm{D}$ & $\mathrm{D}$ & $\mathrm{D}$ & $\mathrm{D}$ & D \\
\hline Mineralization type & MAS & MAS & MAS & MAS & MAS & MAS & MAS & MAS & MAS \\
\hline Descriptor & POD & POD & POD & POD & POD & POD & POD & POD & POD \\
\hline mineral host & MAG & MAG & MAG & MAG & MAG & MAG & MAG & MAG & MAG \\
\hline Mineral analyzed & ILM & ILM & ILM & ILM & ILM & ILM & ILM & ILM & ILM \\
\hline exsolution feature type & sandwich & thin ig & thin ig & composite & composite & composite & thick ig & thick ig & thick ig \\
\hline Point & 16 & 18 & 19 & 23 & 24 & 25 & 26 & 27 & 28 \\
\hline $\mathrm{SiO}_{2}$ & 0.00 & 0.01 & 0.01 & 0.00 & 0.00 & 0.01 & 0.01 & 0.02 & 0.02 \\
\hline $\mathrm{TiO}_{2}$ & 50.62 & 52.60 & 52.85 & 51.02 & 50.95 & 50.26 & 52.23 & 52.33 & 44.97 \\
\hline $\mathrm{Al}_{2} \mathrm{O}_{3}$ & 0.03 & 0.01 & 0.01 & 0.01 & 0.03 & 0.04 & 0.07 & 0.09 & 5.82 \\
\hline $\mathrm{Cr}_{2} \mathrm{O}_{3}$ & 0.03 & 0.03 & 0.03 & 0.01 & 0.02 & 0.04 & 0.03 & 0.05 & 0.20 \\
\hline $\mathrm{V}_{2} \mathrm{O}_{3}$ & 0.18 & 0.16 & 0.14 & 0.18 & 0.18 & 0.19 & 0.19 & 0.15 & 0.16 \\
\hline $\mathrm{FeO}^{*}$ & 47.40 & 45.42 & 44.97 & 46.82 & 47.34 & 48.11 & 45.87 & 45.42 & 43.73 \\
\hline $\mathrm{Fe}_{2} \mathrm{O}_{3}$ recalculated & 4.21 & 0.09 & -0.57 & 3.35 & 3.96 & 5.38 & 0.84 & 0.26 & 6.65 \\
\hline FeO recalculated & 43.61 & 45.34 & 45.49 & 43.81 & 43.77 & 43.27 & 45.12 & 45.18 & 37.74 \\
\hline $\mathrm{MnO}$ & 0.53 & 0.63 & 0.65 & 0.48 & 0.49 & 0.46 & 0.77 & 0.79 & 0.68 \\
\hline $\mathrm{MgO}$ & 0.77 & 0.75 & 0.77 & 0.90 & 0.87 & 0.83 & 0.60 & 0.60 & 1.11 \\
\hline $\mathrm{ZnO}$ & 0.00 & 0.00 & 0.02 & 0.00 & 0.00 & 0.00 & 0.00 & 0.02 & 0.06 \\
\hline $\mathrm{NiO}$ & 0.01 & 0.01 & 0.00 & 0.00 & 0.01 & 0.00 & 0.01 & 0.01 & 0.01 \\
\hline $\mathrm{CaO}$ & 0.00 & 0.01 & 0.00 & 0.00 & 0.00 & 0.00 & 0.00 & 0.00 & 0.01 \\
\hline $\mathrm{Cu}_{2} \mathrm{O}$ & 0.00 & 0.03 & 0.00 & 0.01 & 0.00 & 0.00 & 0.01 & 0.00 & 0.00 \\
\hline $\mathrm{K}_{2} \mathrm{O}$ & 0.00 & 0.00 & 0.00 & 0.00 & 0.00 & 0.00 & 0.00 & 0.01 & 0.00 \\
\hline Total measured & 99.57 & 99.65 & 99.46 & 99.42 & 99.89 & 99.94 & 99.80 & 99.48 & 96.76 \\
\hline MAS & \multicolumn{3}{|c|}{ Massive to semi-massive mineralization } & OBAN & \multicolumn{5}{|c|}{ Orthopyroxene -bearing bands of oxide mineralization } \\
\hline DIS & \multicolumn{3}{|c|}{ Disseminated mineralization } & POD & \multicolumn{5}{|c|}{ Pod of oxide mineralization } \\
\hline BAN & \multicolumn{3}{|c|}{ Bands of oxide mineralization } & OPOD & \multicolumn{5}{|c|}{ Orthopyroxene -bearing pod of oxide mineralization } \\
\hline ANO & \multicolumn{3}{|c|}{ Anorthosite hosted disseminated } & VEIN & \multicolumn{5}{|c|}{ Vein of oxide mineralization } \\
\hline ORT & \multicolumn{3}{|c|}{ Orthopyroxene associated } & MAG & \multicolumn{5}{|l|}{ Magnetite } \\
\hline $\mathrm{CLI}$ & \multicolumn{3}{|c|}{ Clinopyroxene associated } & ILM & Ilmenite & PLE & \multicolumn{3}{|l|}{ Pleonaste } \\
\hline
\end{tabular}




\begin{tabular}{|c|c|c|c|c|c|c|c|c|c|}
\hline Sample \# & CCO25A & CCO25A & CCO25A & CCO25A & CC025A & CCO25A & CCO25A & CCO25A & CCO25A \\
\hline Circle Number & $\mathrm{D}$ & $\mathrm{D}$ & $\mathrm{E}$ & $\mathrm{E}$ & $\mathrm{E}$ & $\mathrm{E}$ & $\mathrm{E}$ & $\mathrm{E}$ & $\mathrm{E}$ \\
\hline Mineralization type & MAS & MAS & MAS & MAS & MAS & MAS & MAS & MAS & MAS \\
\hline Descriptor & POD & POD & POD & POD & POD & POD & POD & POD & POD \\
\hline mineral host & ILM & ILM & MAG & MAG & MAG & MAG & MAG & MAG & MAG \\
\hline Mineral analyzed & ILM & ILM & ILM & ILM & ILM & ILM & ILM & ILM & ILM \\
\hline exsolution feature type & intergrowth inside & intergrowth & sandwich & sandwich & sandwich & comp ig & comp ig & thick ig & thick ig \\
\hline Point & 31 & 32 & 38 & 39 & 40 & 41 & 42 & 45 & 46 \\
\hline $\mathrm{SiO}_{2}$ & 0.00 & 0.00 & 0.01 & 0.00 & 0.00 & 0.01 & 0.02 & 0.00 & 0.00 \\
\hline $\mathrm{TiO}_{2}$ & 52.12 & 52.77 & 53.00 & 50.78 & 50.78 & 52.82 & 52.40 & 52.68 & 52.67 \\
\hline $\mathrm{Al}_{2} \mathrm{O}_{3}$ & 0.01 & 0.01 & 0.01 & 0.02 & 0.03 & 0.01 & 0.43 & 0.01 & 0.01 \\
\hline $\mathrm{Cr}_{2} \mathrm{O}_{3}$ & 0.00 & 0.03 & 0.00 & 0.02 & 0.01 & 0.03 & 0.03 & 0.03 & 0.05 \\
\hline $\mathrm{V}_{2} \mathrm{O}_{3}$ & 0.16 & 0.16 & 0.13 & 0.18 & 0.19 & 0.14 & 0.16 & 0.16 & 0.19 \\
\hline $\mathrm{FeO}^{*}$ & 46.75 & 45.64 & 45.12 & 47.40 & 47.25 & 45.52 & 45.33 & 44.89 & 44.72 \\
\hline $\mathrm{Fe}_{2} \mathrm{O}_{3}$ recalculated & 2.12 & 0.17 & -0.55 & 4.14 & 4.01 & 0.12 & 0.44 & -0.56 & -0.79 \\
\hline FeO recalculated & 44.84 & 45.48 & 45.62 & 43.67 & 43.64 & 45.41 & 44.94 & 45.40 & 45.43 \\
\hline $\mathrm{MnO}$ & 0.58 & 0.63 & 0.62 & 0.53 & 0.51 & 0.65 & 0.62 & 0.84 & 0.80 \\
\hline $\mathrm{MgO}$ & 0.81 & 0.74 & 0.80 & 0.80 & 0.84 & 0.81 & 0.88 & 0.63 & 0.63 \\
\hline $\mathrm{ZnO}$ & 0.00 & 0.03 & 0.00 & 0.03 & 0.00 & 0.00 & 0.00 & 0.02 & 0.00 \\
\hline $\mathrm{NiO}$ & 0.00 & 0.00 & 0.00 & 0.01 & 0.02 & 0.00 & 0.01 & 0.00 & 0.00 \\
\hline $\mathrm{CaO}$ & 0.00 & 0.00 & 0.00 & 0.00 & 0.00 & 0.00 & 0.00 & 0.00 & 0.00 \\
\hline $\mathrm{Cu}_{2} \mathrm{O}$ & 0.00 & 0.00 & 0.00 & 0.00 & 0.01 & 0.02 & 0.00 & 0.00 & 0.00 \\
\hline $\mathrm{K}_{2} \mathrm{O}$ & 0.01 & 0.00 & 0.00 & 0.00 & 0.00 & 0.00 & 0.00 & 0.00 & 0.00 \\
\hline Total measured & 100.44 & 100.01 & 99.69 & 99.76 & 99.64 & 100.00 & 99.89 & 99.26 & 99.08 \\
\hline MAS & \multicolumn{3}{|c|}{ Massive to semi-massive mineralization } & OBAN & \multicolumn{5}{|c|}{ Orthopyroxene -bearing bands of oxide mineralization } \\
\hline DIS & \multicolumn{3}{|c|}{ Disseminated mineralization } & POD & \multicolumn{5}{|c|}{ Pod of oxide mineralization } \\
\hline BAN & \multicolumn{3}{|c|}{ Bands of oxide mineralization } & OPOD & \multicolumn{5}{|c|}{ Orthopyroxene -bearing pod of oxide mineralization } \\
\hline ANO & \multicolumn{3}{|c|}{ Anorthosite hosted disseminated } & VEIN & \multicolumn{5}{|c|}{ Vein of oxide mineralization } \\
\hline ORT & \multicolumn{3}{|c|}{ Orthopyroxene associated } & MAG & \multicolumn{5}{|l|}{ Magnetite } \\
\hline $\mathrm{CLI}$ & \multicolumn{3}{|c|}{ Clinopyroxene associated } & ILM & IImenite & PLE & \multicolumn{3}{|l|}{ Pleonaste } \\
\hline
\end{tabular}




\begin{tabular}{|c|c|c|c|c|c|c|c|c|}
\hline Sample \# & CCO25A & CCO25A & CCO25A & CCO25A & CCO25A & CC025A & CCO25A & CCO25A \\
\hline Circle Number & G & G & $\mathrm{G}$ & G & G & G & $\mathrm{G}$ & 1 \\
\hline Mineralization type & MAS & MAS & MAS & MAS & MAS & MAS & MAS & MAS \\
\hline Descriptor & POD & POD & POD & POD & POD & POD & POD & POD \\
\hline mineral host & MAG & MAG & MAG & MAG & MAG & MAG & MAG & MAG \\
\hline $\begin{array}{l}\text { Mineral analyzed } \\
\text { exsolution feature type }\end{array}$ & $\begin{array}{l}\text { ILM } \\
\text { composite }\end{array}$ & $\begin{array}{l}\text { ILM } \\
\text { composite }\end{array}$ & $\begin{array}{l}\text { ILM } \\
\text { composite }\end{array}$ & $\begin{array}{l}\text { ILM } \\
\text { sandwich }\end{array}$ & $\begin{array}{l}\text { ILM } \\
\text { sandwich }\end{array}$ & $\begin{array}{l}\text { ILM } \\
\text { ig contact }\end{array}$ & $\begin{array}{l}\text { ILM } \\
\text { ig contact }\end{array}$ & $\begin{array}{l}\text { ILM } \\
\text { composite }\end{array}$ \\
\hline $\mathrm{SiO}_{2}$ & 0.00 & 0.00 & 0.00 & 0.00 & 0.00 & 0.00 & 0.00 & 0.01 \\
\hline $\mathrm{TiO}_{2}$ & 51.35 & 50.20 & 49.86 & 51.77 & 50.87 & 52.38 & 52.60 & 52.04 \\
\hline $\mathrm{Al}_{2} \mathrm{O}_{3}$ & 0.03 & 0.05 & 0.04 & 0.01 & 0.03 & 0.01 & 0.01 & 0.02 \\
\hline $\mathrm{Cr}_{2} \mathrm{O}_{3}$ & 0.02 & 0.02 & 0.03 & 0.02 & 0.02 & 0.01 & 0.02 & 0.02 \\
\hline $\mathrm{V}_{2} \mathrm{O}_{3}$ & 0.17 & 0.19 & 0.21 & 0.18 & 0.19 & 0.17 & 0.18 & 0.19 \\
\hline $\mathrm{MnO}$ & 0.53 & 0.46 & 0.46 & 0.55 & 0.52 & 0.64 & 0.69 & 0.55 \\
\hline $\mathrm{MgO}$ & 0.84 & 0.81 & 0.82 & 0.74 & 0.79 & 0.74 & 0.73 & 0.78 \\
\hline $\mathrm{ZnO}$ & 0.04 & 0.03 & 0.00 & 0.01 & 0.03 & 0.02 & 0.03 & 0.00 \\
\hline $\mathrm{NiO}$ & 0.02 & 0.00 & 0.00 & 0.00 & 0.00 & 0.01 & 0.02 & 0.00 \\
\hline $\mathrm{CaO}$ & 0.00 & 0.00 & 0.00 & 0.01 & 0.00 & 0.00 & 0.00 & 0.00 \\
\hline $\mathrm{Cu}_{2} \mathrm{O}$ & 0.01 & 0.01 & 0.00 & 0.01 & 0.00 & 0.00 & 0.00 & 0.00 \\
\hline $\mathrm{K}_{2} \mathrm{O}$ & 0.01 & 0.00 & 0.01 & 0.00 & 0.00 & 0.00 & 0.00 & 0.00 \\
\hline Total measured & 99.57 & 99.90 & 99.37 & 99.34 & 99.76 & 100.14 & 99.93 & 99.78 \\
\hline MAS & \multicolumn{3}{|c|}{ Massive to semi-massive mineralization } & OBAN & \multicolumn{4}{|c|}{ Orthopyroxene -bearing bands of oxide mineralization } \\
\hline DIS & \multicolumn{3}{|c|}{ Disseminated mineralization } & POD & \multicolumn{4}{|c|}{ Pod of oxide mineralization } \\
\hline
\end{tabular}




\begin{tabular}{|c|c|c|c|c|c|c|c|c|}
\hline Sample \# & CCO25A & CCO25A & CCO25A & CC025A & CCO25A & CC031A & CC031A & CC031A \\
\hline Circle Number & 1 & 1 & $\mathrm{~K}$ & $\mathrm{~K}$ & $\mathrm{~K}$ & A & A & B \\
\hline Mineralization type & MAS & MAS & MAS & MAS & MAS & DIS & DIS & DIS \\
\hline Descriptor & POD & POD & POD & POD & POD & ANO & ANO & ANO \\
\hline mineral host & MAG & MAG & ILM & ILM & ILM & MAG & MAG & MAG \\
\hline Mineral analyzed & ILM & ILM & ILM & ILM & ILM & ILM & ILM & ILM \\
\hline $\mathrm{SiO}_{2}$ & 0.01 & 0.01 & 0.00 & 0.00 & 0.01 & 0.00 & 0.01 & 0.00 \\
\hline $\mathrm{TiO}_{2}$ & 50.13 & 50.36 & 49.50 & 47.74 & 49.05 & 52.35 & 51.93 & 51.25 \\
\hline $\mathrm{Al}_{2} \mathrm{O}_{3}$ & 0.03 & 0.03 & 0.03 & 0.07 & 0.06 & 0.00 & 0.02 & 0.01 \\
\hline $\mathrm{Cr}_{2} \mathrm{O}_{3}$ & 0.05 & 0.02 & 0.01 & 0.02 & 0.03 & 0.02 & 0.03 & 0.03 \\
\hline $\mathrm{V}_{2} \mathrm{O}_{3}$ & 0.20 & 0.17 & 0.22 & 0.27 & 0.25 & 0.16 & 0.17 & 0.20 \\
\hline $\mathrm{MnO}$ & 0.44 & 0.41 & 0.34 & 0.32 & 0.33 & 1.31 & 1.32 & 1.19 \\
\hline $\mathrm{MgO}$ & 0.78 & 0.60 & 1.14 & 1.05 & 1.10 & 0.33 & 0.33 & 0.34 \\
\hline $\mathrm{ZnO}$ & 0.00 & 0.01 & 0.00 & 0.00 & 0.00 & 0.03 & 0.00 & 0.00 \\
\hline $\mathrm{NiO}$ & 0.01 & 0.00 & 0.00 & 0.00 & 0.01 & 0.01 & 0.00 & 0.00 \\
\hline $\mathrm{CaO}$ & 0.00 & 0.00 & 0.00 & 0.00 & 0.00 & 0.00 & 0.00 & 0.00 \\
\hline $\mathrm{Cu}_{2} \mathrm{O}$ & 0.00 & 0.00 & 0.00 & 0.01 & 0.00 & 0.01 & 0.01 & 0.01 \\
\hline $\mathrm{K}_{2} \mathrm{O}$ & 0.00 & 0.00 & 0.01 & 0.01 & 0.00 & 0.01 & 0.00 & 0.00 \\
\hline Total measured & 99.74 & 99.72 & 99.68 & 99.22 & 99.69 & 99.23 & 98.93 & 99.52 \\
\hline MAS & \multicolumn{3}{|c|}{ Massive to semi-massive mineralization } & OBAN & \multicolumn{4}{|c|}{ Orthopyroxene -bearing bands of oxide mineralization } \\
\hline DIS & \multicolumn{3}{|c|}{ Disseminated mineralization } & POD & \multicolumn{4}{|c|}{ Pod of oxide mineralization } \\
\hline
\end{tabular}




\begin{tabular}{|c|c|c|c|c|c|c|c|}
\hline Sample \# & CC031A & CC031A & CC031A & CC031A & CC031A & CC031A & CC031A \\
\hline Circle Number & B & B & B & B & $C$ & $C$ & $C$ \\
\hline Mineralization type & DIS & DIS & DIS & DIS & DIS & DIS & DIS \\
\hline Descriptor & ANO & ANO & ANO & ANO & ANO & ANO & ANO \\
\hline mineral host & MAG & MAG & MAG & MAG & MAG & MAG & ILM \\
\hline Mineral analyzed & ILM & ILM & ILM & $\begin{array}{l}\text { ILM } \\
\text { intergrowth }\end{array}$ & ILM & ILM & ILM \\
\hline exsolution feature type & composite & composite & intergrowth contact & contact & host & host & ILM PLE contact \\
\hline Point & 8 & 9 & 10 & 11 & 15 & 16 & 20 \\
\hline $\mathrm{SiO}_{2}$ & 0.00 & 0.01 & 0.01 & 0.00 & 0.00 & 0.00 & 0.00 \\
\hline $\mathrm{TiO}_{2}$ & 51.37 & 52.59 & 52.97 & 52.90 & 50.74 & 49.80 & 52.47 \\
\hline $\mathrm{Al}_{2} \mathrm{O}_{3}$ & 0.03 & 0.01 & 0.06 & 0.03 & 0.01 & 0.04 & 0.01 \\
\hline $\mathrm{Cr}_{2} \mathrm{O}_{3}$ & 0.02 & 0.03 & 0.03 & 0.03 & 0.04 & 0.03 & 0.02 \\
\hline $\mathrm{V}_{2} \mathrm{O}_{3}$ & 0.20 & 0.20 & 0.18 & 0.19 & 0.17 & 0.20 & 0.16 \\
\hline $\mathrm{FeO}^{*}$ & 46.02 & 46.04 & 44.80 & 44.65 & 46.63 & 47.29 & 45.02 \\
\hline $\mathrm{Fe}_{2} \mathrm{O}_{3}$ recalculated & 1.88 & 0.72 & -0.98 & -36.03 & 3.47 & 5.10 & 0.08 \\
\hline FeO recalculated & 44.33 & 45.39 & 45.68 & 77.07 & 43.51 & 42.70 & 44.95 \\
\hline $\mathrm{MnO}$ & 1.22 & 1.29 & 1.33 & 1.37 & 0.79 & 0.75 & 0.89 \\
\hline $\mathrm{MgO}$ & 0.34 & 0.34 & 0.35 & 0.34 & 0.73 & 0.74 & 0.74 \\
\hline $\mathrm{ZnO}$ & 0.03 & 0.00 & 0.00 & 0.01 & 0.03 & 0.01 & 0.01 \\
\hline $\mathrm{NiO}$ & 0.01 & 0.00 & 0.00 & 0.00 & 0.00 & 0.01 & 0.00 \\
\hline $\mathrm{CaO}$ & 0.00 & 0.01 & 0.00 & 0.00 & 0.00 & 0.00 & 0.00 \\
\hline $\mathrm{Cu}_{2} \mathrm{O}$ & 0.00 & 0.00 & 0.00 & 0.00 & 0.01 & 0.00 & 0.00 \\
\hline $\mathrm{K}_{2} \mathrm{O}$ & 0.00 & 0.00 & 0.00 & 0.00 & 0.00 & 0.00 & 0.00 \\
\hline Total measured & 99.25 & 100.51 & 99.72 & 99.52 & 99.16 & 98.86 & 99.33 \\
\hline MAS & \multicolumn{2}{|c|}{ Massive to semi-massive mineralization } & OBAN & \multicolumn{4}{|c|}{ Orthopyroxene -bearing bands of oxide mineralization } \\
\hline DIS & \multicolumn{2}{|c|}{ Disseminated mineralization } & POD & \multicolumn{4}{|c|}{ Pod of oxide mineralization } \\
\hline BAN & \multicolumn{2}{|c|}{ Bands of oxide mineralization } & OPOD & \multicolumn{4}{|c|}{ Orthopyroxene -bearing pod of oxide mineralization } \\
\hline ANO & \multicolumn{2}{|c|}{ Anorthosite hosted disseminated } & VEIN & \multicolumn{4}{|c|}{ Vein of oxide mineralization } \\
\hline ORT & \multicolumn{2}{|c|}{ Orthopyroxene associated } & MAG & \multicolumn{4}{|l|}{ Magnetite } \\
\hline $\mathrm{CLI}$ & \multicolumn{2}{|c|}{ Clinopyroxene associated } & ILM & Ilmenite & PLE & Pleonaste & \\
\hline
\end{tabular}




\begin{tabular}{|c|c|c|c|c|c|c|c|c|}
\hline Sample \# & CC031A & CC031A & CC031A & CC031A & CC031A & CC031A & CC031A & CC031A \\
\hline Circle Number & $\mathrm{C}$ & $\mathrm{D}$ & $\mathrm{D}$ & $\mathrm{D}$ & $\mathrm{D}$ & $\mathrm{D}$ & $\mathrm{D}$ & $\mathrm{D}$ \\
\hline Mineralization type & DIS & DIS & DIS & DIS & DIS & DIS & DIS & DIS \\
\hline Descriptor & ANO & ANO & ANO & ANO & ANO & ANO & ANO & ANO \\
\hline mineral host & ILM & MAG & MAG & MAG & MAG & MAG & MAG & MAG \\
\hline Mineral analyzed & ILM & ILM & ILM & ILM & ILM & ILM & ILM & ILM \\
\hline exsolution feature type & ILM PLE contact & composite & composite & composite & ig contact & ig contact & sandwich & sandwich \\
\hline Point & 21 & 25 & 26 & 27 & 28 & 29 & 33 & 34 \\
\hline $\mathrm{SiO}_{2}$ & 0.00 & 0.00 & 0.02 & 0.00 & 0.00 & 0.00 & 0.00 & 0.01 \\
\hline $\mathrm{TiO}_{2}$ & 52.53 & 51.89 & 51.61 & 51.51 & 52.65 & 52.46 & 52.74 & 52.52 \\
\hline $\mathrm{Al}_{2} \mathrm{O}_{3}$ & 0.13 & 0.01 & 0.01 & 0.03 & 0.01 & 0.02 & 0.00 & 0.01 \\
\hline $\mathrm{Cr}_{2} \mathrm{O}_{3}$ & 0.03 & 0.03 & 0.01 & 0.03 & 0.02 & 0.07 & 0.01 & 0.01 \\
\hline $\mathrm{V}_{2} \mathrm{O}_{3}$ & 0.14 & 0.20 & 0.17 & 0.18 & 0.15 & 0.19 & 0.18 & 0.20 \\
\hline $\mathrm{FeO}^{*}$ & 44.77 & 45.18 & 46.03 & 46.27 & 44.74 & 44.02 & 44.50 & 43.92 \\
\hline $\mathrm{Fe}_{2} \mathrm{O}_{3}$ recalculated & -0.08 & 0.40 & 1.46 & 1.91 & -0.77 & -1.35 & -1.28 & -1.71 \\
\hline FeO recalculated & 44.84 & 44.82 & 44.72 & 44.55 & 45.43 & 45.24 & 45.65 & 45.46 \\
\hline $\mathrm{MnO}$ & 0.94 & 1.27 & 1.18 & 1.22 & 1.31 & 1.35 & 1.26 & 1.27 \\
\hline $\mathrm{MgO}$ & 0.81 & 0.31 & 0.29 & 0.29 & 0.34 & 0.31 & 0.28 & 0.28 \\
\hline $\mathrm{ZnO}$ & 0.02 & 0.00 & 0.00 & 0.01 & 0.00 & 0.03 & 0.01 & 0.00 \\
\hline $\mathrm{NiO}$ & 0.01 & 0.00 & 0.00 & 0.01 & 0.00 & 0.00 & 0.00 & 0.01 \\
\hline $\mathrm{CaO}$ & 0.00 & 0.00 & 0.00 & 0.00 & 0.00 & 0.00 & 0.01 & 0.00 \\
\hline $\mathrm{Cu}_{2} \mathrm{O}$ & 0.00 & 0.00 & 0.00 & 0.00 & 0.00 & 0.01 & 0.00 & 0.01 \\
\hline $\mathrm{K}_{2} \mathrm{O}$ & 0.00 & 0.00 & 0.00 & 0.00 & 0.01 & 0.00 & 0.01 & 0.00 \\
\hline Total measured & 99.37 & 98.89 & 99.33 & 99.56 & 99.22 & 98.47 & 98.98 & 98.24 \\
\hline MAS & \multicolumn{3}{|c|}{ Massive to semi-massive mineralization } & OBAN & \multicolumn{4}{|c|}{ Orthopyroxene -bearing bands of oxide mineralization } \\
\hline DIS & \multicolumn{3}{|c|}{ Disseminated mineralization } & POD & \multicolumn{4}{|c|}{ Pod of oxide mineralization } \\
\hline BAN & \multicolumn{3}{|c|}{ Bands of oxide mineralization } & OPOD & \multicolumn{4}{|c|}{ Orthopyroxene -bearing pod of oxide mineralization } \\
\hline ANO & \multicolumn{3}{|c|}{ Anorthosite hosted disseminated } & VEIN & \multicolumn{4}{|c|}{ Vein of oxide mineralization } \\
\hline ORT & \multicolumn{3}{|c|}{ Orthopyroxene associated } & MAG & \multicolumn{4}{|c|}{ Magnetite } \\
\hline $\mathrm{CLI}$ & \multicolumn{3}{|c|}{ Clinopyroxene associated } & ILM & IImenite & PLE & \multicolumn{2}{|l|}{ Pleonaste } \\
\hline
\end{tabular}




\begin{tabular}{|c|c|c|c|c|c|c|c|c|}
\hline Sample \# & CC031A & CC031A & CC031A & CC031A & CC031A & CC031A & CC031A & CC031A \\
\hline Circle Number & $\mathrm{E}$ & $\mathrm{E}$ & $\mathrm{E}$ & $\mathrm{E}$ & $\mathrm{E}$ & $\mathrm{E}$ & $\mathrm{F}$ & $\mathrm{F}$ \\
\hline Mineralization type & DIS & DIS & DIS & DIS & DIS & DIS & DIS & DIS \\
\hline Descriptor & ANO & ANO & ANO & ANO & ANO & ANO & ANO & ANO \\
\hline mineral host & MAG & MAG & MAG & MAG & MAG & MAG & ILM & ILM \\
\hline Mineral analyzed & ILM & ILM & ILM & ILM & ILM & $\begin{array}{l}\text { ILM } \\
\text { Thick }\end{array}$ & ILM & ILM \\
\hline exsolution feature type & sandwich & sandwich & sandwich & Thick Lamellae & Thick Lamellae & Lamellae & Host & Host \\
\hline Point & 36 & 37 & 38 & 39 & 40 & 41 & 45 & 46 \\
\hline $\mathrm{SiO}_{2}$ & 0.00 & 0.00 & 0.00 & 0.00 & 0.00 & 0.00 & 0.00 & 0.01 \\
\hline $\mathrm{TiO}_{2}$ & 51.78 & 51.49 & 51.73 & 51.95 & 51.93 & 51.87 & 50.39 & 48.83 \\
\hline $\mathrm{Al}_{2} \mathrm{O}_{3}$ & 0.01 & 0.02 & 0.01 & 0.01 & 0.02 & 0.01 & 0.02 & 0.00 \\
\hline $\mathrm{Cr}_{2} \mathrm{O}_{3}$ & 0.01 & 0.03 & 0.03 & 0.04 & 0.03 & 0.03 & 0.02 & 0.02 \\
\hline $\mathrm{V}_{2} \mathrm{O}_{3}$ & 0.18 & 0.18 & 0.21 & 0.18 & 0.19 & 0.18 & 0.18 & 0.21 \\
\hline $\mathrm{FeO}^{*}$ & 45.80 & 45.80 & 45.61 & 45.78 & 45.71 & 45.76 & 47.20 & 48.40 \\
\hline $\mathrm{Fe}_{2} \mathrm{O}_{3}$ recalculated & 0.98 & 1.22 & 0.76 & 0.86 & 0.72 & 0.94 & 4.48 & 7.37 \\
\hline FeO recalculated & 44.92 & 44.70 & 44.92 & 45.00 & 45.06 & 44.91 & 43.17 & 41.77 \\
\hline $\mathrm{MnO}$ & 1.16 & 1.10 & 1.10 & 1.22 & 1.22 & 1.22 & 0.71 & 0.68 \\
\hline $\mathrm{MgO}$ & 0.27 & 0.27 & 0.26 & 0.26 & 0.23 & 0.26 & 0.81 & 0.81 \\
\hline $\mathrm{ZnO}$ & 0.01 & 0.02 & 0.03 & 0.02 & 0.00 & 0.03 & 0.00 & 0.03 \\
\hline $\mathrm{NiO}$ & 0.00 & 0.00 & 0.00 & 0.00 & 0.00 & 0.02 & 0.00 & 0.00 \\
\hline $\mathrm{CaO}$ & 0.00 & 0.00 & 0.00 & 0.00 & 0.00 & 0.00 & 0.00 & 0.00 \\
\hline $\mathrm{Cu}_{2} \mathrm{O}$ & 0.01 & 0.00 & 0.00 & 0.01 & 0.00 & 0.00 & 0.03 & 0.00 \\
\hline $\mathrm{K}_{2} \mathrm{O}$ & 0.00 & 0.00 & 0.00 & 0.01 & 0.00 & 0.00 & 0.00 & 0.00 \\
\hline Total measured & 99.22 & 98.91 & 98.98 & 99.48 & 99.32 & 99.38 & 99.35 & 98.99 \\
\hline MAS & \multicolumn{3}{|c|}{ Massive to semi-massive mineralization } & OBAN & \multicolumn{4}{|c|}{ Orthopyroxene -bearing bands of oxide mineralization } \\
\hline DIS & \multicolumn{3}{|c|}{ Disseminated mineralization } & POD & \multicolumn{4}{|c|}{ Pod of oxide mineralization } \\
\hline BAN & \multicolumn{3}{|c|}{ Bands of oxide mineralization } & OPOD & \multicolumn{4}{|c|}{ Orthopyroxene -bearing pod of oxide mineralization } \\
\hline ANO & \multicolumn{3}{|c|}{ Anorthosite hosted disseminated } & VEIN & \multicolumn{4}{|c|}{ Vein of oxide mineralization } \\
\hline ORT & \multicolumn{3}{|c|}{ Orthopyroxene associated } & MAG & \multicolumn{4}{|l|}{ Magnetite } \\
\hline $\mathrm{CLI}$ & \multicolumn{3}{|c|}{ Clinopyroxene associated } & ILM & Ilmenite & PLE & \multicolumn{2}{|l|}{ Pleonaste } \\
\hline
\end{tabular}




\begin{tabular}{|c|c|c|c|c|c|c|c|c|c|c|c|}
\hline Sample \# & CC031A & CC031A & CC031A & & CC031A & CC031A & CC031A & CC031A & CC031A & CC031A & CC054B \\
\hline Circle Number & $\mathrm{F}$ & $\mathrm{G}$ & $\mathrm{G}$ & & $\mathrm{H}$ & $\mathrm{H}$ & $\mathrm{H}$ & 1 & 1 & 1 & $\mathrm{C}$ \\
\hline Mineralization type & DIS & DIS & DIS & & DIS & DIS & DIS & DIS & DIS & DIS & DIS \\
\hline Descriptor & ANO & ANO & ANO & & ANO & ANO & ANO & ANO & ANO & ANO & ORT \\
\hline mineral host & ILM & MAG & MAG & & ILM & ILM & ILM & ILM & ILM & ILM & ILM \\
\hline Mineral analyzed & ILM & ILM & ILM & & ILM & ILM & ILM & ILM & ILM & ILM & ILM \\
\hline exsolution feature type & Host & composite IIm Spl ig & weird ILM box & & Host & Host & Host & Host & Host & Host & host \\
\hline Point & 47 & 52 & & 55 & 61 & 62 & 63 & 67 & 68 & 69 & 9 \\
\hline $\mathrm{SiO}_{2}$ & 0.00 & 0.00 & 0.01 & & 0.00 & 0.00 & 0.00 & 0.01 & 0.00 & 0.00 & 0.00 \\
\hline $\mathrm{TiO}_{2}$ & 48.41 & 52.92 & 53.21 & & 48.53 & 47.74 & 48.46 & 49.53 & 50.15 & 50.35 & 50.52 \\
\hline $\mathrm{Al}_{2} \mathrm{O}_{3}$ & 0.03 & 0.01 & 0.01 & & 0.04 & 0.03 & 0.02 & 0.05 & 0.03 & 0.03 & 0.04 \\
\hline $\mathrm{Cr}_{2} \mathrm{O}_{3}$ & 0.01 & 0.05 & 0.07 & & 0.02 & 0.03 & 0.02 & 0.02 & 0.01 & 0.02 & 0.02 \\
\hline $\mathrm{V}_{2} \mathrm{O}_{3}$ & 0.24 & 0.16 & 0.16 & & 0.20 & 0.23 & 0.21 & 0.19 & 0.19 & 0.19 & 0.20 \\
\hline $\mathrm{FeO}^{*}$ & 49.13 & 44.19 & 43.64 & & 48.36 & 49.30 & 48.63 & 47.63 & 47.48 & 47.35 & 47.63 \\
\hline $\mathrm{Fe}_{2} \mathrm{O}_{3}$ recalculated & 8.52 & -1.48 & -2.11 & & 7.62 & 9.47 & 7.98 & 5.58 & 5.06 & 4.70 & 5.17 \\
\hline FeO recalculated & 41.46 & 45.52 & 45.54 & & 41.50 & 40.78 & 41.45 & 42.61 & 42.93 & 43.12 & 42.98 \\
\hline $\mathrm{MnO}$ & 0.63 & 0.92 & 1.00 & & 0.64 & 0.62 & 0.66 & 0.64 & 0.70 & 0.69 & 0.54 \\
\hline $\mathrm{MgO}$ & 0.80 & 0.63 & 0.72 & & 0.83 & 0.85 & 0.82 & 0.72 & 0.82 & 0.81 & 1.06 \\
\hline $\mathrm{ZnO}$ & 0.02 & 0.01 & 0.02 & & 0.01 & 0.00 & 0.01 & 0.00 & 0.00 & 0.01 & 0.03 \\
\hline $\mathrm{NiO}$ & 0.01 & 0.00 & 0.00 & & 0.00 & 0.01 & 0.01 & 0.00 & 0.00 & 0.00 & 0.00 \\
\hline $\mathrm{CaO}$ & 0.00 & 0.01 & 0.00 & & 0.00 & 0.01 & 0.00 & 0.00 & 0.00 & 0.01 & 0.00 \\
\hline $\mathrm{Cu}_{2} \mathrm{O}$ & 0.01 & 0.00 & 0.00 & & 0.00 & 0.01 & 0.00 & 0.00 & 0.00 & 0.00 & 0.00 \\
\hline $\mathrm{K}_{2} \mathrm{O}$ & 0.00 & 0.01 & 0.00 & & 0.00 & 0.01 & 0.00 & 0.00 & 0.00 & 0.00 & 0.01 \\
\hline Total measured & 99.29 & 98.91 & 98.85 & & 98.63 & 98.85 & 98.82 & 98.79 & 99.40 & 99.46 & 100.04 \\
\hline MAS & \multicolumn{3}{|c|}{ Massive to semi-massive mineralization } & & OBAN & \multicolumn{6}{|c|}{ Orthopyroxene -bearing bands of oxide mineralization } \\
\hline DIS & \multicolumn{3}{|c|}{ Disseminated mineralization } & & POD & \multicolumn{6}{|c|}{ Pod of oxide mineralization } \\
\hline BAN & \multicolumn{4}{|c|}{ Bands of oxide mineralization } & OPOD & \multicolumn{6}{|c|}{ Orthopyroxene -bearing pod of oxide mineralization } \\
\hline ANO & \multicolumn{4}{|c|}{ Anorthosite hosted disseminated } & VEIN & \multicolumn{6}{|c|}{ Vein of oxide mineralization } \\
\hline ORT & \multicolumn{4}{|c|}{ Orthopyroxene associated } & MAG & \multicolumn{6}{|l|}{ Magnetite } \\
\hline $\mathrm{CLI}$ & \multicolumn{4}{|c|}{ Clinopyroxene associated } & ILM & Ilmenite & PLE & \multicolumn{4}{|l|}{ Pleonaste } \\
\hline
\end{tabular}




\begin{tabular}{|c|c|c|c|c|c|c|c|}
\hline Sample \# & CC054B & CC054B & CC054B & CC054B & CC054B & CC054B & CC054B \\
\hline Circle Number & $\mathrm{C}$ & $\mathrm{D}$ & $\mathrm{D}$ & $\mathrm{D}$ & $E$ & $E$ & $E$ \\
\hline Mineralization type & DIS & DIS & DIS & DIS & DIS & DIS & DIS \\
\hline Descriptor & ORT & ORT & ORT & ORT & ORT & ORT & ORT \\
\hline mineral host & ILM & ILM & ILM & ILM & MAG & MAG & MAG \\
\hline Mineral analyzed & ILM & ILM & ILM & ILM & ILM & ILM & ILM \\
\hline exsolution feature type & host & host & host & host & composite & composite & composite \\
\hline Point & 10 & 16 & 17 & 18 & 21 & 22 & \\
\hline $\mathrm{SiO}_{2}$ & 0.01 & 0.00 & 0.00 & 0.01 & 0.01 & 0.00 & 0.01 \\
\hline $\mathrm{TiO}_{2}$ & 50.09 & 50.68 & 49.05 & 50.59 & 52.03 & 51.95 & 51.85 \\
\hline $\mathrm{Al}_{2} \mathrm{O}_{3}$ & 0.03 & 0.03 & 0.04 & 0.04 & 0.01 & 0.02 & 0.03 \\
\hline $\mathrm{Cr}_{2} \mathrm{O}_{3}$ & 0.03 & 0.01 & 0.01 & 0.01 & 0.01 & 0.00 & 0.01 \\
\hline $\mathrm{V}_{2} \mathrm{O}_{3}$ & 0.21 & 0.19 & 0.24 & 0.21 & 0.17 & 0.16 & 0.15 \\
\hline $\mathrm{FeO}^{*}$ & 47.59 & 47.39 & 48.46 & 47.24 & 46.34 & 46.55 & 46.58 \\
\hline $\mathrm{Fe}_{2} \mathrm{O}_{3}$ recalculated & 5.56 & 4.93 & 7.63 & 4.82 & 2.17 & 2.24 & 2.28 \\
\hline FeO recalculated & 42.59 & 42.95 & 41.60 & 42.91 & 44.39 & 44.54 & 44.53 \\
\hline $\mathrm{MnO}$ & 0.53 & 0.51 & 0.47 & 0.50 & 0.83 & 0.76 & 0.72 \\
\hline $\mathrm{MgO}$ & 1.09 & 1.19 & 1.14 & 1.17 & 0.87 & 0.78 & 0.77 \\
\hline $\mathrm{ZnO}$ & 0.00 & 0.00 & 0.00 & 0.00 & 0.00 & 0.04 & 0.01 \\
\hline $\mathrm{NiO}$ & 0.00 & 0.00 & 0.00 & 0.00 & 0.02 & 0.00 & 0.01 \\
\hline $\mathrm{CaO}$ & 0.00 & 0.00 & 0.01 & 0.01 & 0.00 & 0.00 & 0.00 \\
\hline $\mathrm{Cu}_{2} \mathrm{O}$ & 0.00 & 0.00 & 0.02 & 0.03 & 0.00 & 0.01 & 0.00 \\
\hline $\mathrm{K}_{2} \mathrm{O}$ & 0.00 & 0.00 & 0.00 & 0.00 & 0.00 & 0.00 & 0.01 \\
\hline Total measured & 99.57 & 99.99 & 99.44 & 99.82 & 100.30 & 100.27 & 100.15 \\
\hline MAS & \multicolumn{3}{|c|}{ Massive to semi-massive mineralization } & OBAN & \multicolumn{3}{|c|}{ Orthopyroxene -bearing bands of oxide mineralization } \\
\hline DIS & \multicolumn{3}{|c|}{ Disseminated mineralization } & POD & \multicolumn{3}{|c|}{ Pod of oxide mineralization } \\
\hline BAN & \multicolumn{3}{|c|}{ Bands of oxide mineralization } & OPOD & \multicolumn{3}{|c|}{ Orthopyroxene -bearing pod of oxide mineralization } \\
\hline ANO & \multicolumn{3}{|c|}{ Anorthosite hosted disseminated } & VEIN & \multicolumn{3}{|c|}{ Vein of oxide mineralization } \\
\hline ORT & \multicolumn{3}{|c|}{ Orthopyroxene associated } & MAG & \multicolumn{3}{|l|}{ Magnetite } \\
\hline $\mathrm{CLI}$ & \multicolumn{3}{|c|}{ Clinopyroxene associated } & ILM & Ilmenite & PLE & Pleonaste \\
\hline
\end{tabular}




\begin{tabular}{|c|c|c|c|c|c|c|c|}
\hline Sample \# & CC054B & CC054B & CC054B & CC054B & CC054B & CC054B & CC054B \\
\hline Circle Number & $\mathrm{E}$ & $E$ & $E$ & $E$ & G & G & G \\
\hline Mineralization type & DIS & DIS & DIS & DIS & DIS & DIS & DIS \\
\hline Descriptor & ORT & ORT & ORT & ORT & ORT & ORT & ORT \\
\hline mineral host & MAG & MAG & MAG & MAG & MAG & MAG & MAG \\
\hline Mineral analyzed & ILM & ILM & ILM & $\begin{array}{l}\text { ILM } \\
\text { IIm Spl }\end{array}$ & ILM & ILM & ILM \\
\hline exsolution feature type & IIm Spl composite & IIm Spl composite & IIm Spl contact & contact & composite & composite & composite \\
\hline Point & 24 & 26 & 27 & 28 & 39 & 40 & 41 \\
\hline $\mathrm{SiO}_{2}$ & 0.00 & 0.02 & 0.01 & 0.00 & 0.00 & 0.01 & 0.01 \\
\hline $\mathrm{TiO}_{2}$ & 52.54 & 52.45 & 52.76 & 52.78 & 50.95 & 50.50 & 49.80 \\
\hline $\mathrm{Al}_{2} \mathrm{O}_{3}$ & 0.01 & 0.03 & 0.00 & 0.01 & 0.04 & 0.02 & 0.04 \\
\hline $\mathrm{Cr}_{2} \mathrm{O}_{3}$ & 0.01 & 0.03 & 0.02 & 0.02 & 0.00 & 0.01 & 0.01 \\
\hline $\mathrm{V}_{2} \mathrm{O}_{3}$ & 0.17 & 0.15 & 0.15 & 0.16 & 0.20 & 0.19 & 0.20 \\
\hline $\mathrm{FeO} *$ & 45.82 & 46.09 & 45.92 & 45.56 & 46.32 & 47.09 & 47.85 \\
\hline $\mathrm{Fe}_{2} \mathrm{O}_{3}$ recalculated & 1.57 & 1.20 & 0.73 & 0.57 & 4.21 & 4.76 & 5.99 \\
\hline FeO recalculated & 44.40 & 45.01 & 45.26 & 45.05 & 42.53 & 42.81 & 42.46 \\
\hline $\mathrm{MnO}$ & 0.77 & 0.83 & 0.74 & 0.79 & 0.52 & 0.50 & 0.47 \\
\hline MgO & 1.15 & 0.75 & 0.80 & 0.89 & 1.54 & 1.16 & 1.03 \\
\hline $\mathrm{ZnO}$ & 0.03 & 0.01 & 0.02 & 0.04 & 0.00 & 0.03 & 0.02 \\
\hline $\mathrm{NiO}$ & 0.01 & 0.00 & 0.00 & 0.00 & 0.03 & 0.01 & 0.00 \\
\hline $\mathrm{CaO}$ & 0.00 & 0.00 & 0.00 & 0.00 & 0.00 & 0.01 & 0.01 \\
\hline $\mathrm{Cu}_{2} \mathrm{O}$ & 0.01 & 0.00 & 0.01 & 0.00 & 0.01 & 0.00 & 0.00 \\
\hline $\mathrm{K}_{2} \mathrm{O}$ & 0.00 & 0.00 & 0.00 & 0.00 & 0.00 & 0.00 & 0.00 \\
\hline Total measured & 100.51 & 100.37 & 100.45 & 100.26 & 99.62 & 99.54 & 99.45 \\
\hline MAS & \multicolumn{2}{|c|}{ Massive to semi-massive mineralization } & OBAN & \multicolumn{4}{|c|}{ Orthopyroxene -bearing bands of oxide mineralization } \\
\hline DIS & \multicolumn{2}{|c|}{ Disseminated mineralization } & POD & \multicolumn{4}{|c|}{ Pod of oxide mineralization } \\
\hline BAN & \multicolumn{2}{|c|}{ Bands of oxide mineralization } & OPOD & \multicolumn{4}{|c|}{ Orthopyroxene -bearing pod of oxide mineralization } \\
\hline ANO & \multicolumn{2}{|c|}{ Anorthosite hosted disseminated } & VEIN & \multicolumn{4}{|c|}{ Vein of oxide mineralization } \\
\hline ORT & \multicolumn{2}{|c|}{ Orthopyroxene associated } & MAG & \multicolumn{4}{|l|}{ Magnetite } \\
\hline $\mathrm{CLI}$ & Clinopyroxene associate & & ILM & Ilmenite & PLE & Pleonaste & \\
\hline
\end{tabular}




\begin{tabular}{|c|c|c|c|c|c|c|c|c|}
\hline Sample \# & CC054B & CC054B & CC054B & CC054B & CC054B & CC054B & CC054B & CC054B \\
\hline Circle Number & $\mathrm{H}$ & $\mathrm{H}$ & $\mathrm{J}$ & J & $\mathrm{J}$ & $\mathrm{L}$ & $\mathrm{L}$ & $\mathrm{L}$ \\
\hline Mineralization type & DIS & DIS & DIS & DIS & DIS & DIS & DIS & DIS \\
\hline Descriptor & ORT & ORT & ORT & ORT & ORT & ORT & ORT & ORT \\
\hline mineral host & MAG & MAG & MAG & MAG & MAG & MAG & MAG & MAG \\
\hline Mineral analyzed & ILM & & & ILM & & & & \\
\hline $\mathrm{SiO}_{2}$ & 0.02 & 0.00 & 0.01 & 0.00 & 0.00 & 0.00 & 0.00 & 0.00 \\
\hline $\mathrm{TiO}_{2}$ & 51.47 & 52.05 & 52.33 & 53.43 & 53.59 & 52.29 & 50.59 & 49.93 \\
\hline $\mathrm{Al}_{2} \mathrm{O}_{3}$ & 0.02 & 0.02 & 0.01 & 0.02 & 0.00 & 0.02 & 0.03 & 0.03 \\
\hline $\mathrm{Cr}_{2} \mathrm{O}_{3}$ & 0.01 & 0.03 & 0.00 & 0.02 & 0.01 & 0.01 & 0.00 & 0.01 \\
\hline $\mathrm{V}_{2} \mathrm{O}_{3}$ & 0.18 & 0.17 & 0.18 & 0.17 & 0.18 & 0.15 & 0.19 & 0.19 \\
\hline $\mathrm{MnO}$ & 0.91 & 0.77 & 1.20 & 1.15 & 1.05 & 0.67 & 0.55 & 0.50 \\
\hline $\mathrm{MgO}$ & 0.37 & 0.94 & 0.75 & 2.86 & 2.84 & 1.32 & 0.83 & 1.07 \\
\hline $\mathrm{ZnO}$ & 0.01 & 0.00 & 0.00 & 0.00 & 0.00 & 0.02 & 0.03 & 0.00 \\
\hline $\mathrm{NiO}$ & 0.00 & 0.00 & 0.00 & 0.02 & 0.02 & 0.01 & 0.02 & 0.02 \\
\hline $\mathrm{CaO}$ & 0.00 & 0.01 & 0.00 & 0.01 & 0.01 & 0.00 & 0.00 & 0.00 \\
\hline $\mathrm{Cu}_{2} \mathrm{O}$ & 0.01 & 0.00 & 0.02 & 0.01 & 0.01 & 0.01 & 0.00 & 0.00 \\
\hline $\mathrm{K}_{2} \mathrm{O}$ & 0.00 & 0.00 & 0.00 & 0.00 & 0.00 & 0.00 & 0.00 & 0.00 \\
\hline Total measured & 100.00 & 100.35 & 100.01 & 100.42 & 100.43 & 100.73 & 100.13 & 99.42 \\
\hline MAS & \multicolumn{3}{|c|}{ Massive to semi-massive mineralization } & OBAN & \multicolumn{4}{|c|}{ Orthopyroxene -bearing bands of oxide mineralization } \\
\hline DIS & \multicolumn{3}{|c|}{ Disseminated mineralization } & POD & \multicolumn{4}{|c|}{ Pod of oxide mineralization } \\
\hline
\end{tabular}




\begin{tabular}{|c|c|c|c|c|c|c|c|c|}
\hline Sample \# & CC054B & CC054B & CC054B & CC054B & $\mathrm{CCO} 72 \mathrm{~A}$ & $\mathrm{CCO} 72 \mathrm{~A}$ & $\mathrm{CCO} 72 \mathrm{~A}$ & $\mathrm{CCO} 2 \mathrm{~A}$ \\
\hline Circle Number & $\mathrm{L}$ & $\mathrm{L}$ & $\mathrm{O}$ & $\mathrm{O}$ & A & A & A & B \\
\hline Mineralization type & DIS & DIS & DIS & DIS & MAS & MAS & MAS & MAS \\
\hline Descriptor & ORT & ORT & ORT & ORT & OPOD & OPOD & OPOD & OPOD \\
\hline mineral host & ILM & ILM & ILM & ILM & MAG & MAG & MAG & MAG \\
\hline Mineral analyzed & ILM & $\begin{array}{l}\text { ILM } \\
\text { in IIm Spl }\end{array}$ & ILM & ILM & ILM & ILM & ILM & ILM \\
\hline exsolution feature type & in IIm Spl rim & rim & host & host & composite & composite & composite & composite \\
\hline Point & 66 & 67 & 71 & 72 & 7 & 8 & 9 & 12 \\
\hline $\mathrm{SiO}_{2}$ & 0.00 & 0.01 & 0.02 & 0.00 & 0.00 & 0.01 & 0.00 & 0.00 \\
\hline $\mathrm{TiO}_{2}$ & 52.73 & 52.33 & 49.43 & 48.83 & 53.06 & 51.82 & 51.64 & 52.90 \\
\hline $\mathrm{Al}_{2} \mathrm{O}_{3}$ & 0.01 & 0.04 & 0.06 & 0.06 & 0.02 & 0.03 & 0.03 & 0.03 \\
\hline $\mathrm{Cr}_{2} \mathrm{O}_{3}$ & 0.00 & 0.04 & 0.00 & 0.00 & 0.01 & 0.01 & 0.00 & 0.00 \\
\hline $\mathrm{V}_{2} \mathrm{O}_{3}$ & 0.16 & 0.15 & 0.23 & 0.24 & 0.17 & 0.20 & 0.16 & 0.17 \\
\hline $\mathrm{FeO}^{*}$ & 45.28 & 45.82 & 48.44 & 48.69 & 42.29 & 43.49 & 43.82 & 42.82 \\
\hline $\mathrm{Fe}_{2} \mathrm{O}_{3}$ recalculated & 1.34 & 0.53 & 6.97 & 8.13 & 1.99 & 4.19 & 4.63 & 2.75 \\
\hline FeO recalculated & 44.07 & 45.34 & 42.17 & 41.37 & 40.50 & 39.72 & 39.65 & 40.35 \\
\hline $\mathrm{MnO}$ & 0.74 & 0.83 & 0.45 & 0.44 & 0.86 & 0.81 & 0.79 & 0.79 \\
\hline $\mathrm{MgO}$ & 1.43 & 0.49 & 1.03 & 1.18 & 3.56 & 3.40 & 3.36 & 3.60 \\
\hline $\mathrm{ZnO}$ & 0.04 & 0.02 & 0.00 & 0.01 & 0.00 & 0.00 & 0.00 & 0.00 \\
\hline $\mathrm{NiO}$ & 0.00 & 0.00 & 0.00 & 0.00 & 0.00 & 0.01 & 0.00 & 0.01 \\
\hline $\mathrm{CaO}$ & 0.00 & 0.01 & 0.01 & 0.00 & 0.00 & 0.00 & 0.00 & 0.00 \\
\hline $\mathrm{Cu}_{2} \mathrm{O}$ & 0.00 & 0.02 & 0.00 & 0.00 & 0.00 & 0.00 & 0.01 & 0.02 \\
\hline $\mathrm{K}_{2} \mathrm{O}$ & 0.00 & 0.01 & 0.00 & 0.00 & 0.01 & 0.00 & 0.00 & 0.00 \\
\hline Total measured & 100.40 & 99.75 & 99.67 & 99.45 & 99.98 & 99.77 & 99.81 & 100.34 \\
\hline MAS & \multicolumn{3}{|c|}{ Massive to semi-massive mineralization } & OBAN & \multicolumn{4}{|c|}{ Orthopyroxene -bearing bands of oxide mineralization } \\
\hline DIS & \multicolumn{3}{|c|}{ Disseminated mineralization } & POD & \multicolumn{4}{|c|}{ Pod of oxide mineralization } \\
\hline BAN & \multicolumn{3}{|c|}{ Bands of oxide mineralization } & OPOD & \multicolumn{4}{|c|}{ Orthopyroxene -bearing pod of oxide mineralization } \\
\hline ANO & \multicolumn{3}{|c|}{ Anorthosite hosted disseminated } & VEIN & \multicolumn{4}{|c|}{ Vein of oxide mineralization } \\
\hline ORT & \multicolumn{3}{|c|}{ Orthopyroxene associated } & MAG & \multicolumn{4}{|c|}{ Magnetite } \\
\hline $\mathrm{CLI}$ & \multicolumn{3}{|c|}{ Clinopyroxene associated } & ILM & Ilmenite & PLE & Pleonaste & \\
\hline
\end{tabular}




\begin{tabular}{|c|c|c|c|c|c|c|c|c|c|}
\hline Sample \# & CCO72A & CCO72A & CCO72A & $\mathrm{CCO} 72 \mathrm{~A}$ & $\mathrm{CCO} 72 \mathrm{~A}$ & CC072A & $\mathrm{CCO} 72 \mathrm{~A}$ & $\mathrm{CCO} 72 \mathrm{~A}$ & CC072A \\
\hline Circle Number & $\mathrm{B}$ & B & $\mathrm{C}$ & $\mathrm{C}$ & $\mathrm{C}$ & $\mathrm{D}$ & $\mathrm{D}$ & $\mathrm{E}$ & E \\
\hline Mineralization type & MAS & MAS & MAS & MAS & MAS & MAS & MAS & MAS & MAS \\
\hline Descriptor & OPOD & OPOD & OPOD & OPOD & OPOD & OPOD & OPOD & OPOD & OPOD \\
\hline mineral host & MAG & MAG & MAG & MAG & MAG & ILM & ILM & ILM & ILM \\
\hline Mineral analyzed & ILM & ILM & ILM & ILM & ILM & ILM & ILM & ILM & ILM \\
\hline exsolution feature type & composite & composite & composite & composite & composite & host & host & host & host \\
\hline Point & 13 & 14 & 23 & 24 & 25 & 32 & 34 & 46 & 47 \\
\hline $\mathrm{SiO}_{2}$ & 0.00 & 0.01 & 0.00 & 0.01 & 0.00 & 0.00 & 0.00 & 0.00 & 0.00 \\
\hline $\mathrm{TiO}_{2}$ & 51.80 & 52.13 & 53.31 & 53.12 & 53.36 & 52.05 & 51.55 & 52.21 & 51.88 \\
\hline $\mathrm{Al}_{2} \mathrm{O}_{3}$ & 0.02 & 0.02 & 0.02 & 0.01 & 0.01 & 0.04 & 0.03 & 0.02 & 0.05 \\
\hline $\mathrm{Cr}_{2} \mathrm{O}_{3}$ & 0.00 & 0.02 & 0.01 & 0.00 & 0.00 & 0.03 & 0.00 & 0.01 & 0.01 \\
\hline $\mathrm{V}_{2} \mathrm{O}_{3}$ & 0.18 & 0.19 & 0.17 & 0.17 & 0.16 & 0.15 & 0.18 & 0.16 & 0.20 \\
\hline $\mathrm{FeO}^{*}$ & 44.01 & 43.41 & 42.55 & 41.90 & 42.10 & 42.86 & 43.59 & 43.28 & 43.49 \\
\hline $\mathrm{Fe}_{2} \mathrm{O}_{3}$ recalculated & 4.82 & 4.02 & 2.02 & 1.42 & 1.42 & 3.39 & 4.46 & 3.52 & 3.95 \\
\hline FeO recalculated & 39.67 & 39.79 & 40.73 & 40.63 & 40.82 & 39.81 & 39.58 & 40.12 & 39.93 \\
\hline $\mathrm{MnO}$ & 0.73 & 0.76 & 0.86 & 0.88 & 0.86 & 0.80 & 0.73 & 0.81 & 0.79 \\
\hline $\mathrm{MgO}$ & 3.45 & 3.54 & 3.55 & 3.51 & 3.52 & 3.48 & 3.39 & 3.38 & 3.32 \\
\hline $\mathrm{ZnO}$ & 0.03 & 0.02 & 0.01 & 0.02 & 0.02 & 0.00 & 0.00 & 0.00 & 0.00 \\
\hline $\mathrm{NiO}$ & 0.00 & 0.01 & 0.00 & 0.00 & 0.00 & 0.00 & 0.00 & 0.00 & 0.01 \\
\hline $\mathrm{CaO}$ & 0.00 & 0.00 & 0.01 & 0.00 & 0.00 & 0.00 & 0.00 & 0.00 & 0.00 \\
\hline $\mathrm{Cu}_{2} \mathrm{O}$ & 0.00 & 0.00 & 0.00 & 0.00 & 0.00 & 0.00 & 0.00 & 0.00 & 0.00 \\
\hline $\mathrm{K}_{2} \mathrm{O}$ & 0.00 & 0.00 & 0.01 & 0.00 & 0.00 & 0.00 & 0.00 & 0.00 & 0.01 \\
\hline Total measured & 100.23 & 100.12 & 100.49 & 99.63 & 100.04 & 99.41 & 99.49 & 99.87 & 99.76 \\
\hline MAS & \multicolumn{3}{|c|}{ Massive to semi-massive mineralization } & OBAN & \multicolumn{5}{|c|}{ Orthopyroxene -bearing bands of oxide mineralization } \\
\hline DIS & \multicolumn{3}{|c|}{ Disseminated mineralization } & POD & \multicolumn{5}{|c|}{ Pod of oxide mineralization } \\
\hline BAN & \multicolumn{3}{|c|}{ Bands of oxide mineralization } & OPOD & \multicolumn{5}{|c|}{ Orthopyroxene -bearing pod of oxide mineralization } \\
\hline ANO & \multicolumn{3}{|c|}{ Anorthosite hosted disseminated } & VEIN & \multicolumn{5}{|c|}{ Vein of oxide mineralization } \\
\hline ORT & \multicolumn{3}{|c|}{ Orthopyroxene associated } & MAG & \multicolumn{5}{|l|}{ Magnetite } \\
\hline $\mathrm{CLI}$ & \multicolumn{3}{|c|}{ Clinopyroxene associated } & ILM & IImenite & PLE & \multicolumn{3}{|l|}{ Pleonaste } \\
\hline
\end{tabular}




\begin{tabular}{|c|c|c|c|c|c|c|c|c|c|c|}
\hline Sample \# & $\mathrm{CCO} 72 \mathrm{~A}$ & $\mathrm{CCO} 72 \mathrm{~A}$ & $\mathrm{CCO} 72 \mathrm{~A}$ & CCO72A & CCO72A & CC072A & CCO72A & $\mathrm{CCO} 2 \mathrm{~A}$ & $\mathrm{CCO} 2 \mathrm{~A}$ & $\mathrm{CCO74}$ \\
\hline Circle Number & $\mathrm{E}$ & G & G & G & $\mathrm{H}$ & $\mathrm{H}$ & $\mathrm{H}$ & 1 & 1 & A \\
\hline Mineralization type & MAS & MAS & MAS & MAS & MAS & MAS & MAS & MAS & MAS & DIS \\
\hline Descriptor & OPOD & OPOD & OPOD & OPOD & OPOD & OPOD & OPOD & OPOD & OPOD & $\mathrm{CLI}$ \\
\hline mineral host & ILM & ILM & ILM & ILM & ILM & ILM & ILM & ILM & ILM & MAG \\
\hline Mineral analyzed & ILM & ILM & ILM & ILM & ILM & ILM & ILM & ILM & ILM & ILM \\
\hline exsolution feature type & host & host & host & host & host & host & host & composite & composite & composite \\
\hline Point & 48 & 49 & 50 & 51 & 56 & 57 & 58 & 68 & 69 & 1 \\
\hline $\mathrm{SiO}_{2}$ & 0.00 & 0.00 & 0.00 & 0.00 & 0.00 & 0.00 & 0.00 & 0.00 & 0.00 & 0.01 \\
\hline $\mathrm{TiO}_{2}$ & 51.59 & 50.36 & 52.93 & 52.46 & 52.41 & 51.67 & 51.93 & 50.99 & 51.40 & 49.63 \\
\hline $\mathrm{Al}_{2} \mathrm{O}_{3}$ & 0.03 & 0.05 & 0.02 & 0.01 & 0.03 & 0.05 & 0.02 & 0.03 & 0.02 & 0.03 \\
\hline $\mathrm{Cr}_{2} \mathrm{O}_{3}$ & 0.01 & 0.00 & 0.00 & 0.02 & 0.00 & 0.00 & 0.00 & 0.01 & 0.01 & 0.05 \\
\hline $\mathrm{V}_{2} \mathrm{O}_{3}$ & 0.17 & 0.24 & 0.19 & 0.18 & 0.21 & 0.22 & 0.20 & 0.21 & 0.21 & 0.23 \\
\hline $\mathrm{FeO}^{*}$ & 44.04 & 44.88 & 42.28 & 42.73 & 42.72 & 43.43 & 43.30 & 44.76 & 44.30 & 47.21 \\
\hline $\mathrm{Fe}_{2} \mathrm{O}_{3}$ recalculated & 4.84 & 6.82 & 2.21 & 2.89 & 3.10 & 4.35 & 4.17 & 6.22 & 5.44 & 5.10 \\
\hline FeO recalculated & 39.68 & 38.74 & 40.29 & 40.13 & 39.93 & 39.51 & 39.54 & 39.16 & 39.41 & 42.62 \\
\hline $\mathrm{MnO}$ & 0.76 & 0.69 & 0.83 & 0.77 & 0.77 & 0.73 & 0.75 & 0.68 & 0.71 & 1.21 \\
\hline $\mathrm{MgO}$ & 3.33 & 3.27 & 3.61 & 3.52 & 3.60 & 3.49 & 3.59 & 3.36 & 3.41 & 0.44 \\
\hline $\mathrm{ZnO}$ & 0.00 & 0.03 & 0.03 & 0.00 & 0.00 & 0.00 & 0.00 & 0.02 & 0.00 & 0.01 \\
\hline $\mathrm{NiO}$ & 0.01 & 0.00 & 0.02 & 0.00 & 0.00 & 0.00 & 0.00 & 0.01 & 0.02 & 0.00 \\
\hline $\mathrm{CaO}$ & 0.01 & 0.00 & 0.00 & 0.00 & 0.00 & 0.00 & 0.00 & 0.00 & 0.00 & 0.01 \\
\hline $\mathrm{Cu}_{2} \mathrm{O}$ & 0.01 & 0.00 & 0.00 & 0.00 & 0.00 & 0.00 & 0.03 & 0.00 & 0.01 & 0.00 \\
\hline $\mathrm{K}_{2} \mathrm{O}$ & 0.00 & 0.01 & 0.00 & 0.00 & 0.00 & 0.01 & 0.00 & 0.00 & 0.00 & 0.01 \\
\hline Total measured & 99.95 & 99.53 & 99.90 & 99.70 & 99.75 & 99.60 & 99.83 & 100.06 & 100.09 & 98.84 \\
\hline MAS & & & \multicolumn{3}{|c|}{$\begin{array}{l}\text { Massive to semi-massive } \\
\text { mineralization }\end{array}$} & OBAN & \multicolumn{4}{|c|}{ Orthopyroxene -bearing bands of oxide mineralization } \\
\hline DIS & & & \multicolumn{3}{|c|}{ Disseminated mineralization } & POD & \multicolumn{4}{|c|}{ Pod of oxide mineralization } \\
\hline BAN & & & \multicolumn{3}{|c|}{ Bands of oxide mineralization } & OPOD & \multicolumn{4}{|c|}{ Orthopyroxene -bearing pod of oxide mineralization } \\
\hline ANO & & & \multicolumn{3}{|c|}{ Anorthosite hosted disseminated } & VEIN & \multicolumn{4}{|c|}{ Vein of oxide mineralization } \\
\hline ORT & & & \multicolumn{3}{|c|}{ Orthopyroxene associated } & MAG & Magnetite & & & \\
\hline $\mathrm{CLI}$ & & & \multicolumn{3}{|c|}{ Clinopyroxene associated } & ILM & Ilmenite & PLE & Pleonaste & \\
\hline
\end{tabular}




\begin{tabular}{|c|c|c|c|c|c|c|c|}
\hline Sample \# & $\mathrm{CCO74}$ & $\mathrm{CCO} 74$ & $\mathrm{CCO74}$ & $\mathrm{CCO} 74$ & $\mathrm{CCO74}$ & $\mathrm{CCO74}$ & $\mathrm{CCO74}$ \\
\hline Circle Number & $A$ & $A$ & $A$ & $A$ & B & B & B \\
\hline Mineralization type & DIS & DIS & DIS & DIS & DIS & DIS & DIS \\
\hline Descriptor & $\mathrm{CLI}$ & $\mathrm{CLI}$ & $\mathrm{CLI}$ & $\mathrm{CLI}$ & $\mathrm{CLI}$ & $\mathrm{CLI}$ & $\mathrm{CLI}$ \\
\hline mineral host & MAG & MAG & MAG & MAG & MAG & MAG & MAG \\
\hline $\begin{array}{l}\text { Mineral analyzed } \\
\text { exsolution feature type }\end{array}$ & $\begin{array}{l}\text { ILM } \\
\text { composite }\end{array}$ & $\begin{array}{l}\text { ILM } \\
\text { composite }\end{array}$ & $\begin{array}{l}\text { ILM } \\
\text { around rim }\end{array}$ & $\begin{array}{l}\text { ILM } \\
\text { around rim }\end{array}$ & $\begin{array}{l}\text { ILM } \\
\text { composite }\end{array}$ & $\begin{array}{l}\text { ILM } \\
\text { composite }\end{array}$ & $\begin{array}{l}\text { ILM } \\
\text { composite }\end{array}$ \\
\hline Point & 2 & 3 & 4 & 5 & 11 & 12 & 1 \\
\hline $\mathrm{SiO}_{2}$ & 0.00 & 0.00 & 0.00 & 0.00 & 0.00 & 0.00 & 0.00 \\
\hline $\mathrm{TiO}_{2}$ & 48.43 & 47.66 & 51.80 & 51.57 & 49.89 & 48.01 & 48.36 \\
\hline $\mathrm{Al}_{2} \mathrm{O}_{3}$ & 0.02 & 0.01 & 0.00 & 0.17 & 0.02 & 0.02 & 0.03 \\
\hline $\mathrm{Cr}_{2} \mathrm{O}_{3}$ & 0.06 & 0.06 & 0.03 & 0.05 & 0.04 & 0.07 & 0.06 \\
\hline $\mathrm{V}_{2} \mathrm{O}_{3}$ & 0.22 & 0.22 & 0.20 & 0.19 & 0.20 & 0.23 & 0.25 \\
\hline $\mathrm{FeO}^{*}$ & 48.74 & 48.88 & 44.18 & 44.91 & 46.94 & 48.56 & 48.39 \\
\hline $\mathrm{Fe}_{2} \mathrm{O}_{3}$ recalculated & 8.10 & 8.89 & 1.73 & 1.95 & 4.63 & 8.18 & 7.64 \\
\hline FeO recalculated & 41.45 & 40.89 & 42.63 & 43.15 & 42.77 & 41.20 & 41.52 \\
\hline $\mathrm{MnO}$ & 1.20 & 1.15 & 2.10 & 1.55 & 1.33 & 1.30 & 1.28 \\
\hline $\mathrm{MgO}$ & 0.50 & 0.46 & 1.01 & 0.92 & 0.42 & 0.37 & 0.38 \\
\hline $\mathrm{ZnO}$ & 0.01 & 0.00 & 0.03 & 0.02 & 0.02 & 0.00 & 0.00 \\
\hline $\mathrm{NiO}$ & 0.00 & 0.00 & 0.01 & 0.00 & 0.00 & 0.00 & 0.00 \\
\hline $\mathrm{CaO}$ & 0.00 & 0.00 & 0.01 & 0.00 & 0.00 & 0.00 & 0.00 \\
\hline $\mathrm{Cu}_{2} \mathrm{O}$ & 0.00 & 0.00 & 0.01 & 0.00 & 0.00 & 0.00 & 0.01 \\
\hline $\mathrm{K}_{2} \mathrm{O}$ & 0.00 & 0.00 & 0.00 & 0.00 & 0.00 & 0.00 & 0.00 \\
\hline Total measured & 99.18 & 98.45 & 99.37 & 99.38 & 98.85 & 98.57 & 98.77 \\
\hline MAS & \multicolumn{3}{|c|}{ Massive to semi-massive mineralization } & OBAN & \multicolumn{3}{|c|}{ Orthopyroxene -bearing bands of oxide mineralization } \\
\hline DIS & \multicolumn{3}{|c|}{ Disseminated mineralization } & POD & \multicolumn{3}{|c|}{ Pod of oxide mineralization } \\
\hline BAN & \multicolumn{3}{|c|}{ Bands of oxide mineralization } & OPOD & \multicolumn{3}{|c|}{ Orthopyroxene -bearing pod of oxide mineralization } \\
\hline ANO & \multicolumn{3}{|c|}{ Anorthosite hosted disseminated } & VEIN & \multicolumn{3}{|c|}{ Vein of oxide mineralization } \\
\hline ORT & \multicolumn{3}{|c|}{ Orthopyroxene associated } & MAG & \multicolumn{3}{|c|}{ Magnetite } \\
\hline CLI & \multicolumn{3}{|c|}{ Clinopyroxene associated } & ILM & Ilmenite & PLE & Pleonaste \\
\hline
\end{tabular}




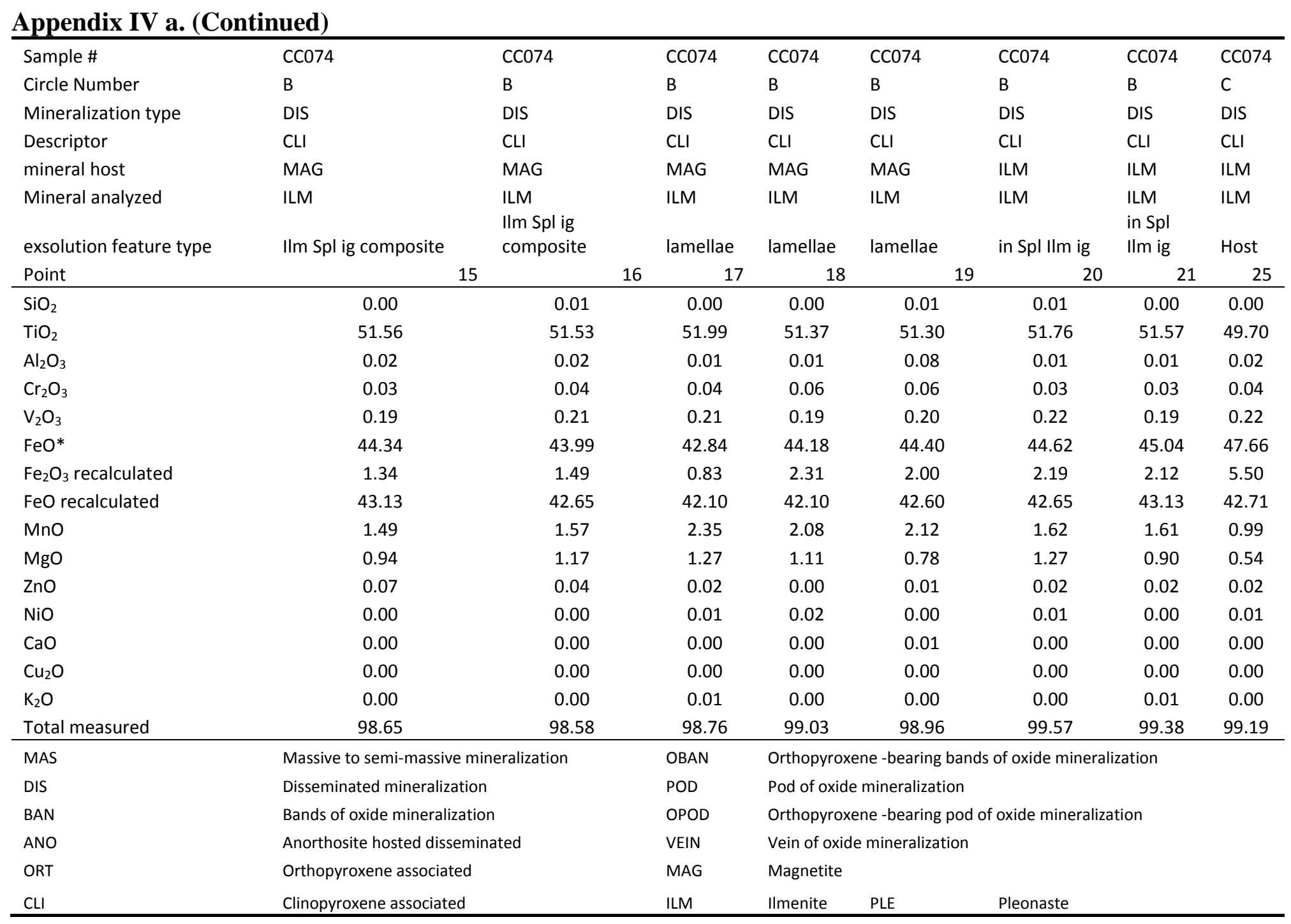




\begin{tabular}{|c|c|c|c|c|c|c|c|c|c|c|}
\hline Sample \# & CCO74 & $\mathrm{CCO74}$ & CCO74 & $\mathrm{CCO74}$ & $\mathrm{CCO} 74$ & $\mathrm{CCO74}$ & $\mathrm{CCO74}$ & $\mathrm{CCO74}$ & & $\mathrm{CCO74}$ \\
\hline Circle Number & $\mathrm{C}$ & $\mathrm{C}$ & $\mathrm{C}$ & $\mathrm{D}$ & $\mathrm{D}$ & $\mathrm{D}$ & $\mathrm{D}$ & $\mathrm{D}$ & & $\mathrm{E}$ \\
\hline Mineralization type & DIS & DIS & DIS & DIS & DIS & DIS & DIS & DIS & & DIS \\
\hline Descriptor & $\mathrm{CLI}$ & $\mathrm{CLI}$ & $\mathrm{CLI}$ & $\mathrm{CLI}$ & $\mathrm{CLI}$ & $\mathrm{CLI}$ & $\mathrm{CLI}$ & $\mathrm{CLI}$ & & $\mathrm{CLI}$ \\
\hline mineral host & ILM & ILM & ILM & ILM & ILM & ILM & ILM & ILM & & MAG \\
\hline Mineral analyzed & ILM & ILM & ILM & ILM & ILM & ILM & ILM & $\begin{array}{l}\text { ILM } \\
\text { IIm Spl ig }\end{array}$ & & ILM \\
\hline exsolution feature type & Host & rim & rim & Host & Host & Host & IIm Spl ig composite & composite & & thick lamellae \\
\hline Point & 26 & 28 & 29 & 33 & 34 & 35 & & & 37 & 41 \\
\hline $\mathrm{SiO}_{2}$ & 0.01 & 0.00 & 0.01 & 0.01 & 0.00 & 0.00 & 0.00 & 0.00 & & 0.00 \\
\hline $\mathrm{TiO}_{2}$ & 48.80 & 51.48 & 51.44 & 48.25 & 47.70 & 48.30 & 51.33 & 51.47 & & 52.03 \\
\hline $\mathrm{Al}_{2} \mathrm{O}_{3}$ & 0.02 & 0.02 & 0.02 & 0.01 & 0.02 & 0.01 & 0.07 & 0.01 & & 0.04 \\
\hline $\mathrm{Cr}_{2} \mathrm{O}_{3}$ & 0.04 & 0.06 & 0.06 & 0.03 & 0.03 & 0.01 & 0.04 & 0.02 & & 0.04 \\
\hline $\mathrm{V}_{2} \mathrm{O}_{3}$ & 0.23 & 0.20 & 0.20 & 0.21 & 0.23 & 0.22 & 0.17 & 0.20 & & 0.19 \\
\hline $\mathrm{FeO}^{*}$ & 48.12 & 45.65 & 45.91 & 48.28 & 48.52 & 47.50 & 45.69 & 45.04 & & 43.02 \\
\hline $\mathrm{Fe}_{2} \mathrm{O}_{3}$ recalculated & 6.80 & 1.81 & 2.15 & 7.39 & 8.45 & 6.94 & 1.42 & 1.20 & & -0.60 \\
\hline FeO recalculated & 42.01 & 44.02 & 43.98 & 41.63 & 40.92 & 41.25 & 44.42 & 43.96 & & 43.56 \\
\hline $\mathrm{MnO}$ & 1.05 & 1.17 & 1.20 & 0.98 & 0.94 & 0.94 & 1.51 & 2.21 & & 3.15 \\
\hline $\mathrm{MgO}$ & 0.46 & 0.58 & 0.58 & 0.42 & 0.58 & 0.68 & 0.09 & 0.02 & & 0.01 \\
\hline $\mathrm{ZnO}$ & 0.00 & 0.06 & 0.04 & 0.01 & 0.01 & 0.00 & 0.05 & 0.05 & & 0.03 \\
\hline $\mathrm{NiO}$ & 0.00 & 0.01 & 0.00 & 0.00 & 0.00 & 0.01 & 0.00 & 0.01 & & 0.00 \\
\hline $\mathrm{CaO}$ & 0.01 & 0.00 & 0.00 & 0.02 & 0.00 & 0.01 & 0.01 & 0.01 & & 0.00 \\
\hline $\mathrm{Cu}_{2} \mathrm{O}$ & 0.00 & 0.02 & 0.00 & 0.02 & 0.01 & 0.01 & 0.00 & 0.00 & & 0.00 \\
\hline $\mathrm{K}_{2} \mathrm{O}$ & 0.00 & 0.00 & 0.01 & 0.00 & 0.00 & 0.00 & 0.00 & 0.00 & & 0.00 \\
\hline Total measured & 98.73 & 99.26 & 99.47 & 98.24 & 98.03 & 97.70 & 98.96 & 99.04 & & 98.52 \\
\hline MAS & & \multicolumn{3}{|c|}{$\begin{array}{l}\text { Massive to semi-massive } \\
\text { mineralization }\end{array}$} & OBAN & Orthopyro & xene -bearing bands of ox & nineralization & & \\
\hline DIS & & \multicolumn{3}{|c|}{ Disseminated mineralization } & POD & \multicolumn{3}{|c|}{ Pod of oxide mineralization } & & \\
\hline BAN & & \multicolumn{3}{|c|}{ Bands of oxide mineralization } & OPOD & \multicolumn{3}{|c|}{ Orthopyroxene -bearing pod of oxide mineralization } & & \\
\hline ANO & & \multicolumn{3}{|c|}{ Anorthosite hosted disseminated } & VEIN & \multicolumn{3}{|c|}{ Vein of oxide mineralization } & & \\
\hline ORT & & \multicolumn{3}{|c|}{ Orthopyroxene associated } & MAG & Magnetite & & & & \\
\hline $\mathrm{CLI}$ & & \multicolumn{3}{|c|}{ Clinopyroxene associated } & ILM & Ilmenite & PLE & Pleonaste & & \\
\hline
\end{tabular}




\begin{tabular}{|c|c|c|c|c|c|c|c|c|c|c|}
\hline Sample \# & $\mathrm{CCO74}$ & $\mathrm{CCO74}$ & $\mathrm{CCO74}$ & $\mathrm{CCO74}$ & $\mathrm{CCO} 44$ & $\mathrm{CCO} 74$ & $\mathrm{CCO74}$ & $\mathrm{CCO} 74$ & CCO76 & CC076 \\
\hline Circle Number & $\mathrm{E}$ & $\mathrm{E}$ & $\mathrm{E}$ & $\mathrm{F}$ & $\mathrm{F}$ & $\mathrm{F}$ & $\mathrm{F}$ & $\mathrm{F}$ & B & B \\
\hline Mineralization type & DIS & DIS & DIS & DIS & DIS & DIS & DIS & DIS & MAS & MAS \\
\hline Descriptor & $\mathrm{CLI}$ & $\mathrm{CLI}$ & $\mathrm{CLI}$ & $\mathrm{CLI}$ & $\mathrm{CLI}$ & $\mathrm{CLI}$ & $\mathrm{CLI}$ & $\mathrm{CLI}$ & VEIN & VEIN \\
\hline mineral host & MAG & MAG & MAG & MAG & MAG & ILM & ILM & ILM & ILM & ILM \\
\hline Mineral analyzed & ILM & ILM & ILM & ILM & ILM & ILM & ILM & ILM & ILM & ILM \\
\hline exsolution feature type & thick lamellae & composite & composite & lamellae & lamellae & Host & Host & Host & host & host \\
\hline Point & 42 & 44 & 45 & 49 & 50 & 51 & 52 & 53 & 4 & 5 \\
\hline $\mathrm{SiO}_{2}$ & 0.00 & 0.00 & 0.00 & 0.00 & 0.06 & 0.00 & 0.00 & 0.00 & 0.00 & 0.00 \\
\hline $\mathrm{TiO}_{2}$ & 51.96 & 49.43 & 48.41 & 51.10 & 50.72 & 50.12 & 47.96 & 47.49 & 47.67 & 48.94 \\
\hline $\mathrm{Al}_{2} \mathrm{O}_{3}$ & 0.00 & 0.01 & 0.03 & 0.05 & 0.28 & 0.03 & 0.01 & 0.03 & 0.02 & 0.03 \\
\hline $\mathrm{Cr}_{2} \mathrm{O}_{3}$ & 0.04 & 0.03 & 0.05 & 0.09 & 0.10 & 0.05 & 0.04 & 0.06 & 0.02 & 0.03 \\
\hline $\mathrm{V}_{2} \mathrm{O}_{3}$ & 0.19 & 0.21 & 0.23 & 0.21 & 0.20 & 0.23 & 0.23 & 0.26 & 0.29 & 0.29 \\
\hline $\mathrm{FeO}^{*}$ & 43.32 & 47.64 & 47.52 & 41.26 & 39.70 & 46.90 & 48.95 & 49.71 & 49.33 & 48.46 \\
\hline $\mathrm{Fe}_{2} \mathrm{O}_{3}$ recalculated & -0.19 & 5.78 & 6.63 & 2.10 & 1.94 & 4.20 & 8.60 & 9.95 & 10.23 & 8.02 \\
\hline FeO recalculated & 43.49 & 42.44 & 41.55 & 39.37 & 37.95 & 43.12 & 41.21 & 40.75 & 40.13 & 41.25 \\
\hline $\mathrm{MnO}$ & 3.13 & 0.88 & 1.37 & 6.47 & 7.45 & 1.22 & 1.19 & 1.20 & 0.99 & 1.02 \\
\hline $\mathrm{MgO}$ & 0.02 & 0.60 & 0.32 & 0.00 & 0.06 & 0.38 & 0.40 & 0.41 & 0.96 & 0.98 \\
\hline $\mathrm{ZnO}$ & 0.02 & 0.04 & 0.02 & 0.02 & 0.03 & 0.03 & 0.01 & 0.00 & 0.03 & 0.00 \\
\hline $\mathrm{NiO}$ & 0.00 & 0.03 & 0.00 & 0.01 & 0.01 & 0.02 & 0.00 & 0.01 & 0.00 & 0.00 \\
\hline $\mathrm{CaO}$ & 0.01 & 0.00 & 0.01 & 0.01 & 0.05 & 0.00 & 0.00 & 0.00 & 0.00 & 0.00 \\
\hline $\mathrm{Cu}_{2} \mathrm{O}$ & 0.00 & 0.00 & 0.02 & 0.00 & 0.02 & 0.00 & 0.00 & 0.00 & 0.00 & 0.00 \\
\hline $\mathrm{K}_{2} \mathrm{O}$ & 0.00 & 0.01 & 0.00 & 0.00 & 0.00 & 0.00 & 0.00 & 0.00 & 0.00 & 0.00 \\
\hline Total measured & 98.72 & 98.87 & 97.98 & 99.23 & 98.66 & 98.98 & 98.79 & 99.18 & 99.31 & 99.74 \\
\hline MAS & \multicolumn{3}{|c|}{ Massive to semi-massive mineralization } & OBAN & \multicolumn{6}{|c|}{ Orthopyroxene -bearing bands of oxide mineralization } \\
\hline DIS & \multicolumn{3}{|c|}{ Disseminated mineralization } & POD & \multicolumn{6}{|c|}{ Pod of oxide mineralization } \\
\hline BAN & \multicolumn{3}{|c|}{ Bands of oxide mineralization } & OPOD & \multicolumn{6}{|c|}{ Orthopyroxene -bearing pod of oxide mineralization } \\
\hline ANO & \multicolumn{3}{|c|}{ Anorthosite hosted disseminated } & VEIN & \multicolumn{6}{|c|}{ Vein of oxide mineralization } \\
\hline ORT & \multicolumn{3}{|c|}{ Orthopyroxene associated } & MAG & \multicolumn{6}{|l|}{ Magnetite } \\
\hline $\mathrm{CLI}$ & Clinopyroxene associat & & & ILM & Ilmenite & PLE & Pleonaste & & & \\
\hline
\end{tabular}




\begin{tabular}{|c|c|c|c|c|c|c|c|c|c|c|c|c|}
\hline Sample \# & CC076 & CC076 & CC076 & CC076 & CC076 & CC076 & CC076 & CC076 & CC076 & CC076 & CC076 & CC076 \\
\hline Circle Number & B & $\mathrm{C}$ & $\mathrm{C}$ & $\mathrm{C}$ & D & D & $\mathrm{F}$ & $\mathrm{F}$ & $\mathrm{F}$ & G & G & G \\
\hline Mineralization type & MAS & MAS & MAS & MAS & MAS & MAS & MAS & MAS & MAS & MAS & MAS & MAS \\
\hline Descriptor & VEIN & VEIN & VEIN & VEIN & VEIN & VEIN & VEIN & VEIN & VEIN & VEIN & VEIN & VEIN \\
\hline mineral host & ILM & MAG & MAG & MAG & ILM & ILM & ILM & ILM & ILM & ILM & ILM & ILM \\
\hline Mineral analyzed & ILM & ILM & ILM & ILM & ILM & ILM & ILM & ILM & ILM & ILM & ILM & ILM \\
\hline exsolution feature type & host & lath & lath & lath & host & host & host & host & host & host & host & host \\
\hline Point & 6 & 13 & 14 & 15 & 29 & 30 & 37 & 38 & 39 & 47 & 48 & 49 \\
\hline $\mathrm{SiO}_{2}$ & 0.01 & 0.00 & 0.01 & 0.00 & 0.00 & 0.01 & 0.00 & 0.01 & 0.01 & 0.01 & 0.00 & 0.01 \\
\hline $\mathrm{TiO}_{2}$ & 48.64 & 50.58 & 49.33 & 48.83 & 48.49 & 50.04 & 46.76 & 48.65 & 49.22 & 48.47 & 47.84 & 48.21 \\
\hline $\mathrm{Al}_{2} \mathrm{O}_{3}$ & 0.02 & 0.01 & 0.01 & 0.02 & 0.01 & 0.02 & 0.02 & 0.02 & 0.01 & 0.02 & 0.11 & 0.02 \\
\hline $\mathrm{Cr}_{2} \mathrm{O}_{3}$ & 0.02 & 0.10 & 0.09 & 0.11 & 0.03 & 0.00 & 0.02 & 0.02 & 0.02 & 0.02 & 0.02 & 0.01 \\
\hline $\mathrm{V}_{2} \mathrm{O}_{3}$ & 0.26 & 0.29 & 0.33 & 0.35 & 0.29 & 0.25 & 0.34 & 0.26 & 0.27 & 0.28 & 0.29 & 0.25 \\
\hline $\mathrm{FeO}^{*}$ & 48.87 & 46.59 & 47.35 & 48.02 & 48.12 & 46.93 & 49.42 & 48.06 & 47.32 & 48.63 & 48.44 & 48.26 \\
\hline $\mathrm{Fe}_{2} \mathrm{O}_{3}$ recalculated & -26.66 & 4.63 & 6.57 & 7.82 & 7.96 & 5.20 & 11.21 & 7.78 & 6.55 & 8.55 & 8.79 & 8.50 \\
\hline FeO recalculated & 72.86 & 42.43 & 41.44 & 40.99 & 40.96 & 42.25 & 39.34 & 41.06 & 41.43 & 40.94 & 40.53 & 40.61 \\
\hline $\mathrm{MnO}$ & 0.98 & 1.45 & 1.36 & 1.40 & 1.09 & 1.07 & 1.05 & 1.07 & 1.14 & 1.08 & 1.06 & 1.12 \\
\hline $\mathrm{MgO}$ & 1.01 & 0.89 & 0.87 & 0.85 & 0.86 & 0.94 & 0.93 & 0.91 & 0.95 & 0.87 & 0.80 & 0.91 \\
\hline $\mathrm{ZnO}$ & 0.02 & 0.01 & 0.00 & 0.00 & 0.00 & 0.00 & 0.00 & 0.00 & 0.00 & 0.01 & 0.01 & 0.00 \\
\hline $\mathrm{NiO}$ & 0.00 & 0.00 & 0.00 & 0.00 & 0.00 & 0.00 & 0.00 & 0.00 & 0.00 & 0.01 & 0.00 & 0.01 \\
\hline $\mathrm{CaO}$ & 0.00 & 0.00 & 0.00 & 0.00 & 0.01 & 0.01 & 0.00 & 0.00 & 0.01 & 0.00 & 0.00 & 0.00 \\
\hline $\mathrm{Cu}_{2} \mathrm{O}$ & 0.00 & 0.01 & 0.00 & 0.01 & 0.00 & 0.00 & 0.00 & 0.00 & 0.02 & 0.00 & 0.00 & 0.00 \\
\hline $\mathrm{K}_{2} \mathrm{O}$ & 0.00 & 0.00 & 0.00 & 0.00 & 0.00 & 0.00 & 0.01 & 0.00 & 0.00 & 0.00 & 0.00 & 0.00 \\
\hline Total measured & 99.84 & 99.93 & 99.35 & 99.59 & 98.91 & 99.28 & 98.55 & 98.99 & 98.97 & 99.40 & 98.58 & 98.80 \\
\hline MAS & \multicolumn{3}{|c|}{$\begin{array}{l}\text { Massive to semi-massive } \\
\text { mineralization }\end{array}$} & OBAN & Orthopyrc & xene -bea & ing bands & of oxide $m$ & ineralizati & & & \\
\hline DIS & \multicolumn{3}{|c|}{ Disseminated mineralization } & POD & Pod of oxi & de minera & zation & & & & & \\
\hline BAN & \multicolumn{3}{|c|}{ Bands of oxide mineralization } & OPOD & Orthopyrc & xene -bea & ing pod o & oxide min & eralization & & & \\
\hline ANO & \multicolumn{3}{|c|}{ Anorthosite hosted disseminated } & VEIN & Vein of ox & de minera & lization & & & & & \\
\hline ORT & \multicolumn{3}{|c|}{ Orthopyroxene associated } & MAG & Magnetite & & & & & & & \\
\hline $\mathrm{CLI}$ & \multicolumn{3}{|c|}{ Clinopyroxene associated } & ILM & Ilmenite & PLE & \multicolumn{5}{|c|}{ Pleonaste } & \\
\hline
\end{tabular}




\begin{tabular}{|c|c|c|c|c|}
\hline Sample \# & CC076 & CC076 & & \\
\hline Circle Number & M & $\mathrm{M}$ & & \\
\hline Mineralization type & MAS & MAS & & \\
\hline Descriptor & VEIN & VEIN & & \\
\hline mineral host & Grt & Grt & & \\
\hline Mineral analyzed & ILM & ILM & & \\
\hline exsolution feature type & myrmekite & myrmekite & & \\
\hline Point & 50 & 51 & & \\
\hline $\mathrm{SiO}_{2}$ & 0.02 & 0.02 & & \\
\hline $\mathrm{TiO}_{2}$ & 51.43 & 50.92 & & \\
\hline $\mathrm{Al}_{2} \mathrm{O}_{3}$ & 0.02 & 0.02 & & \\
\hline $\mathrm{Cr}_{2} \mathrm{O}_{3}$ & 0.04 & 0.04 & & \\
\hline $\mathrm{V}_{2} \mathrm{O}_{3}$ & 0.25 & 0.23 & & \\
\hline $\mathrm{FeO}^{*}$ & 45.22 & 45.28 & & \\
\hline $\mathrm{Fe}_{2} \mathrm{O}_{3}$ recalculated & 2.16 & 1.96 & & \\
\hline FeO recalculated & 43.27 & 43.51 & & \\
\hline $\mathrm{MnO}$ & 1.31 & 1.46 & & \\
\hline $\mathrm{MgO}$ & 0.89 & 0.43 & & \\
\hline $\mathrm{ZnO}$ & 0.02 & 0.03 & & \\
\hline $\mathrm{NiO}$ & 0.00 & 0.00 & & \\
\hline $\mathrm{CaO}$ & 0.06 & 0.03 & & \\
\hline $\mathrm{Cu}_{2} \mathrm{O}$ & 0.00 & 0.01 & & \\
\hline $\mathrm{K}_{2} \mathrm{O}$ & 0.00 & 0.03 & & \\
\hline Total measured & 99.26 & 98.49 & & \\
\hline MAS & \multicolumn{2}{|c|}{ Massive to semi-massive mineralization } & OBAN & Orthopyroxene -bearing bands of oxide mineralization \\
\hline DIS & \multicolumn{2}{|c|}{ Disseminated mineralization } & POD & Pod of oxide mineralization \\
\hline BAN & \multicolumn{2}{|c|}{ Bands of oxide mineralization } & OPOD & Orthopyroxene -bearing pod of oxide mineralization \\
\hline ANO & \multicolumn{2}{|c|}{ Anorthosite hosted disseminated } & VEIN & Vein of oxide mineralization \\
\hline ORT & \multicolumn{2}{|c|}{ Orthopyroxene associated } & MAG & Magnetite \\
\hline $\mathrm{CLI}$ & \multicolumn{2}{|c|}{ Clinopyroxene associated } & ILM & Pleonaste \\
\hline
\end{tabular}




\section{Appendix IV a. (Continued)}

\begin{tabular}{|c|c|c|c|c|c|c|c|c|c|c|c|}
\hline Sample \# & CC008 & CC008 & $\mathrm{CCO08}$ & CC008 & $\mathrm{CCOO8}$ & CC008 & CC008 & CC010 & CC010 & CC010 & CC010 \\
\hline Circle Number & B & B & $\mathrm{C}$ & $\mathrm{C}$ & $\mathrm{C}$ & $\mathrm{D}$ & $\mathrm{D}$ & A & A & $\mathrm{C}$ & $\mathrm{C}$ \\
\hline Mineralization type & MAS & MAS & MAS & MAS & MAS & MAS & MAS & MAS & MAS & MAS & MAS \\
\hline Descriptor & BAN & BAN & BAN & BAN & BAN & BAN & OBAN & OBAN & OBAN & OBAN & OBAN \\
\hline mineral host & PLE & PLE & ILM & ILM & ILM & PLE & PLE & PLE & PLE & PLE & PLE \\
\hline Mineral analyzed & PLE & PLE & PLE & PLE & PLE & PLE & PLE & PLE & PLE & PLE & PLE \\
\hline exsolution feature type & host & host & box rims & box rims & lamellae & host & host & Host & Host & Host & Host \\
\hline Point & 14 & 15 & 18 & 19 & 28 & 31 & 32 & 8 & 9 & 14 & 15 \\
\hline $\mathrm{SiO}_{2}$ & 0.00 & 0.00 & 0.03 & 0.00 & 0.01 & 0.01 & 0.00 & 0.01 & 0.00 & 0.01 & 0.00 \\
\hline $\mathrm{TiO}_{2}$ & 0.00 & 0.01 & 0.56 & 0.50 & 1.14 & 0.02 & 0.03 & 0.01 & 0.00 & 0.01 & 0.02 \\
\hline $\mathrm{Al}_{2} \mathrm{O}_{3}$ & 59.18 & 57.99 & 62.91 & 62.83 & 62.31 & 58.11 & 57.85 & 59.50 & 58.67 & 59.32 & 58.04 \\
\hline $\mathrm{Cr}_{2} \mathrm{O}_{3}$ & 0.25 & 0.34 & 0.65 & 0.56 & 0.50 & 0.25 & 0.28 & 0.26 & 0.26 & 0.25 & 0.25 \\
\hline $\mathrm{V}_{2} \mathrm{O}_{3}$ & 0.09 & 0.08 & 0.06 & 0.06 & 0.06 & 0.09 & 0.09 & 0.06 & 0.10 & 0.07 & 0.10 \\
\hline $\mathrm{FeO} *$ & 28.47 & 28.81 & 21.62 & 22.01 & 21.54 & 28.89 & 29.22 & 27.23 & 28.39 & 27.15 & 29.18 \\
\hline $\mathrm{Fe}_{2} \mathrm{O}_{3}$ recalculated & 5.28 & 6.25 & 2.27 & 2.62 & 1.30 & 5.75 & 6.24 & 5.26 & 6.24 & 5.31 & 6.92 \\
\hline FeO recalculated & 23.72 & 23.19 & 19.57 & 19.65 & 20.37 & 23.72 & 23.60 & 22.50 & 22.78 & 22.37 & 22.96 \\
\hline $\mathrm{MnO}$ & 0.22 & 0.22 & 0.15 & 0.15 & 0.14 & 0.23 & 0.22 & 0.24 & 0.25 & 0.20 & 0.23 \\
\hline $\mathrm{MgO}$ & 10.99 & 11.14 & 14.93 & 14.82 & 14.54 & 10.73 & 10.84 & 11.79 & 11.58 & 11.83 & 11.41 \\
\hline $\mathrm{ZnO}$ & 0.68 & 0.62 & 0.39 & 0.37 & 0.37 & 0.65 & 0.61 & 0.67 & 0.64 & 0.70 & 0.67 \\
\hline $\mathrm{NiO}$ & 0.11 & 0.10 & 0.09 & 0.09 & 0.06 & 0.11 & 0.11 & 0.12 & 0.10 & 0.10 & 0.10 \\
\hline Total (Mass \%) & 99.99 & 99.31 & 101.39 & 101.40 & 100.67 & 99.08 & 99.25 & 99.89 & 99.99 & 99.63 & 100.00 \\
\hline Total recalculated & 100.52 & 99.94 & 101.62 & 101.66 & 100.80 & 99.66 & 99.88 & 100.42 & 100.61 & 100.16 & 100.69 \\
\hline MAS & \multicolumn{4}{|c|}{ Massive to semi-massive mineralization } & OBAN & \multicolumn{6}{|c|}{ Orthopyroxene -bearing bands of oxide mineralization } \\
\hline DIS & \multicolumn{4}{|c|}{ Disseminated mineralization } & POD & \multicolumn{6}{|c|}{ Pod of oxide mineralization } \\
\hline BAN & \multicolumn{4}{|c|}{ Bands of oxide mineralization } & OPOD & \multicolumn{6}{|c|}{ Orthopyroxene -bearing pod of oxide mineralization } \\
\hline ANO & \multicolumn{4}{|c|}{ Anorthosite hosted disseminated } & VEIN & \multicolumn{6}{|c|}{ Vein of oxide mineralization } \\
\hline ORT & \multicolumn{4}{|c|}{ Orthopyroxene associated } & MAG & \multicolumn{6}{|c|}{ Magnetite } \\
\hline CLI & \multicolumn{4}{|c|}{ Clinopyroxene associated } & ILM & \multicolumn{2}{|l|}{ Ilmenite } & PLE & \multicolumn{3}{|c|}{ Pleonaste } \\
\hline
\end{tabular}




\begin{tabular}{|c|c|c|c|c|c|c|c|c|c|c|}
\hline Sample \# & $\mathrm{CCO10}$ & CC010 & CC010 & CC010 & CC010 & CC010 & CC010 & CC013 & CC013 & $\mathrm{CCO13}$ \\
\hline Circle Number & $\mathrm{E}$ & $\mathrm{E}$ & $\mathrm{F}$ & $\mathrm{M}$ & $\mathrm{M}$ & $\mathrm{M}$ & $\mathrm{M}$ & A & A & A \\
\hline Mineralization type & MAS & MAS & MAS & MAS & MAS & MAS & MAS & MAS & MAS & MAS \\
\hline Descriptor & OBAN & OBAN & OBAN & OBAN & OBAN & OBAN & OBAN & BAN & BAN & BAN \\
\hline mineral host & MAG & MAG & ILM & ILM & ILM & MAG & MAG & MAG & ILM & ILM \\
\hline $\begin{array}{l}\text { Mineral analyzed } \\
\text { exsolution feature }\end{array}$ & PLE & PLE & PLE & PLE & PLE & PLE & PLE & PLE & PLE & PLE \\
\hline type & cap & cap & rim & Cap & Cap & granule & granule & granule & lamellae & lamellae \\
\hline Point & 36 & 37 & 49 & 73 & 74 & 75 & 76 & 10 & 11 & 12 \\
\hline $\mathrm{SiO}_{2}$ & 0.01 & 0.01 & 0.01 & 0.00 & 0.02 & 0.00 & 0.09 & 0.00 & 0.00 & 0.00 \\
\hline $\mathrm{TiO}_{2}$ & 0.11 & 0.01 & 0.64 & 0.00 & 0.01 & 0.17 & 0.03 & 0.02 & 0.89 & 1.11 \\
\hline $\mathrm{Al}_{2} \mathrm{O}_{3}$ & 60.99 & 60.65 & 61.66 & 60.61 & 60.05 & 60.89 & 61.97 & 57.40 & 62.00 & 62.13 \\
\hline $\mathrm{Cr}_{2} \mathrm{O}_{3}$ & 0.38 & 0.34 & 0.50 & 0.34 & 0.33 & 0.43 & 0.34 & 0.59 & 0.72 & 0.75 \\
\hline $\mathrm{V}_{2} \mathrm{O}_{3}$ & 0.06 & 0.06 & 0.06 & 0.08 & 0.08 & 0.06 & 0.06 & 0.07 & 0.06 & 0.09 \\
\hline $\mathrm{FeO}^{*}$ & 24.35 & 25.03 & 22.83 & 25.16 & 25.83 & 24.45 & 24.09 & 28.74 & 21.82 & 21.29 \\
\hline $\mathrm{Fe}_{2} \mathrm{O}_{3}$ recalculated & 3.70 & 4.08 & 2.52 & 4.24 & 4.65 & 3.59 & 2.79 & 6.50 & 2.24 & 1.97 \\
\hline FeO recalculated & 21.02 & 21.36 & 20.56 & 21.34 & 21.64 & 21.22 & 21.58 & 22.89 & 19.80 & 19.51 \\
\hline $\mathrm{MnO}$ & 0.22 & 0.22 & 0.20 & 0.20 & 0.22 & 0.23 & 0.25 & 0.26 & 0.16 & 0.16 \\
\hline $\mathrm{MgO}$ & 13.09 & 12.73 & 13.92 & 12.76 & 12.49 & 12.98 & 13.06 & 11.19 & 14.71 & 15.08 \\
\hline $\mathrm{ZnO}$ & 0.46 & 0.48 & 0.42 & 0.47 & 0.50 & 0.43 & 0.23 & 0.58 & 0.48 & 0.50 \\
\hline $\mathrm{NiO}$ & 0.09 & 0.10 & 0.07 & 0.11 & 0.09 & 0.09 & 0.09 & 0.10 & 0.07 & 0.07 \\
\hline Total (Mass \%) & 99.76 & 99.63 & 100.31 & 99.74 & 99.61 & 99.74 & 100.21 & 98.95 & 100.90 & 101.17 \\
\hline Total recalculated & 100.13 & 100.04 & 100.56 & 100.16 & 100.08 & 100.10 & 100.49 & 99.60 & 101.13 & 101.37 \\
\hline MAS & \multicolumn{4}{|c|}{ Massive to semi-massive mineralization } & OBAN & \multicolumn{5}{|c|}{ Orthopyroxene -bearing bands of oxide mineralization } \\
\hline DIS & \multicolumn{4}{|c|}{ Disseminated mineralization } & POD & \multicolumn{5}{|c|}{ Pod of oxide mineralization } \\
\hline BAN & \multicolumn{4}{|c|}{ Bands of oxide mineralization } & OPOD & \multicolumn{5}{|c|}{ Orthopyroxene -bearing pod of oxide mineralization } \\
\hline ANO & \multicolumn{4}{|c|}{ Anorthosite hosted disseminated } & VEIN & \multicolumn{5}{|c|}{ Vein of oxide mineralization } \\
\hline ORT & \multicolumn{4}{|c|}{ Orthopyroxene associated } & MAG & \multicolumn{5}{|c|}{ Magnetite } \\
\hline $\mathrm{CLI}$ & \multicolumn{4}{|c|}{ Clinopyroxene associated } & ILM & \multicolumn{2}{|l|}{ Ilmenite } & PLE & \multicolumn{2}{|l|}{ Pleonaste } \\
\hline
\end{tabular}




\begin{tabular}{|c|c|c|c|c|c|c|c|c|c|c|}
\hline \multicolumn{11}{|c|}{ Appendix IV a. (Continued) } \\
\hline Sample \# & CCO13 & CC013 & CC013 & $\mathrm{CC013}$ & CCO25 & $\mathrm{CCO} 25$ & CCO25 & $\mathrm{CCO} 25$ & $\mathrm{CCO} 25$ & $\mathrm{CCO} 25$ \\
\hline Circle Number & I & I & L & L & D & $\mathrm{D}$ & $\mathrm{D}$ & D & $\mathrm{E}$ & $\mathrm{E}$ \\
\hline Mineralization type & MAS & MAS & MAS & MAS & MAS & MAS & MAS & MAS & MAS & MAS \\
\hline Descriptor & BAN & BAN & BAN & BAN & POD & POD & POD & POD & POD & POD \\
\hline mineral host & PLE & PLE & PLE & PLE & ILM & ILM & hercynite & PLE & PLE & PLE \\
\hline $\begin{array}{l}\text { Mineral analyzed } \\
\text { exsolution feature }\end{array}$ & PLE & PLE & PLE & PLE & $\begin{array}{l}\text { PLE } \\
\text { thick }\end{array}$ & PLE & hercynite & PLE & PLE & $\begin{array}{l}\text { PLE } \\
\text { comp }\end{array}$ \\
\hline type & host & host & Host & Host & ig & thick ig & intergrowth & intergrowth & comp ig & ig \\
\hline Point & 41 & 42 & 54 & 55 & 29 & 30 & 33 & 34 & 43 & 44 \\
\hline $\mathrm{SiO}_{2}$ & 0.00 & 0.00 & 0.00 & 0.00 & 0.05 & 0.11 & 0.01 & 0.18 & 0.10 & 0.11 \\
\hline $\mathrm{TiO}_{2}$ & 0.01 & 0.02 & 0.00 & 0.02 & 0.89 & 0.82 & 1.03 & 1.14 & 0.74 & 1.31 \\
\hline $\mathrm{Al}_{2} \mathrm{O}_{3}$ & 58.37 & 58.24 & 59.91 & 59.68 & 56.86 & 57.12 & 56.58 & 56.28 & 56.30 & 55.88 \\
\hline $\mathrm{Cr}_{2} \mathrm{O}_{3}$ & 0.40 & 0.35 & 0.49 & 0.49 & 1.36 & 0.99 & 1.45 & 1.49 & 1.18 & 1.40 \\
\hline $\mathrm{V}_{2} \mathrm{O}_{3}$ & 0.08 & 0.10 & 0.07 & 0.08 & 0.08 & 0.08 & 0.06 & 0.07 & 0.07 & 0.08 \\
\hline $\mathrm{FeO}^{*}$ & 28.93 & 29.03 & 26.81 & 26.92 & 33.07 & 32.52 & 32.39 & 32.52 & 32.43 & 31.99 \\
\hline $\mathrm{Fe}_{2} \mathrm{O}_{3}$ recalculated & 6.01 & 6.21 & 4.64 & 4.77 & 2.79 & 2.84 & 2.75 & 2.76 & 3.49 & 2.65 \\
\hline FeO recalculated & 23.52 & 23.45 & 22.63 & 22.63 & 30.56 & 29.96 & 29.91 & 30.03 & 29.29 & 29.61 \\
\hline $\mathrm{MnO}$ & 0.30 & 0.29 & 0.28 & 0.28 & 0.19 & 0.19 & 0.16 & 0.16 & 0.16 & 0.17 \\
\hline $\mathrm{MgO}$ & 11.01 & 11.03 & 11.80 & 11.76 & 6.94 & 7.29 & 7.21 & 7.40 & 7.45 & 7.56 \\
\hline $\mathrm{ZnO}$ & 0.61 & 0.63 & 0.58 & 0.60 & 0.58 & 0.54 & 0.76 & 0.71 & 0.63 & 0.58 \\
\hline $\mathrm{NiO}$ & 0.09 & 0.11 & 0.11 & 0.10 & 0.10 & 0.13 & 0.09 & 0.11 & 0.11 & 0.12 \\
\hline Total (Mass \%) & 99.81 & 99.80 & 100.04 & 99.93 & 100.12 & 99.78 & 99.74 & 100.07 & 99.18 & 99.19 \\
\hline Total recalculated & 100.41 & 100.42 & 100.50 & 100.41 & 100.40 & 100.06 & 100.02 & 100.34 & 99.53 & 99.46 \\
\hline MAS & \multicolumn{4}{|c|}{ Massive to semi-massive mineralization } & OBAN & \multicolumn{5}{|c|}{ Orthopyroxene -bearing bands of oxide mineralization } \\
\hline DIS & \multicolumn{4}{|c|}{ Disseminated mineralization } & POD & \multicolumn{5}{|c|}{ Pod of oxide mineralization } \\
\hline BAN & \multicolumn{4}{|c|}{ Bands of oxide mineralization } & OPOD & \multicolumn{5}{|c|}{ Orthopyroxene -bearing pod of oxide mineralization } \\
\hline ANO & \multicolumn{4}{|c|}{ Anorthosite hosted disseminated } & VEIN & \multicolumn{5}{|c|}{ Vein of oxide mineralization } \\
\hline ORT & \multirow{2}{*}{\multicolumn{4}{|c|}{ Orthopyroxene associated }} & MAG & \multicolumn{5}{|c|}{ Magnetite } \\
\hline $\mathrm{CLI}$ & & & & Clinopyroxene associated & ILM & Ilmenite & & PLE & Pleonaste & \\
\hline
\end{tabular}




\begin{tabular}{|c|c|c|c|c|c|c|c|c|c|c|c|}
\hline Sample \# & $\mathrm{CCO} 25$ & $\mathrm{CC054}$ & $\mathrm{CCO54}$ & CC054 & CC054 & CC054 & CC054 & CCO72 & CCO72 & CC076 & CCO76 \\
\hline Circle Number & $\mathrm{E}$ & $\mathrm{D}$ & $\mathrm{D}$ & $\mathrm{E}$ & $\mathrm{E}$ & $\mathrm{F}$ & $\mathrm{F}$ & A & A & B & B \\
\hline Mineralization & & & & & & & & & & & \\
\hline type & MAS & DIS & DIS & DIS & DIS & DIS & DIS & MAS & MAS & MAS & MAS \\
\hline Descriptor & POD & ORT & ORT & ORT & ORT & ORT & ORT & OPOD & OPOD & VEIN & VEIN \\
\hline mineral host & ILM & ILM & ILM & MAG & MAG & MAG & MAG & MAG & MAG & PLE & PLE \\
\hline $\begin{array}{l}\text { Mineral analyzed } \\
\text { exsolution feature }\end{array}$ & PLE & PLE & PLE & PLE & PLE & PLE & PLE & PLE & PLE & PLE & PLE \\
\hline type & thick ig & lamellae & lamellae & granules & granule & granule & granule & granule & granule & host & host \\
\hline Point & 47 & 19 & 20 & 32 & 33 & 37 & 38 & 10 & 11 & 9 & 10 \\
\hline $\mathrm{SiO}_{2}$ & 0.10 & 0.01 & 0.02 & 0.00 & 0.01 & 0.01 & 0.00 & 0.00 & 0.01 & 0.00 & 0.00 \\
\hline $\mathrm{TiO}_{2}$ & 0.63 & 0.89 & 0.86 & 0.04 & 0.03 & 0.03 & 0.03 & 0.02 & 0.04 & 0.02 & 0.00 \\
\hline $\mathrm{Al}_{2} \mathrm{O}_{3}$ & 57.23 & 57.60 & 56.95 & 56.76 & 56.57 & 56.06 & 56.39 & 61.68 & 59.31 & 56.93 & 56.00 \\
\hline $\mathrm{Cr}_{2} \mathrm{O}_{3}$ & 0.86 & 0.51 & 0.51 & 0.51 & 0.46 & 0.46 & 0.46 & 0.38 & 0.39 & 0.60 & 0.51 \\
\hline $\mathrm{V}_{2} \mathrm{O}_{3}$ & 0.09 & 0.06 & 0.07 & 0.07 & 0.07 & 0.07 & 0.07 & 0.05 & 0.06 & 0.07 & 0.10 \\
\hline $\mathrm{FeO}^{*}$ & 32.19 & 30.49 & 31.68 & 33.42 & 33.46 & 33.69 & 33.30 & 21.32 & 24.08 & 31.98 & 32.94 \\
\hline $\mathrm{Fe}_{2} \mathrm{O}_{3}$ recalculated & 2.71 & 3.77 & 4.37 & 5.55 & 5.71 & 5.89 & 5.48 & 5.27 & 6.63 & 5.67 & 6.51 \\
\hline FeO recalculated & 29.76 & 27.10 & 27.75 & 28.42 & 28.33 & 28.39 & 28.37 & 16.58 & 18.11 & 26.88 & 27.08 \\
\hline $\mathrm{MnO}$ & 0.18 & 0.16 & 0.17 & 0.19 & 0.18 & 0.20 & 0.19 & 0.17 & 0.19 & 0.43 & 0.45 \\
\hline MgO & 7.28 & 9.02 & 8.55 & 7.48 & 7.48 & 7.29 & 7.31 & 16.03 & 14.62 & 7.88 & 7.63 \\
\hline $\mathrm{ZnO}$ & 0.40 & 0.81 & 0.79 & 0.87 & 0.88 & 0.92 & 0.90 & 0.80 & 0.75 & 1.83 & 1.70 \\
\hline $\mathrm{NiO}$ & 0.09 & 0.13 & 0.11 & 0.12 & 0.13 & 0.09 & 0.12 & 0.06 & 0.06 & 0.04 & 0.05 \\
\hline Total (Mass \%) & 99.06 & 99.69 & 99.70 & 99.46 & 99.28 & 98.81 & 98.76 & 100.51 & 99.51 & 99.78 & 99.38 \\
\hline Total recalculated & 99.33 & 100.07 & 100.14 & 100.02 & 99.85 & 99.40 & 99.31 & 101.04 & 100.17 & 100.35 & 100.03 \\
\hline MAS & \multicolumn{4}{|c|}{ Massive to semi-massive mineralization } & OBAN & \multicolumn{6}{|c|}{ Orthopyroxene -bearing bands of oxide mineralization } \\
\hline DIS & \multicolumn{4}{|c|}{ Disseminated mineralization } & POD & \multicolumn{6}{|c|}{ Pod of oxide mineralization } \\
\hline BAN & \multicolumn{4}{|c|}{ Bands of oxide mineralization } & OPOD & \multicolumn{6}{|c|}{ Orthopyroxene -bearing pod of oxide mineralization } \\
\hline ANO & \multirow{2}{*}{\multicolumn{4}{|c|}{$\begin{array}{l}\text { Anorthosite hosted disseminated } \\
\text { Orthopyroxene associated }\end{array}$}} & VEIN & \multirow{2}{*}{\multicolumn{6}{|c|}{ Vein of oxide mineralization }} \\
\hline ORT & & & & & MAG & \multirow{2}{*}{\multicolumn{2}{|c|}{ IImenite }} & & & & \\
\hline $\mathrm{CLI}$ & \multicolumn{4}{|c|}{ Clinopyroxene associated } & ILM & & & PLE & \multicolumn{3}{|l|}{ Pleonaste } \\
\hline
\end{tabular}


Appendix V LA-ICPMS line analyses of magnetite, ilmenite and pleonaste. Corresponding photomicrographs are in Appendix VI. Fe, Ti or Al (wt. \%) is measured using EPMA analyses of the same samples.

\begin{tabular}{|c|c|c|c|c|c|c|c|}
\hline Sample & CC008 & CC008 & CC008 & CCOO8 & CC008 & CC008 & CC008 \\
\hline Circle number & A & $A$ & C & C & $\mathrm{D}$ & D & $\mathrm{F}$ \\
\hline Analysis & 08-A-M1 & 08-A-M2 & 08-C-M1 & 08-C-M2 & 08-D-M1 & 08-D-M2 & 08-F-M1 \\
\hline Mineralization type & MAS & MAS & MAS & MAS & MAS & MAS & MAS \\
\hline Descriptor & BAN & BAN & BAN & BAN & BAN & BAN & BAN \\
\hline Mineral host & MAG & MAG & MAG & MAG & MAG & MAG & MAG \\
\hline Mineral analyzed & MAG & MAG & MAG & MAG & MAG & MAG & MAG \\
\hline Fe wt.\% (EPMA)* & 64 & 64 & 64 & 64 & 64 & 64 & 64 \\
\hline${ }^{24} \mathrm{Mg}$ & 721 & 703 & 724 & 545 & 911 & 574 & 468 \\
\hline${ }^{27} \mathrm{Al}$ & 3390 & 2264 & 3320 & 2175 & 3820 & 2745 & 1852 \\
\hline${ }^{29} \mathrm{Si}$ & 249 & 417 & 430 & $<M D L$ & $<M D L$ & 355 & $<M D L$ \\
\hline $31 \mathrm{p}$ & $<M D L$ & 5 & $<M D L$ & $<M D L$ & $<\mathrm{MDL}$ & $<\mathrm{MDL}$ & $<\mathrm{MDL}$ \\
\hline${ }^{44} \mathrm{Ca}$ & $<\mathrm{MDL}$ & $<M D L$ & $<\mathrm{MDL}$ & $<M D L$ & $<M D L$ & $<M D L$ & $<M D L$ \\
\hline${ }^{45} \mathrm{SC}$ & 1 & 1 & 1 & 1 & 1 & 1 & 1 \\
\hline${ }^{47} \mathrm{Ti}$ & 700 & 2770 & 618 & 611 & 1530 & 631 & 313 \\
\hline${ }^{51} \mathrm{~V}$ & 5033 & 4457 & 4899 & 4895 & 4933 & 4899 & 4665 \\
\hline${ }^{52} \mathrm{Cr}$ & 1580 & 1588 & 1654 & 1618 & 1642 & 1617 & 1464 \\
\hline${ }^{55} \mathrm{Mn}$ & 159 & 187 & 143 & 158 & 205 & 139 & 113 \\
\hline${ }^{59} \mathrm{Co}$ & 93 & 66 & 73 & 70 & 78 & 65 & 72 \\
\hline${ }^{60} \mathrm{Ni}$ & 263 & 246 & 280 & 287 & 286 & 286 & 262 \\
\hline${ }^{63} \mathrm{Cu}$ & 0.4 & 0.4 & 0.3 & 0.4 & 2 & 0.2 & 1 \\
\hline${ }^{66} \mathrm{Zn}$ & 8 & 3 & 4 & 6 & 5 & 5 & 3 \\
\hline${ }^{69} \mathrm{Ga}$ & 42 & 38 & 42 & 40 & 45 & 42 & 35 \\
\hline${ }^{74} \mathrm{Ge}$ & 1 & 1 & 1 & 1 & 1 & 1 & 1 \\
\hline${ }^{75} \mathrm{As}$ & 0.5 & 0.3 & $<M D L$ & $<M D L$ & 0.4 & 0.4 & $<M D L$ \\
\hline${ }^{89} \mathrm{Y}$ & 0.001 & 0.001 & $<M D L$ & $<M D L$ & $<M D L$ & 0.002 & $<\mathrm{MDL}$ \\
\hline${ }^{90} \mathrm{Zr}$ & 0.1 & 0.4 & 0.1 & 0.02 & 0.3 & 0.1 & 0.01 \\
\hline${ }^{93} \mathrm{Nb}$ & 0.01 & 0.03 & 0.03 & $<\mathrm{MDL}$ & 0.02 & 0.03 & 0.001 \\
\hline${ }^{95} \mathrm{Mo}$ & 0.1 & 0.1 & $<M D L$ & $<M D L$ & 0.03 & 0.1 & $<M D L$ \\
\hline${ }^{118} \mathrm{Sn}$ & 0.1 & 0.1 & 0.1 & 0.03 & 0.2 & 0.1 & $<M D L$ \\
\hline${ }^{121} \mathrm{Sb}$ & 0.02 & $<M D L$ & 0.02 & 0.03 & $<M D L$ & 0.01 & 0.01 \\
\hline${ }^{178} \mathrm{Hf}$ & 0.001 & 0.01 & $<\mathrm{MDL}$ & $<M D L$ & 0.004 & $<\mathrm{MDL}$ & $<\mathrm{MDL}$ \\
\hline${ }^{181} \mathrm{Ta}$ & $<\mathrm{MDL}$ & $<\mathrm{MDL}$ & 0.000 & $<\mathrm{MDL}$ & $<M D L$ & 0.000 & $<M D L$ \\
\hline${ }^{182} \mathrm{~W}$ & 0.002 & 0.01 & 0.003 & $<M D L$ & 0.02 & $<M D L$ & $<M D L$ \\
\hline${ }^{208} \mathrm{~Pb}$ & 0.4 & 0.3 & 0.2 & 0.3 & 0.2 & 0.3 & 0.5 \\
\hline MAS & \multicolumn{3}{|c|}{$\begin{array}{l}\text { Massive to semi-massive mineralization } \\
\text { Disseminated }\end{array}$} & OBAN & \multicolumn{2}{|c|}{$\begin{array}{l}\text { Orthopyroxene -bearing } \\
\text { band }\end{array}$} & \\
\hline BAN & $\begin{array}{l}\text { mineralizatio } \\
\text { Bands of oxid } \\
\text { mineralizatio }\end{array}$ & & & OPOD & \multicolumn{2}{|c|}{$\begin{array}{l}\text { Pod } \\
\text { Orthopyroxene -bearing }\end{array}$} & \\
\hline ANO & Anorthosite & osted dissemin & ted & VEIN & Vein & & \\
\hline ORT & Orthopyroxe & e associated & & MAG & Magnetite & & \\
\hline $\mathrm{CLI}$ & Clinopyroxen & associated & & ILM & Ilmenite & & \\
\hline
\end{tabular}




\begin{tabular}{|c|c|c|c|c|c|c|}
\hline \multicolumn{7}{|c|}{ Appendix V (Continued) } \\
\hline Sample & CC008 & CCOO8 & CC008 & CC008 & CC008 & CC010 \\
\hline Circle number & $\mathrm{F}$ & $\mathrm{H}$ & $\mathrm{H}$ & J & $J$ & D \\
\hline Analysis & 08-F-M2 & 08-H-M1 & 08-H-M2 & 08-J-M1 & 08-J-M2 & 10-D-M1 \\
\hline Mineralization type & MAS & MAS & MAS & MAS & MAS & MAS \\
\hline Descriptor & BAN & BAN & BAN & BAN & BAN & OBAN \\
\hline Mineral host & MAG & MAG & MAG & MAG & MAG & MAG \\
\hline Mineral analyzed & MAG & MAG & MAG & MAG & MAG & MAG \\
\hline Fe wt.\% (EPMA)* & 64 & 64 & 64 & 64 & 64 & 64 \\
\hline${ }^{24} \mathrm{Mg}$ & 462 & 827 & 603 & 16780 & 933 & 1073 \\
\hline${ }^{27} \mathrm{Al}$ & 2250 & 2700 & 2227 & 294 & 3120 & 4310 \\
\hline${ }^{29} \mathrm{Si}$ & $<\mathrm{MDL}$ & 248 & 310 & 1040 & 550 & $<M D L$ \\
\hline${ }^{31} \mathrm{p}$ & $<M D L$ & $<M D L$ & $<M D L$ & $<\mathrm{MDL}$ & $<\mathrm{MDL}$ & $<\mathrm{MDL}$ \\
\hline${ }^{44} \mathrm{Ca}$ & $<M D L$ & $<M D L$ & $<M D L$ & 41 & $<M D L$ & $<M D L$ \\
\hline${ }^{45} \mathrm{Sc}$ & 0.5 & 1 & 0.3 & 56 & 1 & 1 \\
\hline${ }^{47} \mathrm{Ti}$ & 610 & 1350 & 449 & 511300 & 839 & 1974 \\
\hline${ }^{51} \mathrm{~V}$ & 4728 & 4648 & 4457 & 2535 & 4393 & 4944 \\
\hline${ }^{52} \mathrm{Cr}$ & 1668 & 1748 & 1847 & 193 & 1729 & 1579 \\
\hline${ }^{55} \mathrm{Mn}$ & 137 & 156 & 76 & 8820 & 113 & 316 \\
\hline${ }^{59} \mathrm{Co}$ & 70 & 76 & 68 & 115 & 68 & 96 \\
\hline${ }^{60} \mathrm{Ni}$ & 303 & 247 & 231 & 34 & 192 & 384 \\
\hline${ }^{63} \mathrm{Cu}$ & 0.3 & 0.3 & 2 & 2 & 2 & 0.5 \\
\hline${ }^{66} \mathrm{Zn}$ & 4 & 5 & 21 & 8 & 7 & 7 \\
\hline${ }^{69} \mathrm{Ga}$ & 39 & 38 & 36 & 1 & 40 & 44 \\
\hline${ }^{74} \mathrm{Ge}$ & 1 & 1 & 1 & 0.3 & 1 & 1 \\
\hline${ }^{75} \mathrm{As}$ & $<M D L$ & $<M D L$ & $<M D L$ & 1 & 1 & 1 \\
\hline${ }^{89} \mathrm{Y}$ & $<M D L$ & 0.002 & $<M D L$ & 0.2 & 0.002 & $<M D L$ \\
\hline${ }^{90} \mathrm{Zr}$ & 0.03 & 0.1 & 0.05 & 78 & 0.2 & 0.2 \\
\hline${ }^{93} \mathrm{Nb}$ & 0.005 & 0.02 & 0.01 & 9 & 0.04 & 0.01 \\
\hline${ }^{95} \mathrm{Mo}$ & $<\mathrm{MDL}$ & $<M D L$ & 0.04 & 1 & $<\mathrm{MDL}$ & 0.1 \\
\hline${ }^{118} \mathrm{Sn}$ & $<M D L$ & 0.1 & 0.1 & 4 & 0.2 & 1 \\
\hline${ }^{121} \mathrm{Sb}$ & $<M D L$ & $<\mathrm{MDL}$ & 0.02 & 0.1 & $<\mathrm{MDL}$ & $<M D L$ \\
\hline $178 \mathrm{Hf}$ & $<M D L$ & $<M D L$ & 0.000 & 3 & 0.004 & $<M D L$ \\
\hline${ }^{181} \mathrm{Ta}$ & 0.001 & $<M D L$ & $<\mathrm{MDL}$ & 1 & 0.001 & $<\mathrm{MDL}$ \\
\hline${ }^{182} \mathrm{~W}$ & $<\mathrm{MDL}$ & 0.002 & 0.003 & 0.05 & $<M Q L$ & 0.001 \\
\hline${ }^{208} \mathrm{~Pb}$ & 0.5 & 0.2 & 0.2 & 2 & 0.3 & 0.2 \\
\hline MAS & $\begin{array}{l}\text { Massive to } \mathrm{s} \\
\text { Disseminate }\end{array}$ & ni-massive mi & ralization & OBAN & $\begin{array}{l}\text { Orthopyroxe } \\
\text { band }\end{array}$ & e -bearing \\
\hline DIS & $\begin{array}{l}\text { mineralizatio } \\
\text { Bands of oxic }\end{array}$ & & & POD & $\begin{array}{l}\text { Pod } \\
\text { Orthopyroxe }\end{array}$ & e-bearing \\
\hline BAN & mineralizatio & & & OPOD & pod & \\
\hline ANO & Anorthosite & sted dissemin & ted & VEIN & Vein & \\
\hline ORT & Orthopyroxe & associated & & MAG & Magnetite & \\
\hline CLI & Clinopyroxer & associated & & ILM & Ilmenite & \\
\hline
\end{tabular}




\section{Appendix V (Continued)}

\begin{tabular}{|c|c|c|c|c|c|c|c|}
\hline Sample & CC010 & CC010 & CC010 & CC010 & CC010 & CC010 & CC010 \\
\hline Circle number & $\mathrm{D}$ & $\mathrm{E}$ & $\mathrm{F}$ & $\mathrm{F}$ & $\mathrm{H}$ & $\mathrm{H}$ & 1 \\
\hline Analysis & 10-D-M2 & 10-E-M2 & 10-F-M1 & 10-F-M2 & 10-H-M1 & 10-H-M2 & 10-I-M1 \\
\hline Mineralization type & MAS & MAS & MAS & MAS & MAS & MAS & MAS \\
\hline Descriptor & OBAN & OBAN & OBAN & OBAN & OBAN & OBAN & OBAN \\
\hline Mineral host & MAG & MAG & MAG & MAG & MAG & MAG & MAG \\
\hline Mineral analyzed & MAG & MAG & MAG & MAG & MAG & MAG & MAG \\
\hline Fe wt.\% (EPMA)* & 64 & 64 & 64 & 64 & 64 & 64 & 64 \\
\hline${ }^{24} \mathrm{Mg}$ & 943 & 1855 & 2430 & 2350 & 2520 & 1860 & 2625 \\
\hline${ }^{27} \mathrm{Al}$ & 3570 & 6730 & 9140 & 8110 & 9550 & 6780 & 9820 \\
\hline${ }^{29} \mathrm{Si}$ & $<M D L$ & $<M D L$ & 414 & 293 & 692 & 793 & 573 \\
\hline $31 \mathrm{p}$ & $<M D L$ & $<M D L$ & $<M D L$ & $<M D L$ & $<\mathrm{MDL}$ & $<\mathrm{MDL}$ & $<\mathrm{MDL}$ \\
\hline${ }^{44} \mathrm{Ca}$ & $<M D L$ & $<M D L$ & $<M D L$ & 22 & $<M D L$ & $<M D L$ & $<M D L$ \\
\hline${ }^{45} \mathrm{Sc}$ & 1 & 2 & 2 & 2 & 2 & 1 & 2 \\
\hline${ }^{47} \mathrm{Ti}$ & 1604 & 4150 & 3800 & 5540 & 6160 & 2990 & 6740 \\
\hline${ }^{51} \mathrm{~V}$ & 4919 & 6346 & 6228 & 6318 & 6239 & 6201 & 6222 \\
\hline${ }^{52} \mathrm{Cr}$ & 1536 & 2080 & 2053 & 2106 & 1914 & 2016 & 1982 \\
\hline${ }^{55} \mathrm{Mn}$ & 304 & 562 & 555 & 576 & 704 & 483 & 638 \\
\hline${ }^{59} \mathrm{Co}$ & 93 & 133 & 146 & 144 & 141 & 129 & 136 \\
\hline${ }^{60} \mathrm{Ni}$ & 381 & 460 & 462 & 470 & 440 & 412 & 397 \\
\hline${ }^{63} \mathrm{Cu}$ & 0.2 & 1 & 1 & 1 & 0.3 & 0.1 & 0.5 \\
\hline${ }^{66} \mathrm{Zn}$ & 3 & 12 & 18 & 23 & 27 & 12 & 28 \\
\hline${ }^{69} \mathrm{Ga}$ & 42 & 63 & 66 & 63 & 64 & 57 & 63 \\
\hline${ }^{74} \mathrm{Ge}$ & 1 & 1 & 1 & 1 & 1 & 1 & 1 \\
\hline${ }^{75} \mathrm{As}$ & 1 & 1 & 1 & 1 & 1 & 1 & 2 \\
\hline${ }^{89} \mathrm{Y}$ & 0.002 & 0.005 & 0.001 & 0.001 & $<M D L$ & $<\mathrm{MDL}$ & 0.003 \\
\hline${ }^{90} \mathrm{Zr}$ & 0.1 & 0.4 & 1 & 1 & 1 & 0.4 & 1 \\
\hline${ }^{93} \mathrm{Nb}$ & 0.003 & 0.02 & 0.02 & 0.03 & 0.03 & 0.01 & 0.03 \\
\hline${ }^{95} \mathrm{Mo}$ & 0.1 & $<\mathrm{MDL}$ & 0.2 & 0.2 & 0.1 & 0.1 & 0.1 \\
\hline${ }^{118} \mathrm{Sn}$ & 1 & 1 & 1 & 1 & 1 & 1 & 1 \\
\hline${ }^{121} \mathrm{Sb}$ & 0.02 & 0.3 & 0.02 & $<M D L$ & 0.03 & 0.02 & 0.04 \\
\hline${ }^{178} \mathrm{Hf}$ & 0.001 & 0.01 & 0.01 & 0.03 & 0.01 & 0.004 & 0.02 \\
\hline${ }^{181} \mathrm{Ta}$ & 0.000 & $<\mathrm{MDL}$ & $<M D L$ & $<\mathrm{MDL}$ & $<\mathrm{MDL}$ & $<\mathrm{MDL}$ & 0.000 \\
\hline${ }^{182} \mathrm{~W}$ & 0.01 & 0.005 & 0.003 & 0.01 & 0.01 & 0.004 & 0.01 \\
\hline${ }^{208} \mathrm{~Pb}$ & 0.1 & 0.4 & 0.4 & 0.4 & 0.4 & 0.4 & 0.4 \\
\hline MAS & \multirow{2}{*}{\multicolumn{3}{|c|}{$\begin{array}{l}\text { Massive to semi- } \\
\text { Disseminated } \\
\text { mineralization } \\
\text { Bands of oxide } \\
\text { mineralization }\end{array}$}} & OBAN & \multicolumn{3}{|c|}{$\begin{array}{l}\text { Orthopyroxene -bearing } \\
\text { band }\end{array}$} \\
\hline DIS & & & & OPOD & \multicolumn{3}{|c|}{$\begin{array}{l}\text { Pod } \\
\text { Orthopyroxene -bearing } \\
\text { pod }\end{array}$} \\
\hline ANO & \multicolumn{3}{|c|}{ Anorthosite hosted disseminated } & VEIN & \multicolumn{3}{|l|}{ Vein } \\
\hline ORT & \multicolumn{3}{|c|}{ Orthopyroxene associated } & MAG & \multicolumn{3}{|l|}{ Magnetite } \\
\hline $\mathrm{CLI}$ & \multicolumn{3}{|c|}{ Clinopyroxene associated } & ILM & IImenite & & \\
\hline
\end{tabular}




\section{Appendix V (Continued)}

\begin{tabular}{|c|c|c|c|c|c|c|c|}
\hline Sample & CC010 & CC010 & CC010 & CC010 & CC010 & CC010 & CC013 \\
\hline Circle number & 1 & $\mathrm{~L}$ & $\begin{array}{l}M \\
10-M-\end{array}$ & $\begin{array}{l}M \\
10-M-\end{array}$ & $\mathrm{O}$ & $\mathrm{O}$ & A \\
\hline Analysis & 10-I-M3 & 10-L-M3 & M1 & $\mathrm{M} 2$ & 10-O-M1 & $10-\mathrm{O}-\mathrm{M} 2$ & 13-A-M1 \\
\hline Mineralization type & MAS & MAS & MAS & MAS & MAS & MAS & MAS \\
\hline Descriptor & OBAN & OBAN & OBAN & OBAN & OBAN & OBAN & BAN \\
\hline Mineral host & MAG & MAG & MAG & MAG & MAG & MAG & MAG \\
\hline Mineral analyzed & MAG & MAG & MAG & MAG & MAG & MAG & MAG \\
\hline Fe wt.\% (EPMA)* & 64 & 64 & 64 & 64 & 64 & 64 & 65 \\
\hline${ }^{24} \mathrm{Mg}$ & 1513 & 2550 & 2359 & 2153 & 2130 & 2360 & 963 \\
\hline${ }^{27} \mathrm{Al}$ & 6190 & 4830 & 9110 & 7790 & 7850 & 8300 & 3460 \\
\hline${ }^{29} \mathrm{Si}$ & $<\mathrm{MDL}$ & 210 & 344 & 354 & $<M D L$ & 193 & $<M D L$ \\
\hline${ }^{31} \mathrm{P}$ & $<M D L$ & $<M D L$ & $<\mathrm{MDL}$ & $<M D L$ & $<M D L$ & $<M D L$ & $<M D L$ \\
\hline${ }^{44} \mathrm{Ca}$ & $<M D L$ & $<M D L$ & $<M D L$ & 12 & $<M D L$ & $<M D L$ & $<M D L$ \\
\hline${ }^{45} \mathrm{Sc}$ & $<M D L$ & 2 & 2 & 2 & 2 & 2 & 1 \\
\hline${ }^{47} \mathrm{Ti}$ & $<M D L$ & 18500 & 3300 & 4120 & 3230 & 5330 & 665 \\
\hline${ }^{51} \mathrm{~V}$ & 6270 & 4187 & 6420 & 6308 & 6370 & 6469 & 4839 \\
\hline${ }^{52} \mathrm{Cr}$ & 1964 & 1659 & 2063 & 2049 & 2156 & 2202 & 2729 \\
\hline${ }^{55} \mathrm{Mn}$ & $<\mathrm{MDL}$ & 666 & 569 & 660 & 505 & 602 & 180 \\
\hline${ }^{59} \mathrm{Co}$ & 122 & 128 & 145 & 141 & 138 & 143 & 78 \\
\hline${ }^{60} \mathrm{Ni}$ & 419 & 342 & 450 & 459 & 450 & 463 & 288 \\
\hline${ }^{63} \mathrm{Cu}$ & $<\mathrm{MDL}$ & 1 & 1 & 0.4 & 1 & 1 & 0.2 \\
\hline${ }^{66} \mathrm{Zn}$ & 10 & 14 & 23 & 19 & 19 & 28 & 12 \\
\hline${ }^{69} \mathrm{Ga}$ & 62 & 46 & 66 & 67 & 65 & 65 & 36 \\
\hline${ }^{74} \mathrm{Ge}$ & 1 & 1 & 1 & 1 & 1 & 1 & 1 \\
\hline${ }^{75} \mathrm{As}$ & 1 & 1 & 1 & 1 & 1 & 1 & 1 \\
\hline${ }^{89} \mathrm{Y}$ & $<\mathrm{MDL}$ & 0.005 & 0.001 & $<\mathrm{MDL}$ & 0.000 & $<\mathrm{MDL}$ & 0.001 \\
\hline${ }^{90} \mathrm{Zr}$ & $<\mathrm{MDL}$ & 3 & 1 & 0.4 & 0.3 & 1 & 0.2 \\
\hline${ }^{93} \mathrm{Nb}$ & $<\mathrm{MDL}$ & 0.3 & 0.004 & 0.01 & 0.01 & 0.01 & 0.01 \\
\hline${ }^{95} \mathrm{Mo}$ & 0.1 & 0.1 & 0.1 & 0.2 & 0.1 & 0.1 & 0.04 \\
\hline${ }^{118} \mathrm{Sn}$ & 1 & 0.5 & 1 & 1 & 1 & 1 & 0.03 \\
\hline${ }^{121} \mathrm{Sb}$ & $<M D L$ & 0.02 & 0.02 & 0.02 & 0.02 & 0.04 & 0.01 \\
\hline${ }^{178} \mathrm{Hf}$ & $<M D L$ & 0.1 & 0.02 & 0.01 & 0.01 & 0.01 & 0.003 \\
\hline${ }^{181} \mathrm{Ta}$ & $<M D L$ & 0.01 & $<\mathrm{MDL}$ & $<\mathrm{MDL}$ & 0.001 & 0.000 & 0.000 \\
\hline $182 \mathrm{~W}$ & $<M D L$ & $<M D L$ & 0.01 & 0.01 & 0.01 & 0.01 & 0.001 \\
\hline${ }^{208} \mathrm{~Pb}$ & $<\mathrm{MDL}$ & 0.1 & 0.4 & 0.4 & 1 & 0.4 & 0.4 \\
\hline MAS & \multirow{2}{*}{\multicolumn{3}{|c|}{$\begin{array}{l}\text { Massive to semi- } \\
\text { Disseminated } \\
\text { mineralization } \\
\text { Bands of oxide } \\
\text { mineralization }\end{array}$}} & OBAN & $\begin{array}{l}\text { Orthopyroxe } \\
\text { band }\end{array}$ & e-bearing & \\
\hline BAN & & & & OPOD & $\begin{array}{l}\text { Pod } \\
\text { Orthopyroxe } \\
\text { pod }\end{array}$ & -bearing & \\
\hline ANO & Anorthosite & sted dissemin & & VEIN & Vein & & \\
\hline ORT & Orthopyroxe & e associated & & MAG & Magnetite & & \\
\hline $\mathrm{CLI}$ & Clinopyroxen & associated & & ILM & Ilmenite & & \\
\hline
\end{tabular}




\section{Appendix V (Continued)}

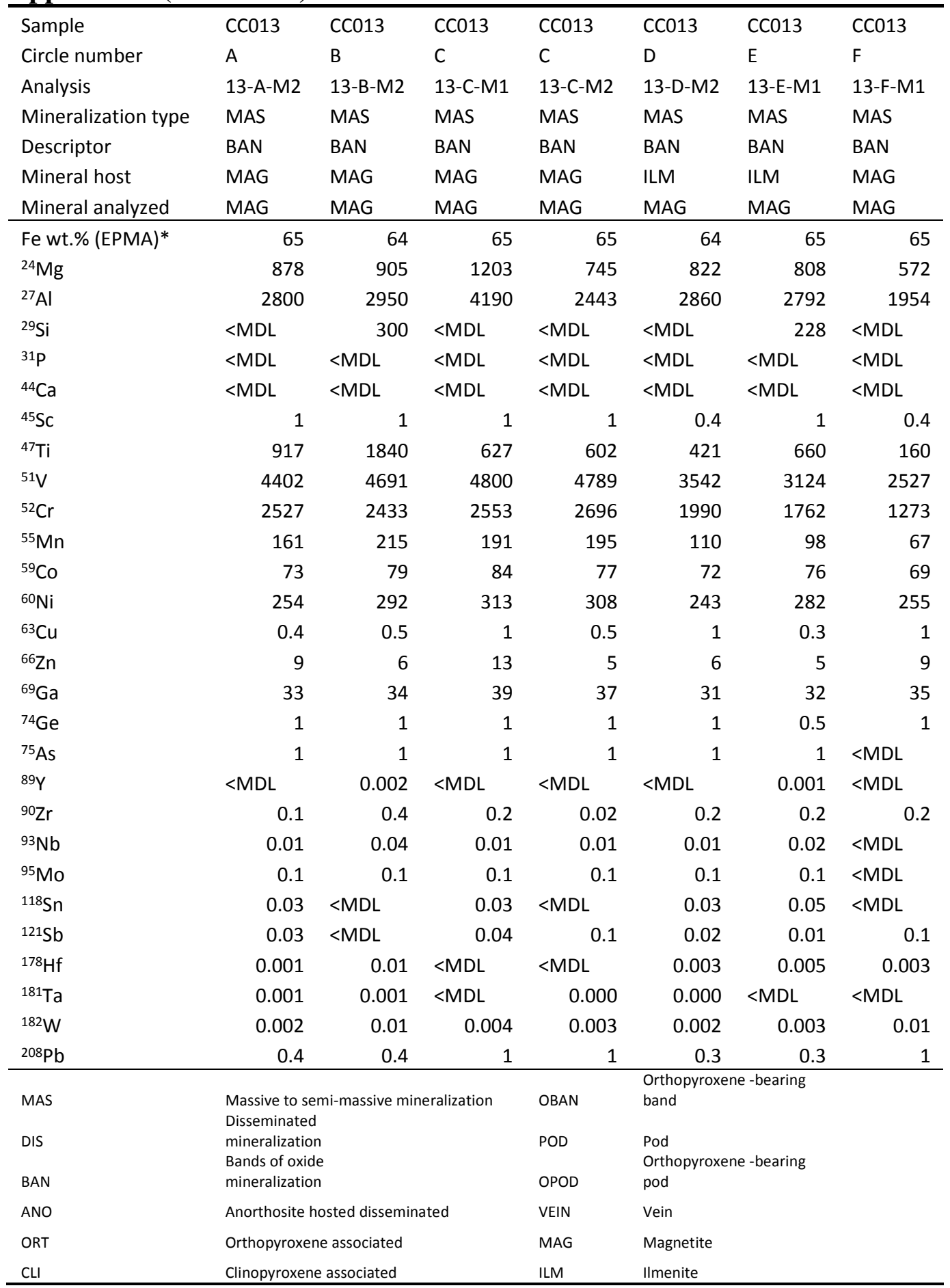




\section{Appendix V (Continued)}

\begin{tabular}{|c|c|c|c|c|c|c|c|}
\hline Sample & CC013 & CC013 & $\mathrm{CC013}$ & CC013 & CC013 & CCO25 & $\mathrm{CCO} 25$ \\
\hline Circle number & L & L & $P$ & $\mathrm{P}$ & $\mathrm{R}$ & A & $A$ \\
\hline Analysis & 13-L-M1 & 13-L-M2 & 13-P-M1 & 13-P-M2 & 13-R-M2 & 25-A-M1 & 25-A-M2 \\
\hline Mineralization type & MAS & MAS & MAS & MAS & MAS & MAS & MAS \\
\hline Descriptor & BAN & BAN & BAN & BAN & BAN & POD & POD \\
\hline Mineral host & MAG & MAG & MAG & MAG & MAG & MAG & MAG \\
\hline Mineral analyzed & MAG & MAG & MAG & MAG & MAG & MAG & MAG \\
\hline Fe wt.\% (EPMA)* & 65 & 65 & 65 & 65 & 65 & 63 & 63 \\
\hline${ }^{24} \mathrm{Mg}$ & 1395 & 994 & 850 & 1030 & 863 & 1442 & 712 \\
\hline${ }^{27} \mathrm{Al}$ & 3007 & 3139 & 3087 & 2780 & 3110 & 11510 & 6560 \\
\hline${ }^{29} \mathrm{Si}$ & 367 & 511 & 162 & 198 & 165 & $<\mathrm{MDL}$ & 410 \\
\hline $31 \mathrm{p}$ & $<M D L$ & $<\mathrm{MDL}$ & $<M D L$ & $<M D L$ & $<M D L$ & $<M D L$ & $<M D L$ \\
\hline${ }^{44} \mathrm{Ca}$ & 64 & $<M D L$ & $<M D L$ & $<M D L$ & $<M D L$ & $<M D L$ & $<M D L$ \\
\hline${ }^{45} \mathrm{SC}$ & 1 & 1 & 1 & 1 & 1 & 1 & 1 \\
\hline${ }^{47} \mathrm{Ti}$ & 8900 & 1860 & 900 & 3160 & 468 & 13520 & 18600 \\
\hline${ }^{51} \mathrm{~V}$ & 4353 & 4428 & 4826 & 4739 & 4736 & 5000 & 4868 \\
\hline${ }^{52} \mathrm{Cr}$ & 2355 & 1946 & 2265 & 2307 & 2257 & 4186 & 4178 \\
\hline${ }^{55} \mathrm{Mn}$ & 496 & 215 & 216 & 394 & 167 & 527 & 692 \\
\hline${ }^{59} \mathrm{Co}$ & 81 & 77 & 74 & 78 & 77 & 110 & 85 \\
\hline${ }^{60} \mathrm{Ni}$ & 264 & 259 & 297 & 305 & 294 & 301 & 270 \\
\hline${ }^{63} \mathrm{Cu}$ & 1 & 1 & 0.2 & 0.5 & 0.3 & 2 & 1 \\
\hline${ }^{66} \mathrm{Zn}$ & 70 & 7 & 4 & 8 & 6 & 46 & 8 \\
\hline${ }^{69} \mathrm{Ga}$ & 35 & 36 & 38 & 39 & 37 & 67 & 58 \\
\hline${ }^{74} \mathrm{Ge}$ & 1 & 1 & 1 & 1 & 1 & 1 & 1 \\
\hline${ }^{75} \mathrm{As}$ & 1 & 1 & 1 & 0.5 & 1 & 0.5 & $<\mathrm{MDL}$ \\
\hline${ }^{89} \mathrm{Y}$ & 0.01 & 0.001 & 0.001 & 0.001 & 0.001 & 0.01 & 0.02 \\
\hline${ }^{90} \mathrm{Zr}$ & 1 & 0.5 & 0.1 & 0.3 & 0.2 & 1 & 0.5 \\
\hline${ }^{93} \mathrm{Nb}$ & 0.2 & 0.1 & 0.01 & 0.1 & 0.01 & 0.1 & 0.01 \\
\hline${ }^{95} \mathrm{Mo}$ & 0.1 & 0.1 & 0.1 & 0.1 & 0.1 & 0.4 & 0.3 \\
\hline${ }^{118} \mathrm{Sn}$ & 0.2 & 0.1 & 0.1 & $<M D L$ & $<M D L$ & 2 & 2 \\
\hline${ }^{121} \mathrm{Sb}$ & 0.1 & 0.03 & 0.02 & $<M D L$ & 0.1 & $<M D L$ & $<M D L$ \\
\hline${ }^{178} \mathrm{Hf}$ & 0.02 & 0.01 & 0.001 & 0.01 & $<M D L$ & 0.02 & 0.03 \\
\hline${ }^{181} \mathrm{Ta}$ & 0.01 & 0.005 & 0.000 & 0.002 & $<M D L$ & 0.002 & $<\mathrm{MDL}$ \\
\hline${ }^{182} \mathrm{~W}$ & 0.02 & 0.02 & 0.002 & 0.01 & 0.004 & 0.01 & 0.005 \\
\hline${ }^{208} \mathrm{~Pb}$ & 1 & 1 & 0.4 & 1 & 0.4 & 0.2 & 0.2 \\
\hline MAS & \multirow{3}{*}{\multicolumn{3}{|c|}{$\begin{array}{l}\text { Massive to semi-- } \\
\text { Disseminated } \\
\text { mineralization } \\
\text { Bands of oxide } \\
\text { mineralization }\end{array}$}} & OBAN & \multicolumn{3}{|c|}{$\begin{array}{l}\text { Orthopyroxene -bearing } \\
\text { band }\end{array}$} \\
\hline DIS & & & & POD & \multirow{2}{*}{\multicolumn{3}{|c|}{$\begin{array}{l}\text { Pod } \\
\text { Orthopyroxene -bearing } \\
\text { pod }\end{array}$}} \\
\hline BAN & & & & OPOD & & & \\
\hline ANO & \multicolumn{3}{|c|}{ Anorthosite hosted disseminated } & VEIN & \multicolumn{3}{|l|}{ Vein } \\
\hline ORT & \multicolumn{3}{|c|}{ Orthopyroxene associated } & MAG & \multicolumn{3}{|l|}{ Magnetite } \\
\hline $\mathrm{CLI}$ & \multicolumn{3}{|c|}{ Clinopyroxene associated } & ILM & \multicolumn{3}{|l|}{ Ilmenite } \\
\hline
\end{tabular}




\section{Appendix V (Continued)}

\begin{tabular}{|c|c|c|c|c|c|c|c|}
\hline Sample & CCO25 & CCO25 & CCO25 & CCO25 & CCO25 & CCO25 & CCO25 \\
\hline Circle number & A & A & C & $\mathrm{C}$ & D & $\mathrm{D}$ & $\mathrm{D}$ \\
\hline Analysis & 25-A-M3 & 25-A-M4 & 25-C-M1 & 25-C-M2 & 25-D-M1 & 25-D-M3 & 25-D-M2 \\
\hline Mineralization type & MAS & MAS & MAS & MAS & MAS & MAS & MAS \\
\hline Descriptor & POD & POD & POD & POD & POD & POD & POD \\
\hline Mineral host & MAG & MAG & MAG & MAG & MAG & MAG & MAG \\
\hline Mineral analyzed & MAG & MAG & MAG & MAG & MAG & MAG & MAG \\
\hline Fe wt.\% (EPMA)* & 63 & 63 & 63 & 63 & 62 & 62 & 62 \\
\hline${ }^{24} \mathrm{Mg}$ & 1082 & 5660 & 1326 & 674 & 760 & 720 & 1371 \\
\hline${ }^{27} \mathrm{Al}$ & 6850 & 32990 & 12460 & 6800 & 7170 & 7420 & 13520 \\
\hline${ }^{29} \mathrm{Si}$ & $<M D L$ & $<M D L$ & 790 & $<M D L$ & 279 & 462 & 601 \\
\hline 31p & $<M D L$ & $<M D L$ & $<M D L$ & $<M D L$ & $<M D L$ & $<M D L$ & $<M D L$ \\
\hline${ }^{44} \mathrm{Ca}$ & $<M D L$ & $<M D L$ & $<M D L$ & $<M D L$ & $<M D L$ & $<M D L$ & 16 \\
\hline${ }^{45} \mathrm{Sc}$ & 1 & 2 & 1 & 1 & 1 & 1 & 1 \\
\hline${ }^{47} \mathrm{Ti}$ & 16870 & 42800 & 13740 & 7820 & 9020 & 8360 & 10820 \\
\hline${ }^{51} \mathrm{~V}$ & 4930 & 4403 & 4800 & 4893 & 4677 & 4649 & 4684 \\
\hline${ }^{52} \mathrm{Cr}$ & 4280 & 4539 & 4055 & 4022 & 3900 & 3577 & 3702 \\
\hline${ }^{55} \mathrm{Mn}$ & 621 & 1006 & 638 & 330 & 344 & 405 & 543 \\
\hline${ }^{59} \mathrm{Co}$ & 102 & 206 & 109 & 71 & 78 & 81 & 109 \\
\hline${ }^{60} \mathrm{Ni}$ & 292 & 338 & 290 & 251 & 253 & 260 & 275 \\
\hline${ }^{63} \mathrm{Cu}$ & 2 & 6 & 1 & 2 & 1 & 1 & 1 \\
\hline${ }^{66} \mathrm{Zn}$ & 48 & 188 & 51 & 40 & 57 & 500 & 37 \\
\hline${ }^{69} \mathrm{Ga}$ & 71 & 83 & 72 & 47 & 49 & 54 & 65 \\
\hline${ }^{74} \mathrm{Ge}$ & 1 & 1 & 1 & 1 & 1 & 1 & 1 \\
\hline${ }^{75} \mathrm{As}$ & $<\mathrm{MDL}$ & 1 & $<M D L$ & $<M D L$ & $<M D L$ & $<\mathrm{MDL}$ & $<M D L$ \\
\hline${ }^{89} \mathrm{Y}$ & 0.01 & 0.03 & 0.02 & 0.002 & 0.01 & 0.003 & 0.004 \\
\hline${ }^{90} \mathrm{Zr}$ & 0.5 & 2 & 0.5 & 1 & 1 & 0.5 & 1 \\
\hline${ }^{93} \mathrm{Nb}$ & 0.1 & 0.04 & 0.04 & 0.02 & 0.1 & 0.02 & 0.02 \\
\hline${ }^{95} \mathrm{Mo}$ & 0.4 & 0.4 & 0.3 & 0.3 & 0.3 & 0.4 & 0.3 \\
\hline${ }^{118} \mathrm{Sn}$ & 2 & 2 & 2 & 1 & 1 & 1 & 2 \\
\hline${ }^{121} \mathrm{Sb}$ & $<M D L$ & $<M D L$ & $<M D L$ & $<M D L$ & 0.02 & $<M D L$ & $<M D L$ \\
\hline${ }^{178} \mathrm{Hf}$ & 0.02 & 0.1 & 0.01 & 0.02 & 0.03 & 0.02 & 0.04 \\
\hline${ }^{181} \mathrm{Ta}$ & 0.001 & 0.004 & 0.001 & $<M D L$ & 0.002 & $<\mathrm{MDL}$ & $<M D L$ \\
\hline${ }^{182} \mathrm{~W}$ & $<M D L$ & $<M D L$ & 0.01 & $<M Q L$ & 0.01 & 0.005 & 0.004 \\
\hline${ }^{208} \mathrm{~Pb}$ & 0.2 & 0.3 & 0.2 & 0.2 & 0.3 & 0.3 & 0.1 \\
\hline MAS & \multicolumn{3}{|c|}{$\begin{array}{l}\text { Massive to semi-massive mineralization } \\
\text { Disseminated }\end{array}$} & OBAN & \multicolumn{2}{|c|}{$\begin{array}{l}\text { Orthopyroxene -bearing } \\
\text { band }\end{array}$} & \\
\hline DIS & mineralization & & & POD & \multicolumn{2}{|c|}{$\begin{array}{l}\text { Orthopyroxene -bearing } \\
\text { pod }\end{array}$} & \\
\hline ANO & \multicolumn{3}{|c|}{ Anorthosite hosted disseminated } & VEIN & \multicolumn{2}{|l|}{ Vein } & \\
\hline ORT & \multicolumn{3}{|c|}{ Orthopyroxene associated } & MAG & \multicolumn{2}{|l|}{ Magnetite } & \\
\hline $\mathrm{CLI}$ & \multicolumn{3}{|c|}{ Clinopyroxene associated } & ILM & Ilmenite & & \\
\hline
\end{tabular}




\section{Appendix V (Continued)}

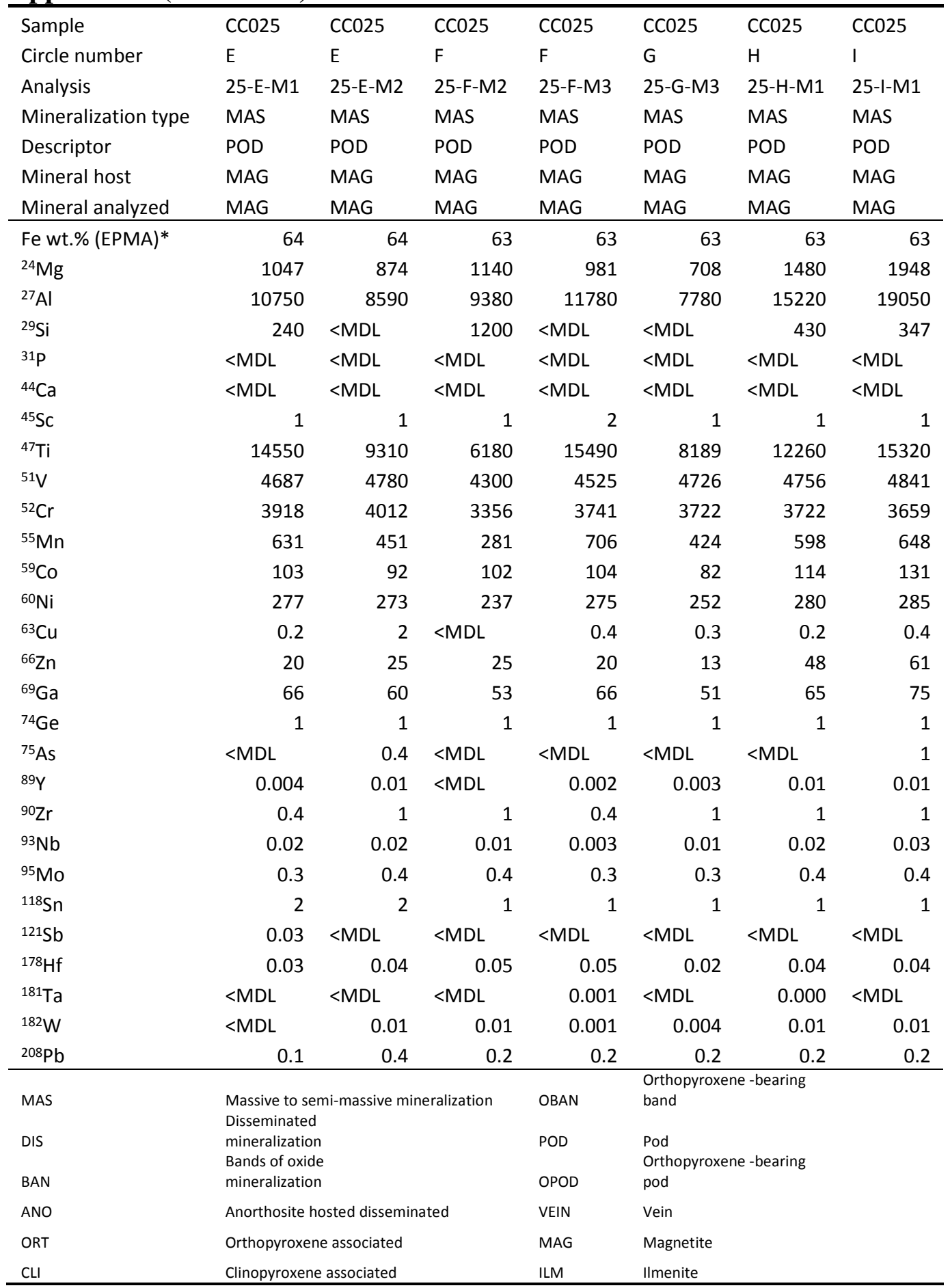




\section{Appendix V (Continued)}

\begin{tabular}{|c|c|c|c|c|c|c|c|}
\hline Sample & CCO25 & CCO25 & CC031 & CC031 & CC031 & CC031 & CC031 \\
\hline Circle number & $\mathrm{L}$ & L & A & A & B & B & C \\
\hline Analysis & 25-L-M1 & 25-L-M2 & 31-A-M1 & 31-A-M2 & 31-B-M1 & 31-B-M2 & 31-C-M1 \\
\hline Mineralization type & MAS & MAS & DIS & DIS & DIS & DIS & DIS \\
\hline Descriptor & POD & POD & ANO & ANO & ANO & ANO & ANO \\
\hline Mineral host & MAG & MAG & MAG & MAG & MAG & MAG & MAG \\
\hline Mineral analyzed & MAG & MAG & MAG & MAG & MAG & MAG & MAG \\
\hline Fe wt.\% (EPMA)* & 63 & 63 & 64 & 64 & 63 & 63 & 64 \\
\hline${ }^{24} \mathrm{Mg}$ & 657 & 1391 & 1200 & 963 & 562 & 346 & 2030 \\
\hline${ }^{27} \mathrm{Al}$ & 7430 & 14670 & 13610 & 10720 & 6320 & 4470 & 17440 \\
\hline${ }^{29} \mathrm{Si}$ & $<M D L$ & 191 & 230 & 356 & 153 & $<M D L$ & 201 \\
\hline $31 \mathrm{p}$ & $<M D L$ & $<\mathrm{MDL}$ & $<M D L$ & $<M D L$ & $<\mathrm{MDL}$ & $<M D L$ & $<\mathrm{MDL}$ \\
\hline${ }^{44} \mathrm{Ca}$ & $<M D L$ & $<M D L$ & $<M D L$ & $<M D L$ & $<M D L$ & $<M D L$ & $<M D L$ \\
\hline${ }^{45} \mathrm{Sc}$ & 1 & 2 & 1 & 1 & 1 & 1 & 2 \\
\hline${ }^{47} \mathrm{Ti}$ & 9640 & 17780 & 2710 & 6590 & 8190 & 2320 & 17920 \\
\hline${ }^{51} \mathrm{~V}$ & 4883 & 4802 & 4221 & 4307 & 4288 & 4383 & 4150 \\
\hline${ }^{52} \mathrm{Cr}$ & 3919 & 3761 & 3261 & 3214 & 2765 & 3015 & 3420 \\
\hline${ }^{55} \mathrm{Mn}$ & 374 & 841 & 461 & 582 & 627 & 320 & 977 \\
\hline${ }^{59} \mathrm{Co}$ & 74 & 113 & 89 & 79 & 57 & 47 & 118 \\
\hline${ }^{60} \mathrm{Ni}$ & 251 & 277 & 472 & 451 & 400 & 411 & 494 \\
\hline${ }^{63} \mathrm{Cu}$ & 1 & 1 & 1 & 2 & 3 & 2 & 5 \\
\hline${ }^{66} \mathrm{Zn}$ & 36 & 37 & 110 & 108 & 60 & 43 & 210 \\
\hline${ }^{69} \mathrm{Ga}$ & 49 & 68 & 56 & 52 & 48 & 42 & 65 \\
\hline${ }^{74} \mathrm{Ge}$ & 1 & 1 & 1 & 1 & 1 & 1 & 1 \\
\hline${ }^{75} \mathrm{As}$ & 0.4 & 0.5 & 1 & 1 & 1 & 1 & 1 \\
\hline${ }^{89} \mathrm{Y}$ & 0.004 & 0.01 & 0.001 & 0.01 & 0.003 & $<\mathrm{MDL}$ & 0.01 \\
\hline${ }^{90} \mathrm{Zr}$ & 1 & 1 & 1 & 1 & 1 & 0.3 & 1 \\
\hline${ }^{93} \mathrm{Nb}$ & 0.01 & 0.01 & 0.01 & 0.01 & 0.05 & 0.02 & 0.01 \\
\hline${ }^{95} \mathrm{Mo}$ & 0.4 & 0.3 & 1 & 1 & 1 & 1 & 1 \\
\hline${ }^{118} \mathrm{Sn}$ & 1 & 2 & 2 & 1 & 1 & 1 & 2 \\
\hline${ }^{121} \mathrm{Sb}$ & 0.02 & 0.04 & 0.02 & 0.02 & 0.03 & $<M D L$ & 0.04 \\
\hline${ }^{178} \mathrm{Hf}$ & 0.02 & 0.03 & 0.02 & 0.03 & 0.03 & 0.003 & 0.04 \\
\hline${ }^{181} \mathrm{Ta}$ & 0.000 & 0.000 & 0.000 & $<\mathrm{MDL}$ & $<\mathrm{MDL}$ & $<\mathrm{MDL}$ & 0.001 \\
\hline${ }^{182} \mathrm{~W}$ & 0.01 & 0.01 & 0.01 & 0.005 & 0.003 & 0.01 & 0.01 \\
\hline${ }^{208} \mathrm{~Pb}$ & 0.2 & 0.2 & 0.4 & 1 & 1 & 1 & 1 \\
\hline MAS & \multicolumn{3}{|c|}{$\begin{array}{l}\text { Massive to semi-massive mineralization } \\
\text { Disseminated }\end{array}$} & OBAN & \multicolumn{2}{|c|}{$\begin{array}{l}\text { Orthopyroxene -bearing } \\
\text { band }\end{array}$} & \\
\hline DIS & $\begin{array}{l}\text { mineralization } \\
\text { Bands of oxide }\end{array}$ & \multicolumn{2}{|c|}{$\begin{array}{l}\text { Bands of oxide } \\
\text { mineralization }\end{array}$} & OPOD & \multicolumn{2}{|c|}{$\begin{array}{l}\text { Pod } \\
\text { Orthopyroxene -bearing }\end{array}$} & \\
\hline ANO & \multicolumn{3}{|c|}{ Anorthosite hosted disseminated } & VEIN & \multicolumn{2}{|l|}{ Vein } & \\
\hline ORT & \multicolumn{3}{|c|}{ Orthopyroxene associated } & MAG & \multicolumn{2}{|l|}{ Magnetite } & \\
\hline $\mathrm{CLI}$ & \multicolumn{3}{|c|}{ Clinopyroxene associated } & ILM & IImenite & & \\
\hline
\end{tabular}




\section{Appendix V (Continued)}

\begin{tabular}{|c|c|c|c|c|c|c|c|}
\hline Sample & CC031 & CC031 & CC031 & CC031 & CC031 & CC031 & CC031 \\
\hline Circle number & C & C & $\mathrm{D}$ & $\mathrm{D}$ & $E$ & $E$ & $\mathrm{~F}$ \\
\hline Analysis & 31-C-M2 & 31-C-M3 & 31-D-M1 & 31-D-M2 & 31-E-M1 & 31-E-M2 & 31-F-M1 \\
\hline Mineralization type & DIS & DIS & DIS & DIS & DIS & DIS & DIS \\
\hline Descriptor & ANO & ANO & ANO & ANO & ANO & ANO & ANO \\
\hline Mineral host & MAG & MAG & MAG & MAG & MAG & MAG & MAG \\
\hline Mineral analyzed & MAG & MAG & MAG & MAG & MAG & MAG & MAG \\
\hline Fe wt.\% (EPMA)* & 64 & 64 & 63 & 63 & 64 & 64 & 64 \\
\hline${ }^{24} \mathrm{Mg}$ & 1630 & 473 & 1103 & 1146 & 1479 & 605 & 897 \\
\hline${ }^{27} \mathrm{Al}$ & 14200 & 5570 & 15390 & 14570 & 14930 & 10190 & 3920 \\
\hline${ }^{29} \mathrm{Si}$ & $<\mathrm{MDL}$ & 191 & 390 & 580 & 540 & 560 & $<M D L$ \\
\hline 31P & $<\mathrm{MDL}$ & $<\mathrm{MDL}$ & $<\mathrm{MDL}$ & $<\mathrm{MDL}$ & 5 & $<M D L$ & $<M D L$ \\
\hline${ }^{44} \mathrm{Ca}$ & $<\mathrm{MDL}$ & $<\mathrm{MDL}$ & $<\mathrm{MDL}$ & $<\mathrm{MDL}$ & $<\mathrm{MDL}$ & $<\mathrm{MDL}$ & $<\mathrm{MDL}$ \\
\hline${ }^{45} \mathrm{Sc}$ & 2 & 1 & 2 & 1 & 2 & 1 & 0.2 \\
\hline${ }^{47} \mathrm{Ti}$ & 15500 & 1173 & 14050 & 6780 & 14600 & 1650 & 1101 \\
\hline${ }^{51} \mathrm{~V}$ & 4163 & 4302 & 4216 & 4311 & 4099 & 4340 & 3544 \\
\hline${ }^{52} \mathrm{Cr}$ & 3371 & 3186 & 3013 & 3033 & 3347 & 3479 & 2707 \\
\hline${ }^{55} \mathrm{Mn}$ & 704 & 181 & 791 & 546 & 870 & 254 & 102 \\
\hline${ }^{59} \mathrm{Co}$ & 105 & 58 & 79 & 85 & 95 & 60 & 89 \\
\hline${ }^{60} \mathrm{Ni}$ & 471 & 423 & 402 & 425 & 455 & 359 & 460 \\
\hline${ }^{63} \mathrm{Cu}$ & 1 & 0.2 & 2 & 3 & 7 & 5 & 0.3 \\
\hline${ }^{66} \mathrm{Zn}$ & 141 & 35 & 172 & 153 & 177 & 58 & 18 \\
\hline${ }^{69} \mathrm{Ga}$ & 57 & 45 & 58 & 53 & 62 & 48 & 34 \\
\hline${ }^{74} \mathrm{Ge}$ & 1 & 1 & 1 & 1 & 1 & 1 & 1 \\
\hline${ }^{75} \mathrm{As}$ & 1 & 1 & 1 & 1 & 1 & 1 & 1 \\
\hline${ }^{89} Y$ & 0.01 & $<\mathrm{MDL}$ & 0.003 & 0.002 & 0.01 & 0.002 & 0.01 \\
\hline${ }^{90} \mathrm{Zr}$ & 1 & 0.4 & 1 & 1 & 2 & 1 & 2 \\
\hline${ }^{93} \mathrm{Nb}$ & 0.01 & 0.01 & 0.02 & 0.005 & 0.02 & 0.01 & 0.01 \\
\hline${ }^{95} \mathrm{Mo}$ & 1 & 1 & 1 & 1 & 1 & 1 & 1 \\
\hline${ }^{118} \mathrm{Sn}$ & 1 & 1 & 1 & 2 & 2 & 1 & 0.3 \\
\hline${ }^{121} \mathrm{Sb}$ & 0.03 & 0.02 & 0.04 & 0.1 & 0.02 & 0.04 & $<\mathrm{MDL}$ \\
\hline${ }^{178} \mathrm{Hf}$ & 0.05 & 0.01 & 0.1 & 0.04 & 0.1 & 0.02 & 0.01 \\
\hline${ }^{181} \mathrm{Ta}$ & 0.004 & 0.001 & 0.02 & $<\mathrm{MDL}$ & $<\mathrm{MDL}$ & $<\mathrm{MDL}$ & $<\mathrm{MDL}$ \\
\hline${ }^{182} \mathrm{~W}$ & 0.02 & 0.000 & 0.1 & 0.003 & 0.02 & 0.003 & $<\mathrm{MDL}$ \\
\hline${ }^{208} \mathrm{~Pb}$ & 1 & 0.3 & 0.4 & 0.5 & 0.4 & 0.2 & 0.4 \\
\hline MAS & \multicolumn{3}{|c|}{$\begin{array}{l}\text { Massive to semi-massive mineralization } \\
\text { Disseminated }\end{array}$} & OBAN & \multicolumn{2}{|c|}{$\begin{array}{l}\text { Orthopyroxene -bearing } \\
\text { band }\end{array}$} & \\
\hline $\begin{array}{l}\text { DIS } \\
\text { BAN }\end{array}$ & $\begin{array}{l}\text { mineralizatio } \\
\text { Bands of oxi } \\
\text { mineralizatio }\end{array}$ & & & OPOD & \multicolumn{2}{|c|}{$\begin{array}{l}\text { Orthopyroxene -bearing } \\
\text { pod }\end{array}$} & \\
\hline ANO & \multicolumn{3}{|c|}{ Anorthosite hosted disseminated } & VEIN & \multicolumn{2}{|l|}{ Vein } & \\
\hline ORT & \multicolumn{3}{|c|}{ Orthopyroxene associated } & MAG & \multicolumn{2}{|l|}{ Magnetite } & \\
\hline $\mathrm{CLI}$ & \multicolumn{3}{|c|}{ Clinopyroxene associated } & ILM & \multicolumn{2}{|l|}{ Ilmenite } & \\
\hline
\end{tabular}




\section{Appendix V (Continued)}

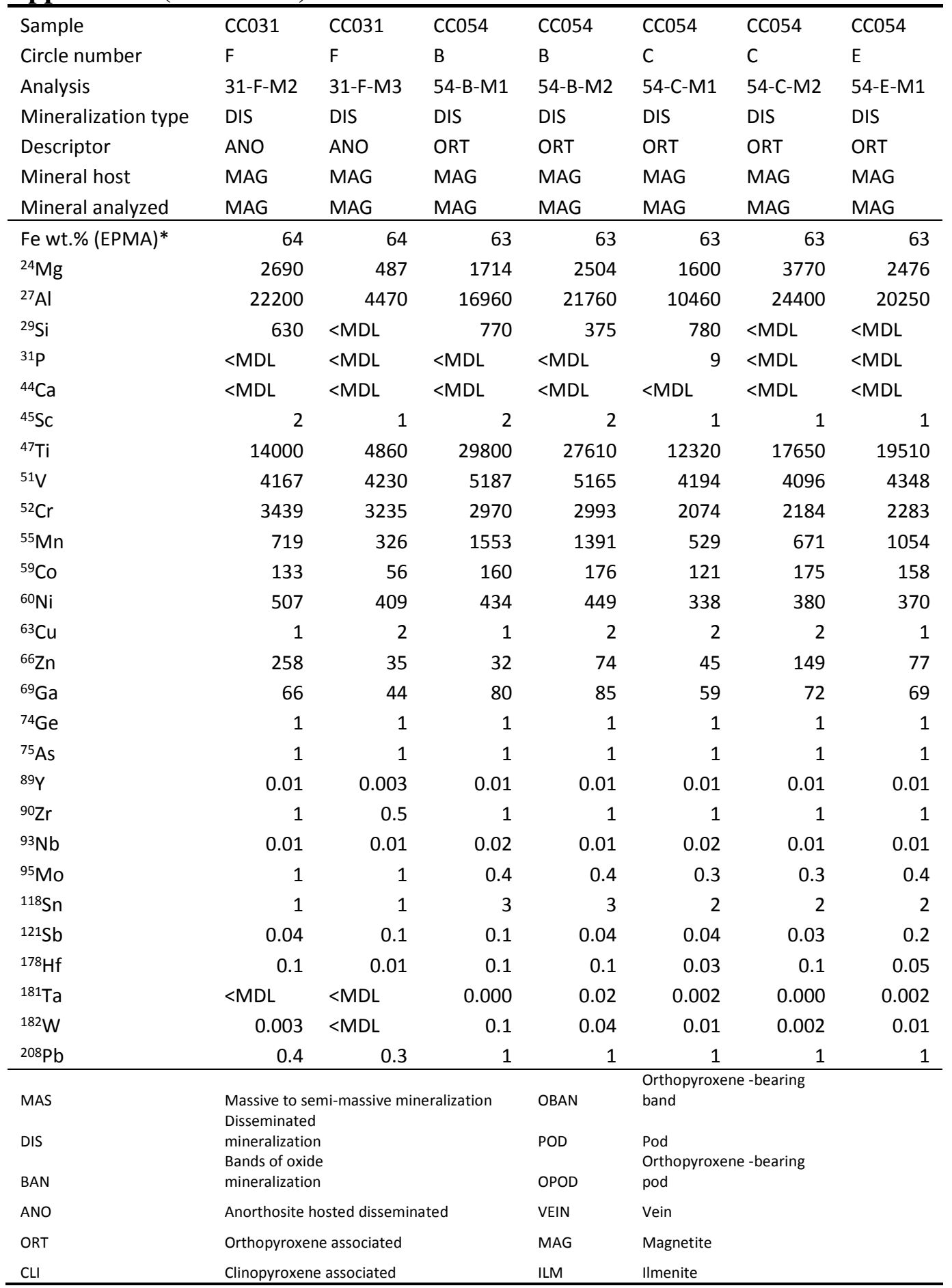




\section{Appendix V (Continued)}

\begin{tabular}{|c|c|c|c|c|c|c|c|}
\hline Sample & CC054 & CC054 & CC054 & CC054 & CC054 & CC054 & CC054 \\
\hline Circle number & $\mathrm{E}$ & $\mathrm{F}$ & $\mathrm{F}$ & G & G & I & I \\
\hline Analysis & 54-E-M2 & 54-F-M1 & 54-F-M2 & 54-G-M1 & 54-G-M2 & 54-I-M1 & 54-I-M2 \\
\hline Mineralization type & DIS & DIS & DIS & DIS & DIS & DIS & DIS \\
\hline Descriptor & ORT & ORT & ORT & ORT & ORT & ORT & ORT \\
\hline Mineral host & MAG & MAG & MAG & MAG & MAG & MAG & MAG \\
\hline Mineral analyzed & MAG & MAG & MAG & MAG & MAG & MAG & MAG \\
\hline Fe wt.\% (EPMA)* & 63 & 63 & 63 & 63 & 63 & 63 & 63 \\
\hline${ }^{24} \mathrm{Mg}$ & 1695 & 1685 & 1930 & 1846 & 1381 & 1581 & 1727 \\
\hline${ }^{27} \mathrm{Al}$ & 15380 & 18600 & 15850 & 14790 & 19100 & 11560 & 15890 \\
\hline${ }^{29} \mathrm{Si}$ & 340 & $<M D L$ & 710 & 440 & 700 & 360 & 274 \\
\hline $31 \mathrm{p}$ & $<M D L$ & $<M D L$ & $<M D L$ & $<M D L$ & $<M D L$ & 8 & $<M D L$ \\
\hline${ }^{44} \mathrm{Ca}$ & $<M D L$ & $<M D L$ & $<M D L$ & 23 & $<M D L$ & $<M D L$ & $<M D L$ \\
\hline${ }^{45} \mathrm{Sc}$ & 2 & 2 & 2 & 1 & 2 & 1 & 2 \\
\hline${ }^{47} \mathrm{Ti}$ & 19210 & 21450 & 24500 & 17940 & 19680 & 14090 & 20020 \\
\hline${ }^{51} \mathrm{~V}$ & 4434 & 4303 & 4328 & 4538 & 4452 & 4470 & 4396 \\
\hline${ }^{52} \mathrm{Cr}$ & 2140 & 2086 & 2105 & 2305 & 2241 & 2453 & 2115 \\
\hline${ }^{55} \mathrm{Mn}$ & 945 & 1232 & 1379 & 928 & 860 & 668 & 1201 \\
\hline${ }^{59} \mathrm{Co}$ & 130 & 130 & 138 & 136 & 129 & 128 & 142 \\
\hline${ }^{60} \mathrm{Ni}$ & 342 & 331 & 334 & 363 & 347 & 364 & 371 \\
\hline${ }^{63} \mathrm{Cu}$ & 0.3 & 1 & 3 & 1 & 1 & 1 & 2 \\
\hline${ }^{66} \mathrm{Zn}$ & 43 & 76 & 67 & 53 & 81 & 41 & 58 \\
\hline${ }^{69} \mathrm{Ga}$ & 63 & 66 & 66 & 65 & 65 & 78 & 71 \\
\hline${ }^{74} \mathrm{Ge}$ & 1 & 1 & 1 & 1 & 1 & 1 & 1 \\
\hline${ }^{75} \mathrm{As}$ & 1 & 1 & 1 & $<M D L$ & 1 & 1 & 1 \\
\hline${ }^{89} Y$ & 0.001 & 0.01 & 0.01 & 0.01 & 0.02 & 0.001 & 0.01 \\
\hline${ }^{90} \mathrm{Zr}$ & 1 & 1 & 1 & 1 & 1 & 1 & 1 \\
\hline${ }^{93} \mathrm{Nb}$ & 0.01 & 0.01 & 0.01 & 0.02 & 0.03 & 0.01 & 0.02 \\
\hline${ }^{95} \mathrm{Mo}$ & 0.3 & 0.4 & 0.4 & 0.4 & 0.4 & 0.3 & 0.4 \\
\hline${ }^{118} \mathrm{Sn}$ & 2 & 2 & 3 & 2 & 2 & 2 & 2 \\
\hline${ }^{121} \mathrm{Sb}$ & $<M D L$ & 0.03 & $<M D L$ & 0.01 & 0.1 & 0.04 & 0.02 \\
\hline${ }^{178} \mathrm{Hf}$ & 0.05 & 0.1 & 0.1 & 0.04 & 0.1 & 0.04 & 0.04 \\
\hline${ }^{181} \mathrm{Ta}$ & $<\mathrm{MDL}$ & 0.000 & 0.002 & 0.002 & $<M D L$ & $<\mathrm{MDL}$ & $<M D L$ \\
\hline${ }^{182} \mathrm{~W}$ & $<M D L$ & 0.004 & $<M D L$ & 0.01 & 0.003 & 0.004 & 0.01 \\
\hline${ }^{208} \mathrm{~Pb}$ & 1 & 1 & 1 & 0.5 & 1 & 1 & 1 \\
\hline MAS & \multicolumn{3}{|c|}{$\begin{array}{l}\text { Massive to semi-massive mineralization } \\
\text { Disseminated }\end{array}$} & OBAN & \multicolumn{2}{|c|}{$\begin{array}{l}\text { Orthopyroxene -bearing } \\
\text { band }\end{array}$} & \\
\hline DIS & \multicolumn{2}{|c|}{ mineralization } & & POD & & \\
\hline BAN & \multicolumn{2}{|c|}{$\begin{array}{l}\text { Bands of oxide } \\
\text { mineralization }\end{array}$} & & OPOD & \multicolumn{2}{|c|}{$\begin{array}{l}\text { Orthopyroxene -bearing } \\
\text { pod }\end{array}$} & \\
\hline ANO & \multicolumn{3}{|c|}{ Anorthosite hosted disseminated } & VEIN & \multicolumn{2}{|l|}{ Vein } & \\
\hline ORT & \multicolumn{3}{|c|}{ Orthopyroxene associated } & MAG & \multicolumn{2}{|l|}{ Magnetite } & \\
\hline CLI & \multicolumn{3}{|c|}{ Clinopyroxene associated } & ILM & \multicolumn{2}{|l|}{ IImenite } & \\
\hline
\end{tabular}




\section{Appendix V (Continued)}

\begin{tabular}{|c|c|c|c|c|c|c|c|}
\hline Sample & $\mathrm{CCO54}$ & CC054 & CC054 & CC054 & CC072 & CC072 & CCO72 \\
\hline \multirow[t]{2}{*}{ Circle number } & \multirow[t]{2}{*}{$\mathrm{L}$} & \multirow[t]{2}{*}{$\mathrm{L}$} & M & $\mathrm{M}$ & \multirow[t]{2}{*}{ A } & \multirow[t]{2}{*}{ A } & \multirow[t]{2}{*}{ B } \\
\hline & & & 54-M- & 54-M- & & & \\
\hline Analysis & 54-L-M1 & 54-L-M2 & M1 & $\mathrm{M} 2$ & 72-A-M1 & 72-A-M2 & 72-B-M2 \\
\hline Mineralization type & DIS & DIS & DIS & DIS & MAS & MAS & MAS \\
\hline Descriptor & ORT & ORT & ORT & ORT & OPOD & OPOD & OPOD \\
\hline Mineral host & MAG & MAG & MAG & MAG & MAG & MAG & MAG \\
\hline Mineral analyzed & MAG & MAG & MAG & MAG & MAG & MAG & MAG \\
\hline Fe wt.\% (EPMA)* & 63 & 63 & 63 & 63 & 60 & 60 & 59 \\
\hline${ }^{24} \mathrm{Mg}$ & 1947 & 1680 & 1372 & 1505 & 5571 & 5240 & 10540 \\
\hline${ }^{27} \mathrm{Al}$ & 17960 & 16290 & 12370 & 16280 & 16860 & 17980 & 28400 \\
\hline${ }^{29} \mathrm{Si}$ & 730 & 529 & 3000 & $<M D L$ & 726 & 178 & $<\mathrm{MDL}$ \\
\hline${ }^{31} \mathrm{p}$ & $<M D L$ & $<M D L$ & $<M D L$ & $<M D L$ & $<M D L$ & $<M D L$ & $<M D L$ \\
\hline${ }^{44} \mathrm{Ca}$ & $<M D L$ & 60 & $<M D L$ & $<M D L$ & 22 & $<M D L$ & $<M D L$ \\
\hline${ }^{45} \mathrm{SC}$ & 2 & 2 & 2 & 2 & 6 & 6 & 5 \\
\hline${ }^{47} \mathrm{Ti}$ & 20110 & 23140 & 17390 & 23930 & 23620 & 23790 & 27050 \\
\hline${ }^{51} \mathrm{~V}$ & 4497 & 4462 & 4528 & 4278 & 4368 & 4252 & 4223 \\
\hline${ }^{52} \mathrm{Cr}$ & 2232 & 2144 & 2045 & 2020 & 2088 & 2085 & 2417 \\
\hline${ }^{55} \mathrm{Mn}$ & 1031 & 1136 & 1001 & 1325 & 1875 & 2070 & 2030 \\
\hline${ }^{59} \mathrm{Co}$ & 139 & 125 & 123 & 137 & 170 & 180 & 206 \\
\hline${ }^{60} \mathrm{Ni}$ & 346 & 327 & 342 & 353 & 316 & 334 & 342 \\
\hline${ }^{63} \mathrm{Cu}$ & 0.4 & 0.3 & 0.4 & 1 & 12 & 1 & 4 \\
\hline${ }^{66} \mathrm{Zn}$ & 52 & 43 & 42 & 38 & 62 & 75 & 455 \\
\hline${ }^{69} \mathrm{Ga}$ & 66 & 63 & 65 & 66 & 56 & 61 & 67 \\
\hline${ }^{74} \mathrm{Ge}$ & 1 & 1 & 1 & 1 & 1 & 1 & 1 \\
\hline${ }^{75} \mathrm{As}$ & 1 & 1 & 0.5 & 1 & 1 & 1 & 1 \\
\hline${ }^{89} \mathrm{Y}$ & 0.01 & 0.01 & 0.01 & 0.01 & 0.01 & 0.02 & 0.02 \\
\hline${ }^{90} \mathrm{Zr}$ & 0.5 & 1 & 1 & 1 & 2 & 2 & 2 \\
\hline${ }^{93} \mathrm{Nb}$ & 0.02 & 0.01 & $<M D L$ & 0.04 & 0.02 & 0.01 & 0.1 \\
\hline${ }^{95} \mathrm{Mo}$ & 0.3 & 0.4 & 1 & 0.4 & 0.2 & 0.2 & 0.2 \\
\hline $118 \mathrm{Sn}$ & 2 & 2 & 2 & 2 & 2 & 2 & 2 \\
\hline${ }^{121} \mathrm{Sb}$ & 0.1 & $<M D L$ & 0.02 & 0.03 & 0.03 & 0.04 & 0.05 \\
\hline${ }^{178} \mathrm{Hf}$ & 0.04 & 0.1 & 0.04 & 0.05 & 0.1 & 0.1 & 0.1 \\
\hline${ }^{181} \mathrm{Ta}$ & 0.001 & $<M D L$ & $<M D L$ & 0.001 & 0.001 & 0.000 & 0.001 \\
\hline${ }^{182} \mathrm{~W}$ & 0.01 & 0.01 & $<M D L$ & 0.01 & 0.01 & 0.004 & 0.01 \\
\hline${ }^{208} \mathrm{~Pb}$ & 0.4 & 0.4 & 1 & 1 & 0.5 & 1 & 1 \\
\hline MAS & $\begin{array}{l}\text { Massive to se } \\
\text { Disseminate }\end{array}$ & ni-massive mir & eralization & OBAN & $\begin{array}{l}\text { Orthopyroxe } \\
\text { band }\end{array}$ & -bearing & \\
\hline DIS & mineralizatio & & & POD & Pod & & \\
\hline BAN & $\begin{array}{l}\text { Bands of oxic } \\
\text { mineralizatio }\end{array}$ & & & OPOD & $\begin{array}{l}\text { Orthopyroxe } \\
\text { pod }\end{array}$ & e-bearing & \\
\hline ANO & Anorthosite & osted dissemin & & VEIN & Vein & & \\
\hline ORT & Orthopyroxe & e associated & & MAG & Magnetite & & \\
\hline $\mathrm{CLI}$ & Clinopyroxen & associated & & ILM & Ilmenite & & \\
\hline
\end{tabular}




\section{Appendix V (Continued)}

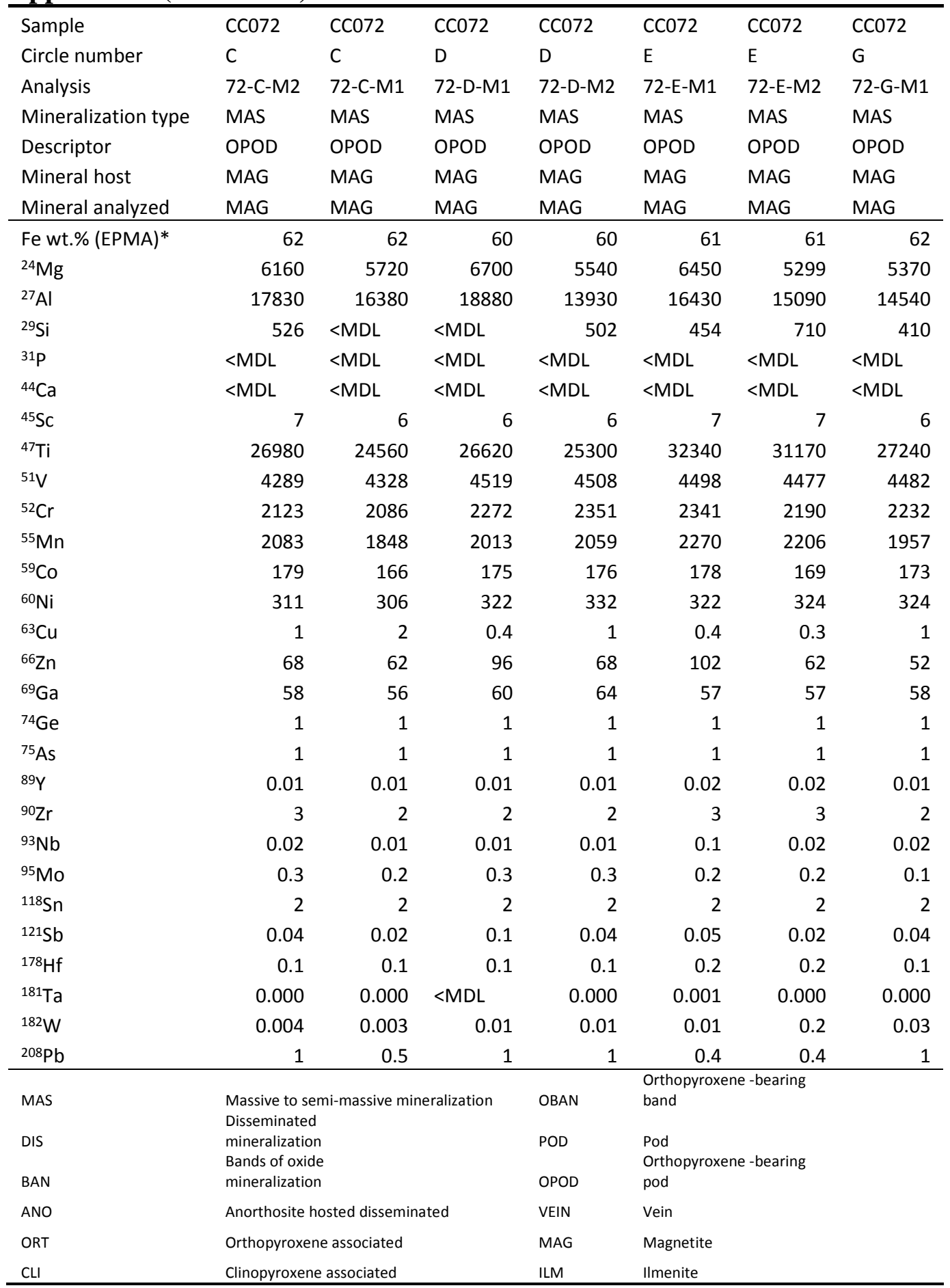




\section{Appendix V (Continued)}

\begin{tabular}{|c|c|c|c|c|c|c|c|}
\hline Sample & CC072 & CCO72 & CC072 & CCO72 & CC072 & CC074 & CC074 \\
\hline Circle number & G & $\mathrm{H}$ & $\mathrm{H}$ & I & I & A & A \\
\hline Analysis & 72-G-M2 & 72-H-M1 & 72-H-M2 & 72-I-M1 & 72-I-M2 & 74-A-M1 & 74-A-M2 \\
\hline Mineralization type & MAS & MAS & MAS & MAS & MAS & DIS & DIS \\
\hline Descriptor & OPOD & OPOD & OPOD & OPOD & OPOD & CLI & CLI \\
\hline Mineral host & MAG & MAG & MAG & MAG & MAG & MAG & MAG \\
\hline Mineral analyzed & MAG & MAG & MAG & MAG & MAG & MAG & MAG \\
\hline Fe wt.\% (EPMA)* & 62 & 60 & 60 & 62 & 62 & 63 & 63 \\
\hline${ }^{24} \mathrm{Mg}$ & 5380 & 5250 & 5490 & 6000 & 5350 & 411 & 333 \\
\hline${ }^{27} \mathrm{Al}$ & 14000 & 13890 & 14520 & 17360 & 14000 & 4450 & 3460 \\
\hline${ }^{29} \mathrm{Si}$ & 404 & $<\mathrm{MDL}$ & 180 & 780 & 404 & $<M D L$ & $<M D L$ \\
\hline $31 \mathrm{p}$ & $<M D L$ & $<M D L$ & $<\mathrm{MDL}$ & $<M D L$ & $<\mathrm{MDL}$ & $<M D L$ & $<M D L$ \\
\hline${ }^{44} \mathrm{Ca}$ & $<M D L$ & $<M D L$ & $<M D L$ & $<M D L$ & $<M D L$ & $<M D L$ & $<M D L$ \\
\hline${ }^{45} \mathrm{SC}$ & 5 & 6 & 5 & 6 & 5 & 1 & 1 \\
\hline${ }^{47} \mathrm{Ti}$ & 25130 & 28140 & 25390 & 24010 & 24490 & 854 & 3180 \\
\hline${ }^{51} \mathrm{~V}$ & 4442 & 4456 & 4451 & 4283 & 4459 & 3584 & 3429 \\
\hline${ }^{52} \mathrm{Cr}$ & 2253 & 2209 & 2268 & 2185 & 2300 & 3178 & 3722 \\
\hline${ }^{55} \mathrm{Mn}$ & 1956 & 2105 & 1911 & 1830 & 1896 & 300 & 356 \\
\hline${ }^{59} \mathrm{Co}$ & 181 & 173 & 179 & 172 & 177 & 86 & 76 \\
\hline${ }^{60} \mathrm{Ni}$ & 335 & 317 & 326 & 317 & 321 & 283 & 275 \\
\hline${ }^{63} \mathrm{Cu}$ & 1 & 0.3 & 1 & 0.4 & 1 & 0.5 & $<M D L$ \\
\hline${ }^{66} \mathrm{Zn}$ & 65 & 59 & 65 & 82 & 59 & 33 & 25 \\
\hline${ }^{69} \mathrm{Ga}$ & 60 & 55 & 57 & 58 & 57 & 56 & 49 \\
\hline${ }^{74} \mathrm{Ge}$ & 1 & 1 & 1 & 1 & 1 & 1 & $<M D L$ \\
\hline${ }^{75} \mathrm{As}$ & 1 & 1 & 1 & 1 & 1 & 2 & $<M D L$ \\
\hline${ }^{89} \mathrm{Y}$ & 0.01 & 0.01 & 0.01 & 0.02 & 0.01 & $<M D L$ & 0.01 \\
\hline${ }^{90} \mathrm{Zr}$ & 2 & 2 & 2 & 2 & 2 & 0.1 & 0.5 \\
\hline${ }^{93} \mathrm{Nb}$ & 0.01 & 0.02 & 0.02 & 0.01 & 0.02 & 0.03 & 0.2 \\
\hline${ }^{95} \mathrm{Mo}$ & 0.3 & 0.2 & 0.2 & 0.2 & 0.2 & 0.3 & $<M D L$ \\
\hline${ }^{118} \mathrm{Sn}$ & 2 & 2 & 2 & 2 & 2 & 0.3 & $<M D L$ \\
\hline${ }^{121} \mathrm{Sb}$ & 0.04 & 0.02 & 0.02 & 0.02 & 0.03 & 0.1 & 0.2 \\
\hline${ }^{178} \mathrm{Hf}$ & 0.1 & 0.1 & 0.1 & 0.1 & 0.1 & $<M D L$ & 0.01 \\
\hline${ }^{181} \mathrm{Ta}$ & 0.002 & 0.000 & 0.01 & $<M D L$ & 0.000 & $<M D L$ & 0.004 \\
\hline${ }^{182} \mathrm{~W}$ & 0.002 & 0.01 & 0.01 & 0.002 & 0.003 & 0.001 & $<M Q L$ \\
\hline${ }^{208} \mathrm{~Pb}$ & 1 & 0.3 & 1 & 1 & 1 & 1 & 1 \\
\hline MAS & Massive to semi- $r$ & mineralization & & OBAN & \multicolumn{2}{|c|}{$\begin{array}{l}\text { Orthopyroxene -bearing } \\
\text { band }\end{array}$} & \\
\hline DIS & Disseminated min & & & POD & \multirow{2}{*}{\multicolumn{2}{|c|}{$\begin{array}{l}\text { Pod } \\
\text { Orthopyroxene -bearing } \\
\text { pod }\end{array}$}} & \\
\hline BAN & Bands of oxide $\mathrm{m}$ & ition & & OPOD & & & \\
\hline ANO & Anorthosite hoste & minated & & VEIN & Vein & & \\
\hline ORT & $\begin{array}{l}\text { Orthopyroxene as } \\
\text { Clinopyroxene }\end{array}$ & & & MAG & Magnetite & & \\
\hline $\mathrm{CLI}$ & associated & & & ILM & IImenite & & \\
\hline
\end{tabular}




\section{Appendix V (Continued)}

\begin{tabular}{|c|c|c|c|c|c|c|c|}
\hline Sample & $\mathrm{CCO} 74$ & CCO74 & $\mathrm{CCO74}$ & CC074 & $\mathrm{CC074}$ & CC074 & CCO74 \\
\hline Circle number & B & B & C & C & $\mathrm{D}$ & $\mathrm{D}$ & $E$ \\
\hline Analysis & 74-B-M1 & 74-B-M2 & 74-C-M1 & 74-C-M2 & 74-D-M2 & 74-D-M2 & 74-E-M1 \\
\hline Mineralization type & DIS & DIS & DIS & DIS & DIS & DIS & DIS \\
\hline Descriptor & CLI & CLI & CLI & CLI & CLI & CLI & CLI \\
\hline Mineral host & MAG & MAG & MAG & MAG & MAG & MAG & MAG \\
\hline Mineral analyzed & MAG & MAG & MAG & MAG & MAG & MAG & MAG \\
\hline Fe wt.\% (EPMA)* & 64 & 64 & 64 & 64 & 64 & 64 & 64 \\
\hline${ }^{24} \mathrm{Mg}$ & 610 & 571 & 367 & 504 & $<\mathrm{MDL}$ & 405 & 406 \\
\hline${ }^{27} \mathrm{Al}$ & 4860 & 4150 & 2410 & 4360 & 4300 & 2618 & 3400 \\
\hline${ }^{29} \mathrm{Si}$ & $<\mathrm{MDL}$ & $<\mathrm{MDL}$ & 584 & 680 & 708 & 395 & 310 \\
\hline 31p & $<M D L$ & $<M D L$ & $<M D L$ & $<M D L$ & 6 & $<M D L$ & $<M D L$ \\
\hline${ }^{44} \mathrm{Ca}$ & $<\mathrm{MDL}$ & $<M D L$ & $<M D L$ & 17 & 15 & $<\mathrm{MDL}$ & $<M D L$ \\
\hline${ }^{45} \mathrm{Sc}$ & 1 & 1 & 0.4 & 1 & 1 & 1 & 1 \\
\hline${ }^{47} \mathrm{Ti}$ & 1170 & 6500 & 2930 & 887 & 12000 & 727 & 557 \\
\hline${ }^{51} \mathrm{~V}$ & 3486 & 3455 & 3380 & 3480 & 3294 & 3462 & 3447 \\
\hline${ }^{52} \mathrm{Cr}$ & 3159 & 3310 & 3047 & 2945 & 3683 & 3159 & 3206 \\
\hline${ }^{55} \mathrm{Mn}$ & 270 & 674 & 293 & 257 & 673 & 233 & 235 \\
\hline${ }^{59} \mathrm{Co}$ & 82 & 91 & 74 & 84 & 98 & 73 & 78 \\
\hline${ }^{60} \mathrm{Ni}$ & 297 & 288 & 250 & 273 & 242 & 232 & 258 \\
\hline${ }^{63} \mathrm{Cu}$ & 0.2 & 1 & 1 & 0.3 & 1 & 14 & 0.3 \\
\hline${ }^{66} \mathrm{Zn}$ & 49 & 95 & 17 & 27 & 30 & 9 & 60 \\
\hline${ }^{69} \mathrm{Ga}$ & 53 & 55 & 46 & 55 & 54 & 47 & 49 \\
\hline${ }^{74} \mathrm{Ge}$ & 1 & 1 & 1 & 1 & 1 & 1 & 1 \\
\hline${ }^{75} \mathrm{As}$ & 2 & 2 & 2 & 2 & 2 & 1 & 1 \\
\hline${ }^{89} Y$ & 0.01 & 0.02 & 0.01 & 0.003 & 0.01 & 0.01 & $<\mathrm{MDL}$ \\
\hline${ }^{90} \mathrm{Zr}$ & 0.3 & 1 & 0.2 & 0.1 & 1 & 0.03 & 0.1 \\
\hline${ }^{93} \mathrm{Nb}$ & 0.02 & 0.2 & 0.1 & 0.01 & 1 & 0.02 & 0.01 \\
\hline${ }^{95} \mathrm{Mo}$ & 0.3 & 0.3 & 0.2 & 0.3 & 0.3 & 0.3 & 0.2 \\
\hline${ }^{118} \mathrm{Sn}$ & 0.2 & 0.4 & 0.1 & 0.1 & 0.4 & 0.1 & 0.1 \\
\hline${ }^{121} \mathrm{Sb}$ & 0.1 & 0.1 & 0.02 & 0.03 & 0.1 & 0.01 & $<\mathrm{MDL}$ \\
\hline${ }^{178} \mathrm{Hf}$ & 0.002 & 0.01 & 0.01 & 0.002 & 0.04 & 0.001 & $<M D L$ \\
\hline${ }^{181} \mathrm{Ta}$ & 0.001 & 0.003 & 0.002 & 0.000 & 0.02 & 0.000 & $<M D L$ \\
\hline${ }^{182} \mathrm{~W}$ & 0.002 & 0.004 & 0.001 & 0.01 & 0.01 & 0.005 & 0.003 \\
\hline${ }^{208} \mathrm{~Pb}$ & 1 & 1 & 1 & 1 & 1 & 1 & 1 \\
\hline MAS & \multicolumn{3}{|c|}{$\begin{array}{l}\text { Massive to semi-massive mineralization } \\
\text { Disseminated } \\
\text { mineralization }\end{array}$} & $\begin{array}{l}\text { OBAN } \\
\text { POD }\end{array}$ & \multicolumn{2}{|c|}{$\begin{array}{l}\text { Orthopyroxene -bearing } \\
\text { band }\end{array}$} & \\
\hline BAN & \multicolumn{3}{|c|}{$\begin{array}{l}\text { Bands of oxide } \\
\text { mineralization }\end{array}$} & OPOD & \multicolumn{2}{|c|}{$\begin{array}{l}\text { Orthopyroxene -bearing } \\
\text { pod }\end{array}$} & \\
\hline ANO & \multicolumn{3}{|c|}{ Anorthosite hosted disseminated } & VEIN & \multicolumn{2}{|l|}{ Vein } & \\
\hline ORT & \multicolumn{3}{|c|}{ Orthopyroxene associated } & MAG & \multicolumn{2}{|l|}{ Magnetite } & \\
\hline CLI & \multicolumn{3}{|c|}{ Clinopyroxene associated } & ILM & \multicolumn{2}{|l|}{ Ilmenite } & \\
\hline
\end{tabular}




\section{Appendix V (Continued)}

\begin{tabular}{|c|c|c|c|c|c|c|}
\hline Sample & CCO74 & CC074 & CC076 & CC076 & CC076 & CC076 \\
\hline Circle number & $\mathrm{E}$ & $\mathrm{F}$ & C & C & $\mathrm{D}$ & K \\
\hline Analysis & 74-E-M2 & 74-F-M1 & 76-C-M1 & 76-C-M2 & 76-D-M1 & 76-K-M1 \\
\hline Mineralization type & DIS & DIS & MAS & MAS & MAS & MAS \\
\hline Descriptor & CLI & CLI & VEIN & VEIN & VEIN & VEIN \\
\hline Mineral host & MAG & MAG & MAG & MAG & MAG & MAG \\
\hline Mineral analyzed & MAG & MAG & MAG & MAG & MAG & MAG \\
\hline Fe wt.\% (EPMA)* & 64 & 64 & 64 & 64 & 64 & 64 \\
\hline${ }^{24} \mathrm{Mg}$ & 2940 & 489 & 517 & 702 & 624 & 806 \\
\hline${ }^{27} \mathrm{Al}$ & 17700 & 2990 & 2810 & 5570 & 3610 & 4780 \\
\hline${ }^{29} \mathrm{Si}$ & 240 & 1630 & $<M D L$ & $<M D L$ & 209 & 149 \\
\hline 31p & $<\mathrm{MDL}$ & 7 & $<M D L$ & $<M D L$ & $<M D L$ & $<M D L$ \\
\hline${ }^{44} \mathrm{Ca}$ & 16 & 72 & $<M D L$ & $<M D L$ & $<M D L$ & $<M D L$ \\
\hline${ }^{45} \mathrm{SC}$ & 1 & 0.4 & 1 & 1 & 1 & 1 \\
\hline${ }^{47} \mathrm{Ti}$ & 1370 & 1340 & 601 & 808 & 524 & 1410 \\
\hline${ }^{51} \mathrm{~V}$ & 3453 & 3362 & 4200 & 4420 & 3476 & 4300 \\
\hline${ }^{52} \mathrm{Cr}$ & 3792 & 4070 & 2277 & 3103 & 2591 & 2969 \\
\hline${ }^{55} \mathrm{Mn}$ & 517 & 259 & 345 & 273 & 205 & 358 \\
\hline${ }^{59} \mathrm{Co}$ & 181 & 90 & 58 & 64 & 59 & 64 \\
\hline${ }^{60} \mathrm{Ni}$ & 337 & 269 & 96 & 101 & 93 & 98 \\
\hline${ }^{63} \mathrm{Cu}$ & 0.4 & 1 & 1 & 0.2 & 0.1 & 0.1 \\
\hline${ }^{66} \mathrm{Zn}$ & 1320 & 38 & 7 & 47 & 18 & 38 \\
\hline${ }^{69} \mathrm{Ga}$ & 68 & 54 & 34 & 42 & 36 & 43 \\
\hline${ }^{74} \mathrm{Ge}$ & 1 & 1 & 1 & 1 & 1 & 1 \\
\hline${ }^{75} \mathrm{As}$ & 1 & 1 & $<M D L$ & $<M D L$ & 0.4 & 0.4 \\
\hline${ }^{89} \mathrm{Y}$ & 0.001 & 0.002 & $<M D L$ & 0.001 & $<M D L$ & 0.001 \\
\hline${ }^{90} \mathrm{Zr}$ & 0.1 & 0.1 & 0.01 & 0.02 & 0.1 & 0.1 \\
\hline${ }^{93} \mathrm{Nb}$ & 0.02 & 0.03 & $<M D L$ & 0.01 & 0.01 & 0.01 \\
\hline${ }^{95} \mathrm{Mo}$ & 0.2 & 0.2 & 0.3 & $<\mathrm{MDL}$ & 0.2 & 0.2 \\
\hline $118 \mathrm{Sn}$ & 0.3 & 0.1 & $<M D L$ & $<M D L$ & 0.05 & $<M D L$ \\
\hline${ }^{121} \mathrm{Sb}$ & 0.02 & 0.02 & $<M D L$ & $<M D L$ & 0.01 & $<M D L$ \\
\hline${ }^{178} \mathrm{Hf}$ & 0.001 & $<M D L$ & $<M D L$ & $<M D L$ & 0.002 & 0.001 \\
\hline${ }^{181} \mathrm{Ta}$ & 0.001 & 0.001 & $<M D L$ & $<M D L$ & 0.01 & 0.000 \\
\hline${ }^{182} \mathrm{~W}$ & 0.01 & $<M D L$ & $<M D L$ & $<M D L$ & 0.001 & $<M D L$ \\
\hline${ }^{208} \mathrm{~Pb}$ & 1 & 1 & 0.4 & 0.2 & 0.2 & 0.2 \\
\hline MAS & \multirow{2}{*}{\multicolumn{3}{|c|}{$\begin{array}{l}\text { Massive to semi- } \\
\text { Disseminated } \\
\text { mineralization } \\
\text { Bands of oxide } \\
\text { mineralization }\end{array}$}} & OBAN & \multicolumn{2}{|c|}{$\begin{array}{l}\text { Orthopyroxene -bearing } \\
\text { band }\end{array}$} \\
\hline BAN & & & & OPOD & \multicolumn{2}{|c|}{$\begin{array}{l}\text { Pod } \\
\text { Orthopyroxene -bearing } \\
\text { pod }\end{array}$} \\
\hline ANO & \multicolumn{3}{|c|}{ Anorthosite hosted disseminated } & VEIN & \multicolumn{2}{|l|}{ Vein } \\
\hline ORT & \multicolumn{3}{|c|}{ Orthopyroxene associated } & MAG & \multicolumn{2}{|l|}{ Magnetite } \\
\hline $\mathrm{CLI}$ & \multicolumn{3}{|c|}{ Clinopyroxene associated } & ILM & \multicolumn{2}{|l|}{ IImenite } \\
\hline
\end{tabular}




\section{Appendix V (Continued)}

\begin{tabular}{|c|c|c|c|c|c|c|c|c|}
\hline Sample & CC008 & CCOO8 & $\mathrm{CCOO8}$ & $\mathrm{CCOO8}$ & CCOO8 & CC008 & CC008 & CC008 \\
\hline Circle number & $A$ & A & A & C & D & D & $\mathrm{F}$ & $\mathrm{F}$ \\
\hline Analysis number & $08-A-I 1$ & $08-A-13$ & $08-A-14$ & $08-\mathrm{C}-\mathrm{I1}$ & 08-D-I1 & $08-D-12$ & 08-F-I1 & $08-F-12$ \\
\hline Mineralization style & MAS & MAS & MAS & MAS & MAS & MAS & MAS & MAS \\
\hline Descriptor & BAN & BAN & BAN & BAN & BAN & BAN & BAN & BAN \\
\hline Ilmenite texture & COMP & COMP & COMP & COMP & COMP & COMP & COMP & COMP \\
\hline Exsolution? & $\mathrm{y}$ & $\mathrm{y}$ & $\mathrm{y}$ & $\mathrm{y}$ & $\mathrm{y}$ & $\mathrm{y}$ & $\mathrm{n}$ & $\mathrm{n}$ \\
\hline Ti wt. \% (EPMA) & 29.1 & 29.0 & 29.1 & 29.4 & 29.5 & 29.6 & 29.6 & 29.7 \\
\hline${ }^{24} \mathrm{Mg}$ & 8670 & 9710 & 8920 & 9050 & 8970 & 8488 & 8940 & 9140 \\
\hline${ }^{27} \mathrm{Al}$ & 508 & 4470 & 204 & 266 & 1600 & 235 & 261 & 452 \\
\hline${ }^{29} \mathrm{Si}$ & 296 & 259 & 307 & 231 & 123 & 252 & 540 & 410 \\
\hline 31p & 4 & $<M D L$ & 4 & $<M D L$ & $<M D L$ & $<M D L$ & $<M D L$ & $<M D L$ \\
\hline${ }^{44} \mathrm{Ca}$ & $<M D L$ & $<M D L$ & $<M D L$ & $<M D L$ & $<M D L$ & $<M D L$ & 36 & 32 \\
\hline${ }^{45} \mathrm{SC}$ & 41 & 40 & 41 & 41 & 40 & 40 & 37 & 38 \\
\hline${ }^{51} \mathrm{~V}$ & 1866 & 1603 & 1786 & 1929 & 1445 & 1719 & 1590 & 1867 \\
\hline${ }^{52} \mathrm{Cr}$ & 116 & 140 & 99 & 179 & 150 & 184 & 193 & 208 \\
\hline${ }^{55} \mathrm{Mn}$ & 6177 & 6178 & 6356 & 5769 & 6323 & 6283 & 6120 & 6010 \\
\hline${ }^{57} \mathrm{Fe}$ & 413300 & 433700 & 436800 & 432200 & 416000 & 424000 & 404900 & 432800 \\
\hline${ }^{59} \mathrm{Co}$ & 91 & 99 & 93 & 92 & 96 & 93 & 99 & 102 \\
\hline${ }^{60} \mathrm{Ni}$ & 43 & 42 & 41 & 49 & 55 & 52 & 53 & 56 \\
\hline${ }^{63} \mathrm{Cu}$ & 2 & 2 & 3 & 17 & 1 & 2 & 2 & 2 \\
\hline${ }^{65} \mathrm{Cu}$ & 4 & 5 & 6 & 4 & 4 & 4 & 5 & 5 \\
\hline${ }^{69} \mathrm{Ga}$ & 2 & 9 & 2 & 2 & 3 & 1 & 1 & 2 \\
\hline${ }^{74} \mathrm{Ge}$ & 0.2 & 0.1 & 0.2 & 0.2 & 0.2 & 0.2 & 0.2 & 0.2 \\
\hline${ }^{75} \mathrm{As}$ & 0.4 & 0.4 & 0.5 & 1 & 0.4 & 1 & 1 & 1 \\
\hline${ }^{89} Y$ & 0.1 & 0.1 & 0.1 & 0.1 & 0.1 & 0.1 & 0.1 & 0.1 \\
\hline${ }^{90} \mathrm{Zr}$ & 73 & 79 & 82 & 66 & 67 & 69 & 55 & 64 \\
\hline${ }^{93} \mathrm{Nb}$ & 3 & 3 & 3 & 4 & 4 & 3 & 3 & 4 \\
\hline${ }^{95} \mathrm{Mo}$ & 0.4 & 0.5 & 1 & 0.4 & 0.4 & 0.4 & 0.4 & 0.4 \\
\hline${ }^{118} \mathrm{Sn}$ & 3 & 3 & 3 & 4 & 3 & 4 & 4 & 4 \\
\hline${ }^{121} \mathrm{Sb}$ & 0.1 & 0.1 & 0.1 & 0.1 & 0.1 & 0.1 & 0.1 & 0.05 \\
\hline${ }^{178} \mathrm{Hf}$ & 2 & 2 & 2 & 3 & 2 & 3 & 2 & 2 \\
\hline${ }^{181} \mathrm{Ta}$ & 0.1 & 0.1 & 0.1 & 0.1 & 0.1 & 0.1 & 0.2 & 0.2 \\
\hline${ }^{182} \mathrm{~W}$ & 0.01 & 0.00 & 0.02 & 0.01 & 0.00 & 0.01 & 0.01 & 0.01 \\
\hline${ }^{208} \mathrm{~Pb}$ & 1 & 1 & 1 & 1 & 1 & 1 & 1 & 1 \\
\hline MAS & \multicolumn{4}{|c|}{ Massive to semi-massive mineralization } & OBAN & \multicolumn{3}{|c|}{ Orthopyroxene -bearing band } \\
\hline DIS & \multicolumn{4}{|c|}{ Disseminated mineralization } & POD & \multicolumn{3}{|l|}{ Pod } \\
\hline BAN & \multicolumn{4}{|c|}{ Bands of oxide mineralization } & OPOD & \multicolumn{3}{|c|}{ Orthopyroxene -bearing pod } \\
\hline ANO & \multicolumn{4}{|c|}{ Anorthosite hosted disseminated } & VEIN & \multicolumn{3}{|c|}{ Vein } \\
\hline ORT & \multicolumn{4}{|c|}{ Orthopyroxene associated } & COMP & \multicolumn{3}{|c|}{ composite ilmenite } \\
\hline $\mathrm{CLI}$ & \multicolumn{4}{|c|}{ Clinopyroxene associated } & SAN & \multicolumn{3}{|c|}{ sandwich ilmenite } \\
\hline
\end{tabular}

* Internal calibrant was taken from EPMA analyses performed on the same grain as LA-ICPMS analyses; when LA-ICPMS analyses were performed on magnetite without EPMA analyses, the internal calibrant used was the average of all texturally similar ilmenite in the sample 


\begin{tabular}{|c|c|c|c|c|c|c|c|c|}
\hline \multicolumn{9}{|c|}{ Appendix V (Continued) } \\
\hline Sample & $\mathrm{CCO08}$ & CC008 & CC008 & CC008 & CC010 & CC010 & CC010 & CC010 \\
\hline Circle number & $\mathrm{H}$ & $\mathrm{H}$ & J & J & D & D & D & $\mathrm{E}$ \\
\hline Analysis number & 08-H-I1 & $08-\mathrm{H}-12$ & $08-J-11$ & $08-J-12$ & 10-D-I1 & 10-D-I1 & $10-D-12$ & $10-\mathrm{E}-\mathrm{S} 1$ \\
\hline Mineralization style & MAS & MAS & MAS & MAS & MAS & MAS & MAS & MAS \\
\hline Descriptor & BAN & BAN & BAN & BAN & OBAN & OBAN & OBAN & OBAN \\
\hline Ilmenite texture & COMP & COMP & COMP & COMP & COMP & COMP & COMP & SAN \\
\hline Exsolution? & y & y & $\mathrm{n}$ & $\mathrm{n}$ & y & y & y & $\mathrm{n}$ \\
\hline Ti wt. \% (EPMA) & 29.5 & 29.5 & 29.6 & 29.5 & 29.8 & 28.2 & 28.3 & 30.69 \\
\hline${ }^{24} \mathrm{Mg}$ & 9893 & 9870 & 10000 & 9743 & 11540 & 10840 & 10663 & 9940 \\
\hline${ }^{27} \mathrm{Al}$ & 483 & 134 & 423 & 310 & 326 & 294 & 272 & 173 \\
\hline${ }^{29} \mathrm{Si}$ & 552 & 201 & 2600 & 271 & $<\mathrm{MDL}$ & 290 & 986 & 668 \\
\hline${ }^{31} \mathrm{p}$ & 5 & 4 & 13 & $<\mathrm{MDL}$ & $<M D L$ & $<M D L$ & $<\mathrm{MDL}$ & $<\mathrm{MDL}$ \\
\hline${ }^{44} \mathrm{Ca}$ & $<\mathrm{MDL}$ & $<\mathrm{MDL}$ & 390 & $<M D L$ & $<\mathrm{MDL}$ & $<M D L$ & 17 & $<\mathrm{MDL}$ \\
\hline${ }^{45} \mathrm{Sc}$ & 40 & 40 & 40 & 39 & 45 & 44 & 45 & 44 \\
\hline${ }^{51} \mathrm{~V}$ & 1717 & 1222 & 2031 & 1755 & 1565 & 1348 & 1601 & 975 \\
\hline${ }^{52} \mathrm{Cr}$ & 141 & 74 & 170 & 130 & 148 & 132 & 108 & 113 \\
\hline${ }^{55} \mathrm{Mn}$ & 4769 & 4804 & 4787 & 4767 & 6020 & 5522 & 5468 & 8249 \\
\hline${ }^{57} \mathrm{Fe}$ & 463600 & 380500 & 479800 & 464000 & 442000 & 403000 & 413400 & 390000 \\
\hline${ }^{59} \mathrm{Co}$ & 91 & 87 & 76 & 82 & 123 & 113 & 113 & 114 \\
\hline${ }^{60} \mathrm{Ni}$ & 50 & 38 & 27 & 30 & 64 & 64 & 68 & 81 \\
\hline${ }^{63} \mathrm{Cu}$ & 1 & 1 & 4 & 1 & 2 & 1 & 1 & 2 \\
\hline${ }^{65} \mathrm{Cu}$ & 4 & 3 & 6 & 3 & 5 & 5 & 5 & 6 \\
\hline${ }^{69} \mathrm{Ga}$ & 3 & 1 & 2 & 2 & 1 & 1 & 1 & 1 \\
\hline${ }^{74} \mathrm{Ge}$ & 0.2 & 0.1 & 0.2 & 0.2 & 0.2 & 0.1 & 0.1 & 0.1 \\
\hline${ }^{75} \mathrm{As}$ & 0.5 & 0.3 & 1 & 0.5 & 1 & 1 & 1 & 1 \\
\hline${ }^{89} \mathrm{Y}$ & 0.1 & 0.1 & 0.1 & 0.1 & 0.1 & 0.1 & 0.1 & 0.1 \\
\hline${ }^{90} \mathrm{Zr}$ & 71 & 48 & 63 & 82 & 75 & 69 & 91 & 49 \\
\hline${ }^{93} \mathrm{Nb}$ & 5 & 5 & 5 & 5 & 3 & 3 & 3 & 2 \\
\hline${ }^{95} \mathrm{Mo}$ & 0.4 & 0.3 & 0.4 & 0.4 & 0.4 & 0.3 & 0.4 & 0.5 \\
\hline${ }^{118} \mathrm{Sn}$ & 3 & 2 & 4 & 3 & 4 & 3 & 3 & 3 \\
\hline${ }^{121} \mathrm{Sb}$ & 0.04 & 0.03 & 0.1 & 0.04 & 0.04 & 0.02 & 0.02 & 0.04 \\
\hline $178 \mathrm{Hf}$ & 3 & 2 & 3 & 3 & 2 & 2 & 2 & 2 \\
\hline${ }^{181} \mathrm{Ta}$ & 0.4 & 0.4 & 0.5 & 0.4 & 0.1 & 0.1 & 0.1 & 0.1 \\
\hline${ }^{182} \mathrm{~W}$ & 0.01 & 0.01 & 0.03 & 0.02 & 0.02 & 0.01 & 0.01 & 0.02 \\
\hline${ }^{208} \mathrm{~Pb}$ & 1 & 1 & 2 & 1 & 1 & 1 & 1 & 1 \\
\hline MAS & Massive to & semi-mas & ive minerali & ration & OBAN & Orthopyro & xene -beari & g band \\
\hline DIS & Dissemina & ted minera & zation & & POD & Pod & & \\
\hline BAN & Bands of $c$ & xide miner & lization & & OPOD & Orthopyro & xene -beari & g pod \\
\hline ANO & Anorthosi & e hosted d & sseminated & & VEIN & Vein & & \\
\hline ORT & Orthopyrc & xene assoc & ated & & COMP & composite & ilmenite & \\
\hline $\mathrm{CLI}$ & Clinopyror & ene associ & & & SAN & sandwich $\mathrm{i}$ & & \\
\hline
\end{tabular}




\section{Appendix V (Continued)}

\begin{tabular}{|c|c|c|c|c|c|c|c|c|}
\hline Sample & CCO10 & CCO10 & CC010 & CCO10 & $\mathrm{CCO10}$ & $\mathrm{CCO10}$ & CC010 & $\mathrm{CCO10}$ \\
\hline Circle number & $E$ & $E$ & $\begin{array}{l}E \\
10-E-\end{array}$ & $\begin{array}{l}E \\
10-E-\end{array}$ & $F$ & $\mathrm{~F}$ & I & 1 \\
\hline Analysis number & $10-E-S 2$ & $10-E-C 2$ & $\mathrm{C} 1$ & S1 & 10-F-I1 & $10-F-12$ & 10-I-I1 & $10-\mid-12$ \\
\hline Mineralization style & MAS & MAS & MAS & MAS & MAS & MAS & MAS & MAS \\
\hline Descriptor & OBAN & OBAN & OBAN & OBAN & OBAN & OBAN & OBAN & OBAN \\
\hline Ilmenite texture & SAN & COMP & COMP & SAN & COMP & COMP & COMP & COMP \\
\hline Exsolution? & $\mathrm{n}$ & $\mathrm{y}$ & $\mathrm{y}$ & $\mathrm{n}$ & $\mathrm{n}$ & $\mathrm{n}$ & $\mathrm{n}$ & $\mathrm{n}$ \\
\hline Ti wt. \% (EPMA) & 30.7 & 28.3 & 28.1 & 31.2 & 29.5 & 29.3 & 31.2 & 29.2 \\
\hline${ }^{24} \mathrm{Mg}$ & 9830 & 9244 & 9150 & 10430 & 9908 & 9890 & 13380 & 10115 \\
\hline${ }^{27} \mathrm{Al}$ & 141 & 210 & 160 & 525 & 204 & 322 & 11630 & 209 \\
\hline${ }^{29} \mathrm{Si}$ & 769 & 310 & $<M D L$ & $<M D L$ & 533 & 355 & 958 & 599 \\
\hline${ }^{31} \mathrm{P}$ & 8 & $<M D L$ & $<M D L$ & $<M D L$ & $<M D L$ & $<M D L$ & 8 & 4 \\
\hline${ }^{44} \mathrm{Ca}$ & 14 & $<M D L$ & $<M D L$ & $<M D L$ & $<M D L$ & $<M D L$ & 23 & 17 \\
\hline${ }^{45} \mathrm{Sc}$ & 42 & 46 & 42 & 44 & 44 & 45 & 37 & 37 \\
\hline${ }^{51} \mathrm{~V}$ & 913 & 1174 & 1041 & 1129 & 1009 & 1148 & 857 & 840 \\
\hline${ }^{52} \mathrm{Cr}$ & 117 & 165 & 119 & 169 & 132 & 141 & 337 & 144 \\
\hline${ }^{55} \mathrm{Mn}$ & 8510 & 7161 & 7328 & 8549 & 7897 & 7469 & 7555 & 6990 \\
\hline${ }^{57} \mathrm{Fe}$ & 379900 & 375000 & 370700 & 426000 & 382000 & 404000 & 398000 & 372000 \\
\hline${ }^{59} \mathrm{Co}$ & 115 & 110 & 115 & 124 & 110 & 114 & 152 & 103 \\
\hline${ }^{60} \mathrm{Ni}$ & 81 & 82 & 82 & 77 & 62 & 68 & 68 & 49 \\
\hline${ }^{63} \mathrm{Cu}$ & 2 & 1 & 2 & 2 & 1 & 1 & 2 & 2 \\
\hline${ }^{65} \mathrm{Cu}$ & 6 & 5 & 5 & 5 & 4 & 4 & 25 & 5 \\
\hline${ }^{69} \mathrm{Ga}$ & 0.5 & 1 & 1 & 3 & 1 & 1 & 13 & 1 \\
\hline${ }^{74} \mathrm{Ge}$ & 0.1 & 0.1 & 0.1 & 0.2 & 0.1 & 0.1 & 0.1 & 0.2 \\
\hline${ }^{75} \mathrm{As}$ & 1 & 1 & 1 & 1 & 1 & 1 & 1 & 1 \\
\hline${ }^{89} \mathrm{Y}$ & 0.1 & 0.1 & 0.1 & 0.1 & 0.1 & 0.1 & 0.1 & 0.1 \\
\hline${ }^{90} \mathrm{Zr}$ & 42 & 67 & 59 & 50 & 52 & 62 & 44 & 44 \\
\hline${ }^{93} \mathrm{Nb}$ & 2 & 3 & 2 & 3 & 2 & 3 & 2 & 2 \\
\hline${ }^{95} \mathrm{Mo}$ & 1 & 0.4 & 1 & 0.5 & 0.4 & 0.4 & 0.4 & 0.4 \\
\hline${ }^{118} \mathrm{Sn}$ & 3 & 4 & 4 & 3 & 3 & 3 & 3 & 2 \\
\hline${ }^{121} \mathrm{Sb}$ & 0.1 & 0.05 & 0.04 & 0.1 & 0.03 & 0.04 & 0.1 & 0.05 \\
\hline${ }^{178} \mathrm{Hf}$ & 1 & 2 & 2 & 2 & 2 & 2 & 2 & 1 \\
\hline${ }^{181} \mathrm{Ta}$ & 0.1 & 0.1 & 0.1 & 0.1 & 0.1 & 0.1 & 0.04 & 0.04 \\
\hline $182 \mathrm{~W}$ & 0.03 & 0.01 & 0.01 & 0.03 & 0.01 & 0.03 & 0.01 & 0.03 \\
\hline${ }^{208} \mathrm{~Pb}$ & 1 & 1 & 1 & 1 & 1 & 1 & 1 & 1 \\
\hline MAS & \multicolumn{4}{|c|}{ Massive to semi-massive mineralization } & OBAN & \multicolumn{3}{|c|}{ Orthopyroxene -bearing band } \\
\hline DIS & \multicolumn{4}{|c|}{ Disseminated mineralization } & POD & \multicolumn{3}{|l|}{ Pod } \\
\hline BAN & \multicolumn{4}{|c|}{ Bands of oxide mineralization } & OPOD & \multicolumn{3}{|c|}{ Orthopyroxene -bearing pod } \\
\hline ANO & \multicolumn{4}{|c|}{ Anorthosite hosted disseminated } & VEIN & \multicolumn{3}{|l|}{ Vein } \\
\hline ORT & \multicolumn{4}{|c|}{ Orthopyroxene associated } & COMP & \multicolumn{3}{|c|}{ composite ilmenite } \\
\hline $\mathrm{CLI}$ & \multicolumn{4}{|c|}{ Clinopyroxene associated } & SAN & \multicolumn{3}{|c|}{ sandwich ilmenite } \\
\hline
\end{tabular}




\section{Appendix V (Continued)}

\begin{tabular}{|c|c|c|c|c|c|c|c|}
\hline Sample & CC010 & CC010 & CC010 & CC010 & CC010 & CC010 & CC013 \\
\hline Circle number & L & $M$ & M & M & M & $\begin{array}{l}\text { A } \\
10-0-\end{array}$ & A \\
\hline Analysis number & $10-L-12$ & 10-M-S1 & $10-M-S 2$ & 10-M-I1 & $10-M-12$ & S1 & $13-A-S 1$ \\
\hline Mineralization style & MAS & MAS & MAS & MAS & MAS & MAS & MAS \\
\hline Descriptor & OBAN & OBAN & OBAN & OBAN & OBAN & OBAN & BAN \\
\hline Ilmenite texture & COMP & SAN & SAN & COMP & COMP & SAN & SAN \\
\hline Exsolution? & $\mathrm{y}$ & $\mathrm{n}$ & $\mathrm{n}$ & $\mathrm{y}$ & $\mathrm{n}$ & $\mathrm{n}$ & $\mathrm{n}$ \\
\hline Ti wt. \% (EPMA) & 29.3 & 31.2 & 31.1 & 29.1 & 29.1 & 31 & 30.6 \\
\hline${ }^{24} \mathrm{Mg}$ & 12090 & 9632 & 9552 & 9750 & 9609 & 12190 & 9940 \\
\hline${ }^{27} \mathrm{Al}$ & 377 & 109 & 161 & 266 & 224 & 3920 & 630 \\
\hline${ }^{29} \mathrm{Si}$ & 620 & 160 & $<M D L$ & 207 & 213 & 2750 & $<M D L$ \\
\hline${ }^{31} \mathrm{p}$ & 4 & $<M D L$ & $<M D L$ & $<M D L$ & $<M D L$ & $<M D L$ & $<M D L$ \\
\hline${ }^{44} \mathrm{Ca}$ & 9 & $<M D L$ & $<M D L$ & $<M D L$ & $<M D L$ & 10 & $<M D L$ \\
\hline${ }^{45} \mathrm{Sc}$ & 42 & 42 & 46 & 47 & 47 & 44 & 37 \\
\hline${ }^{51} \mathrm{~V}$ & 1464 & 826 & 984 & 1267 & 1307 & 875 & 1177 \\
\hline${ }^{52} \mathrm{Cr}$ & 101 & 99 & 125 & 178 & 178 & 139 & 163 \\
\hline${ }^{55} \mathrm{Mn}$ & 5472 & 9550 & 9140 & 7277 & 7398 & 9010 & 6998 \\
\hline${ }^{57} \mathrm{Fe}$ & 460000 & 391000 & 399000 & 400000 & 406000 & 402000 & 378800 \\
\hline${ }^{59} \mathrm{Co}$ & 122 & 118 & 116 & 112 & 114 & 116 & 101 \\
\hline${ }^{60} \mathrm{Ni}$ & 61 & 62 & 64 & 65 & 68 & 68 & 47 \\
\hline${ }^{63} \mathrm{Cu}$ & 2 & 1 & 3 & 1 & 1 & 132 & 3 \\
\hline${ }^{65} \mathrm{Cu}$ & 5 & 5 & 5 & 4 & 4 & 141 & 6 \\
\hline${ }^{69} \mathrm{Ga}$ & 2 & 0.4 & 1 & 1 & 1 & 3 & 1 \\
\hline${ }^{74} \mathrm{Ge}$ & 0.2 & 0.1 & 0.2 & 0.1 & 0.1 & 0.1 & $<M D L$ \\
\hline${ }^{75} \mathrm{As}$ & 1 & 1 & 1 & 1 & 1 & 1 & $<M D L$ \\
\hline${ }^{89} \mathrm{Y}$ & 0.1 & 0.1 & 0.1 & 0.1 & 0.1 & 0.1 & 0.1 \\
\hline${ }^{90} \mathrm{Zr}$ & 73 & 39 & 47 & 70 & 70 & 39 & 24 \\
\hline${ }^{93} \mathrm{Nb}$ & 5 & 2 & 2 & 3 & 3 & 2 & 6 \\
\hline${ }^{95} \mathrm{Mo}$ & 0.4 & 1 & 1 & 0.4 & 1 & 1 & 0.4 \\
\hline${ }^{118} \mathrm{Sn}$ & 3 & 3 & 3 & 3 & 3 & 3 & 0.3 \\
\hline${ }^{121} \mathrm{Sb}$ & 0.04 & 0.1 & 0.1 & 0.04 & 0.03 & 0.1 & 0.1 \\
\hline${ }^{178} \mathrm{Hf}$ & 3 & 1 & 2 & 2 & 2 & 2 & 1 \\
\hline${ }^{181} \mathrm{Ta}$ & 0.2 & 0.04 & 0.1 & 0.1 & 0.05 & 0.1 & 0.4 \\
\hline $182 \mathrm{~W}$ & 0.02 & 0.03 & 0.02 & 0.04 & 0.01 & 0.05 & 0.1 \\
\hline${ }^{208} \mathrm{~Pb}$ & 1 & 1 & 1 & 1 & 1 & 2 & 3 \\
\hline MAS & \multicolumn{3}{|c|}{ Massive to semi-massive mineralization } & OBAN & \multicolumn{3}{|c|}{ Orthopyroxene -bearing band } \\
\hline DIS & \multicolumn{3}{|c|}{ Disseminated mineralization } & POD & \multicolumn{3}{|c|}{ Pod } \\
\hline BAN & \multicolumn{3}{|c|}{ Bands of oxide mineralization } & OPOD & \multicolumn{3}{|c|}{ Orthopyroxene -bearing pod } \\
\hline ANO & \multicolumn{3}{|c|}{ Anorthosite hosted disseminated } & VEIN & \multicolumn{3}{|c|}{ Vein } \\
\hline ORT & \multicolumn{3}{|c|}{ Orthopyroxene associated } & COMP & \multicolumn{3}{|c|}{ composite ilmenite } \\
\hline $\mathrm{CLI}$ & \multicolumn{3}{|c|}{ Clinopyroxene associated } & SAN & \multicolumn{3}{|c|}{ sandwich ilmenite } \\
\hline
\end{tabular}




\section{Appendix V (Continued)}

\begin{tabular}{|c|c|c|c|c|c|c|}
\hline Sample & CC013 & CC013 & CC013 & CC013 & CC013 & CC013 \\
\hline Circle number & A & $A$ & $A$ & B & B & $\mathrm{C}$ \\
\hline Analysis number & $13-A-S 2$ & $13-A-I 1$ & $13-A-12$ & $13-B-12$ & $13-B-13$ & $13-C-S 1$ \\
\hline Mineralization style & MAS & MAS & MAS & MAS & MAS & MAS \\
\hline Descriptor & BAN & BAN & BAN & BAN & BAN & BAN \\
\hline Ilmenite texture & SAN & COMP & COMP & COMP & SAN & SAN \\
\hline Exsolution? & $\mathrm{n}$ & $\mathrm{y}$ & $\mathrm{y}$ & $\mathrm{y}$ & $\mathrm{n}$ & $\mathrm{n}$ \\
\hline Ti wt. \% (EPMA) & 30.62 & 29.5 & 29.7 & 29.3 & 29.2 & 28.4 \\
\hline${ }^{24} \mathrm{Mg}$ & 9647 & 9575 & 9978 & 9816 & 9670 & 9145 \\
\hline${ }^{27} \mathrm{Al}$ & 239 & 573 & 240 & 366 & 1060 & 317 \\
\hline${ }^{29} \mathrm{Si}$ & 350 & 473 & 178 & 559 & 334 & 1057 \\
\hline $31 \mathrm{p}$ & $<M D L$ & $<M D L$ & $<M D L$ & 4 & $<M D L$ & 10 \\
\hline${ }^{44} \mathrm{Ca}$ & $<M D L$ & 28 & $<M D L$ & 11 & $<M D L$ & 32 \\
\hline${ }^{45} \mathrm{Sc}$ & 39 & 44 & 41 & 45 & 41 & 33 \\
\hline${ }^{51} \mathrm{~V}$ & 1146 & 2208 & 2033 & 2329 & 1926 & 1443 \\
\hline${ }^{52} \mathrm{Cr}$ & 146 & 236 & 247 & 256 & 198 & 241 \\
\hline${ }^{55} \mathrm{Mn}$ & 6952 & 6157 & 6190 & 5786 & 6259 & 6582 \\
\hline${ }^{57} \mathrm{Fe}$ & 369800 & 439200 & 438900 & 479300 & 420900 & 391300 \\
\hline${ }^{59} \mathrm{Co}$ & 95 & 85 & 95 & 96 & 98 & 96 \\
\hline${ }^{60} \mathrm{Ni}$ & 43 & 45 & 46 & 56 & 48 & 60 \\
\hline${ }^{63} \mathrm{Cu}$ & 3 & 2 & 2 & 2 & 2 & 3 \\
\hline${ }^{65} \mathrm{Cu}$ & 6 & 5 & 5 & 5 & 5 & 6 \\
\hline${ }^{69} \mathrm{Ga}$ & 1 & 2 & 1 & 2 & 1 & 3 \\
\hline${ }^{74} \mathrm{Ge}$ & $<M D L$ & 0.2 & 0.2 & 0.2 & 0.1 & 0.2 \\
\hline${ }^{75} \mathrm{As}$ & $<M D L$ & 1 & 1 & 1 & 1 & 1 \\
\hline${ }^{89} \mathrm{Y}$ & 0.1 & 0.1 & 0.1 & 0.1 & 0.2 & 0.1 \\
\hline${ }^{90} \mathrm{Zr}$ & 24 & 46 & 57 & 62 & 109 & 22 \\
\hline${ }^{93} \mathrm{Nb}$ & 5 & 7 & 6 & 6 & 6 & 5 \\
\hline${ }^{95} \mathrm{Mo}$ & 0.4 & 1 & 1 & 1 & 1 & 0.4 \\
\hline${ }^{118} \mathrm{Sn}$ & 0.3 & 3 & 2 & 2 & 1 & 1 \\
\hline${ }^{121} \mathrm{Sb}$ & 0.1 & 0.1 & 0.1 & 0.1 & 0.1 & 0.1 \\
\hline${ }^{178} \mathrm{Hf}$ & 1 & 2 & 2 & 2 & 2 & 1 \\
\hline${ }^{181} \mathrm{Ta}$ & 0.4 & 0.4 & 0.4 & 0.5 & 0.4 & 0.3 \\
\hline${ }^{182} \mathrm{~W}$ & 0.1 & 0.05 & 0.1 & 0.1 & 0.1 & 0.1 \\
\hline${ }^{208} \mathrm{~Pb}$ & 2 & 2 & 1 & 1 & 1 & 2 \\
\hline MAS & \multicolumn{3}{|c|}{ Massive to semi-massive mineralization } & OBAN & \multicolumn{2}{|c|}{$\begin{array}{l}\text { Orthopyroxene -bearing } \\
\text { band }\end{array}$} \\
\hline DIS & \multicolumn{3}{|c|}{ Disseminated mineralization } & POD & \multicolumn{2}{|l|}{ Pod } \\
\hline BAN & \multicolumn{3}{|c|}{ Bands of oxide mineralization } & OPOD & \multicolumn{2}{|c|}{ Orthopyroxene -bearing pod } \\
\hline ANO & \multicolumn{3}{|c|}{ Anorthosite hosted disseminated } & VEIN & \multicolumn{2}{|l|}{ Vein } \\
\hline ORT & \multicolumn{3}{|c|}{ Orthopyroxene associated } & COMP & \multicolumn{2}{|c|}{ composite ilmenite } \\
\hline CLI & \multicolumn{3}{|c|}{ Clinopyroxene associated } & SAN & \multicolumn{2}{|c|}{ sandwich ilmenite } \\
\hline
\end{tabular}




\section{Appendix V (Continued)}

\begin{tabular}{|c|c|c|c|c|c|c|c|}
\hline Sample & CC013 & CC013 & CC013 & $\mathrm{CCO13}$ & $\mathrm{CC013}$ & CC013 & CC013 \\
\hline Circle number & $\mathrm{E}$ & $\mathrm{F}$ & $\mathrm{F}$ & D & D & $\mathrm{E}$ & $\mathrm{L}$ \\
\hline Analysis number & 13-E-I1 & 13-F-I1 & $13-\mathrm{F}-12$ & 13-D-I1 & $13-D-12$ & $13-E-12$ & 13-L-I1 \\
\hline Mineralization style & MAS & MAS & MAS & MAS & MAS & MAS & MAS \\
\hline Descriptor & BAN & BAN & BAN & BAN & BAN & BAN & BAN \\
\hline Ilmenite texture & COMP & COMP & COMP & COMP & COMP & COMP & COMP \\
\hline Exsolution? & $\mathrm{y}$ & $\mathrm{y}$ & $\mathrm{y}$ & $\mathrm{y}$ & $\mathrm{y}$ & $\mathrm{n}$ & $\mathrm{y}$ \\
\hline Ti wt. \% (EPMA) & 29.7 & 29.6 & 29.6 & 31.0 & 29.0 & 29.4 & 29.0 \\
\hline${ }^{24} \mathrm{Mg}$ & 9900 & 9780 & 9830 & 10609 & 9891 & 10250 & 9437 \\
\hline${ }^{27} \mathrm{Al}$ & 298 & 234 & 296 & 523 & 460 & 479 & 422 \\
\hline${ }^{29} \mathrm{Si}$ & 970 & 690 & $<\mathrm{MDL}$ & 458 & 446 & 279 & $<\mathrm{MDL}$ \\
\hline 31p & $<M D L$ & $<M D L$ & $<M D L$ & 5 & $<M D L$ & 3 & $<M D L$ \\
\hline${ }^{44} \mathrm{Ca}$ & $<M D L$ & $<M D L$ & $<M D L$ & 11 & 12 & 9 & $<M D L$ \\
\hline${ }^{45} \mathrm{SC}$ & 45 & 48 & 46 & 49 & 45 & 45 & 43 \\
\hline${ }^{51} \mathrm{~V}$ & 1872 & 1770 & 1612 & 2800 & 2480 & 1861 & 2197 \\
\hline${ }^{52} \mathrm{Cr}$ & 279 & 234 & 222 & 312 & 267 & 270 & 200 \\
\hline${ }^{55} \mathrm{Mn}$ & 5700 & 5896 & 5933 & 6019 & 5532 & 6027 & 6045 \\
\hline${ }^{57} \mathrm{Fe}$ & 527000 & 507400 & 503000 & 579300 & 518000 & 497300 & 435700 \\
\hline${ }^{59} \mathrm{Co}$ & 101 & 100 & 102 & 97 & 90 & 110 & 88 \\
\hline${ }^{60} \mathrm{Ni}$ & 49 & 45 & 45 & 48 & 48 & 76 & 43 \\
\hline${ }^{63} \mathrm{Cu}$ & 3 & 4 & 4 & 4 & 3 & 3 & 2 \\
\hline${ }^{65} \mathrm{Cu}$ & 7 & 6 & 6 & 6 & 5 & 6 & 5 \\
\hline${ }^{69} \mathrm{Ga}$ & 2 & 2 & 2 & 3 & 3 & 4 & 2 \\
\hline${ }^{74} \mathrm{Ge}$ & 0.5 & $<M D L$ & 0.4 & 0.2 & 0.2 & 0.1 & 0.2 \\
\hline${ }^{75} \mathrm{As}$ & $<\mathrm{MDL}$ & $<M D L$ & 1 & 1 & 1 & 1 & 1 \\
\hline${ }^{89} Y$ & 0.1 & 0.1 & 0.1 & 0.1 & 0.1 & 0.1 & 0.1 \\
\hline${ }^{90} \mathrm{Zr}$ & 149 & 223 & 207 & 107 & 56 & 63 & 48 \\
\hline${ }^{93} \mathrm{Nb}$ & 7 & 6 & 7 & 8 & 7 & 7 & 6 \\
\hline${ }^{95} \mathrm{Mo}$ & 0.4 & 1 & 1 & 1 & 1 & 1 & 1 \\
\hline${ }^{118} \mathrm{Sn}$ & 2 & 2 & 2 & 4 & 3 & 2 & 2 \\
\hline${ }^{121} \mathrm{Sb}$ & 0.2 & 0.2 & 0.1 & 0.1 & 0.1 & 0.1 & 0.1 \\
\hline${ }^{178} \mathrm{Hf}$ & 3 & 4 & 3 & 3 & 2 & 2 & 2 \\
\hline${ }^{181} \mathrm{Ta}$ & 0.4 & 0.4 & 0.4 & 0.5 & 0.5 & 0.4 & 0.3 \\
\hline $182 \mathrm{~W}$ & 0.1 & 0.1 & 0.04 & 0.04 & 0.1 & 0.05 & 0.1 \\
\hline${ }^{208} \mathrm{~Pb}$ & 3 & 2 & 2 & 3 & 2 & 2 & 2 \\
\hline MAS & \multicolumn{3}{|c|}{$\begin{array}{l}\text { Massive to semi-massive } \\
\text { mineralization }\end{array}$} & OBAN & \multicolumn{3}{|c|}{ Orthopyroxene -bearing band } \\
\hline DIS & \multicolumn{3}{|c|}{ Disseminated mineralization } & POD & \multicolumn{3}{|l|}{ Pod } \\
\hline BAN & \multicolumn{3}{|c|}{ Bands of oxide mineralization } & OPOD & \multicolumn{3}{|c|}{ Orthopyroxene -bearing pod } \\
\hline ANO & \multicolumn{3}{|c|}{ Anorthosite hosted disseminated } & VEIN & \multicolumn{3}{|l|}{ Vein } \\
\hline ORT & \multicolumn{3}{|c|}{ Orthopyroxene associated } & COMP & \multicolumn{3}{|c|}{ composite ilmenite } \\
\hline CLI & \multicolumn{3}{|c|}{ Clinopyroxene associated } & SAN & \multicolumn{3}{|c|}{ sandwich ilmenite } \\
\hline
\end{tabular}




\section{Appendix V (Continued)}

\begin{tabular}{|c|c|c|c|c|c|c|}
\hline Sample & CC013 & CC013 & CC013 & CCO25 & CCO25 & $\mathrm{CCO} 25$ \\
\hline Circle number & $\mathrm{L}$ & $\mathrm{P}$ & $\mathrm{R}$ & A & A & B \\
\hline Analysis number & $13-L-12$ & 13-P-S1 & 13-R-S1 & $25-A-11$ & $25-A-12$ & 25-B-I1 \\
\hline Mineralization style & MAS & MAS & MAS & MAS & MAS & MAS \\
\hline Descriptor & BAN & BAN & BAN & POD & POD & POD \\
\hline Ilmenite texture & COMP & SAN & SAN & COMP & COMP & COMP \\
\hline Exsolution? & $\mathrm{y}$ & $\mathrm{n}$ & $\mathrm{n}$ & $\mathrm{y}$ & $\mathrm{n}$ & $\mathrm{y}$ \\
\hline Ti wt. \% (EPMA) & 28.8 & 29.4 & 30.58 & 29.3 & 29.6 & 29.7 \\
\hline${ }^{24} \mathrm{Mg}$ & 9525 & 8810 & 9605 & 7065 & 6882 & 7580 \\
\hline${ }^{27} \mathrm{Al}$ & 790 & 178 & 144 & 511 & 274 & 291 \\
\hline${ }^{29} \mathrm{Si}$ & $<M D L$ & 377 & $<B D L$ & 367 & $<M D L$ & $<M D L$ \\
\hline $31 \mathrm{p}$ & $<M D L$ & 4 & 14 & $<M D L$ & $<M D L$ & $<M D L$ \\
\hline${ }^{44} \mathrm{Ca}$ & $<M D L$ & 11 & $<M D L$ & $<M D L$ & $<M D L$ & $<M D L$ \\
\hline${ }^{45} \mathrm{Sc}$ & 41 & 49 & 36 & 28 & 25 & 22 \\
\hline${ }^{51} \mathrm{~V}$ & 1920 & 1553 & 1089 & 985 & 822 & 709 \\
\hline${ }^{52} \mathrm{Cr}$ & 186 & 256 & 122 & 183 & 192 & 69 \\
\hline${ }^{55} \mathrm{Mn}$ & 6112 & 8904 & 7515 & 2690 & 2756 & 2581 \\
\hline${ }^{57} \mathrm{Fe}$ & 408800 & 385000 & 368300 & 406100 & 390100 & 377500 \\
\hline${ }^{59} \mathrm{Co}$ & 90 & 90 & 95 & 98 & 97 & 106 \\
\hline${ }^{60} \mathrm{Ni}$ & 44 & 46 & 48 & 52 & 52 & 52 \\
\hline${ }^{63} \mathrm{Cu}$ & 2 & 2 & 3 & 5 & 4 & 4 \\
\hline${ }^{65} \mathrm{Cu}$ & 5 & 5 & 5 & 10 & 10 & 7 \\
\hline${ }^{69} \mathrm{Ga}$ & 2 & 1 & 1 & 1 & 1 & 1 \\
\hline${ }^{74} \mathrm{Ge}$ & 0.2 & 0.2 & $<M D L$ & 0.1 & 0.1 & 0.1 \\
\hline${ }^{75} \mathrm{As}$ & 1 & 0.5 & $<M D L$ & 0.3 & $<M D L$ & 0.3 \\
\hline${ }^{89} \mathrm{Y}$ & 0.1 & 0.1 & 0.1 & 0.1 & 0.1 & 0.1 \\
\hline${ }^{90} \mathrm{Zr}$ & 53 & 32 & 19 & 150 & 124 & 113 \\
\hline${ }^{93} \mathrm{Nb}$ & 5 & 4 & 5 & 23 & 23 & 32 \\
\hline${ }^{95} \mathrm{Mo}$ & 1 & 1 & 1 & 0.5 & 0.5 & 1 \\
\hline${ }^{118} \mathrm{Sn}$ & 1 & 1 & 0.3 & 3 & 2 & 3 \\
\hline${ }^{121} \mathrm{Sb}$ & 0.1 & 0.1 & 0.04 & 0.1 & 0.1 & 0.1 \\
\hline${ }^{178} \mathrm{Hf}$ & 1 & 1 & 1 & 5 & 4 & 4 \\
\hline${ }^{181} \mathrm{Ta}$ & 0.3 & 0.2 & 0.3 & 1 & 1 & 2 \\
\hline${ }^{182} \mathrm{~W}$ & 0.1 & 0.04 & 0.1 & 0.1 & 0.1 & 0.1 \\
\hline${ }^{208} \mathrm{~Pb}$ & 2 & 2 & 3 & 1 & 0.5 & 0.5 \\
\hline MAS & \multicolumn{3}{|c|}{ Massive to semi-massive mineralization } & OBAN & \multicolumn{2}{|c|}{ Orthopyroxene -bearing band } \\
\hline DIS & \multicolumn{3}{|c|}{ Disseminated mineralization } & POD & \multicolumn{2}{|l|}{ Pod } \\
\hline BAN & \multicolumn{3}{|c|}{ Bands of oxide mineralization } & OPOD & \multicolumn{2}{|c|}{ Orthopyroxene -bearing pod } \\
\hline ANO & \multicolumn{3}{|c|}{ Anorthosite hosted disseminated } & VEIN & \multicolumn{2}{|c|}{ Vein } \\
\hline ORT & \multicolumn{3}{|c|}{ Orthopyroxene associated } & COMP & \multicolumn{2}{|c|}{ composite ilmenite } \\
\hline $\mathrm{CLI}$ & \multicolumn{3}{|c|}{ Clinopyroxene associated } & SAN & \multicolumn{2}{|c|}{ sandwich ilmenite } \\
\hline
\end{tabular}




\section{Appendix V (Continued)}

\begin{tabular}{|c|c|c|c|c|c|c|c|}
\hline Sample & CCO25 & CCO25 & CCO25 & CCO25 & CCO25 & CCO25 & CCO25 \\
\hline Circle number & B & $\mathrm{C}$ & $\mathrm{C}$ & $\mathrm{D}$ & $\mathrm{D}$ & $E$ & $E$ \\
\hline Analysis number & $25-B-12$ & 25-C-S1 & $25-C-S 2$ & 25-D-I1 & $25-D-12$ & $25-E-I 1$ & $25-E-12$ \\
\hline Mineralization style & MAS & MAS & MAS & MAS & MAS & MAS & MAS \\
\hline Descriptor & POD & POD & POD & POD & POD & POD & POD \\
\hline Ilmenite texture & COMP & SAN & SAN & COMP & COMP & COMP & COMP \\
\hline Exsolution? & $\mathrm{y}$ & $\mathrm{n}$ & $\mathrm{n}$ & $\mathrm{n}$ & $\mathrm{n}$ & $\mathrm{n}$ & $\mathrm{n}$ \\
\hline Ti wt. \% (EPMA) & 29.4 & 30.5 & 30.5 & 30.3 & 30.3 & 30.3 & 30.1 \\
\hline${ }^{24} \mathrm{Mg}$ & 7300 & 4765 & 4815 & 5137 & 5500 & 5170 & 5236 \\
\hline${ }^{27} \mathrm{Al}$ & 349 & 124 & 124 & 174 & 147 & 158 & 151 \\
\hline${ }^{29} \mathrm{Si}$ & 362 & 485 & 435 & 470 & 339 & $<M D L$ & $<M D L$ \\
\hline 31p & $<M D L$ & $<M D L$ & $<M D L$ & $<M D L$ & $<M D L$ & $<M D L$ & $<M D L$ \\
\hline${ }^{44} \mathrm{Ca}$ & $<M D L$ & $<M D L$ & 10 & $<M D L$ & 9 & $<M D L$ & $<M D L$ \\
\hline${ }^{45} \mathrm{Sc}$ & 27 & 21 & 20 & 20 & 18 & 20 & 20 \\
\hline${ }^{51} \mathrm{~V}$ & 946 & 392 & 374 & 454 & 393 & 390 & 394 \\
\hline${ }^{52} \mathrm{Cr}$ & 113 & 130 & 129 & 123 & 104 & 144 & 146 \\
\hline${ }^{55} \mathrm{Mn}$ & 2446 & 4326 & 4227 & 3940 & 3935 & 4259 & 4313 \\
\hline${ }^{57} \mathrm{Fe}$ & 404600 & 386300 & 379600 & 387300 & 386800 & 381700 & 387000 \\
\hline${ }^{59} \mathrm{Co}$ & 107 & 85 & 88 & 92 & 95 & 87 & 90 \\
\hline${ }^{60} \mathrm{Ni}$ & 53 & 48 & 49 & 51 & 53 & 46 & 48 \\
\hline${ }^{63} \mathrm{Cu}$ & 4 & 3 & 3 & 11 & 2 & 1 & 1 \\
\hline${ }^{65} \mathrm{Cu}$ & 8 & 7 & 6 & 5 & 5 & 4 & 4 \\
\hline${ }^{69} \mathrm{Ga}$ & 1 & 0.3 & 0.3 & 0.3 & 0.3 & 0.4 & 0.3 \\
\hline${ }^{74} \mathrm{Ge}$ & 0.1 & $<M D L$ & 0.1 & 0.1 & 0.1 & 0.1 & 0.1 \\
\hline${ }^{75} \mathrm{As}$ & $<M D L$ & $<M D L$ & $<M D L$ & 0.2 & 0.3 & 1 & $<M D L$ \\
\hline${ }^{89} Y$ & 0.1 & 0.1 & 0.1 & 0.1 & 0.1 & 0.1 & 0.1 \\
\hline${ }^{90} \mathrm{Zr}$ & 152 & 62 & 59 & 65 & 56 & 54 & 53 \\
\hline${ }^{93} \mathrm{Nb}$ & 35 & 17 & 22 & 18 & 23 & 19 & 19 \\
\hline${ }^{95} \mathrm{Mo}$ & 0.5 & 0.5 & 1 & 0.4 & 0.4 & 0.4 & 0.4 \\
\hline${ }^{118} \mathrm{Sn}$ & 3 & 2 & 1 & 2 & 1 & 2 & 1 \\
\hline${ }^{121} \mathrm{Sb}$ & 0.2 & 0.04 & 0.05 & 0.1 & 0.03 & 0.02 & 0.02 \\
\hline${ }^{178} \mathrm{Hf}$ & 6 & 3 & 2 & 3 & 2 & 2 & 2 \\
\hline${ }^{181} \mathrm{Ta}$ & 2 & 1 & 1 & 1 & 1 & 1 & 1 \\
\hline $182 \mathrm{~W}$ & 0.1 & 0.1 & 0.1 & 0.05 & 0.1 & 0.1 & 0.1 \\
\hline${ }^{208} \mathrm{~Pb}$ & 0.4 & 1 & 1 & 0.5 & 0.3 & 0.4 & 0.3 \\
\hline MAS & \multicolumn{3}{|c|}{ Massive to semi-massive mineralization } & OBAN & \multicolumn{3}{|c|}{ Orthopyroxene -bearing band } \\
\hline DIS & \multicolumn{3}{|c|}{ Disseminated mineralization } & POD & \multicolumn{3}{|l|}{ Pod } \\
\hline BAN & \multicolumn{3}{|c|}{ Bands of oxide mineralization } & OPOD & \multicolumn{3}{|c|}{ Orthopyroxene -bearing pod } \\
\hline ANO & \multicolumn{3}{|c|}{ Anorthosite hosted disseminated } & VEIN & \multicolumn{3}{|l|}{ Vein } \\
\hline ORT & \multicolumn{3}{|c|}{ Orthopyroxene associated } & COMP & \multicolumn{3}{|c|}{ composite ilmenite } \\
\hline $\mathrm{CLI}$ & \multicolumn{3}{|c|}{ Clinopyroxene associated } & SAN & \multicolumn{3}{|c|}{ sandwich ilmenite } \\
\hline
\end{tabular}




\section{Appendix V (Continued)}

\begin{tabular}{|c|c|c|c|c|c|c|c|}
\hline Sample & CCO25 & $\mathrm{CCO} 25$ & CCO25 & $\mathrm{CCO} 25$ & CCO25 & CCO25 & CCO25 \\
\hline Circle number & G & G & G & G & I & I & $\mathrm{K}$ \\
\hline Analysis number & 25-G-S1 & $25-G-S 2$ & 25-G-I1 & $25-G-12$ & $25-I-I 1$ & $25-1-12$ & $25-K-I 1$ \\
\hline Mineralization style & MAS & MAS & MAS & MAS & MAS & MAS & MAS \\
\hline Descriptor & POD & POD & POD & POD & POD & POD & POD \\
\hline Ilmenite texture & SAN & SAN & COMP & COMP & COMP & COMP & COMP \\
\hline Exsolution? & $\mathrm{n}$ & $\mathrm{n}$ & $\mathrm{n}$ & $\mathrm{n}$ & $\mathrm{n}$ & $\mathrm{n}$ & $\mathrm{y}$ \\
\hline Ti wt. \% (EPMA) & 30.2 & 30.4 & 30.2 & 30.0 & 29.7 & 29.86 & 29 \\
\hline${ }^{24} \mathrm{Mg}$ & 4755 & 5212 & 5123 & 5051 & 4722 & 4247 & 6526 \\
\hline${ }^{27} \mathrm{Al}$ & 142 & 152 & 217 & 241 & 327 & 580 & 310 \\
\hline${ }^{29} \mathrm{Si}$ & $<\mathrm{MDL}$ & 181 & $<M D L$ & 251 & 422 & 171 & 289 \\
\hline 31P & $<M D L$ & $<M D L$ & $<M D L$ & $<M D L$ & $<M D L$ & $<M D L$ & $<M D L$ \\
\hline${ }^{44} \mathrm{Ca}$ & $<M D L$ & $<M D L$ & $<M D L$ & $<M D L$ & 14 & $<M D L$ & 20 \\
\hline${ }^{45} \mathrm{Sc}$ & 20 & 20 & 22 & 24 & 24 & 24 & 25 \\
\hline${ }^{51} \mathrm{~V}$ & 382 & 390 & 479 & 538 & 539 & 461 & 888 \\
\hline${ }^{52} \mathrm{Cr}$ & 110 & 117 & 160 & 183 & 267 & 241 & 155 \\
\hline${ }^{55} \mathrm{Mn}$ & 4371 & 4213 & 3894 & 3942 & 3580 & 3850 & 2606 \\
\hline${ }^{57} \mathrm{Fe}$ & 379700 & 389500 & 390600 & 392800 & 390000 & 384000 & 397100 \\
\hline${ }^{59} \mathrm{Co}$ & 83 & 92 & 89 & 89 & 88 & 82 & 99 \\
\hline${ }^{60} \mathrm{Ni}$ & 43 & 47 & 46 & 46 & 48 & 46 & 48 \\
\hline${ }^{63} \mathrm{Cu}$ & 2 & 2 & 2 & 2 & 2 & 3 & 2 \\
\hline${ }^{65} \mathrm{Cu}$ & 4 & 4 & 4 & 5 & 4 & 5 & 4 \\
\hline${ }^{69} \mathrm{Ga}$ & 0.3 & 0.4 & 0.5 & 1 & 1 & 1 & 1 \\
\hline${ }^{74} \mathrm{Ge}$ & $<M D L$ & $<M D L$ & 0.1 & 0.1 & 0.1 & $<M D L$ & 0.1 \\
\hline${ }^{75} \mathrm{As}$ & 0.2 & 0.2 & 0.3 & $<M D L$ & 0.3 & 0.3 & 0.2 \\
\hline${ }^{89} \mathrm{Y}$ & 0.1 & 0.1 & 0.1 & 0.1 & 0.1 & 0.1 & 0.1 \\
\hline${ }^{90} \mathrm{Zr}$ & 50 & 56 & 66 & 72 & 75 & 60 & 106 \\
\hline${ }^{93} \mathrm{Nb}$ & 15 & 19 & 18 & 20 & 19 & 12 & 21 \\
\hline${ }^{95} \mathrm{Mo}$ & 0.4 & 0.5 & 0.5 & 0.4 & 0.5 & 0.4 & 1 \\
\hline${ }^{118} \mathrm{Sn}$ & 2 & 2 & 2 & 2 & 2 & 2 & 3 \\
\hline${ }^{121} \mathrm{Sb}$ & 0.02 & 0.04 & 0.04 & 0.1 & 0.1 & 0.03 & 0.1 \\
\hline${ }^{178} \mathrm{Hf}$ & 2 & 2 & 3 & 3 & 3 & 3 & 4 \\
\hline${ }^{181} \mathrm{Ta}$ & 0.4 & 0.5 & 0.5 & 1 & 0.5 & 0.2 & 1 \\
\hline${ }^{182} \mathrm{~W}$ & 0.02 & 0.02 & 0.03 & 0.03 & 0.02 & 0.01 & 0.05 \\
\hline${ }^{208} \mathrm{~Pb}$ & 0.4 & 0.3 & 1 & 1 & 1 & 1 & 0.4 \\
\hline MAS & \multicolumn{3}{|c|}{$\begin{array}{l}\text { Massive to semi-massive } \\
\text { mineralization }\end{array}$} & OBAN & \multicolumn{3}{|c|}{ Orthopyroxene -bearing band } \\
\hline DIS & \multicolumn{3}{|c|}{ Disseminated mineralization } & POD & \multicolumn{3}{|l|}{ Pod } \\
\hline BAN & \multicolumn{3}{|c|}{ Bands of oxide mineralization } & OPOD & \multicolumn{3}{|c|}{ Orthopyroxene -bearing pod } \\
\hline ANO & \multicolumn{3}{|c|}{ Anorthosite hosted disseminated } & VEIN & \multicolumn{3}{|l|}{ Vein } \\
\hline ORT & \multicolumn{3}{|c|}{ Orthopyroxene associated } & COMP & \multicolumn{3}{|c|}{ composite ilmenite } \\
\hline $\mathrm{CLI}$ & \multicolumn{3}{|c|}{ Clinopyroxene associated } & SAN & \multicolumn{3}{|c|}{ sandwich ilmenite } \\
\hline
\end{tabular}




\section{Appendix V (Continued)}

\begin{tabular}{|c|c|c|c|c|c|c|c|c|}
\hline Sample & $\mathrm{CCO} 25$ & $\mathrm{CCO} 25$ & CCO25 & CCO25 & CC031 & CC031 & CC031 & CC031 \\
\hline Circle number & K & L & $\mathrm{L}$ & $\mathrm{L}$ & B & $\mathrm{C}$ & $\mathrm{C}$ & $\mathrm{F}$ \\
\hline Analysis number & $25-K-13$ & 25-L-I1 & $25-L-12$ & $25-L-13$ & 31-B-I1 & $31-C-11$ & $31-C-12$ & 31-F-I1 \\
\hline Mineralization style & MAS & MAS & MAS & MAS & DIS & DIS & DIS & DIS \\
\hline Descriptor & POD & POD & POD & POD & ANO & ANO & ANO & ANO \\
\hline IImenite texture & COMP & COMP & COMP & COMP & COMP & COMP & COMP & COMP \\
\hline Exsolution? & y & $\mathrm{y}$ & y & y & $\mathrm{n}$ & y & y & $\mathrm{y}$ \\
\hline Ti wt. \% (EPMA) & 29.2 & 29.1 & 29.2 & 29.0 & 29.49 & 29.7 & 29.6 & 28.59 \\
\hline${ }^{24} \mathrm{Mg}$ & 6590 & 4783 & 4809 & 5141 & 2089 & 4645 & 4729 & 4998 \\
\hline${ }^{27} \mathrm{Al}$ & 441 & 220 & 557 & 175 & 310 & 203 & 154 & 307 \\
\hline${ }^{29} \mathrm{Si}$ & 118 & 235 & 262 & 233 & 488 & $<M D L$ & 314 & 394 \\
\hline${ }^{31} \mathrm{p}$ & $<M D L$ & $<M D L$ & $<M D L$ & $<M D L$ & $<M D L$ & $<M D L$ & $<M D L$ & $<M D L$ \\
\hline${ }^{44} \mathrm{Ca}$ & $<M D L$ & $<M D L$ & $<M D L$ & $<M D L$ & 12 & $<M D L$ & $<M D L$ & 12 \\
\hline${ }^{45} \mathrm{Sc}$ & 25 & 24 & 20 & 20 & 29 & 30 & 29 & 31 \\
\hline${ }^{51} \mathrm{~V}$ & 954 & 563 & 418 & 505 & 433 & 519 & 489 & 642 \\
\hline${ }^{52} \mathrm{Cr}$ & 169 & 218 & 138 & 95 & 216 & 286 & 255 & 141 \\
\hline${ }^{55} \mathrm{Mn}$ & 2634 & 3743 & 4198 & 3627 & 9711 & 5883 & 5787 & 5378 \\
\hline${ }^{57} \mathrm{Fe}$ & 399100 & 383600 & 368900 & 371200 & 360200 & 386200 & 384200 & 389000 \\
\hline${ }^{59} \mathrm{Co}$ & 101 & 88 & 83 & 92 & 47 & 73 & 76 & 80 \\
\hline${ }^{60} \mathrm{Ni}$ & 51 & 50 & 46 & 50 & 53 & 81 & 82 & 80 \\
\hline${ }^{63} \mathrm{Cu}$ & 1 & 3 & 3 & 2 & 3 & 2 & 1 & 2 \\
\hline${ }^{65} \mathrm{Cu}$ & 4 & 5 & 6 & 5 & 5 & 4 & 4 & 4 \\
\hline${ }^{69} \mathrm{Ga}$ & 1 & 0.5 & 1 & 0.4 & 1 & 1 & 1 & 1 \\
\hline${ }^{74} \mathrm{Ge}$ & 0.1 & 0.1 & 0.1 & 0.1 & $<M D L$ & 0.1 & 0.1 & 0.1 \\
\hline${ }^{75} \mathrm{As}$ & $<\mathrm{MDL}$ & $<M D L$ & $<M D L$ & 0.3 & 1 & 1 & 1 & 1 \\
\hline${ }^{89} \mathrm{Y}$ & 0.1 & 0.1 & 0.1 & 0.1 & 0.1 & 0.1 & 0.2 & 0.1 \\
\hline${ }^{90} \mathrm{Zr}$ & 114 & 78 & 58 & 68 & 47 & 111 & 105 & 151 \\
\hline${ }^{93} \mathrm{Nb}$ & 22 & 19 & 17 & 20 & 3 & 15 & 15 & 18 \\
\hline${ }^{95} \mathrm{Mo}$ & 1 & 0.5 & 0.5 & 1 & 1 & 1 & 1 & 1 \\
\hline${ }^{118} \mathrm{Sn}$ & 3 & 2 & 1 & 2 & 2 & 2 & 2 & 2 \\
\hline${ }^{121} \mathrm{Sb}$ & 0.1 & 0.1 & 0.04 & 0.05 & 0.1 & 0.2 & 0.2 & 0.2 \\
\hline${ }^{178} \mathrm{Hf}$ & 4 & 3 & 2 & 3 & 2 & 4 & 3 & 5 \\
\hline${ }^{181} \mathrm{Ta}$ & 1 & 0.5 & 0.5 & 1 & 0.1 & 1 & 1 & 1 \\
\hline${ }^{182} \mathrm{~W}$ & 0.1 & 0.04 & 0.04 & 0.03 & 0.2 & 3 & 3 & 1 \\
\hline${ }^{208} \mathrm{~Pb}$ & 0.4 & 1 & 1 & 1 & 1 & 1 & 1 & 1 \\
\hline MAS & \multicolumn{3}{|c|}{$\begin{array}{l}\text { Massive to semi-massive } \\
\text { mineralization }\end{array}$} & OBAN & \multicolumn{4}{|c|}{ Orthopyroxene -bearing band } \\
\hline DIS & \multicolumn{3}{|c|}{ Disseminated mineralization } & POD & \multicolumn{4}{|l|}{ Pod } \\
\hline BAN & \multicolumn{3}{|c|}{ Bands of oxide mineralization } & OPOD & \multicolumn{4}{|c|}{ Orthopyroxene -bearing pod } \\
\hline ANO & \multicolumn{3}{|c|}{ Anorthosite hosted disseminated } & VEIN & \multicolumn{4}{|c|}{ Vein } \\
\hline ORT & \multicolumn{3}{|c|}{ Orthopyroxene associated } & COMP & \multicolumn{4}{|c|}{ composite ilmenite } \\
\hline $\mathrm{CLI}$ & \multicolumn{3}{|c|}{ Clinopyroxene associated } & SAN & \multicolumn{4}{|c|}{ sandwich ilmenite } \\
\hline
\end{tabular}




\section{Appendix V (Continued)}

\begin{tabular}{|c|c|c|c|c|c|c|c|}
\hline Sample & CC031 & CC031 & CC031 & CC031 & CC054 & CC054 & CC054 \\
\hline Circle number & $\mathrm{H}$ & $\mathrm{H}$ & I & I & $\mathrm{C}$ & $\mathrm{C}$ & $\mathrm{D}$ \\
\hline Analysis number & 31-H-I1 & $31-H-12$ & $31-I-I 1$ & $31-1-12$ & 54-C-I1 & $54-C-12$ & 54-D-I1 \\
\hline Mineralization style & DIS & DIS & DIS & DIS & DIS & DIS & DIS \\
\hline Descriptor & ANO & ANO & ANO & ANO & ORT & ORT & ORT \\
\hline Ilmenite texture & COMP & COMP & COMP & COMP & COMP & COMP & COMP \\
\hline Exsolution? & y & $\mathrm{y}$ & $\mathrm{y}$ & $\mathrm{y}$ & y & $\mathrm{y}$ & y \\
\hline Ti wt. \% (EPMA) & 28.1 & 28.3 & 29.4 & 29.5 & 30.2 & 30.2 & 30.8 \\
\hline${ }^{24} \mathrm{Mg}$ & 4919 & 4963 & 5035 & 4927 & 7715 & 7611 & 7372 \\
\hline${ }^{27} \mathrm{Al}$ & 242 & 243 & 243 & 276 & 274 & 234 & 325 \\
\hline${ }^{29} \mathrm{Si}$ & 223 & 161 & 123 & $<M D L$ & $<M D L$ & $<M D L$ & 650 \\
\hline $31 \mathrm{p}$ & $<M D L$ & $<M D L$ & $<M D L$ & $<M D L$ & $<M D L$ & $<M D L$ & 7 \\
\hline${ }^{44} \mathrm{Ca}$ & $<M D L$ & $<M D L$ & $<M D L$ & $<M D L$ & $<M D L$ & $<M D L$ & $<M D L$ \\
\hline${ }^{45} \mathrm{Sc}$ & 30 & 28 & 33 & 36 & 25 & 25 & 33 \\
\hline${ }^{51} \mathrm{~V}$ & 604 & 518 & 682 & 786 & 521 & 533 & 706 \\
\hline${ }^{52} \mathrm{Cr}$ & 151 & 129 & 112 & 140 & 91 & 92 & 89 \\
\hline${ }^{55} \mathrm{Mn}$ & 5194 & 5115 & 5531 & 5590 & 4102 & 4156 & 3864 \\
\hline${ }^{57} \mathrm{Fe}$ & 381200 & 365200 & 396700 & 406900 & 411000 & 403000 & 412500 \\
\hline${ }^{59} \mathrm{Co}$ & 78 & 77 & 78 & 79 & 122 & 119 & 111 \\
\hline${ }^{60} \mathrm{Ni}$ & 80 & 78 & 81 & 79 & 70 & 67 & 65 \\
\hline${ }^{63} \mathrm{Cu}$ & 2 & 1 & 2 & 2 & 5 & 4 & 3 \\
\hline${ }^{65} \mathrm{Cu}$ & 4 & 4 & 4 & 4 & 14 & 9 & 8 \\
\hline${ }^{69} \mathrm{Ga}$ & 1 & 1 & 1 & 1 & 1 & 1 & 1 \\
\hline${ }^{74} \mathrm{Ge}$ & 0.1 & 0.1 & 0.1 & 0.1 & 0.1 & $<M D L$ & 0.1 \\
\hline${ }^{75} \mathrm{As}$ & 1 & 1 & 1 & 1 & 1 & 1 & 1 \\
\hline${ }^{89} Y$ & 0.2 & 0.2 & 0.2 & 0.2 & 0.1 & 0.1 & 0.2 \\
\hline${ }^{90} \mathrm{Zr}$ & 143 & 125 & 162 & 187 & 74 & 84 & 138 \\
\hline${ }^{93} \mathrm{Nb}$ & 19 & 19 & 18 & 18 & 26 & 29 & 35 \\
\hline${ }^{95} \mathrm{Mo}$ & 1 & 1 & 1 & 1 & 0.4 & 0.4 & 0.4 \\
\hline${ }^{118} \mathrm{Sn}$ & 2 & 2 & 2 & 2 & 3 & 2 & 3 \\
\hline${ }^{121} \mathrm{Sb}$ & 0.3 & 0.2 & 0.3 & 0.3 & 0.1 & 0.1 & 0.03 \\
\hline${ }^{178} \mathrm{Hf}$ & 4 & 4 & 5 & 5 & 3 & 3 & 5 \\
\hline${ }^{181} \mathrm{Ta}$ & 1 & 1 & 1 & 1 & 1 & 1 & 2 \\
\hline${ }^{182} \mathrm{~W}$ & 1 & 1 & 0.1 & 0.2 & 0.1 & 0.1 & 0.1 \\
\hline${ }^{208} \mathrm{~Pb}$ & 1 & 1 & 0.5 & 0.4 & 2 & 2 & 1 \\
\hline MAS & \multicolumn{3}{|c|}{ Massive to semi-massive mineralization } & OBAN & \multicolumn{3}{|c|}{ Orthopyroxene -bearing band } \\
\hline DIS & \multicolumn{3}{|c|}{ Disseminated mineralization } & POD & \multicolumn{3}{|l|}{ Pod } \\
\hline BAN & \multicolumn{3}{|c|}{ Bands of oxide mineralization } & OPOD & \multicolumn{3}{|c|}{ Orthopyroxene -bearing pod } \\
\hline ANO & \multicolumn{3}{|c|}{ Anorthosite hosted disseminated } & VEIN & \multicolumn{3}{|c|}{ Vein } \\
\hline ORT & \multicolumn{3}{|c|}{ Orthopyroxene associated } & COMP & \multicolumn{3}{|c|}{ composite ilmenite } \\
\hline $\mathrm{CLI}$ & \multicolumn{3}{|c|}{ Clinopyroxene associated } & SAN & \multicolumn{3}{|c|}{ sandwich ilmenite } \\
\hline
\end{tabular}




\section{Appendix V (Continued)}

\begin{tabular}{|c|c|c|c|c|c|c|c|}
\hline Sample & CC054 & CC054 & CC054 & CC054 & CC054 & CC054 & CC054 \\
\hline Circle number & $\mathrm{D}$ & $\mathrm{D}$ & $\mathrm{E}$ & G & G & L & L \\
\hline Analysis number & 54-D-12 & 54-D-13 & $54-E-12$ & 54-G-I1 & $54-G-12$ & 54-L-I1 & $54-L-12$ \\
\hline Mineralization style & DIS & DIS & DIS & DIS & DIS & DIS & DIS \\
\hline Descriptor & ORT & ORT & ORT & ORT & ORT & ORT & ORT \\
\hline Ilmenite texture & COMP & COMP & COMP & COMP & COMP & COMP & COMP \\
\hline Exsolution? & y & $\mathrm{y}$ & $\mathrm{y}$ & $\mathrm{y}$ & $\mathrm{y}$ & $\mathrm{y}$ & y \\
\hline Ti wt. \% (EPMA) & 30.6 & 30.8 & 30.9 & 30.0 & 29.8 & 29.6 & 29.6 \\
\hline${ }^{24} \mathrm{Mg}$ & 7284 & 7180 & 6993 & 7257 & 7372 & 6829 & 6915 \\
\hline${ }^{27} \mathrm{Al}$ & 154 & 416 & 306 & 291 & 243 & 256 & 257 \\
\hline${ }^{29} \mathrm{Si}$ & 540 & 621 & 293 & 628 & 388 & 586 & 483 \\
\hline 31P & $<M D L$ & 6 & $<M D L$ & 6 & $<M D L$ & $<M D L$ & $<M D L$ \\
\hline${ }^{44} \mathrm{Ca}$ & $<M D L$ & 33 & $<M D L$ & 27 & $<M D L$ & 15 & 17 \\
\hline${ }^{45} \mathrm{Sc}$ & 23 & 27 & 29 & 25 & 26 & 27 & 26 \\
\hline${ }^{51} \mathrm{~V}$ & 395 & 681 & 624 & 439 & 481 & 573 & 575 \\
\hline${ }^{52} \mathrm{Cr}$ & 70 & 81 & 110 & 65 & 66 & 100 & 101 \\
\hline${ }^{55} \mathrm{Mn}$ & 4567 & 4203 & 3982 & 4187 & 4064 & 3834 & 3949 \\
\hline${ }^{57} \mathrm{Fe}$ & 393400 & 415400 & 402500 & 379900 & 388600 & 392300 & 398000 \\
\hline${ }^{59} \mathrm{Co}$ & 114 & 118 & 112 & 111 & 112 & 108 & 111 \\
\hline${ }^{60} \mathrm{Ni}$ & 63 & 74 & 69 & 64 & 65 & 61 & 63 \\
\hline${ }^{63} \mathrm{Cu}$ & 3 & 4 & 3 & 3 & 3 & 1 & 1 \\
\hline${ }^{65} \mathrm{Cu}$ & 7 & 9 & 6 & 7 & 6 & 4 & 4 \\
\hline${ }^{69} \mathrm{Ga}$ & 0.4 & 1 & 1 & 1 & 1 & 1 & 1 \\
\hline${ }^{74} \mathrm{Ge}$ & 0.1 & 0.1 & 0.1 & 0.1 & 0.1 & 0.1 & 0.1 \\
\hline${ }^{75} \mathrm{As}$ & 1 & 1 & 1 & 1 & 1 & 1 & 1 \\
\hline${ }^{89} \mathrm{Y}$ & 0.2 & 0.2 & 0.2 & 0.2 & 0.2 & 0.1 & 0.2 \\
\hline${ }^{90} \mathrm{Zr}$ & 75 & 124 & 106 & 70 & 81 & 92 & 85 \\
\hline${ }^{93} \mathrm{Nb}$ & 24 & 34 & 27 & 27 & 30 & 29 & 27 \\
\hline${ }^{95} \mathrm{Mo}$ & 0.4 & 1 & 0.5 & 0.4 & 0.4 & 0.5 & 0.4 \\
\hline${ }^{118} \mathrm{Sn}$ & 2 & 3 & 2 & 2 & 2 & 2 & 2 \\
\hline${ }^{121} \mathrm{Sb}$ & 0.04 & 0.04 & 0.03 & 0.04 & 0.03 & 0.01 & $<M D L$ \\
\hline${ }^{178} \mathrm{Hf}$ & 3 & 5 & 4 & 3 & 3 & 3 & 3 \\
\hline${ }^{181} \mathrm{Ta}$ & 1 & 2 & 1 & 1 & 1 & 1 & 1 \\
\hline${ }^{182} \mathrm{~W}$ & 0.1 & 0.1 & 0.05 & 0.1 & 0.1 & 0.1 & 0.1 \\
\hline${ }^{208} \mathrm{~Pb}$ & 1 & 2 & 1 & 1 & 1 & 0.2 & 0.2 \\
\hline MAS & \multicolumn{3}{|c|}{ Massive to semi-massive mineralization } & OBAN & \multicolumn{3}{|c|}{ Orthopyroxene -bearing band } \\
\hline DIS & \multicolumn{3}{|c|}{ Disseminated mineralization } & POD & \multicolumn{3}{|c|}{ Pod } \\
\hline BAN & \multicolumn{3}{|c|}{ Bands of oxide mineralization } & OPOD & \multicolumn{3}{|c|}{ Orthopyroxene -bearing pod } \\
\hline ANO & \multicolumn{3}{|c|}{ Anorthosite hosted disseminated } & VEIN & \multicolumn{3}{|l|}{ Vein } \\
\hline ORT & \multicolumn{3}{|c|}{ Orthopyroxene associated } & COMP & \multicolumn{3}{|c|}{ composite ilmenite } \\
\hline $\mathrm{CLI}$ & \multicolumn{3}{|c|}{ Clinopyroxene associated } & SAN & \multicolumn{3}{|c|}{ sandwich ilmenite } \\
\hline
\end{tabular}




\section{Appendix V (Continued)}

\begin{tabular}{|c|c|c|c|c|c|c|c|}
\hline Sample & CC054 & CC054 & CC072 & CCO72 & CC072 & CC072 & CC072 \\
\hline Circle number & $\mathrm{O}$ & $\mathrm{O}$ & $A$ & A & B & C & $\mathrm{C}$ \\
\hline Analysis number & 54-O-11 & $54-0-12$ & $72-A-11$ & $72-A-12$ & $72-B-12$ & $72-C-11$ & $72-C-12$ \\
\hline Mineralization style & DIS & DIS & MAS & MAS & MAS & MAS & MAS \\
\hline Descriptor & ORT & ORT & OPOD & OPOD & OPOD & OPOD & OPOD \\
\hline Ilmenite texture & COMP & COMP & COMP & COMP & COMP & COMP & COMP \\
\hline Exsolution? & $\mathrm{y}$ & $\mathrm{y}$ & $\mathrm{n}$ & $\mathrm{n}$ & $\mathrm{n}$ & $\mathrm{n}$ & $\mathrm{n}$ \\
\hline Ti wt. \% (EPMA) & 28.9 & 28.8 & 30.1 & 30.2 & 30.4 & 29.6 & 29.7 \\
\hline${ }^{24} \mathrm{Mg}$ & 7289 & 7135 & 20800 & 20600 & 20960 & 19730 & 19870 \\
\hline${ }^{27} \mathrm{Al}$ & 404 & 358 & 1627 & 448 & 156 & 293 & 252 \\
\hline${ }^{29} \mathrm{Si}$ & 415 & 280 & 245 & 293 & 558 & 137 & 158 \\
\hline $31 \mathrm{p}$ & $<M D L$ & $<M D L$ & $<M D L$ & 4 & $<M D L$ & $<M D L$ & $<M D L$ \\
\hline${ }^{44} \mathrm{Ca}$ & $<M D L$ & $<M D L$ & $<M D L$ & 9 & 32 & $<M D L$ & $<M D L$ \\
\hline${ }^{45} \mathrm{Sc}$ & 25 & 30 & 70 & 73 & 67 & 71 & 73 \\
\hline${ }^{51} \mathrm{~V}$ & 613 & 733 & 431 & 399 & 379 & 416 & 383 \\
\hline${ }^{52} \mathrm{Cr}$ & 89 & 74 & 125 & 87 & 64 & 112 & 120 \\
\hline${ }^{55} \mathrm{Mn}$ & 3826 & 3669 & 6870 & 6535 & 6035 & 6114 & 6317 \\
\hline${ }^{57} \mathrm{Fe}$ & 390800 & 393900 & 357900 & 348000 & 341500 & 339900 & 339200 \\
\hline${ }^{59} \mathrm{Co}$ & 111 & 113 & 121 & 120 & 118 & 117 & 116 \\
\hline${ }^{60} \mathrm{Ni}$ & 73 & 66 & 58 & 55 & 52 & 54 & 52 \\
\hline${ }^{63} \mathrm{Cu}$ & 3 & 3 & 3 & 3 & 1 & 2 & 2 \\
\hline${ }^{65} \mathrm{Cu}$ & 5 & 6 & 6 & 6 & 4 & 5 & 5 \\
\hline${ }^{69} \mathrm{Ga}$ & 2 & 1 & 2 & 1 & 0.3 & 1 & 1 \\
\hline${ }^{74} \mathrm{Ge}$ & $<M D L$ & 0.1 & 0.1 & 0.1 & 0.1 & 0.1 & 0.1 \\
\hline${ }^{75} \mathrm{As}$ & 1 & 1 & 1 & 1 & 1 & 1 & 1 \\
\hline${ }^{89} Y$ & 0.1 & 0.1 & 0.1 & 0.2 & 0.2 & 0.2 & 0.2 \\
\hline${ }^{90} \mathrm{Zr}$ & 99 & 128 & 124 & 129 & 120 & 129 & 130 \\
\hline${ }^{93} \mathrm{Nb}$ & 39 & 40 & 4 & 5 & 5 & 5 & 4 \\
\hline${ }^{95} \mathrm{Mo}$ & 0.4 & 0.3 & 0.4 & 0.4 & 0.4 & 0.4 & 0.3 \\
\hline${ }^{118} \mathrm{Sn}$ & 2 & 3 & 2 & 2 & 2 & 1 & 2 \\
\hline${ }^{121} \mathrm{Sb}$ & 0.03 & 0.04 & 0.1 & 0.1 & 0.04 & 0.1 & 0.03 \\
\hline${ }^{178} \mathrm{Hf}$ & 4 & 4 & 4 & 4 & 4 & 4 & 4 \\
\hline${ }^{181} \mathrm{Ta}$ & 2 & 2 & 0.1 & 0.1 & 0.1 & 0.1 & 0.1 \\
\hline${ }^{182} \mathrm{~W}$ & 0.1 & 0.1 & 0.02 & 0.01 & 0.01 & 0.01 & 0.01 \\
\hline${ }^{208} \mathrm{~Pb}$ & 1 & 1 & 1 & 1 & 1 & 1 & 1 \\
\hline MAS & \multicolumn{3}{|c|}{$\begin{array}{l}\text { Massive to semi-massive } \\
\text { mineralization }\end{array}$} & OBAN & \multicolumn{3}{|c|}{ Orthopyroxene -bearing band } \\
\hline DIS & \multicolumn{3}{|c|}{ Disseminated mineralization } & POD & \multicolumn{3}{|l|}{ Pod } \\
\hline BAN & \multicolumn{3}{|c|}{ Bands of oxide mineralization } & OPOD & \multicolumn{3}{|c|}{ Orthopyroxene -bearing pod } \\
\hline ANO & \multicolumn{3}{|c|}{ Anorthosite hosted disseminated } & VEIN & \multicolumn{3}{|l|}{ Vein } \\
\hline ORT & \multicolumn{3}{|c|}{ Orthopyroxene associated } & COMP & \multicolumn{3}{|c|}{ composite ilmenite } \\
\hline CLI & \multicolumn{3}{|c|}{ Clinopyroxene associated } & SAN & \multicolumn{3}{|c|}{ sandwich ilmenite } \\
\hline
\end{tabular}




\section{Appendix V (Continued)}

\begin{tabular}{|c|c|c|c|c|c|c|c|}
\hline Sample & CC072 & CC072 & CC072 & CC072 & CC072 & CC072 & CC072 \\
\hline Circle number & D & $\mathrm{D}$ & $\mathrm{E}$ & $\mathrm{E}$ & G & G & $\mathrm{H}$ \\
\hline Analysis number & 72-D-I1 & 72-D-13 & $72-E-I 1$ & $72-E-12$ & $72-G-11$ & $72-G-12$ & $72-\mathrm{H}-12$ \\
\hline Mineralization style & MAS & MAS & MAS & MAS & MAS & MAS & MAS \\
\hline Descriptor & OPOD & OPOD & OPOD & OPOD & OPOD & OPOD & OPOD \\
\hline Ilmenite texture & COMP & COMP & COMP & COMP & COMP & COMP & COMP \\
\hline Exsolution? & $\mathrm{n}$ & $\mathrm{n}$ & $\mathrm{n}$ & $\mathrm{n}$ & $\mathrm{n}$ & $\mathrm{n}$ & $\mathrm{n}$ \\
\hline Ti wt. \% (EPMA) & 31.1 & 31.0 & 31.0 & 31.0 & 31.0 & 31.3 & 31.0 \\
\hline${ }^{24} \mathrm{Mg}$ & 22270 & 21430 & 28670 & 23680 & 22300 & 21490 & 20820 \\
\hline${ }^{27} \mathrm{Al}$ & 175 & 187 & 15700 & 6950 & 451 & 264 & 245 \\
\hline${ }^{29} \mathrm{Si}$ & 406 & 218 & 360 & 552 & 301 & $<M D L$ & 445 \\
\hline $31 \mathrm{p}$ & $<M D L$ & $<M D L$ & $<M D L$ & 5 & $<M D L$ & $<M D L$ & 4 \\
\hline${ }^{44} \mathrm{Ca}$ & $<M D L$ & $<M D L$ & $<M D L$ & $<M D L$ & $<M D L$ & $<M D L$ & 10 \\
\hline${ }^{45} \mathrm{Sc}$ & 53 & 63 & 56 & 68 & 51 & 76 & 71 \\
\hline${ }^{51} \mathrm{~V}$ & 311 & 382 & 373 & 417 & 546 & 557 & 540 \\
\hline${ }^{52} \mathrm{Cr}$ & 88 & 69 & 268 & 209 & 69 & 63 & 39 \\
\hline${ }^{55} \mathrm{Mn}$ & 6274 & 6170 & 6710 & 6583 & 6463 & 5946 & 5667 \\
\hline${ }^{57} \mathrm{Fe}$ & 335900 & 343800 & 368800 & 362700 & 375900 & 360900 & 353100 \\
\hline${ }^{59} \mathrm{Co}$ & 121 & 119 & 165 & 146 & 130 & 123 & 123 \\
\hline${ }^{60} \mathrm{Ni}$ & 54 & 53 & 105 & 79 & 71 & 58 & 55 \\
\hline${ }^{63} \mathrm{Cu}$ & 2 & 2 & 3 & 6 & 2 & 1 & 1 \\
\hline${ }^{65} \mathrm{Cu}$ & 6 & 6 & 7 & 10 & 5 & 5 & 4 \\
\hline${ }^{69} \mathrm{Ga}$ & 0.4 & 0.4 & 13 & 7 & 2 & 1 & 1 \\
\hline${ }^{74} \mathrm{Ge}$ & 0.1 & 0.1 & $<M D L$ & 0.1 & 0.1 & 0.1 & 0.2 \\
\hline${ }^{75} \mathrm{As}$ & 1 & 1 & 1 & 1 & 1 & 0.4 & 1 \\
\hline${ }^{89} Y$ & 0.2 & 0.2 & 0.1 & 0.2 & 0.2 & 0.1 & 0.2 \\
\hline${ }^{90} \mathrm{Zr}$ & 91 & 112 & 91 & 114 & 120 & 139 & 155 \\
\hline${ }^{93} \mathrm{Nb}$ & 4 & 5 & 5 & 5 & 5 & 5 & 9 \\
\hline${ }^{95} \mathrm{Mo}$ & 0.4 & 0.4 & 1 & 0.5 & 0.4 & 0.5 & 0.4 \\
\hline${ }^{118} \mathrm{Sn}$ & 1 & 1 & 1 & 1 & 2 & 2 & 2 \\
\hline${ }^{121} \mathrm{Sb}$ & 0.03 & 0.1 & 0.1 & 0.1 & 0.04 & 0.02 & 0.04 \\
\hline${ }^{178} \mathrm{Hf}$ & 3 & 4 & 3 & 3 & 5 & 4 & 4 \\
\hline${ }^{181} \mathrm{Ta}$ & 0.1 & 0.1 & 0.1 & 0.1 & 0.2 & 0.2 & 0.4 \\
\hline${ }^{182} \mathrm{~W}$ & 0.01 & 0.01 & 0.01 & 0.01 & 0.00 & 0.01 & 0.01 \\
\hline${ }^{208} \mathrm{~Pb}$ & 1 & 1 & 2 & 1 & 2 & 1 & 1 \\
\hline MAS & \multicolumn{3}{|c|}{ Massive to semi-massive mineralization } & OBAN & \multicolumn{3}{|c|}{ Orthopyroxene -bearing band } \\
\hline DIS & \multicolumn{3}{|c|}{ Disseminated mineralization } & POD & \multicolumn{3}{|l|}{ Pod } \\
\hline BAN & \multicolumn{3}{|c|}{ Bands of oxide mineralization } & OPOD & \multicolumn{3}{|c|}{ Orthopyroxene -bearing pod } \\
\hline ANO & \multicolumn{3}{|c|}{ Anorthosite hosted disseminated } & VEIN & \multicolumn{3}{|l|}{ Vein } \\
\hline ORT & \multicolumn{3}{|c|}{ Orthopyroxene associated } & COMP & \multicolumn{3}{|c|}{ composite ilmenite } \\
\hline $\mathrm{CLI}$ & \multicolumn{3}{|c|}{ Clinopyroxene associated } & SAN & \multicolumn{3}{|c|}{ sandwich ilmenite } \\
\hline
\end{tabular}




\section{Appendix V (Continued)}

\begin{tabular}{|c|c|c|c|c|c|c|c|}
\hline Sample & CCO74 & CCO74 & CC074 & CC074 & CC074 & CC074 & CC074 \\
\hline Circle number & $A$ & A & A & B & B & C & C \\
\hline Analysis number & 74-A-I1 & $74-A-12$ & $74-A-14$ & 74-B-I1 & $74-B-12$ & $74-C-I 1$ & $74-C-12$ \\
\hline Mineralization style & DIS & DIS & DIS & DIS & DIS & DIS & DIS \\
\hline Descriptor & CLI & $\mathrm{CLI}$ & CLI & CLI & CLI & CLI & CLI \\
\hline Ilmenite texture & COMP & COMP & COMP & COMP & COMP & COMP & COMP \\
\hline Exsolution? & $\mathrm{y}$ & $\mathrm{y}$ & $\mathrm{y}$ & $\mathrm{n}$ & $\mathrm{n}$ & $\mathrm{n}$ & $\mathrm{n}$ \\
\hline Ti wt. \% (EPMA) & 29.2 & 29.3 & 29.2 & 29.2 & 29.4 & 29.4 & 29.3 \\
\hline${ }^{24} \mathrm{Mg}$ & 3079 & 3150 & 3205 & 2469 & 2664 & 3000 & 2715 \\
\hline${ }^{27} \mathrm{Al}$ & 258 & 245 & 18070 & 143 & 155 & 812 & 385 \\
\hline${ }^{29} \mathrm{Si}$ & 1450 & $<M D L$ & 430 & 1490 & 990 & 1107 & 651 \\
\hline $31 \mathrm{p}$ & 14 & $<M D L$ & $<M D L$ & 200 & 9 & $<M D L$ & $<M D L$ \\
\hline${ }^{44} \mathrm{Ca}$ & 18 & $<M D L$ & 24 & 500 & 15 & 32 & 15 \\
\hline${ }^{45} \mathrm{Sc}$ & 32 & 32 & 27 & 32 & 31 & 29 & 27 \\
\hline${ }^{51} \mathrm{~V}$ & 925 & 944 & 811 & 903 & 900 & 850 & 900 \\
\hline${ }^{52} \mathrm{Cr}$ & 406 & 402 & 1169 & 347 & 337 & 304 & 292 \\
\hline${ }^{55} \mathrm{Mn}$ & 9853 & 9830 & 10160 & 10788 & 11170 & 9730 & 9120 \\
\hline${ }^{57} \mathrm{Fe}$ & 434800 & 444100 & 405200 & 404500 & 411500 & 411300 & 419100 \\
\hline${ }^{59} \mathrm{Co}$ & 92 & 97 & 205 & 83 & 88 & 73 & 90 \\
\hline${ }^{60} \mathrm{Ni}$ & 49 & 54 & 102 & 45 & 48 & 32 & 36 \\
\hline${ }^{63} \mathrm{Cu}$ & 2 & 2 & 2 & 2 & 2 & 2 & 10 \\
\hline${ }^{65} \mathrm{Cu}$ & 6 & 6 & 6 & 10 & 6 & 6 & 13 \\
\hline${ }^{69} \mathrm{Ga}$ & 2 & 2 & 32 & 1 & 1 & 1 & 1 \\
\hline${ }^{74} \mathrm{Ge}$ & 0.1 & 0.2 & 0.2 & 0.2 & 0.2 & 0.1 & 0.2 \\
\hline${ }^{75} \mathrm{As}$ & 2 & 2 & 2 & 2 & 1 & 2 & 2 \\
\hline${ }^{89} \mathrm{Y}$ & 0.1 & 0.2 & 0.2 & 0.3 & 0.1 & 0.2 & 0.3 \\
\hline${ }^{90} \mathrm{Zr}$ & 52 & 51 & 25 & 36 & 34 & 47 & 43 \\
\hline${ }^{93} \mathrm{Nb}$ & 16 & 17 & 5 & 11 & 11 & 14 & 14 \\
\hline${ }^{95} \mathrm{Mo}$ & 1 & 1 & 1 & 1 & 1 & 1 & 1 \\
\hline${ }^{118} \mathrm{Sn}$ & 3 & 3 & 3 & 3 & 3 & 2 & 3 \\
\hline${ }^{121} \mathrm{Sb}$ & 0.1 & 0.1 & 0.1 & 0.1 & 0.1 & 0.1 & 0.1 \\
\hline${ }^{178} \mathrm{Hf}$ & 2 & 2 & 1 & 1 & 2 & 2 & 2 \\
\hline${ }^{181} \mathrm{Ta}$ & 1 & 1 & 0.1 & 0.4 & 0.4 & 1 & 0.5 \\
\hline${ }^{182} \mathrm{~W}$ & 0.04 & 0.1 & 0.01 & 0.02 & 0.02 & 0.03 & 0.04 \\
\hline${ }^{208} \mathrm{~Pb}$ & 2 & 2 & 2 & 2 & 1 & 1 & 2 \\
\hline MAS & \multicolumn{3}{|c|}{ Massive to semi-massive mineralization } & OBAN & \multicolumn{3}{|c|}{ Orthopyroxene -bearing band } \\
\hline DIS & \multicolumn{3}{|c|}{ Disseminated mineralization } & POD & \multicolumn{3}{|c|}{ Pod } \\
\hline BAN & \multicolumn{3}{|c|}{ Bands of oxide mineralization } & OPOD & \multicolumn{3}{|c|}{ Orthopyroxene -bearing pod } \\
\hline ANO & \multicolumn{3}{|c|}{ Anorthosite hosted disseminated } & VEIN & \multicolumn{3}{|l|}{ Vein } \\
\hline ORT & \multicolumn{3}{|c|}{ Orthopyroxene associated } & COMP & \multicolumn{3}{|c|}{ composite ilmenite } \\
\hline $\mathrm{CLI}$ & \multicolumn{3}{|c|}{ Clinopyroxene associated } & SAN & \multicolumn{3}{|c|}{ sandwich ilmenite } \\
\hline
\end{tabular}




\section{Appendix V (Continued)}

\begin{tabular}{|c|c|c|c|c|c|c|c|}
\hline Sample & CCO74 & CCO74 & CCO74 & CC074 & CCO74 & CC076 & CC076 \\
\hline Circle number & $\mathrm{D}$ & $\mathrm{D}$ & $\mathrm{E}$ & $\mathrm{E}$ & $\mathrm{F}$ & B & C \\
\hline Analysis number & 74-D-I1 & 74-D-13 & 74-E-I1 & $74-E-12$ & 74-F-I1 & 76-B-I1 & $76-C-I 1$ \\
\hline Mineralization style & DIS & DIS & DIS & DIS & DIS & MAS & MAS \\
\hline Descriptor & CLI & CLI & CLI & CLI & CLI & VEIN & VEIN \\
\hline Ilmenite texture & COMP & COMP & COMP & COMP & COMP & COMP & SAN \\
\hline Exsolution? & $\mathrm{y}$ & $\mathrm{n}$ & $\mathrm{y}$ & y & $\mathrm{n}$ & $\mathrm{n}$ & $\mathrm{y}$ \\
\hline Ti wt. \% (EPMA) & 28.7 & 28.7 & 29.3 & 29.2 & 28.6 & 28.4 & 28.3 \\
\hline${ }^{24} \mathrm{Mg}$ & 3076 & 3433 & 3915 & 3742 & 2578 & 5558 & 5521 \\
\hline${ }^{27} \mathrm{Al}$ & 2570 & 160 & 402 & 260 & 324 & 237 & 3460 \\
\hline${ }^{29} \mathrm{Si}$ & 3760 & 804 & $<M D L$ & $<M D L$ & 528 & 385 & 282 \\
\hline $31 \mathrm{p}$ & $<M D L$ & 5 & $<M D L$ & $<M D L$ & $<M D L$ & $<M D L$ & $<M D L$ \\
\hline${ }^{44} \mathrm{Ca}$ & 870 & 13 & $<M D L$ & $<M D L$ & $<M D L$ & $<M D L$ & 24 \\
\hline${ }^{45} \mathrm{Sc}$ & 29 & 27 & 29 & 31 & 25 & 52 & 54 \\
\hline${ }^{51} \mathrm{~V}$ & 769 & 712 & 843 & 813 & 947 & 1393 & 1420 \\
\hline${ }^{52} \mathrm{Cr}$ & 273 & 288 & 432 & 405 & 417 & 267 & 733 \\
\hline${ }^{55} \mathrm{Mn}$ & 12530 & 7906 & 7310 & 7131 & 9651 & 9928 & 11023 \\
\hline${ }^{57} \mathrm{Fe}$ & 412000 & 384400 & 409800 & 421300 & 418800 & 400400 & 370600 \\
\hline${ }^{59} \mathrm{Co}$ & 120 & 94 & 105 & 103 & 100 & 68 & 79 \\
\hline${ }^{60} \mathrm{Ni}$ & 56 & 39 & 45 & 46 & 42 & 18 & 19 \\
\hline${ }^{63} \mathrm{Cu}$ & 7 & 1 & 1 & 2 & 5 & 1 & 6 \\
\hline${ }^{65} \mathrm{Cu}$ & 11 & 5 & 5 & 5 & 8 & 4 & 9 \\
\hline${ }^{69} \mathrm{Ga}$ & 5 & 1 & 2 & 2 & 2 & 1 & 7 \\
\hline${ }^{74} \mathrm{Ge}$ & 0.2 & 0.1 & 0.1 & 0.1 & 0.1 & 0.2 & 0.1 \\
\hline${ }^{75} \mathrm{As}$ & 2 & 2 & 1 & 1 & 2 & 0.5 & 1 \\
\hline${ }^{89} Y$ & 0.2 & 0.1 & 0.1 & 0.1 & 0.1 & 0.1 & 0.1 \\
\hline${ }^{90} \mathrm{Zr}$ & 46 & 26 & 39 & 52 & 26 & 13 & 6 \\
\hline${ }^{93} \mathrm{Nb}$ & 19 & 13 & 14 & 19 & 18 & 15 & 12 \\
\hline${ }^{95} \mathrm{Mo}$ & 1 & 1 & 1 & 0.5 & 1 & 1 & 1 \\
\hline${ }^{118} \mathrm{Sn}$ & 2 & 2 & 2 & 2 & 2 & 0.1 & 0.03 \\
\hline${ }^{121} \mathrm{Sb}$ & 0.1 & 0.04 & 0.04 & 0.02 & 0.1 & 0.2 & 0.1 \\
\hline${ }^{178} \mathrm{Hf}$ & 2 & 1 & 2 & 2 & 1 & 0.5 & 0.1 \\
\hline${ }^{181} \mathrm{Ta}$ & 1 & 1 & 1 & 1 & 1 & 0.5 & 0.3 \\
\hline${ }^{182} \mathrm{~W}$ & 0.1 & 0.03 & 0.03 & 0.04 & 0.1 & 0.2 & 0.1 \\
\hline${ }^{208} \mathrm{~Pb}$ & 2 & 2 & 1 & 1 & 2 & 1 & 1 \\
\hline MAS & \multicolumn{3}{|c|}{ Massive to semi-massive mineralization } & OBAN & \multicolumn{3}{|c|}{ Orthopyroxene -bearing band } \\
\hline DIS & \multicolumn{3}{|c|}{ Disseminated mineralization } & POD & \multicolumn{3}{|l|}{ Pod } \\
\hline BAN & \multicolumn{3}{|c|}{ Bands of oxide mineralization } & OPOD & \multicolumn{3}{|c|}{ Orthopyroxene -bearing pod } \\
\hline ANO & \multicolumn{3}{|c|}{ Anorthosite hosted disseminated } & VEIN & \multicolumn{3}{|c|}{ Vein } \\
\hline ORT & \multicolumn{3}{|c|}{ Orthopyroxene associated } & COMP & \multicolumn{3}{|c|}{ composite ilmenite } \\
\hline $\mathrm{CLI}$ & \multicolumn{3}{|c|}{ Clinopyroxene associated } & SAN & \multicolumn{3}{|c|}{ sandwich ilmenite } \\
\hline
\end{tabular}




\section{Appendix V (Continued)}

\begin{tabular}{|c|c|c|c|c|c|c|}
\hline Sample & CC076 & CC076 & CC076 & CC076 & CC076 & CC076 \\
\hline Circle number & $\mathrm{D}$ & $\mathrm{D}$ & $\mathrm{D}$ & $\mathrm{F}$ & G & $\mathrm{K}$ \\
\hline Analysis number & 76-D-I1 & $76-D-12$ & 76-D-13 & 76-F-I1 & $76-G-11$ & 76-K-I1 \\
\hline Mineralization style & MAS & MAS & MAS & MAS & MAS & MAS \\
\hline Descriptor & VEIN & VEIN & VEIN & VEIN & VEIN & VEIN \\
\hline Ilmenite texture & COMP & COMP & COMP & COMP & COMP & COMP \\
\hline Exsolution? & $\mathrm{y}$ & $y$ & $\mathrm{y}$ & $y$ & $\mathrm{y}$ & $\mathrm{y}$ \\
\hline Ti wt. \% (EPMA) & 29.9 & 28.9 & 29.1 & 29.0 & 28.3 & 28.4 \\
\hline${ }^{24} \mathrm{Mg}$ & 5787 & 5539 & 5535 & 5547 & 5286 & 5556 \\
\hline${ }^{27} \mathrm{Al}$ & 351 & 310 & 311 & 279 & 249 & 1220 \\
\hline${ }^{29} \mathrm{Si}$ & 1990 & 424 & 481 & 390 & 264 & 234 \\
\hline${ }^{31} \mathrm{p}$ & 17 & 5 & $<M D L$ & $<M D L$ & $<M D L$ & $<M D L$ \\
\hline${ }^{44} \mathrm{Ca}$ & 81 & 12 & $<M D L$ & $<M D L$ & $<\mathrm{MDL}$ & $<M D L$ \\
\hline${ }^{45} \mathrm{Sc}$ & 61 & 68 & 67 & 62 & 67 & 69 \\
\hline${ }^{51} \mathrm{~V}$ & 1896 & 1698 & 1633 & 2012 & 1633 & 1864 \\
\hline${ }^{52} \mathrm{Cr}$ & 315 & 252 & 262 & 224 & 276 & 295 \\
\hline${ }^{55} \mathrm{Mn}$ & 9050 & 8545 & 8576 & 8670 & 8229 & 8519 \\
\hline${ }^{57} \mathrm{Fe}$ & 521800 & 472100 & 477800 & 498400 & 456000 & 468800 \\
\hline${ }^{59} \mathrm{Co}$ & 76 & 68 & 68 & 70 & 65 & 71 \\
\hline${ }^{60} \mathrm{Ni}$ & 19 & 17 & 16 & 14 & 15 & 19 \\
\hline${ }^{63} \mathrm{Cu}$ & 3 & 1 & 1 & 2 & 1 & 1 \\
\hline${ }^{65} \mathrm{Cu}$ & 5 & 3 & 4 & 4 & 4 & 4 \\
\hline${ }^{69} \mathrm{Ga}$ & 3 & 2 & 2 & 2 & 2 & 3 \\
\hline${ }^{74} \mathrm{Ge}$ & 0.2 & 0.2 & 0.2 & $<M D L$ & 0.2 & 0.1 \\
\hline${ }^{75} \mathrm{As}$ & $<M D L$ & 1 & 1 & 1 & 0.3 & 0.4 \\
\hline${ }^{89} \mathrm{Y}$ & 0.1 & 0.1 & 0.1 & 0.1 & 0.1 & 0.1 \\
\hline${ }^{90} \mathrm{Zr}$ & 17 & 26 & 26 & 30 & 27 & 25 \\
\hline${ }^{93} \mathrm{Nb}$ & 20 & 19 & 18 & 18 & 19 & 15 \\
\hline${ }^{95} \mathrm{Mo}$ & 1 & 1 & 1 & 1 & 1 & 1 \\
\hline${ }^{118} \mathrm{Sn}$ & 3 & 2 & 2 & 2 & 2 & 2 \\
\hline${ }^{121} \mathrm{Sb}$ & 0.3 & 0.2 & 0.2 & 0.2 & 0.2 & 0.2 \\
\hline${ }^{178} \mathrm{Hf}$ & 1 & 2 & 2 & 2 & 2 & 2 \\
\hline${ }^{181} \mathrm{Ta}$ & 1 & 1 & 1 & 1 & 1 & 0.4 \\
\hline${ }^{182} \mathrm{~W}$ & 0.1 & 0.03 & 0.03 & 0.04 & 0.02 & 0.03 \\
\hline${ }^{208} \mathrm{~Pb}$ & 2 & 1 & 1 & 1 & 1 & 1 \\
\hline MAS & \multicolumn{3}{|c|}{$\begin{array}{l}\text { Massive to semi-massive } \\
\text { mineralization }\end{array}$} & OBAN & \multicolumn{2}{|c|}{ Orthopyroxene -bearing band } \\
\hline DIS & \multicolumn{3}{|c|}{ Disseminated mineralization } & POD & \multicolumn{2}{|c|}{ Pod } \\
\hline BAN & \multicolumn{3}{|c|}{ Bands of oxide mineralization } & OPOD & \multicolumn{2}{|c|}{ Orthopyroxene -bearing pod } \\
\hline ANO & \multicolumn{3}{|c|}{ Anorthosite hosted disseminated } & VEIN & \multicolumn{2}{|c|}{ Vein } \\
\hline ORT & \multicolumn{3}{|c|}{ Orthopyroxene associated } & COMP & \multicolumn{2}{|c|}{ composite ilmenite } \\
\hline $\mathrm{CLI}$ & \multicolumn{3}{|c|}{ Clinopyroxene associated } & SAN & \multicolumn{2}{|c|}{ sandwich ilmenite } \\
\hline
\end{tabular}




\section{Appendix V (Continued)}

\begin{tabular}{|c|c|c|c|c|c|c|}
\hline Sample & CCOO8 & CC008 & CCOO8 & CC008 & CC008 & CC010 \\
\hline Circle & B & B & $\mathrm{D}$ & D & $\mathrm{H}$ & $A$ \\
\hline Source file & 08-B-H1.D & 08-B-H2.D & 08-D-H1.D & 08-D-H2.D & 08-H-H2.D & 10-A-H1.D \\
\hline Mineralization type & MAS & MAS & MAS & MAS & MAS & MAS \\
\hline Descriptor & BAN & BAN & BAN & BAN & BAN & OBAN \\
\hline Mineral host & PLE & PLE & PLE & PLE & ILM & PLE \\
\hline Mineral analyzed & PLE & PLE & PLE & PLE & PLE & PLE \\
\hline Al wt. \% (EPMA)* & 31.0 & 31.0 & 30.7 & 30.7 & 30.8 & 31.3 \\
\hline${ }^{24} \mathrm{Mg}$ & 138800 & 143400 & 140890 & 74400 & 73730 & 86900 \\
\hline${ }^{29} \mathrm{Si}$ & 5020 & 4830 & 1240 & $<M D L$ & 2300 & 900 \\
\hline $31 \mathrm{p}$ & 39 & 70 & $<M D L$ & $<M D L$ & $<M D L$ & 21 \\
\hline${ }^{44} \mathrm{Ca}$ & 56 & 39 & $<M D L$ & $<M D L$ & 300 & 19 \\
\hline${ }^{45} \mathrm{Sc}$ & 1 & 1 & 0.5 & $<M D L$ & 2 & $<M D L$ \\
\hline${ }^{47} \mathrm{Ti}$ & $<M D L$ & $<M D L$ & $<M D L$ & 780 & 22800 & $<M D L$ \\
\hline${ }^{51} \mathrm{~V}$ & 1102 & 1375 & 1223 & 751 & 1780 & 793 \\
\hline${ }^{52} \mathrm{Cr}$ & 3560 & 3622 & 4160 & 1923 & 3110 & 2275 \\
\hline${ }^{55} \mathrm{Mn}$ & 3801 & 3799 & 3537 & 2056 & 2390 & 2500 \\
\hline${ }^{57} \mathrm{Fe}$ & 517600 & 578400 & 534000 & 286000 & 464000 & 337000 \\
\hline${ }^{59} \mathrm{Co}$ & 1473 & 1423 & 1500 & 940 & 1054 & 869 \\
\hline${ }^{60} \mathrm{Ni}$ & 1660 & 1583 & 1506 & 909 & 963 & 1113 \\
\hline${ }^{63} \mathrm{Cu}$ & 1 & 0.5 & 1 & 1 & 6 & 1 \\
\hline${ }^{66} \mathrm{Zn}$ & 7480 & 8550 & 7990 & 5960 & 5710 & 8680 \\
\hline${ }^{69} \mathrm{Ga}$ & 460 & 444 & 461 & 230 & 301 & 266 \\
\hline${ }^{74} \mathrm{Ge}$ & 1 & 0.4 & 0.1 & 1 & 0.5 & 0.3 \\
\hline${ }^{75} \mathrm{As}$ & 5 & 5 & 8 & $<M D L$ & 1 & 2 \\
\hline${ }^{89} \mathrm{Y}$ & $<M D L$ & $<M D L$ & $<M D L$ & $<M D L$ & 0.02 & $<M D L$ \\
\hline${ }^{90} \mathrm{Zr}$ & 0.05 & 0.03 & 0.1 & 0.1 & 2 & 0.03 \\
\hline${ }^{93} \mathrm{Nb}$ & $<M D L$ & $<M D L$ & $<M D L$ & $<M D L$ & 0.4 & $<M D L$ \\
\hline${ }^{95} \mathrm{Mo}$ & 0.1 & 0.2 & 0.5 & $<M D L$ & 0.1 & 0.1 \\
\hline${ }^{118} \mathrm{Sn}$ & 0.01 & 0.2 & $<M D L$ & 0.1 & 1 & 0.1 \\
\hline${ }^{121} \mathrm{Sb}$ & 0.1 & 0.02 & 0.1 & 0.05 & 0.01 & 0.1 \\
\hline${ }^{178} \mathrm{Hf}$ & $<M D L$ & $<M D L$ & $<M D L$ & $<M D L$ & 0.1 & $<M D L$ \\
\hline${ }^{181} \mathrm{Ta}$ & $<M D L$ & $<M D L$ & $<M D L$ & $<M D L$ & 0.03 & $<M D L$ \\
\hline${ }^{182} \mathrm{~W}$ & $<M D L$ & $<M D L$ & $<M D L$ & 0.00 & $<M D L$ & 0.02 \\
\hline${ }^{208} \mathrm{~Pb}$ & 0.4 & 0.4 & 0.3 & 1 & 0.3 & 0.4 \\
\hline MAS & \multicolumn{3}{|c|}{ Massive to semi-massive mineralization } & OBAN & \multicolumn{2}{|c|}{ Orthopyroxene -bearing band } \\
\hline DIS & \multicolumn{3}{|c|}{ Disseminated mineralization } & POD & \multicolumn{2}{|l|}{ Pod } \\
\hline BAN & \multicolumn{3}{|c|}{ Bands of oxide mineralization } & OPOD & \multicolumn{2}{|c|}{ Orthopyroxene -bearing pod } \\
\hline ANO & \multicolumn{3}{|c|}{ Anorthosite hosted disseminated } & VEIN & \multicolumn{2}{|l|}{ Vein } \\
\hline ORT & \multicolumn{3}{|c|}{ Orthopyroxene associated } & MAG & \multicolumn{2}{|l|}{ Magnetite } \\
\hline $\mathrm{CLI}$ & \multicolumn{3}{|c|}{ Clinopyroxene associated } & ILM & Ilmenite & PLE \\
\hline
\end{tabular}

* Internal calibrant was taken from EPMA analyses performed on the same grain as LA-ICPMS analyses; when LA-ICPMS analyses were performed on pleonaste without EPMA analyses, the internal calibrant used was the average of all texturally similar pleonaste in the sample 


\section{Appendix V (Continued)}

\begin{tabular}{|c|c|c|c|c|c|c|}
\hline Sample & CC010 & CC010 & CC010 & CC010 & CC010 & CC010 \\
\hline Circle & $A$ & B & B & E & $\mathrm{H}$ & I \\
\hline $\begin{array}{l}\text { Source file } \\
\text { Mineralization }\end{array}$ & 10-A-H2.D & 10-B-H1.D & 10-B-H2.D & 10-E-H1.D & 10-H-H1.D & 10-I-H1.D \\
\hline type & MAS & MAS & MAS & MAS & MAS & MAS \\
\hline Descriptor & OBAN & OBAN & OBAN & OBAN & OBAN & OBAN \\
\hline Mineral host & PLE & PLE & PLE & MAG & MAG & MAG \\
\hline Mineral analyzed & PLE & PLE & PLE & PLE & PLE & PLE \\
\hline Al wt. \% (EPMA)* & 31.3 & 31.2 & 31.2 & 32.2 & 31.8 & 31.8 \\
\hline${ }^{24} \mathrm{Mg}$ & 78000 & 67240 & 95000 & 85670 & 84320 & 75200 \\
\hline${ }^{29} \mathrm{Si}$ & $<\mathrm{MDL}$ & $<\mathrm{MDL}$ & 630 & 6030 & 2900 & 2030 \\
\hline${ }^{31} \mathrm{p}$ & 6 & $<M D L$ & 19 & $<M D L$ & $<M D L$ & 16 \\
\hline${ }^{44} \mathrm{Ca}$ & $<M D L$ & $<M D L$ & $<M D L$ & 22 & 79 & $<M D L$ \\
\hline${ }^{45} \mathrm{Sc}$ & 0.1 & $<M D L$ & $<M D L$ & 1 & 2 & 0.2 \\
\hline${ }^{47} \mathrm{Ti}$ & $<M D L$ & $<M D L$ & $<M D L$ & 4900 & 25300 & 1120 \\
\hline${ }^{51} \mathrm{~V}$ & 785 & 506 & 924 & 433 & 1380 & 1198 \\
\hline${ }^{52} \mathrm{Cr}$ & 2120 & 2098 & 3150 & 2076 & 2642 & 2335 \\
\hline${ }^{55} \mathrm{Mn}$ & 2122 & 1631 & 2600 & 2311 & 2964 & 1876 \\
\hline${ }^{57} \mathrm{Fe}$ & 321000 & 227000 & 386000 & 262400 & 447000 & 361000 \\
\hline${ }^{59} \mathrm{Co}$ & 827 & 719 & 1084 & 1410 & 1423 & 906 \\
\hline${ }^{60} \mathrm{Ni}$ & 1071 & 832 & 1392 & 1121 & 1119 & 866 \\
\hline${ }^{63} \mathrm{Cu}$ & 1 & 0.2 & 1 & 59 & 24 & 39 \\
\hline${ }^{66} \mathrm{Zn}$ & 5970 & 3711 & 8600 & 4595 & 4860 & 3780 \\
\hline${ }^{69} \mathrm{Ga}$ & 239 & 217 & 294 & 372 & 384 & 233 \\
\hline${ }^{74} \mathrm{Ge}$ & 0.4 & 0.3 & 0.2 & 0.2 & 1 & 0.3 \\
\hline${ }^{75} \mathrm{As}$ & 5 & 6 & 4 & 2 & 1 & 4 \\
\hline${ }^{89} \mathrm{Y}$ & $<M D L$ & $<M D L$ & $<M D L$ & $<M D L$ & $<M D L$ & $<M D L$ \\
\hline${ }^{90} \mathrm{Zr}$ & 0.03 & 0.01 & 0.02 & 2 & 3 & 0.1 \\
\hline${ }^{93} \mathrm{Nb}$ & $<M D L$ & $<M D L$ & $<M D L$ & $<M D L$ & $<M D L$ & $<M D L$ \\
\hline${ }^{95} \mathrm{Mo}$ & 0.1 & 0.1 & 0.1 & 0.1 & 0.2 & 0.2 \\
\hline${ }^{118} \mathrm{Sn}$ & 0.1 & 0.1 & 0.02 & 0.3 & 1 & 0.4 \\
\hline${ }^{121} \mathrm{Sb}$ & 0.1 & 0.04 & 0.02 & 0.00 & -0.01 & 0.1 \\
\hline${ }^{178} \mathrm{Hf}$ & $<M D L$ & $<M D L$ & $<M D L$ & 0.03 & 0.1 & 0.01 \\
\hline${ }^{181} \mathrm{Ta}$ & $<M D L$ & $<M D L$ & $<M D L$ & $<M D L$ & $<M D L$ & $<M D L$ \\
\hline${ }^{182} \mathrm{~W}$ & 0.01 & $<M D L$ & 0.01 & $<M D L$ & $<M D L$ & 0.02 \\
\hline${ }^{208} \mathrm{~Pb}$ & 1 & 0.1 & 0.4 & 0.3 & 0.2 & 0.4 \\
\hline MAS & \multicolumn{3}{|c|}{ Massive to semi-massive mineralization } & OBAN & \multicolumn{2}{|c|}{ Orthopyroxene -bearing band } \\
\hline DIS & \multicolumn{3}{|c|}{ Disseminated mineralization } & POD & \multicolumn{2}{|l|}{ Pod } \\
\hline BAN & \multicolumn{3}{|c|}{ Bands of oxide mineralization } & OPOD & \multicolumn{2}{|c|}{ Orthopyroxene -bearing pod } \\
\hline ANO & \multicolumn{3}{|c|}{ Anorthosite hosted disseminated } & VEIN & \multicolumn{2}{|c|}{ Vein } \\
\hline ORT & \multicolumn{3}{|c|}{ Orthopyroxene associated } & MAG & \multicolumn{2}{|l|}{ Magnetite } \\
\hline \multirow[t]{2}{*}{$\mathrm{CLI}$} & \multirow{2}{*}{\multicolumn{3}{|c|}{ Clinopyroxene associated }} & ILM & \multicolumn{2}{|l|}{ Ilmenite } \\
\hline & & & & PLE & Pleonaste & \\
\hline
\end{tabular}




\section{Appendix V (Continued)}

\begin{tabular}{|c|c|c|c|c|c|c|}
\hline Sample & CC010 & CC013 & CC013 & CC013 & CCO25 & CCO25 \\
\hline Circle & M & $A$ & I & $\mathrm{L}$ & $A$ & $D$ \\
\hline Source file & 10-M-H1.D & 13-A-H1.D & 13-I-H1.D & 13-L-H1.D & 25-A-H1.D & 25-D-H2.D \\
\hline Mineralization type & MAS & MAS & MAS & MAS & MAS & MAS \\
\hline Descriptor & OBAN & BAN & BAN & BAN & POD & POD \\
\hline Mineral host & MAG & MAG & PLE & PLE & MAG & PLE \\
\hline Mineral analyzed & PLE & PLE & PLE & PLE & PLE & PLE \\
\hline Al wt. \% (EPMA)* & 31.9 & 30.4 & 30.9 & 31.6 & 30.0 & 30.0 \\
\hline${ }^{24} \mathrm{Mg}$ & 63800 & 65850 & 61270 & 63290 & 53760 & 47560 \\
\hline${ }^{29} \mathrm{Si}$ & 6410 & 860 & 260 & $<M D L$ & 2100 & 2590 \\
\hline $31 \mathrm{p}$ & 8 & $<M D L$ & 10 & 9 & $<M D L$ & $<M D L$ \\
\hline${ }^{44} \mathrm{Ca}$ & 61 & $<M D L$ & 22 & $<M D L$ & $<M D L$ & 24 \\
\hline${ }^{45} \mathrm{Sc}$ & 1 & 0.4 & $<M D L$ & 0.2 & $<M D L$ & 1 \\
\hline${ }^{47} \mathrm{Ti}$ & 2900 & 4450 & $<\mathrm{MDL}$ & $<M D L$ & 720 & $<M D L$ \\
\hline${ }^{51} \mathrm{~V}$ & 2560 & 546 & 577 & 545 & 598 & 484 \\
\hline${ }^{52} \mathrm{Cr}$ & 3157 & 3560 & 2326 & 3120 & 6000 & 4067 \\
\hline${ }^{55} \mathrm{Mn}$ & 1983 & 2125 & 2120 & 2020 & 1558 & 1607 \\
\hline${ }^{57} \mathrm{Fe}$ & 577000 & 240600 & 227100 & 238900 & 369000 & 327000 \\
\hline${ }^{59} \mathrm{Co}$ & 969 & 765 & 655 & 738 & 1405 & 1237 \\
\hline${ }^{60} \mathrm{Ni}$ & 929 & 755 & 741 & 803 & 1207 & 1155 \\
\hline${ }^{63} \mathrm{Cu}$ & 72 & 1 & 4 & 1 & 8 & $<M D L$ \\
\hline${ }^{66} \mathrm{Zn}$ & 3210 & 3164 & 3270 & 4100 & 5560 & 5580 \\
\hline${ }^{69} \mathrm{Ga}$ & 331 & 206 & 221 & 217 & 413 & 363 \\
\hline${ }^{74} \mathrm{Ge}$ & 1 & 0.3 & 0.4 & 0.3 & $<M D L$ & $<M D L$ \\
\hline${ }^{75} \mathrm{As}$ & 3 & 3 & 4 & 3 & $<M D L$ & 1 \\
\hline${ }^{89} \mathrm{Y}$ & 0.03 & $<M D L$ & $<M D L$ & $<M D L$ & $<M D L$ & $<M D L$ \\
\hline${ }^{90} \mathrm{Zr}$ & 1 & 1 & 0.01 & 0.03 & 4 & 3 \\
\hline${ }^{93} \mathrm{Nb}$ & $<\mathrm{MDL}$ & $<M D L$ & $<M D L$ & $<M D L$ & $<M D L$ & $<M D L$ \\
\hline${ }^{95} \mathrm{Mo}$ & 0.1 & $<M D L$ & 0.2 & 0.2 & 0.3 & 0.3 \\
\hline${ }^{118} \mathrm{Sn}$ & 1 & 0.1 & 0.1 & 0.1 & 0.03 & 0.3 \\
\hline${ }^{121} \mathrm{Sb}$ & 0.2 & 0.02 & 0.1 & 0.1 & 0.4 & 0.2 \\
\hline${ }^{178} \mathrm{Hf}$ & 0.01 & 0.00 & $<M D L$ & $<M D L$ & 0.03 & 0.1 \\
\hline${ }^{181} \mathrm{Ta}$ & 1 & 0.01 & $<\mathrm{MDL}$ & $<M D L$ & $<M D L$ & $<M D L$ \\
\hline${ }^{182} \mathrm{~W}$ & 0.3 & $<M D L$ & $<M D L$ & 0.00 & $<M D L$ & 0.01 \\
\hline${ }^{208} \mathrm{~Pb}$ & 1 & 1 & 0.3 & 0.3 & $<\mathrm{MDL}$ & $<M D L$ \\
\hline MAS & \multicolumn{3}{|c|}{ Massive to semi-massive mineralization } & OBAN & \multicolumn{2}{|c|}{$\begin{array}{l}\text { Orthopyroxene -bearing } \\
\text { band }\end{array}$} \\
\hline DIS & \multicolumn{3}{|c|}{ Disseminated mineralization } & POD & \multicolumn{2}{|l|}{ Pod } \\
\hline BAN & \multicolumn{3}{|c|}{ Bands of oxide mineralization } & OPOD & \multicolumn{2}{|c|}{ Orthopyroxene -bearing pod } \\
\hline ANO & \multicolumn{3}{|c|}{ Anorthosite hosted disseminated } & VEIN & \multicolumn{2}{|c|}{ Vein } \\
\hline ORT & \multicolumn{3}{|c|}{ Orthopyroxene associated } & MAG & \multicolumn{2}{|l|}{ Magnetite } \\
\hline \multirow[t]{2}{*}{$\mathrm{CLI}$} & \multirow{2}{*}{\multicolumn{3}{|c|}{ Clinopyroxene associated }} & ILM & \multicolumn{2}{|l|}{ Ilmenite } \\
\hline & & & & PLE & Pleonaste & \\
\hline
\end{tabular}




\section{Appendix V (Continued)}

\begin{tabular}{|c|c|c|c|c|c|c|}
\hline Sample & CCO25 & $\mathrm{CCO} 25$ & CCO54 & CC054 & CC054 & CC054 \\
\hline Circle & $\mathrm{H}$ & I & A & A & D & $\mathrm{F}$ \\
\hline Source file & 25-H-H1.D & 25-I-H1.D & 54-A-H1.D & 54-A-H2.D & 54-D-H1.D & 54-F-H1.D \\
\hline Mineralization type & MAS & MAS & DIS & DIS & DIS & DIS \\
\hline Descriptor & POD & POD & ORT & ORT & ORT & ORT \\
\hline Mineral host & MAG & MAG & PLE & PLE & MAG & MAG \\
\hline Mineral analyzed & PLE & PLE & PLE & PLE & PLE & PLE \\
\hline Al wt. \% (EPMA)* & 30.0 & 30.0 & 32.0 & 32.0 & 31.1 & 29.8 \\
\hline${ }^{24} \mathrm{Mg}$ & 49630 & 42650 & 39710 & 42000 & 42430 & 39910 \\
\hline${ }^{29} \mathrm{Si}$ & 2070 & 2570 & 390 & 300 & 3020 & 9140 \\
\hline 31p & $<M D L$ & 25 & 21 & 21 & 14 & 189 \\
\hline${ }^{44} \mathrm{Ca}$ & 55 & 34 & 19 & 54 & 73 & 352 \\
\hline${ }^{45} \mathrm{Sc}$ & 0.4 & $<M D L$ & $<M D L$ & 0.2 & 0.3 & 2 \\
\hline${ }^{47} \mathrm{Ti}$ & 2590 & $<\mathrm{MDL}$ & $<M D L$ & $<M D L$ & 4600 & $<M D L$ \\
\hline${ }^{51} \mathrm{~V}$ & 1053 & 602 & 577 & 603 & 510 & 530 \\
\hline${ }^{52} \mathrm{Cr}$ & 5020 & 4411 & 2037 & 2053 & 2793 & 2760 \\
\hline${ }^{55} \mathrm{Mn}$ & 1564 & 1084 & 1747 & 1786 & 1426 & 1368 \\
\hline${ }^{57} \mathrm{Fe}$ & 422000 & 281800 & 332000 & 326200 & 267200 & 291500 \\
\hline${ }^{59} \mathrm{Co}$ & 1133 & 664 & 552 & 552 & 713 & 725 \\
\hline${ }^{60} \mathrm{Ni}$ & 1016 & 630 & 755 & 782 & 755 & 765 \\
\hline${ }^{63} \mathrm{Cu}$ & 2 & 2 & 1 & 1 & 4 & 235 \\
\hline${ }^{66} \mathrm{Zn}$ & 5520 & 6871 & 5328 & 4808 & 4989 & 5160 \\
\hline${ }^{69} \mathrm{Ga}$ & 283 & 210 & 184 & 182 & 188 & 167 \\
\hline${ }^{74} \mathrm{Ge}$ & 0.4 & 0.1 & 1 & 1 & 0.2 & 0.4 \\
\hline${ }^{75} \mathrm{As}$ & $<M D L$ & 1 & 4 & 5 & 4 & 3 \\
\hline${ }^{89} \mathrm{Y}$ & $<M D L$ & $<M D L$ & $<M D L$ & $<M D L$ & $<M D L$ & 0.3 \\
\hline${ }^{90} \mathrm{Zr}$ & 2 & 0.04 & $<M D L$ & $<M D L$ & 1 & 0.3 \\
\hline${ }^{93} \mathrm{Nb}$ & $<M D L$ & $<M D L$ & $<M D L$ & $<M D L$ & 0.3 & $<M D L$ \\
\hline${ }^{95} \mathrm{Mo}$ & 0.1 & 0.1 & 0.1 & 0.1 & 0.1 & 0.3 \\
\hline${ }^{118} \mathrm{Sn}$ & 0.2 & 0.01 & 0.2 & 0.1 & 0.1 & 0.3 \\
\hline${ }^{121} \mathrm{Sb}$ & 0.3 & 0.1 & 0.05 & 0.04 & $<\mathrm{MDL}$ & 0.2 \\
\hline${ }^{178} \mathrm{Hf}$ & 0.03 & $<M D L$ & $<M D L$ & $<M D L$ & 0.02 & 0.01 \\
\hline${ }^{181} \mathrm{Ta}$ & $<M D L$ & $<\mathrm{MDL}$ & $<M D L$ & $<M D L$ & 0.01 & $<M D L$ \\
\hline${ }^{182} W$ & 0.01 & 0.01 & 0.01 & 0.02 & $<M D L$ & 0.2 \\
\hline${ }^{208} \mathrm{~Pb}$ & 0.04 & 0.1 & 0.5 & 0.5 & 0.2 & 1 \\
\hline MAS & \multicolumn{3}{|c|}{ Massive to semi-massive mineralization } & OBAN & \multicolumn{2}{|c|}{ Orthopyroxene -bearing band } \\
\hline DIS & \multicolumn{3}{|c|}{ Disseminated mineralization } & POD & \multicolumn{2}{|l|}{ Pod } \\
\hline BAN & \multicolumn{3}{|c|}{ Bands of oxide mineralization } & OPOD & \multicolumn{2}{|c|}{ Orthopyroxene -bearing pod } \\
\hline ANO & \multicolumn{3}{|c|}{ Anorthosite hosted disseminated } & VEIN & \multicolumn{2}{|l|}{ Vein } \\
\hline ORT & \multicolumn{3}{|c|}{ Orthopyroxene associated } & MAG & \multicolumn{2}{|l|}{ Magnetite } \\
\hline \multirow[t]{2}{*}{$\mathrm{CLI}$} & \multirow{2}{*}{\multicolumn{3}{|c|}{ Clinopyroxene associated }} & ILM & \multicolumn{2}{|l|}{ Ilmenite } \\
\hline & & & & PLE & Pleonaste & \\
\hline
\end{tabular}




\section{Appendix V (Continued)}

\begin{tabular}{|c|c|c|c|c|c|c|}
\hline Sample & CC054 & CC072 & CCO72 & CCO72 & $\mathrm{CCO72}$ & CCO72 \\
\hline Circle & $\mathrm{F}$ & A & B & B & D & $E$ \\
\hline Source file & 54-F-H2.D & 72-A-H1.D & 72-B-H1.D & 72-B-H2.D & 72-D-H1.D & 72-E-H1.D \\
\hline Mineralization type & DIS & MAS & MAS & MAS & MAS & MAS \\
\hline Descriptor & ORT & OPOD & OPOD & OPOD & OPOD & OPOD \\
\hline Mineral host & MAG & MAG & MAG & MAG & MAG & MAG \\
\hline Mineral analyzed & PLE & PLE & PLE & PLE & PLE & PLE \\
\hline Al wt. \% (EPMA)* & 29.8 & 31.1 & 31.1 & 31.1 & 31.1 & 31.1 \\
\hline${ }^{24} \mathrm{Mg}$ & 44400 & 193100 & 95600 & 96300 & 80900 & 82400 \\
\hline${ }^{29} \mathrm{Si}$ & 11600 & $<M D L$ & 1630 & 1820 & 1590 & 1030 \\
\hline 31p & 140 & 31 & 14 & 17 & $<\mathrm{MDL}$ & 10 \\
\hline${ }^{44} \mathrm{Ca}$ & 219 & 30 & 38 & 38 & $<M D L$ & 45 \\
\hline${ }^{45} \mathrm{Sc}$ & 1 & 1 & 2 & 5 & 0.3 & 0.1 \\
\hline${ }^{47} \mathrm{Ti}$ & $<M D L$ & 1020 & 26600 & 55000 & $<M D L$ & $<M D L$ \\
\hline${ }^{51} \mathrm{~V}$ & 567 & 942 & 508 & 620 & 427 & 414 \\
\hline${ }^{52} \mathrm{Cr}$ & 3118 & 5470 & 3260 & 3163 & 2326 & 2406 \\
\hline${ }^{55} \mathrm{Mn}$ & 1531 & 3200 & 2860 & 3490 & 1482 & 1430 \\
\hline${ }^{57} \mathrm{Fe}$ & 307000 & 458000 & 266000 & 334000 & 195100 & 191000 \\
\hline${ }^{59} \mathrm{Co}$ & 876 & 1141 & 659 & 630 & 500 & 487 \\
\hline${ }^{60} \mathrm{Ni}$ & 876 & 1240 & 622 & 627 & 523 & 477 \\
\hline${ }^{63} \mathrm{Cu}$ & 182 & 21 & 53 & 436 & 14 & 1 \\
\hline${ }^{66} \mathrm{Zn}$ & 5820 & 9500 & 6700 & 5920 & 4080 & 3830 \\
\hline${ }^{69} \mathrm{Ga}$ & 192 & 414 & 207 & 209 & 183 & 187 \\
\hline${ }^{74} \mathrm{Ge}$ & 0.3 & 0.4 & 0.4 & 0.4 & 0.3 & 0.2 \\
\hline${ }^{75} \mathrm{As}$ & 3 & 8 & 3 & 3 & 4 & 3 \\
\hline${ }^{89} \mathrm{Y}$ & 0.1 & $<M D L$ & 0.02 & 0.1 & $<M D L$ & $<M D L$ \\
\hline${ }^{90} \mathrm{Zr}$ & 0.1 & 0.1 & 2 & 6 & 0.04 & 0.04 \\
\hline${ }^{93} \mathrm{Nb}$ & $<M D L$ & $<M D L$ & 1 & 1 & $<M D L$ & $<M D L$ \\
\hline${ }^{95} \mathrm{Mo}$ & 0.2 & 0.1 & 0.2 & 0.2 & 0.1 & 0.1 \\
\hline${ }^{118} \mathrm{Sn}$ & 0.2 & 0.3 & 1 & 1 & 0.1 & 0.1 \\
\hline${ }^{121} \mathrm{Sb}$ & 0.03 & 0.1 & 0.1 & 0.1 & 0.04 & 0.1 \\
\hline${ }^{178} \mathrm{Hf}$ & 0.01 & $<M D L$ & 0.1 & 0.2 & 0.00 & $<M D L$ \\
\hline${ }^{181} \mathrm{Ta}$ & $<M D L$ & 0.4 & $<M D L$ & 0.1 & $<M D L$ & $<M D L$ \\
\hline${ }^{182} \mathrm{~W}$ & 0.2 & 9 & 0.1 & 0.1 & 0.01 & 0.01 \\
\hline${ }^{208} \mathrm{~Pb}$ & 1 & 1 & 0.5 & 1 & 0.1 & 0.2 \\
\hline MAS & \multicolumn{3}{|c|}{ Massive to semi-massive mineralization } & OBAN & \multicolumn{2}{|c|}{ Orthopyroxene -bearing band } \\
\hline DIS & \multicolumn{3}{|c|}{ Disseminated mineralization } & POD & \multicolumn{2}{|l|}{ Pod } \\
\hline BAN & \multicolumn{3}{|c|}{ Bands of oxide mineralization } & OPOD & \multicolumn{2}{|c|}{ Orthopyroxene -bearing pod } \\
\hline ANO & \multicolumn{3}{|c|}{ Anorthosite hosted disseminated } & VEIN & \multicolumn{2}{|l|}{ Vein } \\
\hline ORT & \multicolumn{3}{|c|}{ Orthopyroxene associated } & MAG & \multicolumn{2}{|l|}{ Magnetite } \\
\hline \multirow[t]{2}{*}{$\mathrm{CLI}$} & \multirow{2}{*}{\multicolumn{3}{|c|}{ Clinopyroxene associated }} & ILM & \multicolumn{2}{|l|}{ Ilmenite } \\
\hline & & & & PLE & Pleonaste & \\
\hline
\end{tabular}




\section{Appendix V (Continued)}

\begin{tabular}{|c|c|c|c|c|c|c|}
\hline Sample & CCO72 & CCO72 & CC072 & CCO74 & CCO74 & CC076 \\
\hline Circle & $\mathrm{E}$ & K & K & $\mathrm{D}$ & $E$ & A \\
\hline Source file & 72-E-H2.D & 72-K-H1.D & 72-K-H2.D & 74-D-H1.D & 74-E-H1.D & 76-A-H2.D \\
\hline Mineralization type & MAS & MAS & MAS & DIS & DIS & MAS \\
\hline Descriptor & OPOD & OPOD & OPOD & CLI & CLI & VEIN \\
\hline Mineral host & MAG & PLE & PLE & MAG & MAG & ILM \\
\hline Mineral analyzed & PLE & PLE & PLE & PLE & PLE & PLE \\
\hline Al wt. \% (EPMA)* & 31.1 & 31.1 & 31.1 & 31.1 & 31.1 & 29.9 \\
\hline${ }^{24} \mathrm{Mg}$ & 83300 & 75900 & 91400 & 46200 & 36040 & 39500 \\
\hline${ }^{29} \mathrm{Si}$ & 990 & 580 & 500 & 6690 & 6000 & 830 \\
\hline 31p & 17 & $<M D L$ & 7 & 6 & 63 & $<M D L$ \\
\hline${ }^{44} \mathrm{Ca}$ & $<M D L$ & $<M D L$ & 29 & 680 & 149 & 29 \\
\hline${ }^{45} \mathrm{Sc}$ & 0.2 & 0.4 & 0.4 & 2 & $<M D L$ & 18 \\
\hline${ }^{47} \mathrm{Ti}$ & $<M D L$ & $<M D L$ & $<M D L$ & 46700 & $<M D L$ & 27750 \\
\hline${ }^{51} \mathrm{~V}$ & 405 & 500 & 705 & 981 & 388 & 648 \\
\hline${ }^{52} \mathrm{Cr}$ & 2350 & 2068 & 2750 & 7160 & 4733 & 3040 \\
\hline${ }^{55} \mathrm{Mn}$ & 1440 & 1711 & 2058 & 5310 & 2674 & 2420 \\
\hline${ }^{57} \mathrm{Fe}$ & 198000 & 228200 & 287000 & 492000 & 282100 & 209100 \\
\hline${ }^{59} \mathrm{Co}$ & 513 & 472 & 586 & 1901 & 1333 & 324 \\
\hline${ }^{60} \mathrm{Ni}$ & 493 & 557 & 686 & 936 & 661 & 219 \\
\hline${ }^{63} \mathrm{Cu}$ & 10 & 0.2 & 1 & 4 & 3 & 1 \\
\hline${ }^{66} \mathrm{Zn}$ & 3910 & 3680 & 5820 & 12610 & 9380 & 6320 \\
\hline${ }^{69} \mathrm{Ga}$ & 177 & 177 & 212 & 326 & 251 & 305 \\
\hline${ }^{74} \mathrm{Ge}$ & 0.2 & 0.3 & 0.3 & 0.4 & 0.2 & $<M D L$ \\
\hline${ }^{75} \mathrm{As}$ & 4 & 2 & 3 & 6 & 4 & 3 \\
\hline${ }^{89} \mathrm{Y}$ & $<M D L$ & $<M D L$ & $<M D L$ & 0.1 & $<M D L$ & $<M D L$ \\
\hline${ }^{90} \mathrm{Zr}$ & $<M D L$ & 0.03 & $<M D L$ & 1 & $<M D L$ & 59 \\
\hline${ }^{93} \mathrm{Nb}$ & $<M D L$ & $<M D L$ & $<M D L$ & 2 & $<M D L$ & 1 \\
\hline${ }^{95} \mathrm{Mo}$ & 0.1 & $<M D L$ & 0.2 & 1 & $<M D L$ & 0.1 \\
\hline${ }^{118} \mathrm{Sn}$ & 0.1 & 0.1 & 0.1 & 1 & $<M D L$ & 10 \\
\hline${ }^{121} \mathrm{Sb}$ & 0.03 & 0.1 & 0.1 & 0.03 & $<M D L$ & 0.1 \\
\hline${ }^{178} \mathrm{Hf}$ & $<M D L$ & $<M D L$ & $<M D L$ & 0.03 & $<M D L$ & 3 \\
\hline${ }^{181} \mathrm{Ta}$ & $<M D L$ & $<M D L$ & $<M D L$ & 0.1 & $<M D L$ & 0.1 \\
\hline${ }^{182} \mathrm{~W}$ & 0.01 & $<M D L$ & $<M D L$ & 0.02 & $<M D L$ & 0.01 \\
\hline${ }^{208} \mathrm{~Pb}$ & 0.2 & 0.3 & 1 & 2 & 0.4 & 1 \\
\hline MAS & \multicolumn{3}{|c|}{ Massive to semi-massive mineralization } & OBAN & \multicolumn{2}{|c|}{ Orthopyroxene -bearing band } \\
\hline DIS & \multicolumn{3}{|c|}{ Disseminated mineralization } & POD & \multicolumn{2}{|l|}{ Pod } \\
\hline BAN & \multicolumn{3}{|c|}{ Bands of oxide mineralization } & OPOD & \multicolumn{2}{|c|}{ Orthopyroxene -bearing pod } \\
\hline ANO & \multicolumn{3}{|c|}{ Anorthosite hosted disseminated } & VEIN & \multicolumn{2}{|l|}{ Vein } \\
\hline ORT & \multicolumn{3}{|c|}{ Orthopyroxene associated } & MAG & \multicolumn{2}{|l|}{ Magnetite } \\
\hline \multirow[t]{2}{*}{$\mathrm{CLI}$} & \multirow{2}{*}{\multicolumn{3}{|c|}{ Clinopyroxene associated }} & ILM & \multicolumn{2}{|l|}{ Ilmenite } \\
\hline & & & & PLE & Pleonaste & \\
\hline
\end{tabular}




\section{Appendix V (Continued)}

\begin{tabular}{|c|c|c|c|c|c|}
\hline Sample & CC076 & CC076 & CC076 & & \\
\hline Circle & $A$ & B & G & & \\
\hline Source file & 76-A-H3.D & 76-B-H1.D & 76-G-H1.D & & \\
\hline Mineralization type & MAS & MAS & MAS & & \\
\hline Descriptor & VEIN & VEIN & VEIN & & \\
\hline Mineral host & PLE & PLE & PLE & & \\
\hline Mineral analyzed & PLE & PLE & PLE & & \\
\hline Al wt. \% (EPMA)* & 29.9 & 29.9 & 29.9 & & \\
\hline${ }^{24} \mathrm{Mg}$ & 48600 & 45170 & 44700 & & \\
\hline${ }^{29} \mathrm{Si}$ & $<M D L$ & 1360 & 390 & & \\
\hline${ }^{31} \mathrm{p}$ & $<M D L$ & 9 & 12 & & \\
\hline${ }^{44} \mathrm{Ca}$ & $<\mathrm{MDL}$ & 21 & $<M D L$ & & \\
\hline${ }^{45} \mathrm{SC}$ & $<\mathrm{MDL}$ & 0.2 & $<M D L$ & & \\
\hline${ }^{47} \mathrm{Ti}$ & 1090 & $<M D L$ & $<M D L$ & & \\
\hline${ }^{51} \mathrm{~V}$ & 549 & 507 & 576 & & \\
\hline${ }^{52} \mathrm{Cr}$ & 2620 & 3158 & 4270 & & \\
\hline${ }^{55} \mathrm{Mn}$ & 3383 & 3164 & 3537 & & \\
\hline${ }^{57} \mathrm{Fe}$ & 237800 & 250600 & 295100 & & \\
\hline${ }^{59} \mathrm{Co}$ & 527 & 410 & 453 & & \\
\hline${ }^{60} \mathrm{Ni}$ & 225 & 234 & 260 & & \\
\hline${ }^{63} \mathrm{Cu}$ & 1 & 0.2 & 2 & & \\
\hline${ }^{66} \mathrm{Zn}$ & 12000 & 9810 & 11900 & & \\
\hline${ }^{69} \mathrm{Ga}$ & 195 & 214 & 224 & & \\
\hline${ }^{74} \mathrm{Ge}$ & 0.3 & $<M D L$ & 0.2 & & \\
\hline${ }^{75} \mathrm{As}$ & $<M D L$ & 2 & 3 & & \\
\hline${ }^{89} Y$ & $<M D L$ & $<M D L$ & $<M D L$ & & \\
\hline${ }^{90} \mathrm{Zr}$ & 0.3 & 0.05 & 0.03 & & \\
\hline${ }^{93} \mathrm{Nb}$ & $<\mathrm{MDL}$ & $<M D L$ & $<M D L$ & & \\
\hline${ }^{95} \mathrm{Mo}$ & 0.1 & 0.1 & 0.2 & & \\
\hline${ }^{118} \mathrm{Sn}$ & 0.3 & 0.1 & 0.04 & & \\
\hline${ }^{121} \mathrm{Sb}$ & 0.01 & 0.1 & 0.1 & & \\
\hline${ }^{178} \mathrm{Hf}$ & 0.01 & 0.00 & $<\mathrm{MDL}$ & & \\
\hline${ }^{181} \mathrm{Ta}$ & $<\mathrm{MDL}$ & $<M D L$ & $<\mathrm{MDL}$ & & \\
\hline${ }^{182} \mathrm{~W}$ & $<M D L$ & $<M D L$ & 0.01 & & \\
\hline${ }^{208} \mathrm{~Pb}$ & 0.3 & 0.2 & 0.4 & & \\
\hline MAS & \multicolumn{3}{|c|}{ Massive to semi-massive mineralization } & OBAN & $\begin{array}{l}\text { Orthopyroxene -bearing } \\
\text { band }\end{array}$ \\
\hline DIS & \multicolumn{3}{|c|}{ Disseminated mineralization } & POD & $\begin{array}{l}\text { Pod } \\
\text { Orthopyroxene -bearing }\end{array}$ \\
\hline BAN & \multicolumn{3}{|c|}{ Bands of oxide mineralization } & OPOD & pod \\
\hline ANO & \multicolumn{3}{|c|}{ Anorthosite hosted disseminated } & VEIN & Vein \\
\hline ORT & \multicolumn{3}{|c|}{ Orthopyroxene associated } & MAG & Magnetite \\
\hline \multirow[t]{2}{*}{$\mathrm{CLI}$} & \multirow{2}{*}{\multicolumn{3}{|c|}{ Clinopyroxene associated }} & ILM & IImenite \\
\hline & & & & PLE & Pleonaste \\
\hline
\end{tabular}


Appendix VI. LA-ICPMS and EPMA spot and line analysis locations on BSE images and photomicrographs, respectively.

CC008 circle A LA-ICPMS

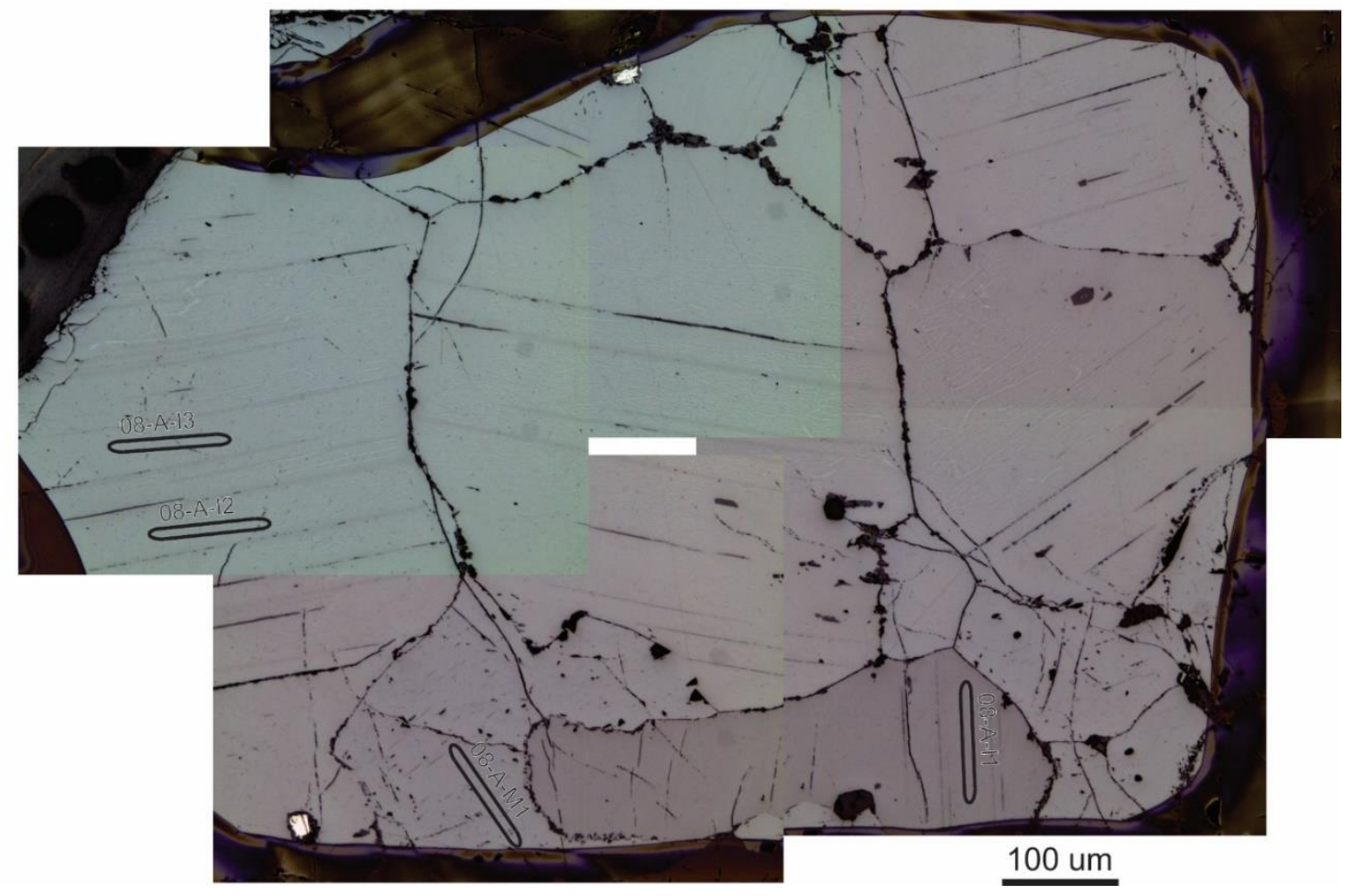


CC008 circle A EPMA
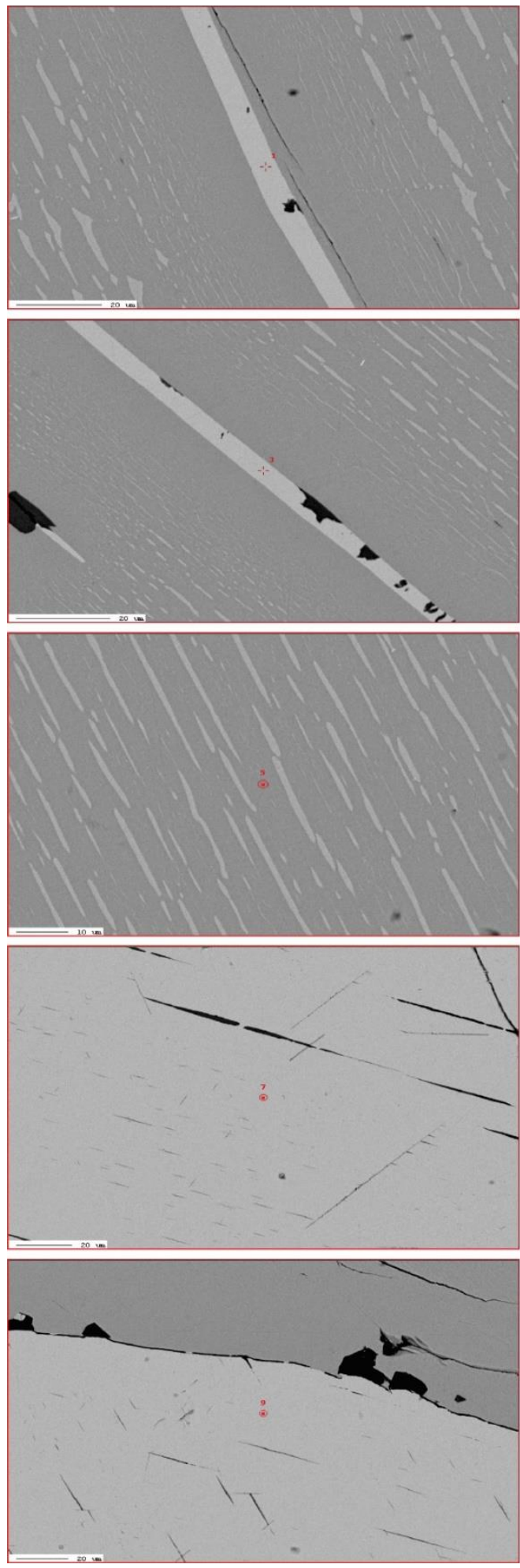

CC008 circle B LA-ICPMS
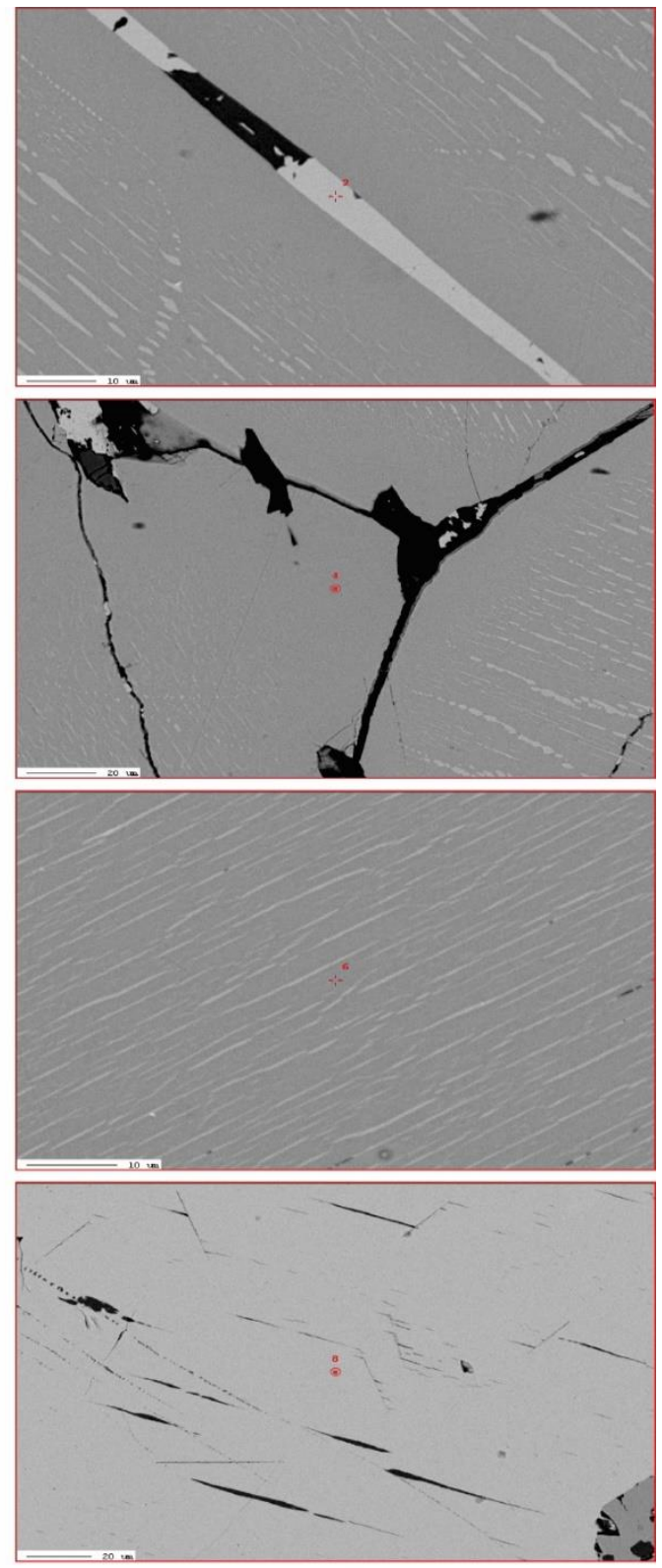


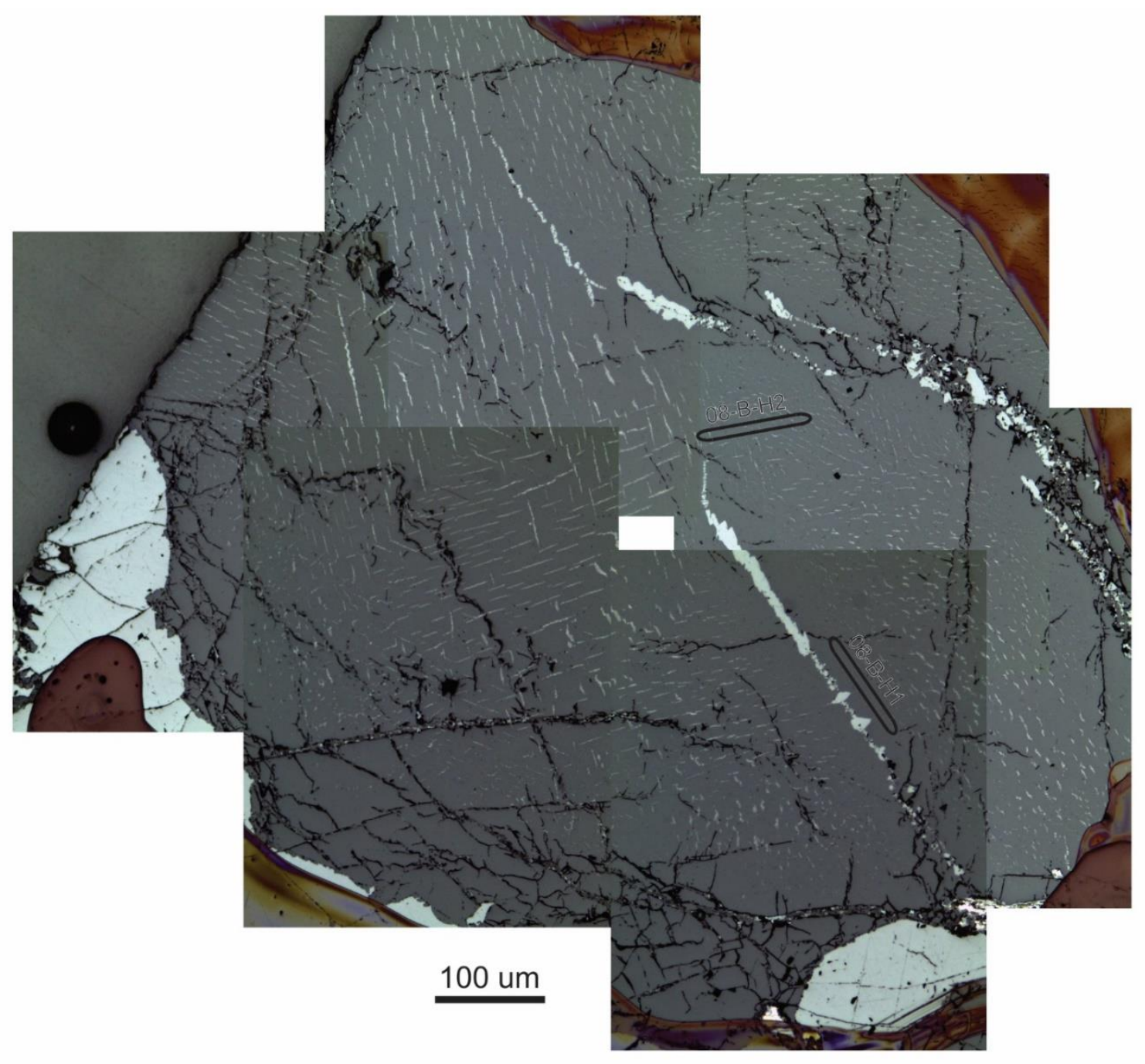


CC008 circle B EPMA
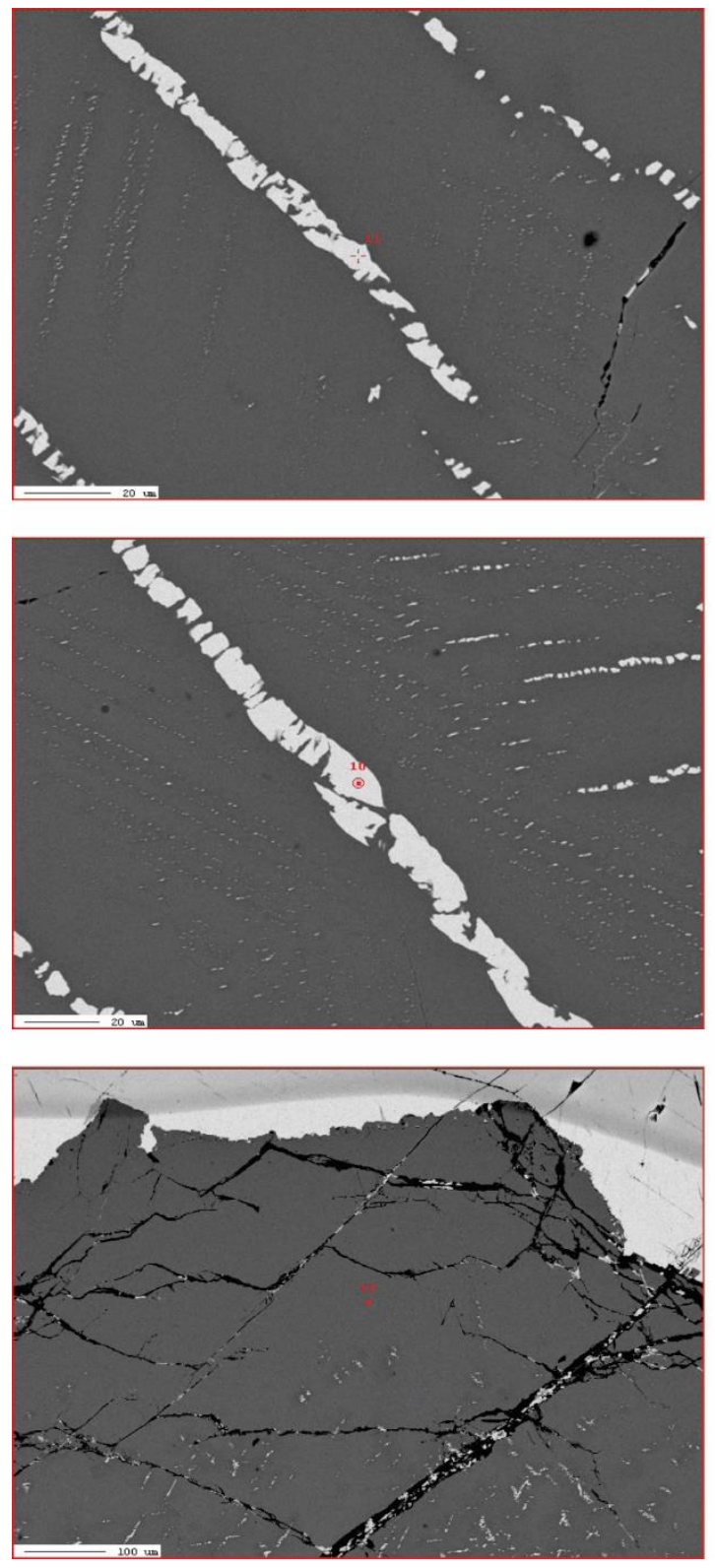
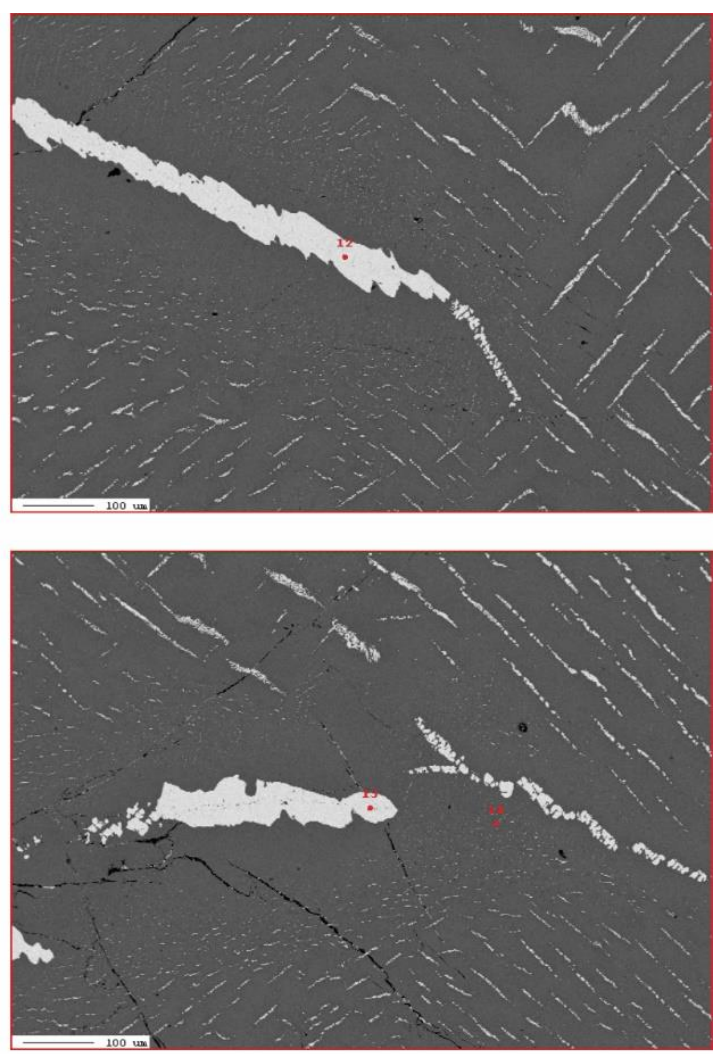
CC008 circle C EPMA
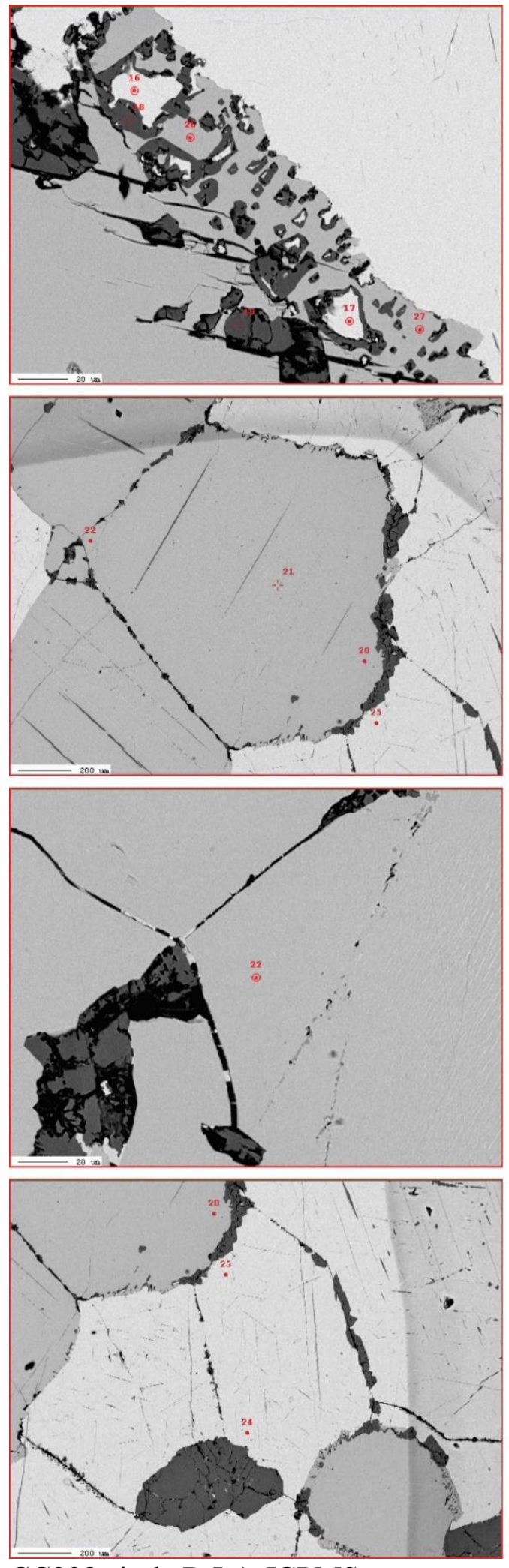

CC008 circle D LA-ICPMS
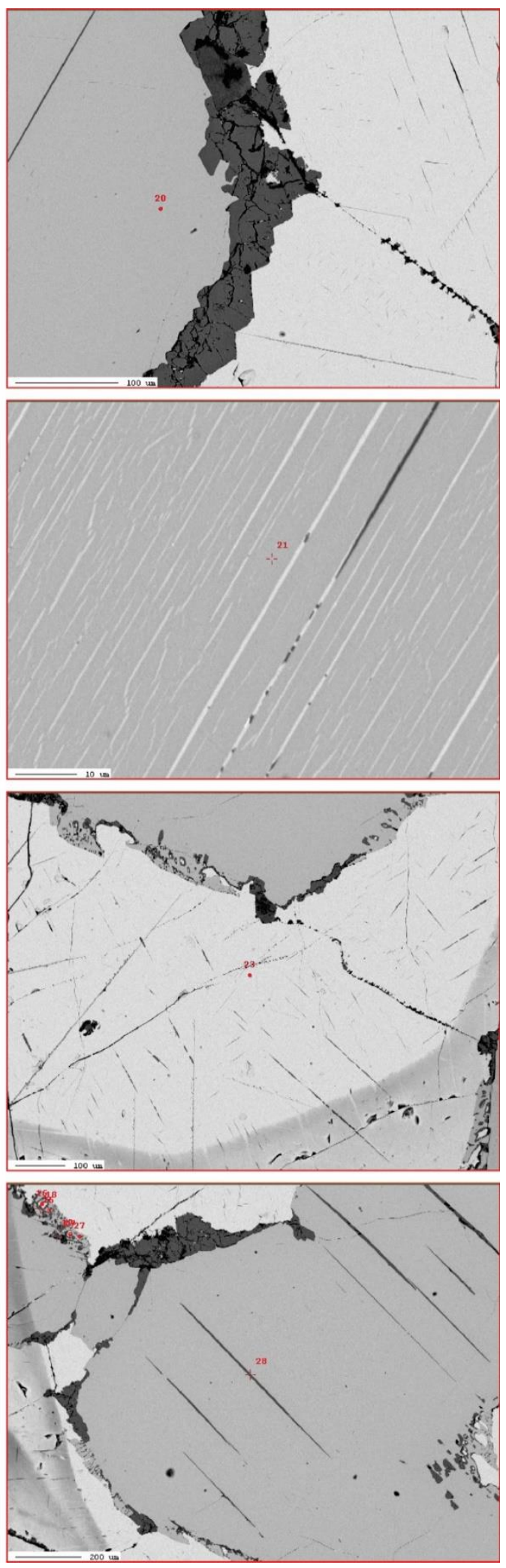


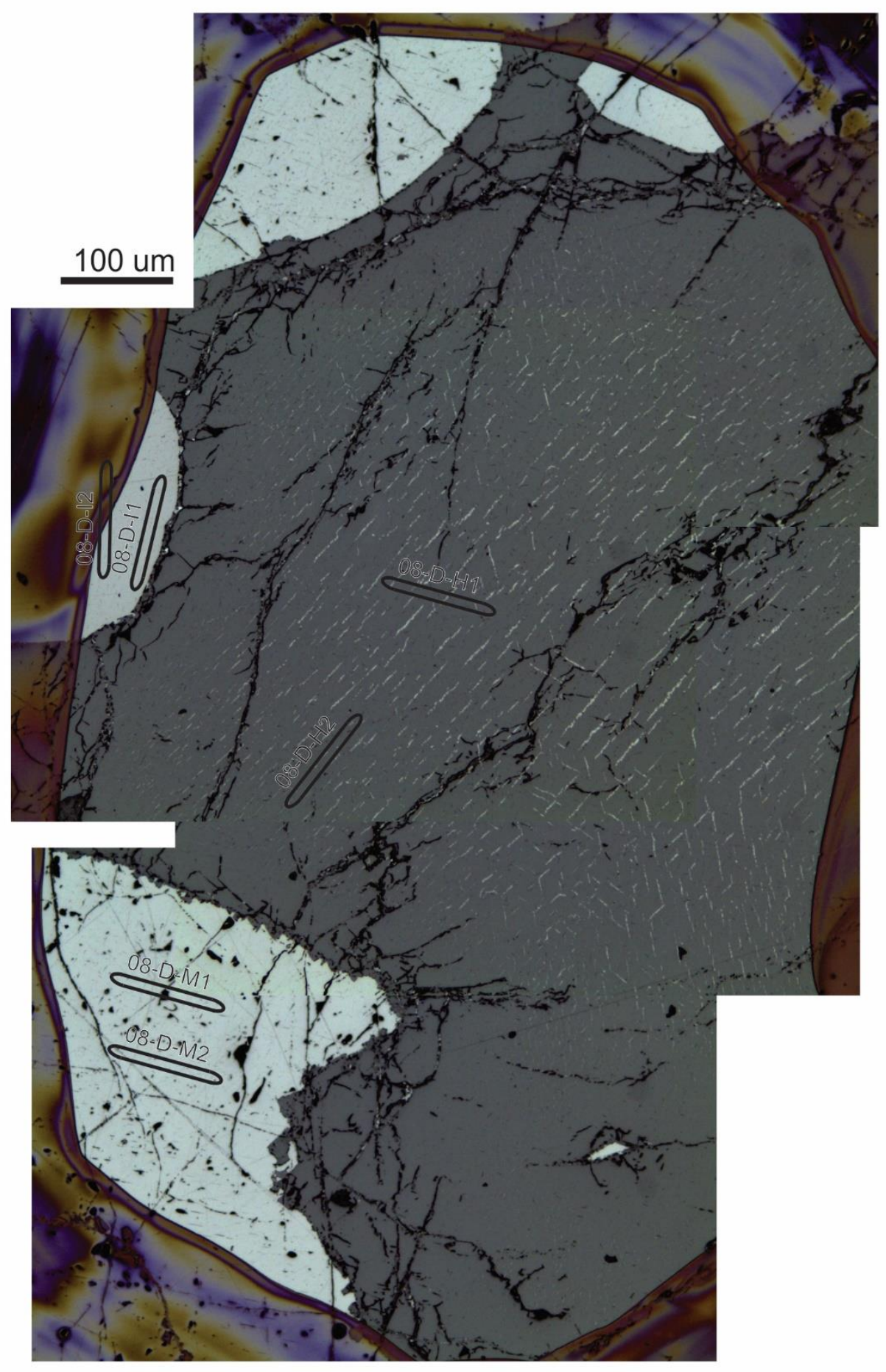


CC008 circle D EPMA
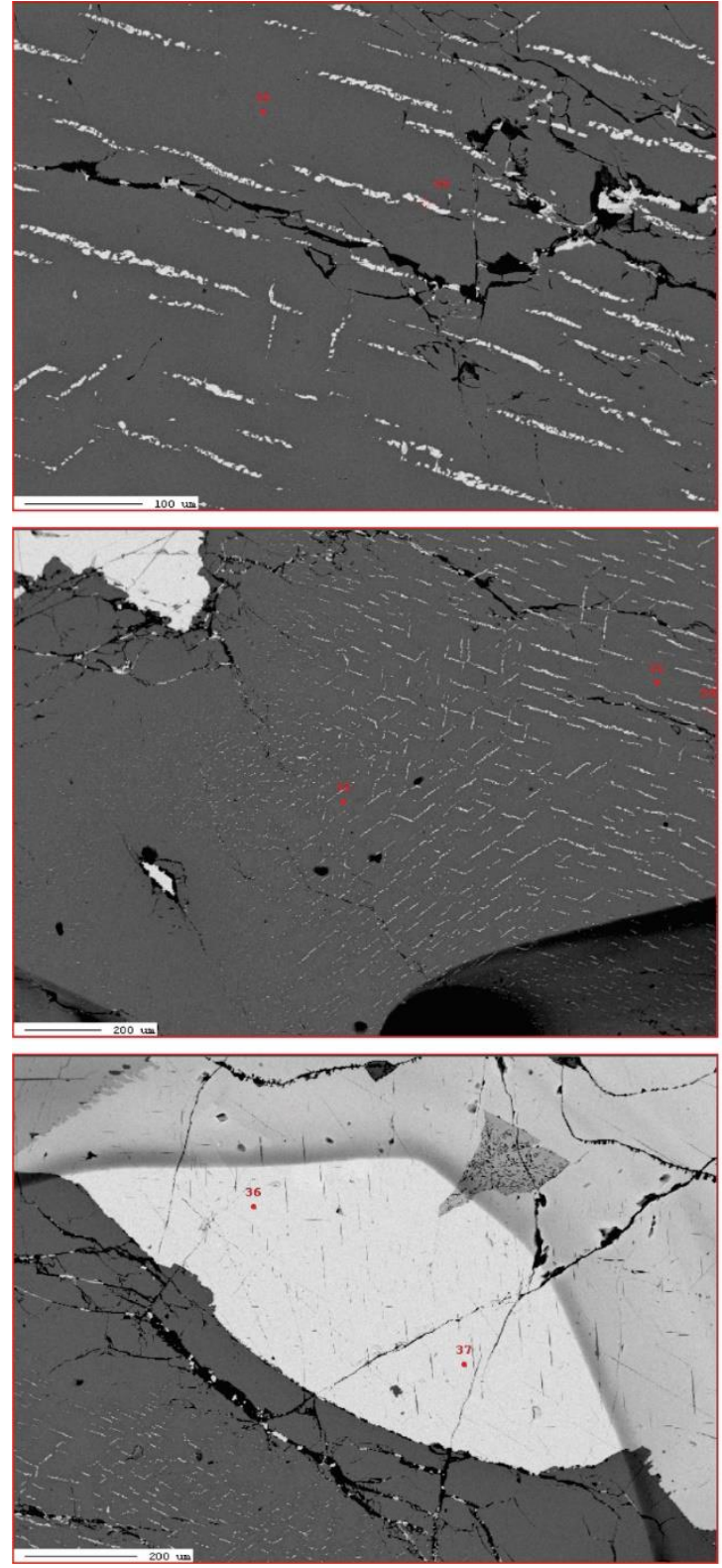
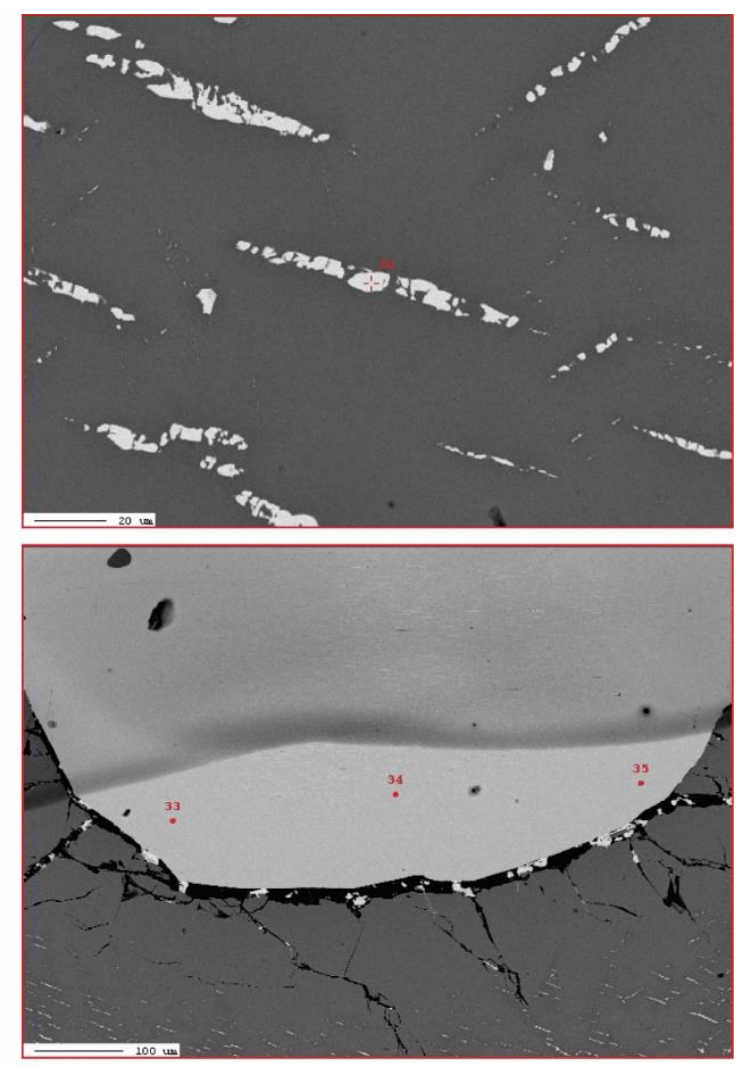
CC008 circle E EPMA

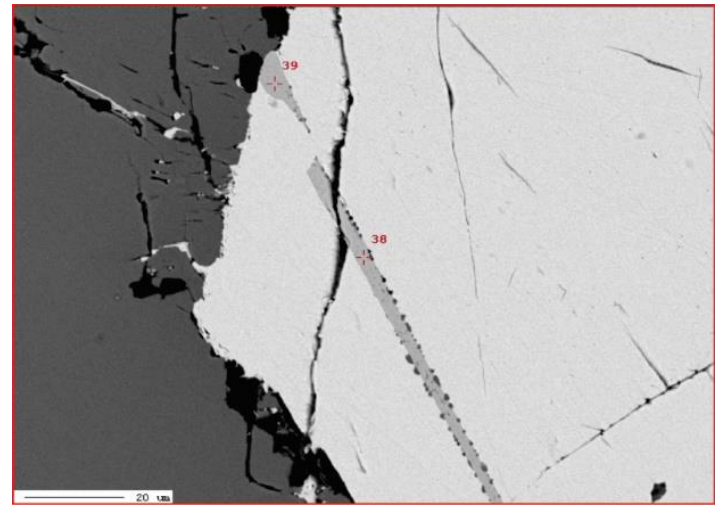


CC008 circle F LA-ICPMS

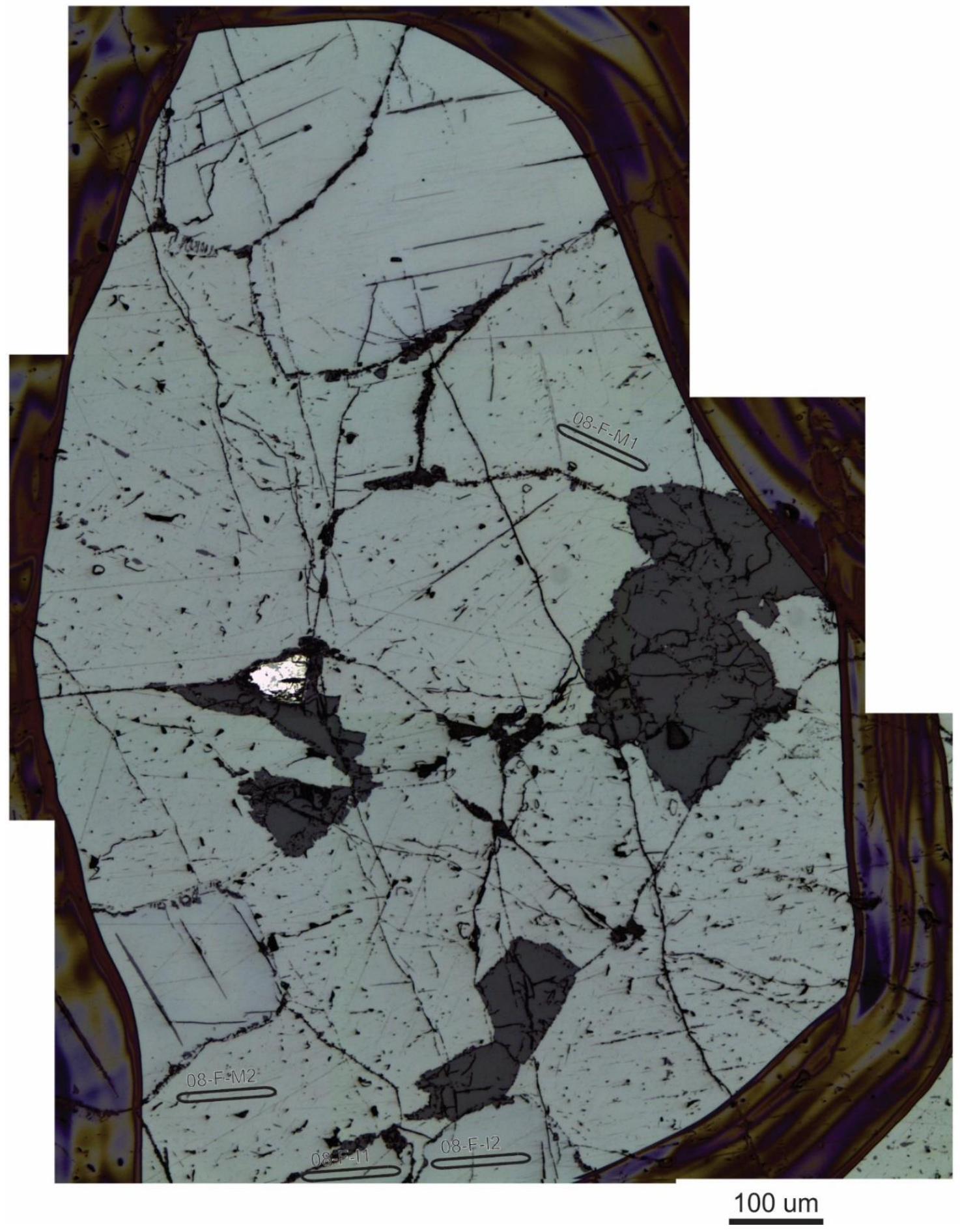


CC008 circle F EPMA
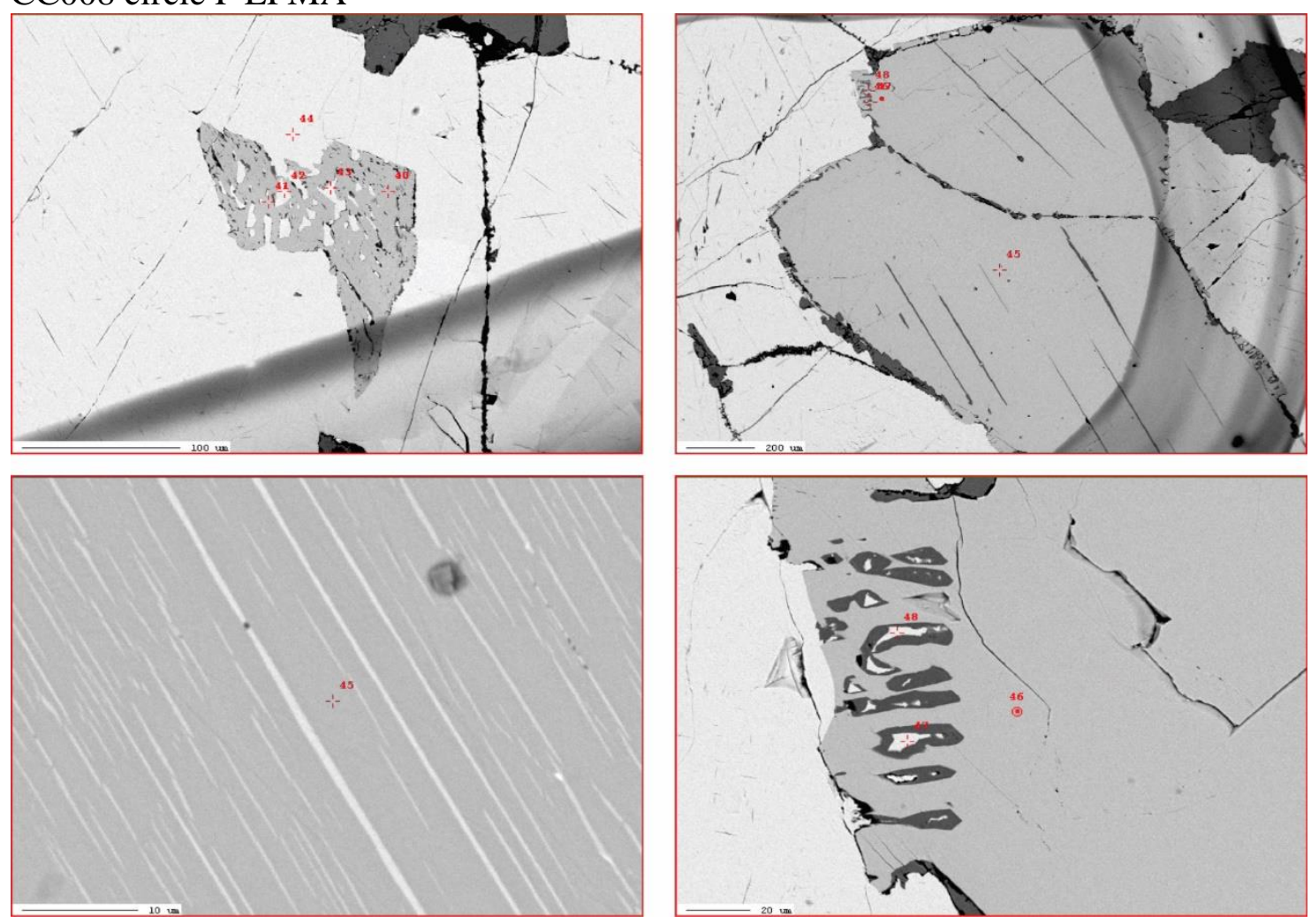
CC008 circle H LA-ICPMS

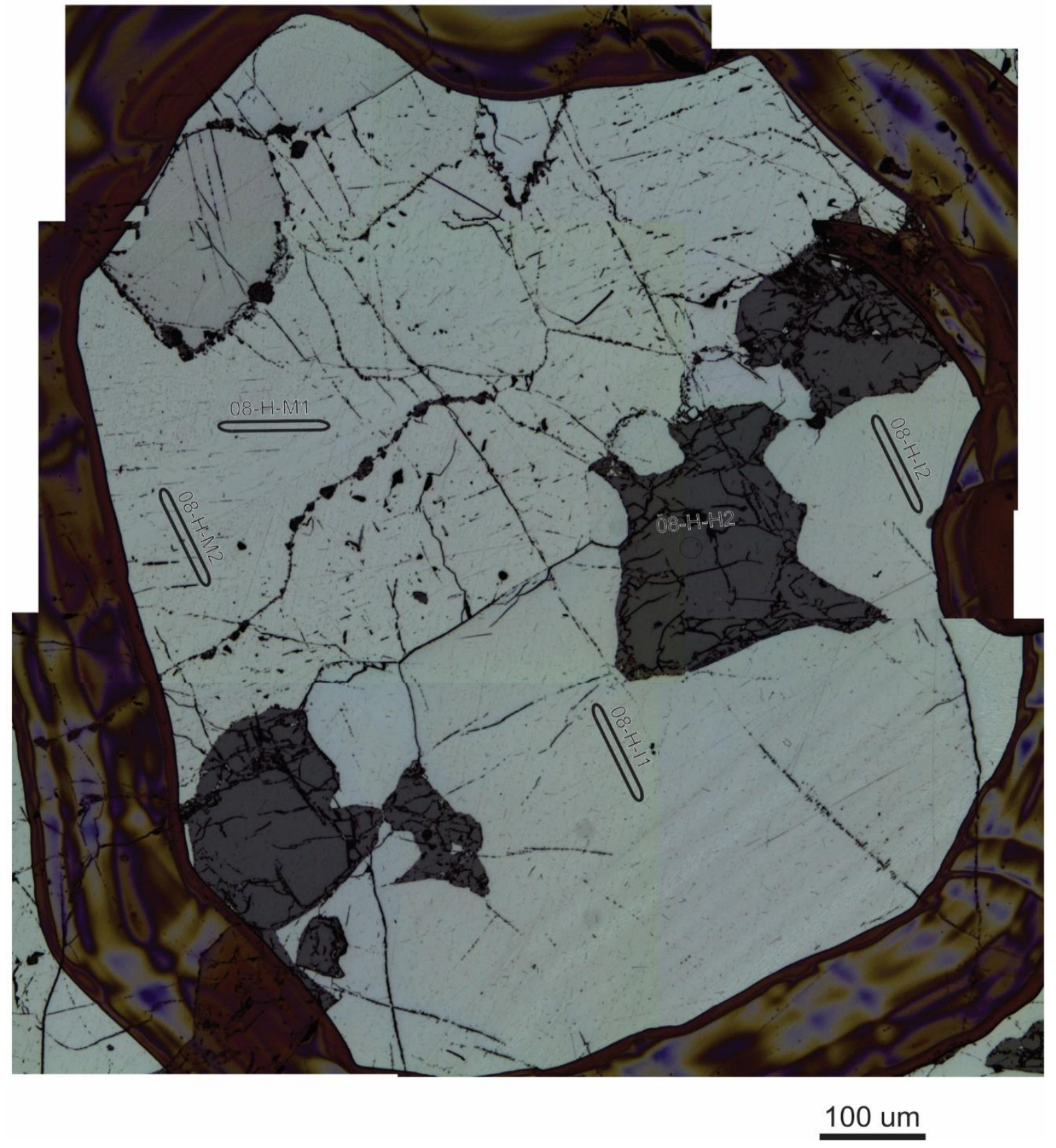


CC008 circle I EPMA
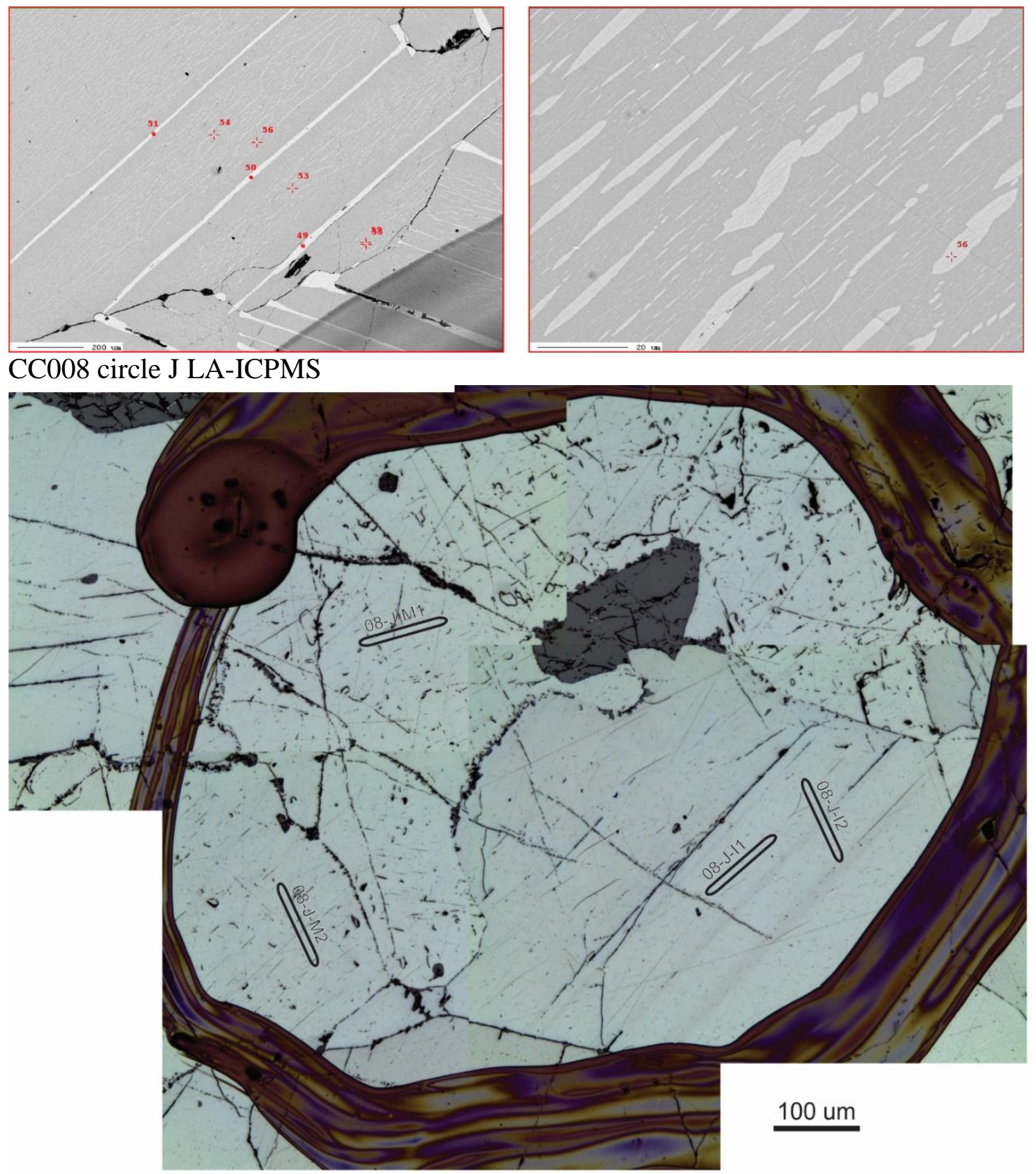
CC010 circle A LA-ICPMS

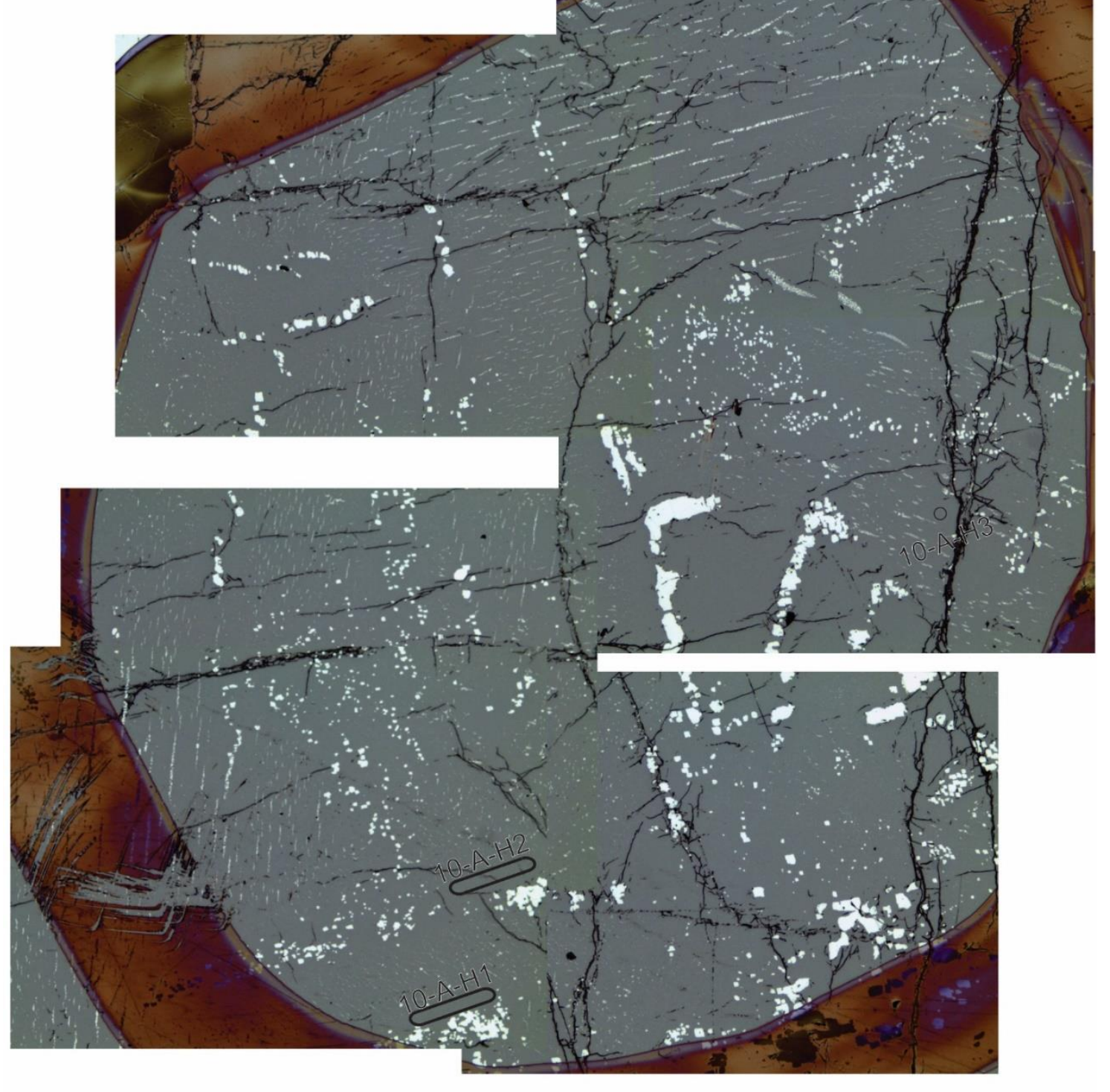

100 um 
CC010 circle A EPMA
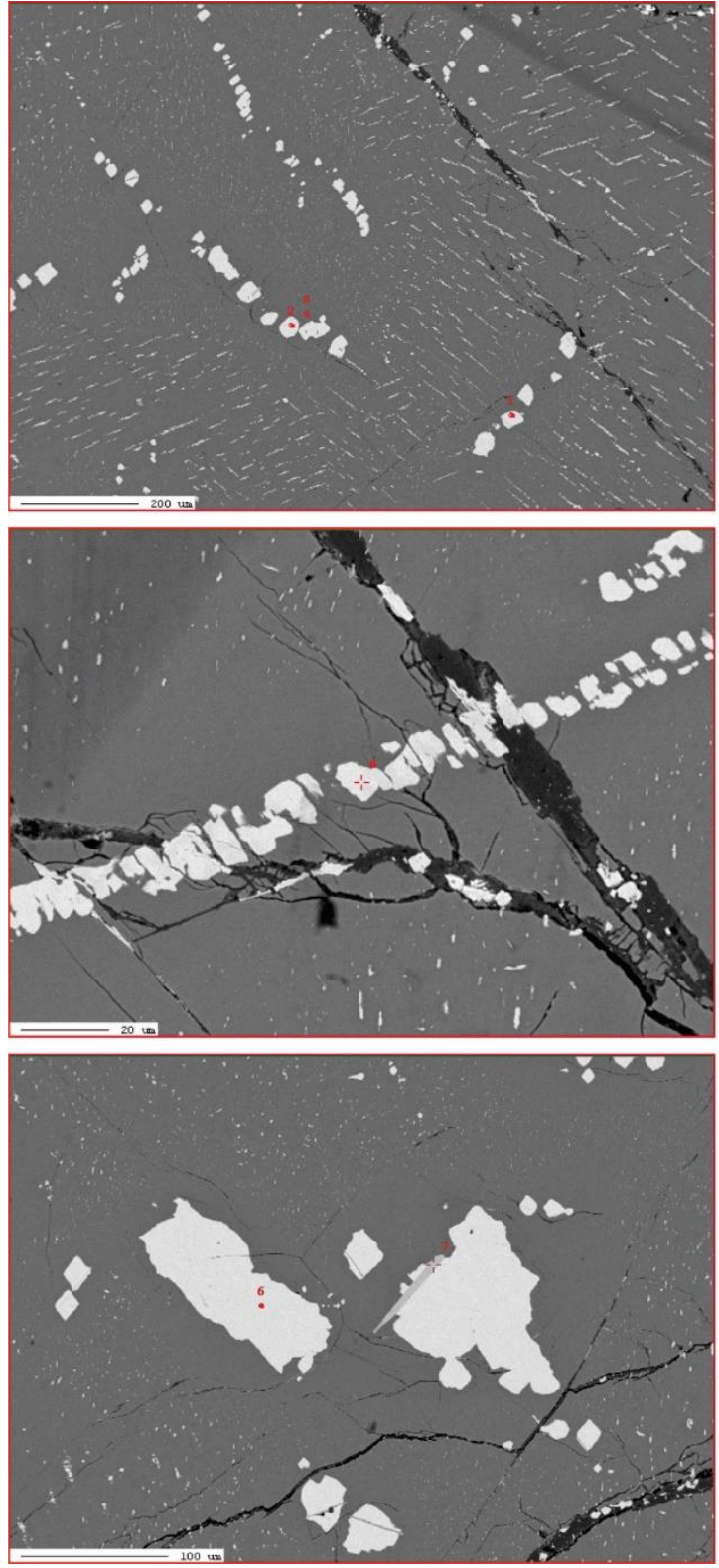
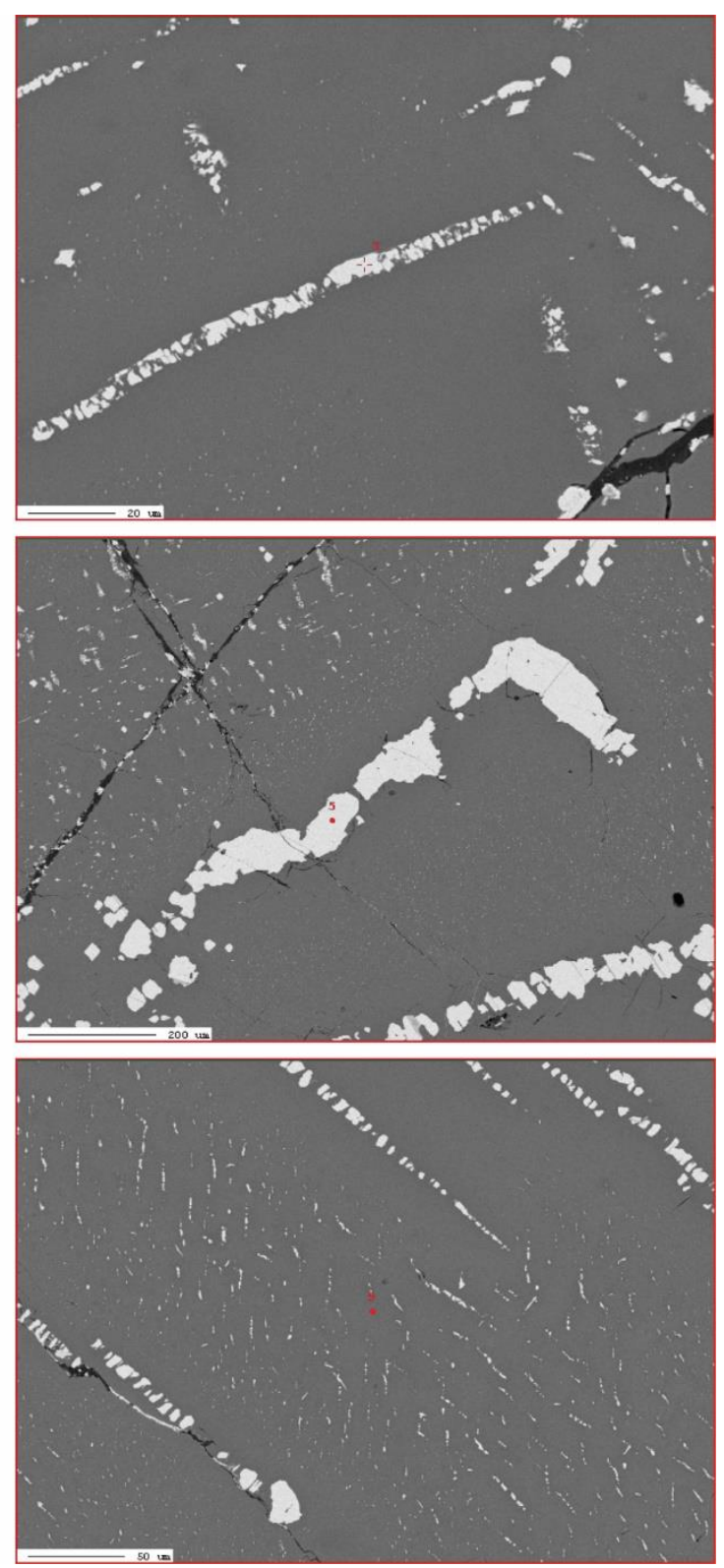


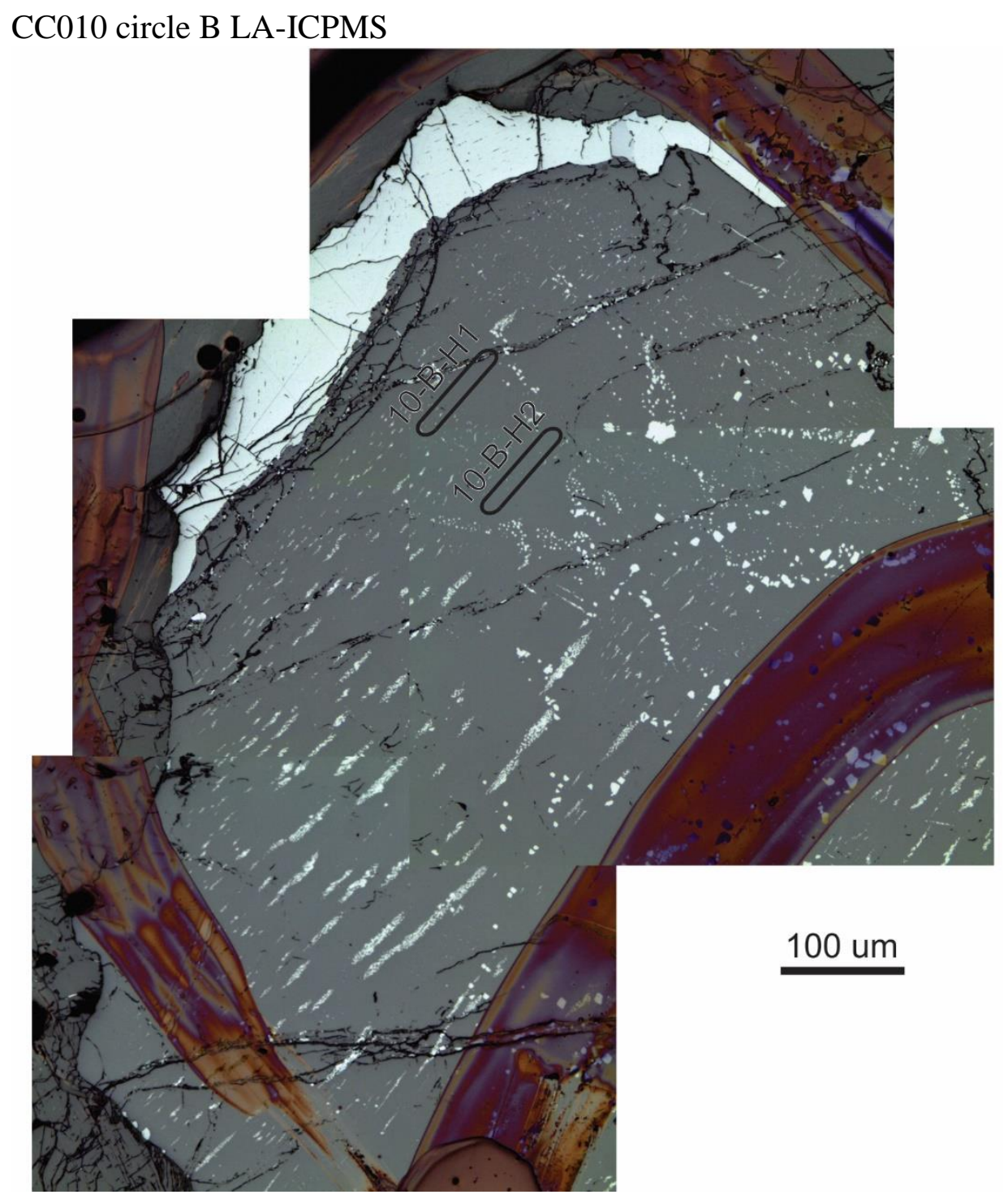


CC010 circle D LA-ICPMS

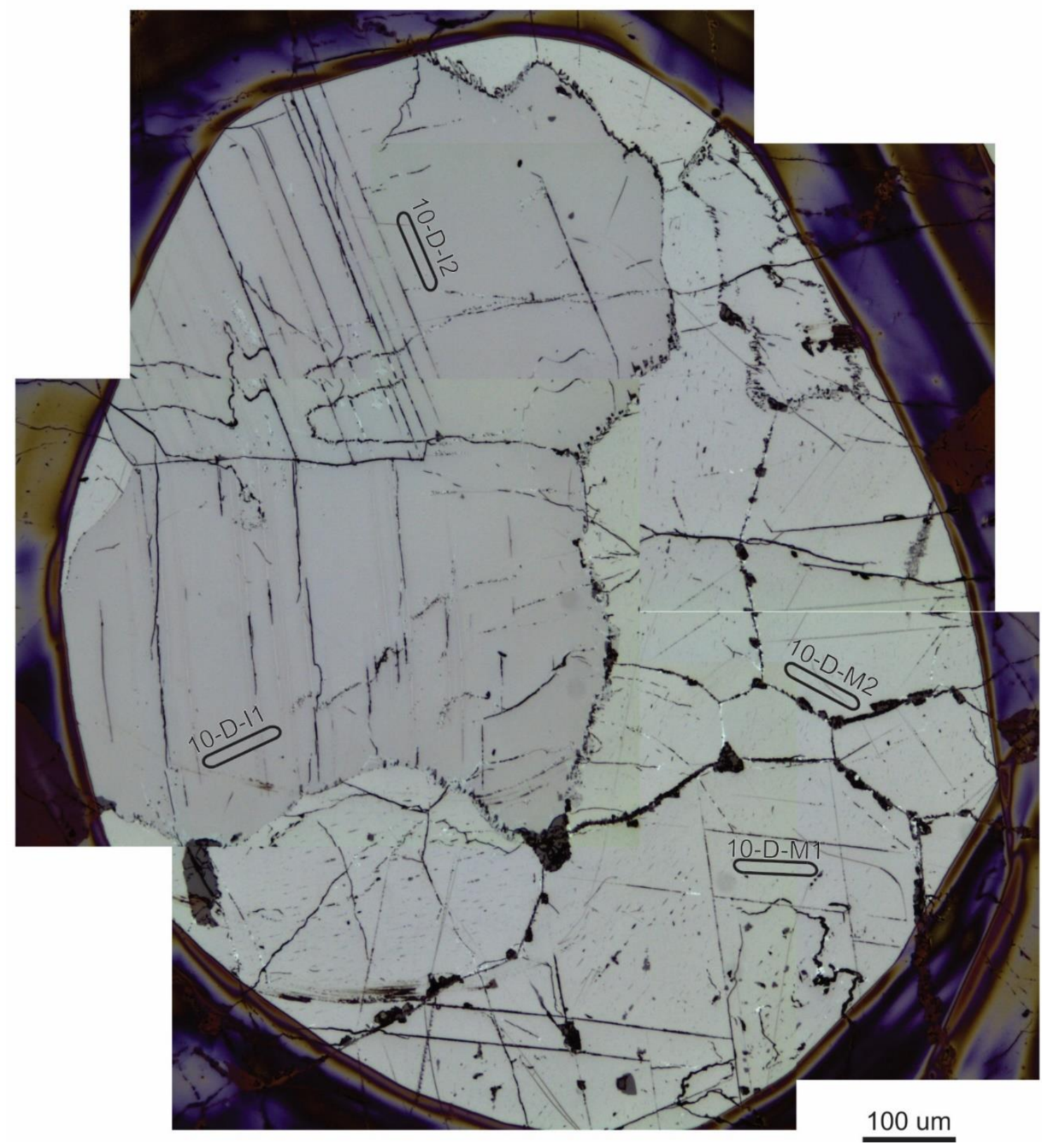


CC010 circle D EPMA
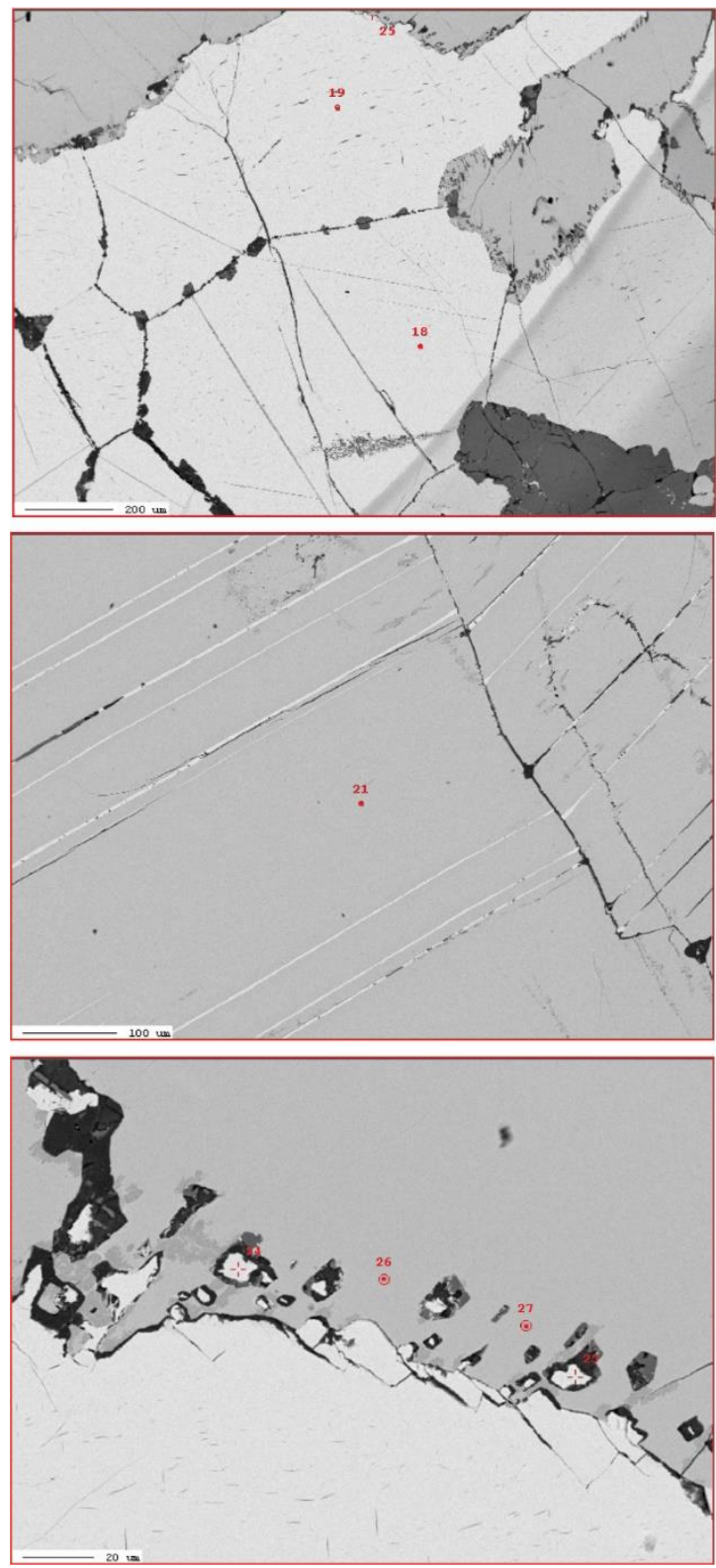
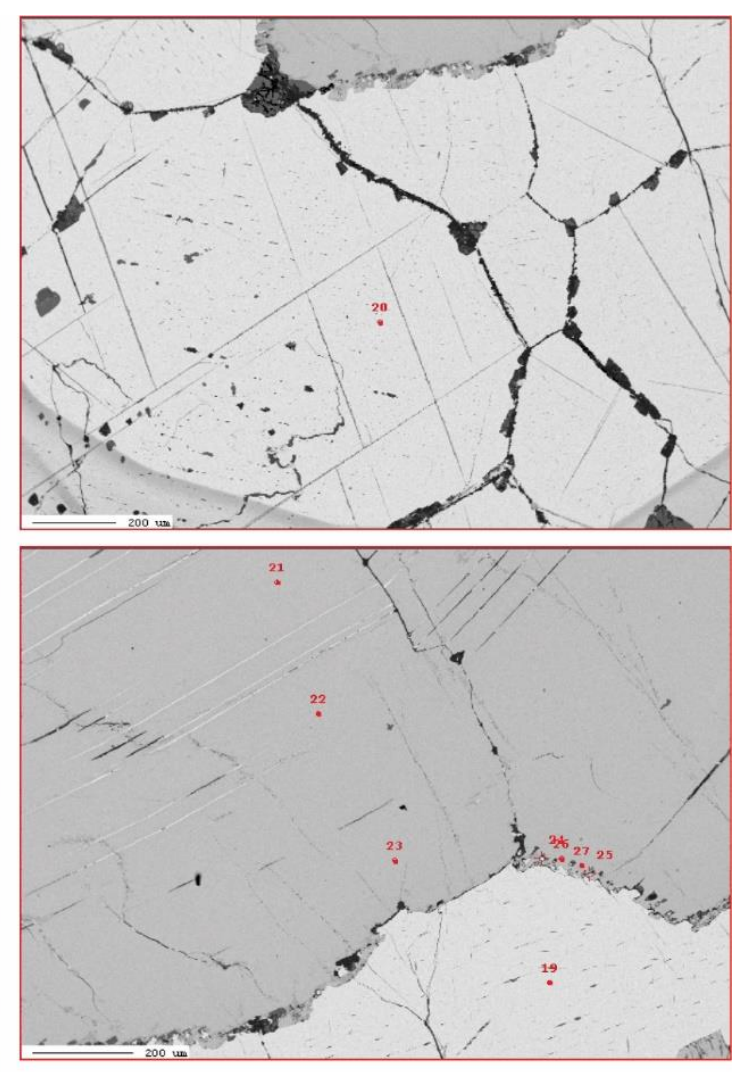
CC010 circle E LA-ICPMS

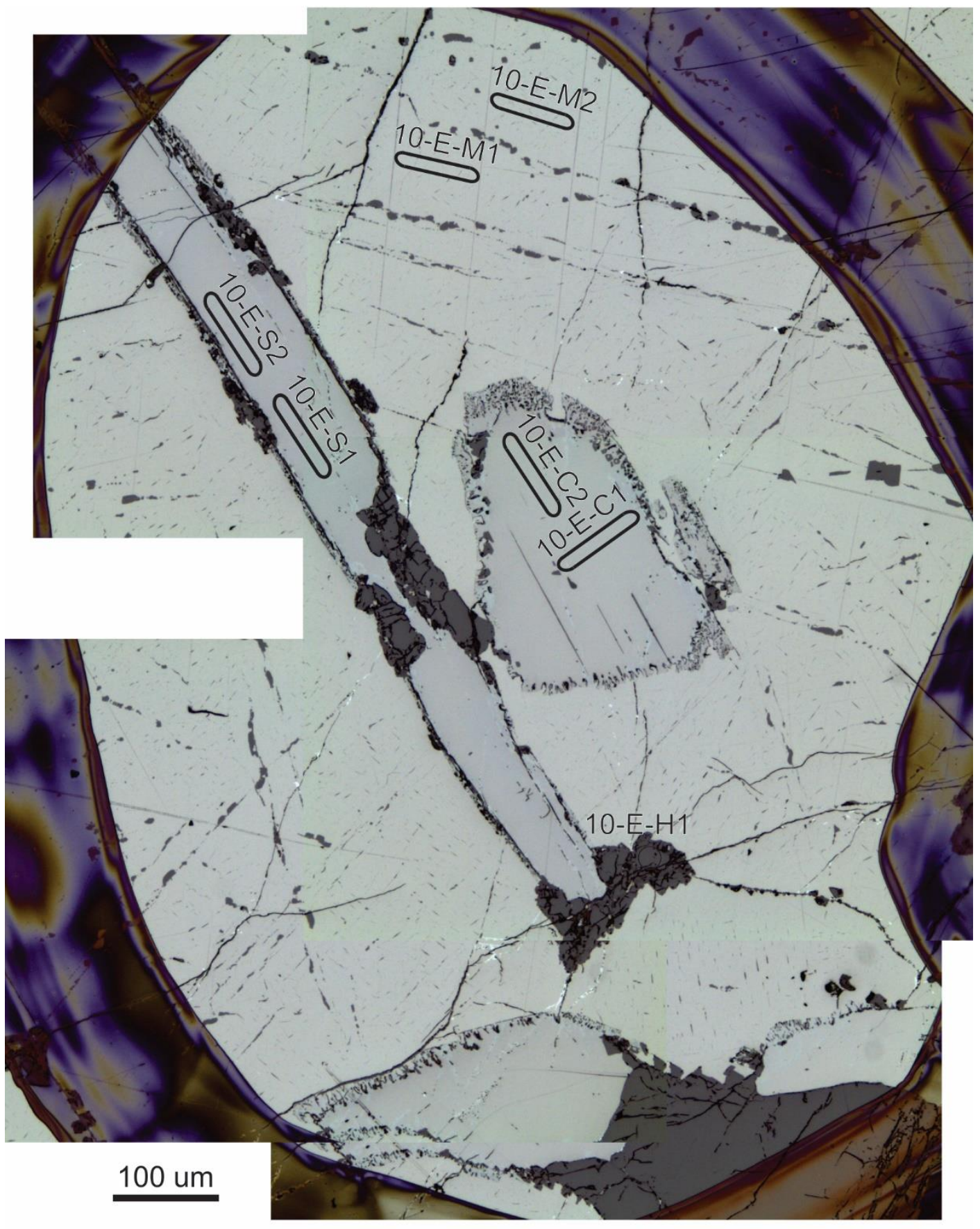


CC010 circle E EPMA
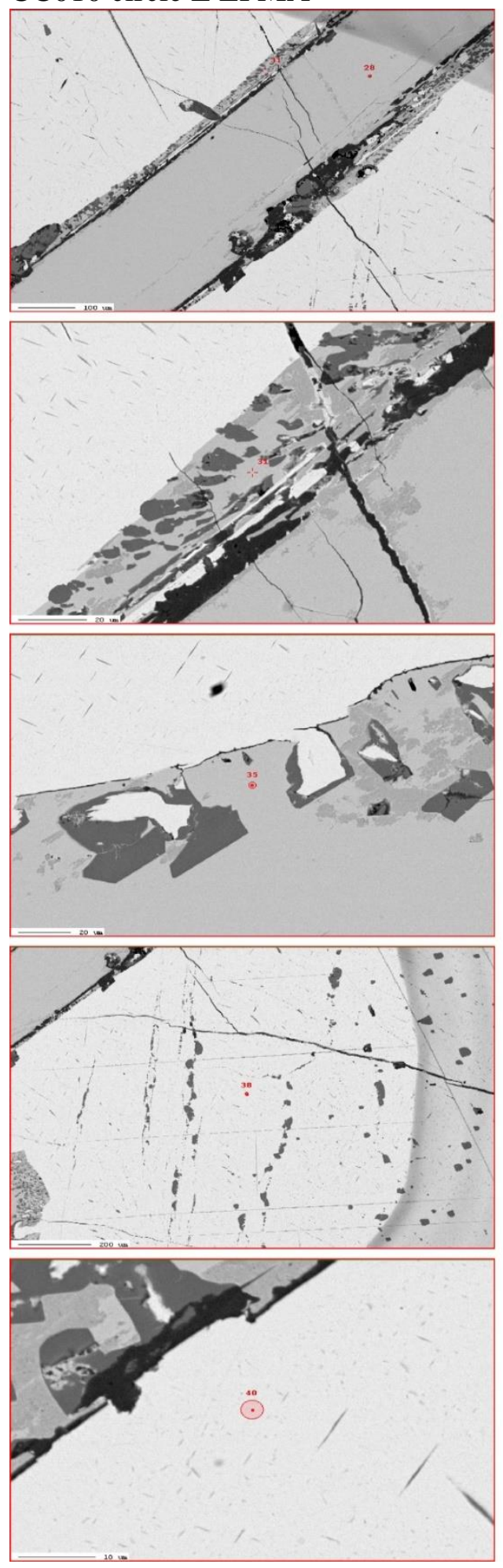
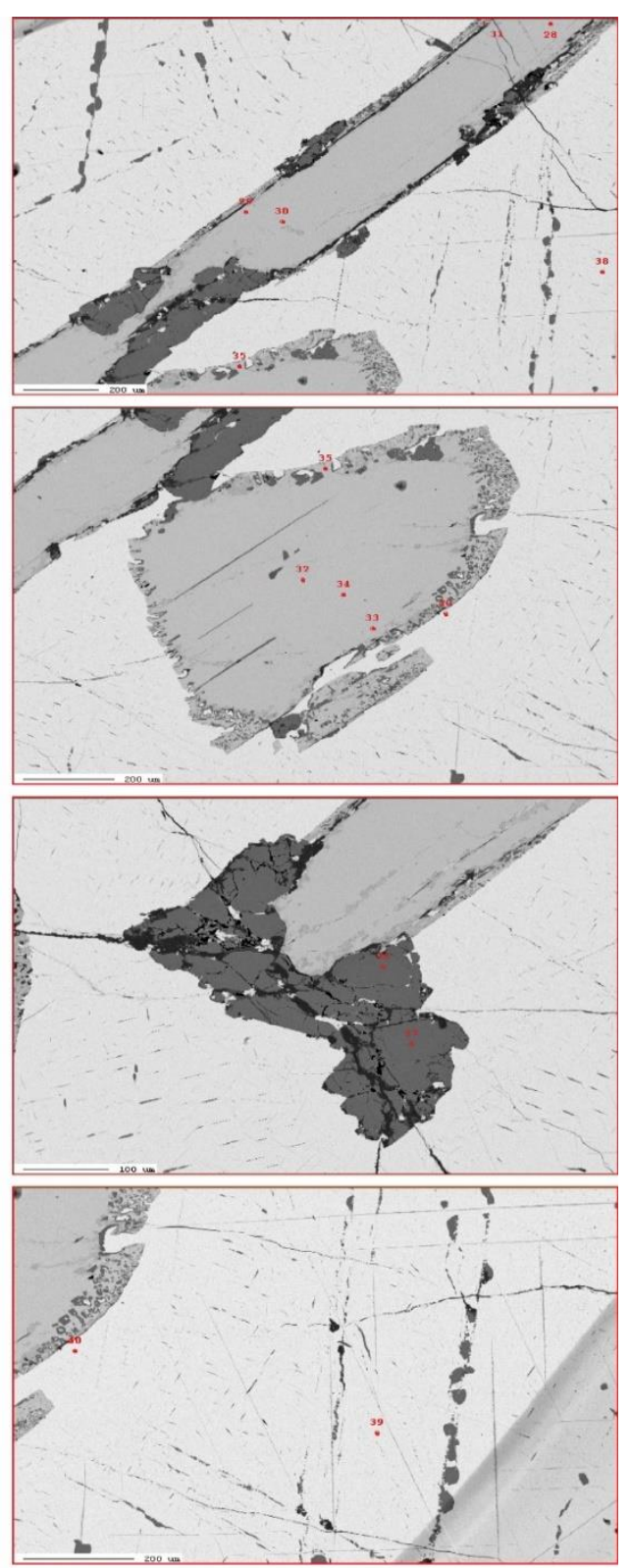
CC010 circle F LA-ICPMS

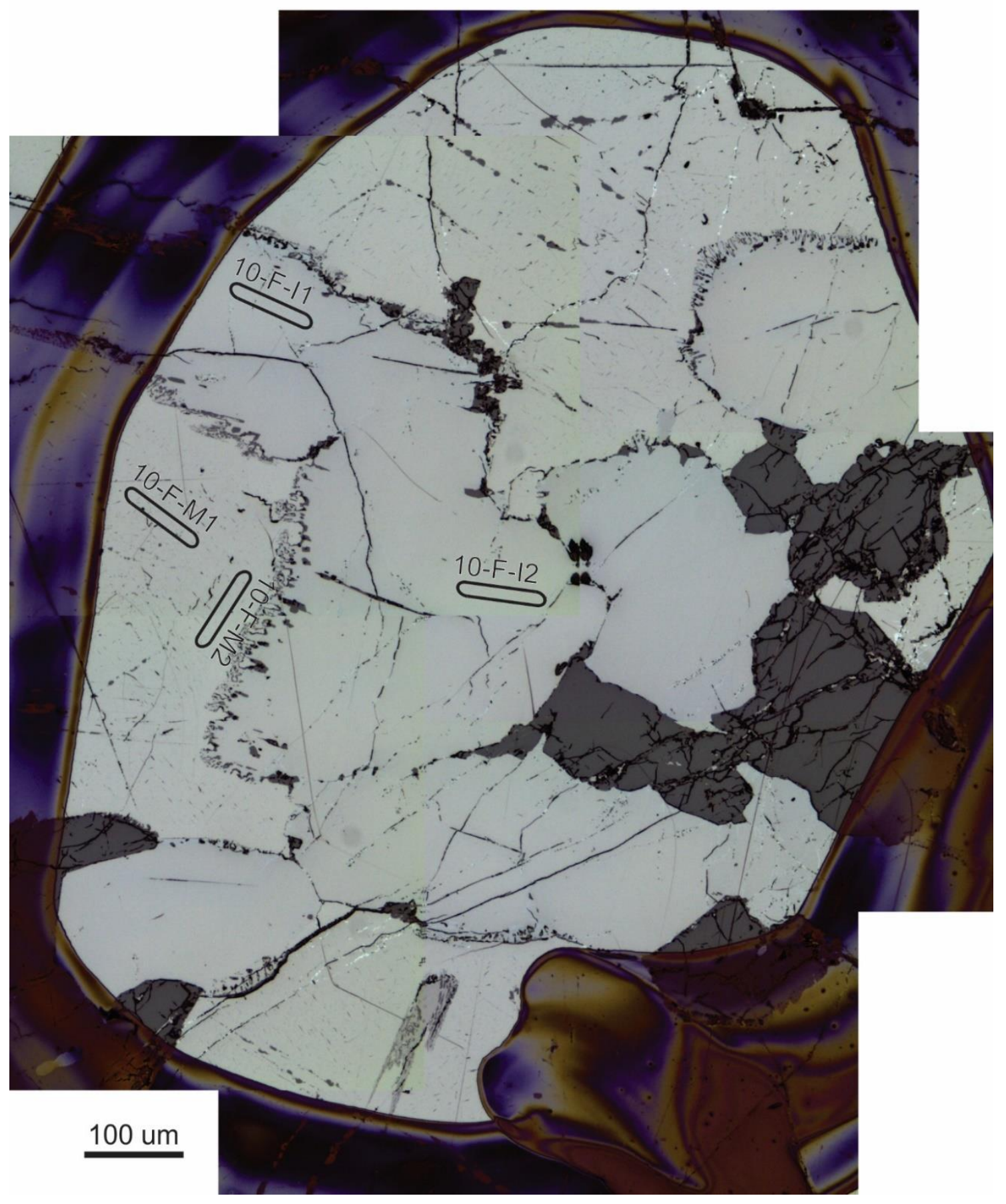


CC010 circle F EPMA
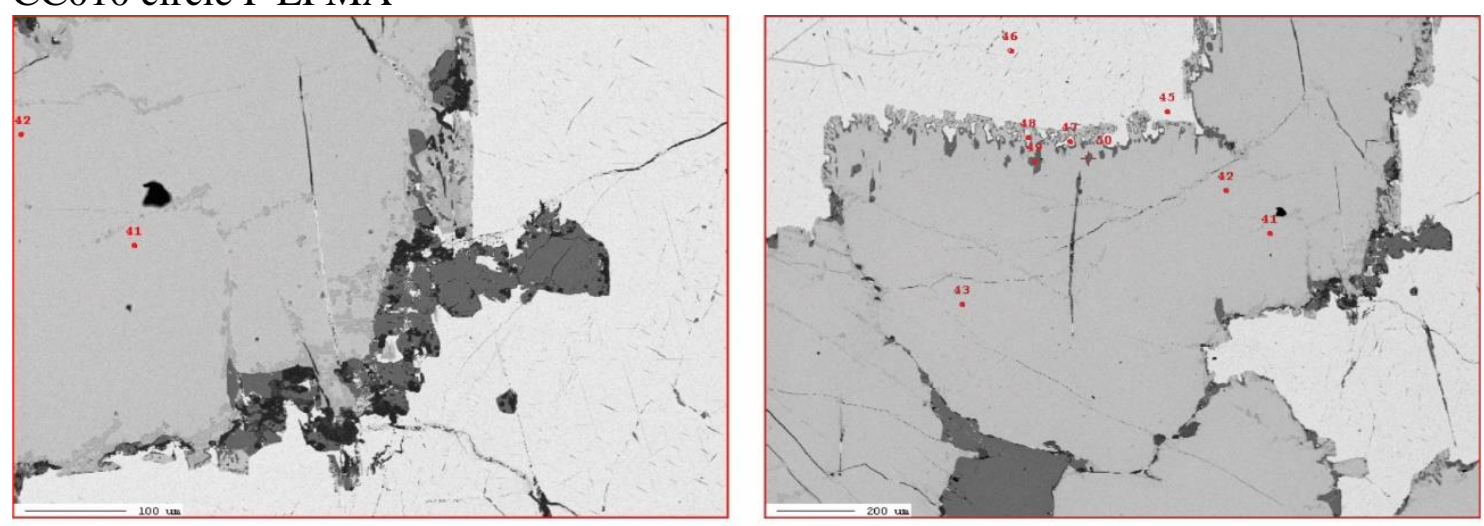

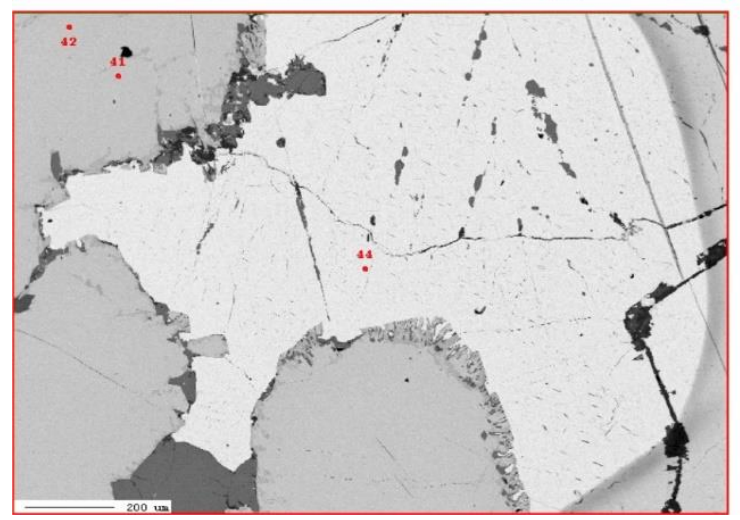




\section{CC010 circle H LA-ICPMS}

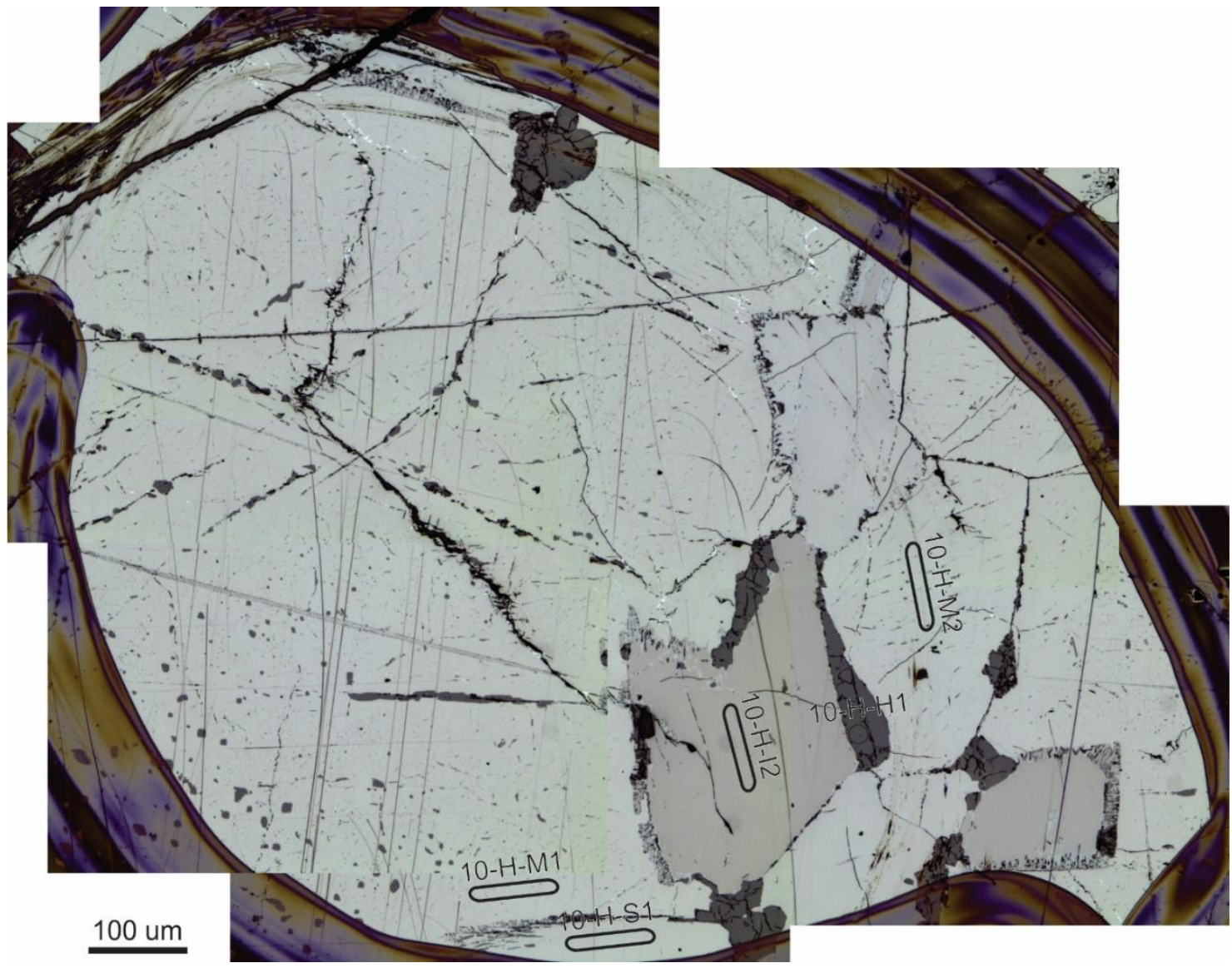

CC010 circle H EPMA
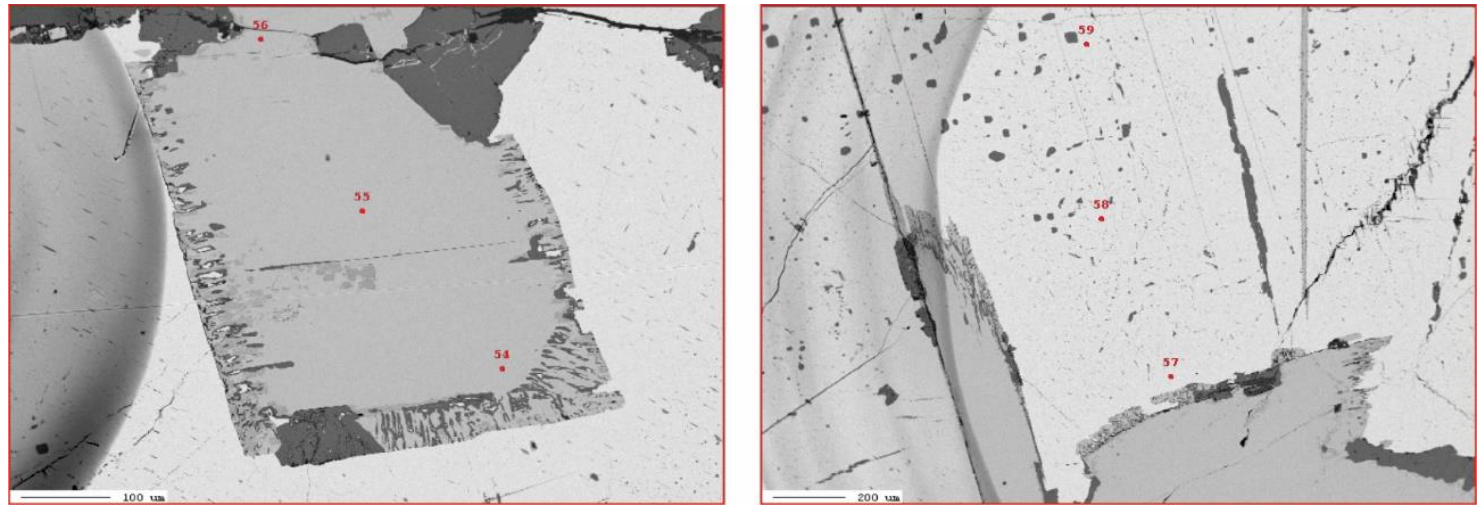
CC010 circle I LA-ICPMS

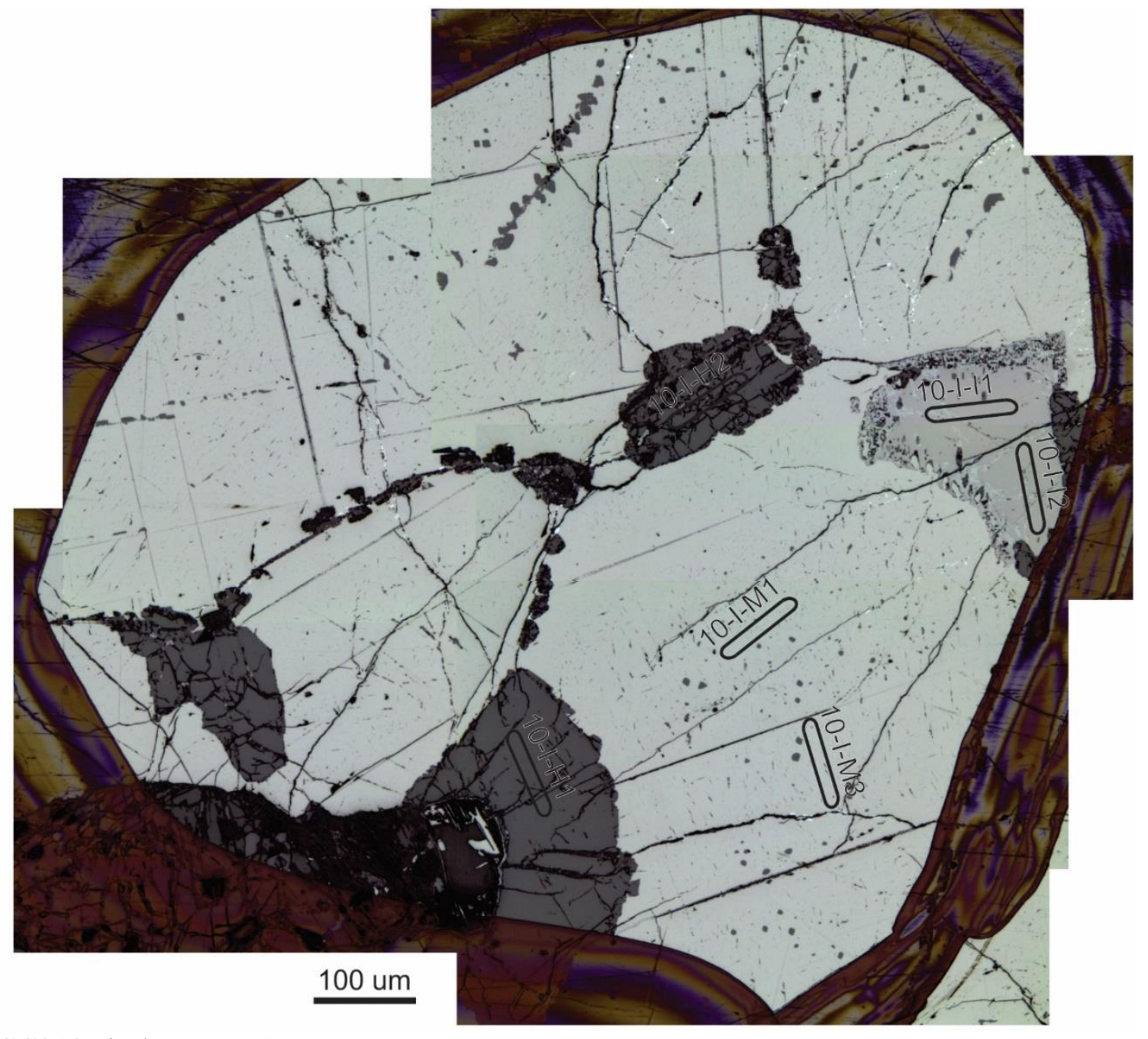

CC010 circle I EPMA

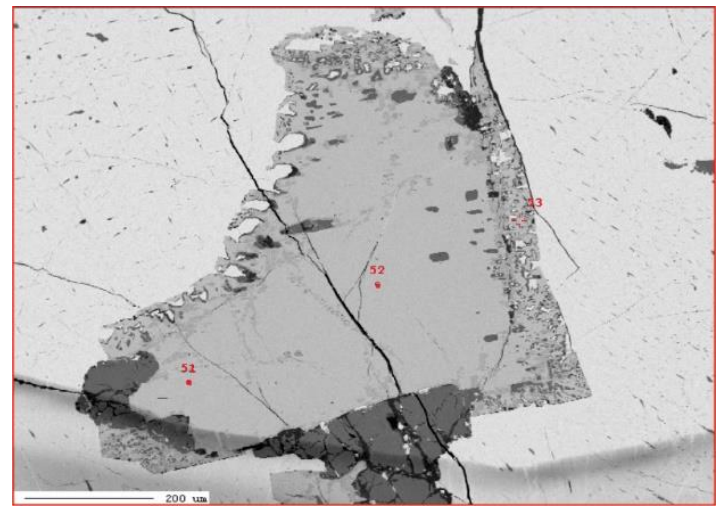




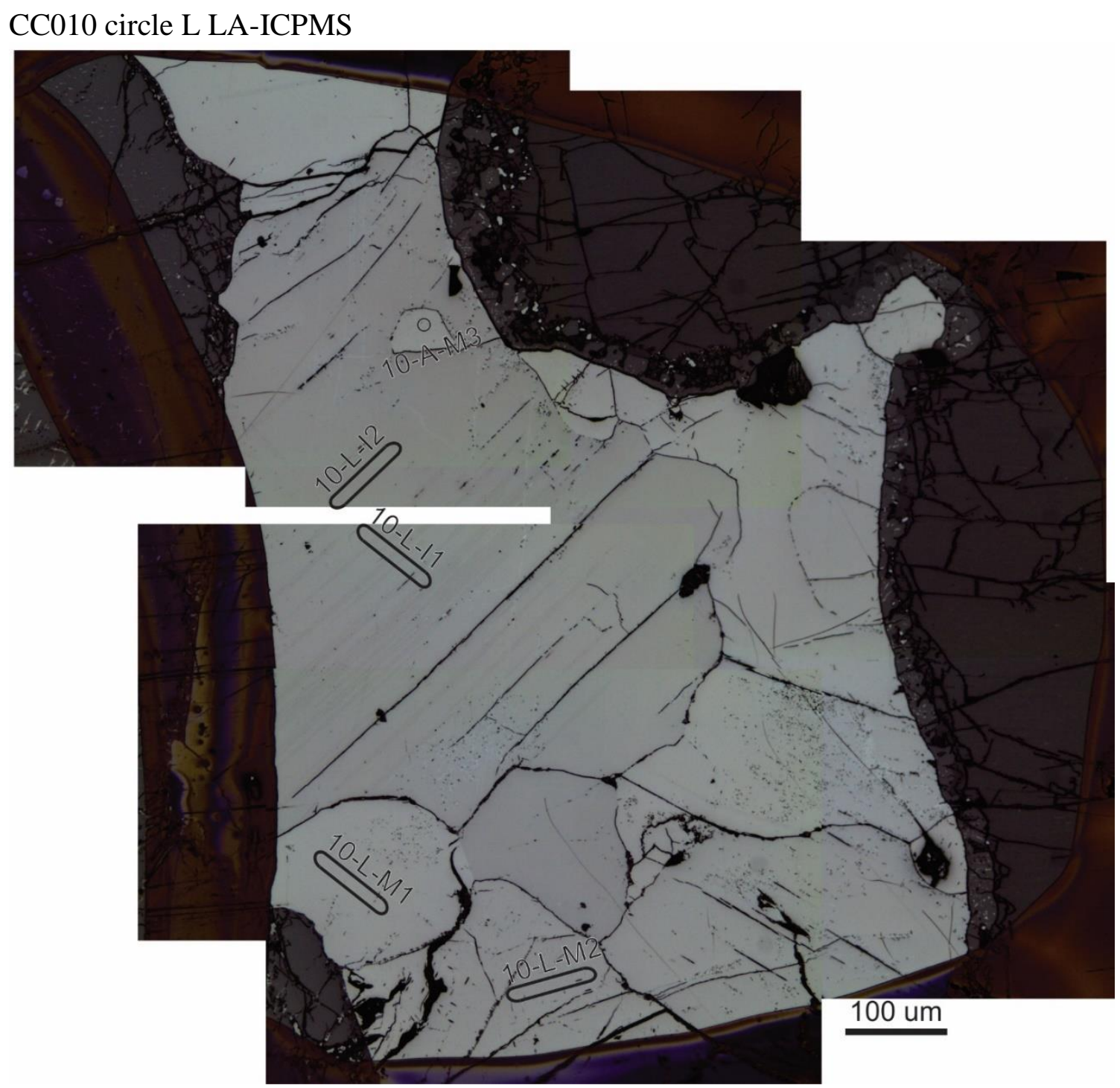


CC010 circle L EPMA

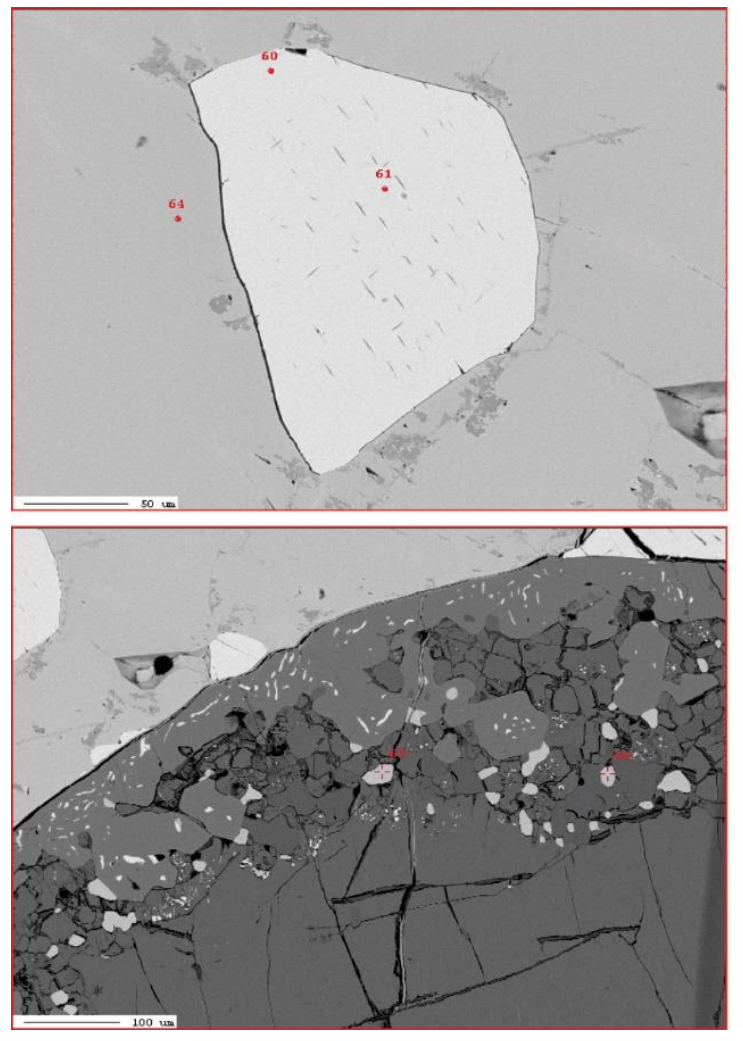

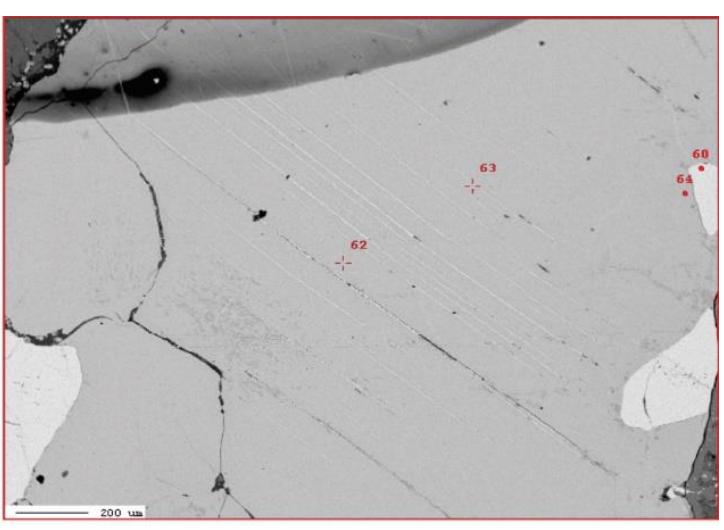




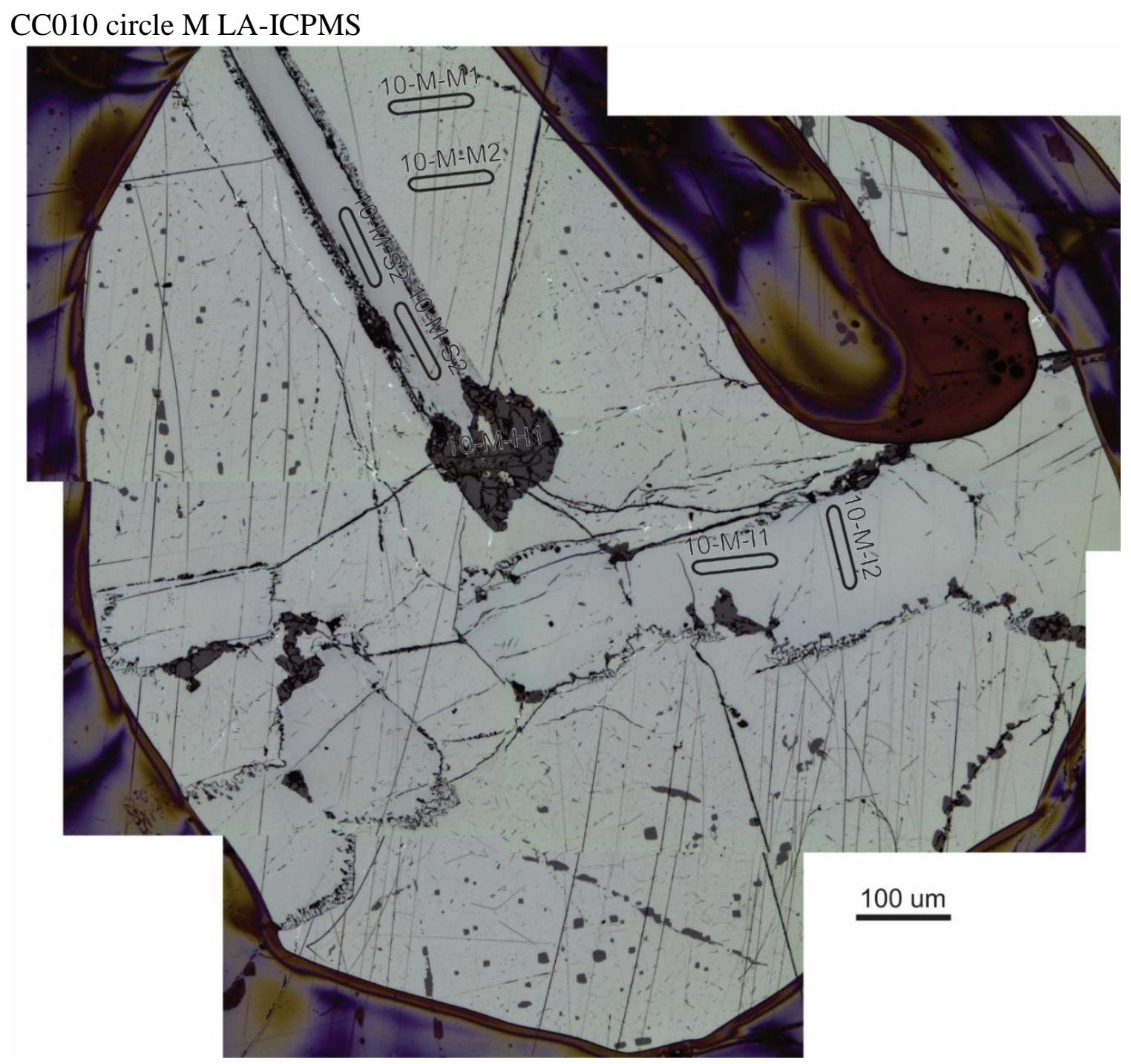


CC010 circle M EPMA
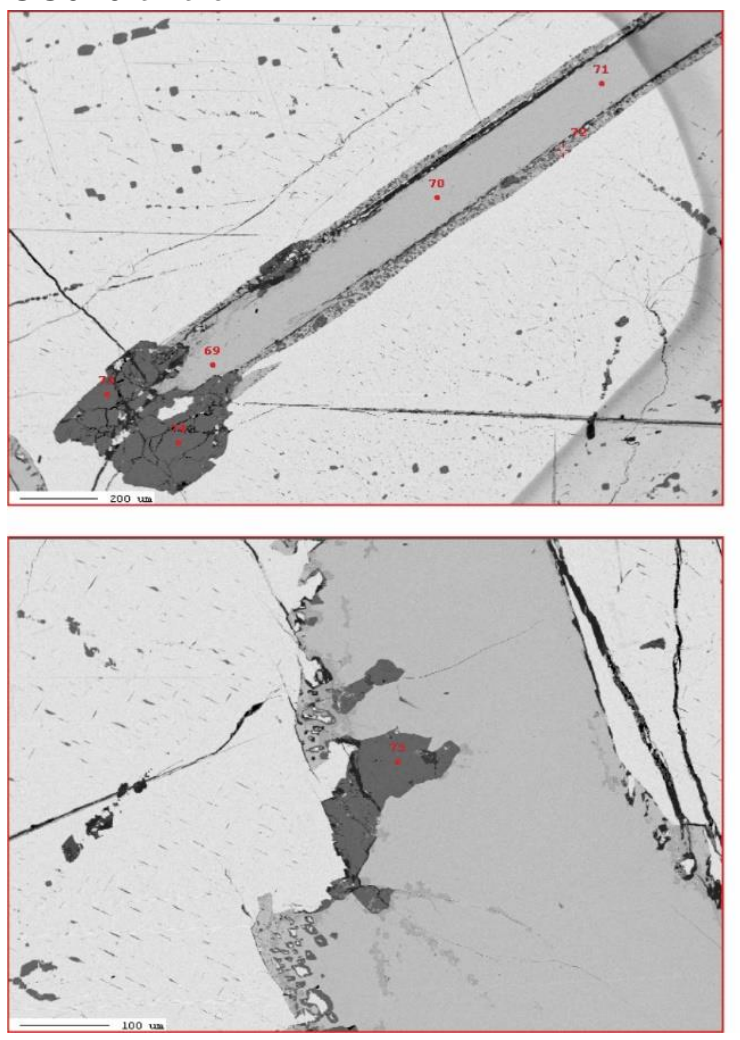
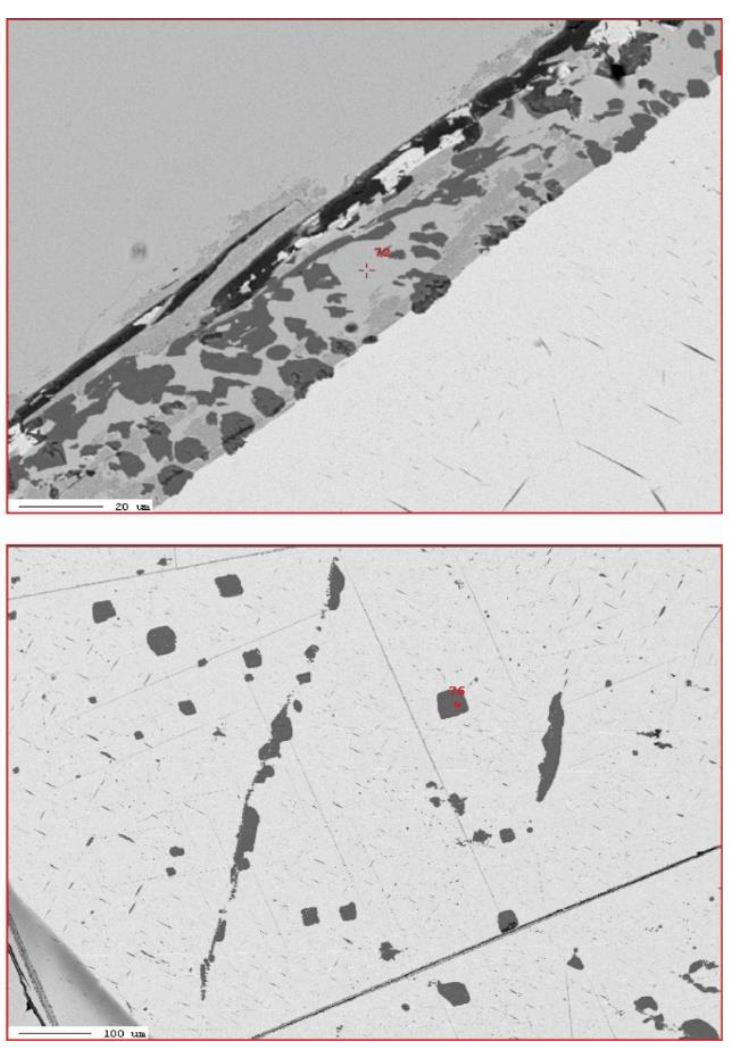


\section{CC010 circle O LA-ICPMS}

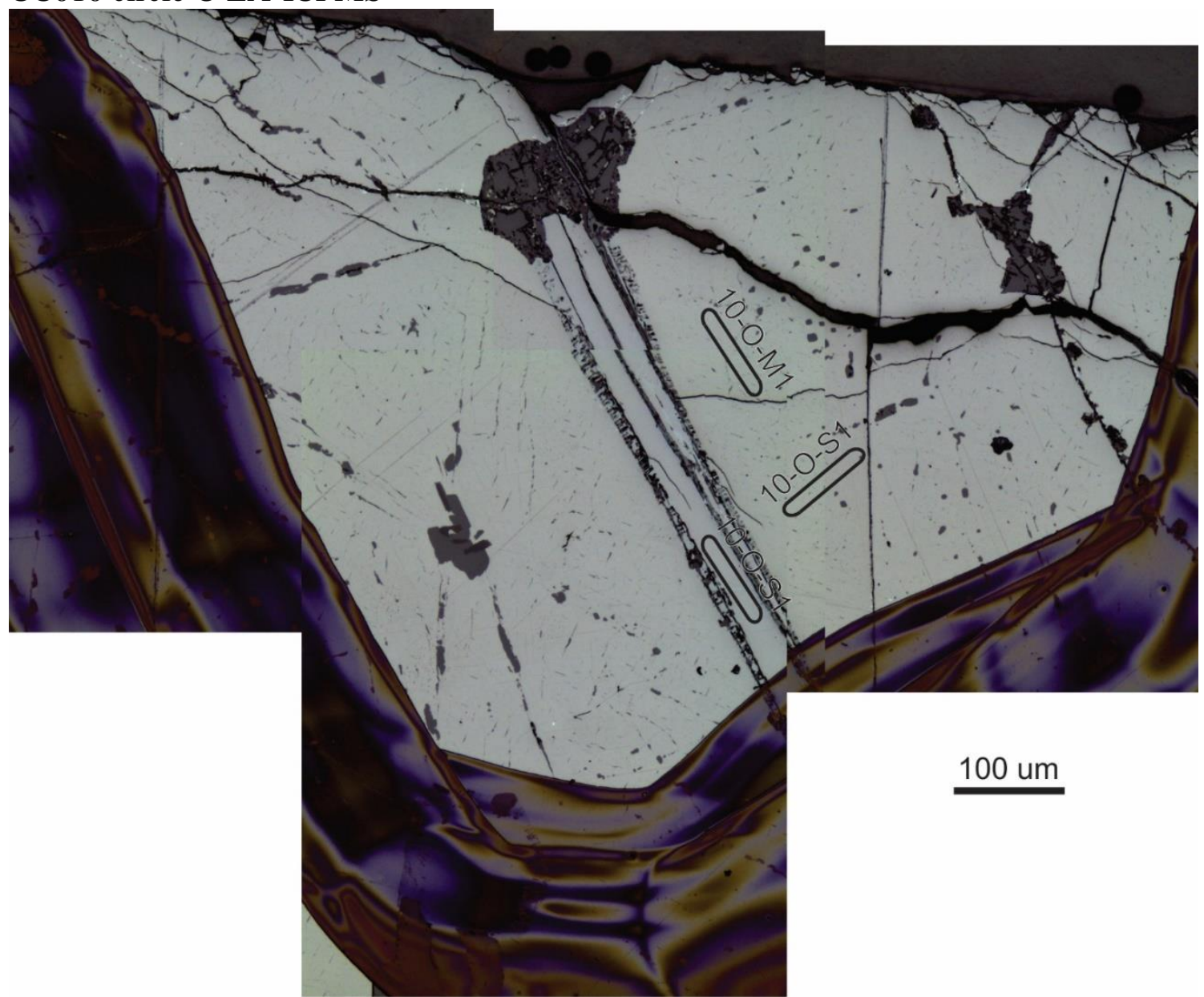

CC010 circle O EPMA

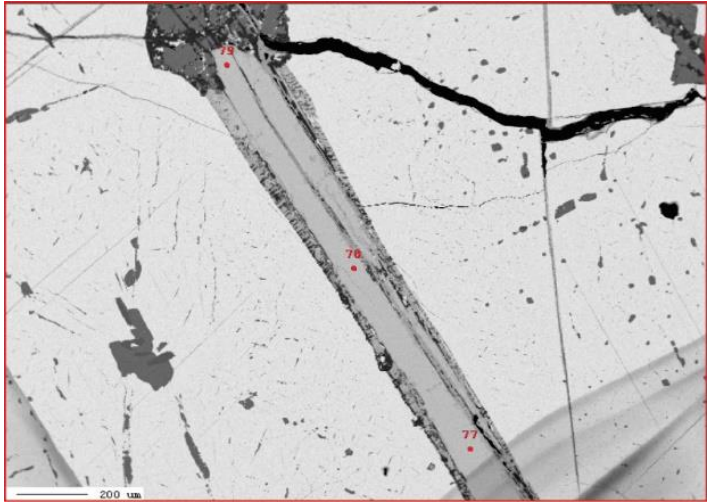


CC013 circle A LA-ICPMS

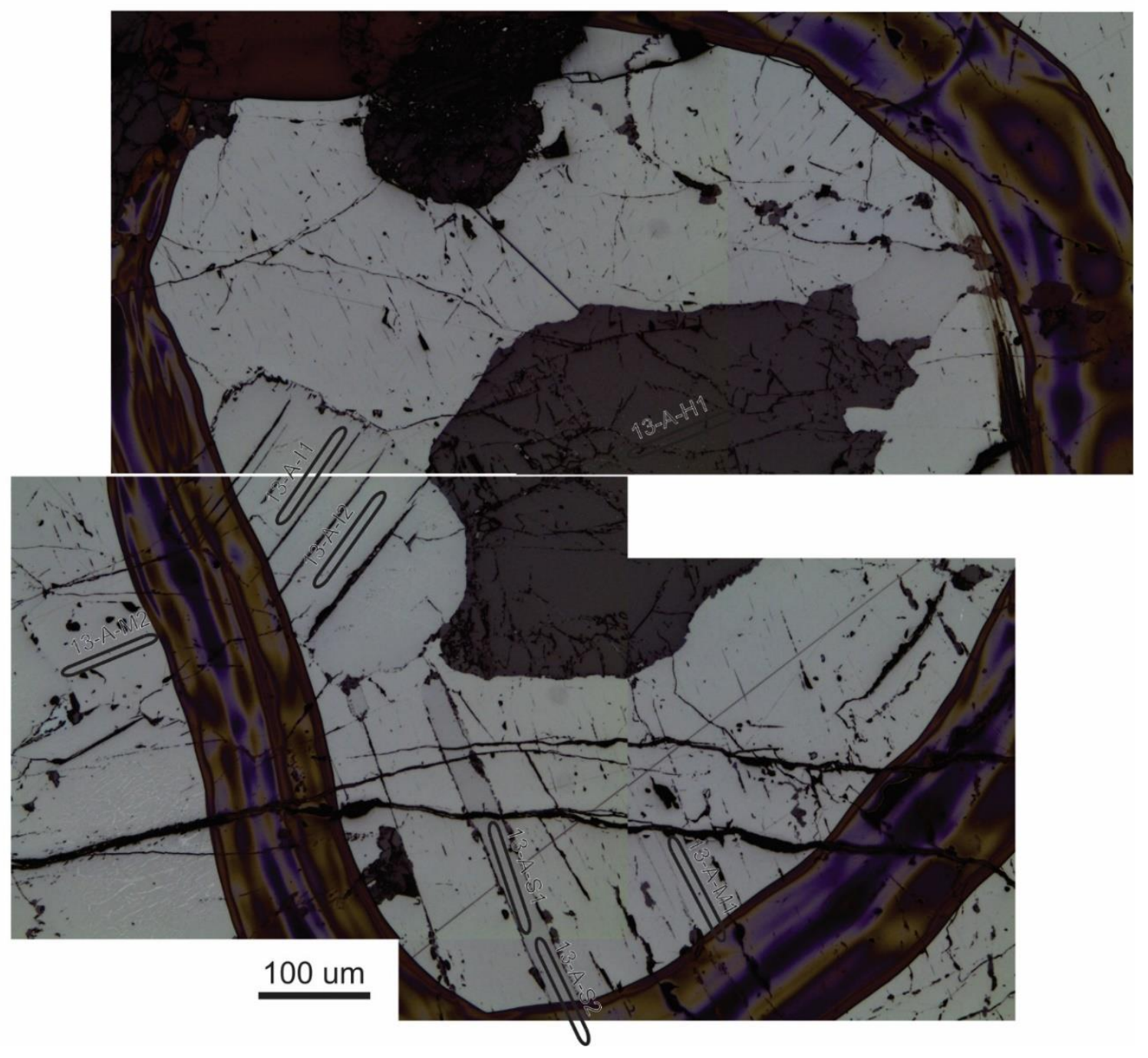


CC013 circle A EPMA
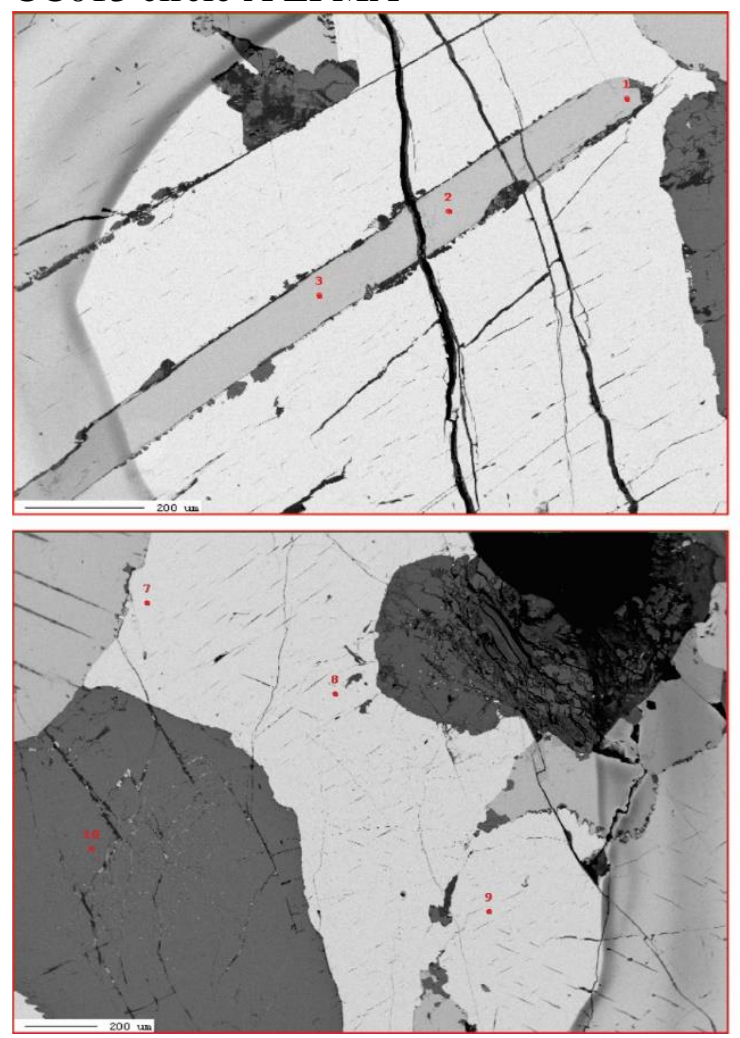

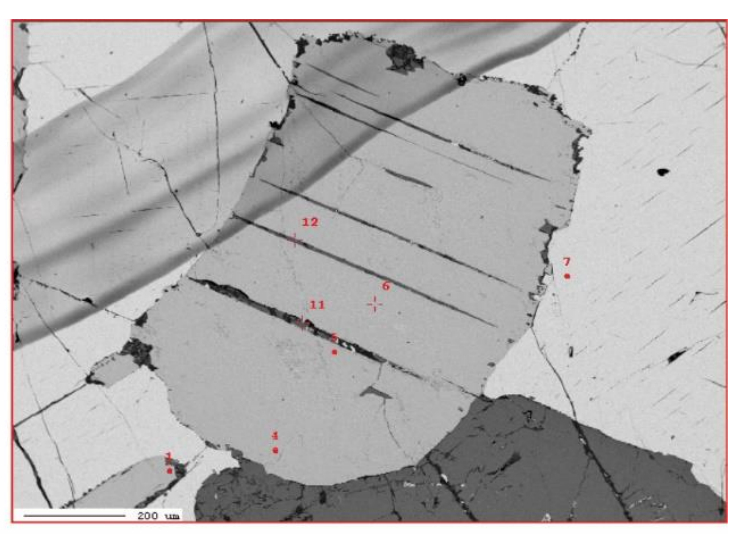




\section{CC013 circle B LA-ICPMS}

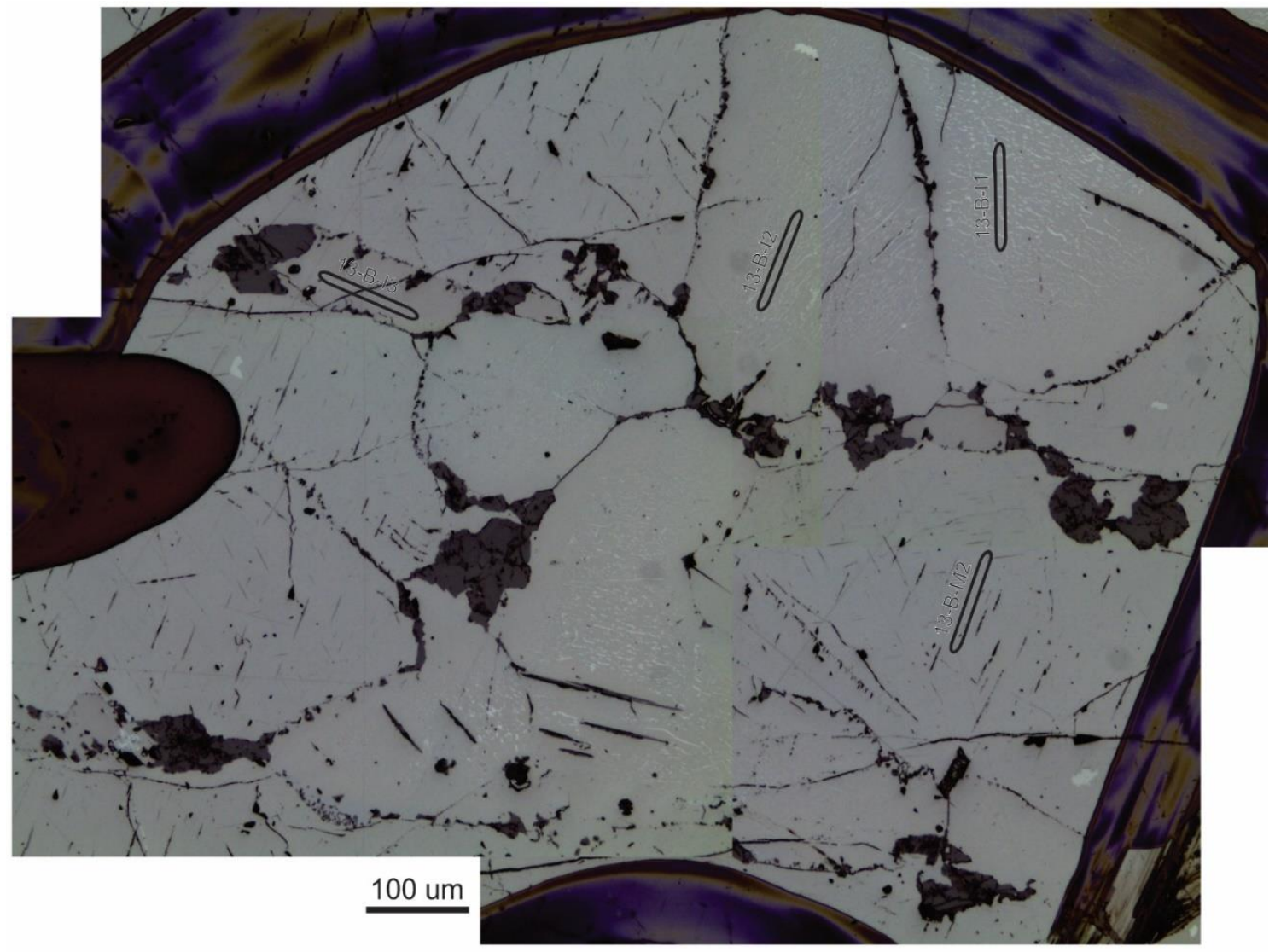


CC013 circle B EPMA
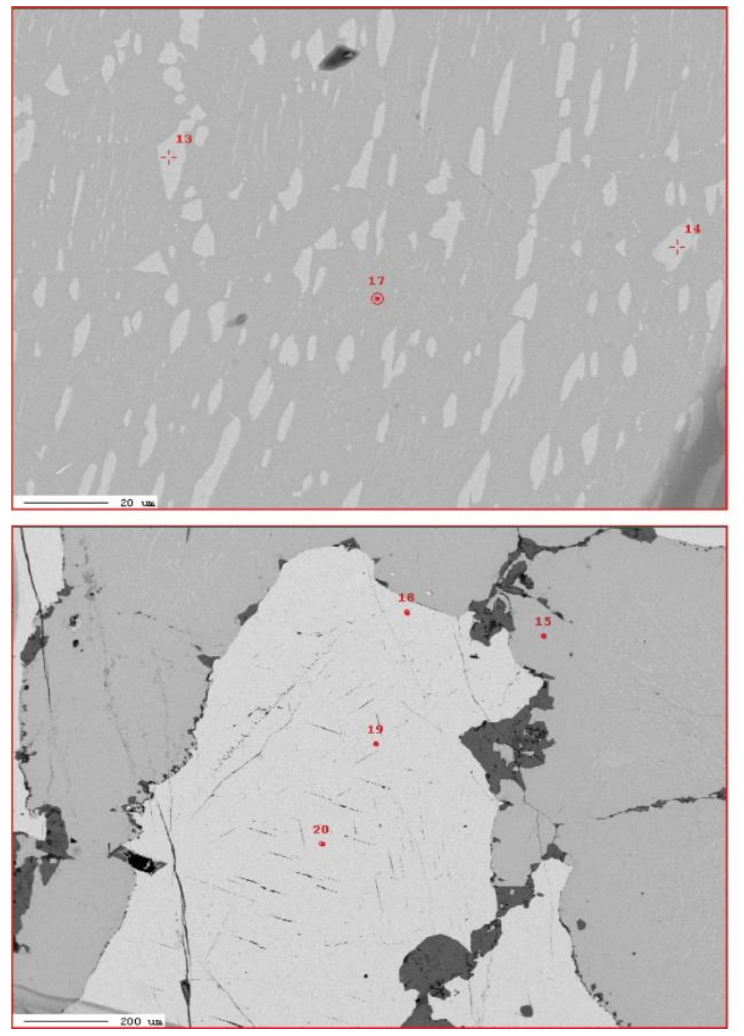

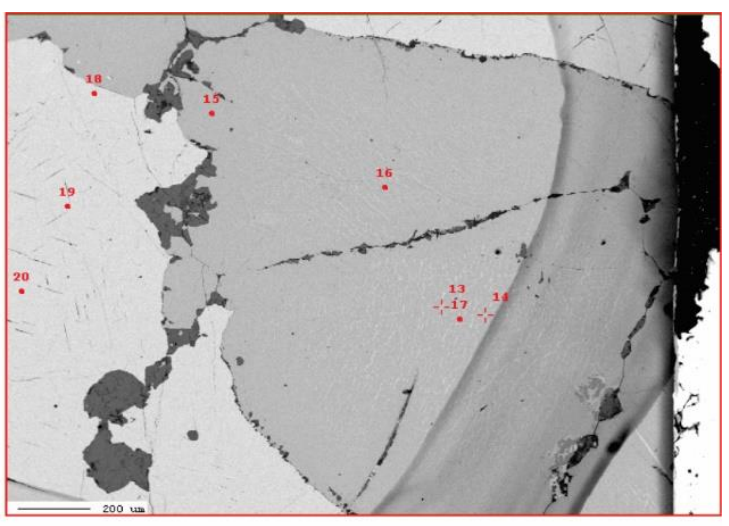


CC013 circle C LA-ICPMS
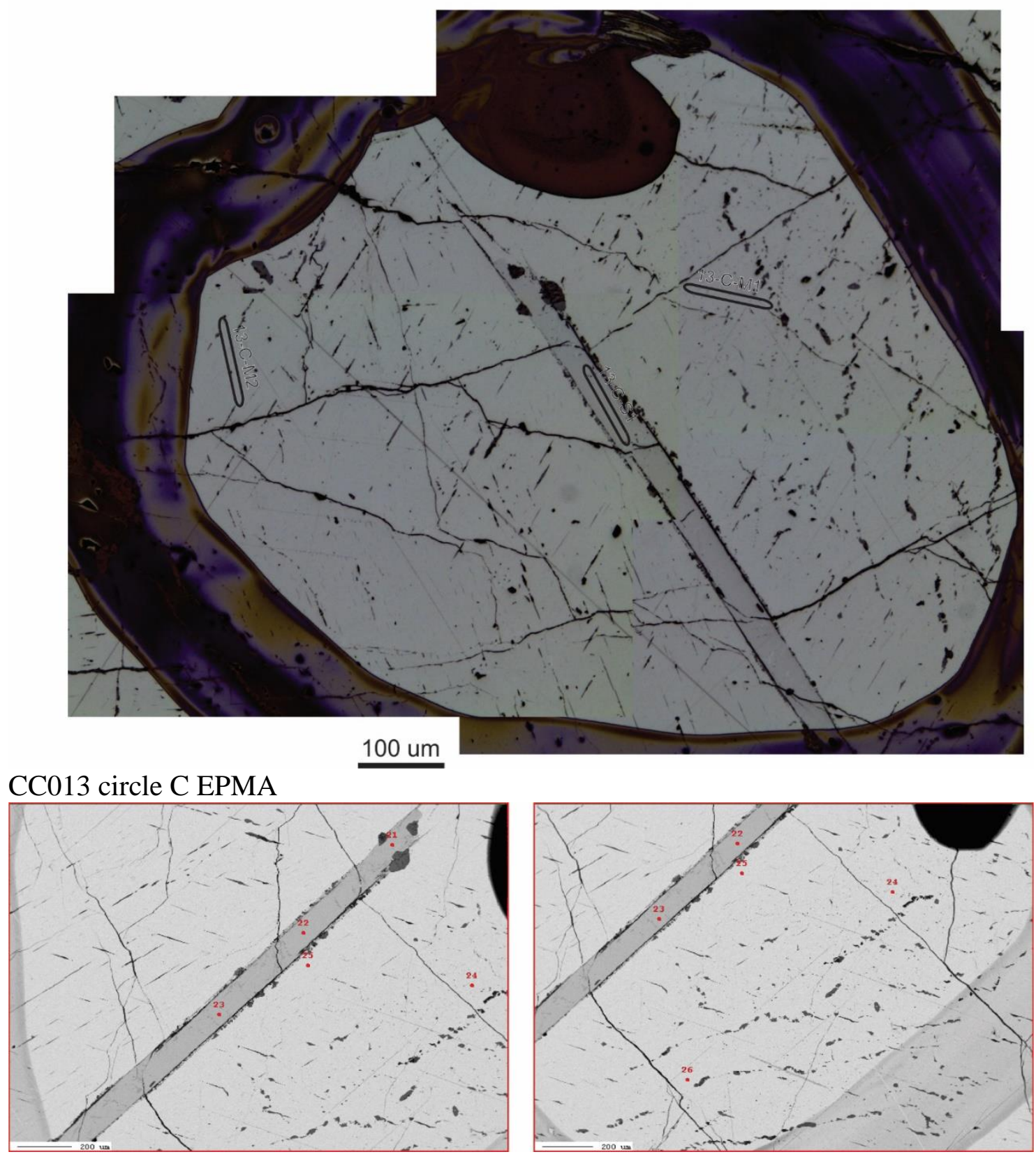
CC013 circle D LA-ICPMS

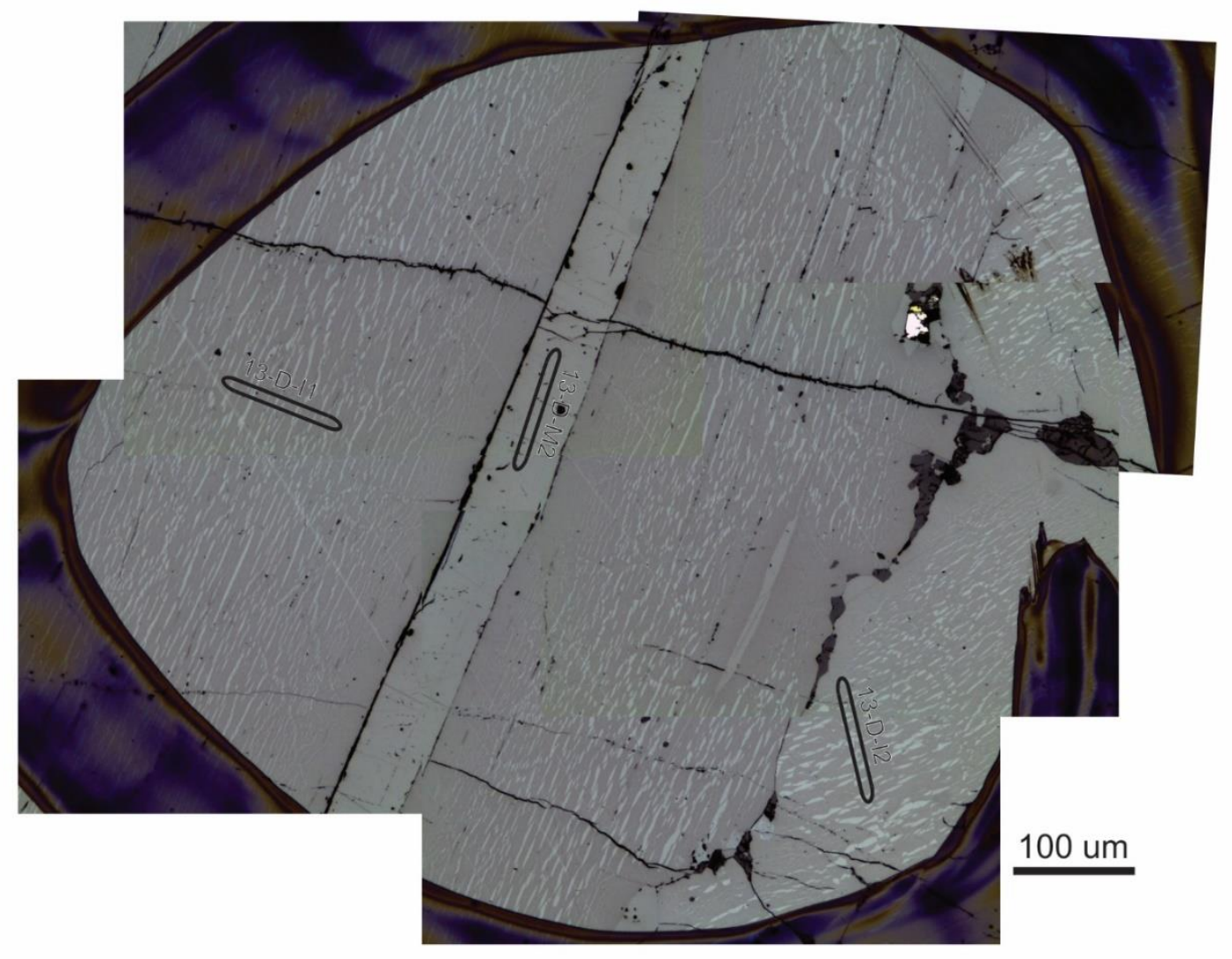


CC013 circle D EPMA
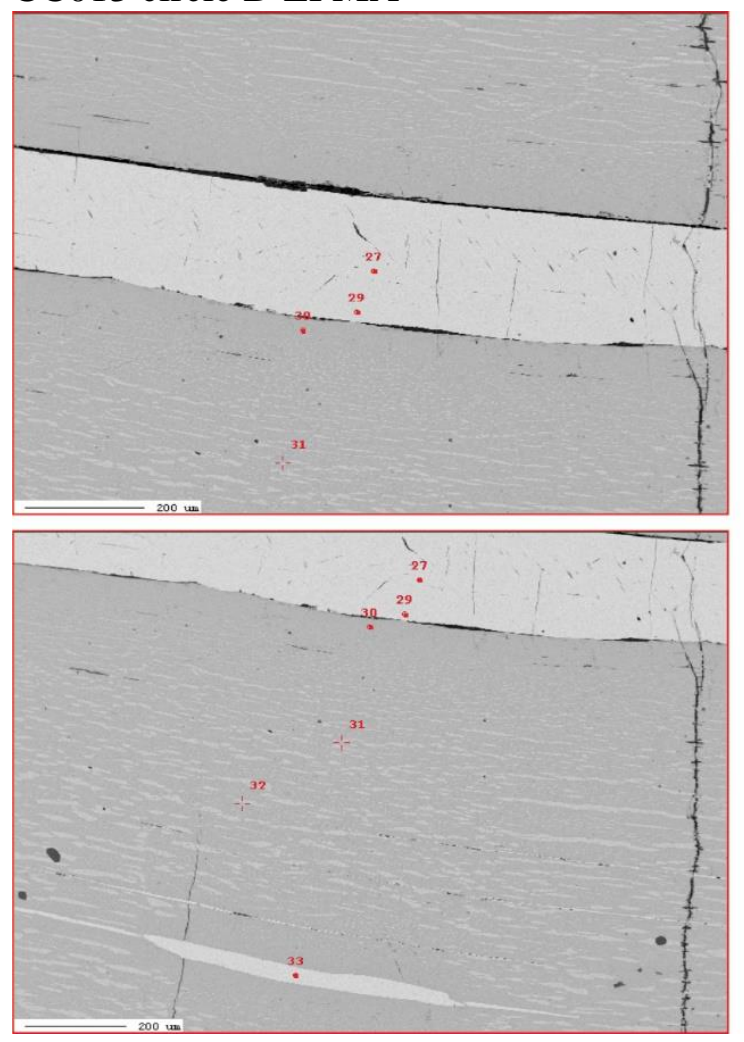

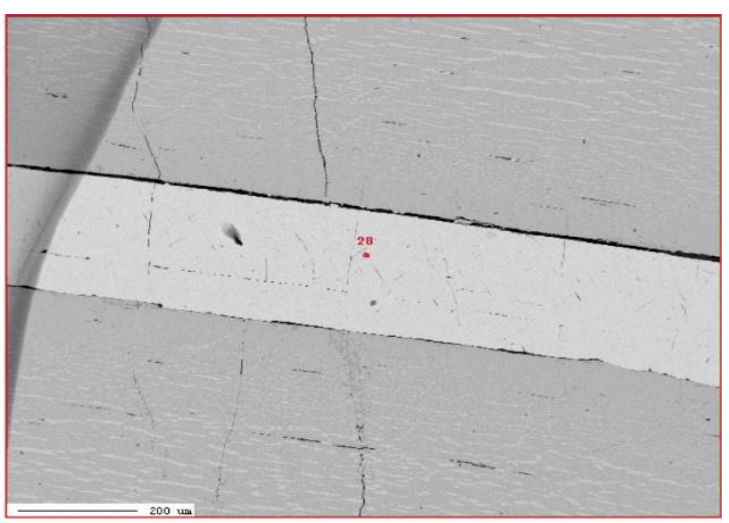


CC013 circle E LA-ICPMS

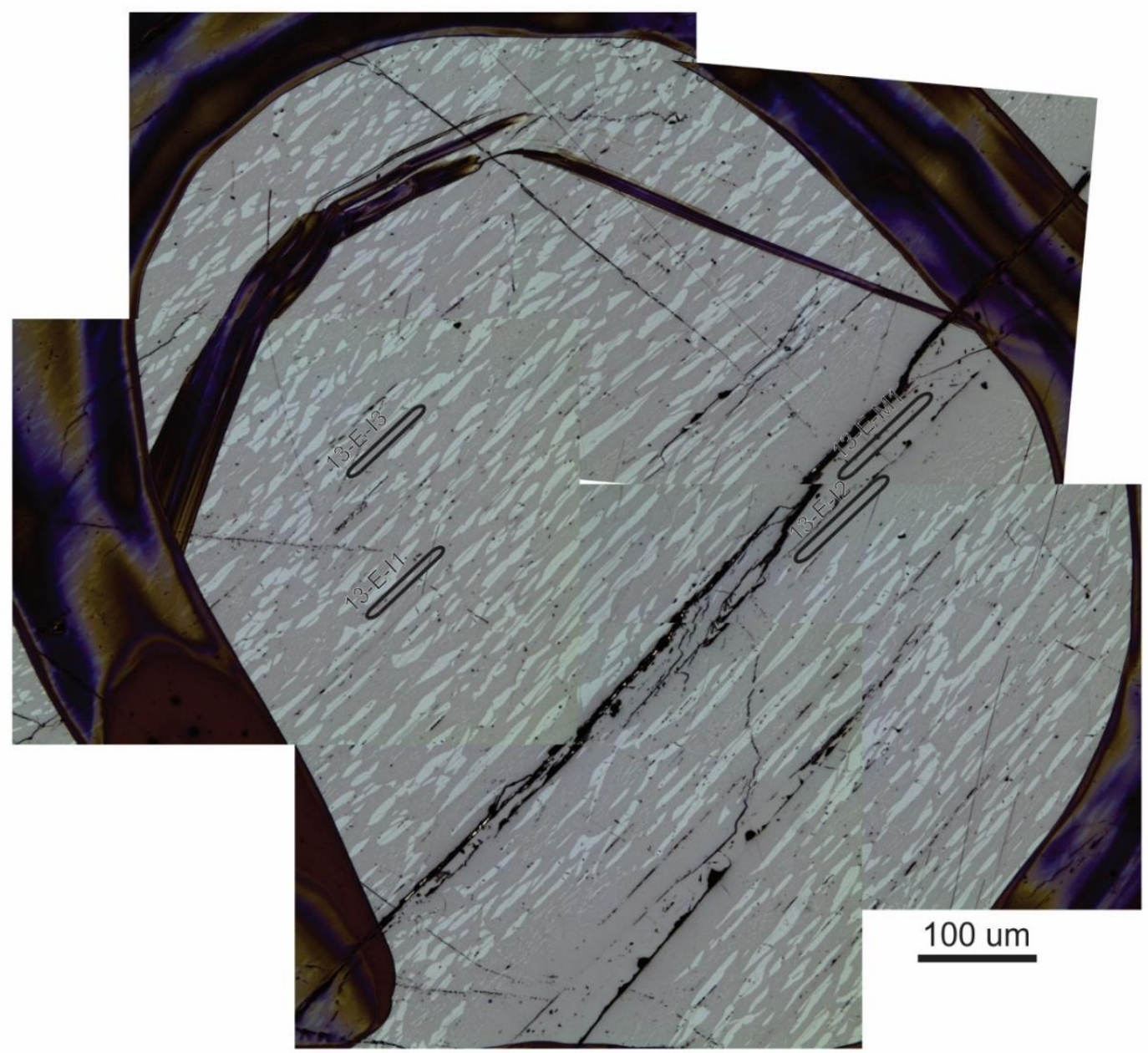

CC013 circle E EPMA
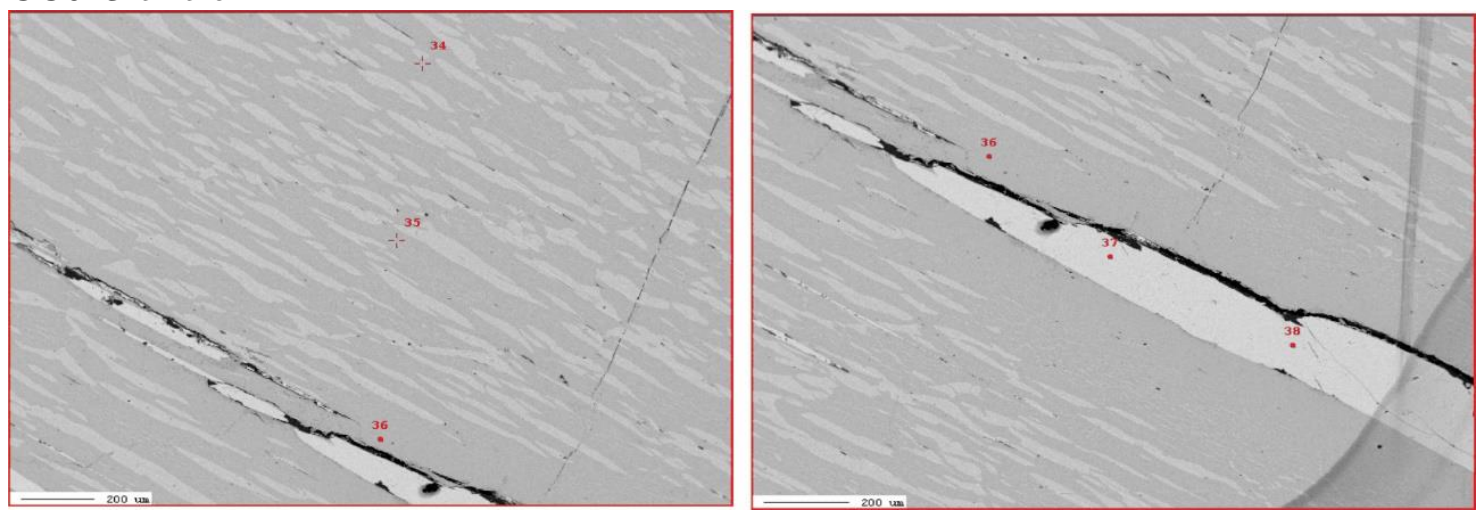
CC013 circle F LA-ICPMS

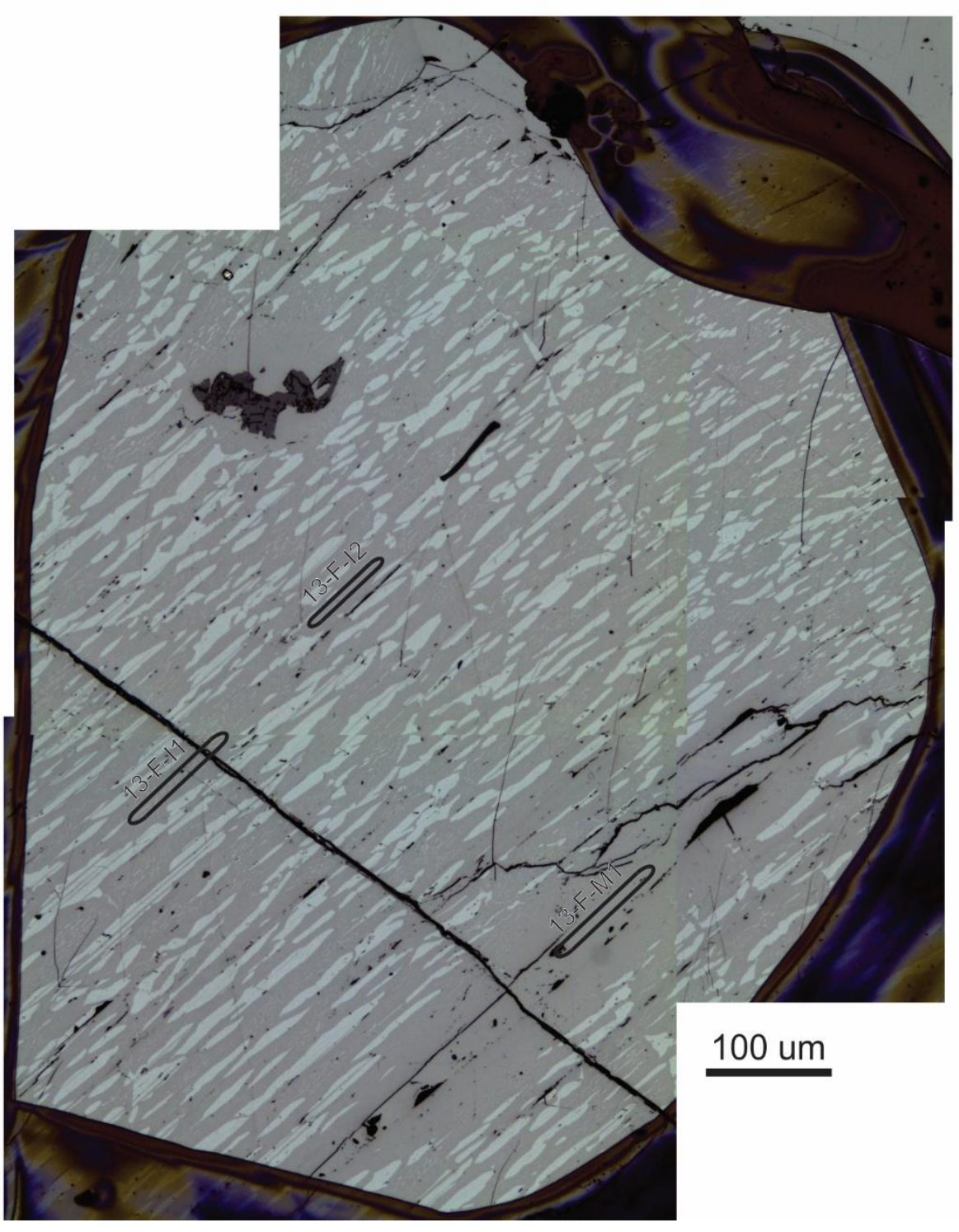


CC013 circle H LA-ICPMS

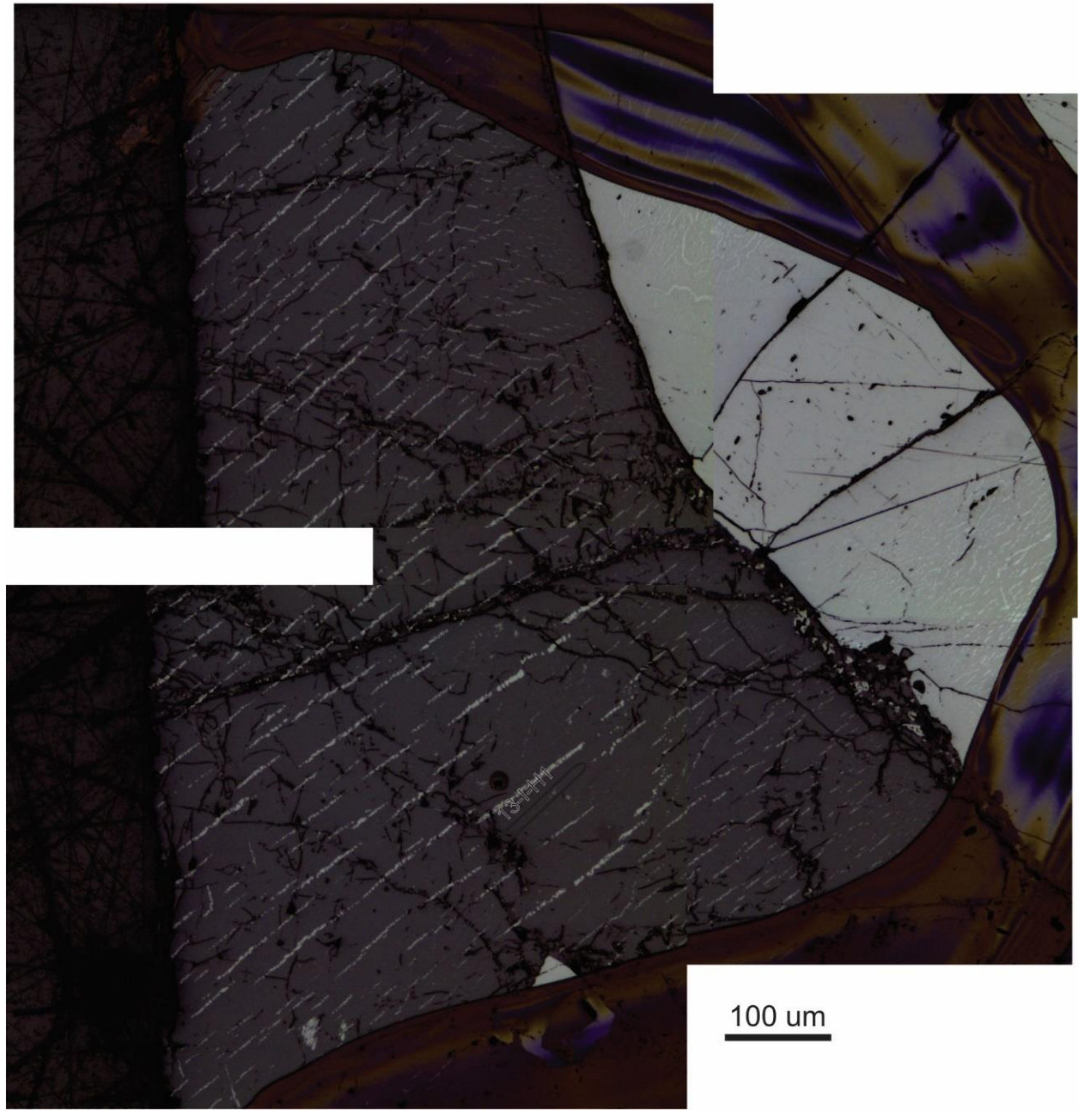


CC013 circle I EPMA
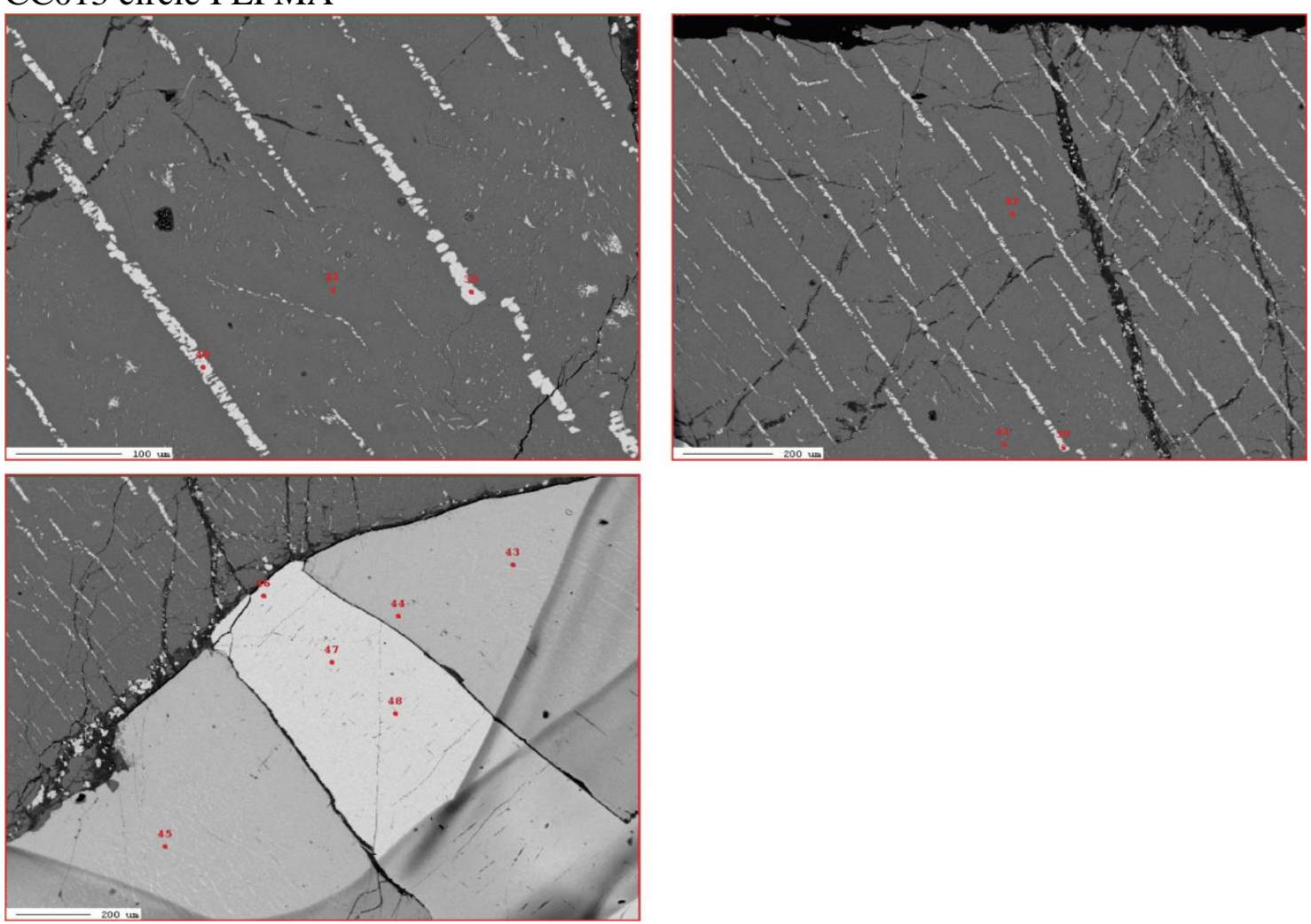
CC013 circle L LA-ICPMS

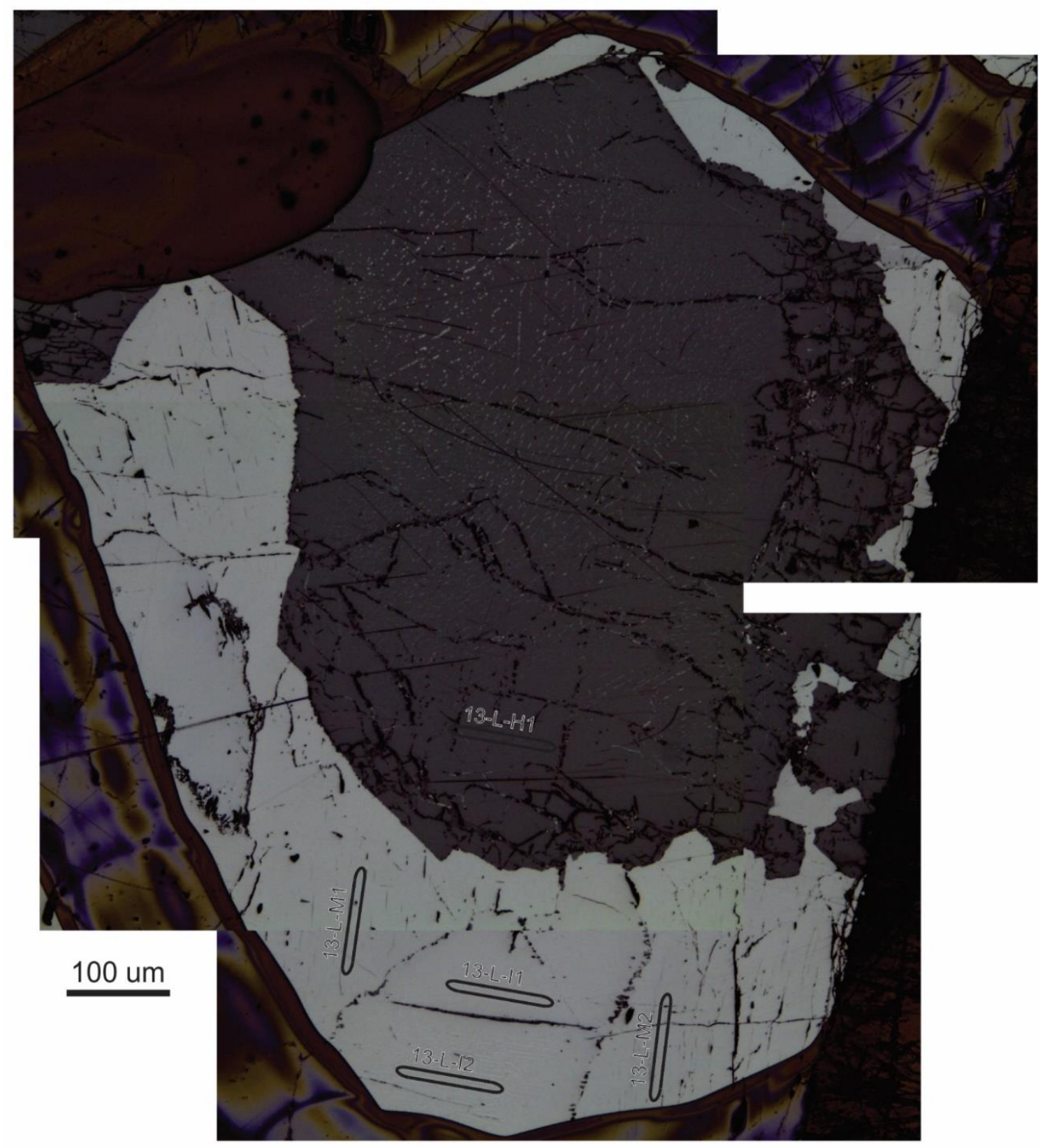


CC013 circle L EPMA
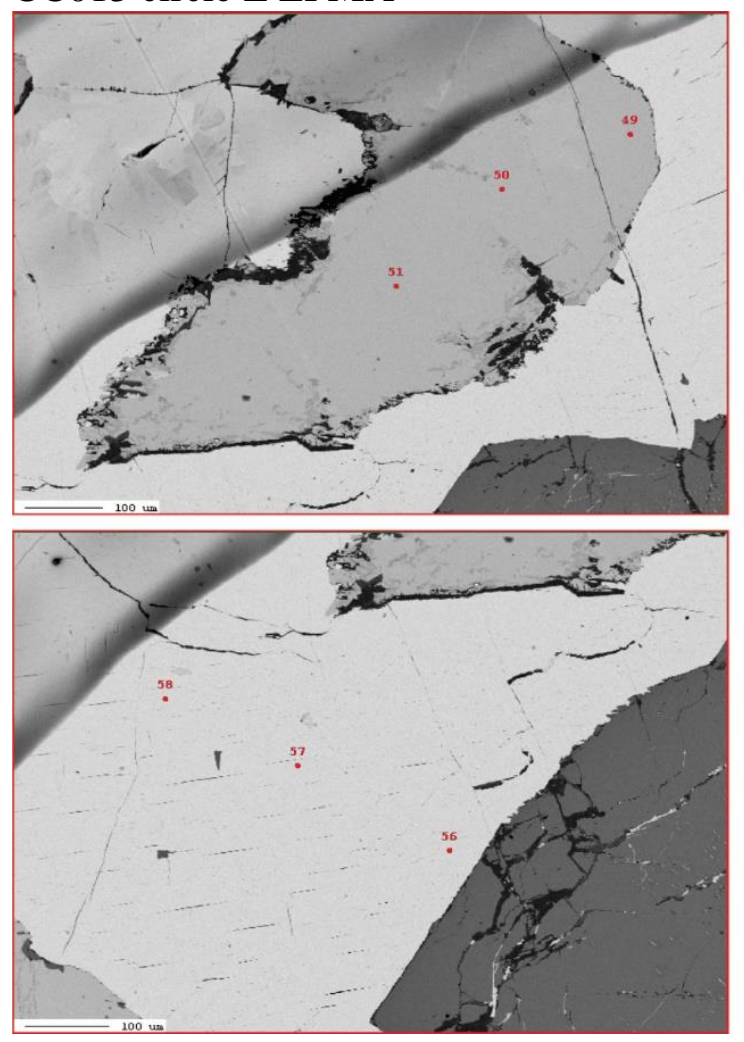

CC013 circle M EPMA

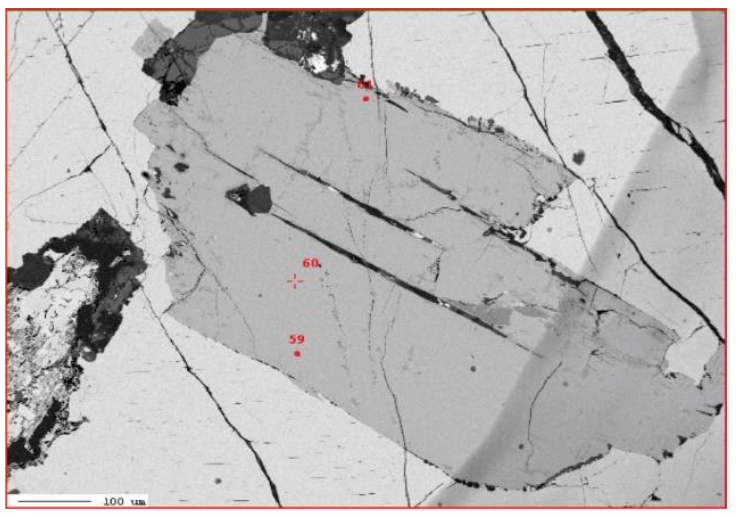

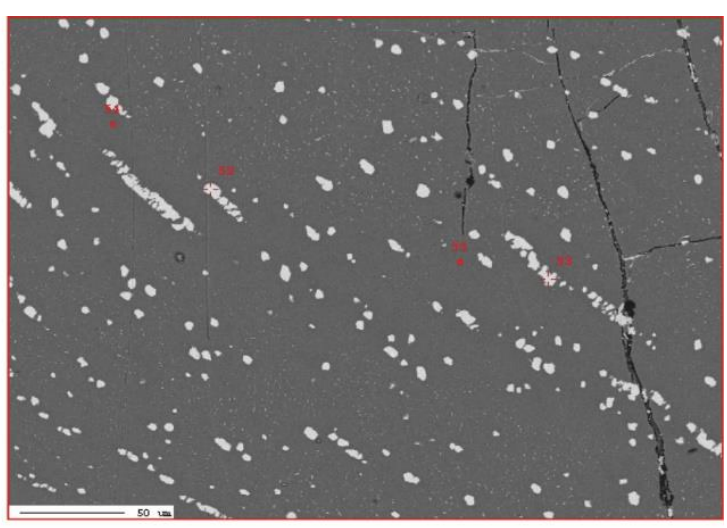

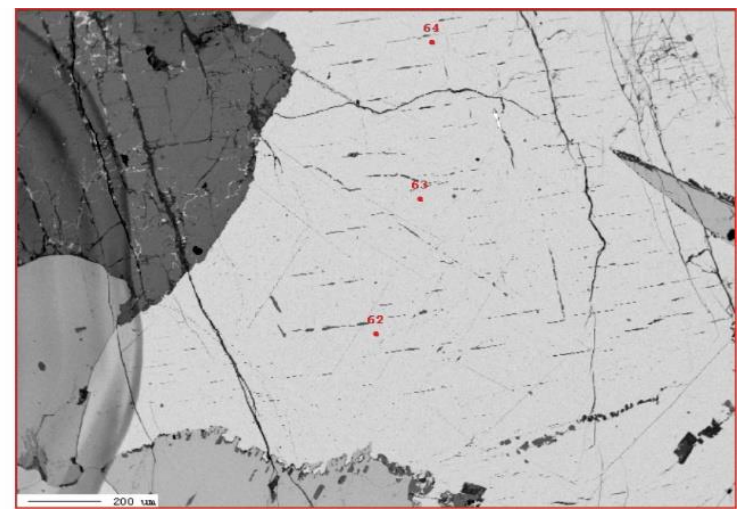


CC013 circle P LA-ICPMS

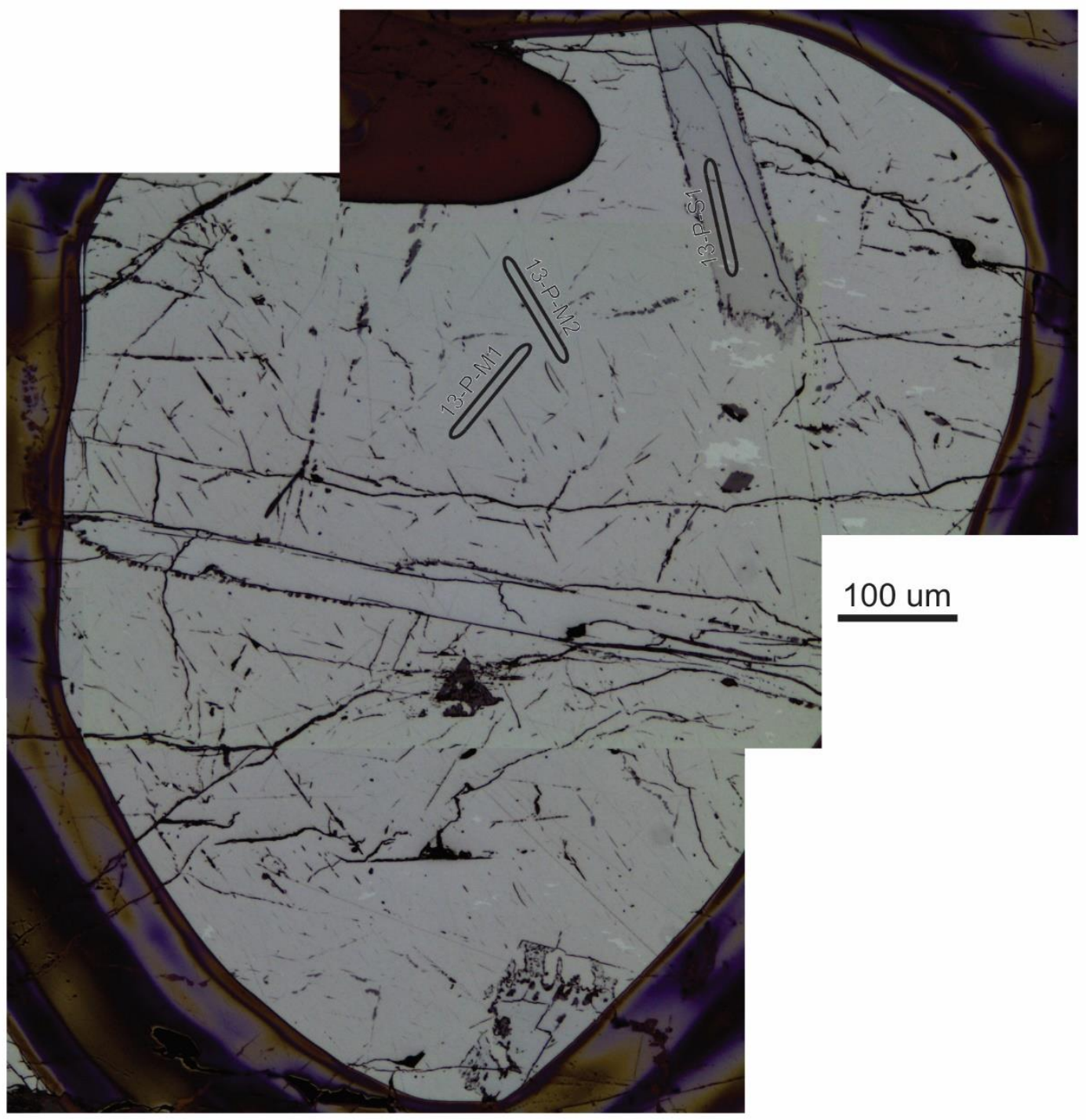

CC013 circle P EPMA
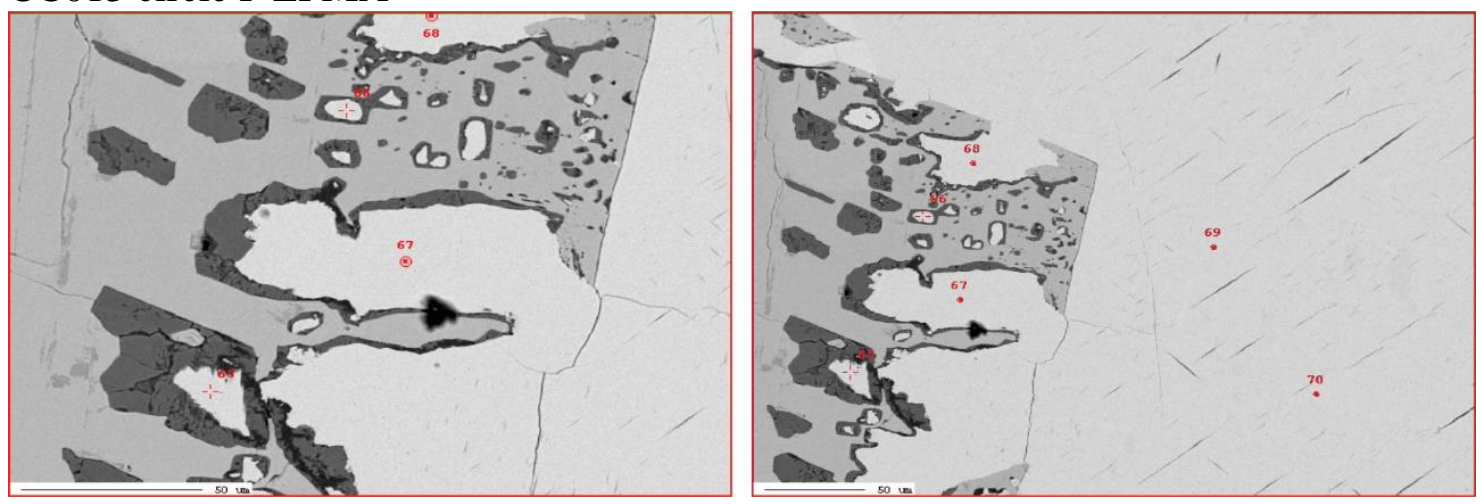
CC025 circle A EPMA

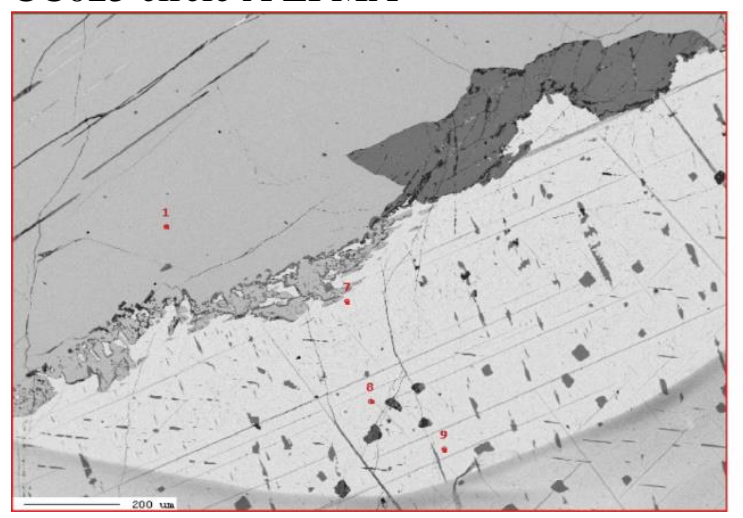

CC025 circle B EPMA

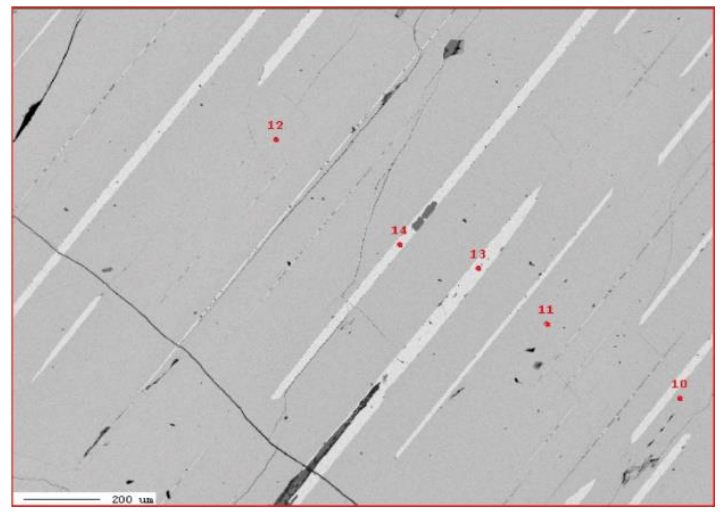

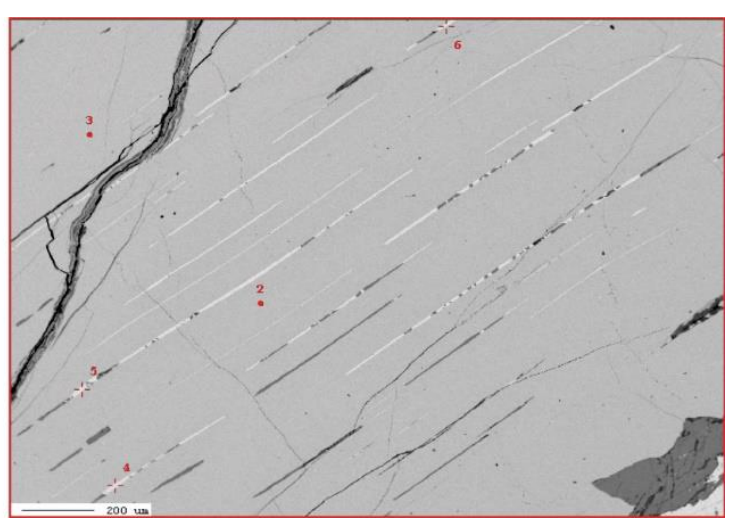


CC025 circle C LA-ICPMS

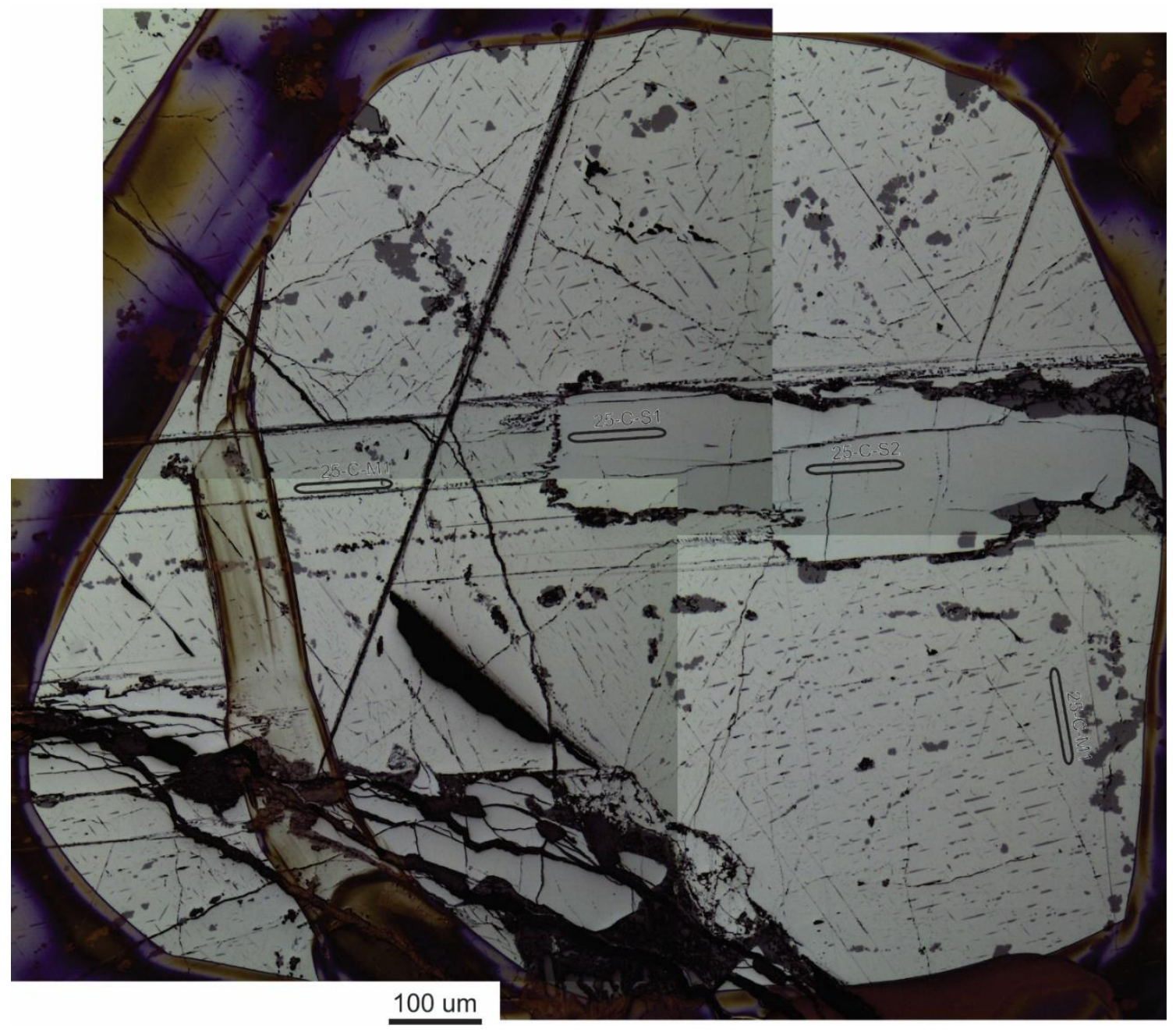


CC025 circle C EPMA
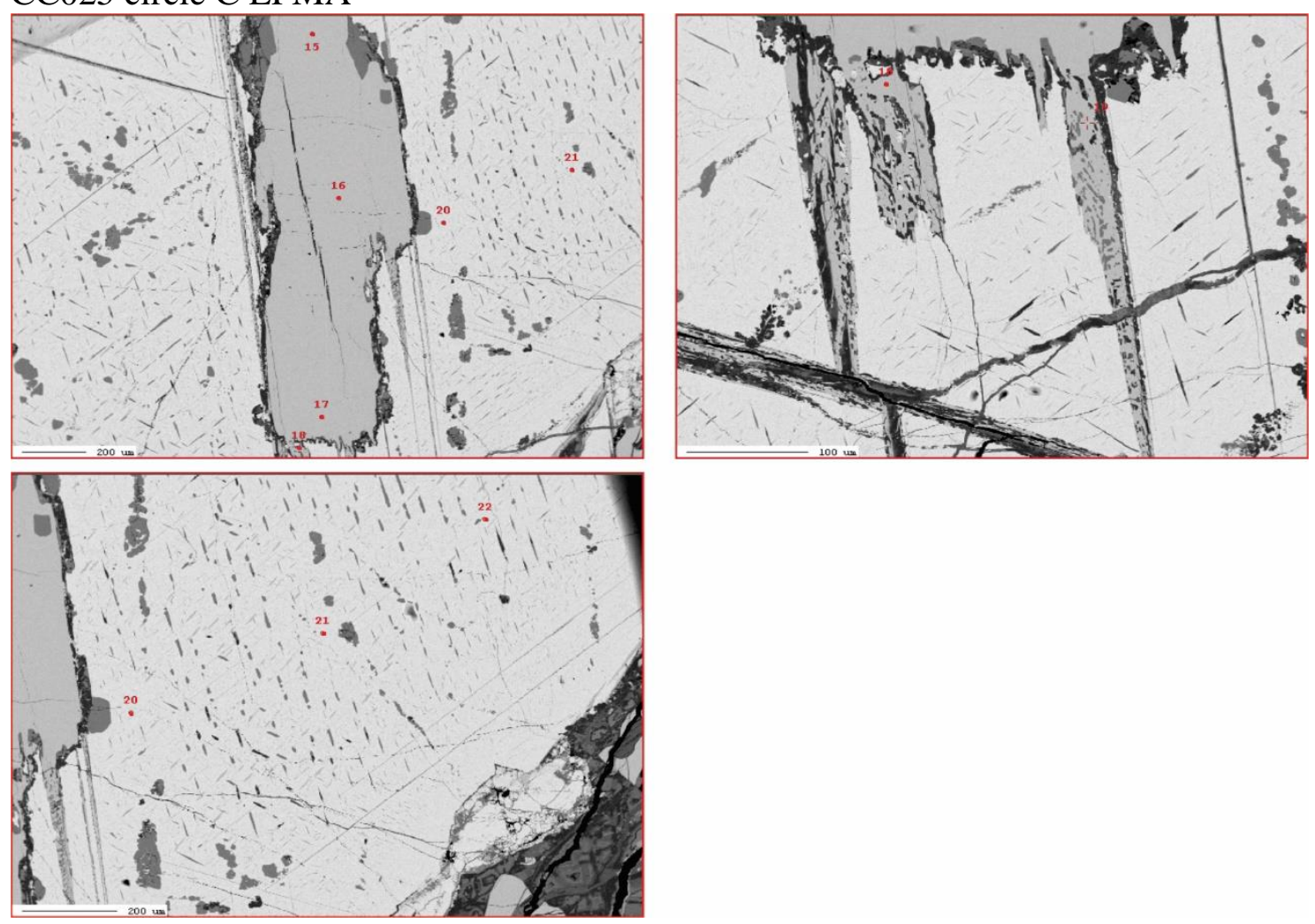
CC025 circle D LA-ICPMS

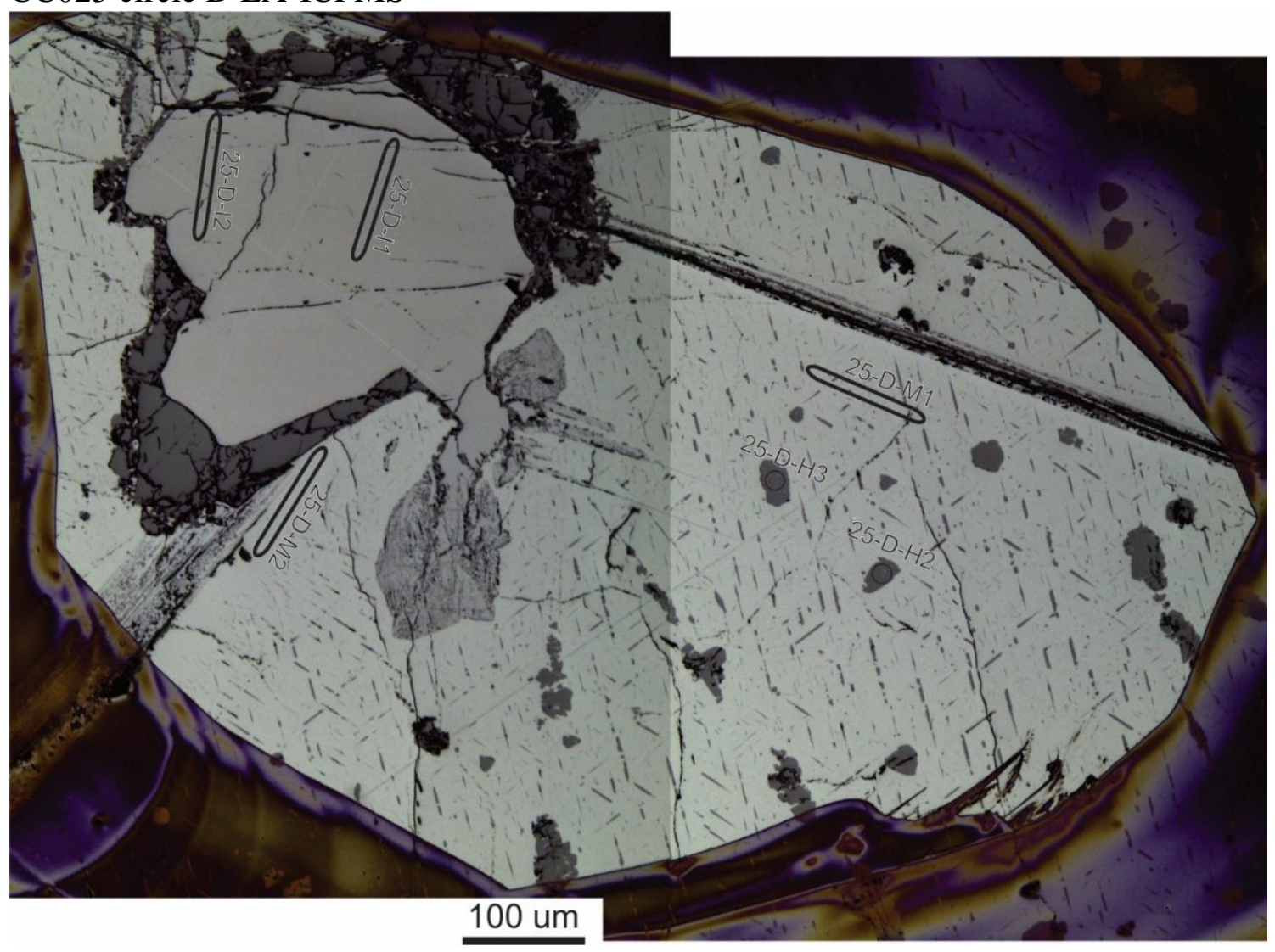


CC025 circle D EPMA
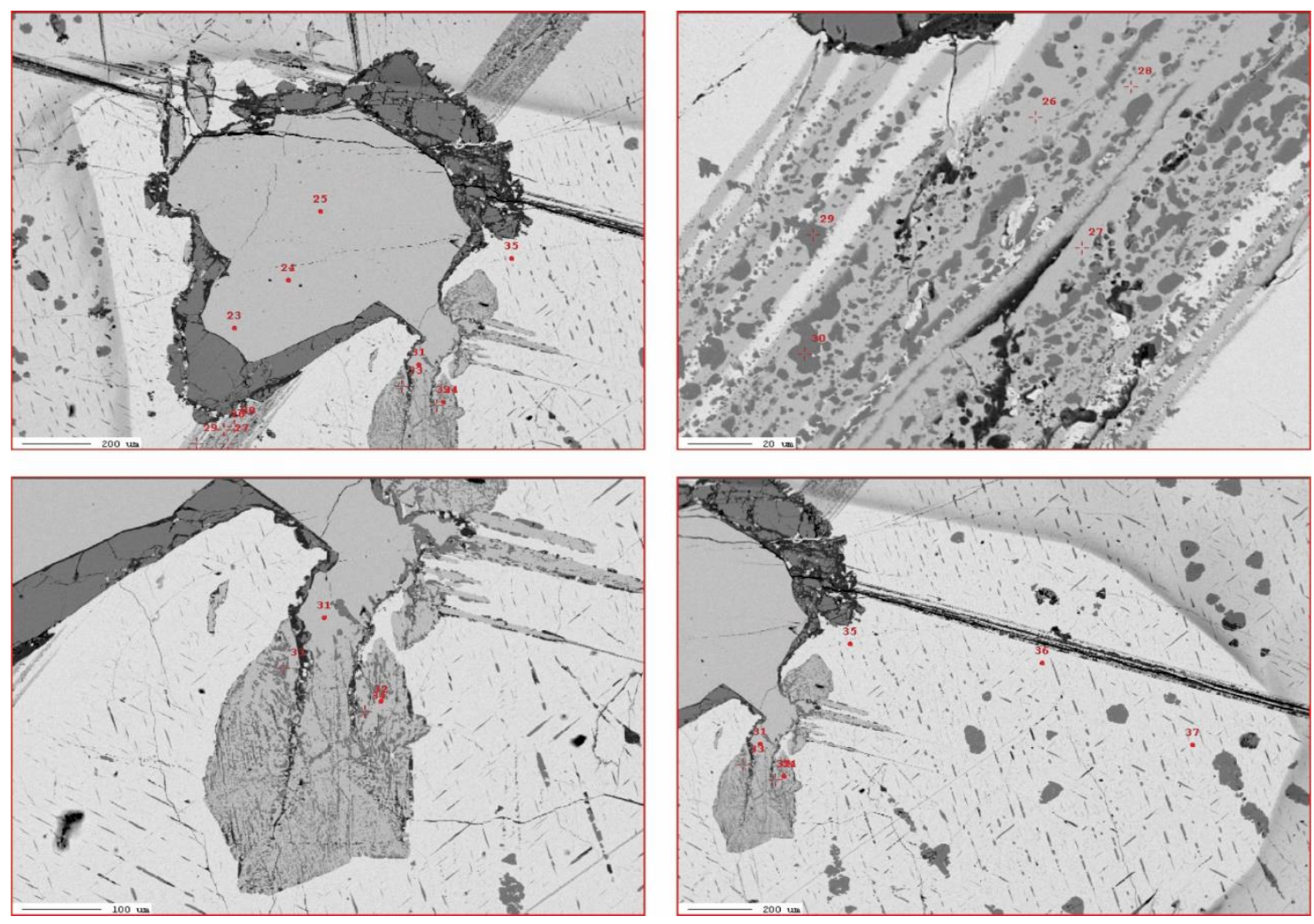
CC025 circle E LA-ICPMS

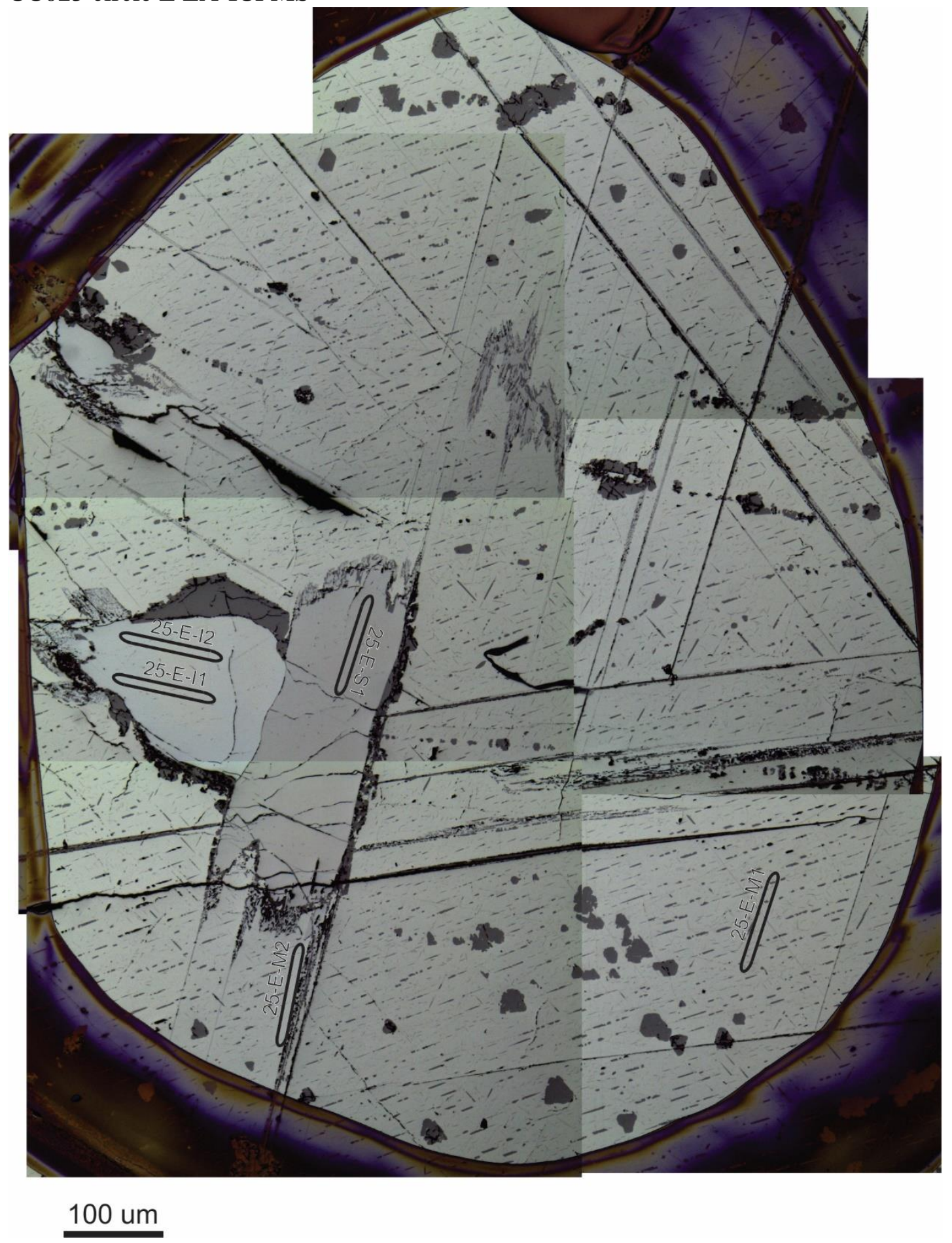


CC025 circle E EPMA
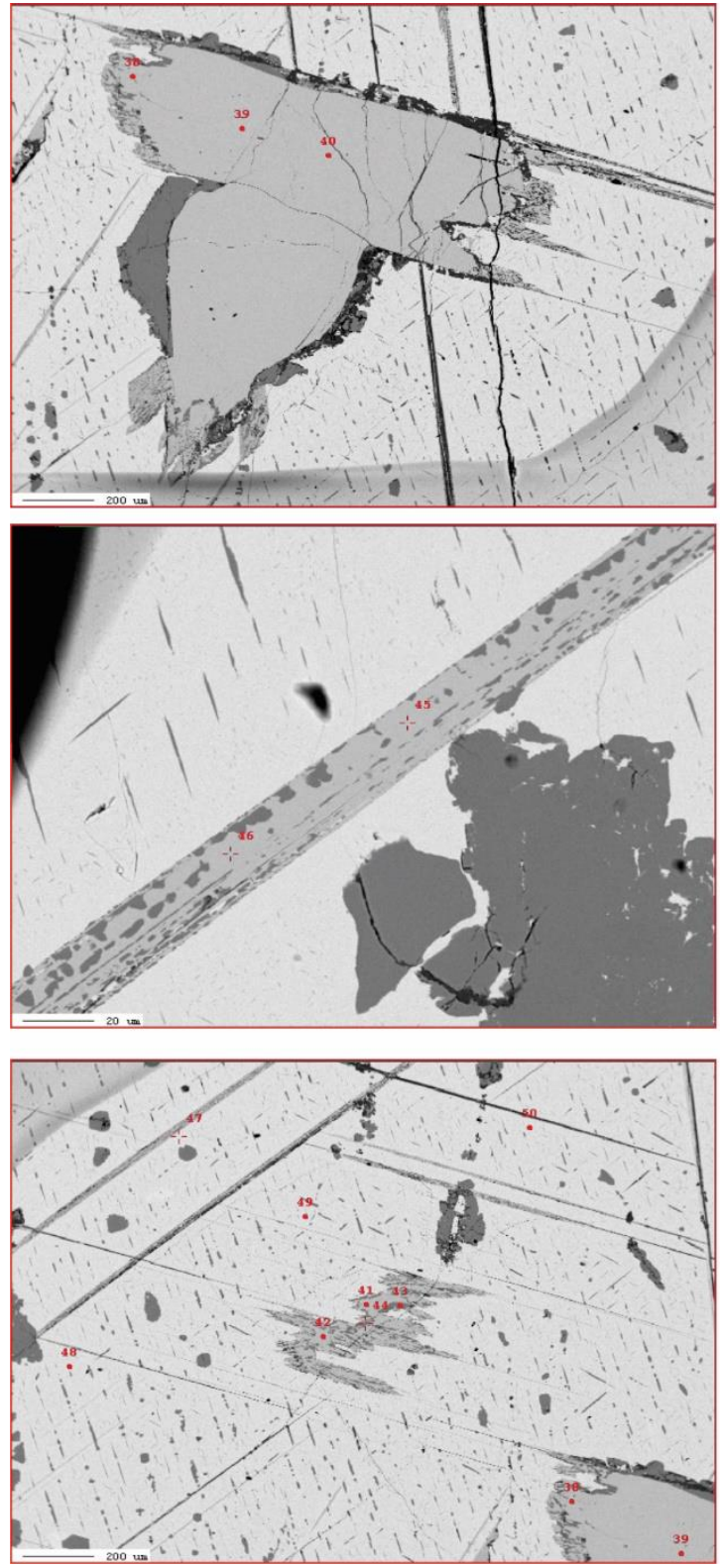
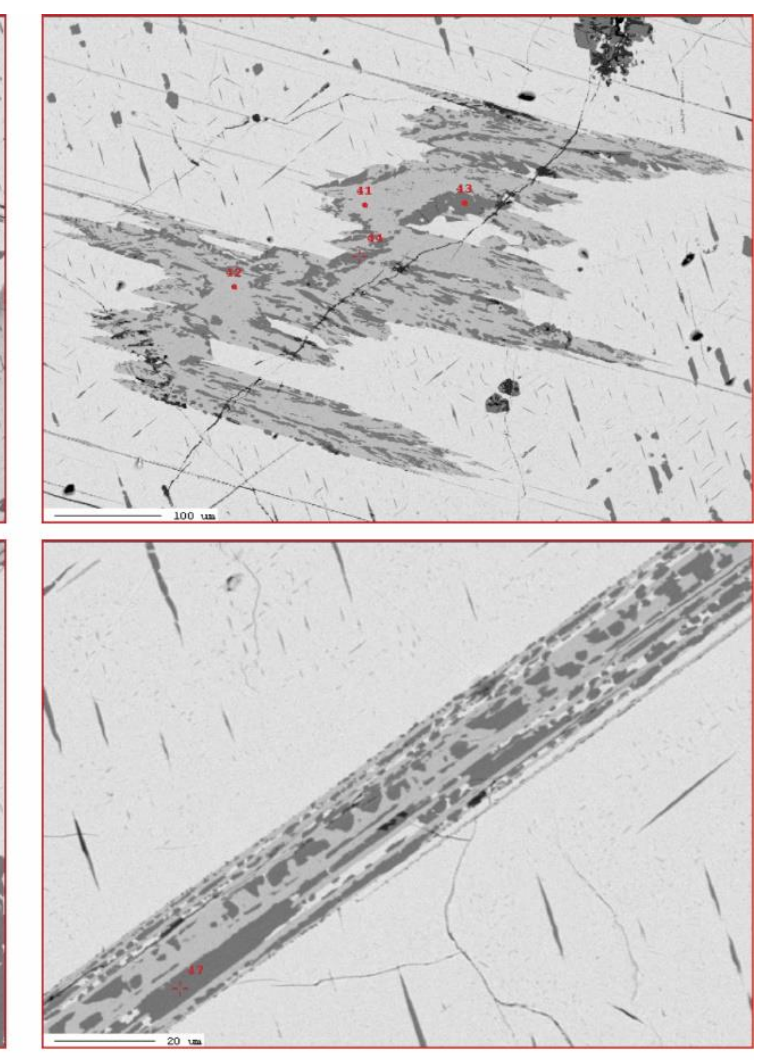
CC025 circle F LA-ICPMS

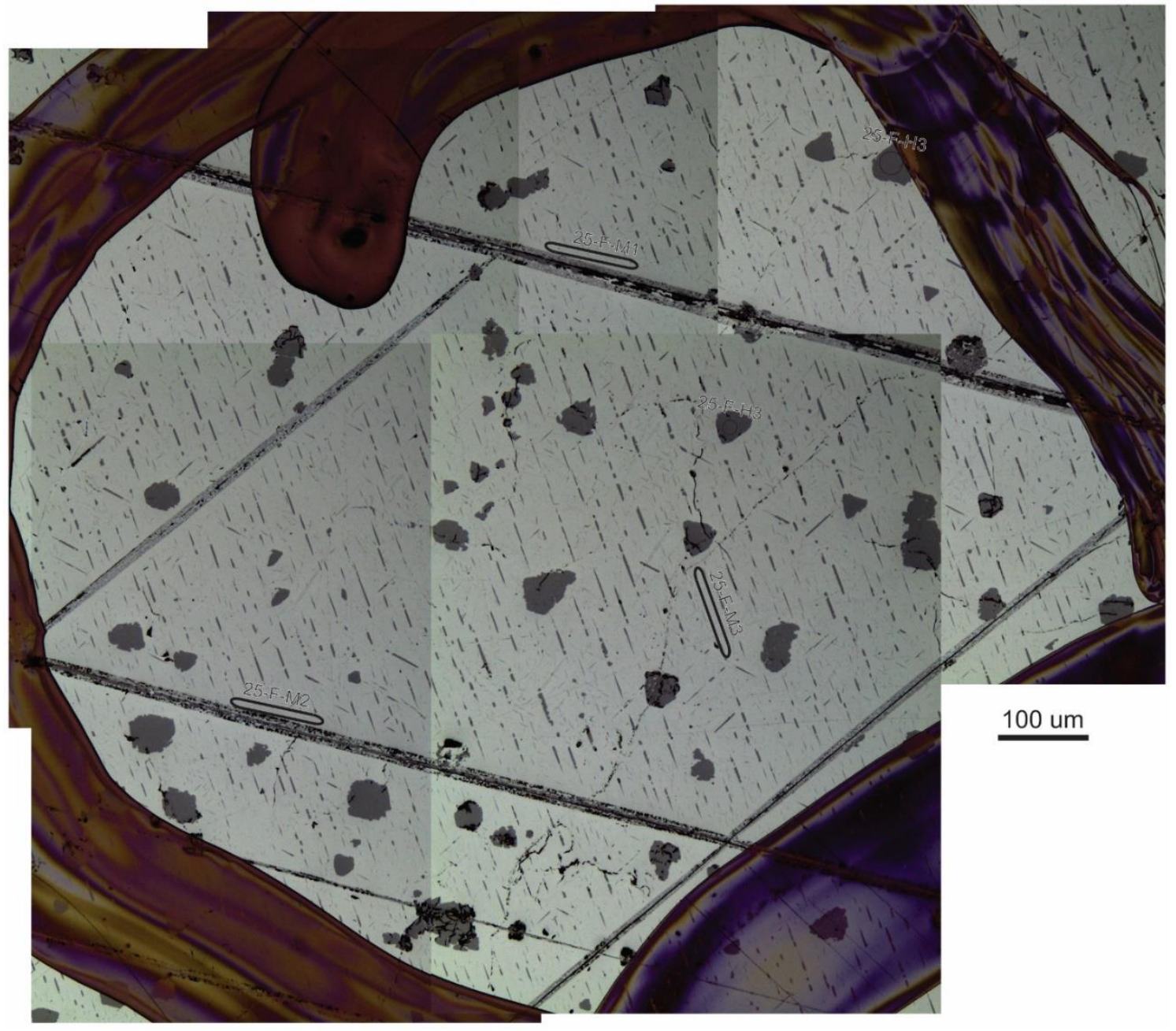


CC025 circle G LA-ICPMS

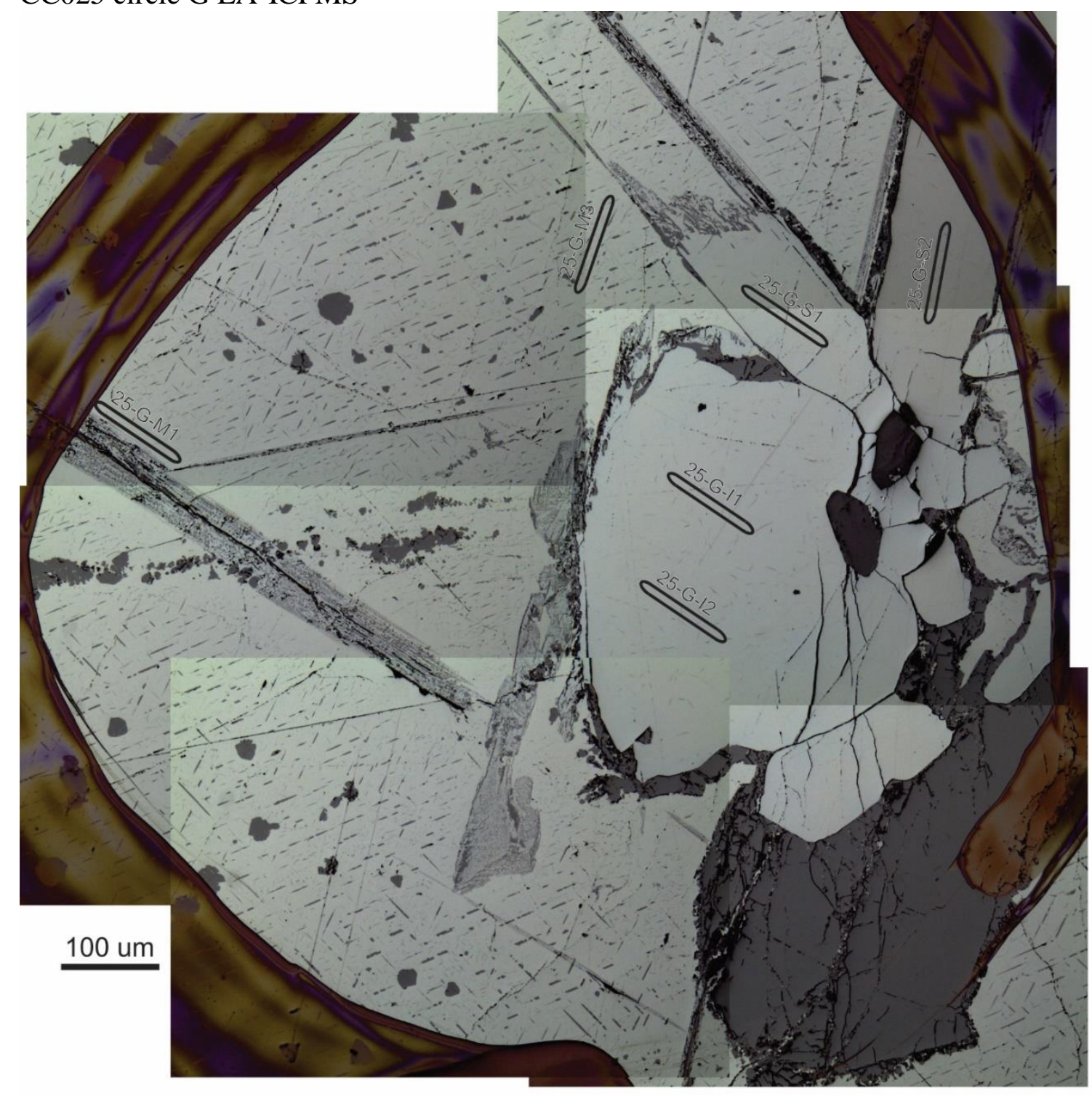


CC025 circle G EPMA
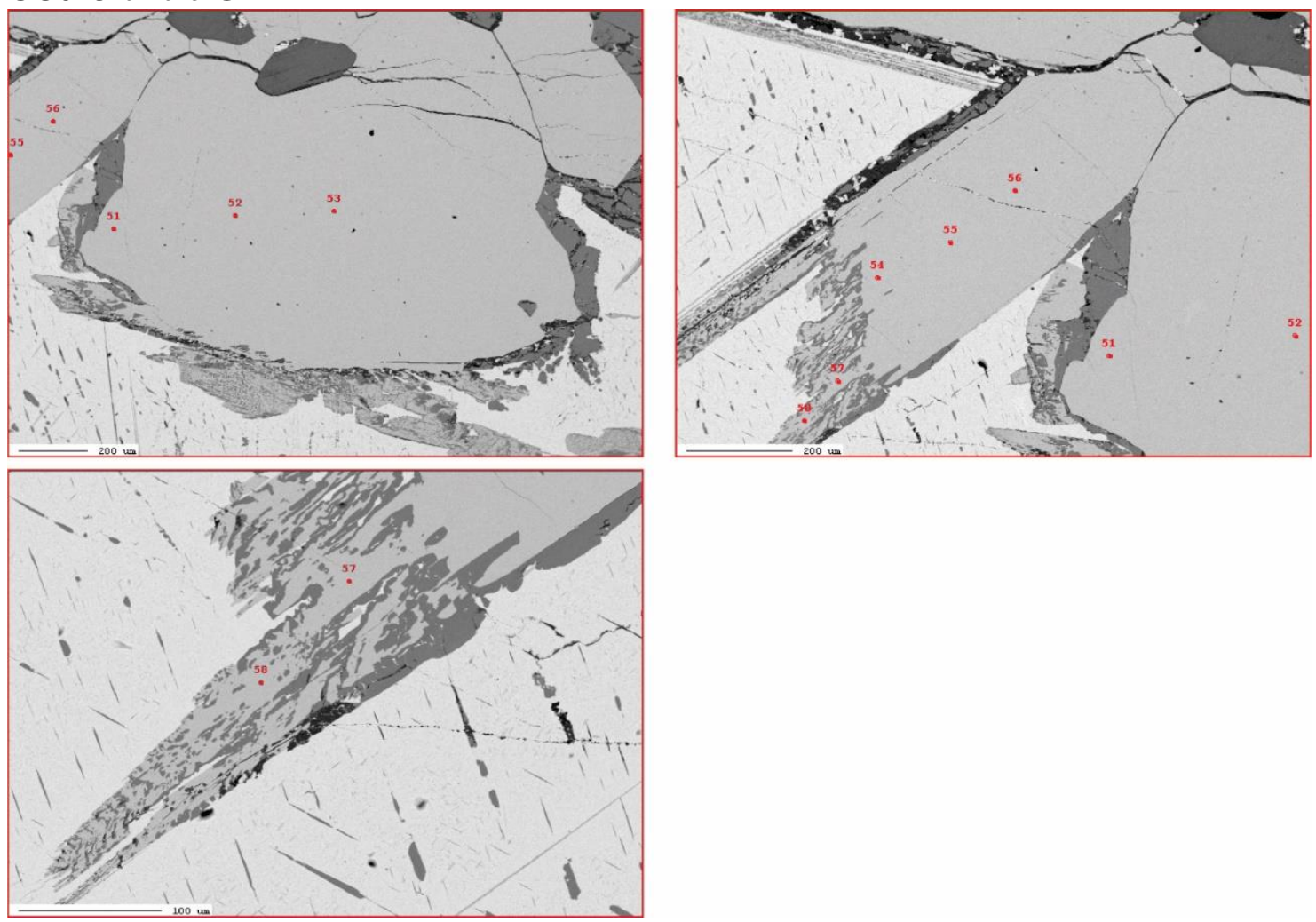
CC025 circle H LA-ICPMS

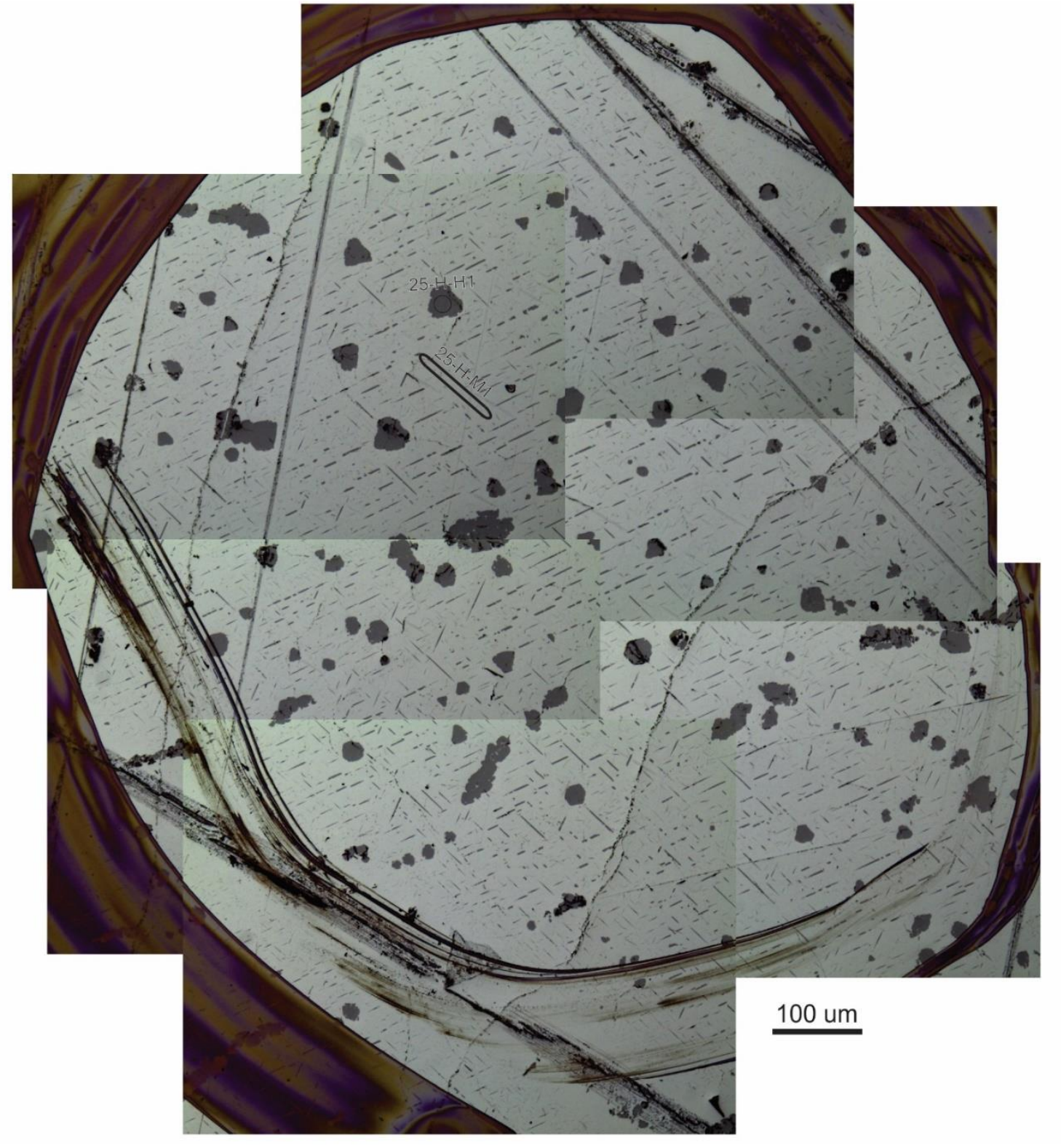


CC025 circle I LA-ICPMS

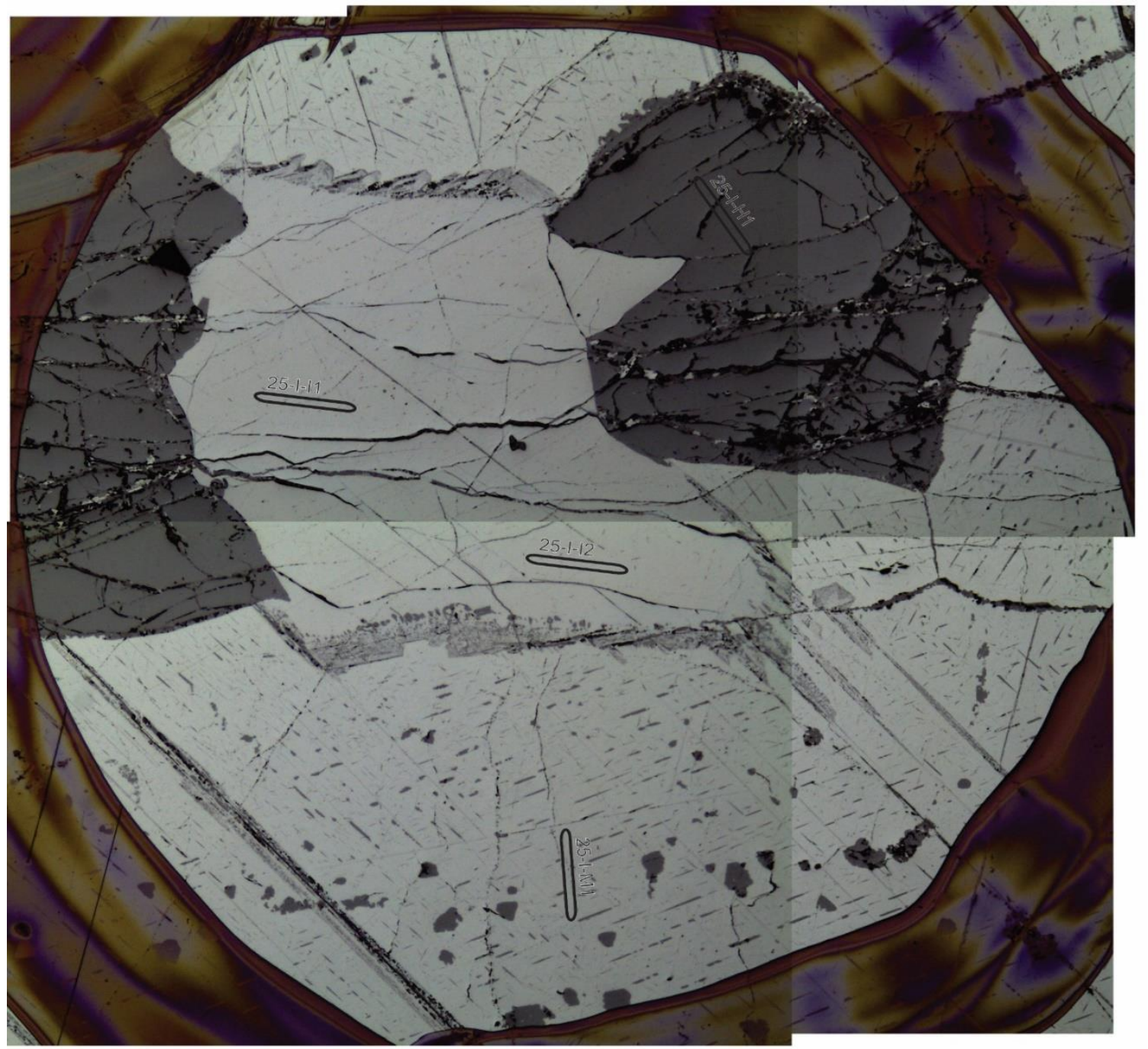

100 um

CC025 circle I EPMA

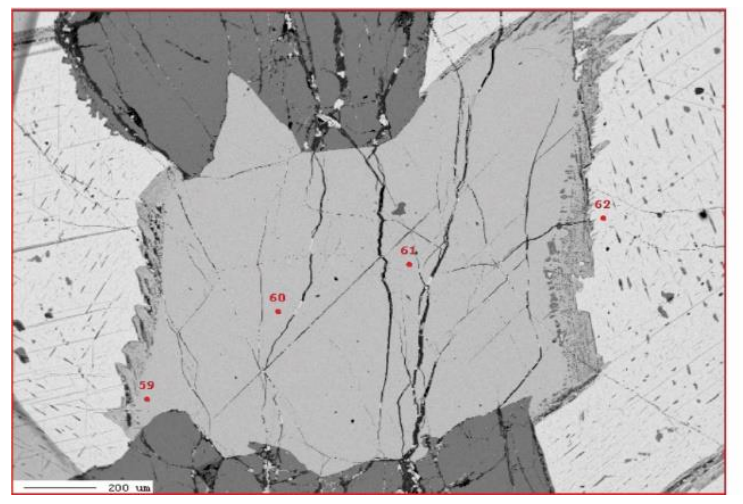

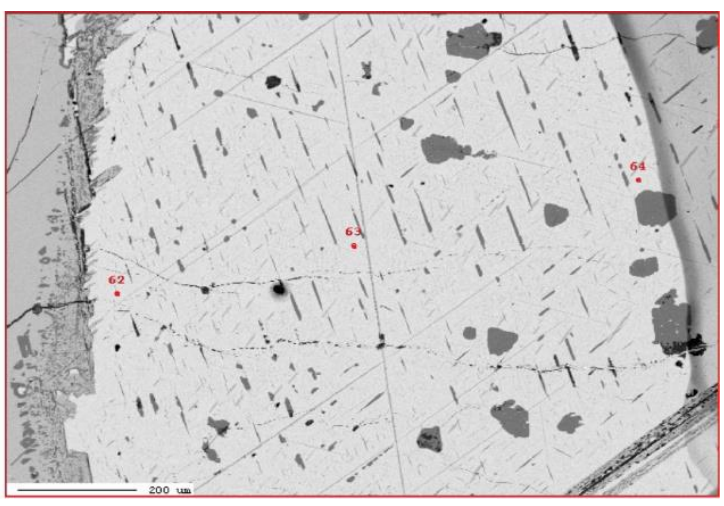


CC025 circle K LA-ICPMS

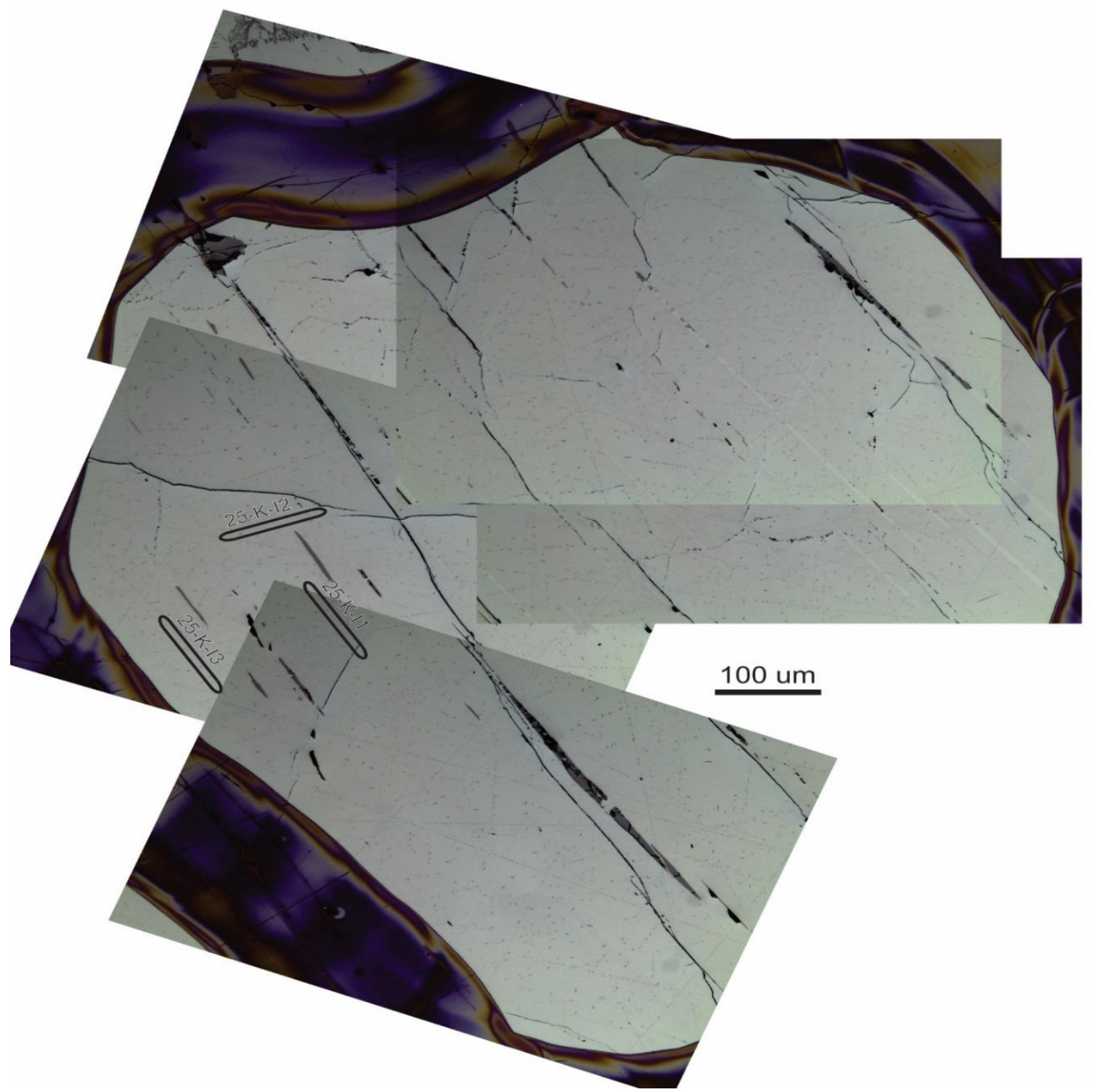

CC025 circle K EPMA

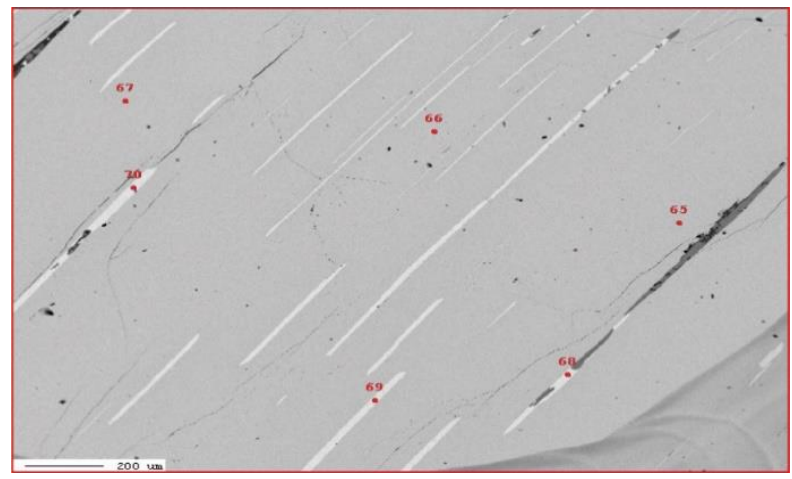

CC025 circle L La-ICPMS 


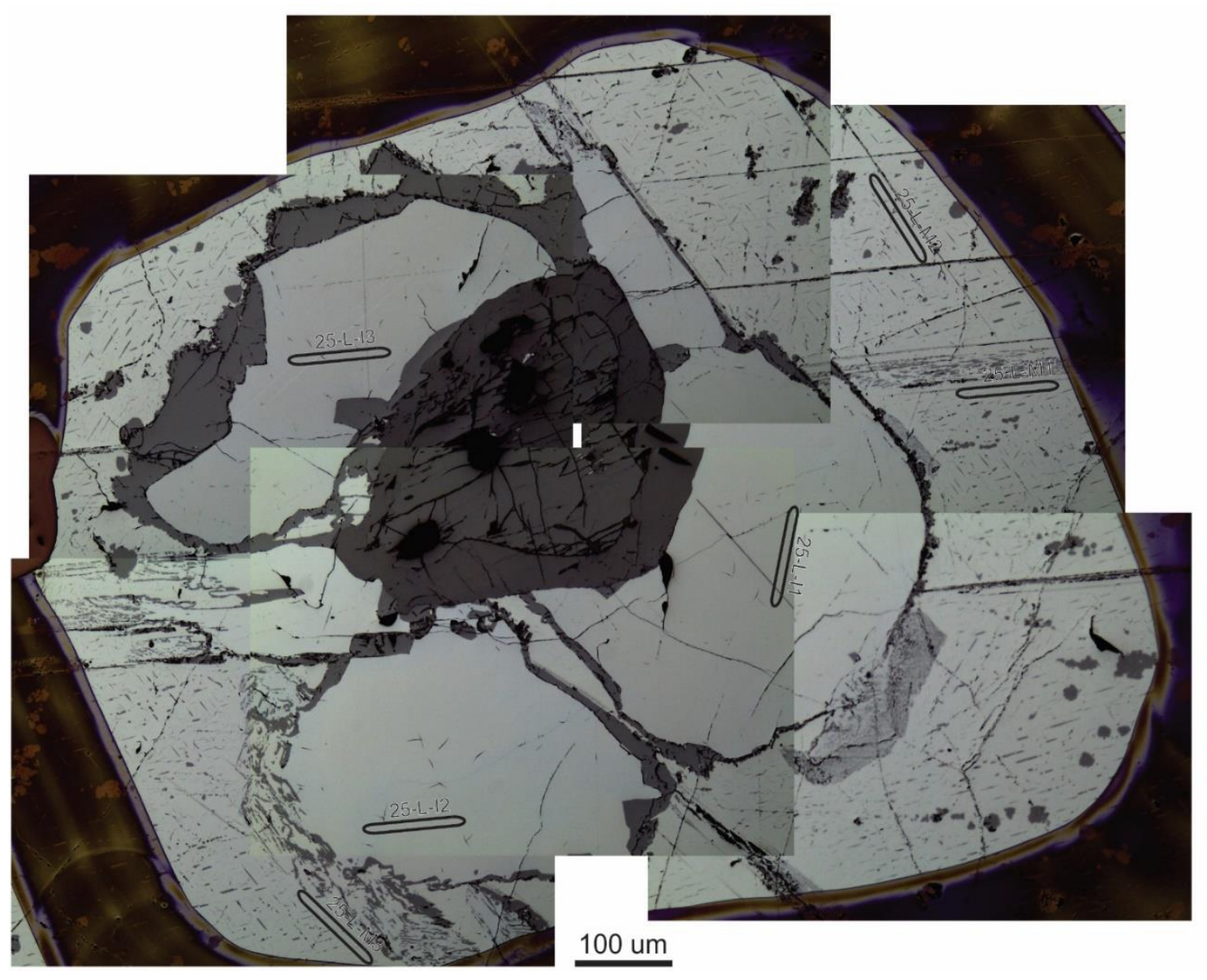


CC031 circle A LA-ICPMS

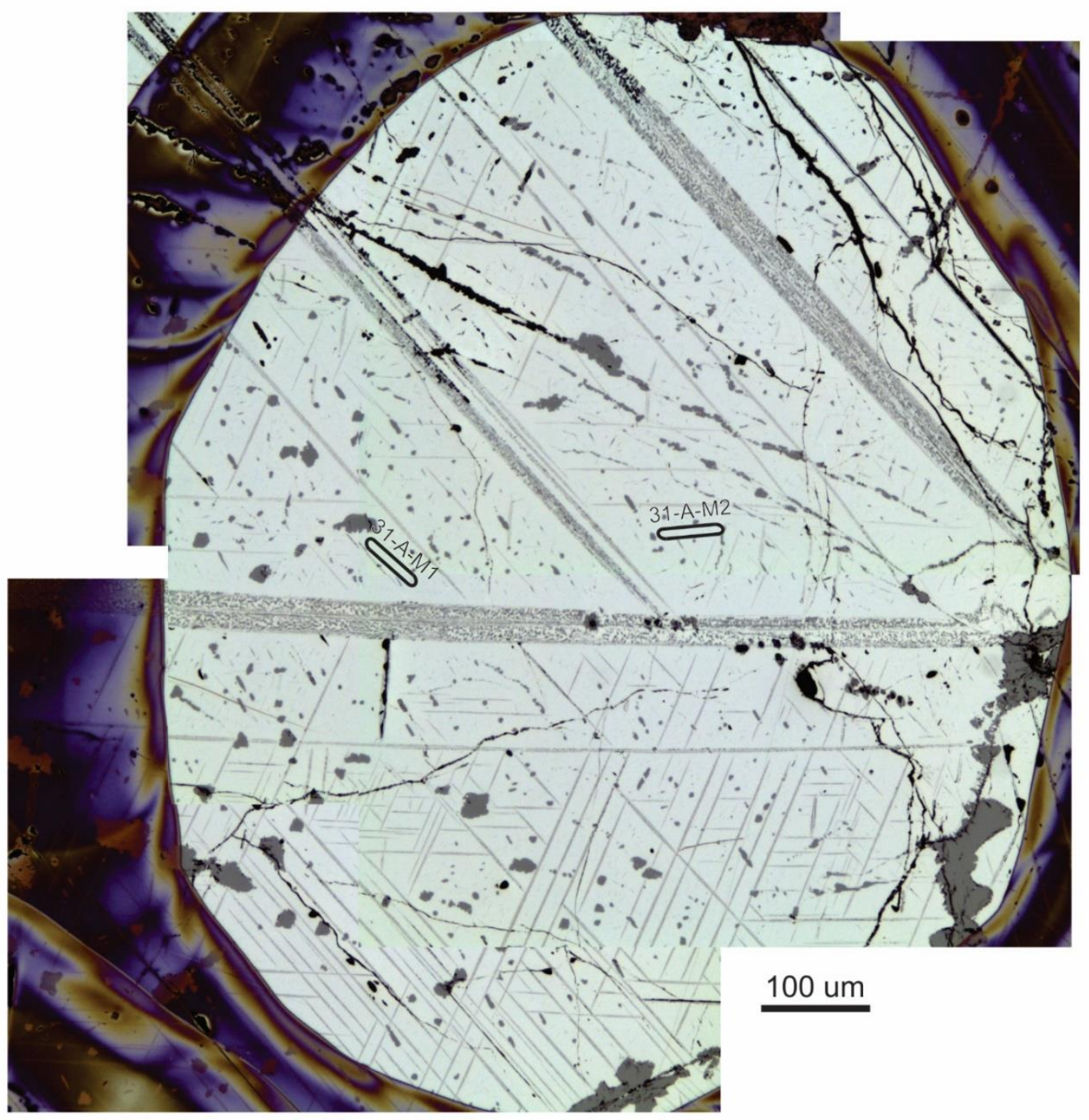


CC031 circle A EPMA
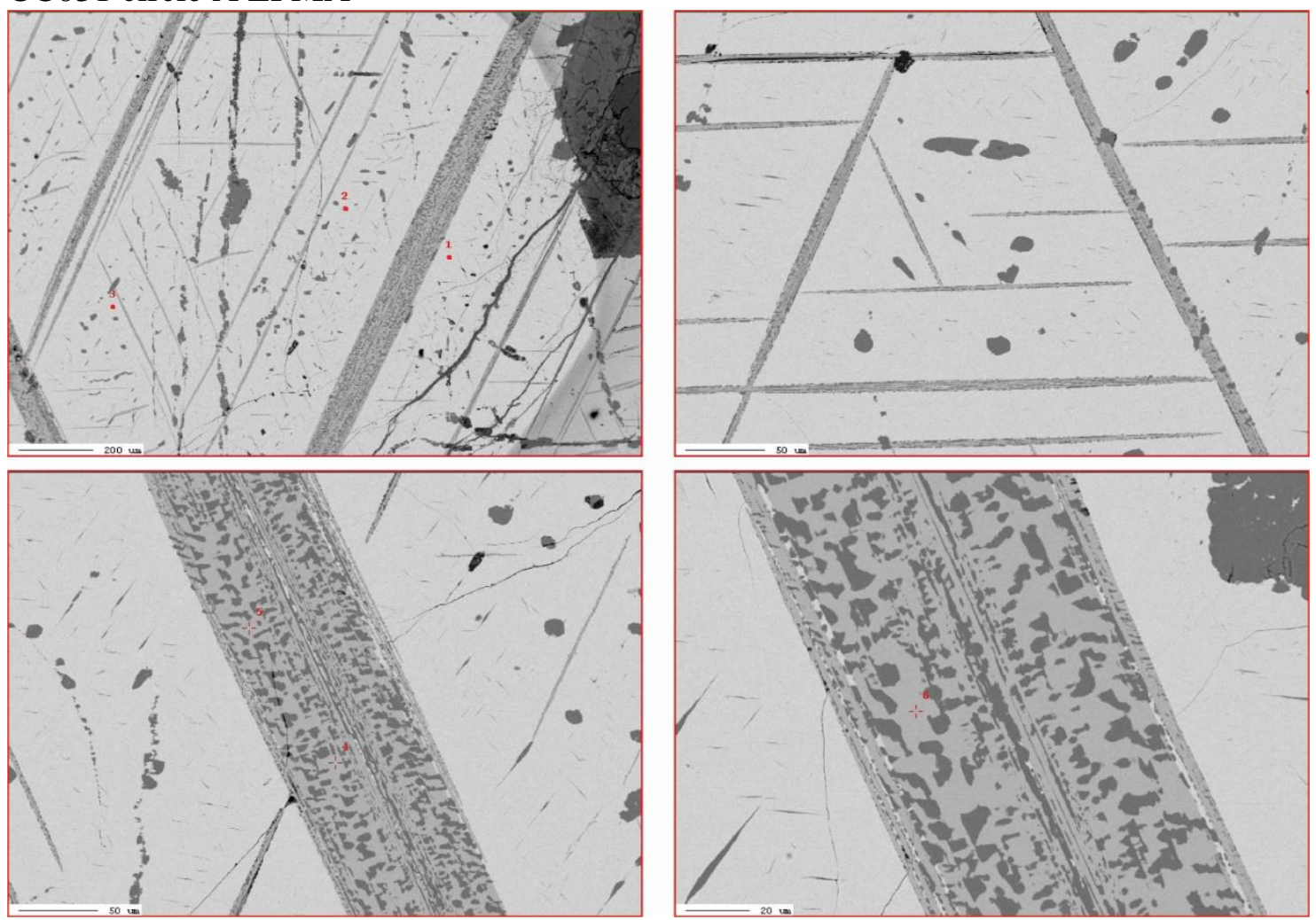
CC031 circle B LA-ICPMS

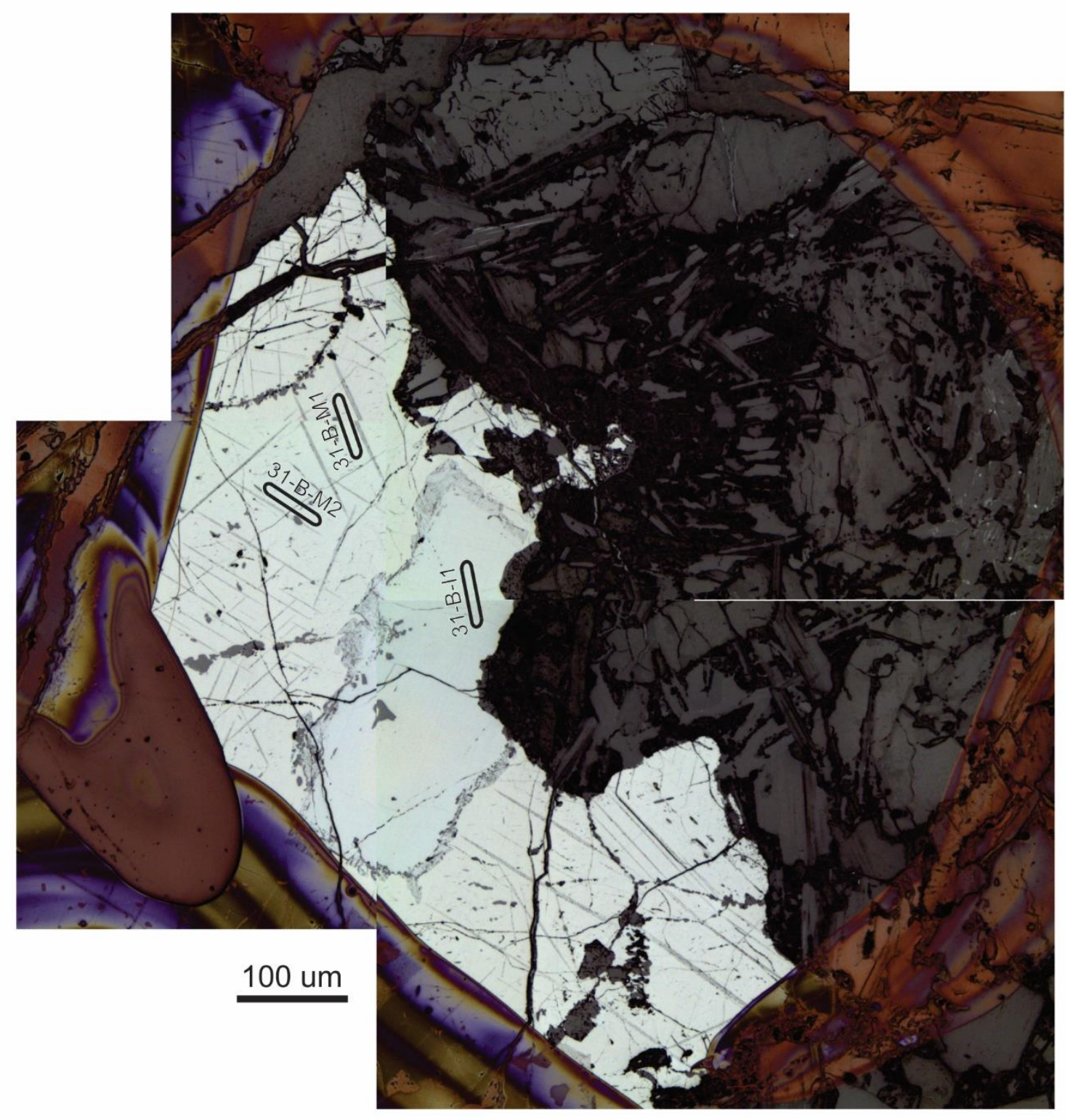


CC031 circle B EPMA
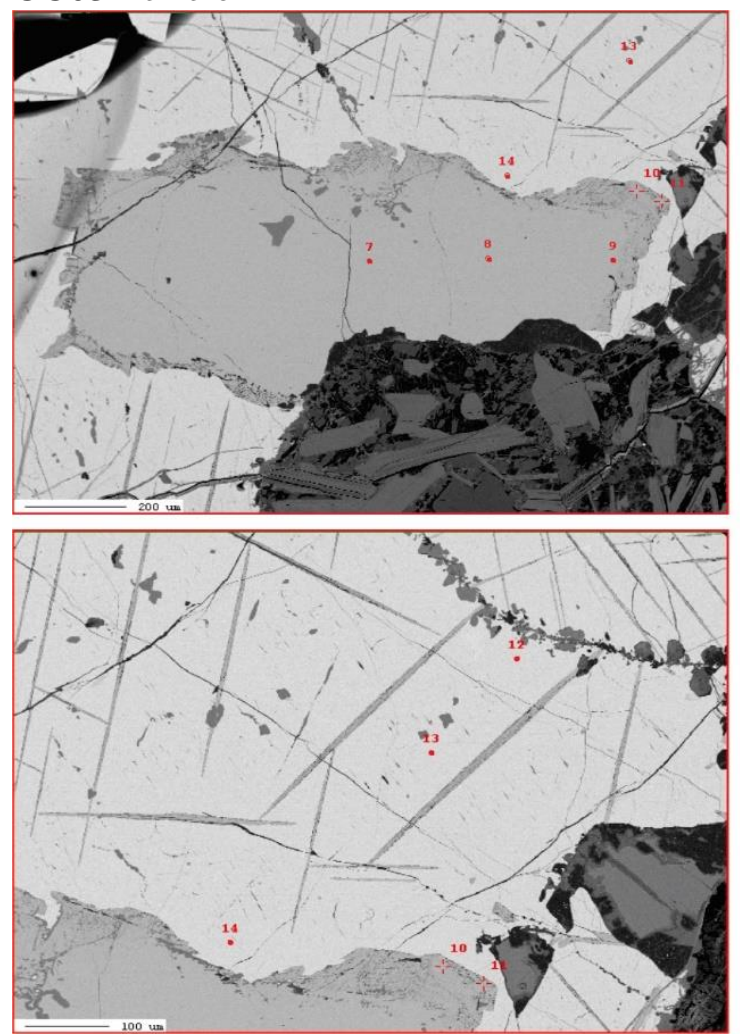

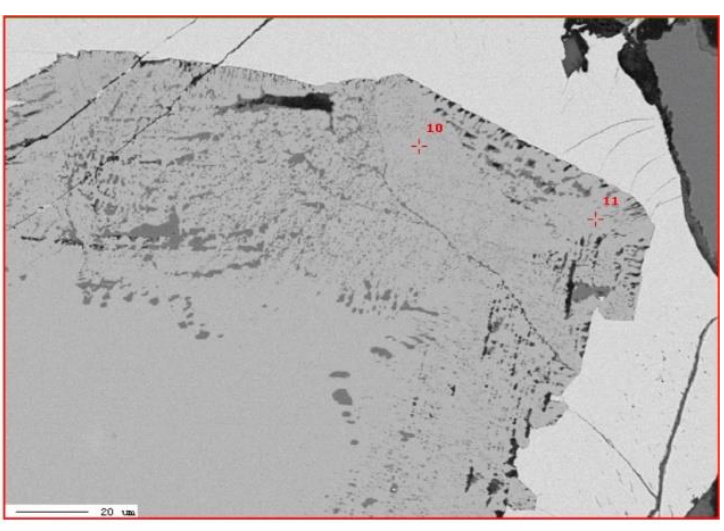


CC031 circle C LA-ICPMS

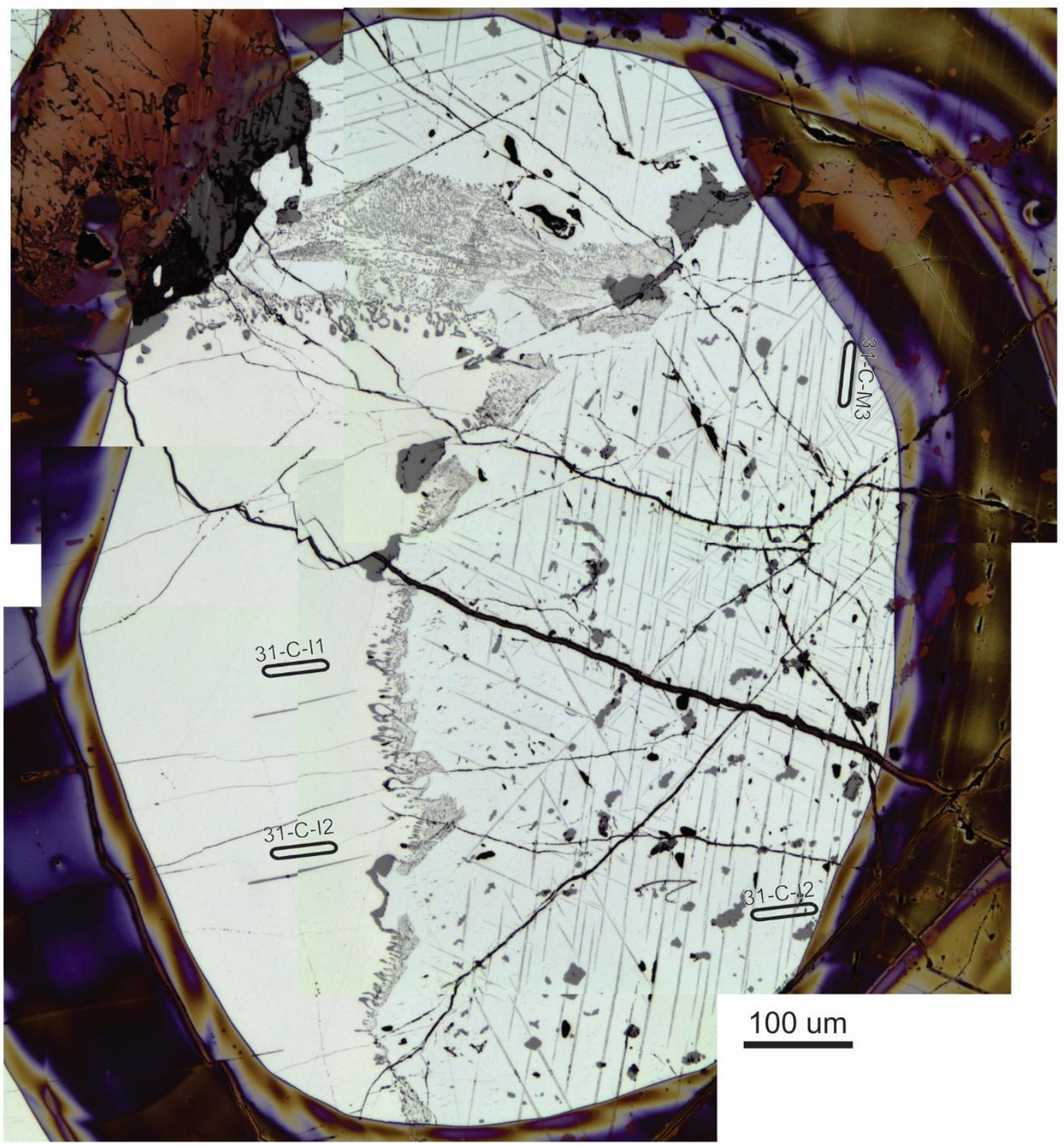


CC031 circle C EPMA
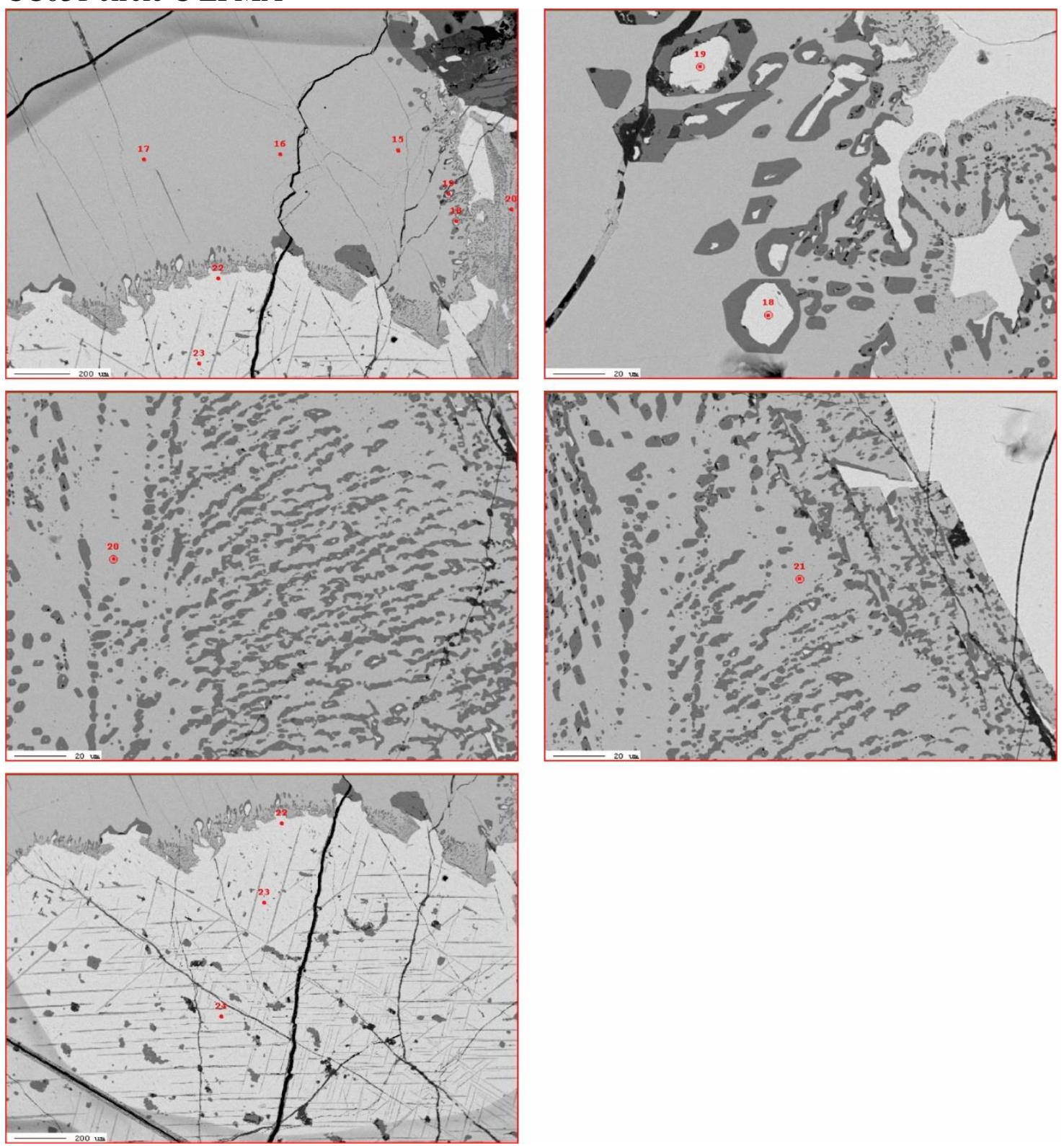
CC031 circle D LA-ICPMS

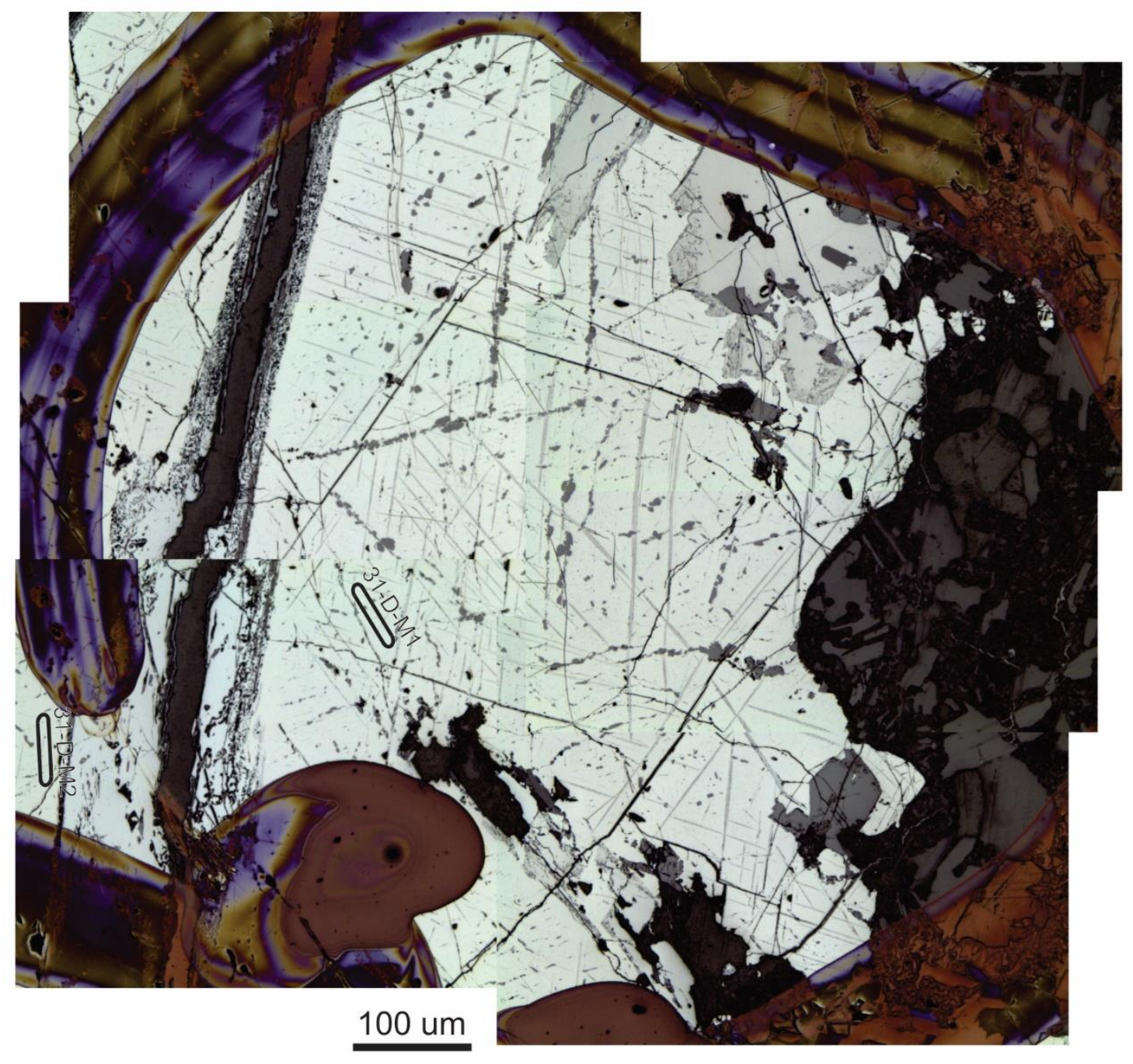


CC031 circle D EPMA
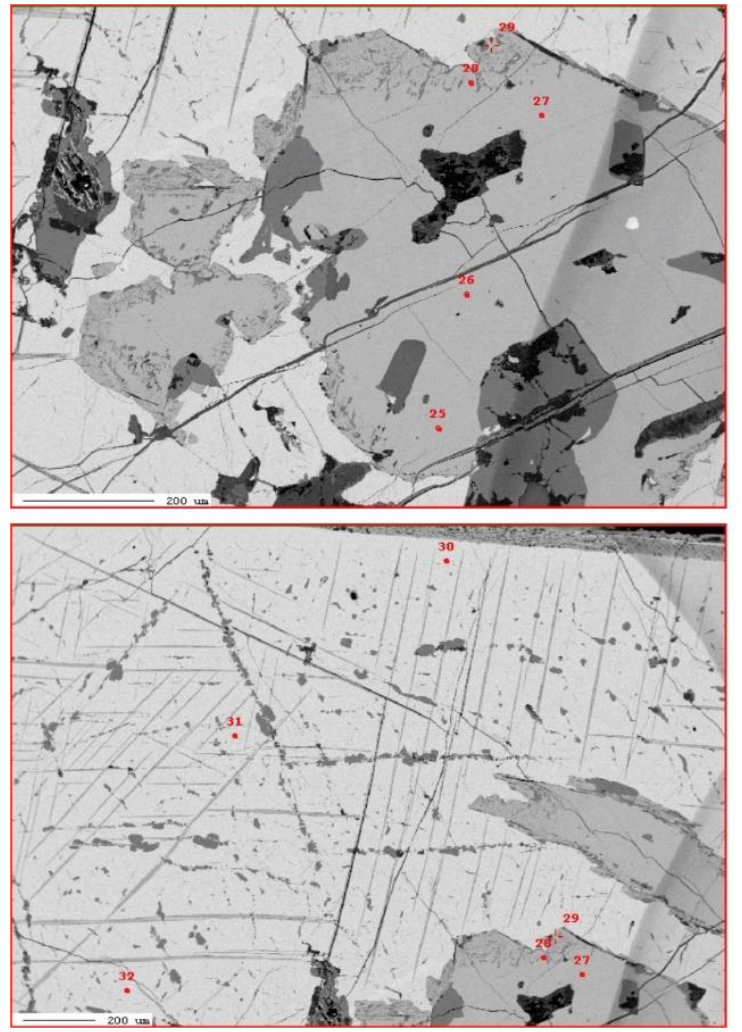
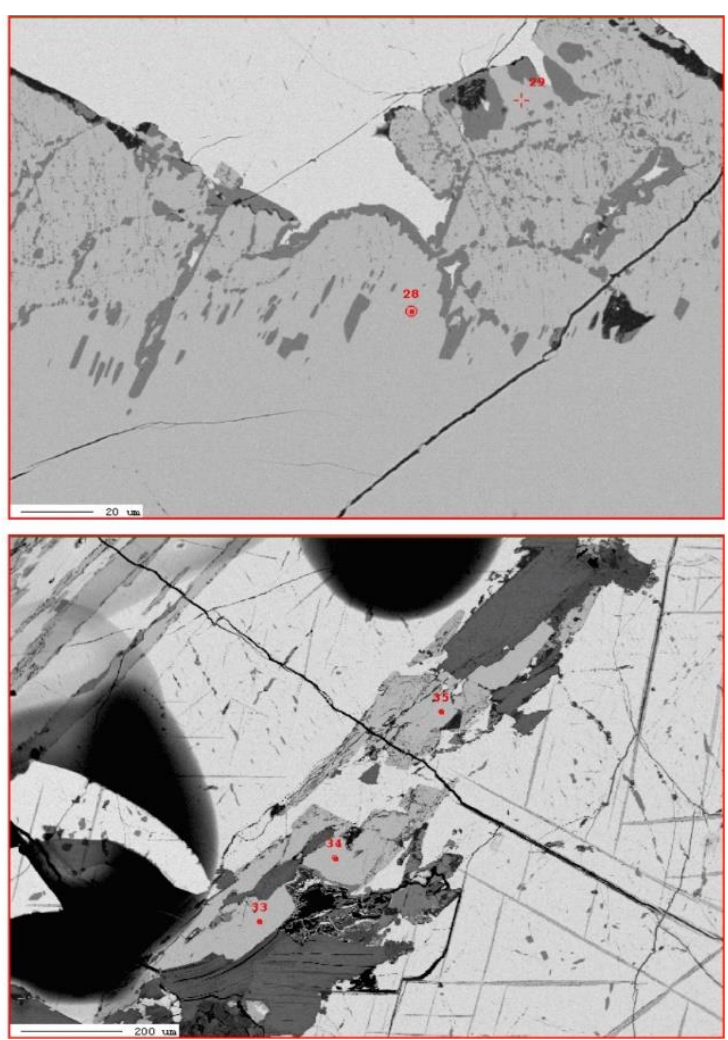


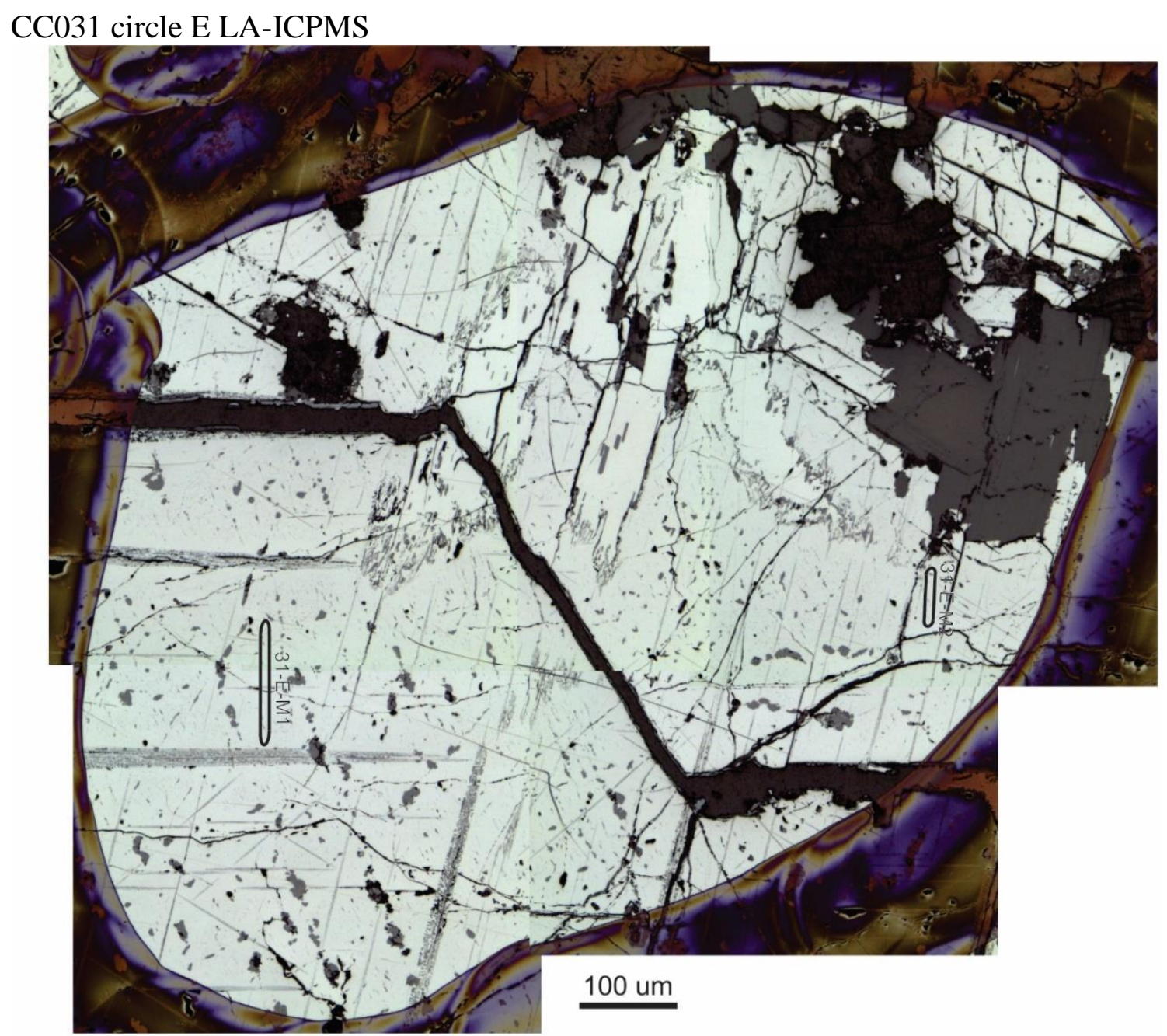


CC031 circle E EPMA
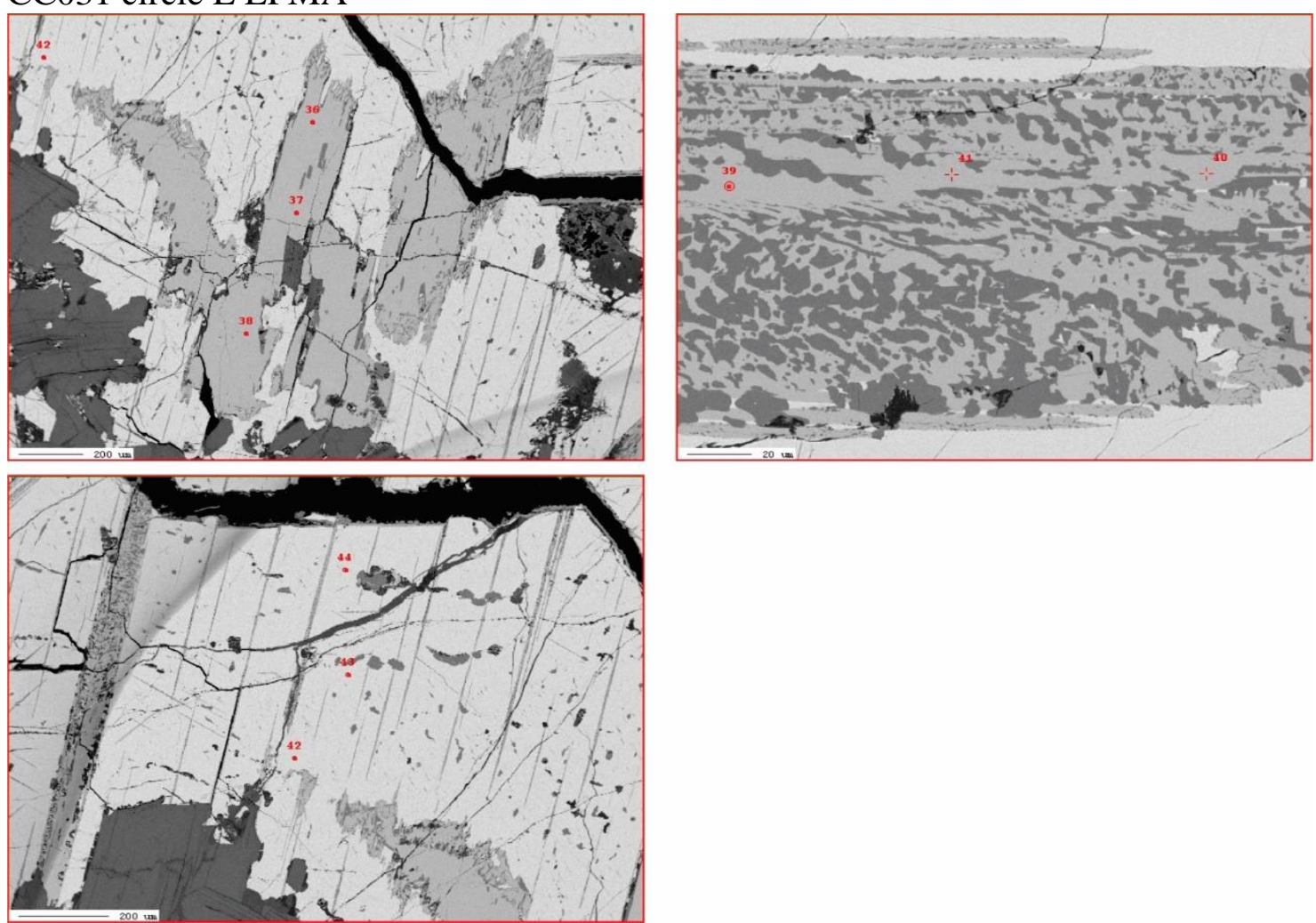
CC031 circle F LA-ICPMS

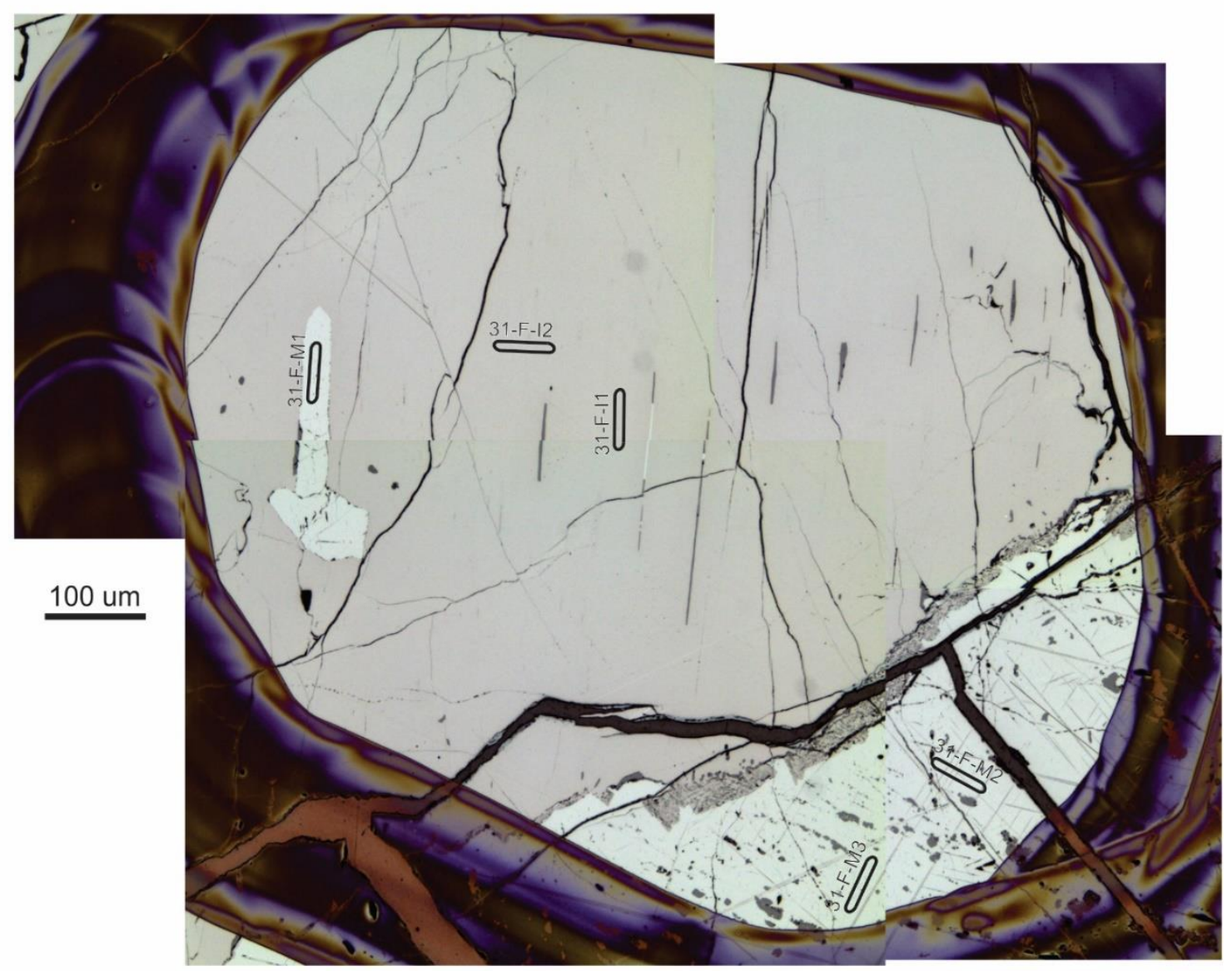

CC031 circle F EPMA

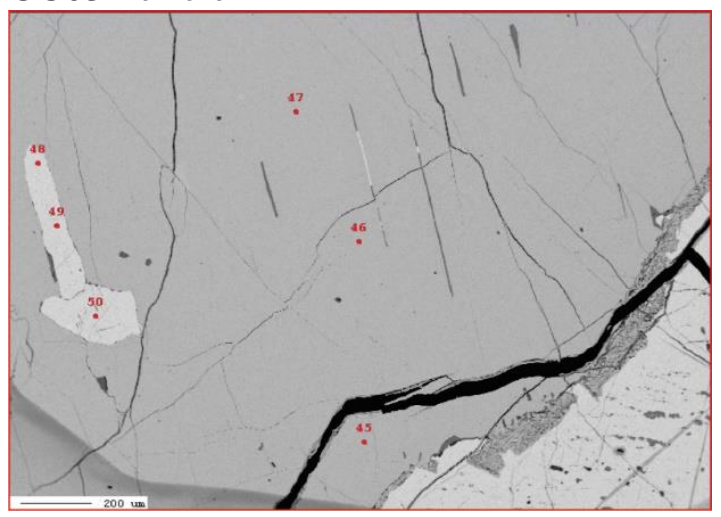


CC031 circle G EPMA
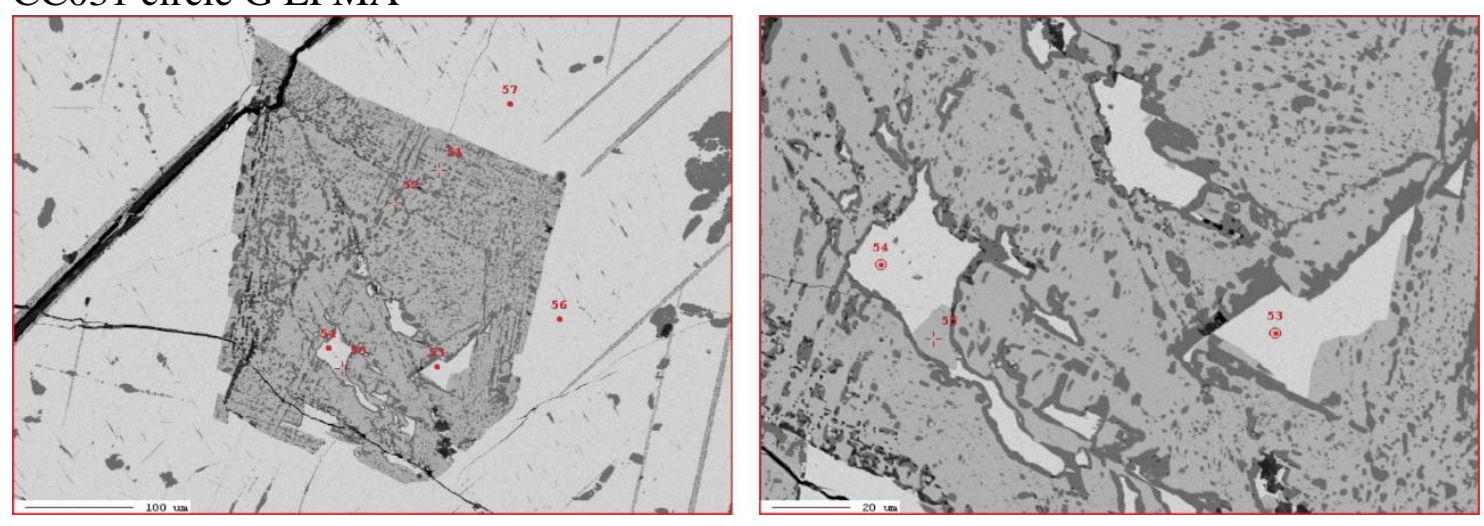
CC031 circle H LA-ICPMS

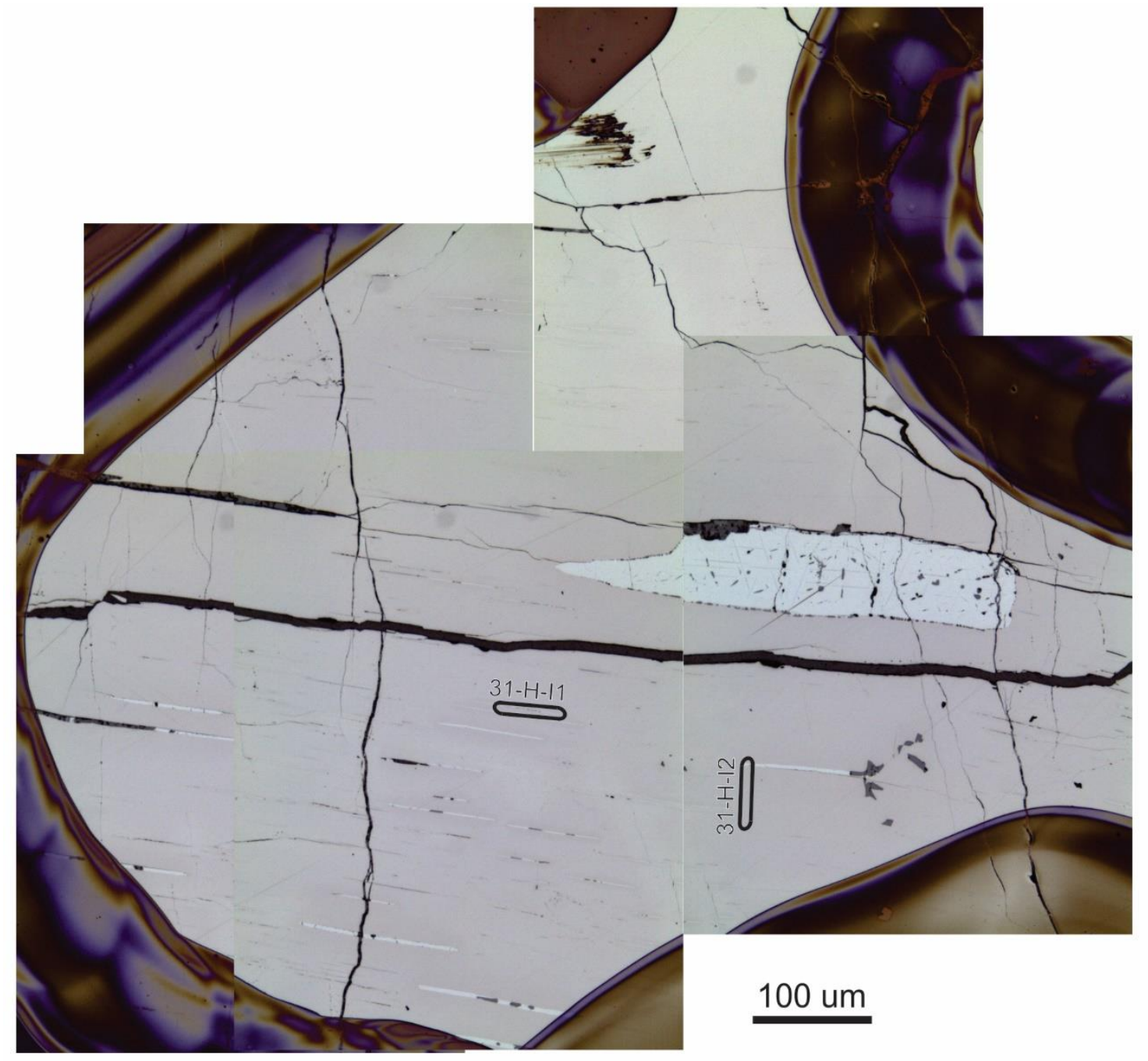

CC031 circle H EPMA

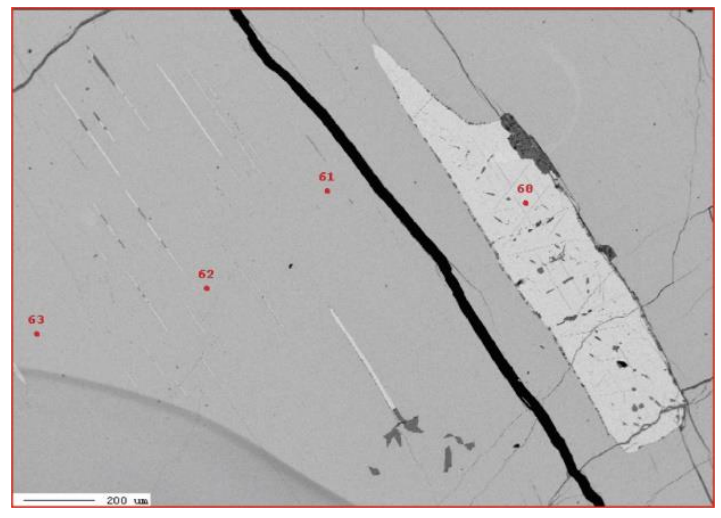


CC031 circle I LA-ICPMS

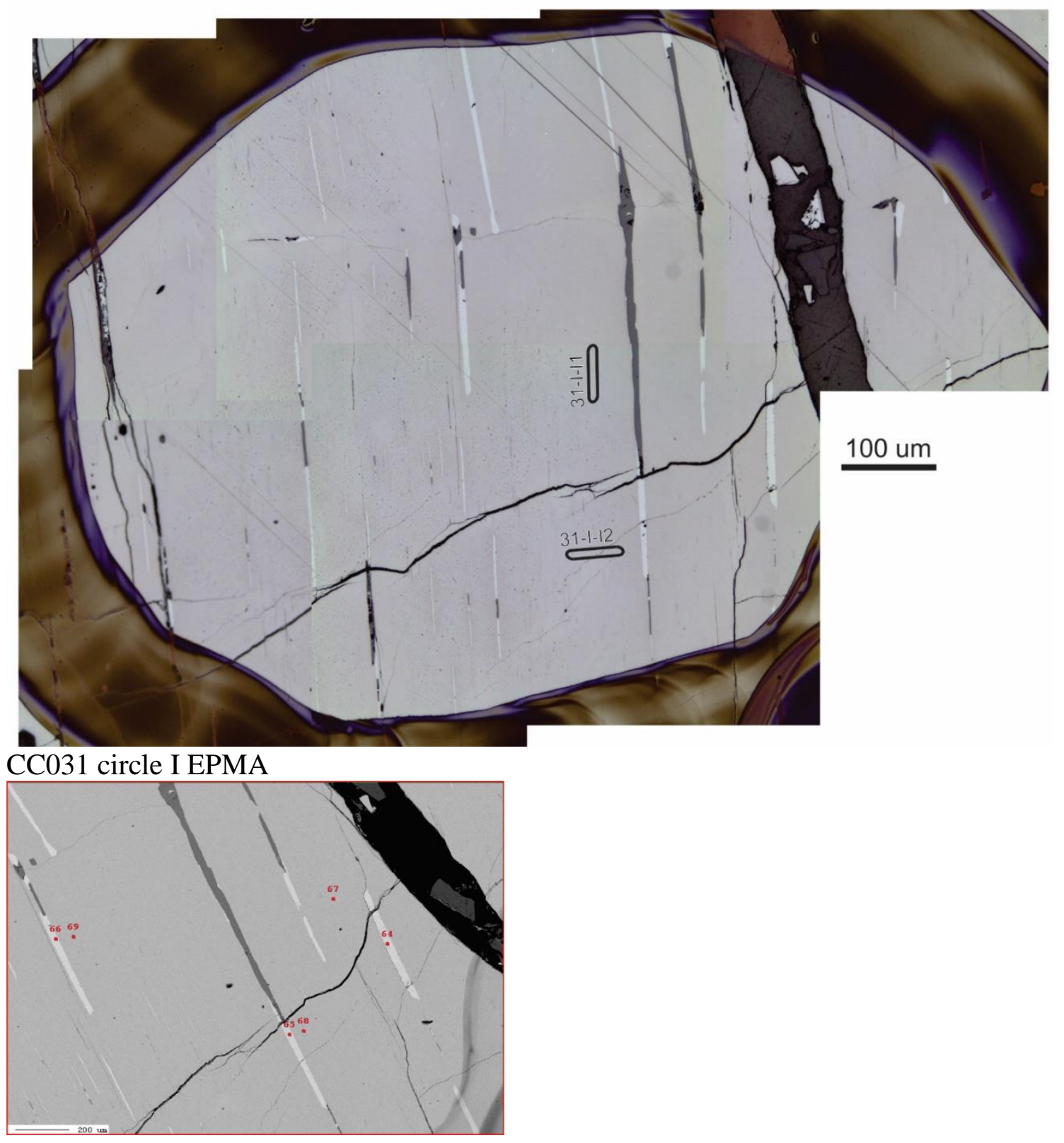




\section{CC054 circle A LA-ICPMS}

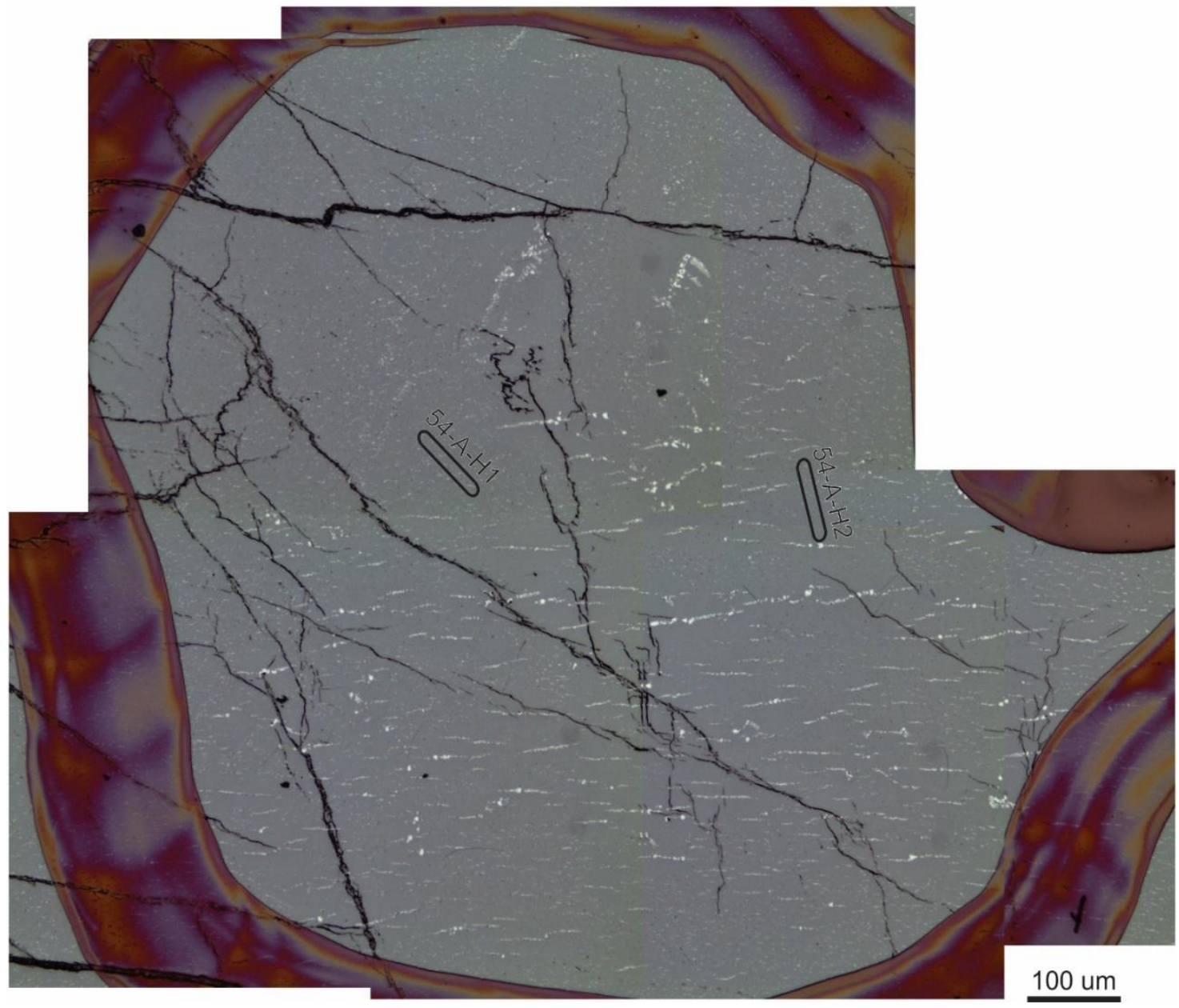


CC054 circle B LA-ICPMS

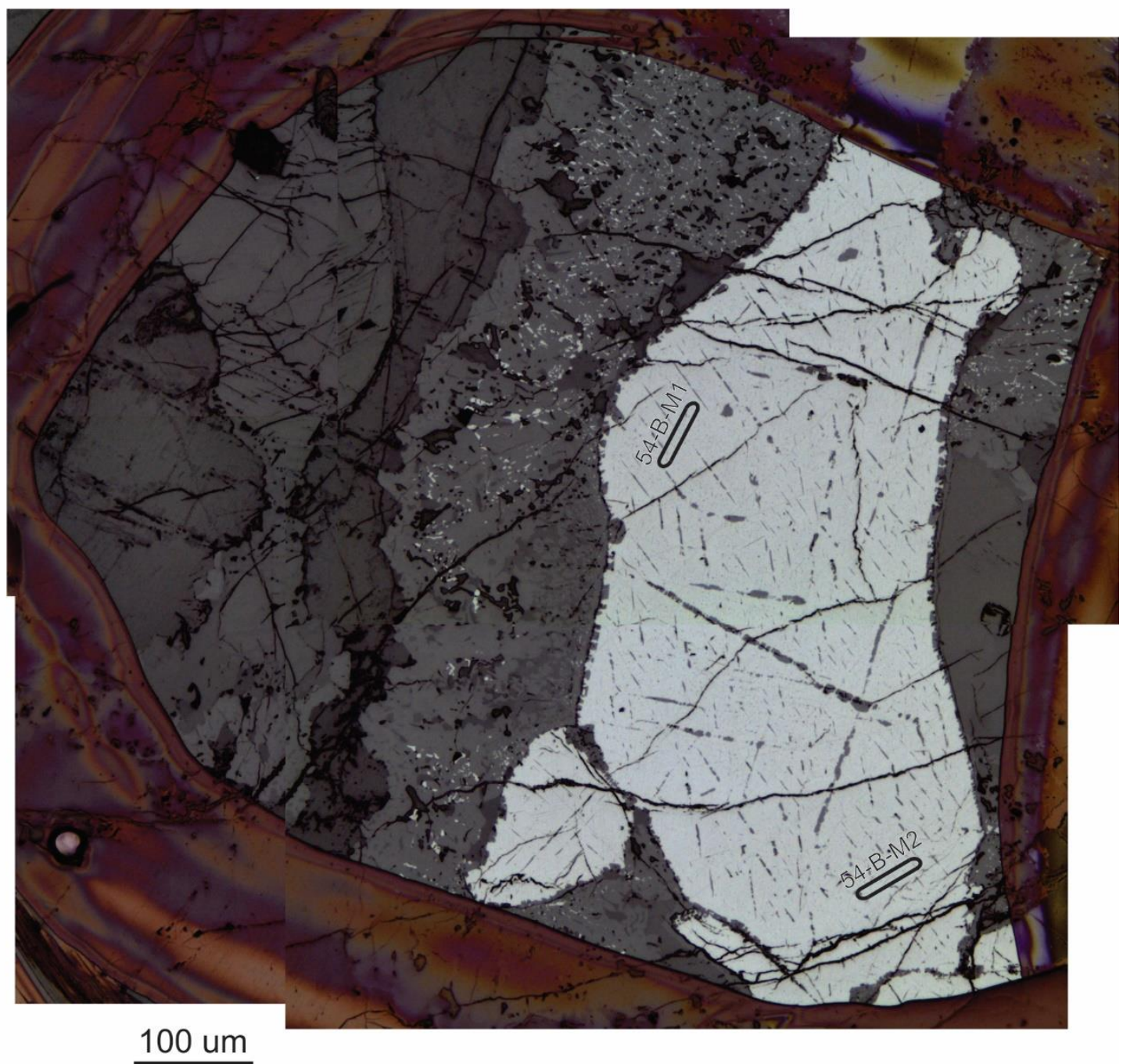

CC054 circle B EPMA

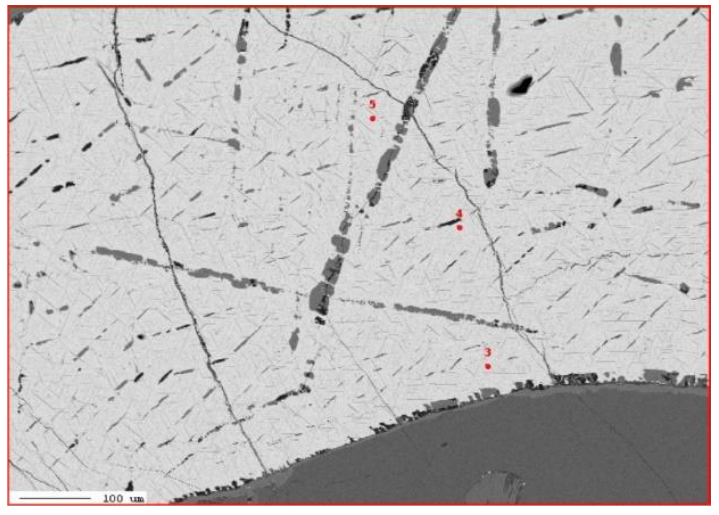


CC054 circle C LA-ICPMS
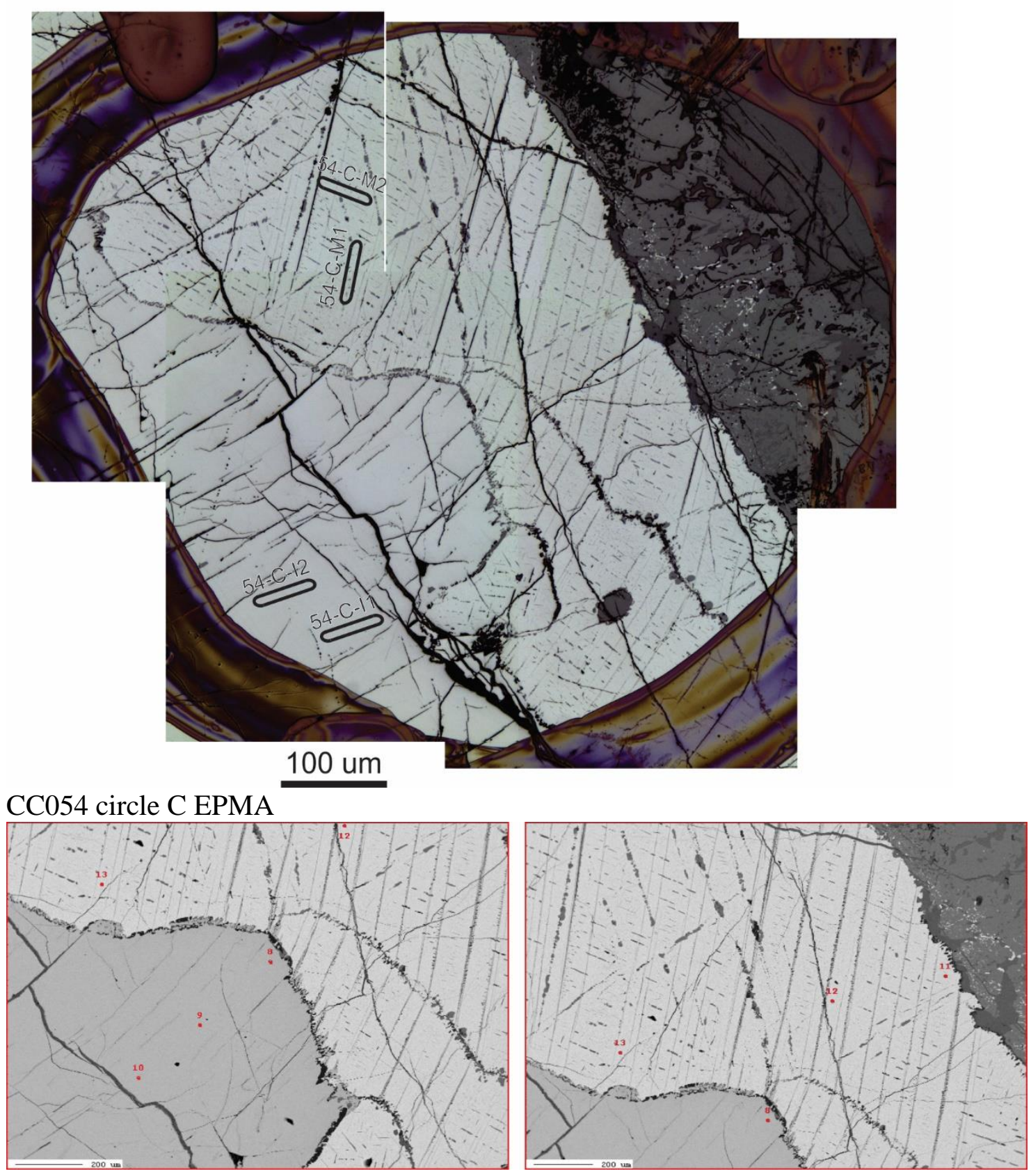
CC054 circle D LA-ICPMS

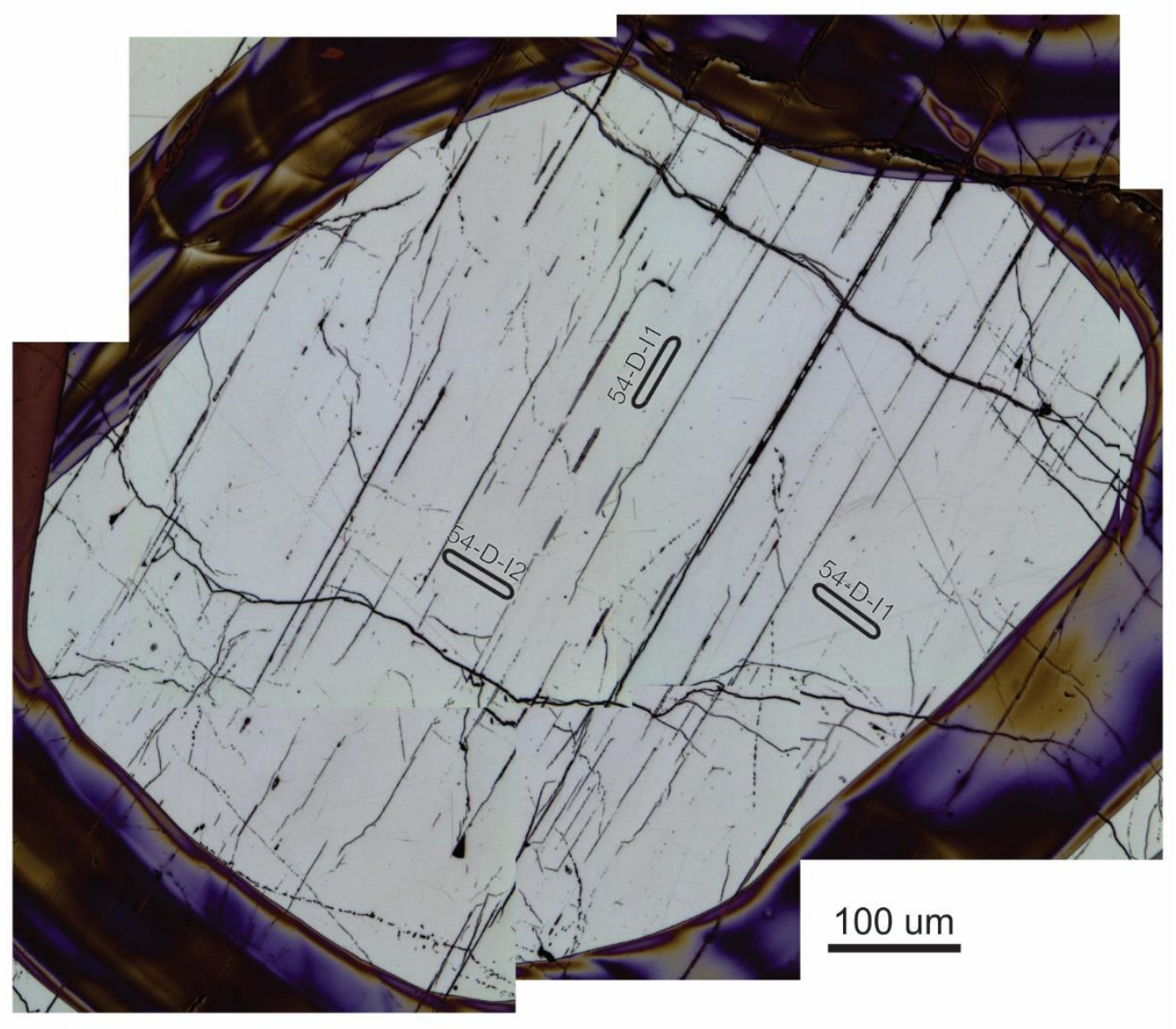


CC054 circle D EPMA
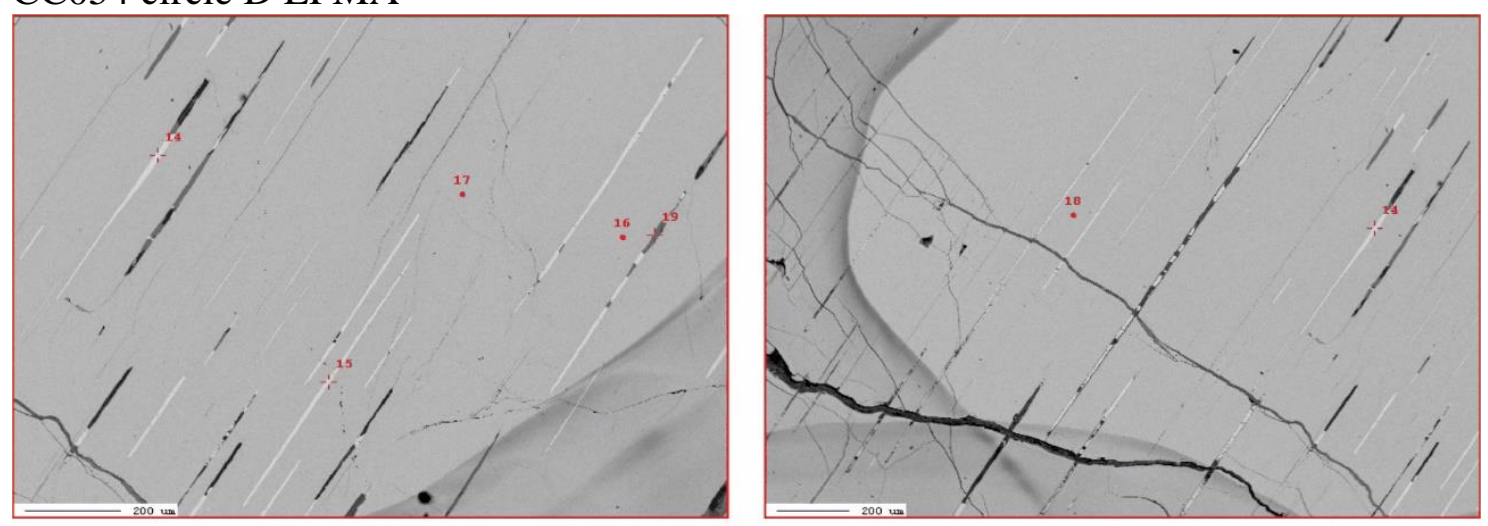

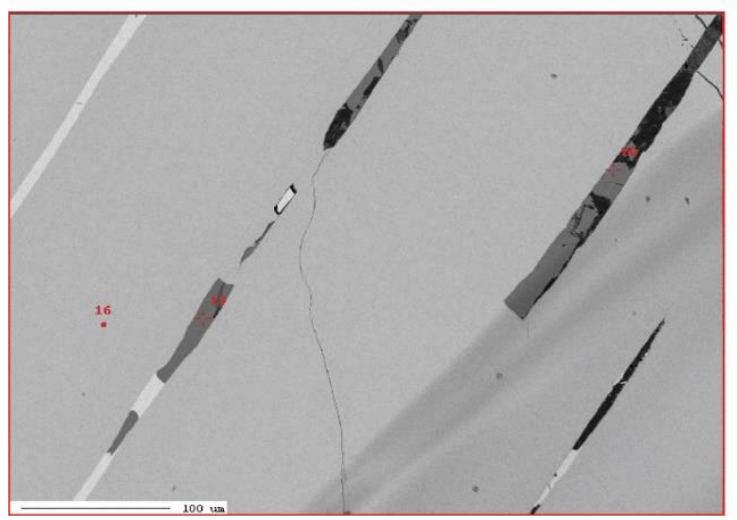


CC054 circle E EPMA
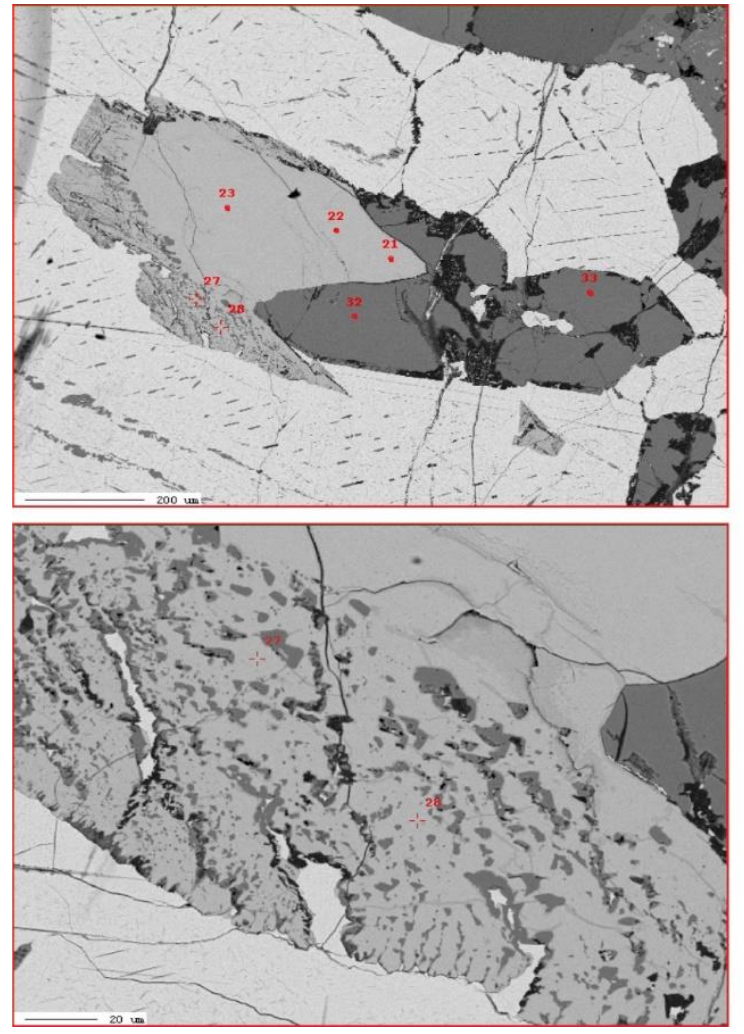
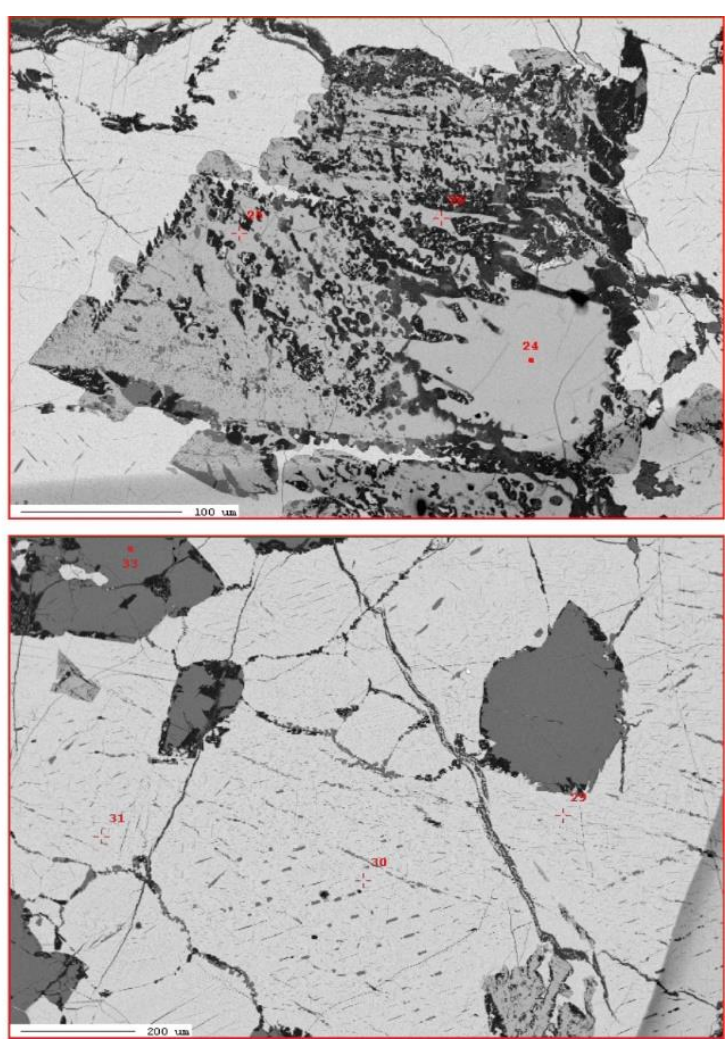


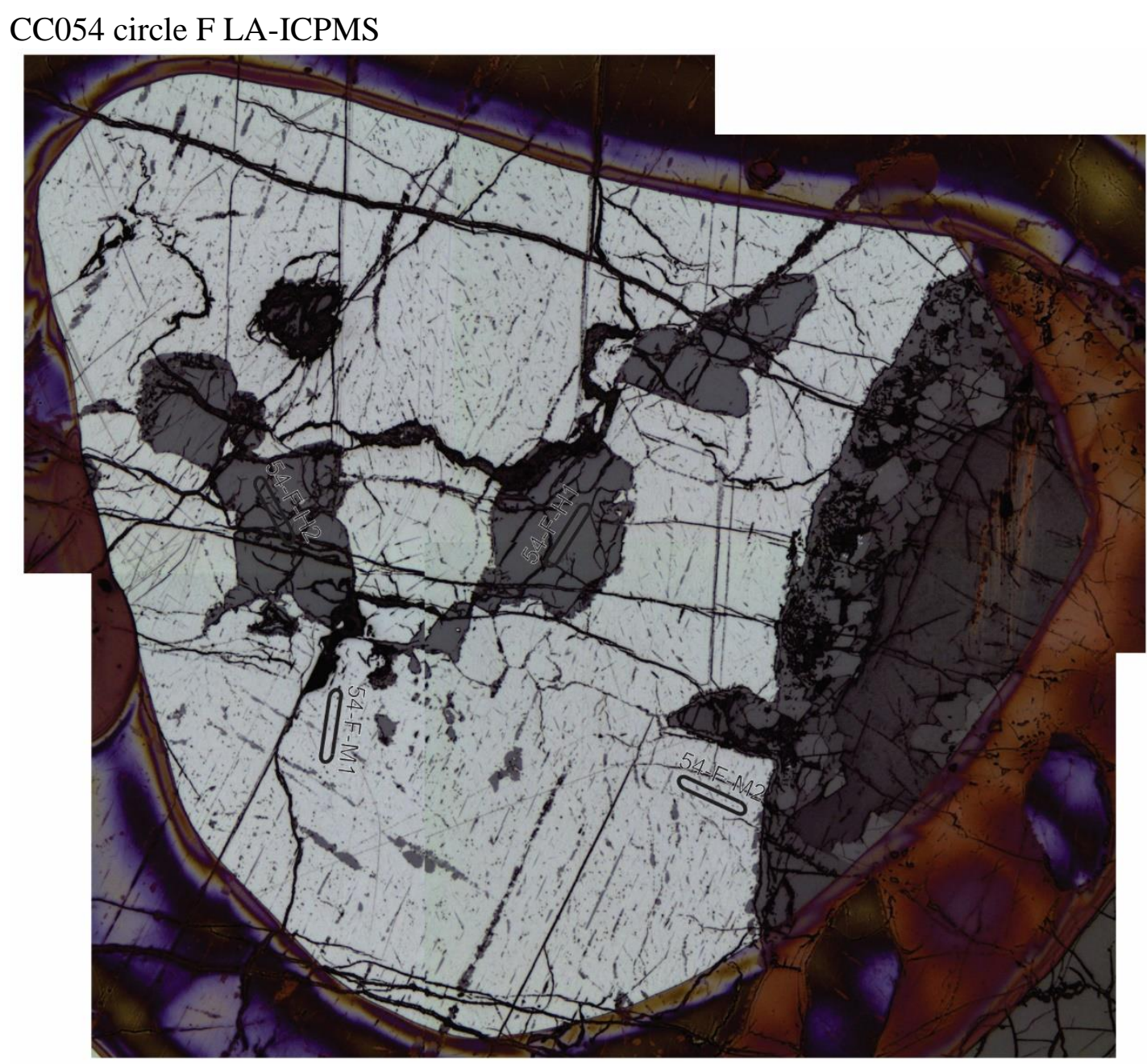

100 um

CC054 circle F EPMA

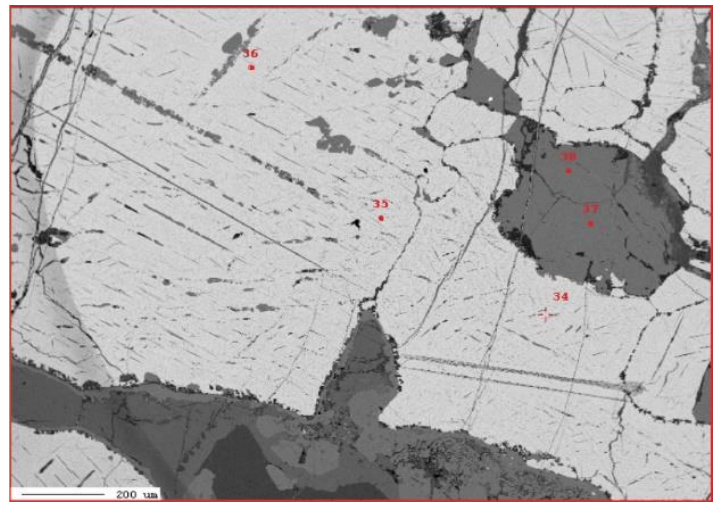


CC054 circle G LA-ICPMS

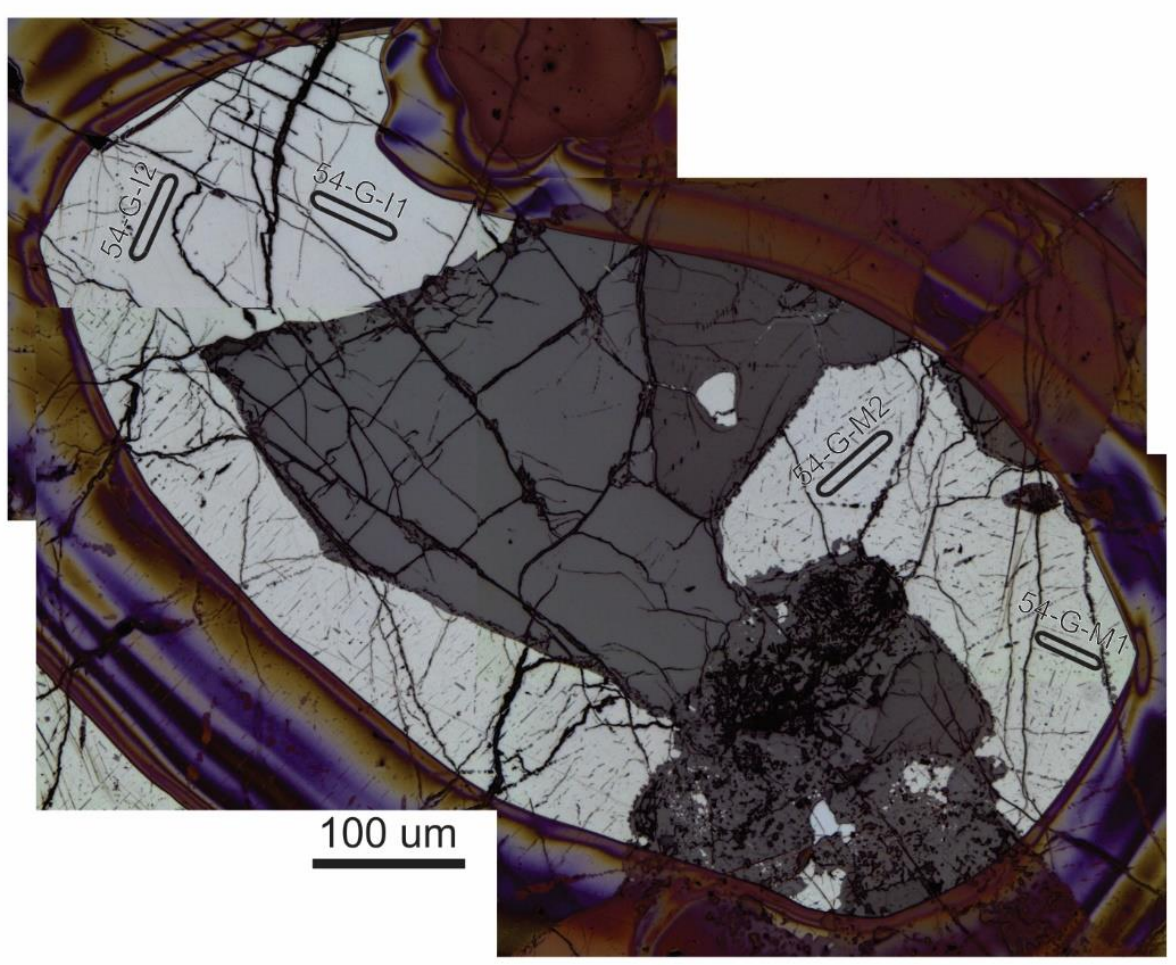

CC054 circle G EPMA
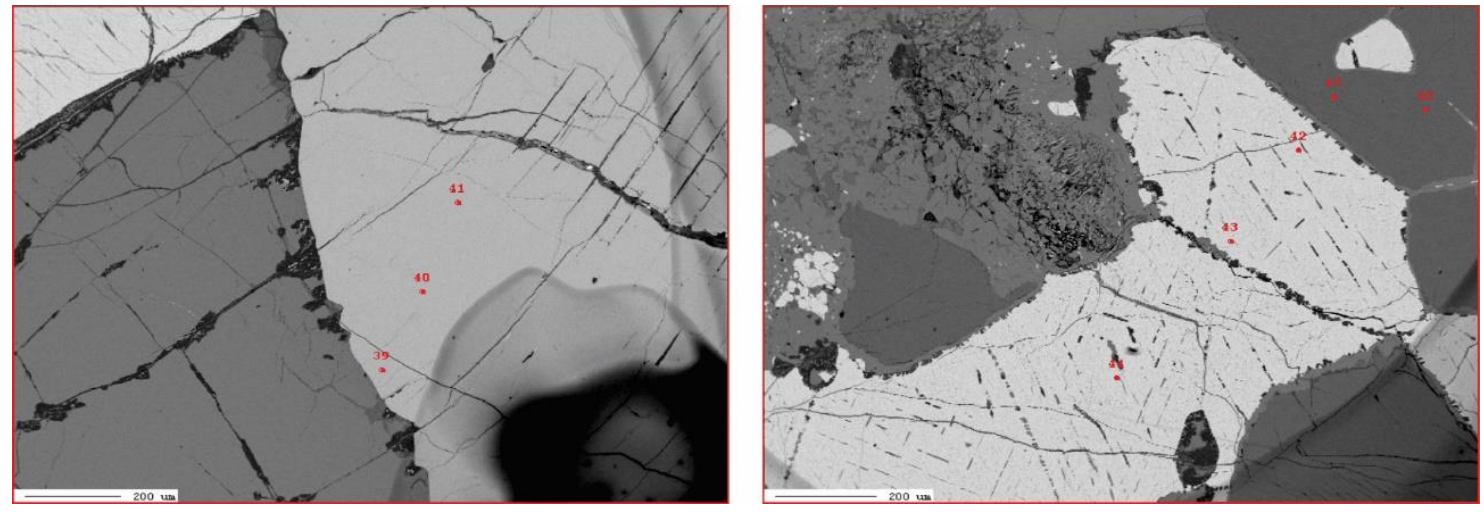
CC054 circle H EPMA
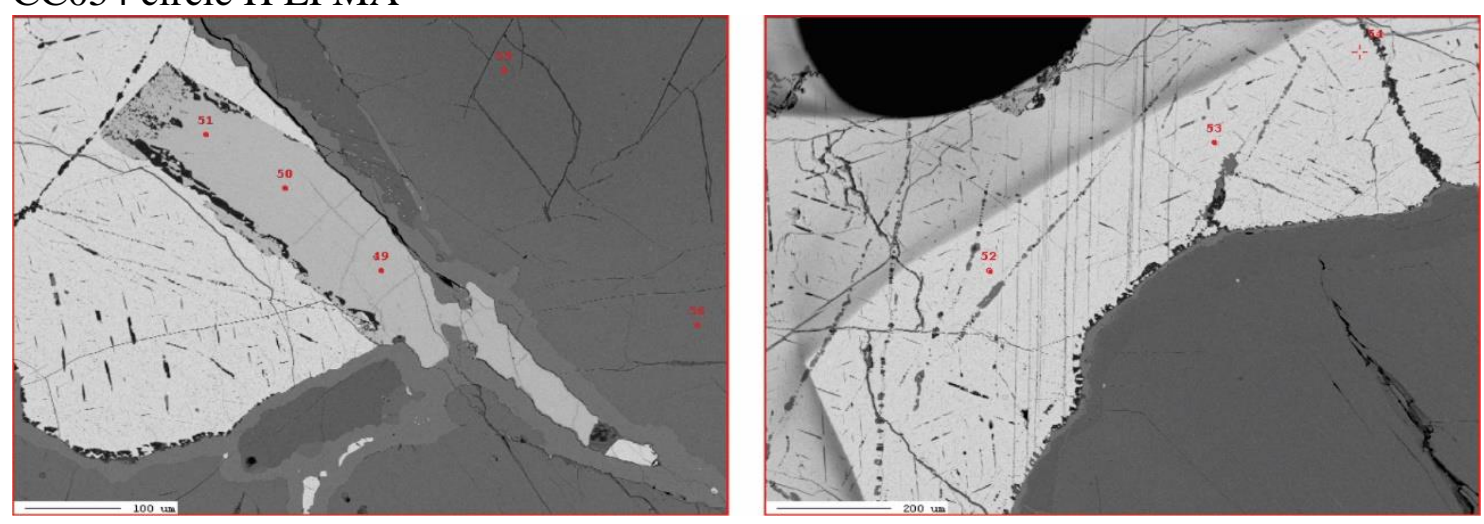


\section{CC054 Circle I LA-ICPMS}

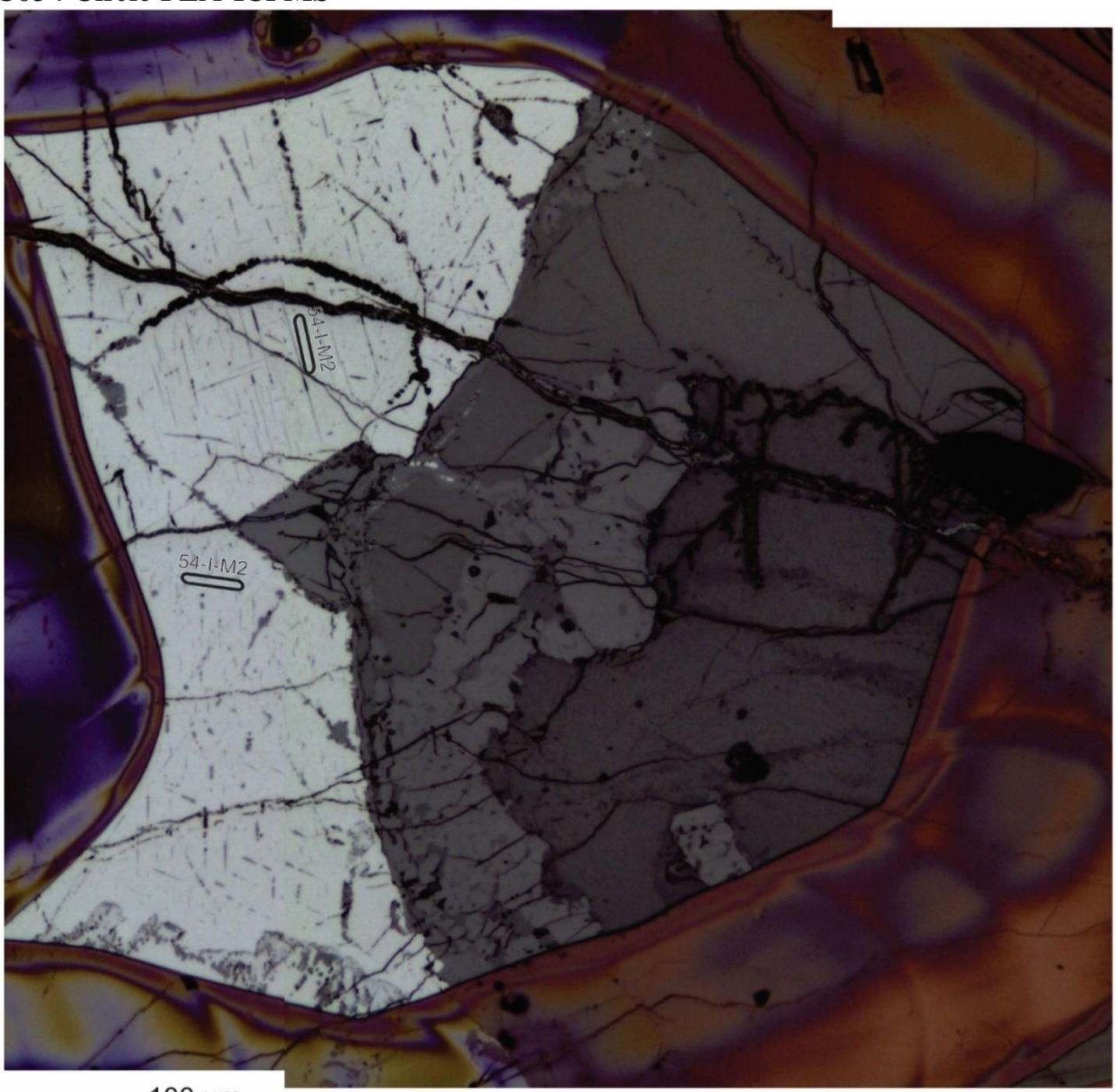

$$
100 \mathrm{um}
$$

CC054 circle J EPMA
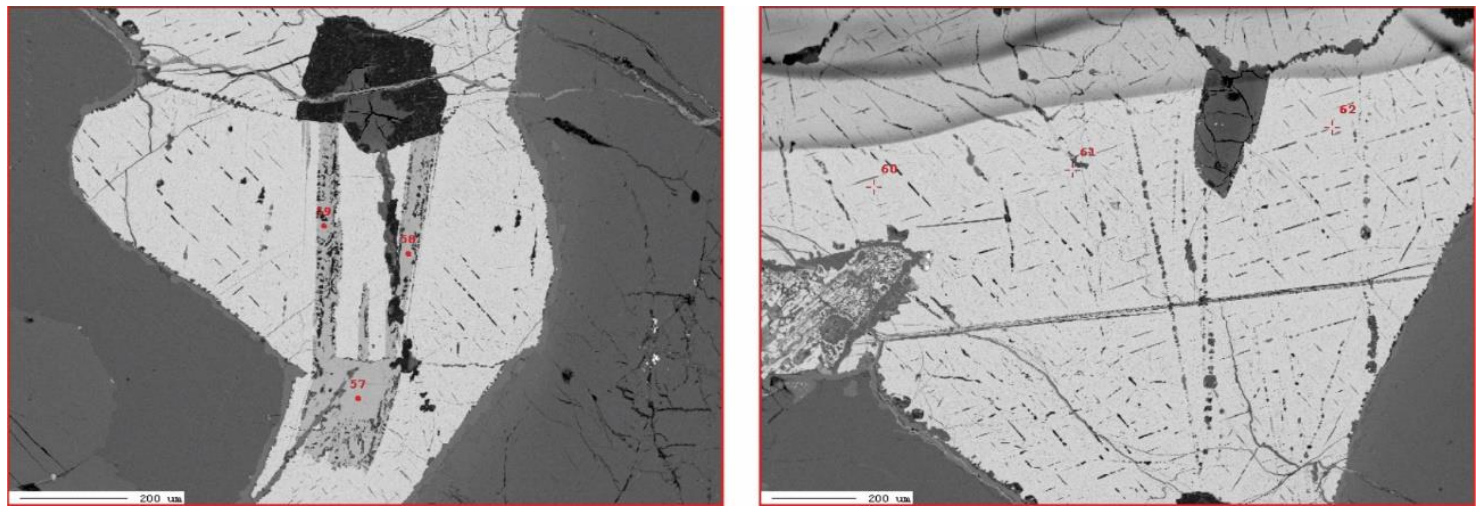
CC054 circle L LA-ICPMS

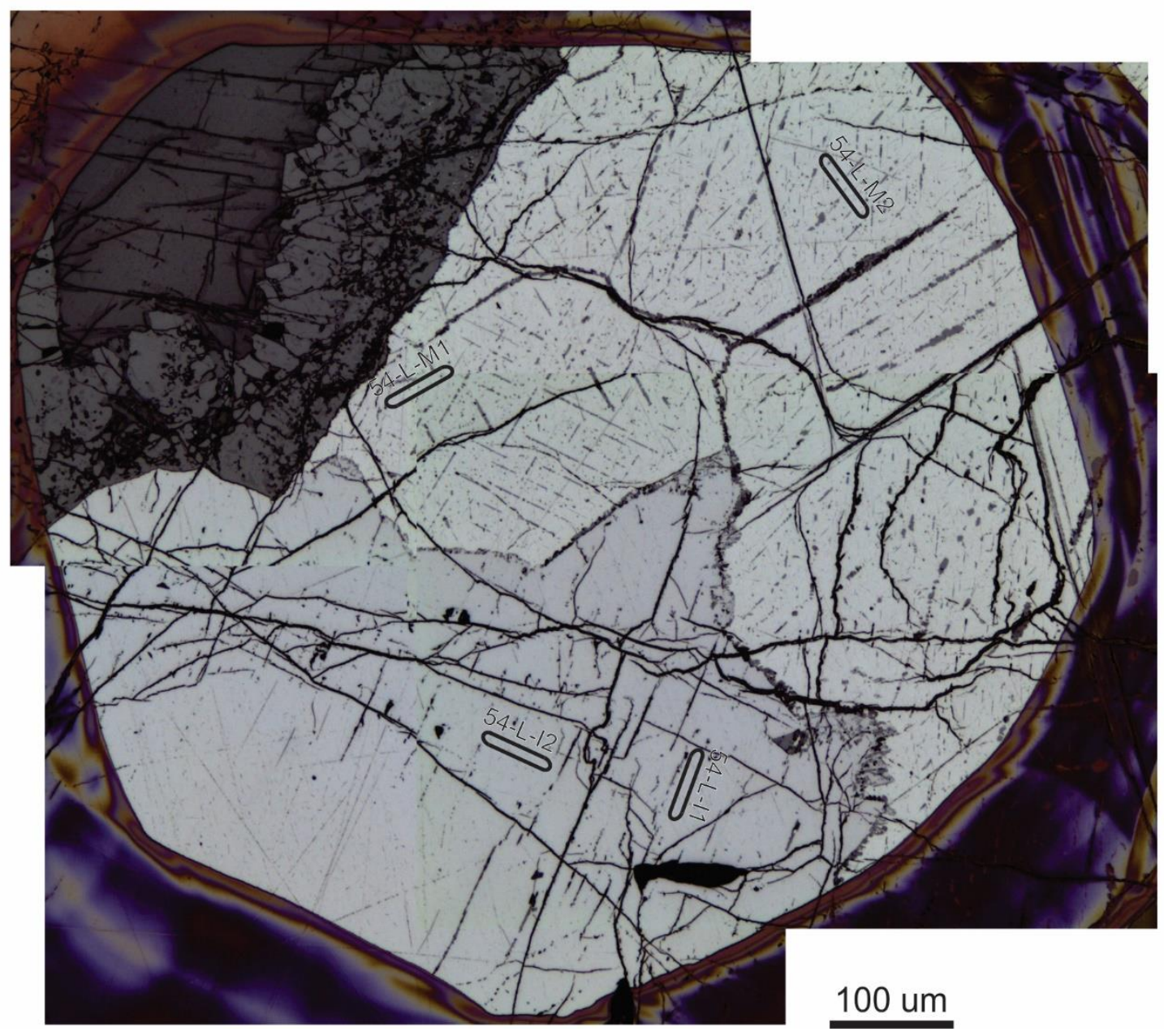


CC054 circle L EPMA
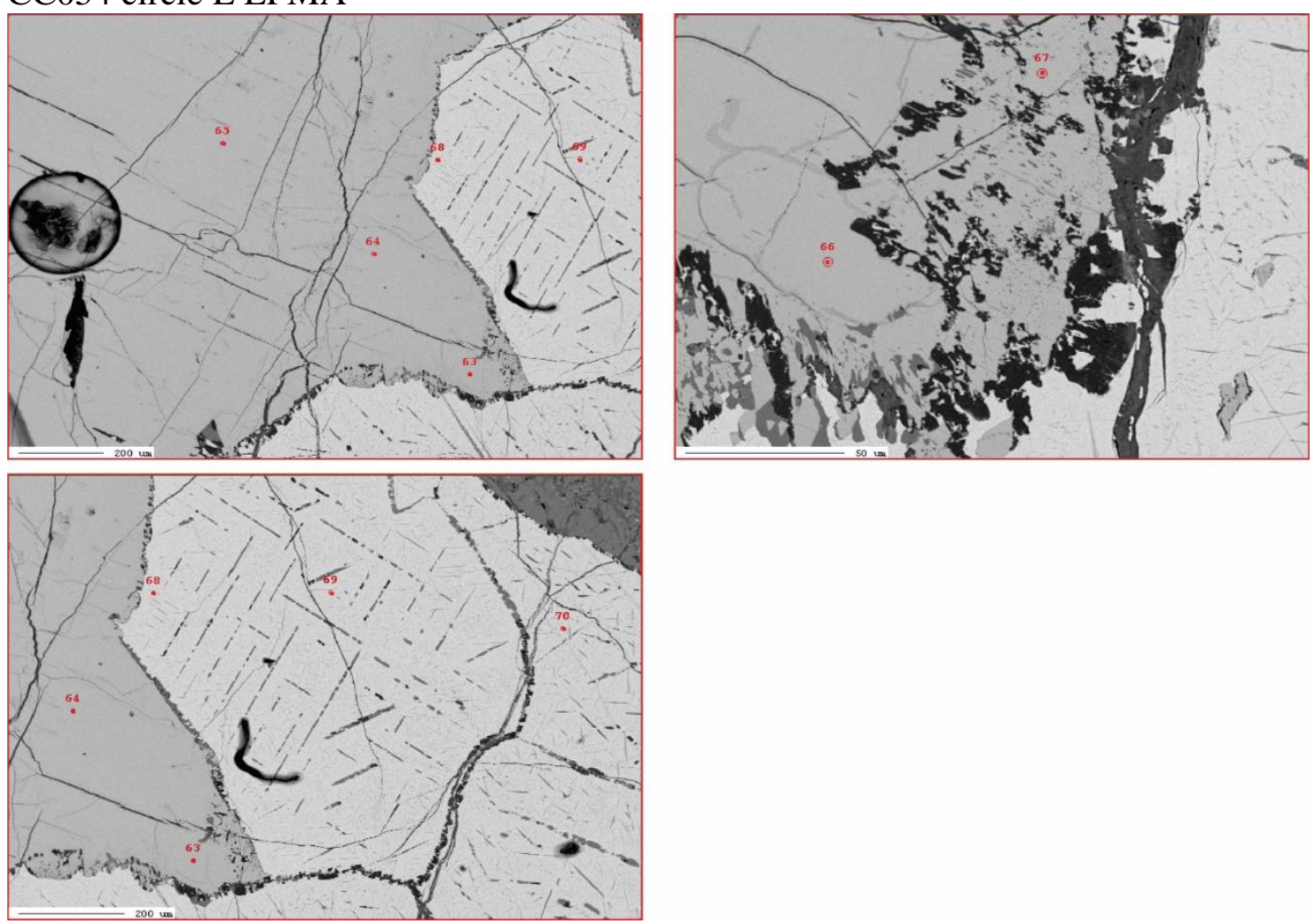
CC054 circle M LA-ICPMS

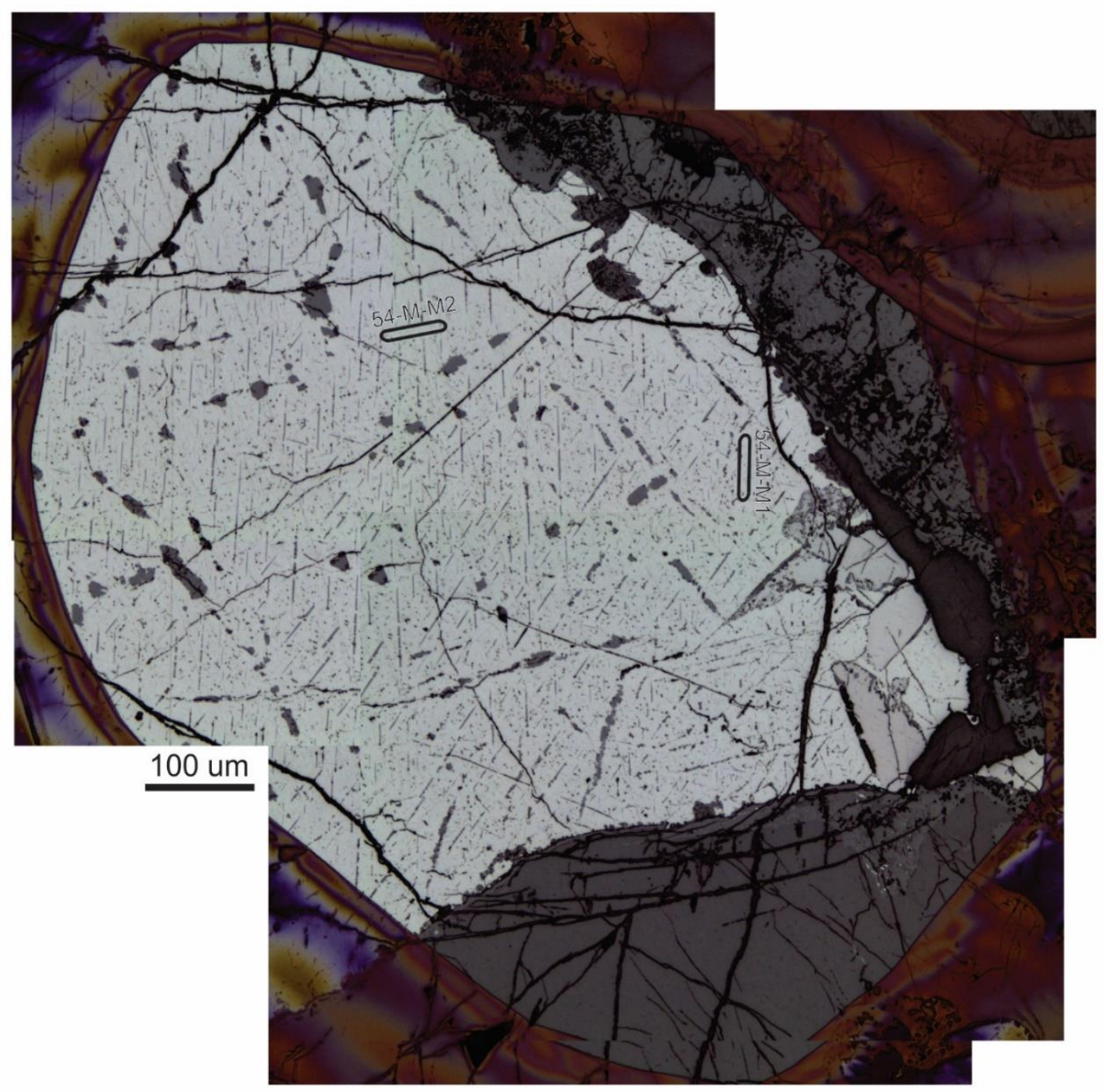


CC054 circle O LA-ICPMS
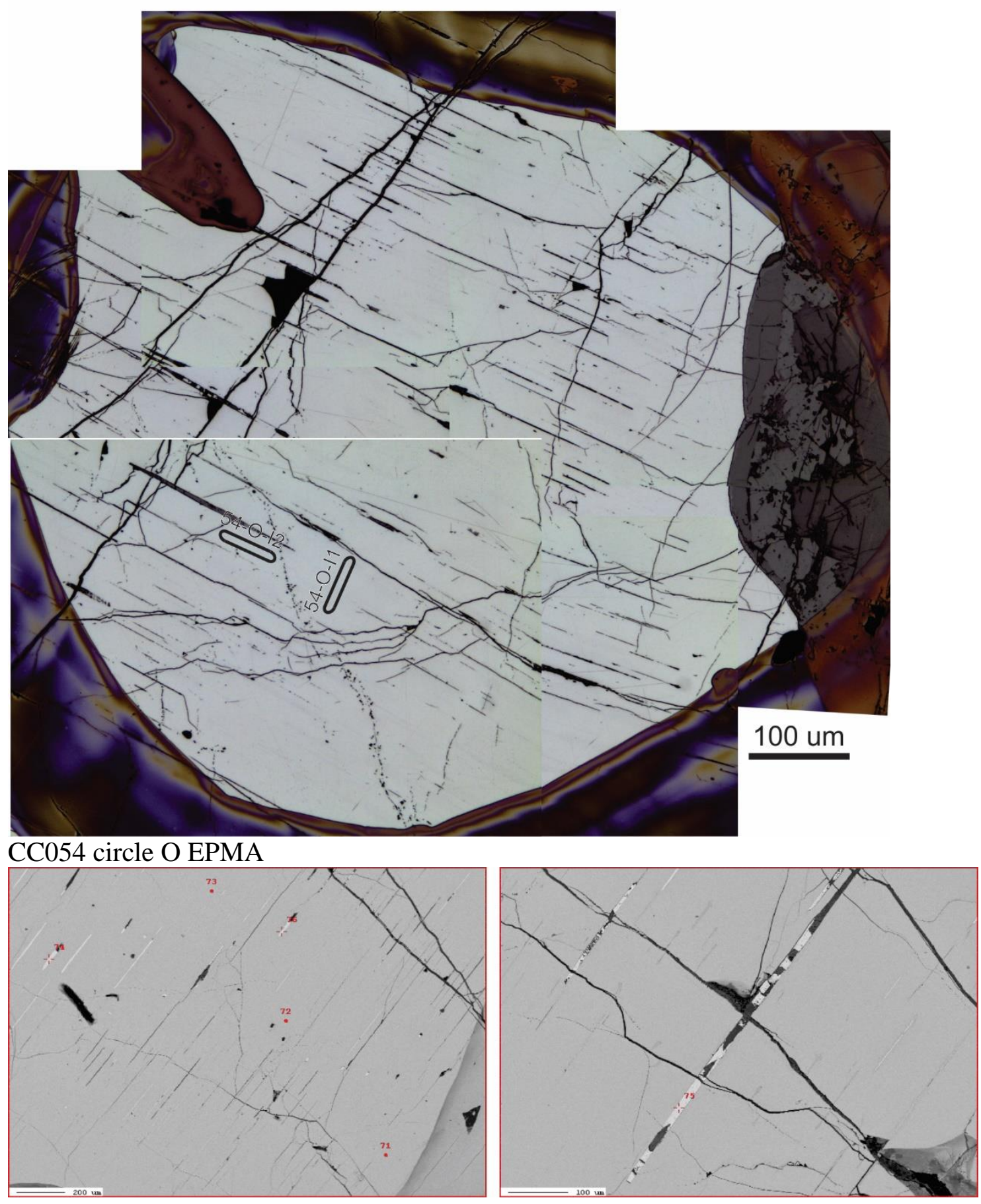
CC072 circle A LA-ICPMS

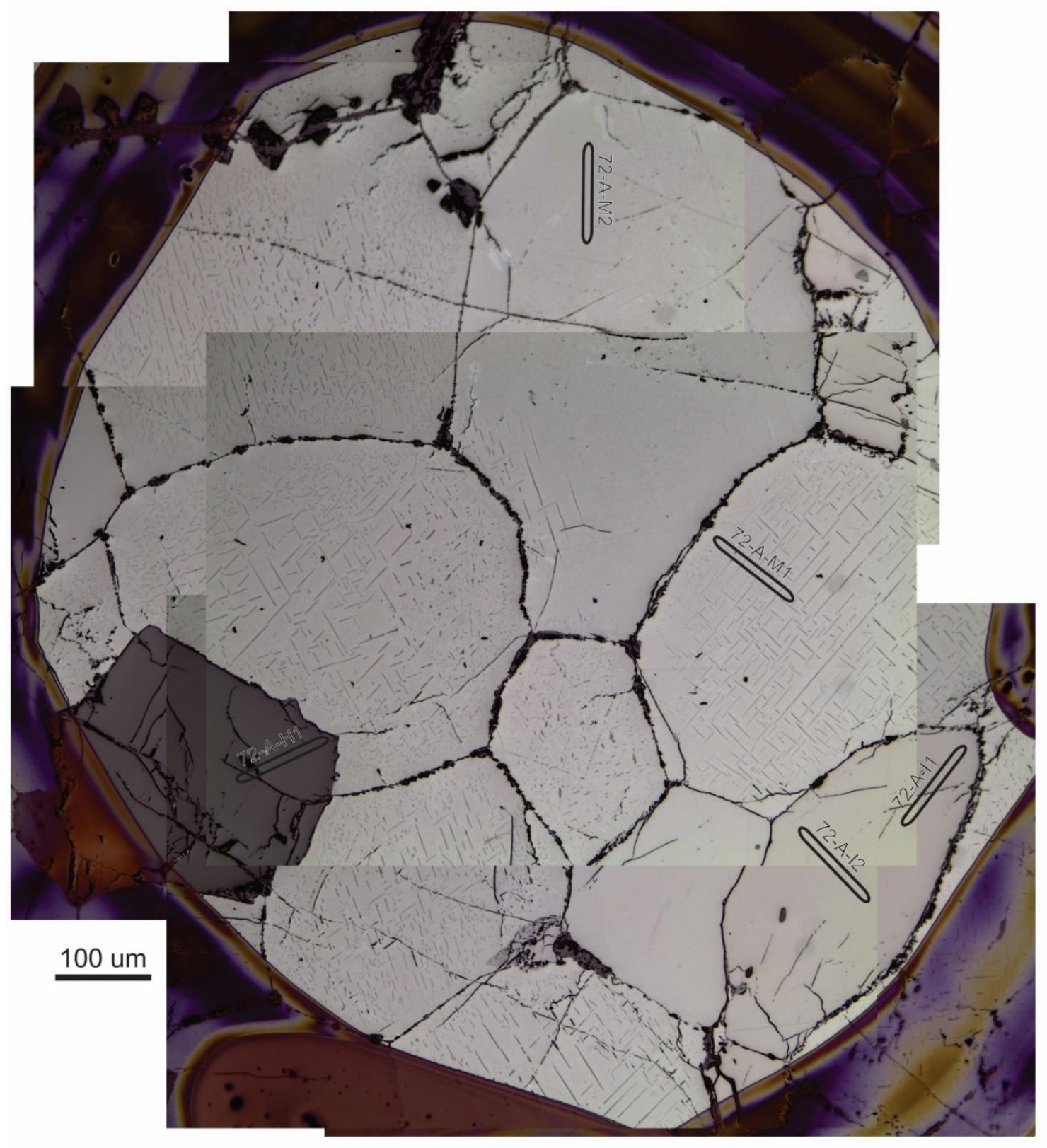


CC072 circle A EPMA
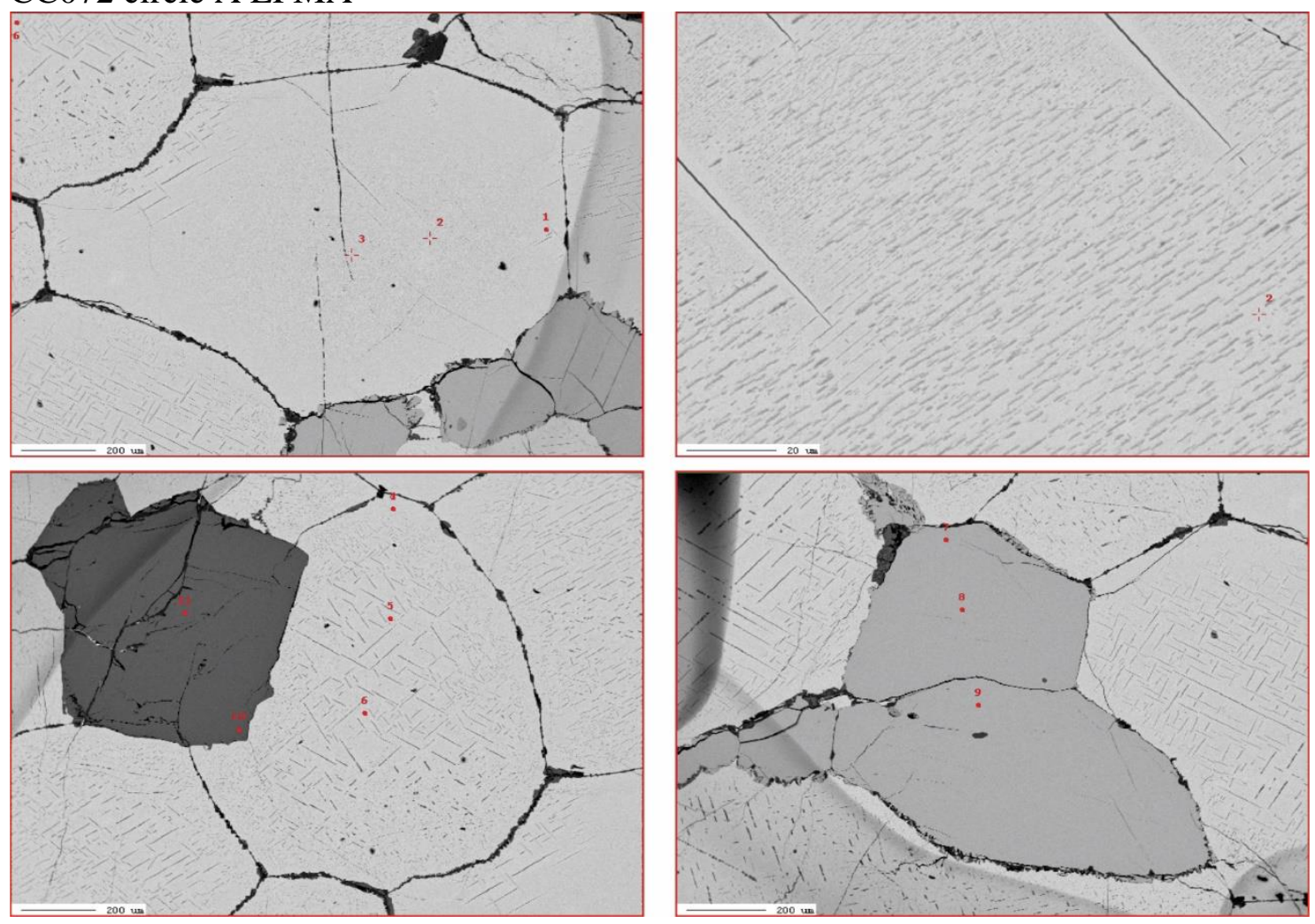
CC072 circle B LA-ICPMS

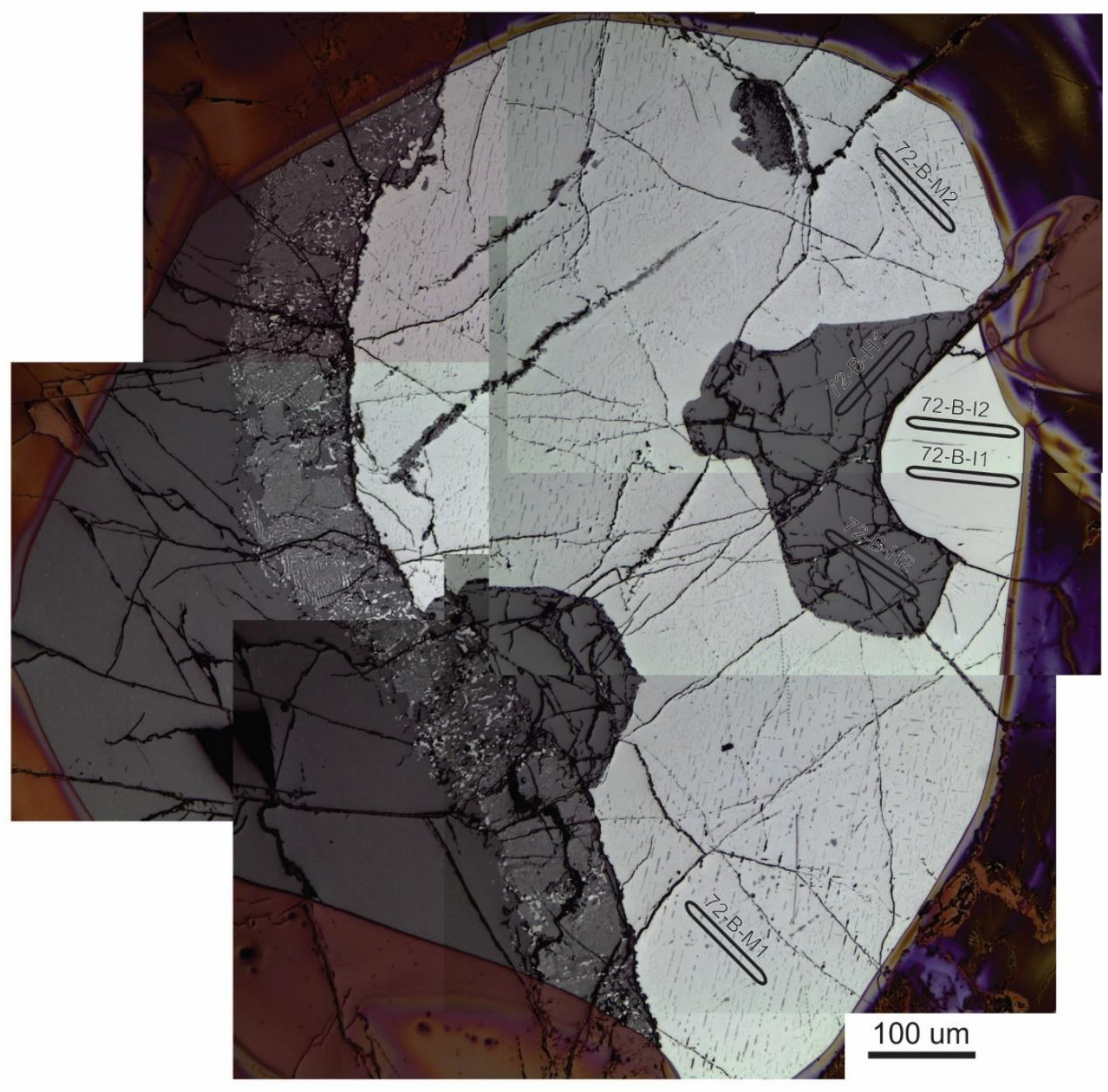


CC072 circle B EPMA
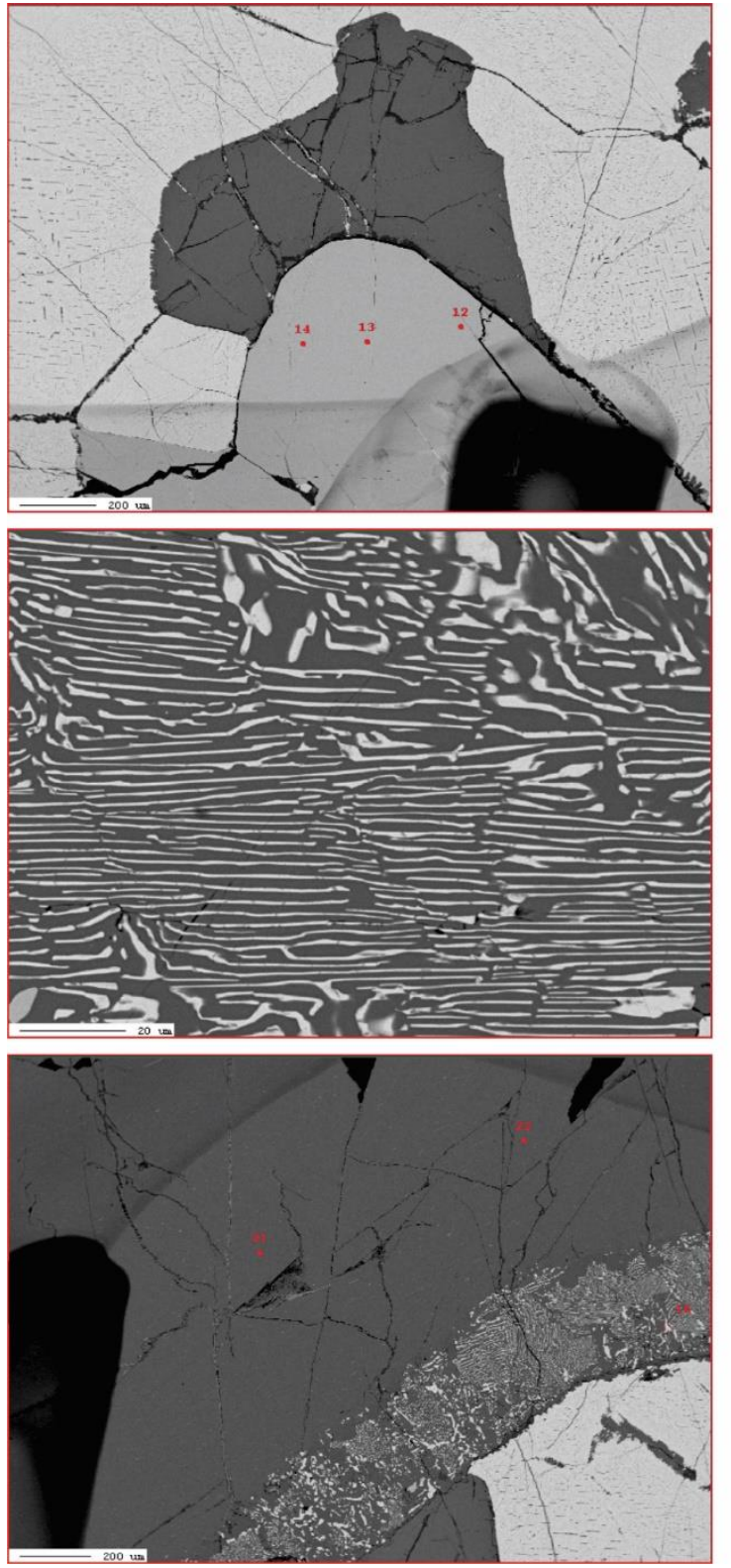
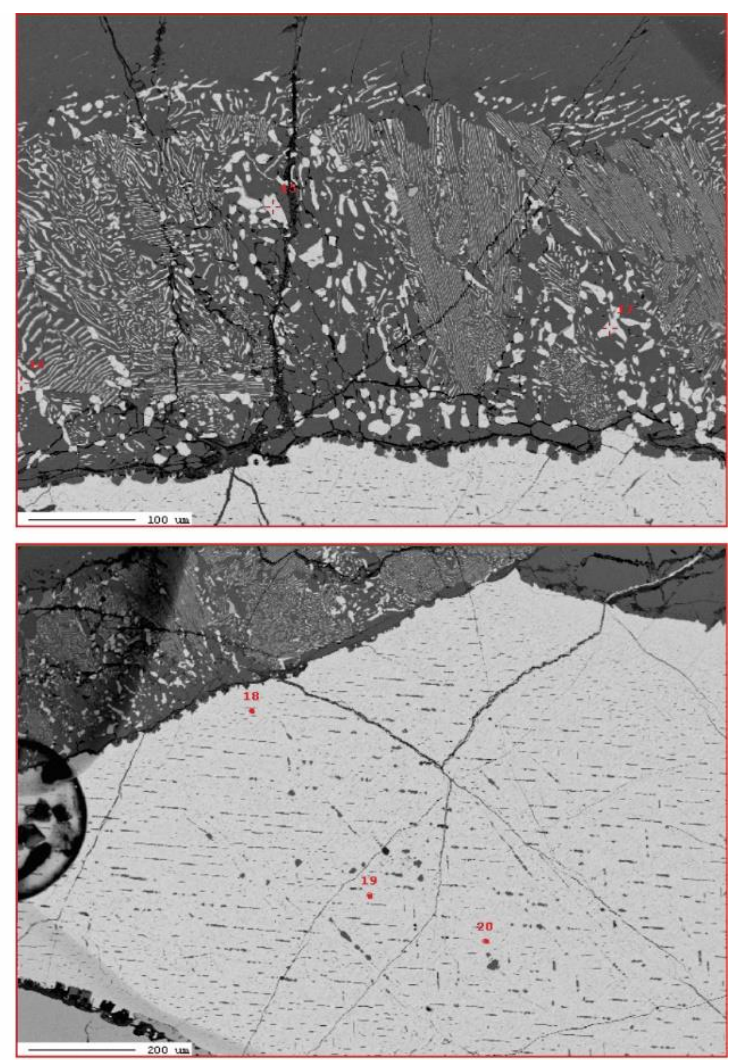
CC072 circle C LA-ICPMS

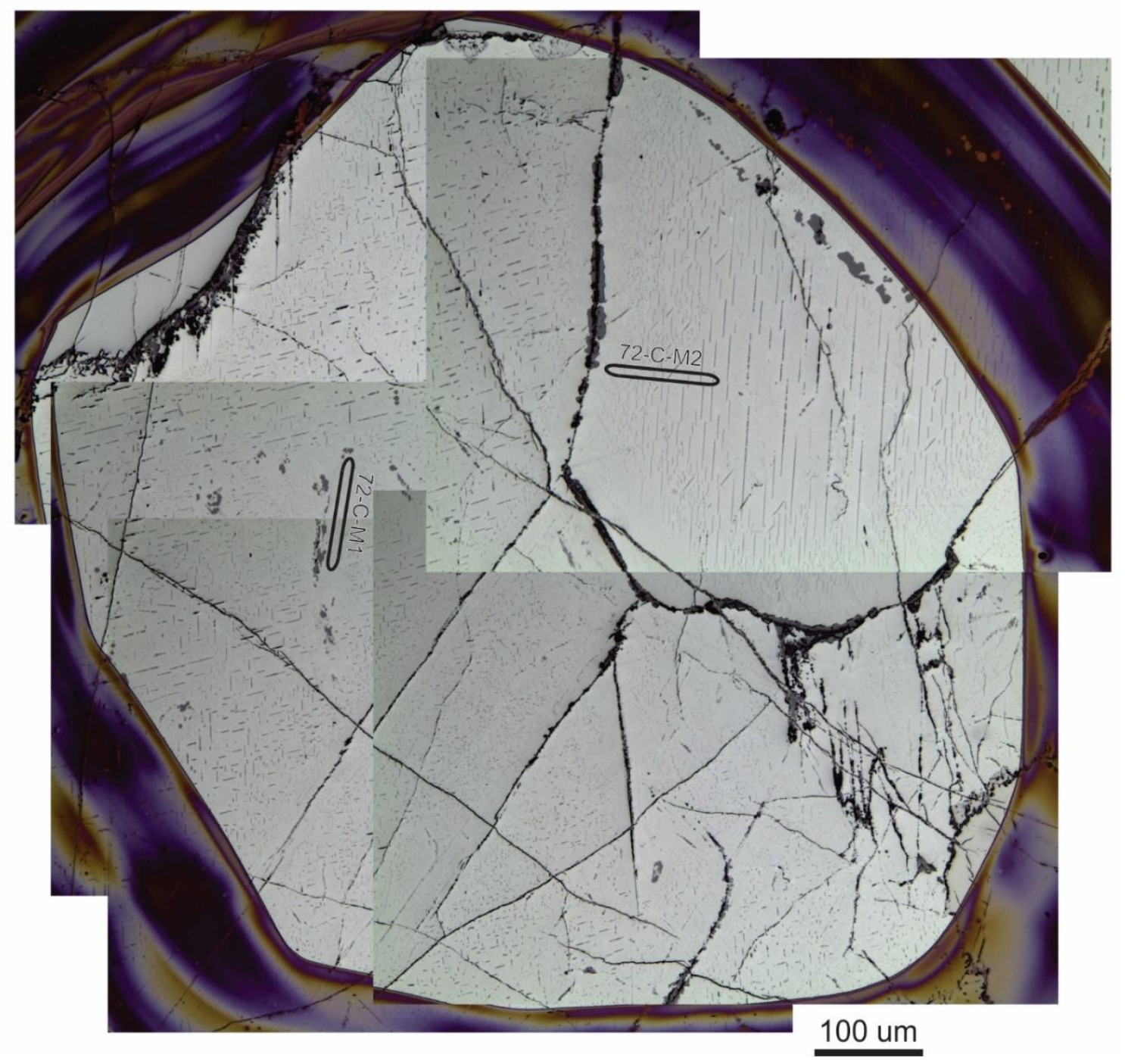


CC072 circle C EPMA
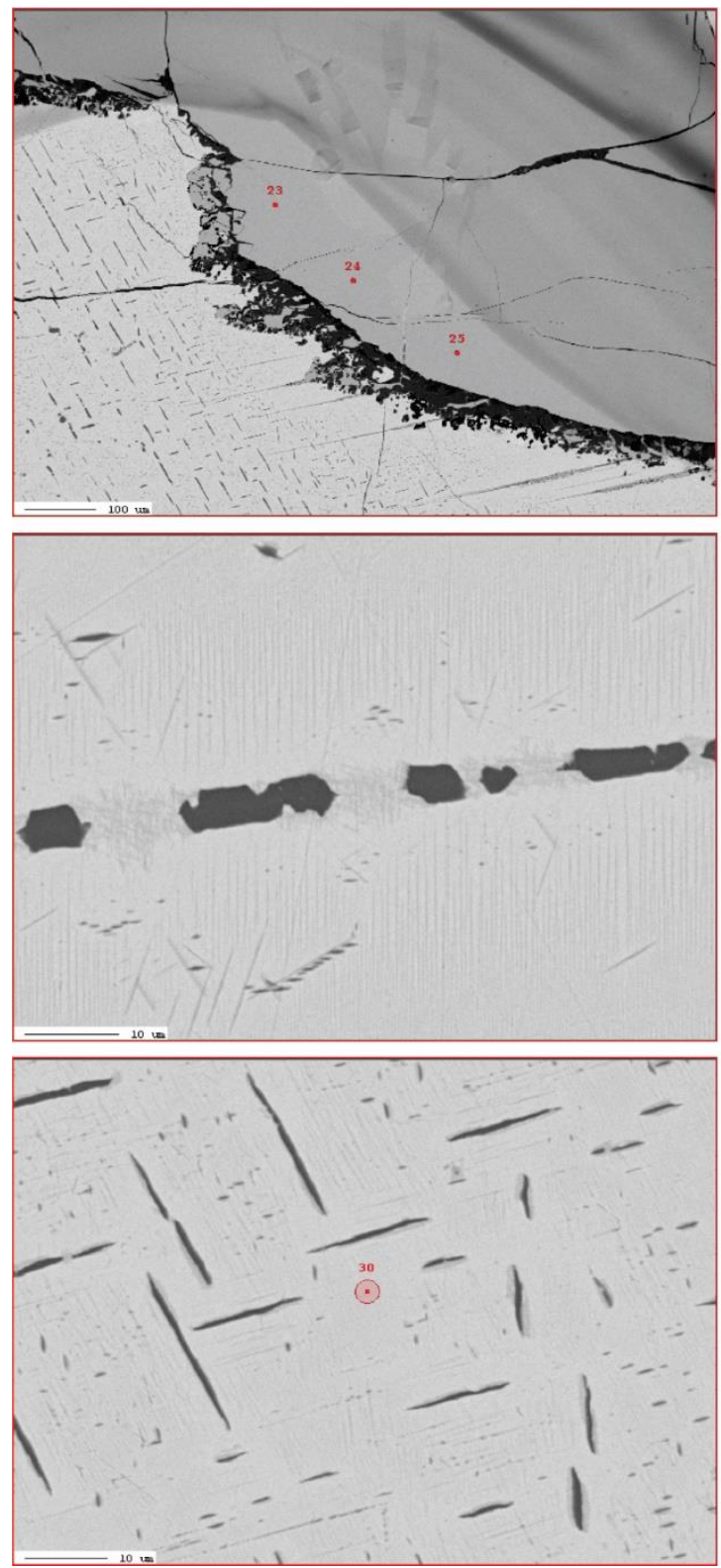
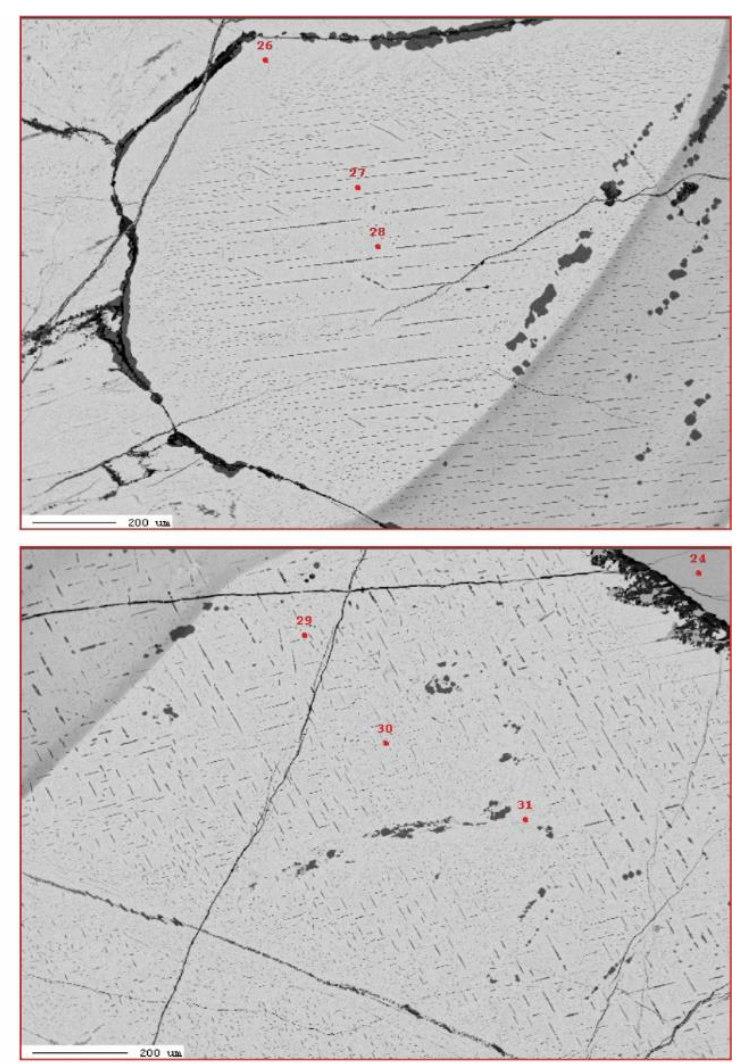
CC072 circle D LA-ICPMS

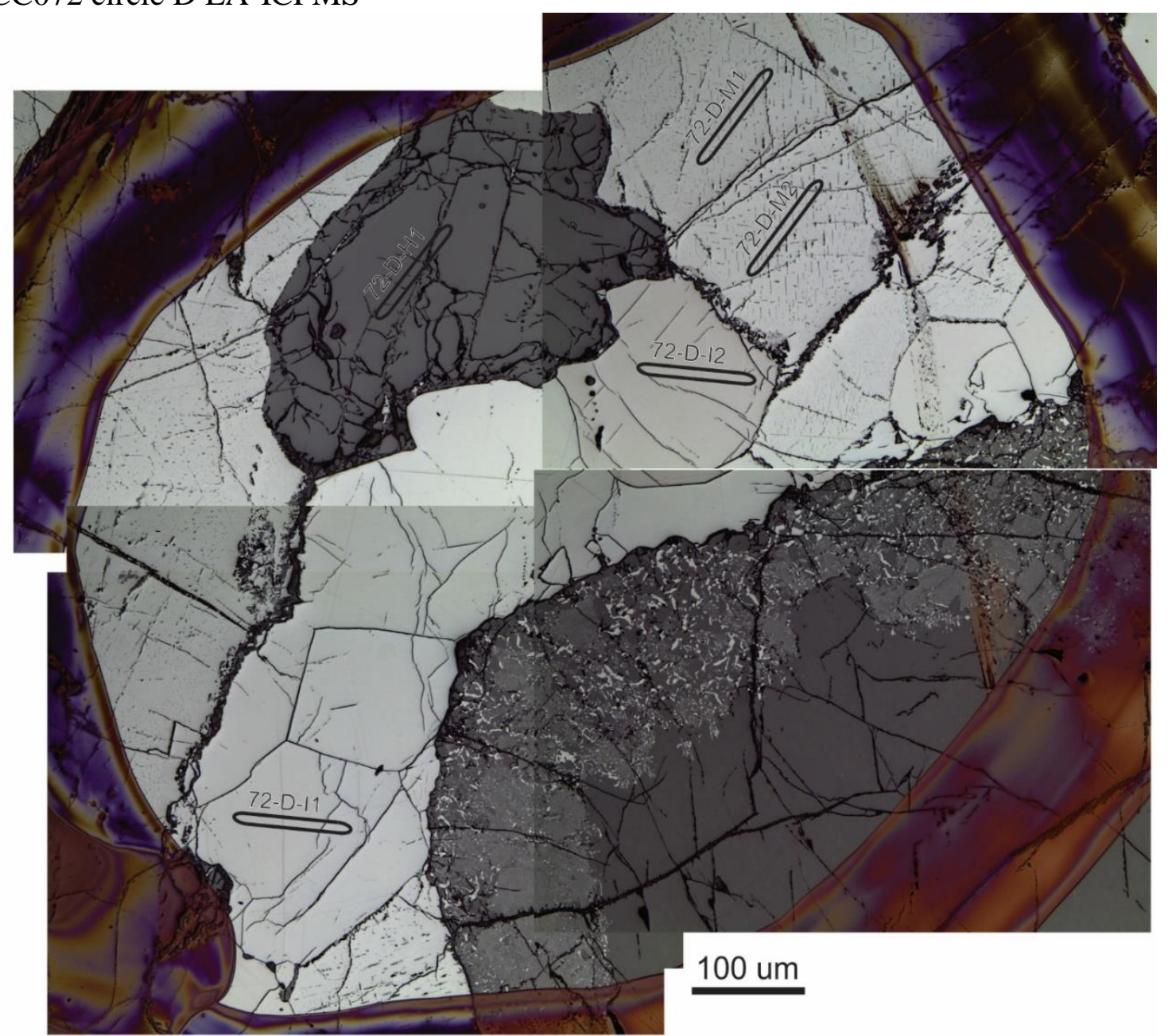

CC072 circle D EPMA
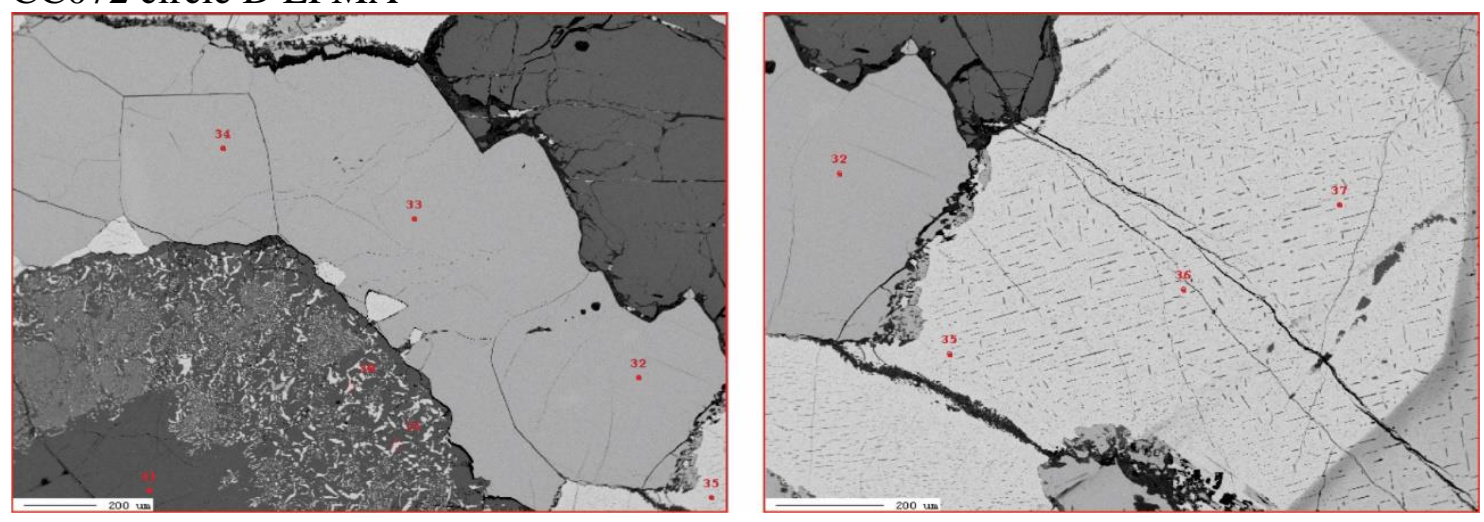


\section{CC072 circle E LA-ICPMS}
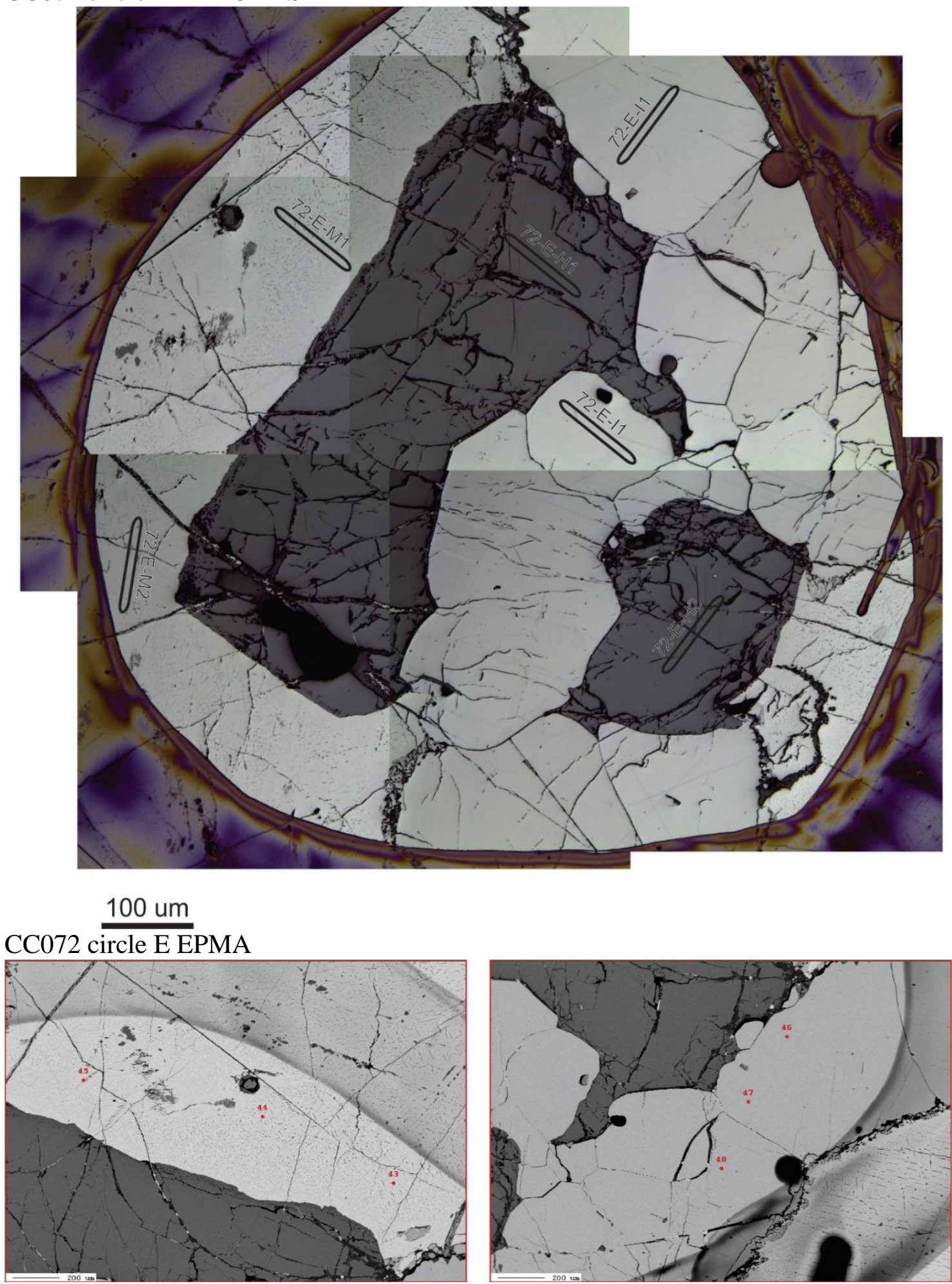

CC072 circle G LA-ICPMS

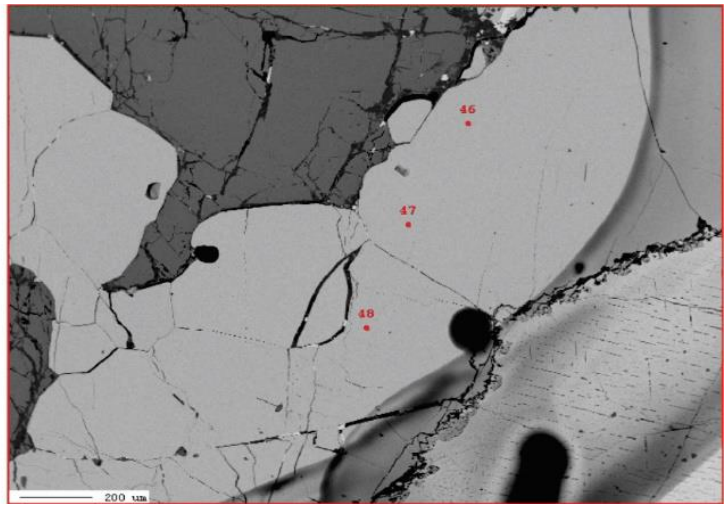




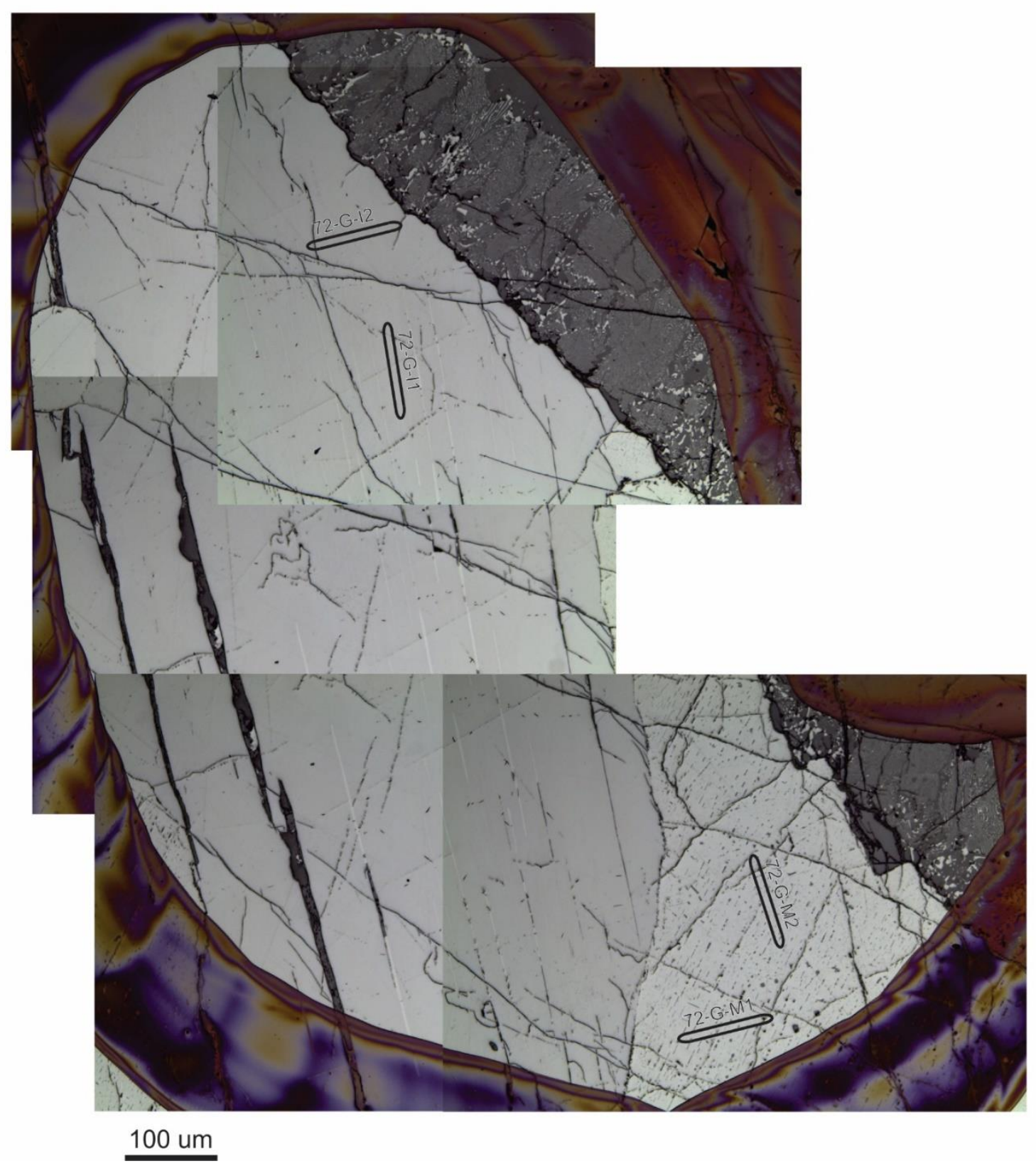


CC072 circle G EPMA
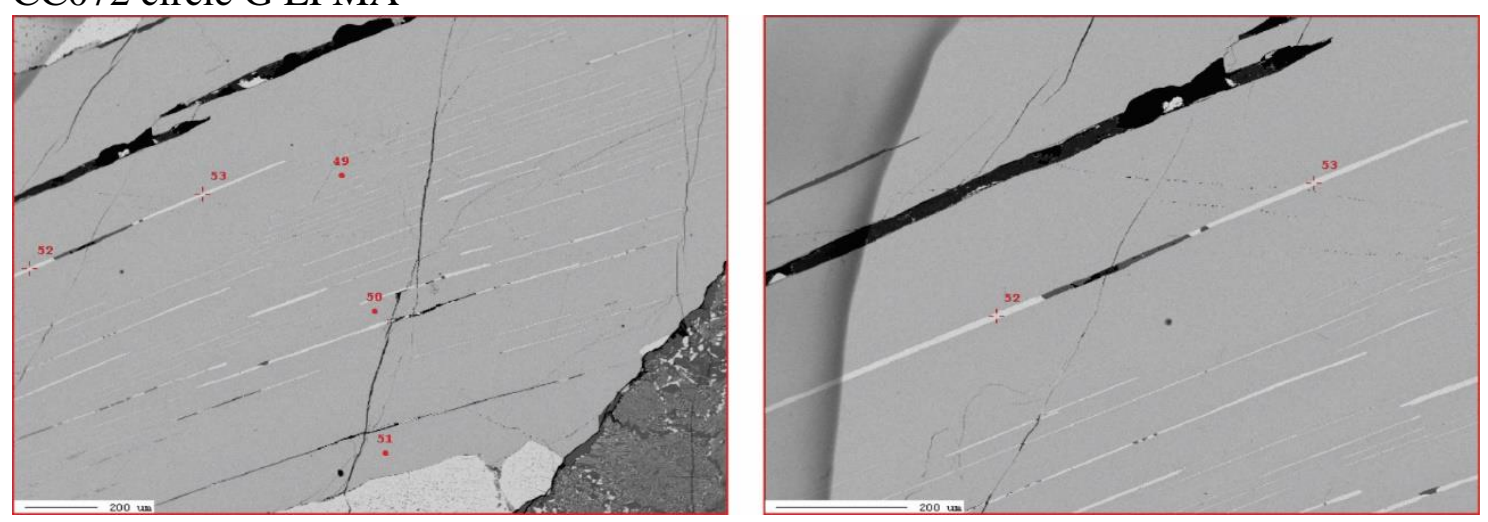
CC072 circle H LA-ICPMS

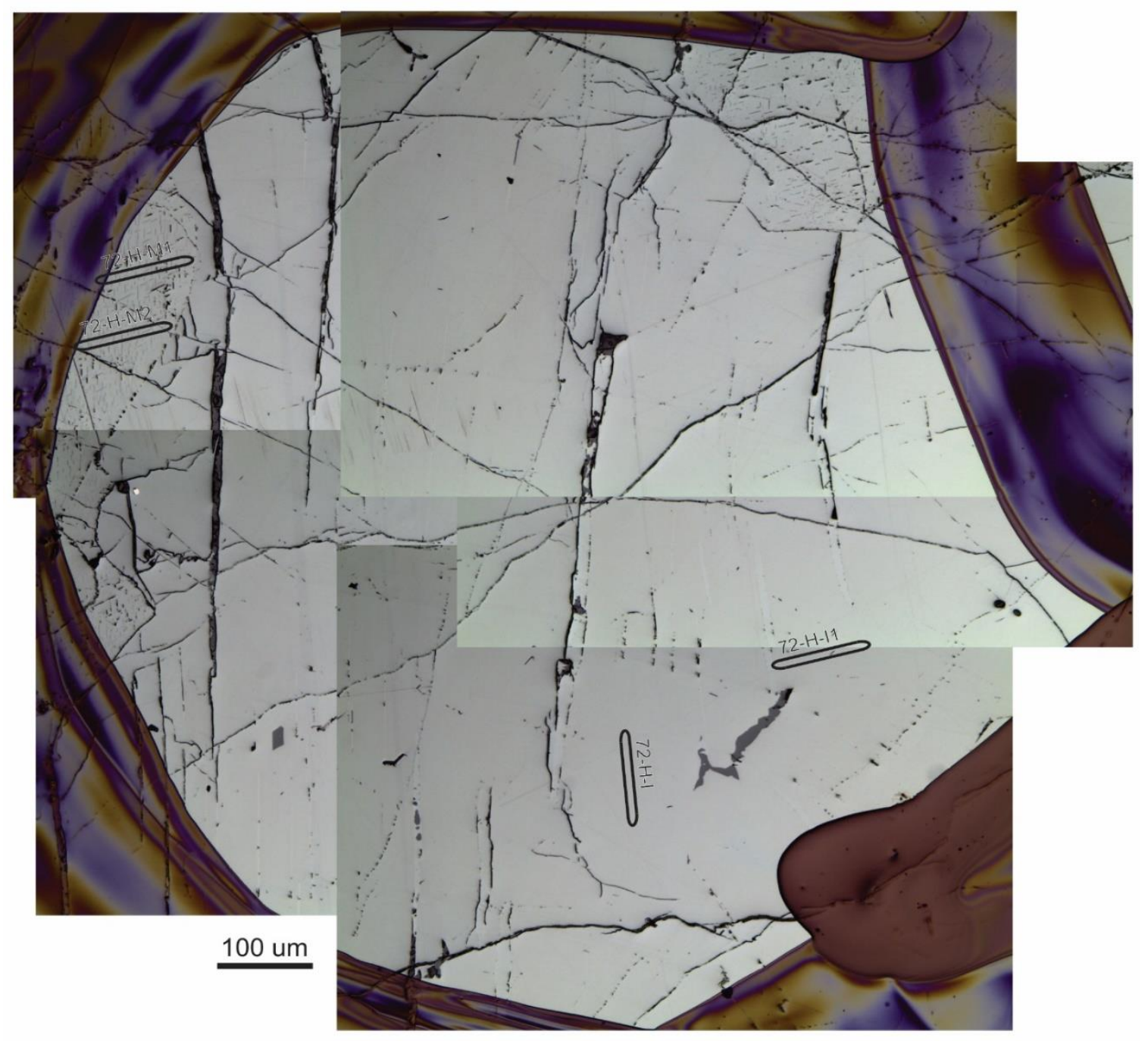

CC072 circle H EPMA

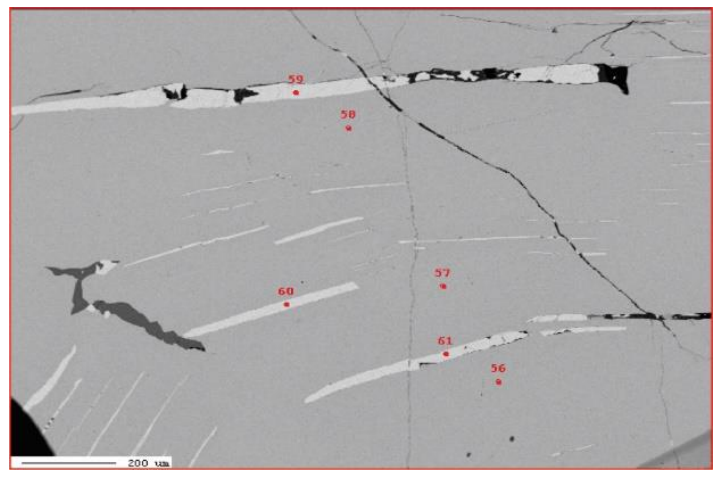

CC072 circle I LA-ICPMS 


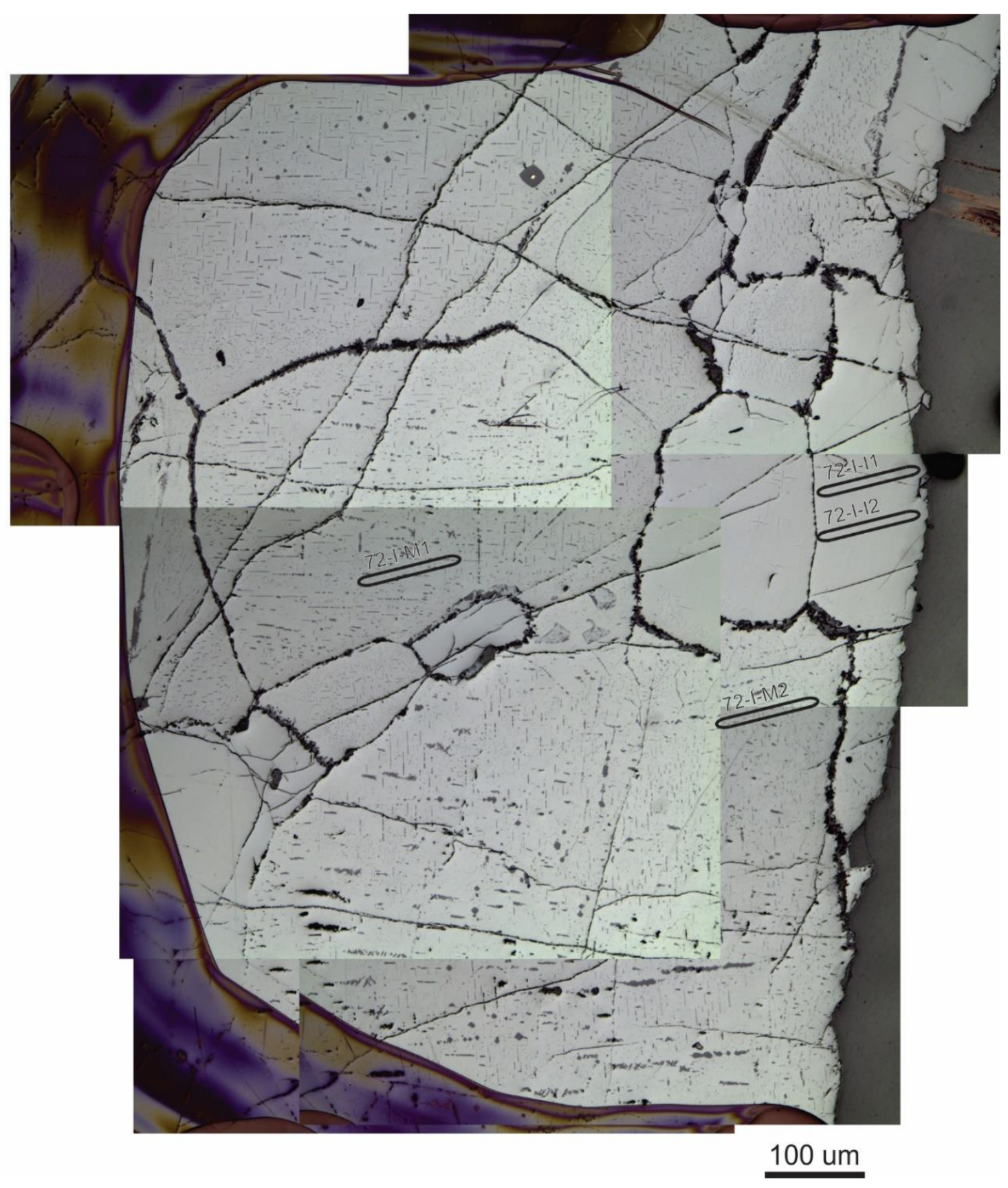


CC072 circle I EPMA
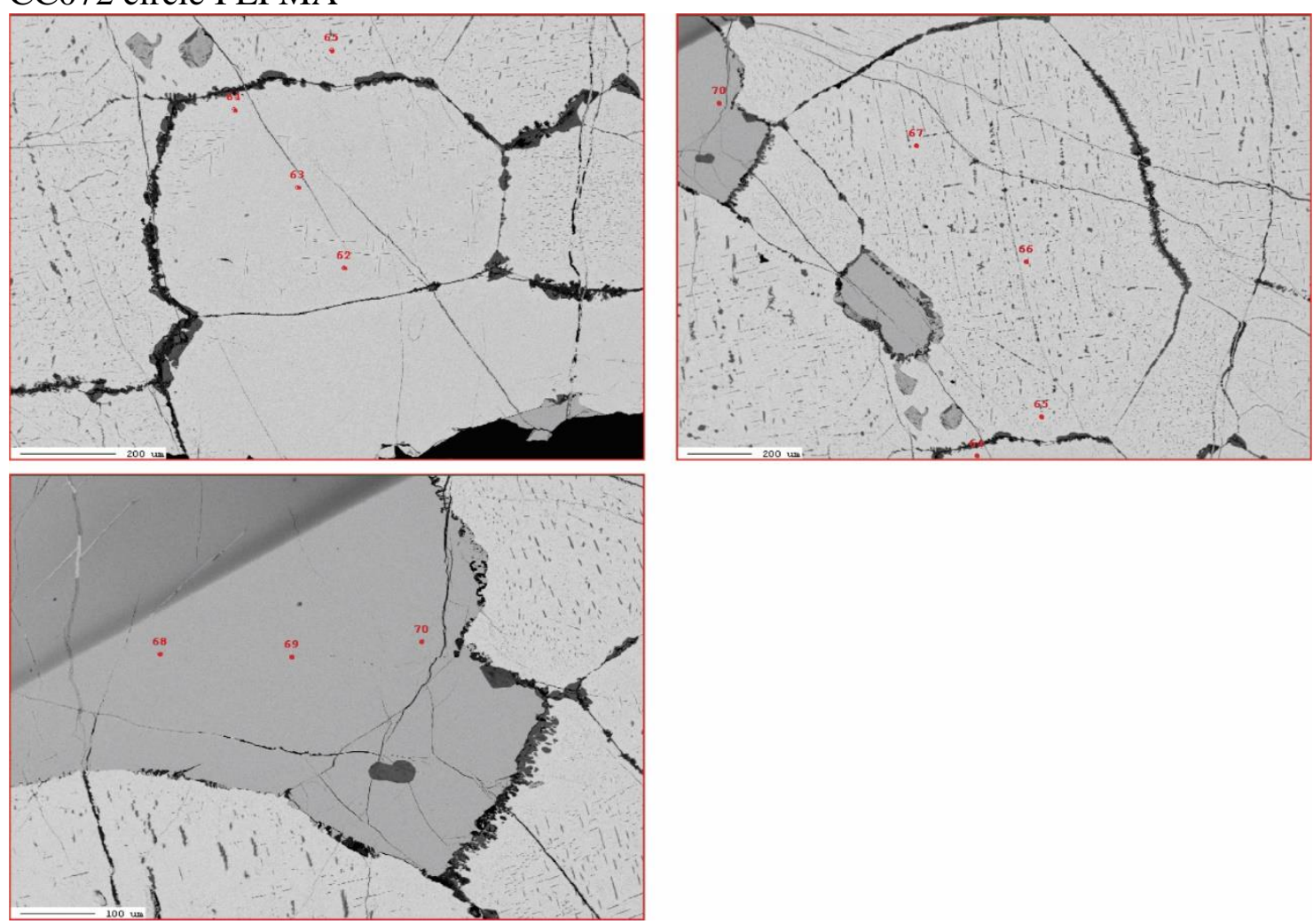
CC072 circle K LA-ICPMS

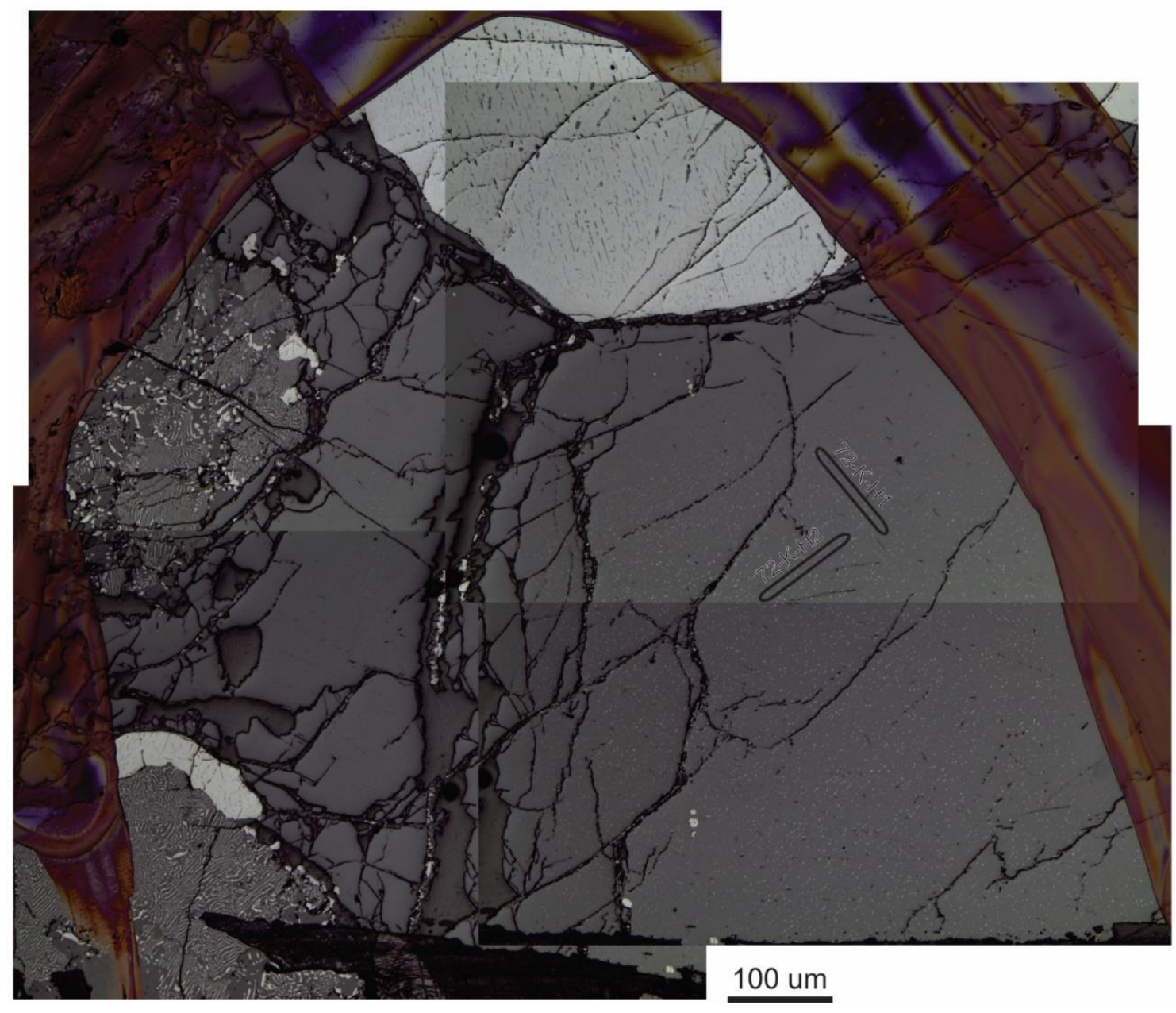




\section{CC074 circle A LA-ICPMS}

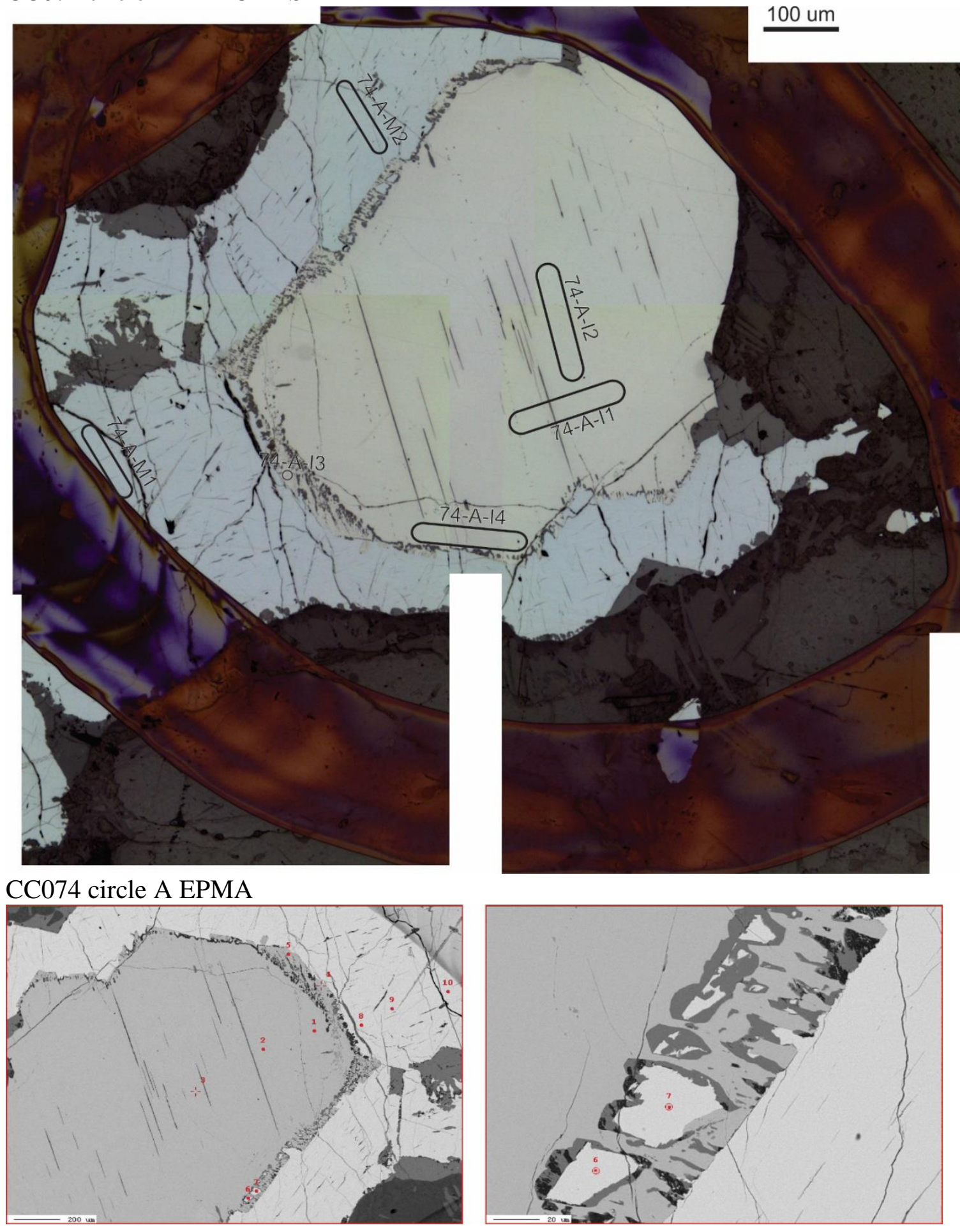


CC074 circle B LA-ICPMS

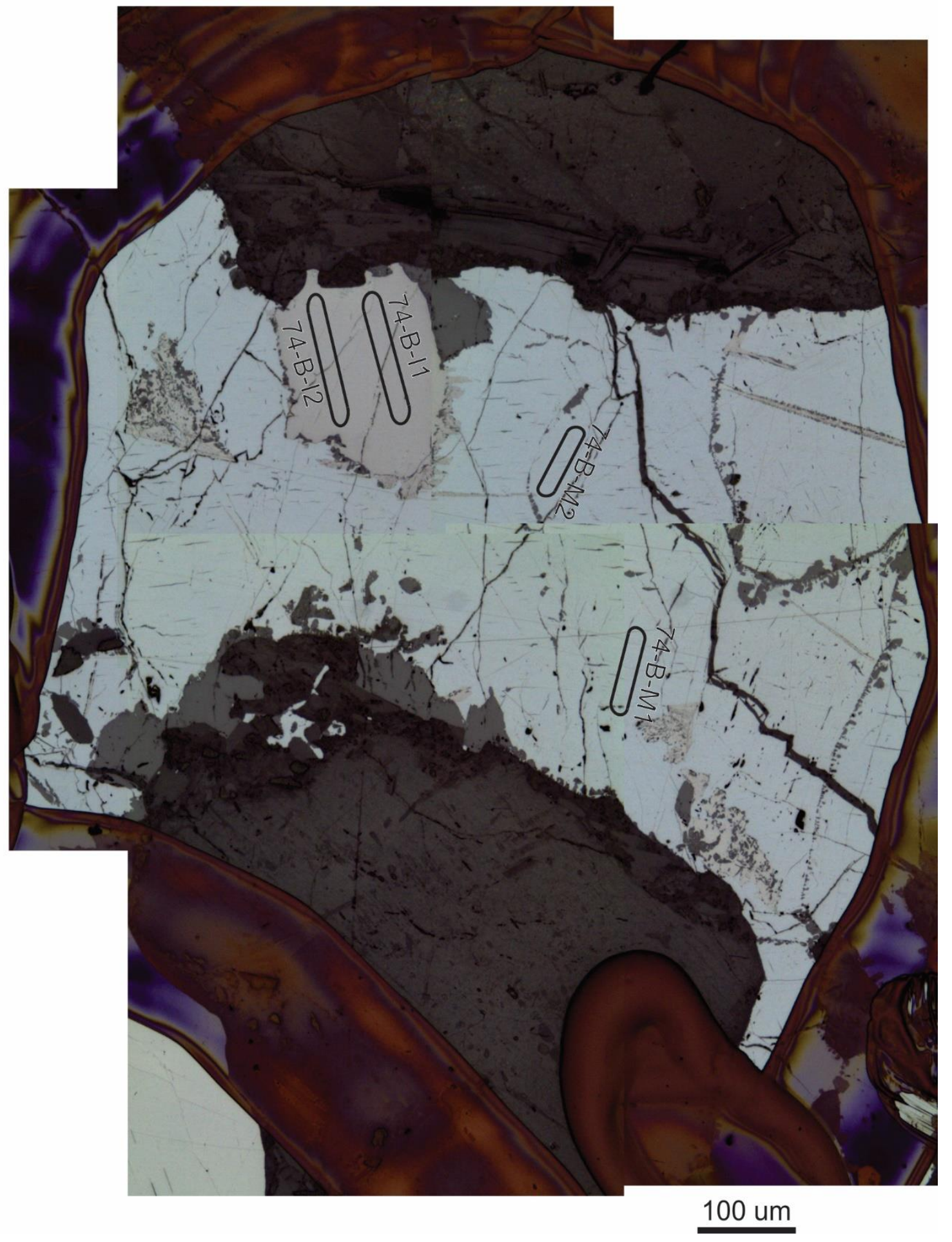


CC074 circle B EPMA
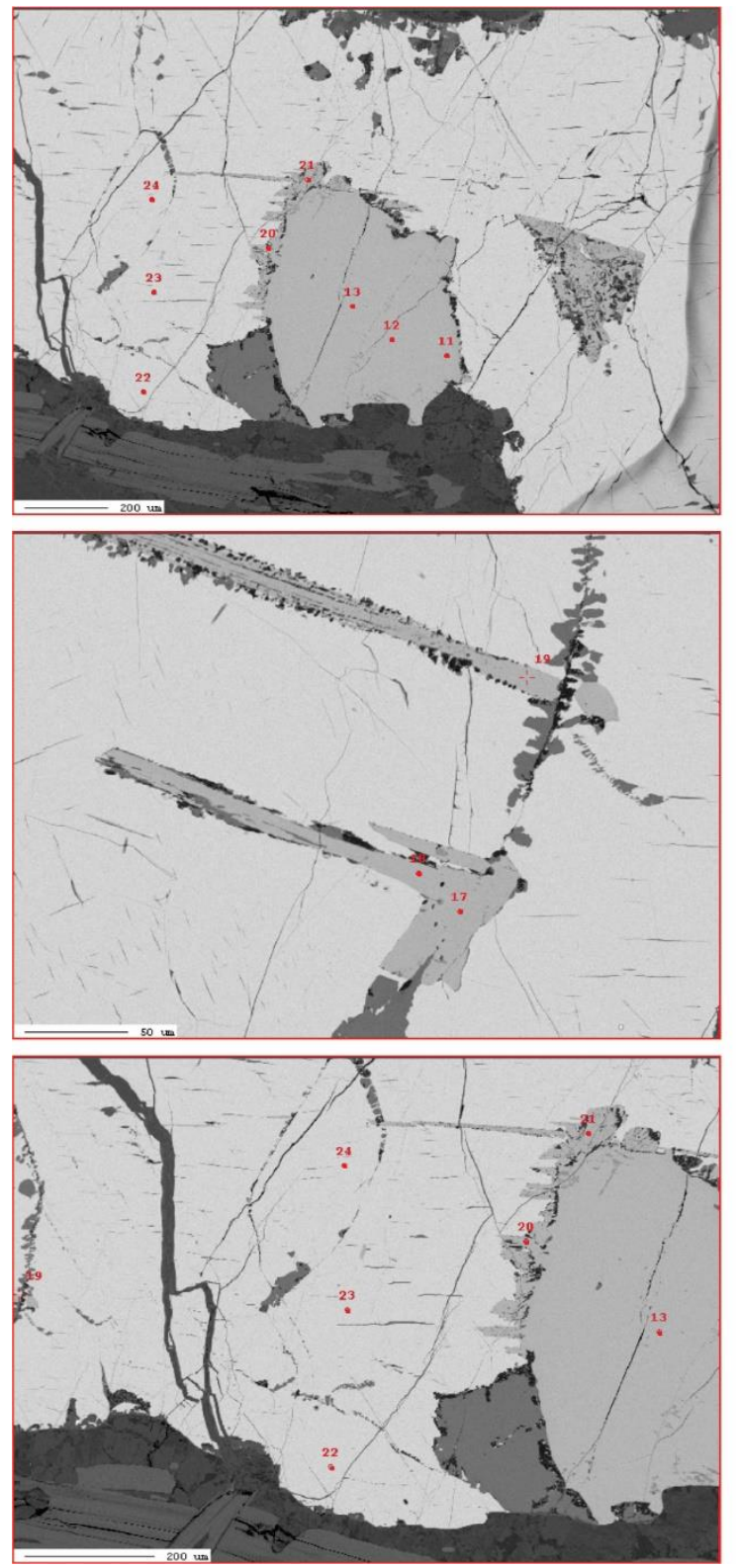
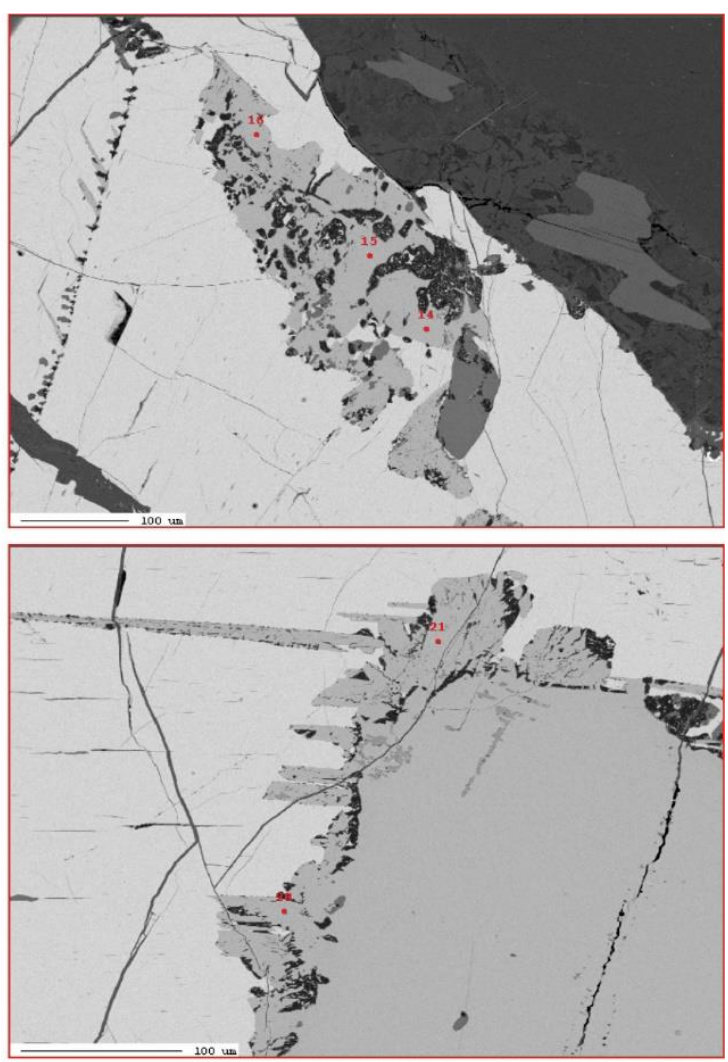
CC074 circle C LA-ICPMS
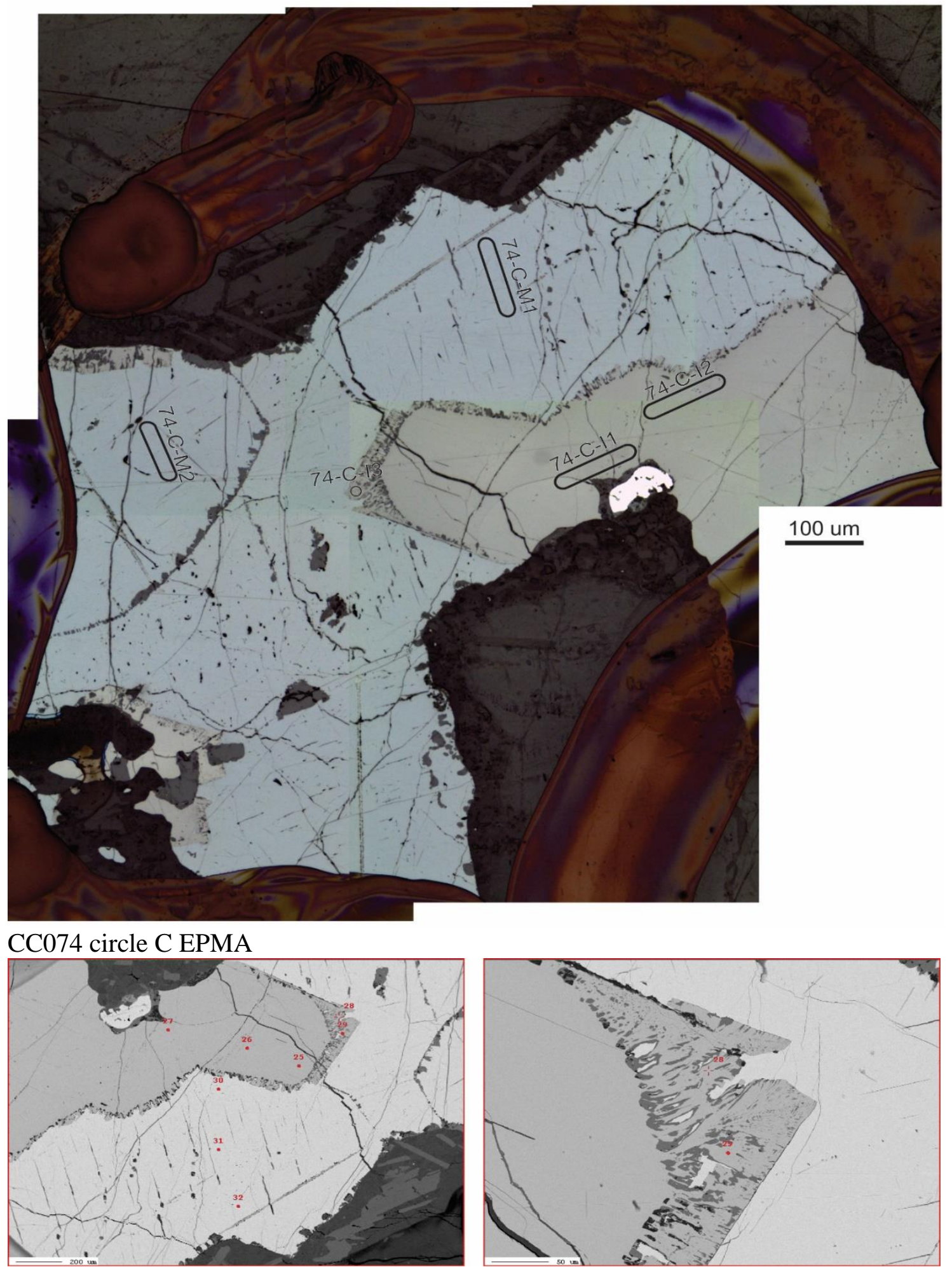

CC074 circle D LA-ICPMS 


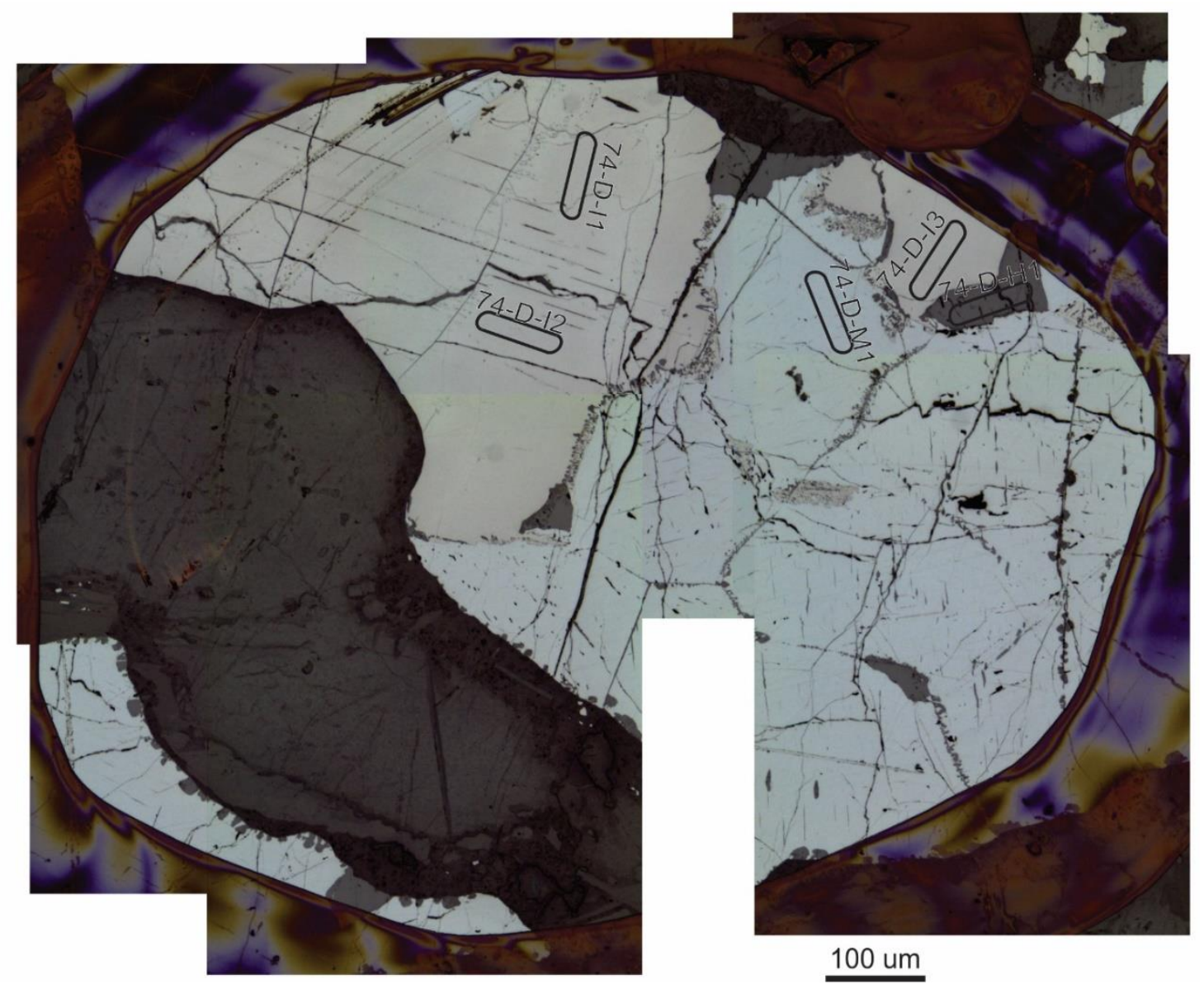


CC074 circle D EPMA
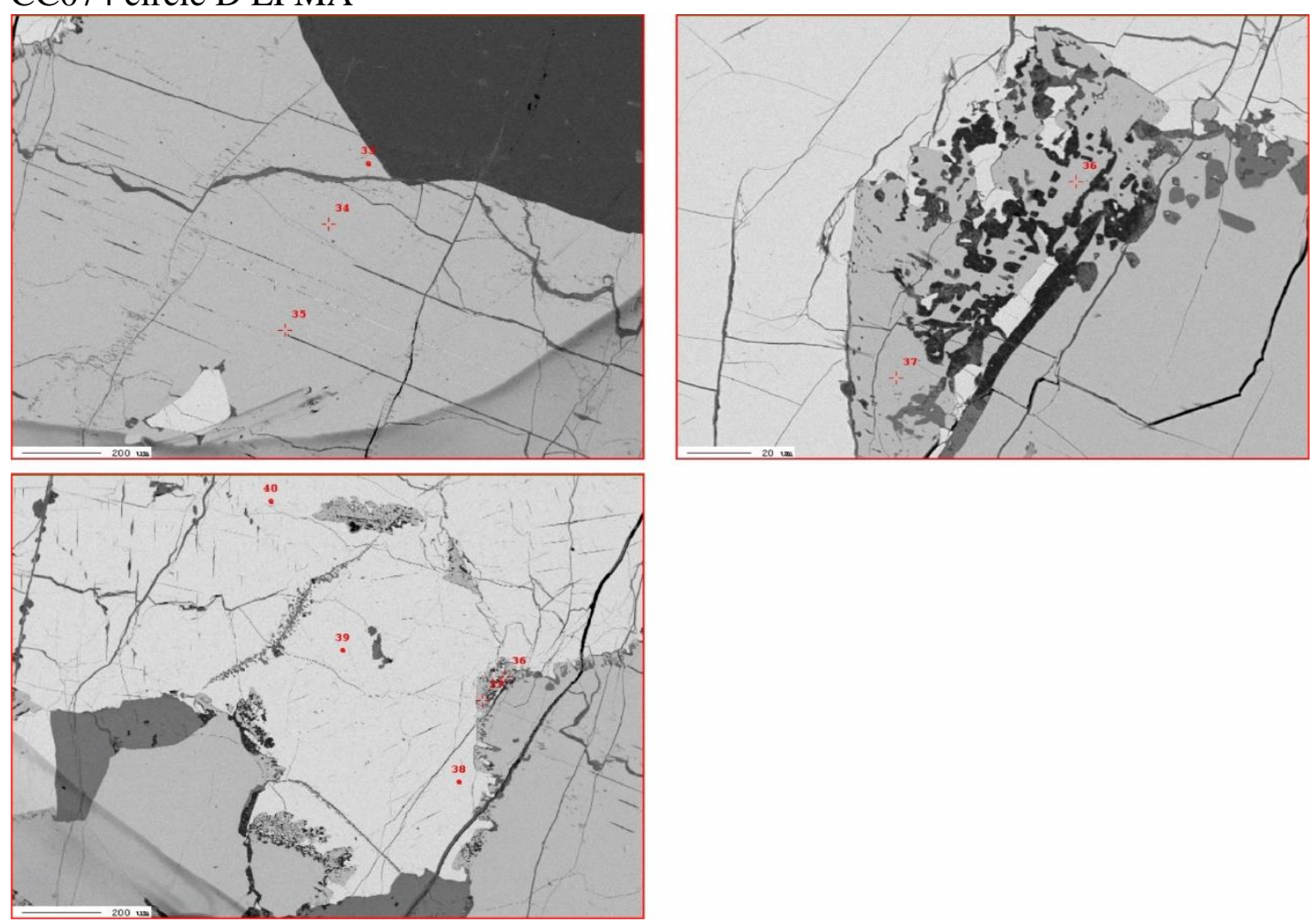


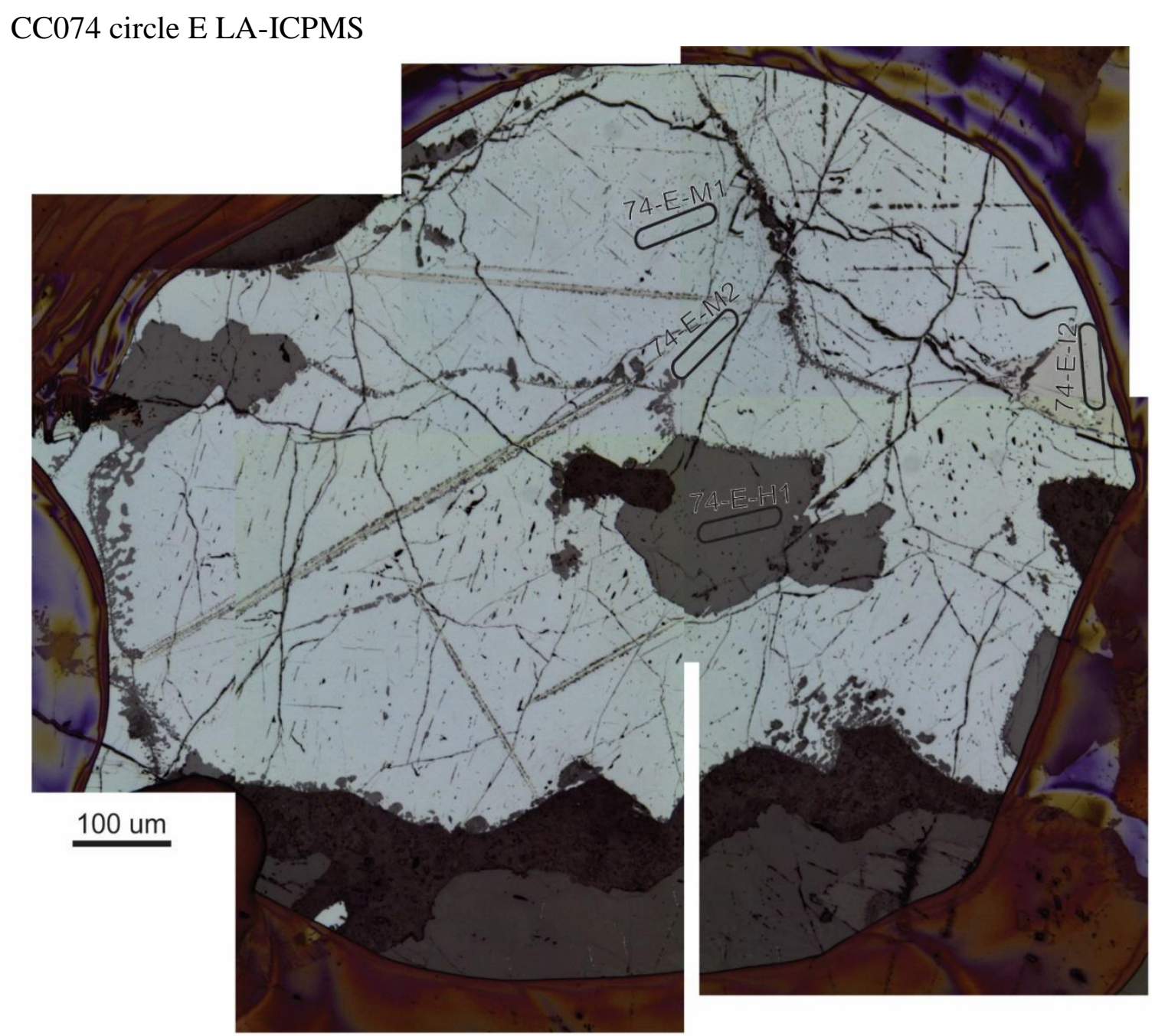


CC074 circle E EPMA
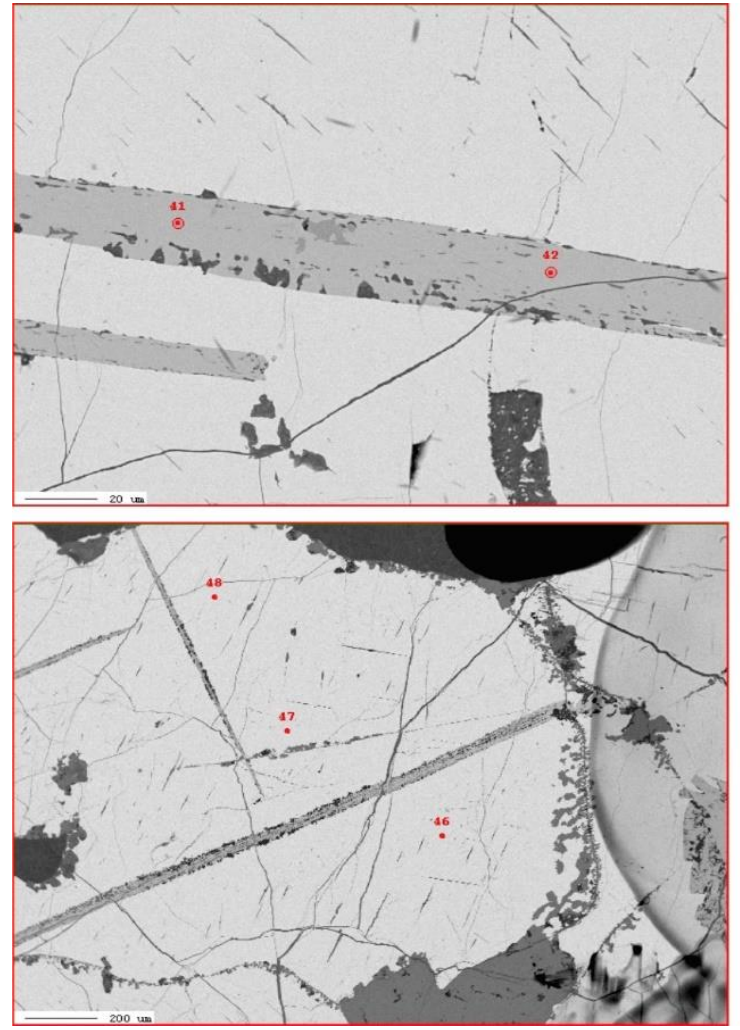

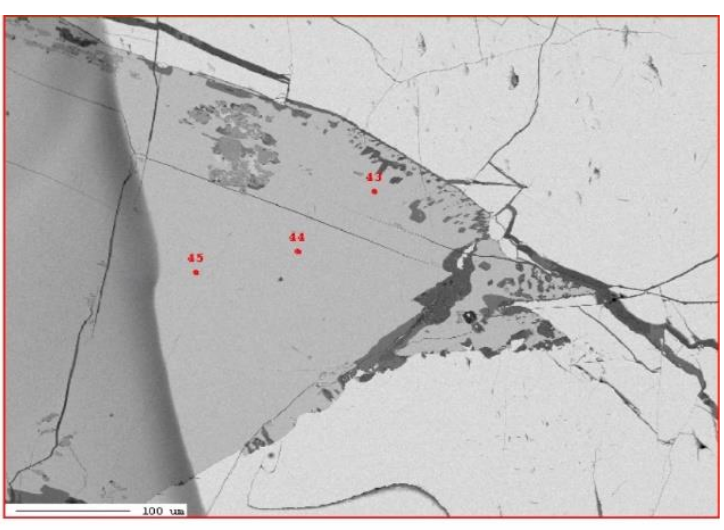


CC074 circle F LA-ICPMS

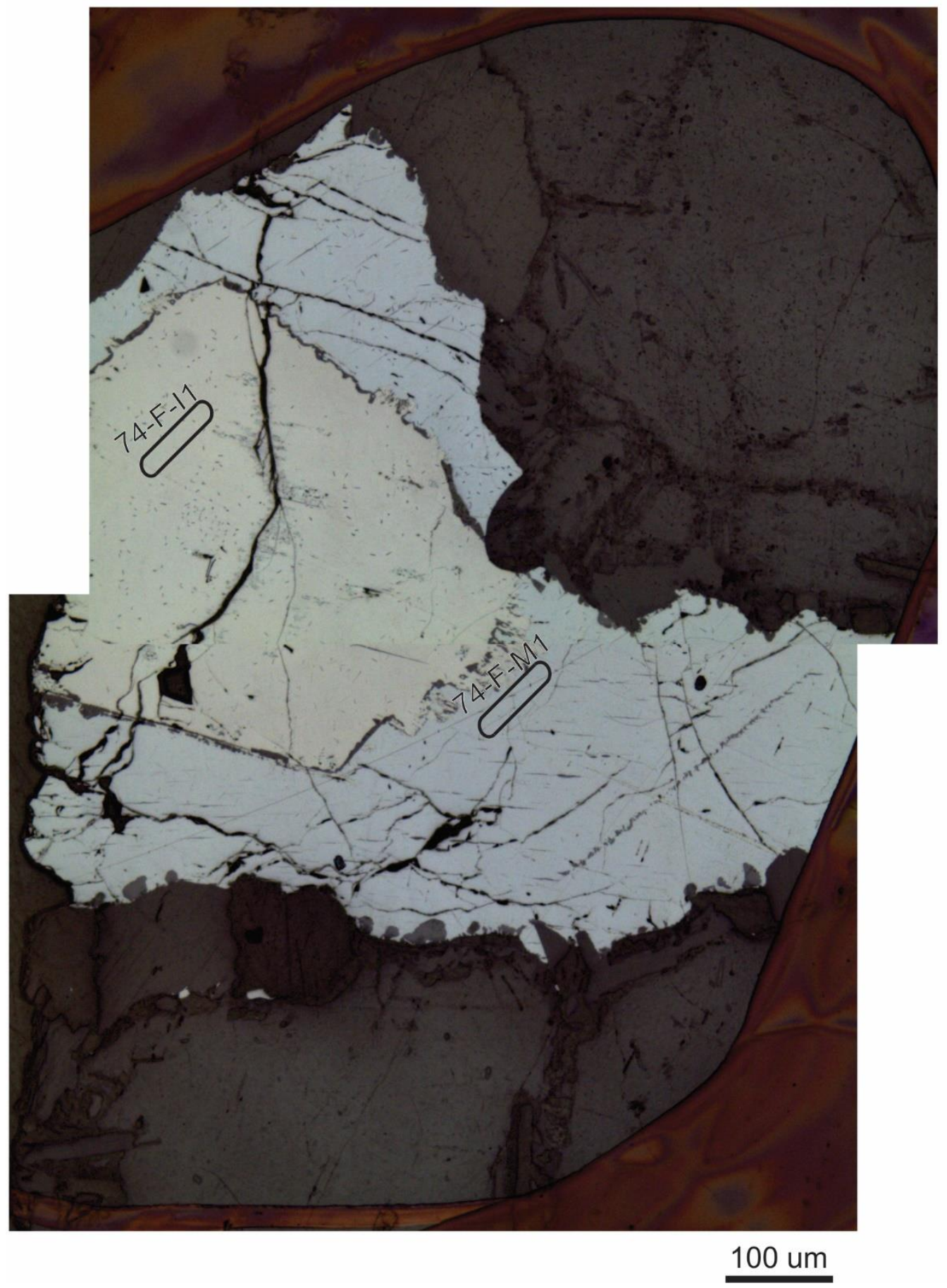


CC074 circle F EPMA
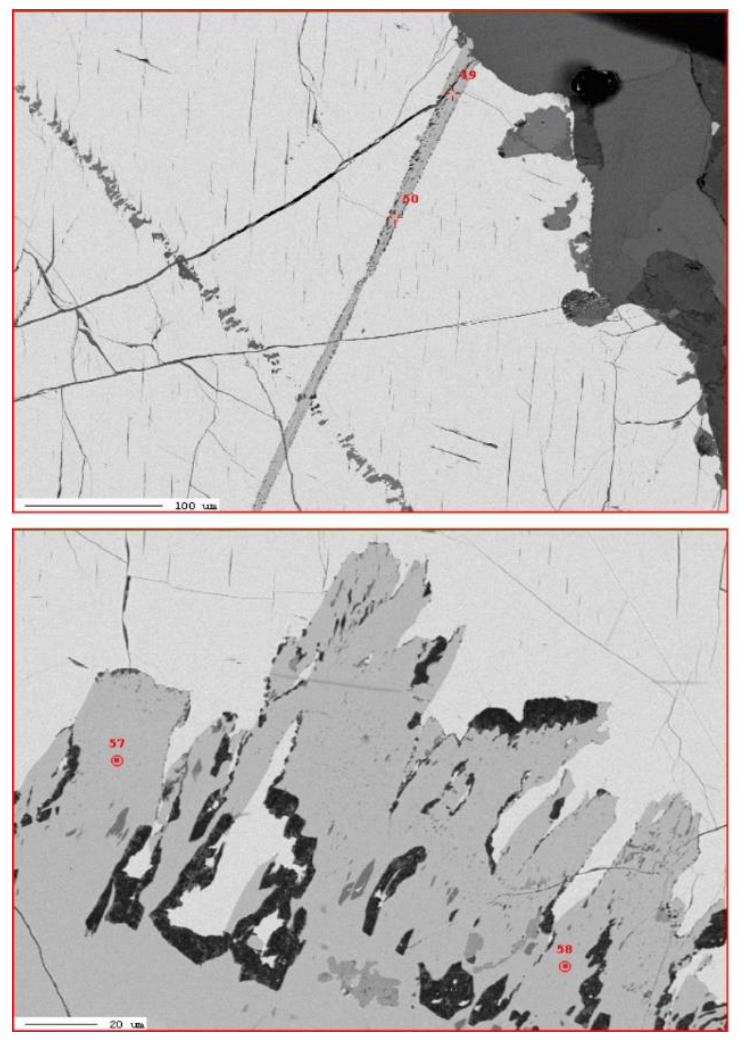

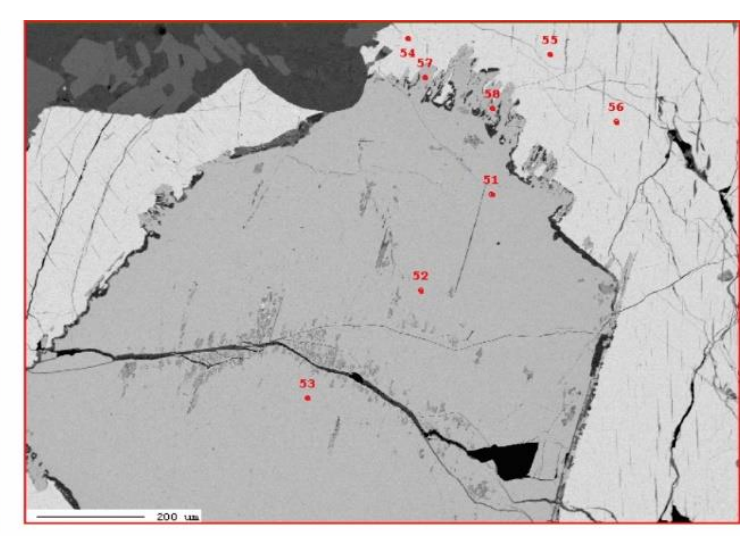




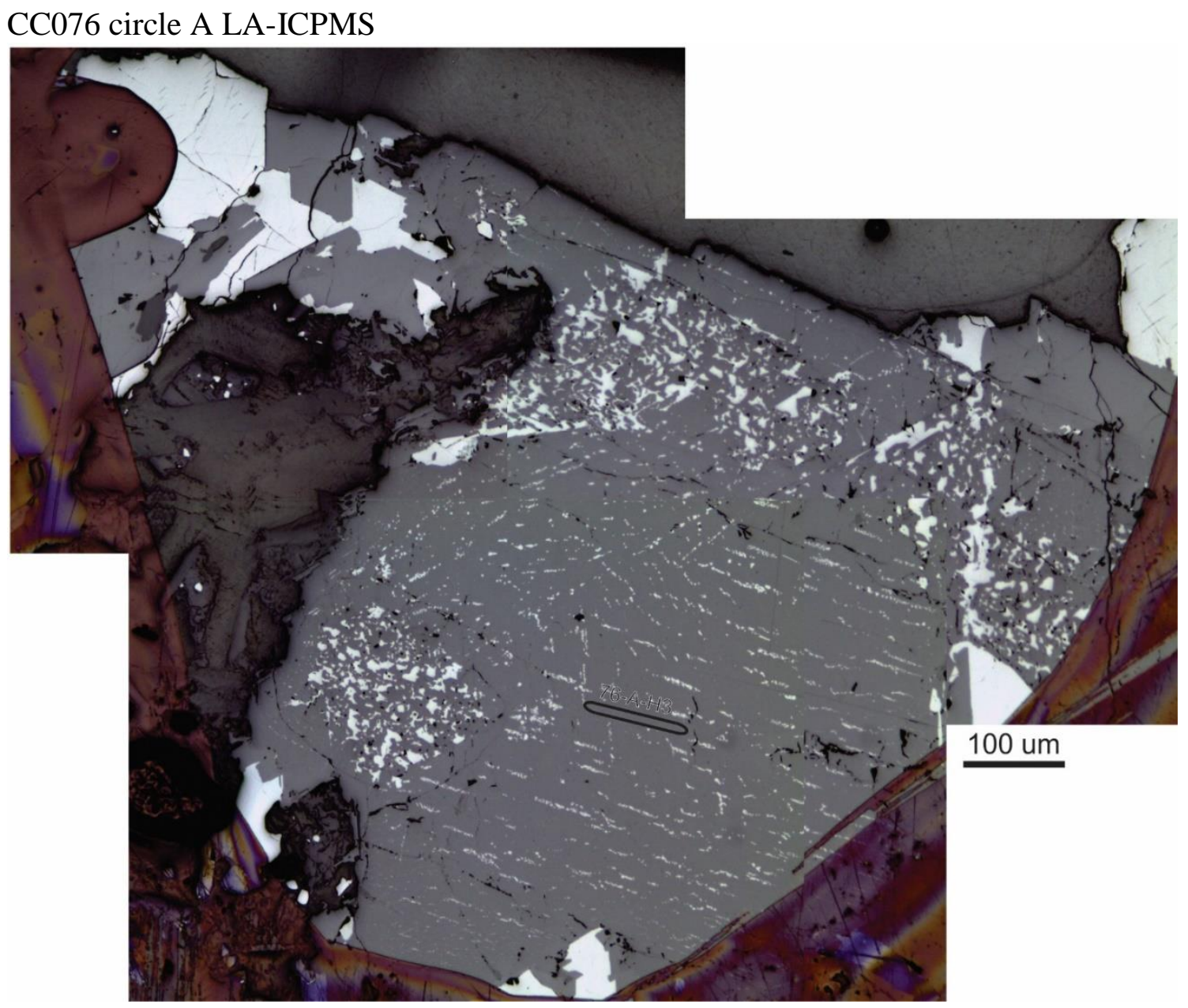


CC076 circle B LA-ICPMS

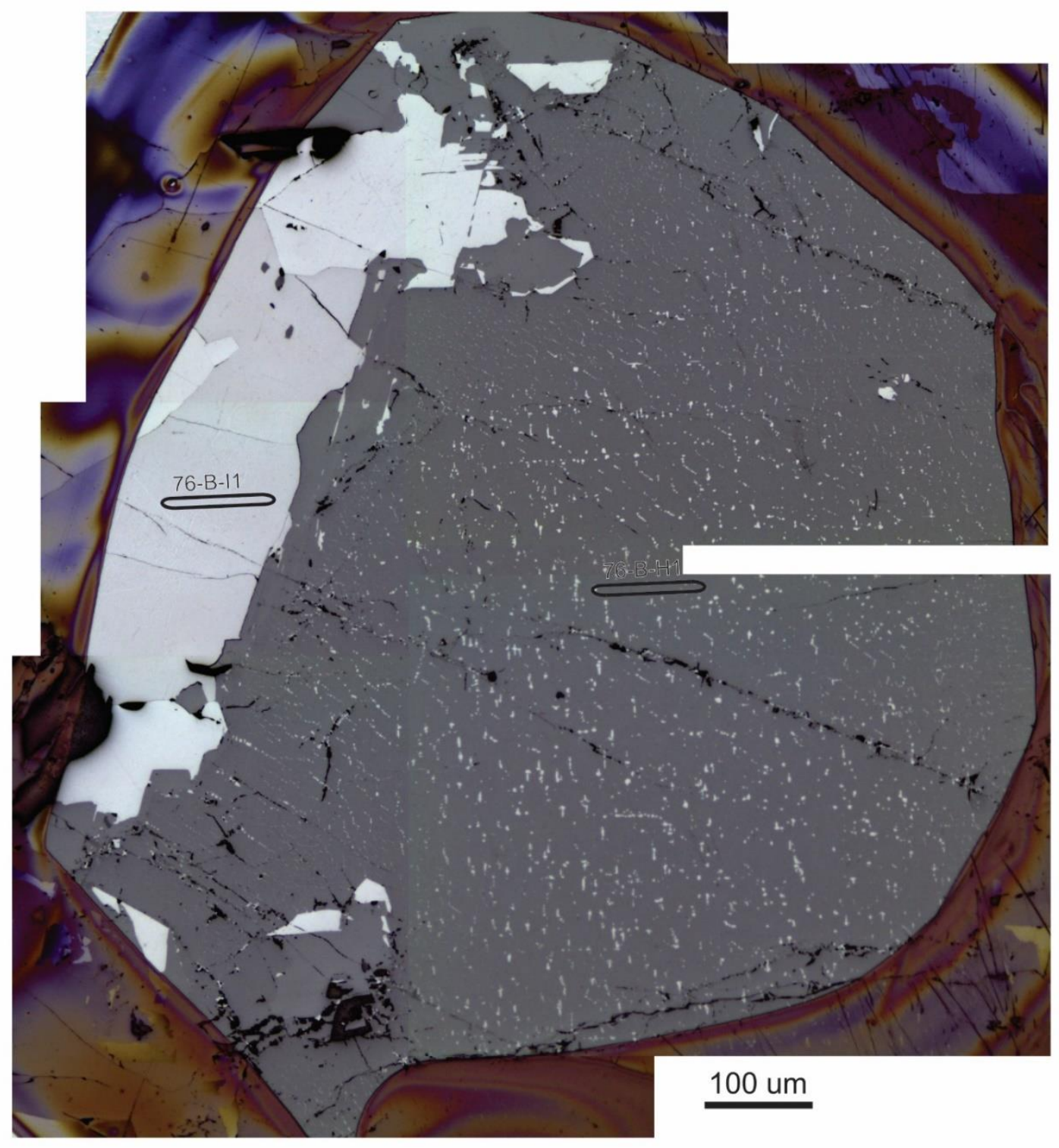


CC076 circle B EPMA
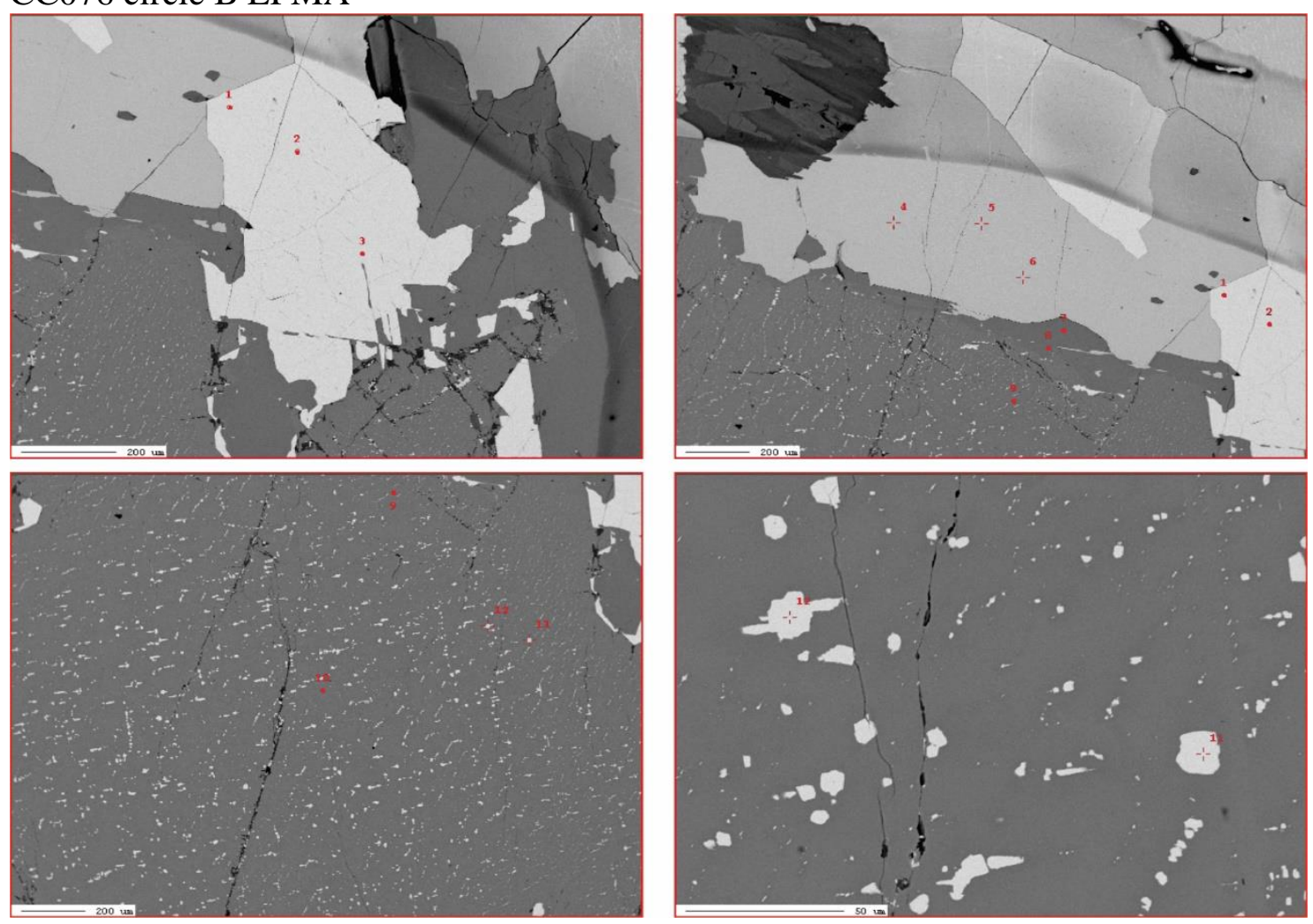
CC076 circle C LA-ICPMS

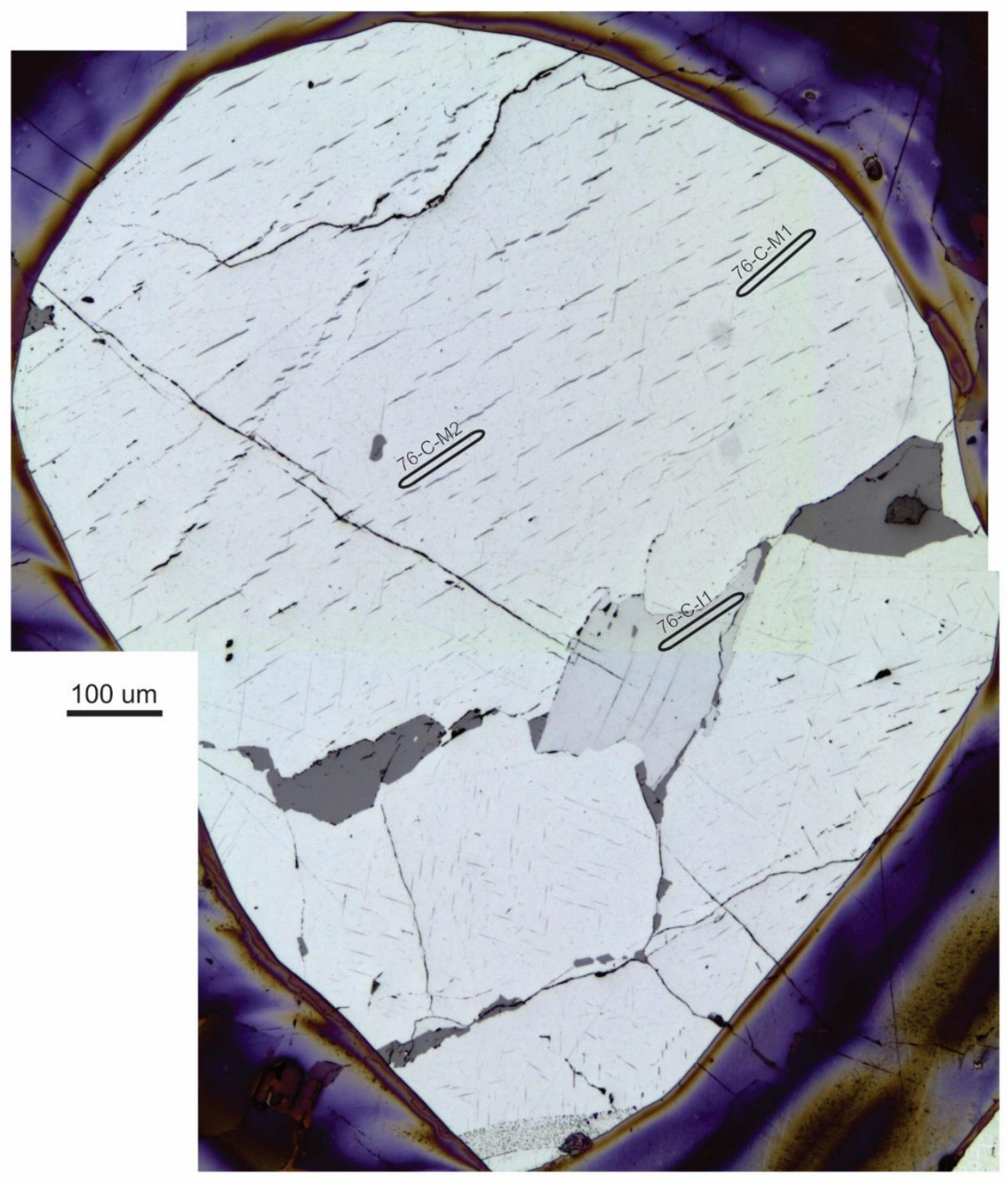


CC076 circle C EPMA
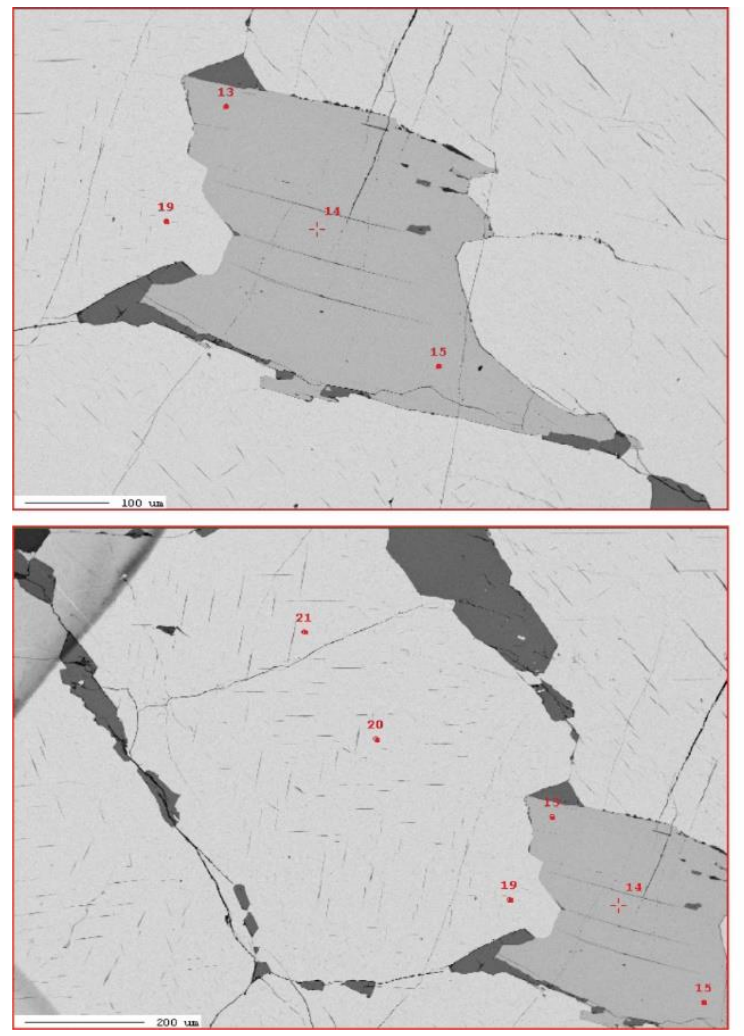

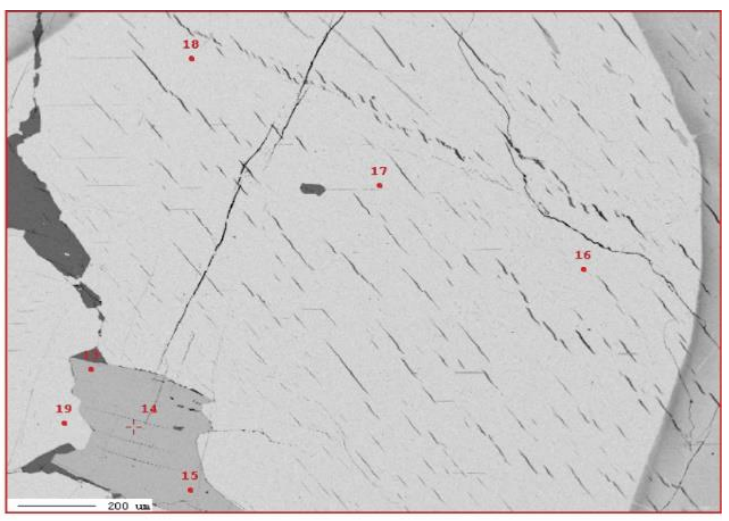




\section{CC076 circle D LA-ICPMS}

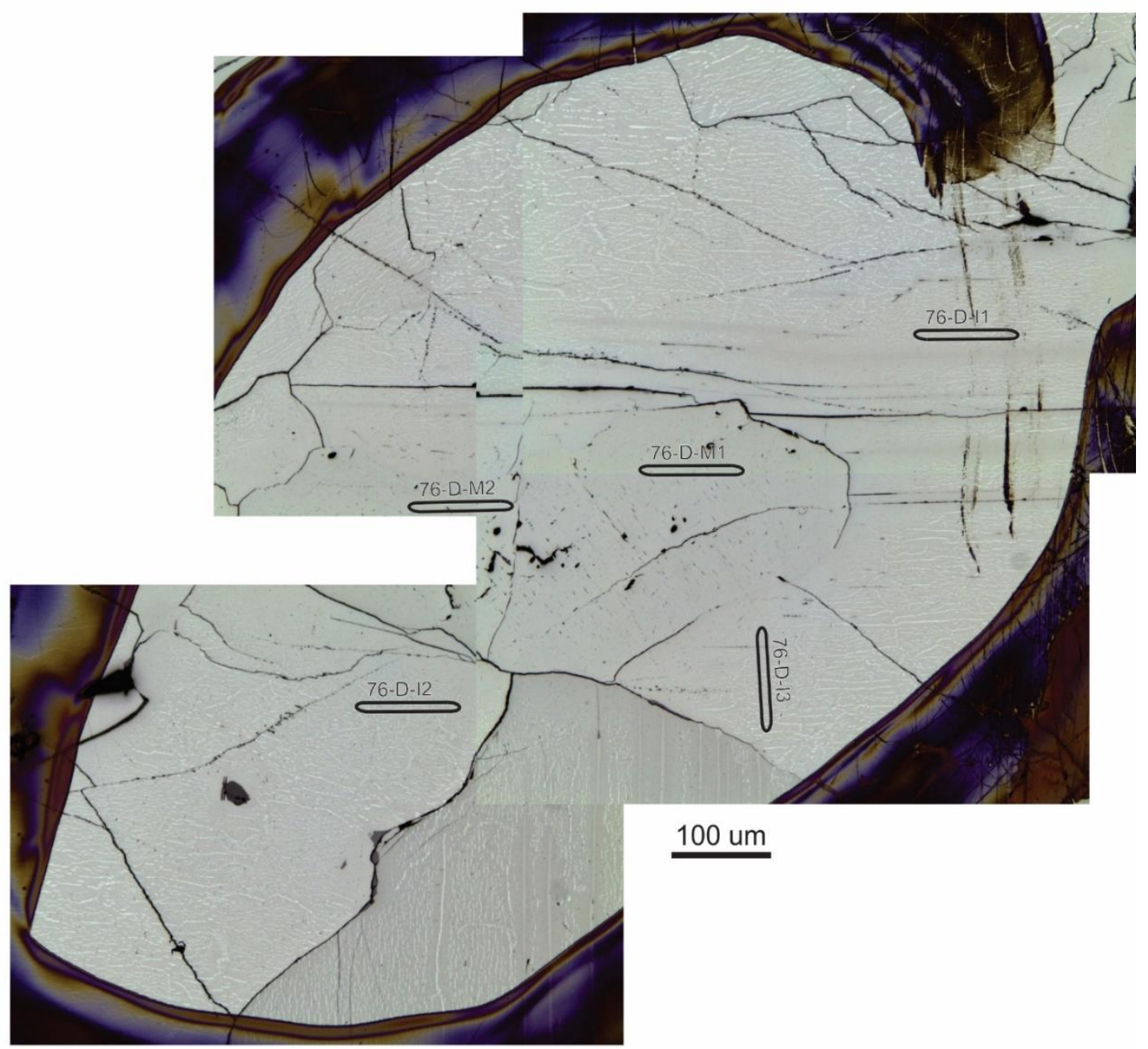

CC076 circle D EPMA
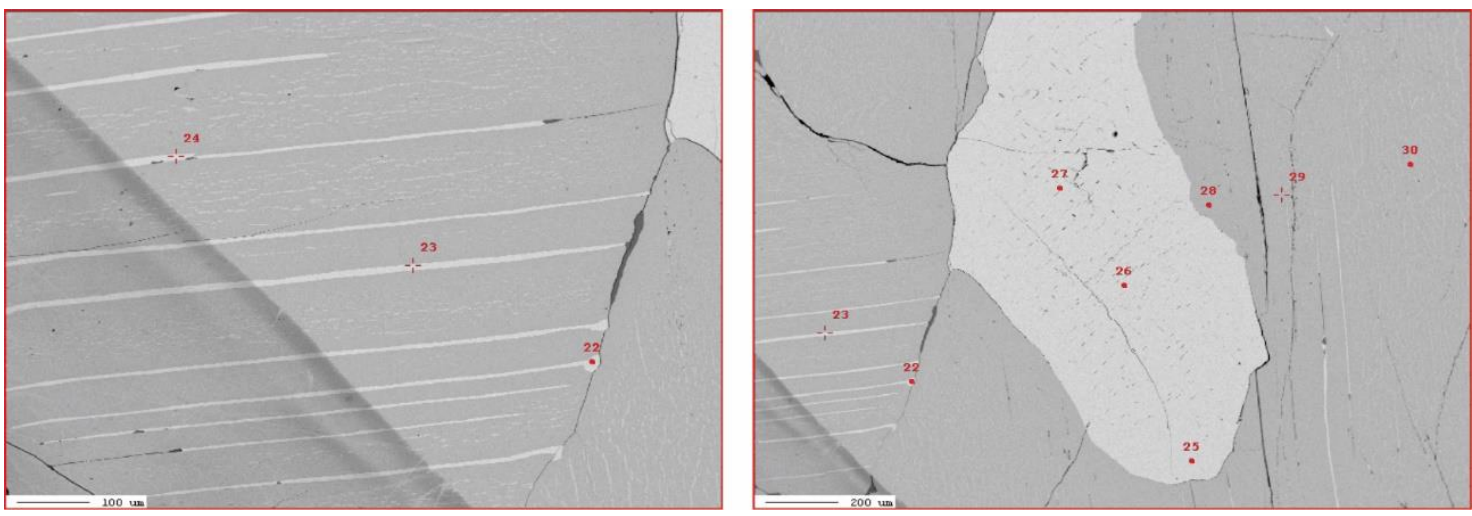

CC076 circle F LA-ICPMS 


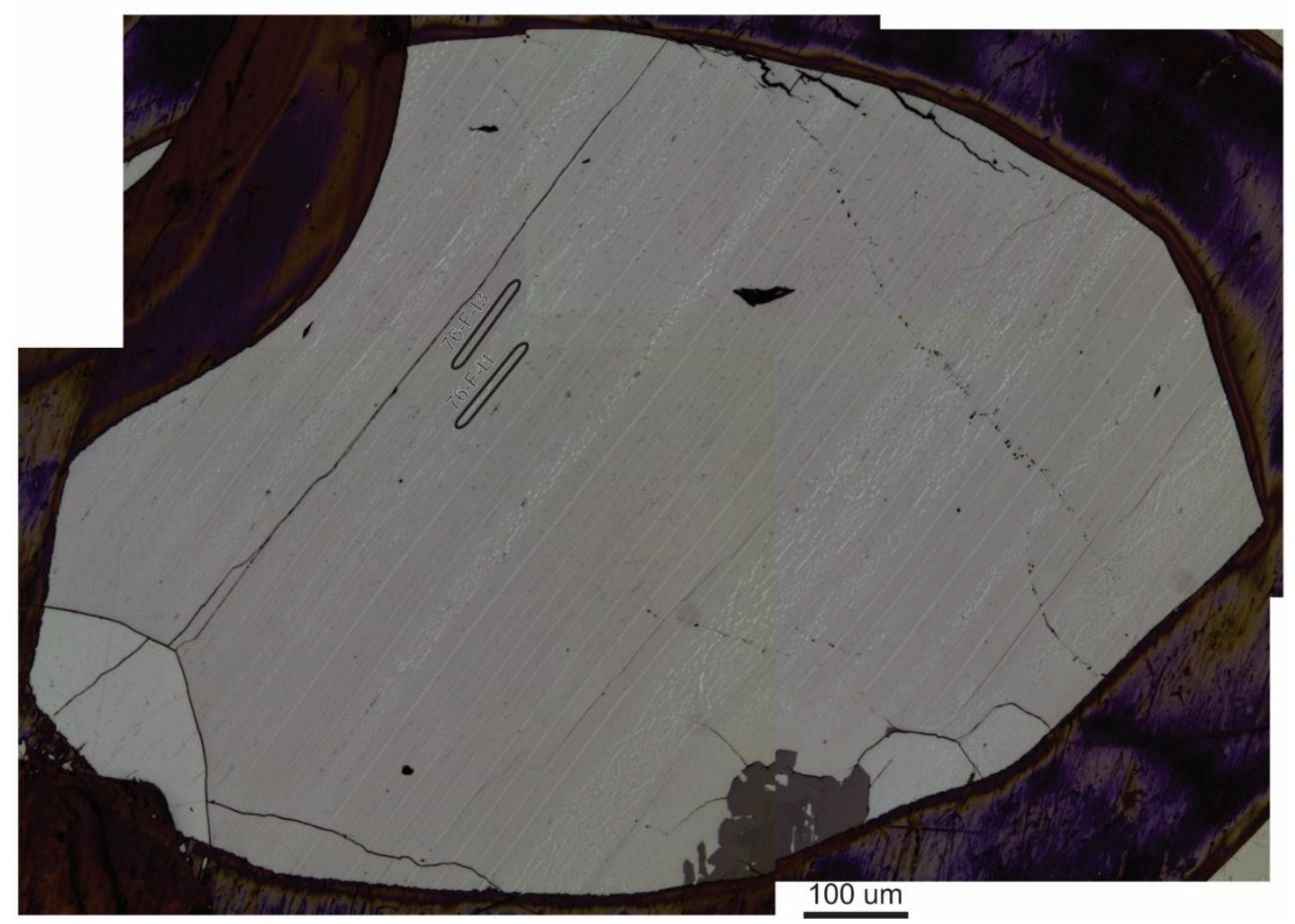

CC076 circle F EPMA
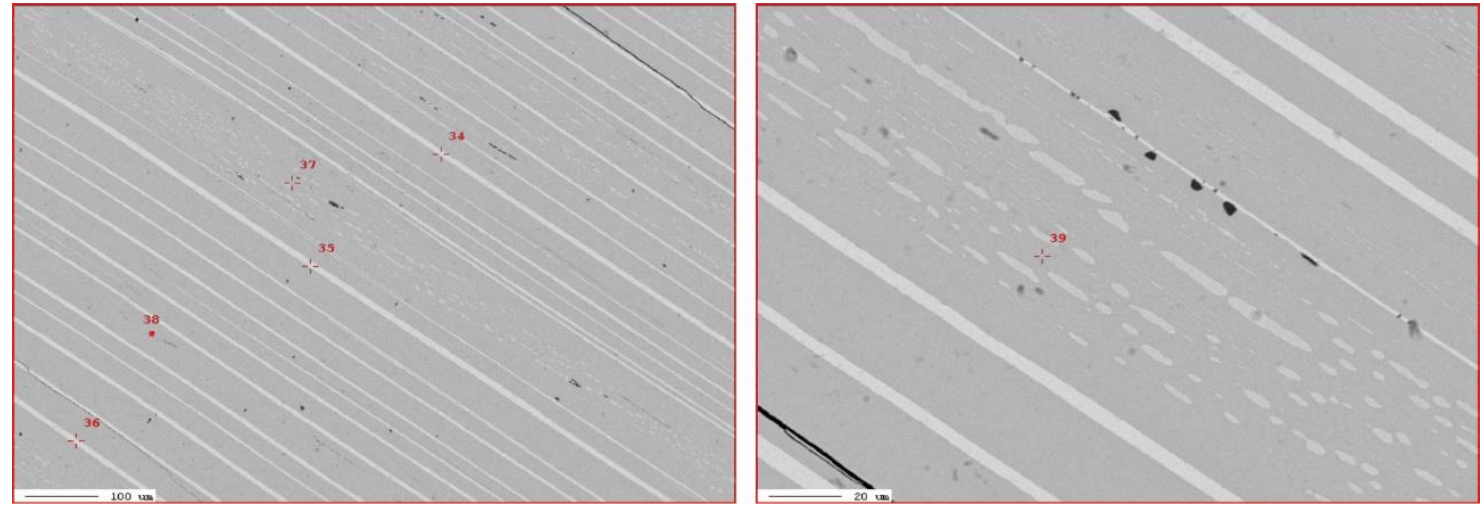
CC076 Circle G LAICPMS

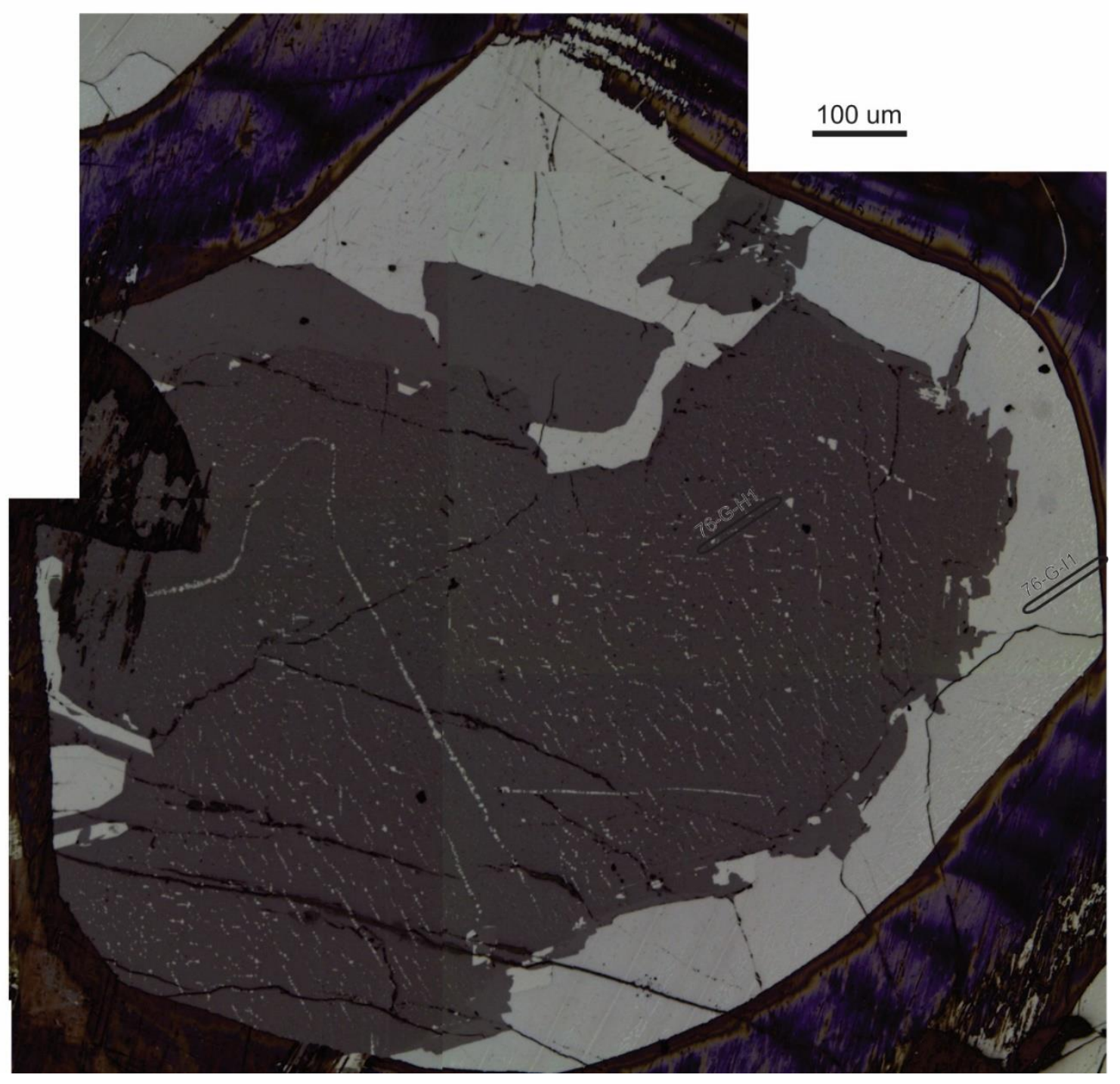


CC076 circle G EPMA
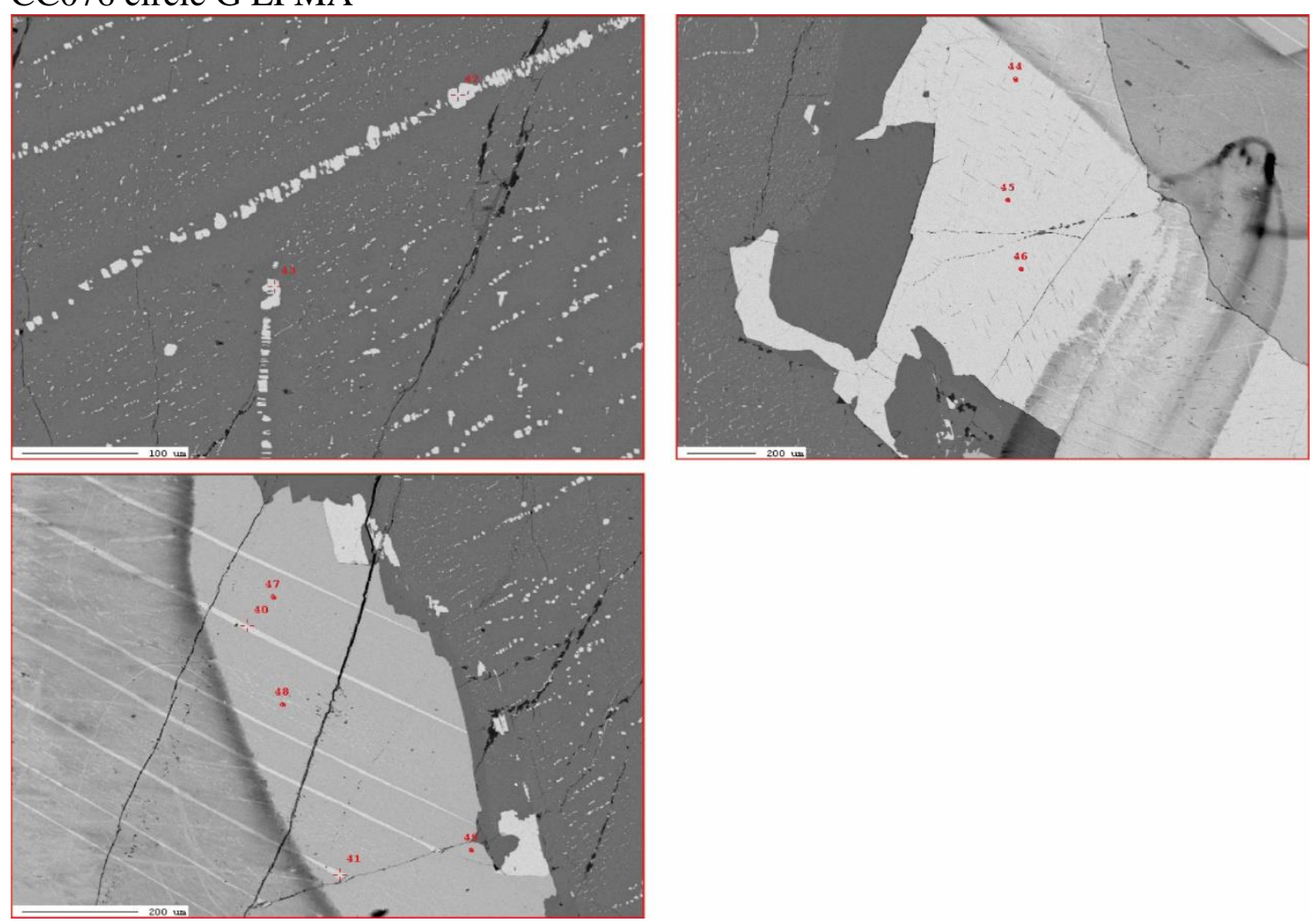
CC076 circle K LA-ICPMS
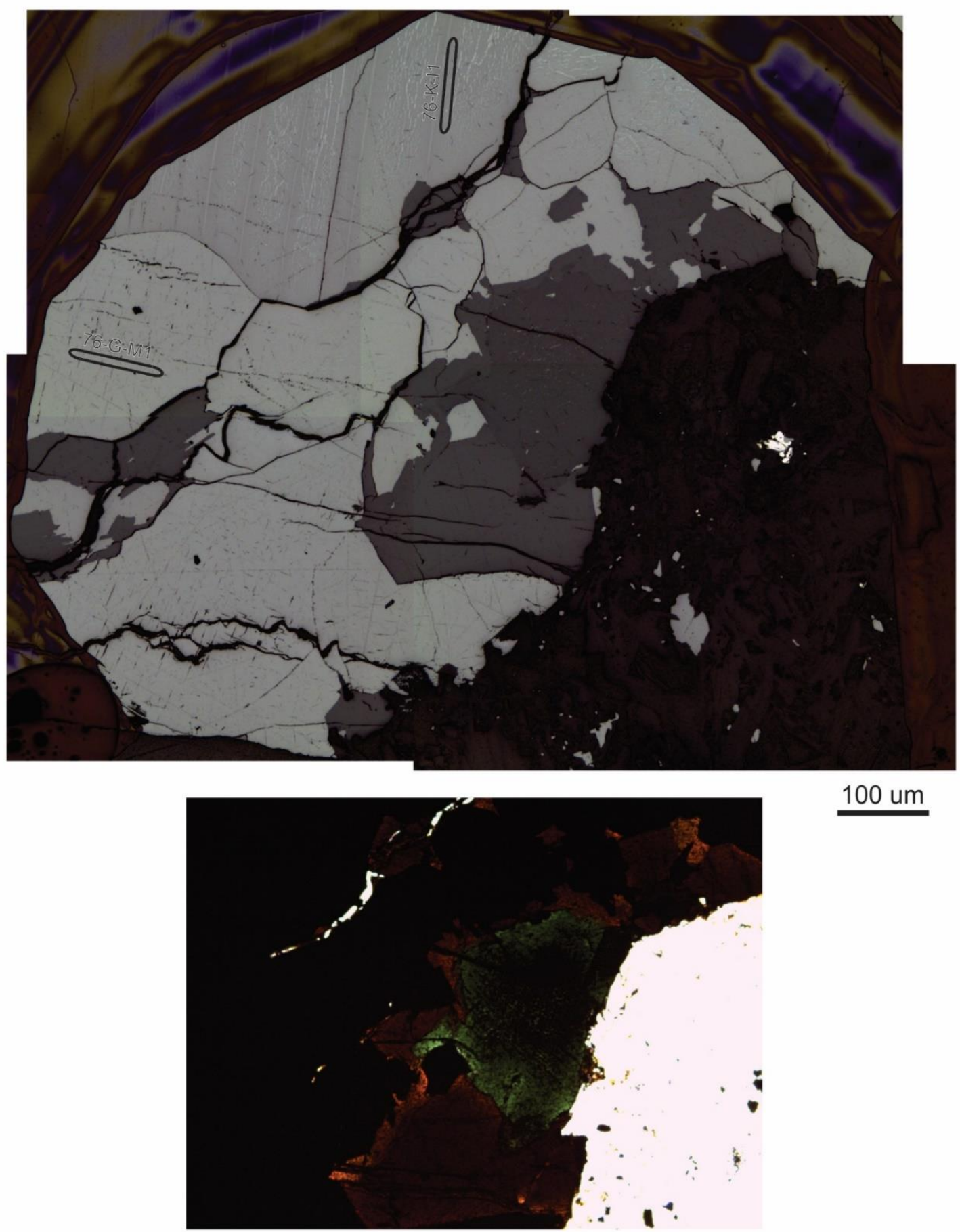


\section{CC076 circle L LA-ICPMS}

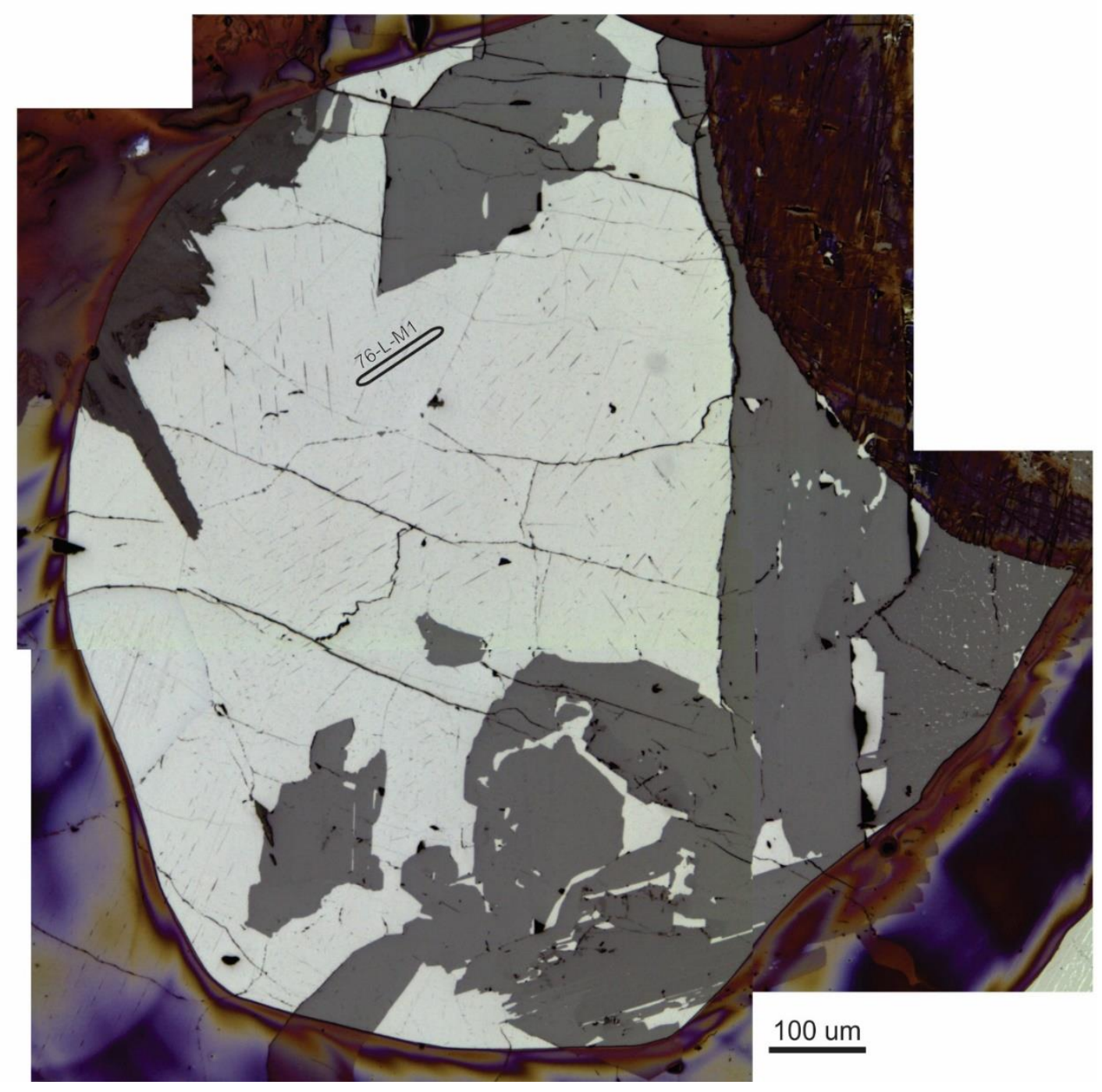




\section{Appendix VII: LA-ICPMS secondary standards}

Table aVII: LA-ICPMS secondary standards

\begin{tabular}{|c|c|c|c|c|}
\hline \multirow{4}{*}{ Source } & \multicolumn{2}{|l|}{ GSE } & \multicolumn{2}{|l|}{ Gp6 } \\
\hline & $\begin{array}{l}\text { Certificate } \\
\text { Value }\end{array}$ & $\begin{array}{l}\text { This } \\
\text { study } \\
\text { (n=15) }\end{array}$ & $\begin{array}{l}\text { Certificate } \\
\text { value }\end{array}$ & $\begin{array}{l}\text { This } \\
\text { study } \\
(n=13)\end{array}$ \\
\hline & \multicolumn{2}{|l|}{ GEOREM } & \multicolumn{2}{|l|}{ GEOREM } \\
\hline & Average & Average & Average & Average \\
\hline${ }^{24} \mathrm{Mg}$ & 21106 & 21077 & 51318 & 49616 \\
\hline${ }^{27} \mathrm{Al}$ & 68804 & 68348 & 92145 & 85829 \\
\hline${ }^{29} \mathrm{Si}$ & 250994 & 246793 & 224259 & 217000 \\
\hline 31P & 70 & 28 & 611 & 514 \\
\hline${ }^{44} \mathrm{Ca}$ & 52858 & 52247 & 86787 & 82534 \\
\hline${ }^{45} \mathrm{Sc}$ & 530 & 532 & 36.75 & 35 \\
\hline${ }^{47} \mathrm{Ti}$ & 450 & 413 & 7012 & 6351 \\
\hline${ }^{49} \mathrm{Ti}$ & 450 & 419 & 7012 & 6336 \\
\hline${ }^{51} \mathrm{~V}$ & 440 & 440 & 238 & 256 \\
\hline${ }^{52} \mathrm{Cr}$ & 400 & 368 & 300.2 & 313 \\
\hline${ }^{53} \mathrm{Cr}$ & 400 & 370 & 300.2 & 318 \\
\hline${ }^{55} \mathrm{Mn}$ & 590 & 589 & 1255 & 1286 \\
\hline${ }^{59} \mathrm{Co}$ & 380 & 381 & 46.9 & 47 \\
\hline${ }^{60} \mathrm{Ni}$ & 440 & 416 & 145.7 & 144 \\
\hline${ }^{63} \mathrm{Cu}$ & 380 & 363 & 89.5 & 73 \\
\hline${ }^{65} \mathrm{Cu}$ & 380 & 369 & 89.5 & 79 \\
\hline $66 \mathrm{Zn}$ & 460 & 442 & 70.8 & 79 \\
\hline${ }^{69} \mathrm{Ga}$ & 490 & 501 & 16.02 & 27 \\
\hline${ }^{71} \mathrm{Ga}$ & 490 & 510 & 16.02 & 15 \\
\hline${ }^{74} \mathrm{Ge}$ & 320 & 318 & 1.26 & 1 \\
\hline${ }^{75} \mathrm{As}$ & 260 & 260 & N.R. & N.R. \\
\hline${ }^{89} \mathrm{Y}$ & 410 & 433 & 19.33 & 17 \\
\hline${ }^{90} \mathrm{Zr}$ & 410 & 404 & 55.1 & 48 \\
\hline${ }^{92} \mathrm{Zr}$ & 410 & 408 & 55.1 & 27 \\
\hline${ }^{93} \mathrm{Nb}$ & 420 & 429 & 4.16 & 4 \\
\hline${ }^{95} \mathrm{Mo}$ & 390 & 382 & N.R. & N.R. \\
\hline${ }^{118} \mathrm{Sn}$ & 280 & 277 & 1.33 & 3 \\
\hline${ }^{121} \mathrm{Sb}$ & 450 & 432 & 0.13 & 0 \\
\hline${ }^{178} \mathrm{Hf}$ & 395 & 409 & 1.52 & 1 \\
\hline${ }^{181} \mathrm{Ta}$ & 390 & 416 & 0.28 & 0 \\
\hline${ }^{182} \mathrm{~W}$ & 430 & 441 & N.R. & N.R. \\
\hline${ }^{208} \mathrm{~Pb}$ & 378 & 406 & 3.28 & 4 \\
\hline
\end{tabular}

N.R.- Not recorded 


\section{Appendix VII (Continued)}

Gp6 concentrations
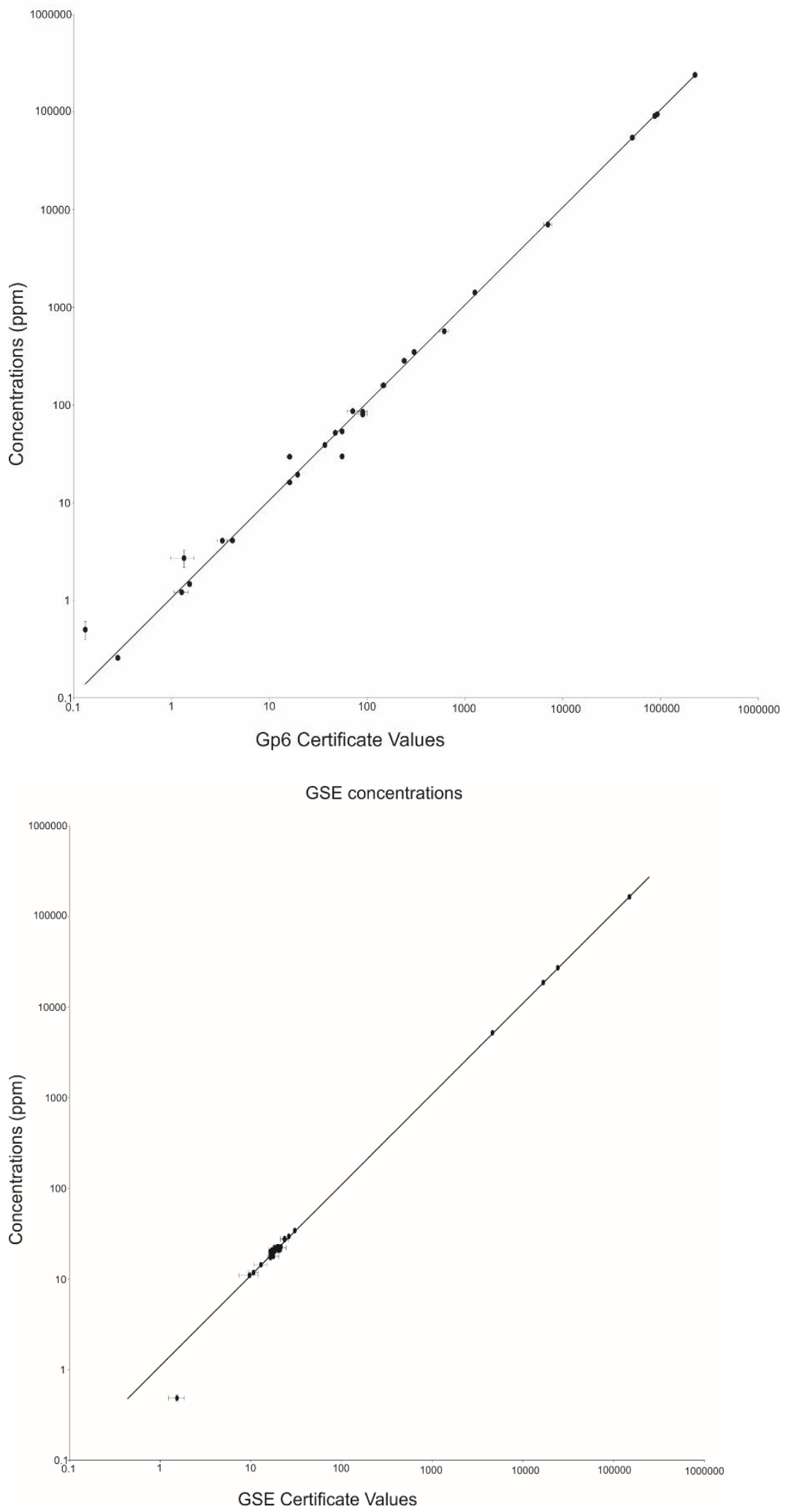